Louisiana State University

LSU Digital Commons

Faculty Publications

Department of Biological Sciences

$1-1-2016$

\title{
Urban microbiomes and urban agriculture: What are the connections and why should we care?
}

Gary M. King

Louisiana State University

Follow this and additional works at: https://digitalcommons.Isu.edu/biosci_pubs

\section{Recommended Citation}

King, G. (2016). Urban microbiomes and urban agriculture: What are the connections and why should we care?. Sowing Seeds in the City: Ecosystem and Municipal Services, 191-206. https://doi.org/10.1007/ 978-94-017-7453-6_14

This Article is brought to you for free and open access by the Department of Biological Sciences at LSU Digital Commons. It has been accepted for inclusion in Faculty Publications by an authorized administrator of LSU Digital Commons. For more information, please contact ir@lsu.edu. 
Sally Brown - Kristen Mclvor Elizabeth Hodges Snyder Editors
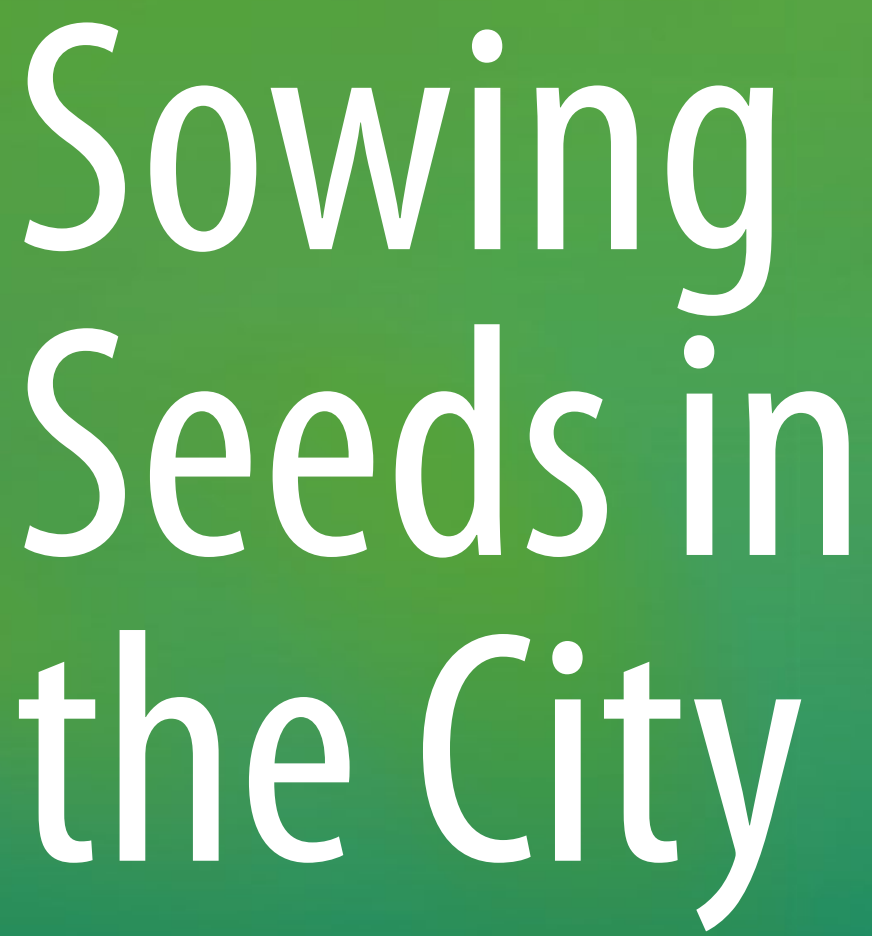

Ecosystem and Municipal Services

Springer 
Sowing Seeds in the City 

Sally Brown - Kristen McIvor

Elizabeth Hodges Snyder

Editors

\section{Sowing Seeds in the City}

Ecosystem and Municipal Services

包 Springer 


\section{Editors}

Sally Brown

School of Environmental and Forest

Sciences

University of Washington

Seattle, WA, USA

\author{
Elizabeth Hodges Snyder \\ Department of Health Sciences \\ University of Alaska Anchorage \\ Anchorage, AK, USA
}

\author{
Kristen McIvor \\ Harvest Pierce County \\ Pierce Conservation District \\ Puyallup, WA, USA
}

ISBN 978-94-017-7451-2
DOI 10.1007/978-94-017-7453-6

Library of Congress Control Number: 2016937712

Springer Dordrecht Heidelberg New York London

(C) Springer Science+Business Media Dordrecht 2016

This work is subject to copyright. All rights are reserved by the Publisher, whether the whole or part of the material is concerned, specifically the rights of translation, reprinting, reuse of illustrations, recitation, broadcasting, reproduction on microfilms or in any other physical way, and transmission or information storage and retrieval, electronic adaptation, computer software, or by similar or dissimilar methodology now known or hereafter developed.

The use of general descriptive names, registered names, trademarks, service marks, etc. in this publication does not imply, even in the absence of a specific statement, that such names are exempt from the relevant protective laws and regulations and therefore free for general use.

The publisher, the authors and the editors are safe to assume that the advice and information in this book are believed to be true and accurate at the date of publication. Neither the publisher nor the authors or the editors give a warranty, express or implied, with respect to the material contained herein or for any errors or omissions that may have been made.

Printed on acid-free paper

Springer Science+Business Media B.V. Dordrecht is part of Springer Science+Business Media (www. springer.com) 


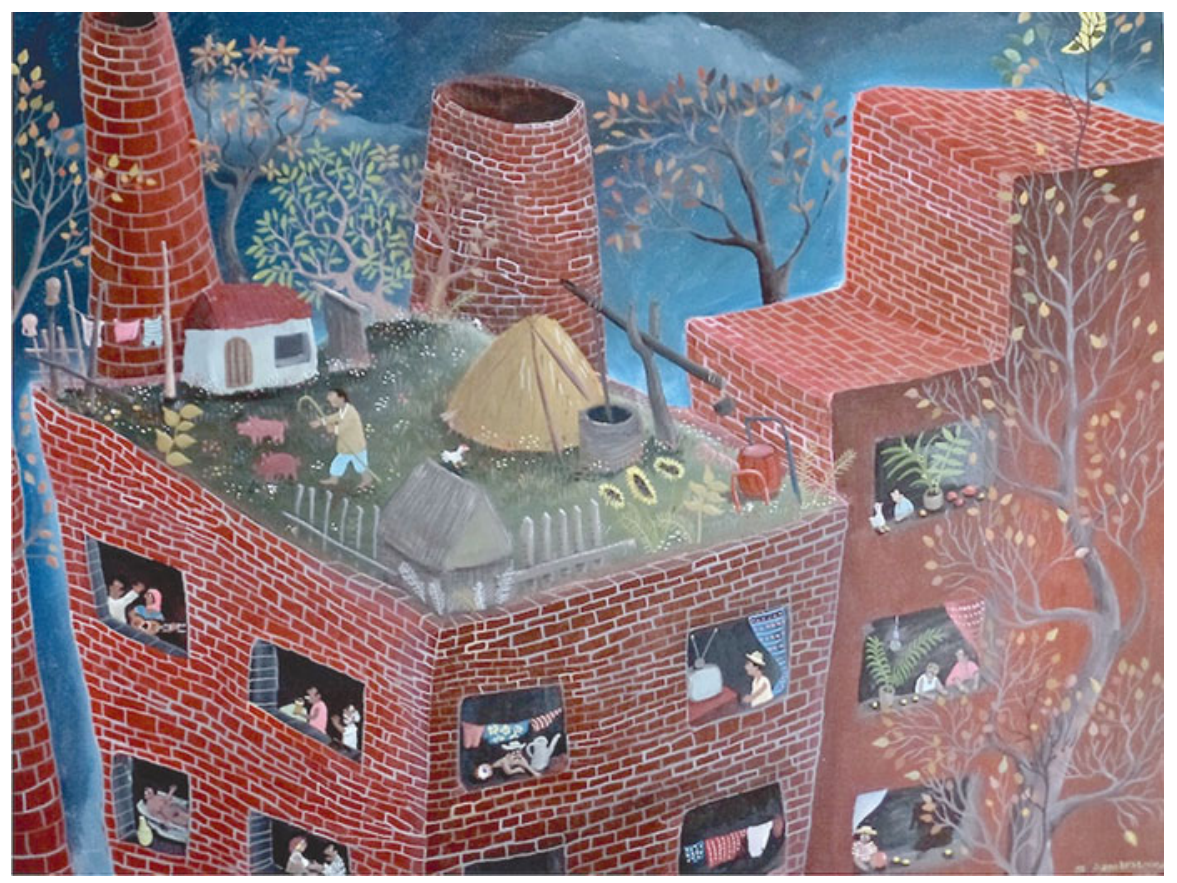

Painting credit:

Seva Rzhondkovsky

http://sevaart.com 


\section{Book I}

\section{Part I}

"A lifetime of accomplishments of which the dirt knows none, only in death can one truly return Return the carrots, the apples and potatoes, The chickens, the cows, the fish and tomatoes."

-Poi Dog Pondering

"Well I love that dirty water"

-Standells

\section{Part II}

"Let me tell ya 'bout the birds and the bees And the flowers and the trees"

-Herbert Newman

Well, you get the cherry, Jerry

Now look, don't be so picky, Mickey

Cause everybody eats when they come to my house

-Cab Calloway

\section{Part III}

On the roof's the only place I know

Where you just have to wish to make it so

Let's go up on the roof (Up on the roof)

-Drifters 


\section{Preface}

The two volumes of Sowing Seeds in the City were inspired by a National Academy of Science Keck Foundation (NAKFI) conference on ecosystem services (http:// www.keckfutures.org/conferences/ecosystem-services_podcast_home.html). Each attendee was asked to select an area of inquiry from a potential list of nine topics. At the meeting we worked in groups to come up with innovative solutions to each question. I was struck by how urban agriculture has the potential to address so many of the questions on that list. When the conference was held, urban agriculture was not on the radar. Six of those nine areas of inquiry from the NAKFI conference are shown below, along with the related sections in Sowing Seeds in the City:

- How ecosystem services affect infectious and chronic disease: Volume 2, Section 1

- Identify what resources can be produced renewably or recovered by developing intense technologies that can be applied on a massive scale: Volume 1, sections on water and waste

- Design agricultural and aquacultural systems that provide food security while maintaining the full set of ecosystem services needed from landscapes and seascapes: Volume 1, all sections, and Volume 2, sections on food security

- Design production systems for ecosystem services that improve human outcomes related to food and nutrition: Volume 1, sections on ecosystems services and food production, and Volume 2, sections on health and food security

- Design a federal policy to maintain or improve natural capital and ecosystem services within the United States including measuring and documenting the effectiveness of the policy: Volume 1, sections on municipal infrastructure, and Volume 2, case studies and the sections on research, education, and programming

- Develop a program that increases the American public's appreciation of the basic principles of ecosystem services: Volume 2, case studies and the sections on research, education, and programming

The scientific community is starting to recognize the potential for urban agriculture to address the issues listed above, and a social movement in urban agriculture is already well underway. To be successful, this social movement also has to be 
embraced by public health officials, residuals managers, municipal governments, as well as the people who actually plant the seeds. Right now, urban agriculture is many things to many people. At a minimum it provides fresh tomatoes for salads and sandwiches for urban growers during hot summer months. From a broader perspective, urban agriculture has the potential to revolutionize our food systems, reintegrate both knowledge of and higher-level ecosystem services into our cities, change how our children learn, and have a broad impact on public health. The recent rebirth of urban agriculture began primarily as a social movement. With these two volumes we explore urban agriculture from a broad perspective. We hope that these books can encourage and inspire the broad range of individuals who stand to benefit from urban agriculture.

The first volume focuses on urban agriculture and ecosystem services and how growing food can be integrated into the physical and legal framework of cities in the United States. The first chapter describes a "city of the future" where agriculture is well integrated into the fabric of a municipality. This sets the tone for the remainder of the books. The next part focuses on the natural resources soil and water. A basic guide to soils in urban areas and how to improve them is the focus of the soil chapter. The water chapters describe the different types of water that can be recycled in urban areas with supporting regulations and guidelines; provide details on gray water, the water from homes used to wash our bodies, clothes, and dishes; and give a broad call on the importance of maximizing our use of recycled water in urban areas.

The next part of the first volume focuses on ecosystem services. Waste treatment is the first section. The first chapter provides an overview and guide to the role of organic residuals in urban agriculture. The next chapter provides an engineering perspective including infrastructure, economic and climate requirements, and costs for different waste management alternatives. The section closes with a case study of Seattle where food scraps are now composted along with yard waste. The discussion focuses on the political background that enabled landfill diversion of organics and describes the factors needed to compost the food and yard waste.

The next section describes how urban agriculture can impact climate change. The role of soils in climate change is the focus of the first chapter, followed by an analysis of the climate impacts of different waste management options. The section concludes with a life cycle assessment of lettuce grown in a community garden or on a large-scale farm.

Habitat is the next component of ecosystem services. This section begins with an introduction to microbial ecology and function in urban agriculture. It continues with a more theoretical consideration of the microbiome and urban agriculture. Moving up the food chain, the next chapters go from bees to birds to recommendations of how urban farms can be designed to provide optimal habitat.

One question that is frequently asked about urban farms is how much food can be produced on the small plots so typical of urban lots. The section on food production begins with a detailed description of the productivity of a lot in a community garden in Seattle. Permaculture, a tool for managing soil plant systems, is described for a home in Alaska. Seed preservation is discussed in the next chapter. 
This section concludes with a detailed description of aquaponic systems, a potential means to grow fish in urban settings.

From here the book focuses on the pragmatic side of this issue. Where to farm and how to incorporate farming into the fabric of a city? The first question is addressed in a section on location options. This includes chapters on community gardens, rooftop gardens, and growing on brownfield sites and on parking strips. The final section of this volume gives examples from Michigan; Portland, OR; and Boston, MA, on how municipal codes were changed to encourage agriculture.

Seattle, WA, USA

Puyallup, WA, USA

Anchorage, AK, USA
Sally Brown Kristen McIvor Elizabeth Hodges Snyder 



\section{Contents}

Ecosystem Services from Urban Agriculture

in the City of the Future

Corinne Cooley and Isaac Emery

Part I Soil and Water Resources

Soil Formation and Nutrient Cycling.

Craig Cogger and Sally Brown

A Guide to Types of Non Potable Water and the

Potential for Reuse in Urban Systems

Sally Brown

Graywater Reuse for Irrigation: Benefits and Potential Hazards

Ian Pepper

Planting Abundance: Alternative Water Sources for Urban Farms.

Brad Lancaster

Part II Ecosystem Services - Waste Treatment

The Role of Organic Residuals in Urban Agriculture

Sally Brown and Nora Goldstein

Municipal Food Waste Management Options:

Climate and Economic Impacts

David Parry

Food Waste Composting in Seattle: The Political Perspective

Alexis Schulman

Cedar Grove Compost: Developing a Combined

Food-Yard Waste Centralized Composting Program

Denise Bartlett 
Part III Ecosystem Services - Climate Regulation

Soils and Climate Change

Sally Brown

Soil Carbon Sequestration and Organic Wastes

Andrew Trlica

Lettuce to Reduce Greenhouse Gases: A Comparative Life Cycle

Assessment of Conventional and Community Agriculture

Isaac Emery and Sally Brown

Part IV Ecosystem Services - Habitat

Basics of Microbial Ecology and Function in Urban Agriculture

Karl A. Wyant

Urban Microbiomes and Urban Agriculture: What Are

the Connections and Why Should We Care?

Gary M. King

Wild Bees in Cultivated City Gardens

J. Scott MacIvor

Urban Agriculture as Habitat for Birds.

Amanda D. Rodewald

Improving the Suitability of Urban Farms for Wildlife

Zoe A. Marzluff and John M. Marzluff

Part V Ecosystem Services - Food Production

How Much Can You Grow? Quantifying Yield in a Community

Garden Plot - One Family's Experience.

Michael McGoodwin, Rebecca McGoodwin, and Wendy McGoodwin

Applying Permaculture in Alaska: The Williams Street Farmhouse

Saskia Esslinger

Seed Libraries

Melissa Desa

Recirculating Aquaculture Systems (RAS) and Aquaponics for Urban Food Production, with a Pictorial Guide to Aquaponics.

Miles Medina, Krish Jayachandran, Mahadev Bhat, and David Specca 
Part VI Integration into Municipal Infrastructure - Location Options

Community Garden Basics

Kristen McIvor

Up on the Roof: Considerations for Food Production on Rooftops

Leigh Whittinghill and Olyssa Starry

Brownfields as Sites for Urban Farms

Ann Carroll

Curbside Gardens

Craig Cogger and Sally Brown

Part VII Integration into Municipal Infrastructure - Zoning and Legal Considerations

A Case Study: Zoning and Urban Agriculture in Michigan Megan Masson-Minock

A Case Study: Urban Agriculture in Portland, Oregon 2002-2012

Molly M. Hatfield and Steve Cohen

A Case Study: Legalizing Commercial Agriculture in Boston A Logical Step Towards Integrating Farming into Urban Life

Michele Kaufman and John Read

Index 



\section{About the Editors}

Sally Brown is a research associate professor at the University of Washington School of Forest and Environmental Science. She is a fellow in the Soil Science Society of America, was a two-term member of the National Academy of Science Standing Committee on Soil Science, and is a member on the National Academy of Science Committee on the Bioavailability of Contaminants in Soils and Sediments. She has won multiple awards for her work on residual use in soils. Dr. Brown writes a monthly column for BioCycle Magazine, a journal that focuses on sustainable management of organics. She has a BA in political science from Williams College (1980) and an MS (1993) and PhD (1996) from the University of Maryland. Before returning to graduate school, she worked as a chef in New York City, New Orleans, and Connecticut. In 1986 she started a business delivering locally grown vegetables to stores and restaurants in New York City and Connecticut. She currently grows greens, onions, potatoes, and currants on two plots near her home with the assistance of her husband and TAGRO, the biosolids-based soil amendment from Tacoma, WA.

Kristen McIvor is the director of Harvest Pierce County, a program of the Pierce Conservation District. Their mission is to invest in people to foster and sustain an equitable and healthy community-based food system throughout Pierce County. She is also an adjunct professor at Pinchot University where she teaches classes on food systems. Dr. McIvor got her MS at Antioch University in environment and community and her $\mathrm{PhD}$ at the University of Washington. Her academic work has focused on improving soils in urban areas to support the growing of food, and much of her time is spent working with community groups to do just that. She lives in the soggy Pacific Northwest and loves its mild climate for year-round growing. In her spare time, she gets her hands dirty as often as she can and loves preparing and sharing the bounty of her garden with her family and friends. 
Elizabeth Hodges Snyder is an assistant professor of public health and the Master of Public Health Program coordinator at the University of Alaska Anchorage. She also serves as cochair of the Alaska Food Policy Council (AFPC). Dr. Snyder is trained in environmental health (MPH, Global Environmental Health, Emory University, 2004) and soil and water science (PhD, Soil and Water Science, University of Florida, 2009). Her career began with a focus on environmental contaminant fate and transport and human and ecological risk assessment, but her research program and teaching agenda have since evolved to address the fields of food security and health impact assessment. She has coauthored several works on food security in Alaska; supervises graduate student projects addressing food access, availability, and utilization; and advocates for strengthened rural and urban food systems. Originally from Florida, Dr. Snyder has adjusted well to the climate of Alaska - successfully raising backyard chickens, utilizing vertical drip irrigation to produce greenhouse tomatoes, growing beautiful peonies, chasing moose out of her raised beds, and instilling in her children a love for Alaska-grown carrots made sugar-sweet in the cold soil. 


\title{
Ecosystem Services from Urban Agriculture in the City of the Future
}

\author{
Corinne Cooley and Isaac Emery
}

What do we dream of when we imagine the City of the Future? Many science fiction portrayals have imagined cityscapes filled with hovercraft, immense and intricate architecture, dazzling lights and a bustlingly dense population. These technological wonderlands often neglect parks and green space, much less the concepts of urban agriculture. But researchers and visionaries are beginning to propose more and more alternative ideas for how cities of the future could embrace and integrate food production on a fundamental level. Attempts to clarify these ideas and their benefits to the humans within those cities offer a glimpse into a very different kind of a future; one where nature, sustenance, and human communities are deeply intertwined.

\section{What Are Ecosystem Services, and How Do They Apply to City of the Future?}

The language of ecosystem services provides a useful framework to discuss the benefits that might emerge in such a city. Ecosystem services build on the common economic concept of goods and services. Any ecosystem - even a human-created or influenced one, such as a farm - provides an array of services that may include but also go far beyond simply growing food or fuel. Ecosystems may clean air and regulate

\footnotetext{
C. Cooley $(\bowtie)$

Earth Economics, Tacoma, WA, USA

e-mail: cooleycr@gmail.com; http://www.eartheconomics.org

I. Emery, Ph.D. ( $\square)$

School of Forest Resources, University of Washington, Seattle, WA, USA

Department of Systems Engineering and Management, Air Force Institute of Technology,

Wright-Patterson Air Force Base, OH, USA

e-mail: isaac.emery@gmail.com; http://Isaacemery.com
} 
Fig. 1 A bee in a community garden. The borage was planted specifically to attract the pollinator (Photo by Michael McGoodwin)

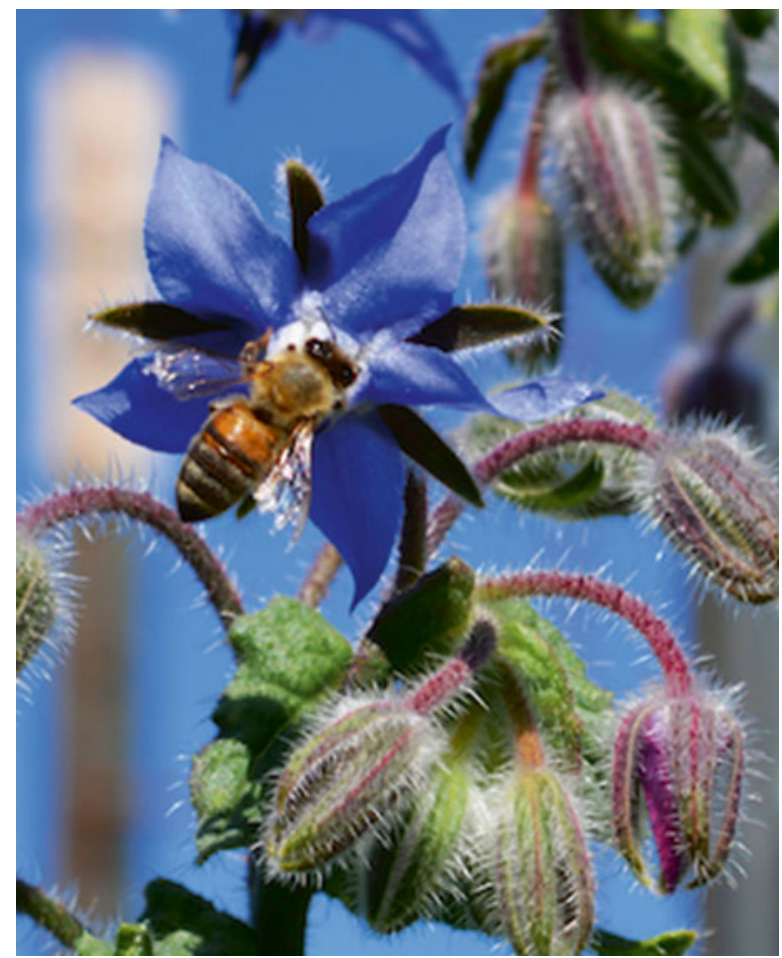

temperatures, hold soil that would otherwise erode, provide sustenance to pollinators, and they are frequently central to culture and community of place (Fig. 1).

Ecosystem services are frequently broken into three major categories:

- Provisioning: Ecosystems provide goods such as food, feed, fuel, clean water, medical resources, ornamental resources, and so on.

- Regulating: Ecosystems regulate geophysical, biological, or atmospheric processes such as temperature and climate regulation, soil stabilization, water treatment, pest or invasive species control, disaster mitigation (hurricane buffering, flood control, reducing wildfire severity etc.) and so on.

- Informational / Cultural: Ecosystems have value directly to humans scientifically, educationally, aesthetically, culturally, spiritually, and through their direct contributions to better human health.

Different land cover types (a coniferous forest and a brackish marsh, for example) provide different ecosystem services. Conventional agriculture and urban green space have unique patterns of ecosystem services contributions, which are discussed below. In the City of the Future, a carefully designed combination of the two could provide food, water, habitat, and many other services, resulting in a healthier and more productive urban environment. 


\section{Ecosystem Services from Agriculture}

All land used by humans has been at some point been converted from native land covers - sometimes in the distant past, sometimes quite recently. Agriculture has transformed the Earth's surface, with crop and pastureland now covering nearly $40 \%$ of global land area (Foley et al. 2005). The fraction of land devoted to agriculture can vary dramatically between nations, but it is expected to continue to increase in order to meet the demands of a growing population and increasingly meat-heavy diets (Foley et al. 2005; Bank 2013). While agricultural land can provide a wide array of ecosystem services, current conventional practices go to an extreme, optimizing farmland for food provisioning to the near-exclusion of all else (Foley et al. 2005; Sandhu et al. 2010). High-density monoculture cropping may lead to very high corn or soy yields, but also leads to greatly increased erosion and runoff, the expulsion of native wildlife, greater vulnerability to pests, and many other problems. Leaving fields bare of living plants for up to 8 months per year leads to high rates of erosion and loss of fertilizers and pesticides in runoff. Fertilizer runoff from cropland leads to massive dead zones in estuaries around the world (Diaz and Rosenberg 2008). In almost all cases, converting land to 'conventional' agriculture greatly reduces the provision of all ecosystem services save those that directly result in marketable goods (Fig. 2).

A number of farming practices seek to reduce these impacts, some more successfully than others. No-till farming, practiced in a large and growing area of the United States, can reduce erosion, evaporative water loss, fuel use, and planting costs in many landscapes (Chiras and Reganold 2005). Leaving crop residues exposed, rather than tilling them into the soil, also provides habitat for wildlife. No-till

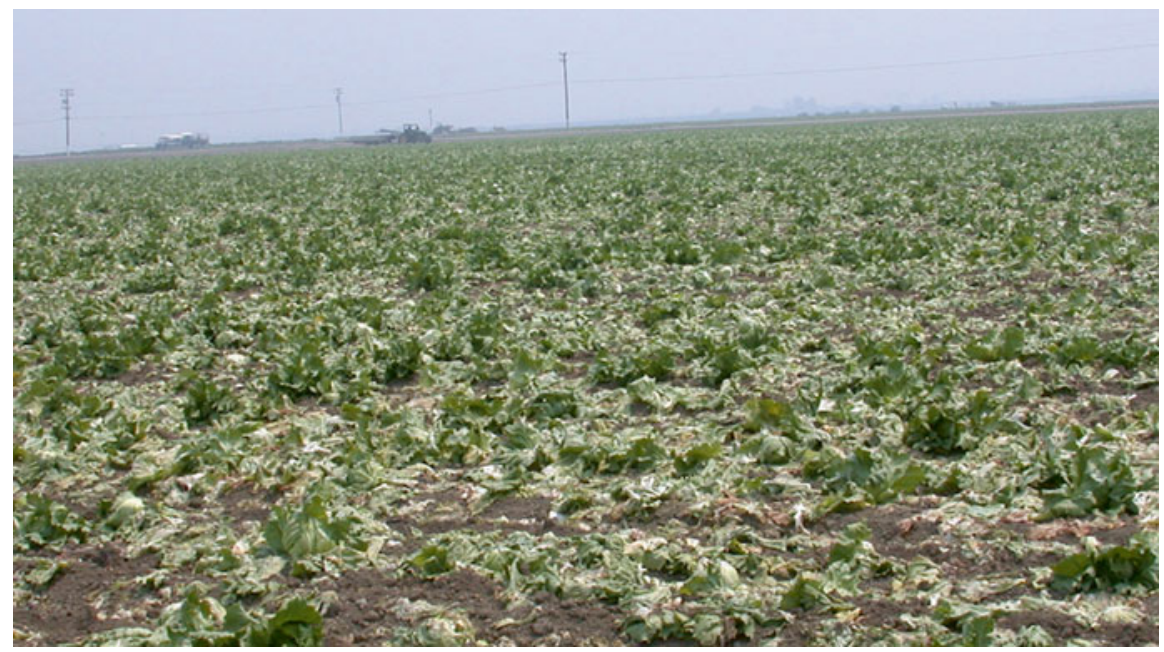

Fig. 2 A field of recently harvested lettuce in Monterey, CA (Photo by Sally Brown) 


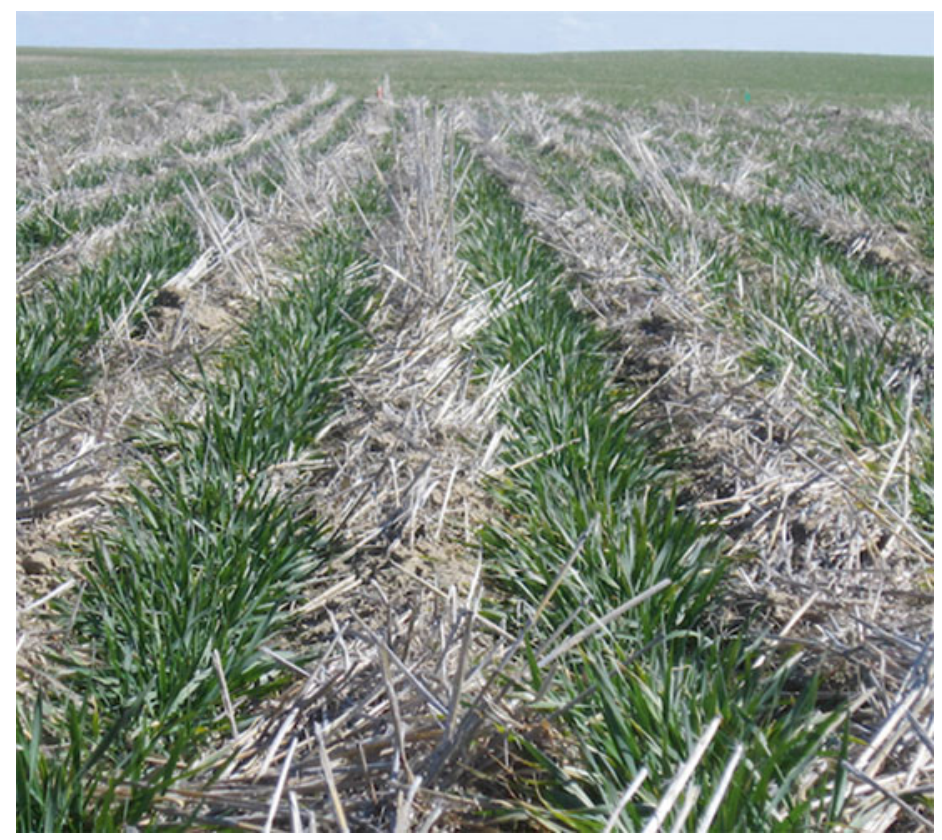

Fig. 3 Wheat growing in residue from a previous cropping is an example of no till agriculture (Photo by William Schillinger)

practices can also facilitate dual cropping or cover crops by reducing the number of passes over the field between harvest of one crop and planting of the next (Fig. 3).

In many temperate regions, growing multiple crops in a year is rare, but doing so can vastly reduce soil exposure to wind and rain erosion, improve soil quality, reduce fertilizer requirements, and in some cases provide additional income for the farmer. Organic farming, one of the fastest-growing agricultural programs in the United States and Europe, has the potential to improve soil quality, habitat and biodiversity. By reducing fertilizer application and runoff, and prohibiting the use of many toxic pesticides, organic farms have been shown to provide a broader range of ecosystem services than comparative conventional farms (Sandhu et al. 2008). Although they represent an investment of time, machinery, and financial resources, these activities can increase a range of ecosystem services from agricultural areas.

Other approaches go further still to integrate natural and agricultural systems. Perennial and polyculture agricultural systems differ from conventional practices by growing crops which continue to grow for many years without replanting, or by growing many different plant species in the same field. They can provide a much wider array of ecosystem services by maintaining biodiversity, habitat, and soil cover year-round. These systems also tend to require fewer chemical inputs and less energy-intensive farming, which reduces dependence on petroleum and other externalized ecological impacts (Brummer et al. 2011). For example, at the Land Institute, a non-profit organization in Kansas, ecologists and crop specialists work to develop 
a perennial polyculture of grains, legumes, and oilseeds that will require few inputs and virtually eliminate erosion and runoff (The Land Institute 2013). Rather than focusing on the developing new crops, permaculture farm systems utilize combinations of existing plants and technologies to provide a broad range of services, maximizing the self-sufficiency of each farm or homestead. Permaculture systems often integrate landscaping to maximize water recovery during droughts, renewable energy technologies, and cycle plant and animal wastes on-site to minimize costs and pollution (Permaculture Association 2013).

Polyculture systems are still rare. Many are labor-intensive, expensive, or limited to small-scale applications. Even the best large-scale organic farms still result in agricultural land that is good at producing food, but lag far behind native land cover in providing most other ecosystem services. As global populations continue to grow and demand for food and fuel continues to increase, solutions which increase food production, improve the supply of food when and where it is needed, and minimize the displacement of the ecosystems which provide vital services are becoming increasingly necessary.

\section{Ecosystem Services from Urban Areas}

Urban landscapes in their 'purest' form - buildings and streets - do not provide any ecosystem services at all. Even the most basic integration of nature, such as street trees, can make a big difference in temperature regulation, air quality, and aesthetic value. A small, tightly manicured lawn can reduce stormwater runoff in comparison with a rooftop or a patch of bare concrete. A forested hillside can protect properties above and below from erosion and landslides.

Parks and other larger scale urban refugia make an even bigger impact. In addition to playing a large and crucial role in air quality, stormwater regulation, climate regulation, and other benefits discussed above, parks play an essential role in human health and community, providing a space where people can exercise and gather together (Fig. 4).

A study done to quantify the value of urban parks in Tacoma, Washington, a city with a population of 200,000, arrived on economic values of over $\$ 20$ million per year for the services provided by the parks (Christin et al. 2011). Although Tacoma's 2960 acres of parks and managed open space cover only $9 \%$ of the city's land area, their value is greater than $10 \%$ the city's GDP. While the integration of nature into urban settings can introduce problems, such as damage to concrete by tree roots, species that are toxic to pets, and so on, overall the consequences are overwhelmingly and quantifiably positive.

Agriculture in urban areas has the potential to provide an equal or greater value than parks or landscaped areas. Integrating agriculture in urban areas will both increase ecosystem services in urban areas while simultaneously easing agricultural pressure on native landscapes. There are other potential benefits as well. For example, integrating combined food production and wastewater management could vastly reduce the pressure of cities on the surrounding landscape (Fig. 5). 
Fig. 4 Wright Park in Tacoma, WA
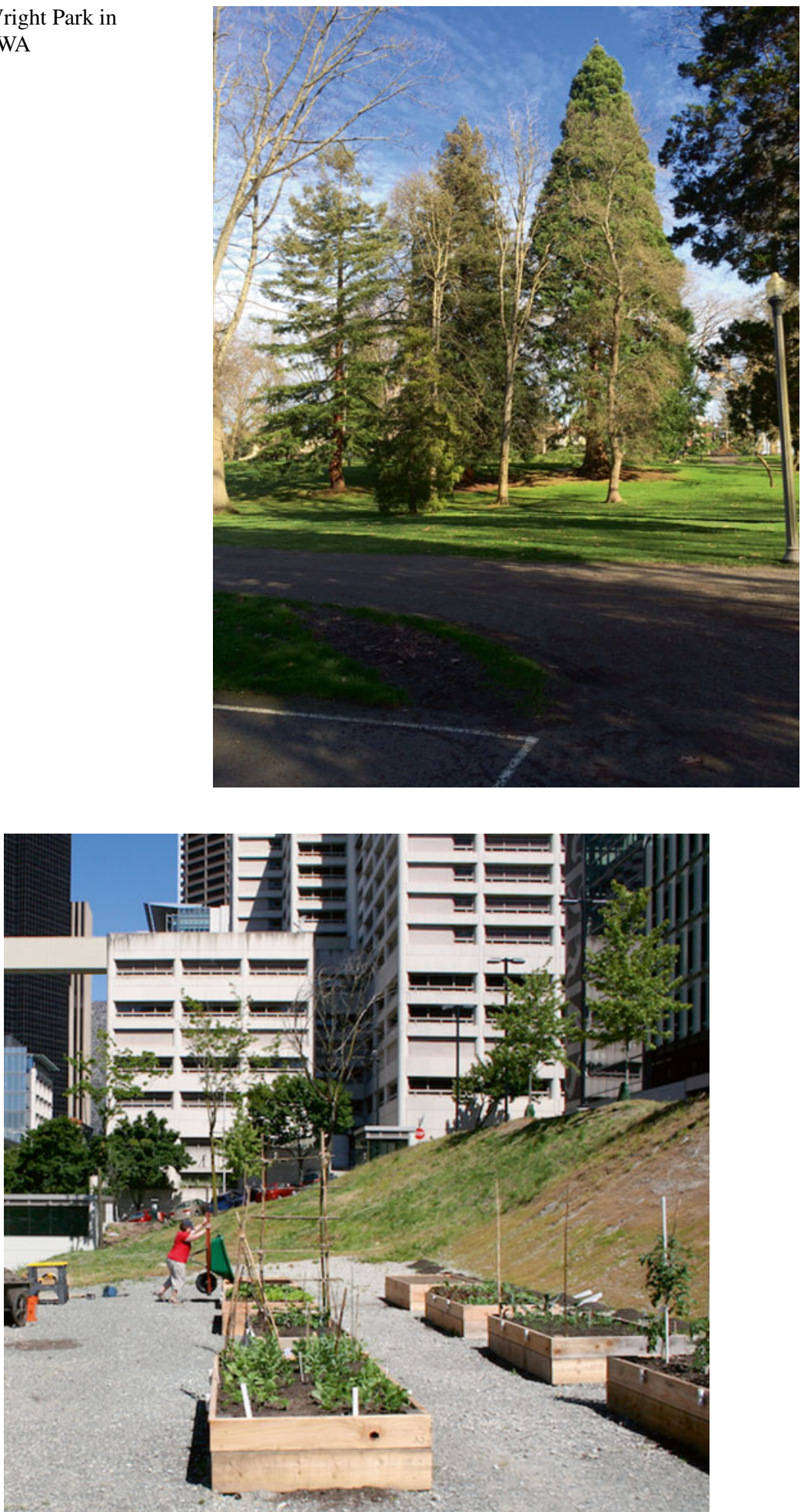

Fig. 5 A garden in downtown Seattle. Raised beds were filled with a biosolids compost (Photo from Kate Kurtz) 
Reduced energy and fuel consumption and greater land availability for wildlife habitat (both integrated with and external to urban green spaces) could minimize indirect land use change effects. As the global population grows, and becomes increasingly urban, massive investments in infrastructure loom. When the values of ecosystem services are considered, directing those investments to integrated urban agricultural systems could generate vast returns.

\section{Combined Urban/Agricultural Landscapes}

Many cities have already begun integrating agriculture into urban landscapes, privately and publicly. Homeowners cultivating kitchen gardens and fruit trees in their own yards is nothing new, and many of the recent developments in urban agriculture echo the strategies developed early in the twentieth century to supplement national food supplies during the first and second world wars (Brown and Jameton 2000). Food can be grown at a wide range of scales, by individuals, families, and public or private organizations. Apartment dwellers without yards may turn to window boxes or potted plants on balconies or windowsills, neighbors can work individual or collaborative plots in community gardens, and entrepreneurial urban farmers can transform vacant lots into farms. Long wait lists for community garden plots through programs in the US and the UK show the popularity of urban agriculture (Fig. 6).

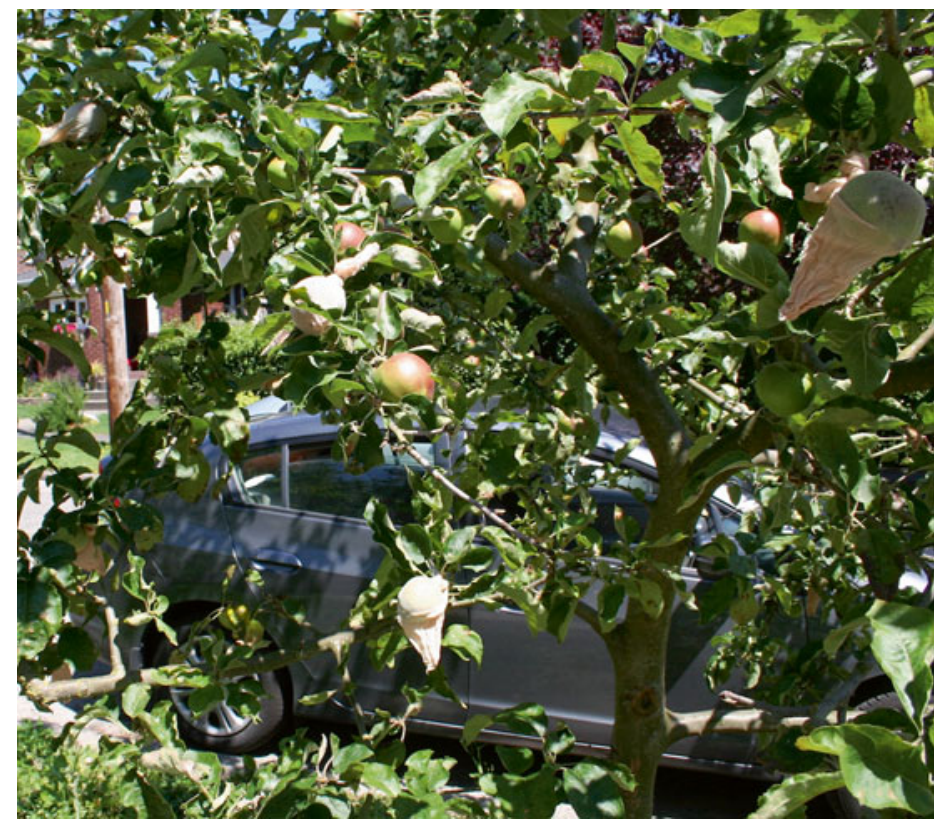

Fig. 6 An apple tree grown on a parking strip, the area between the sidewalk and the street in a residential neighborhood in Seattle, WA (Photo by Kate Kurtz) 
Seattle's P-Patch program oversees hundreds of plots on over 13 acres of community garden space. Since its inception in 1973, the program has become so popular that prospective stewards must wait a year or more for a plot to become available (City of Seattle 2013). Community gardens can go beyond private patches, as well; many programs around the United States are beginning to provide a network of small urban farms on private property and vacant lots, providing food for those who work the land, the public, and donating to local food banks. Many of these organizations are in disadvantaged areas, particularly in cities which were in poor financial shape before the real estate crash of 2008. Home Gr/own in Milwaukee, D-town Farms and Earthworks Urban Farm in Detroit, and Stone's Throw in Minneapolis/ St Paul are just a few of many grassroots organizations looking for a place to plant that have turned to a growing number of vacant lots with an intention to turn them from neighborhood blights to local food oases. Many of these work in cooperation with city government, to ensure agreement with city codes and cooperation of local officials. In some cases, government has taken a more active role. The City of Cleveland and Ohio State Department of Agriculture, in cooperation the USDA and local community groups, have committed funding to transform a large number of vacant lots to urban farms in a newly minted 26-acre Urban Agriculture Zone. The initial 6-acre Kinsman farm project reportedly generated over 14,000 lbs of vegetables in its first harvest in 2012 (ICIC 2013).

Redeveloping existing open space is only the beginning. When considering a forward looking urban design approach that intentionally integrates agriculture, still more possibilities arise:

\section{Green Rooftops}

Some cities have already begun experimenting with permitting for green rooftops, where plant cover contributes significantly to reducing water runoff, cleaner air, better building temperature regulation, and more (Clark et al. 2008). But creating actual rooftop gardens goes a step farther, providing a new space for growing produce that takes no additional building footprint. This can be particularly appealing for restaurants. Uncommon Ground in Chicago is already having a great deal of success with this model, which could be readily expanded in other cities (Rosenthal 2013) (Fig. 7).

\section{Green Buildings/Complexes}

Integrating urban green space and food production into architecture is a developing focus area in the green building movement. The LEED certification program, run by the US Green Building Council, encourages the use of urban green space by providing certification points for projects with native vegetation covering at least half of each site (USGBC 2005). The Living Building Challenge 2.1, a more far-reaching green building certification system, requires projects meeting site sustainability criteria to 

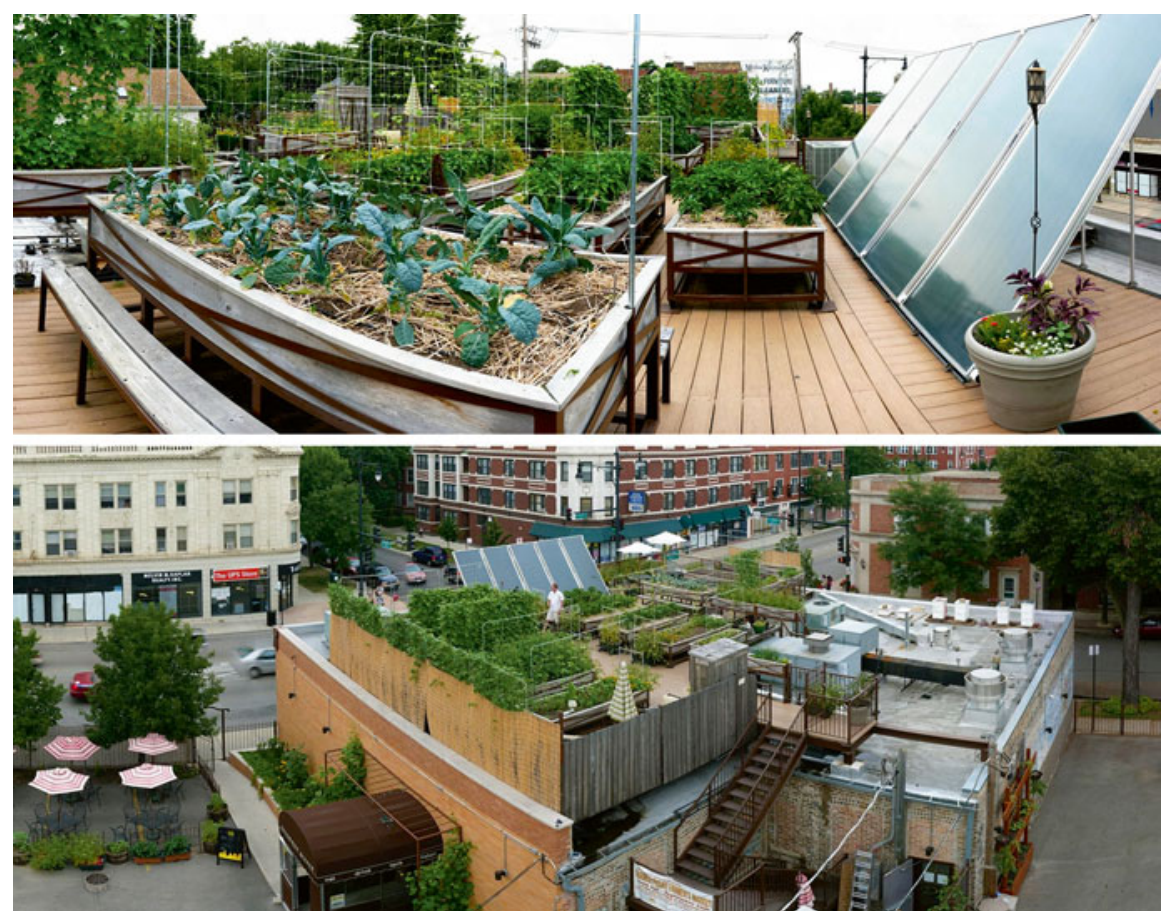

Fig. 7 Rooftop gardens at the Uncommon Ground restaurant in Chicago, IL (Photo by Zoran Orlic www.zoranorlic.com)

dedicate a fraction of the site area to urban agriculture (ILFI 2013). While no projects have yet been certified under these relatively new and aggressive standards, other noteworthy examples of integrated urban agriculture include the headquarters of the Rocky Mountain Institute in Snowmass, Colorado, in which banana trees and other tropical plants flourish at an elevation of $6800 \mathrm{ft}$ in a building with virtually no space heating and minimal water use.

\section{Vertical or Tower Farms}

Entire city structures dedicated to farming are not common yet, but ideas abound. Many ideas have been proposed to multiply the available acreage for urban farming by creating tower farms or incorporating food production into multi-story apartment or commercial buildings. In existing buildings, adding high-density, often hydroponic farm space to balconies, roofs, or abandoned structures can serve many of the functions of outdoor green space: providing food for residents, serving as a catchment for rainwater, and beautifying the area. These indoor facilities can supplement or substitute for larger outdoor gardens in areas where such space is limited or in high demand. 
More extensive modifications to existing buildings, or entire skyscrapers devoted to urban farming, have also been proposed. Concept plans for high-rise farms in London, New York, and other major cities would bring large-scale, high-tech food production to the inner city, using a variety of designs to maximize the use of urban real estate and sunlight (Doron 2005). Continuous Productive Urban Landscapes (Viljoen and Howe 2005) would use a combination of existing green space, modifications to existing structures, and new architectural designs to create a network of interconnected urban gardens to provide food, reduce and absorb stormwater runoff, and improve the effectiveness of existing urban wildlife habitat by connecting previously fragmented open space. The Vertical Farm project through Columbia University seeks to design a spiral tower farm which would integrate water treatment and re-use, composting and nutrient cycling, and energy production. The Vertical Farm could protect crops from disastrous weather, dramatically reducing many of the risks associated with farm operations, reducing fossil fuel use, and providing high-calorie and high-value crops near the point of consumption (Despommier 2010).

While many of these ideas seem highly ambitious and beyond what might currently be economically feasible, one entrepreneurial urban farm in Chicago is showing they might not be so distant after all. FarmedHere is a windowless indoor farm in a previously abandoned warehouse where specialty greens are grown in stacked aquaponic growing beds (FarmedHere 2013). Already the largest vertical farm in the United States, FarmedHere will eventually use 3.5 acres of growing space, supplying basil, arugula, and other greens "on demand" with a turnaround time of less than 1 month (Irvine 2013).

\section{Integrated Landscapes}

As city planners become more aware of the values that ecosystems can provide to cities, and as permaculture approaches for farming become better understood and more widespread, the creation and integration of multi-functional, integrated landscapes becomes more and more possible. Urban agriculture, by definition, provides food, but there's a lot more to be gained from these spaces, and when we start thinking about how to weave them into city systems, we open ourselves to more fully realizing the potential benefits this integration can offer.

\section{The Promise: What We Have to Gain from Urban Agriculture in the City of the Future}

A forested hillside park that stabilizes the property of uphill landowners, provides habitat for local species, produces berries and fruit for local families, and provides a gathering place for local children to play and learn about the land; a wetland which provides stormwater collection and filtration, and which supplies the cleaned water 
to a nearby community garden; a playground buffered by an orchard where native bird species congregate, and adorned by a myriad of flower species specifically chosen to attract the native pollinators that fertilize the fruit trees... more and more possibilities emerge as we begin to conceive of a City of the Future that integrates natural and human systems together (Fig. 8).

Food production is obviously an important benefit of substantially investing in urban agriculture, but when all potential ecosystem service benefits are included the merit of the investment becomes even clearer. We will discuss three of the major categories of ecosystem service benefits and how they can be provided by urban agriculture:

- Provisioning

- Regulating

- Informational/Cultural

\section{Provisioning Services: Food Production and Beyond}

Having a local source of fresh vegetables, fruits, and other products of agriculture is of course the clearest benefit of urban agriculture. This can be particularly crucial in neighborhoods that lack easy access to these foods - a problem often found in lower income areas (Whelan et al. 2002). Whether individuals or families are producing their own fresh food or having greater availability through local markets (the profit from which then is returned to the local economy of growers), the community benefits. And particularly for culturally diverse communities whose preferred foods may not be readily available from big supermarkets, locally based agriculture which they participate in or heavily inform also provides a much greater opportunity to have access to the foods connected with their cultural heritage (Redwood 2009) (Fig. 9).

This is more than just a minor supplement; focused urban agriculture can provide a major portion of a city's total food needs. Particularly when it comes to vegetables and livestock products such as milk and eggs, cities around the world have already demonstrated they can produce a significant portion of what they consume. A study done in 2006 found Chinese cities making huge strides towards self sufficiency, with Shanghai producing $76 \%$ of its vegetable intake locally, and Beijing even more at $85 \%$. Meanwhile Dar es Salaam in Tanzania sourced "as much as $90 \%$ of leafy vegetables and $60 \%$ of milk" using urban agriculture. A recent study modeling various urban agricultural scenarios in Cleveland, estimated that the city could produce almost $50 \%$ of its fresh vegetables and $25 \%$ of its poultry and eggs just by using existing vacant lots. Adding a portion of residential yards and open rooftops into the mix put the figures at up to $100 \%$ of vegetable needs and $94 \%$ of poultry and eggs (Grewal and Grewal 2012). In all scenarios, they were also able to include hives to supply $100 \%$ of the city's honey. All this is possible without any new land for agriculture, or any of the more intensive options such as vertical farms (Fig. 10). 
Fig. 8 Kids and community gardens (Photos by GRuB http:// goodgrub.org/)
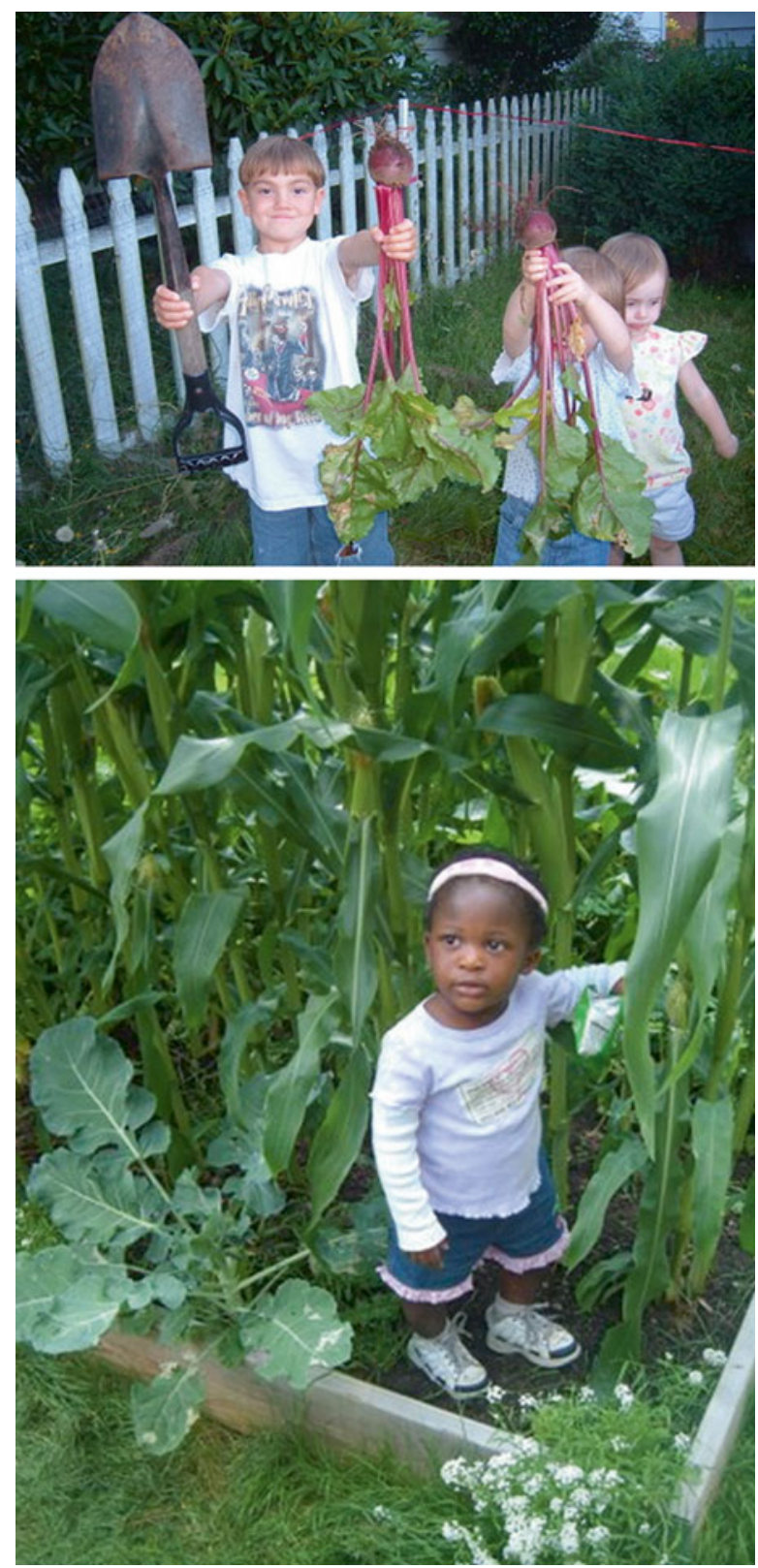

There are other crop possibilities beyond food as well, particularly when considering more ecologically diverse or permaculture focused options for urban agriculture and its integration with other forms of green space. Historically, urban forests in Europe were specifically cultivated for the production of non food items; building 
Fig. 9 Bountiful greens from a garden in Tacoma, WA

Fig. 10 Chickens in urban gardens can provide a majority of the poultry and eggs that we consume (Photo by Kate Kurtz)
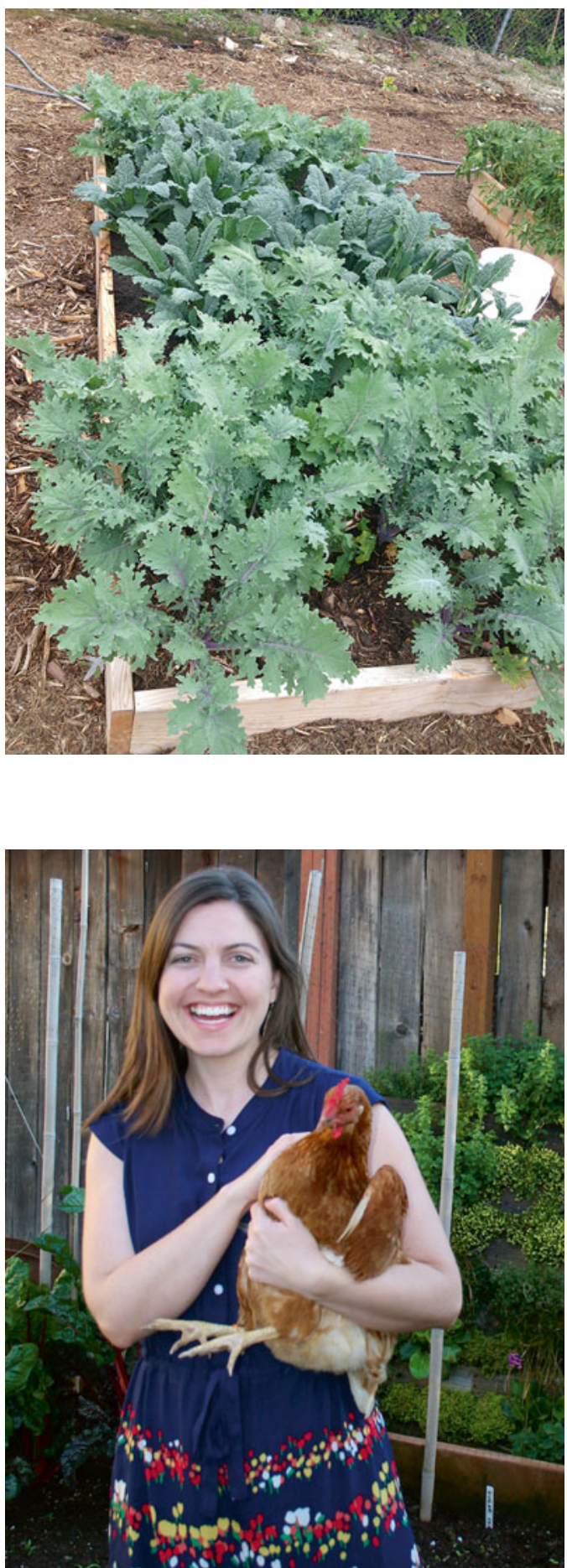


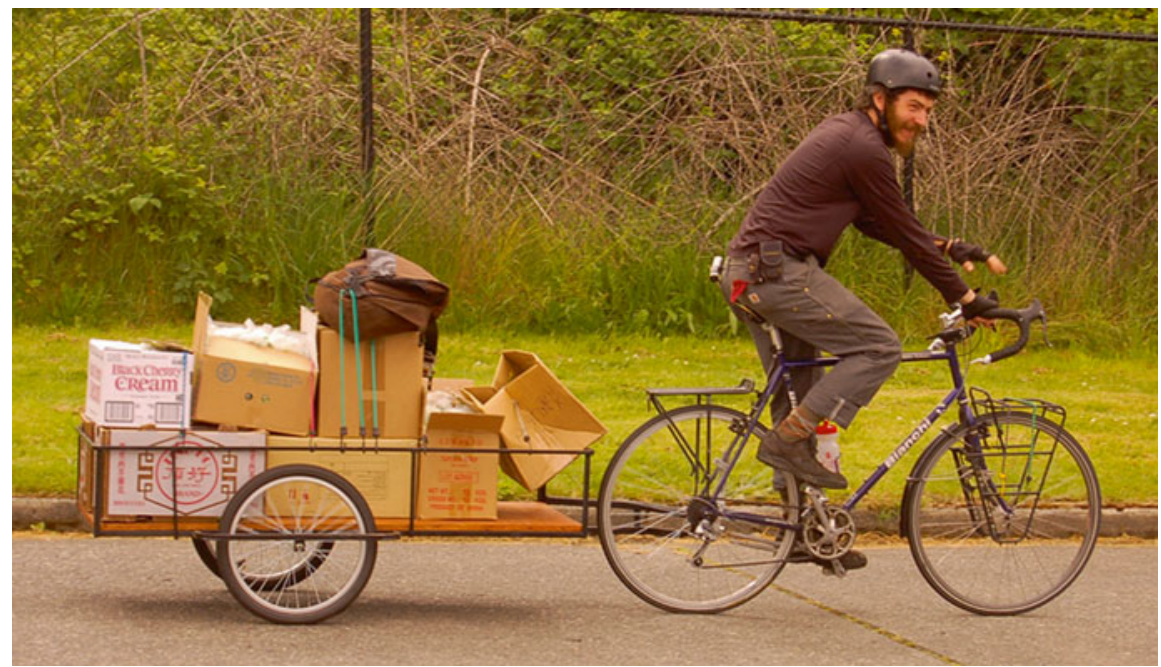

Fig. 11 A bicycle based delivery of produce grown in a community garden to a food bank in Seattle, WA (Photo by Kate Kurtz)

materials, fuel, and fodder for animals (Konijnendijk 2008). In some parts of the world these kinds of uses persist to the present day (Van Veenhuizen 2006).

In a City of the Future that fully integrates urban agriculture, the city's populace would be self sufficient for a major portion of their total food consumption, including vegetables, fruit, eggs, honey, and potentially milk and poultry. With easy access to participate in the production of their own food, either as growers or as active consumers engaging with their local farmers, the exact foods grown will be directly attuned to the desires of the denizens of the city. In addition, the city's own food waste and manures can be composted in turn to fertilize its gardens and farms. And equipment and facilities needed for certain types of food production can be fueled by locally produced biodiesel using agricultural waste, non-food crops, and other forms of food waste such as kitchen oil. Food is no longer a major import, but a locally grounded cycle. The City feeds itself and its own (Fig. 11).

\section{Regulating Services: Air, Water, and More}

Simply by producing food locally to where it is consumed, urban agriculture will have a serious impact on the air quality and carbon emissions of the City of the Future. Instead of the hundreds to thousands of miles that most food travels to reach our plates, the distance shrinks to, at most, a hop from one neighborhood to another. In addition to lower transportation distance, less packaging is needed, and the entire food supply chain becomes far more efficient; one study estimates that replacing the current import-heavy food system of the UK with organic, local urban and rural 


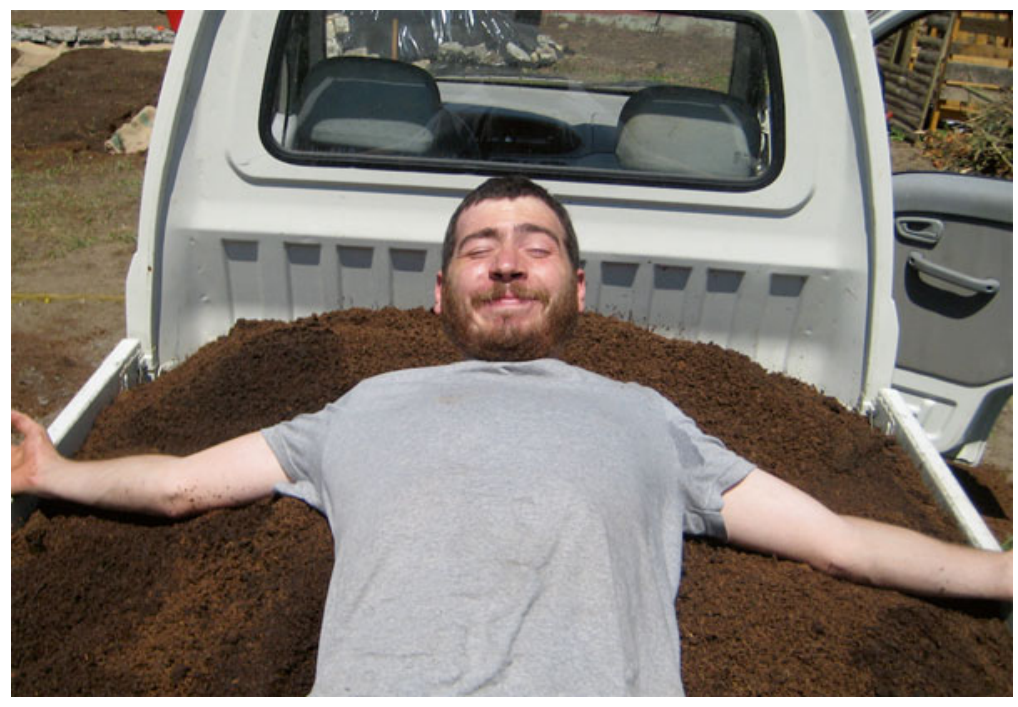

Fig. 12 A load of compost produced from municipal biosolids and yard waste, about to be applied to community garden plots in Seattle, WA (Photo by Kate Kurtz)

food production could reduce national emissions by $22 \%$, which amounts to 143 million tons of $\mathrm{CO}_{2}$ per year (Doron 2005). On top of this comes the carbon sequestration from increased gardening - particularly in polyculture systems that incorporate fruit or nut trees and other perennials (Grewal and Grewal 2012). Well tended soils, amended with composts from urban feedstocks, will also reduce emissions by diverting wastes from landfills and restoring soil carbon reserves (Fig. 12).

And it's not just about carbon - all those trains, trucks and ships that are no longer bringing food into the city also no longer add to the burden of the city's air pollution. Meanwhile, every acre of green space - particularly trees, whether through agro-forestry, fruit orchards, or permaculture-oriented spaces including forest cover - will provide hundreds of dollars worth of pollution removal per year (Christin et al. 2011).

Temperature regulation is an additional benefit, particularly in warmer climes urban green space in general, including urban agricultural space, can give shade, moderate wind, regulate humidity (Bakker et al. 2000), and overall reduce the urban heat island effect (EPA 2008), making for cooler, happier city residents both indoors and out.

Urban agriculture can reintroduce the hydrological cycle to urban areas. For example, stormwater runoff, frequently a serious problem in cities, can become a boon for urban agriculture rather than a burden for the city's infrastructure (Grewal and Grewal 2012). Rooftop gardens absorb the water before it ever reaches the ground, and earthbound urban farms and gardens retain the rain that falls on them. Well designed, integrated landscapes can include wetlands that act as stormwater sinks and drainage areas which prevent flooding of nearby homes and businesses, 
then provide water to nearby growers (Christin et al. 2011). Use of alternative water sources, including stormwater and greywater, for growing crops can reduce demand for potable water resources and allow for a larger portion of urban water to enter the hydrological cycle via subsurface flow.

Such integrated systems, particularly when they include native species, can also contribute to the local conservation of biodiversity (Bernholt et al. 2009) as well as providing habitat for wildlife, including pollinators (Holzschuh et al. 2008). In many cities, residential gardens are a major fraction of total urban green space. Across the UK, gardens comprise between $20 \%$ and $47 \%$ of green space (Loram et al. 2007). The figure varies widely between cities and countries, but in all cases gardens contribute substantially to urban biodiversity (Goddard et al. 2010).

The City of the Future, then, has cleaner air, lower emissions, a more moderate climate, fewer difficulties with water runoff and flooding, and boasts greater biodiversity. Adding these benefits on top of the locally produced food already paints a compelling picture, but further benefits can be found-those that touch us most directly in our bodies, minds, and hearts.

\section{Cultural Services: Health, Happiness, Community}

While the concrete benefits of provisioning services are clear, and the value of regulating benefits is immense, some of the most powerful benefits derived by the residents of the City of the Future from urban agriculture will be far more direct; impacts on health, happiness, and relationships with the world and one other.

It is not surprising that having direct access to fresh, healthy, nutritious food would be a benefit to physical health. This, however, is particularly crucial for lower income populations, who typically have less access to fresh vegetables and fruits, which may not be readily found in whatever markets do exist in these neighborhoods. In Seattle, a variety of community and private gardens donate hundreds of pounds of produce to "Lettuce Link", a program which coordinates harvest and delivery of locally grown produce and seeds for distribution to two dozen food banks across the city (McLain et al. 2012) (Fig. 13).

For those citizens who participate directly in their own food production, additional health benefits arise. Community garden work tends to actually increase vegetable intake (Alaimo et al. 2008; Blaine et al. 2010), provides physical exercise (Brown and Jameton 2000), and can relax or serve as an outlet for stress, thus also improving psychological health (Kaplan 1973; Malakoff 1995). This is often particularly true for retirees and the elderly, especially those who previously lived in more rural areas (Milligan et al. 2004; Pudup 2008).

But the benefits of participating in urban agriculture go beyond personal health, into the health of the community. Studies in San Francisco and Philadelphia found that urban food gardens provided a revitalizing influence in troubled communities (Ferris et al. 2001), notably reducing theft and overt drug dealing (Malakoff 1995). 


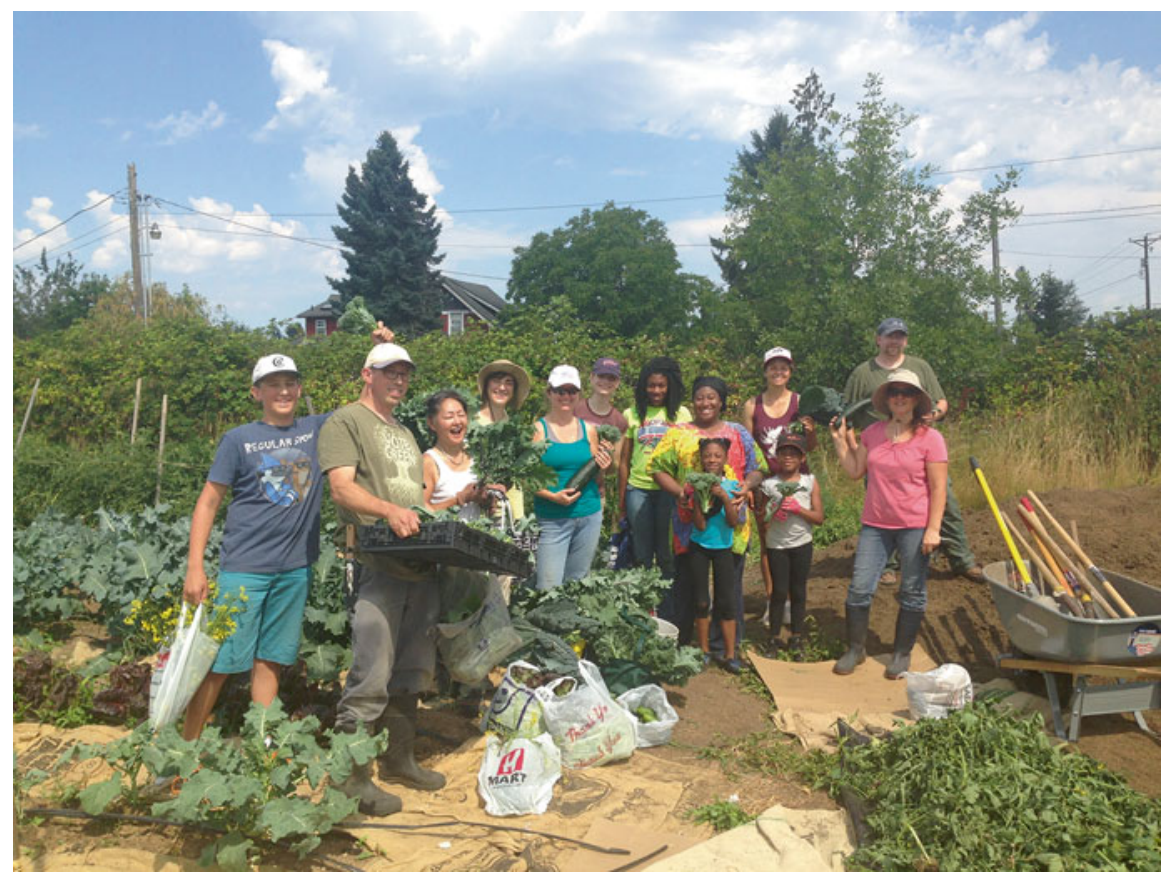

Fig. 13 A group of co-op gardeners celebrates the harvest in Tacoma, WA

And community gardening has been found to "cut across social, economic, and racial barriers and [to bring] together people of all ages and backgrounds." (Patel 1991)

Even as relationships within a community are strengthened, so too may be the relationships between these human individuals and nature itself. Direct, sensual encounters with the environment arise, and as citizens participate in the process of growing their own food, they develop their own awareness and reflections of what that means to them (Bhatti and Church 2001; Delind 2006). This process of engagement and learning can extend to children and young adults, as well; in parks today we can see models for mutually beneficial arrangements where students aid in the creation, restoration, or upkeep of shared green space, enhancing the environment of their community and learning biology and ecology in the process. The enhancement in beauty through the creation of urban gardens - particularly in contrast with urban lots going vacant and unused - is not only visually and emotionally appealing but has a material impact on property values, providing an aesthetic benefit with real economic consequence (Malakoff 1995) (Fig. 14).

Through a deep integration of urban agriculture into not only its physical layout but the fabric of its community, the City of the Future becomes more beautiful and enables its citizens to live happier, healthier, more connected lives, with one another and with the place in which they live. 


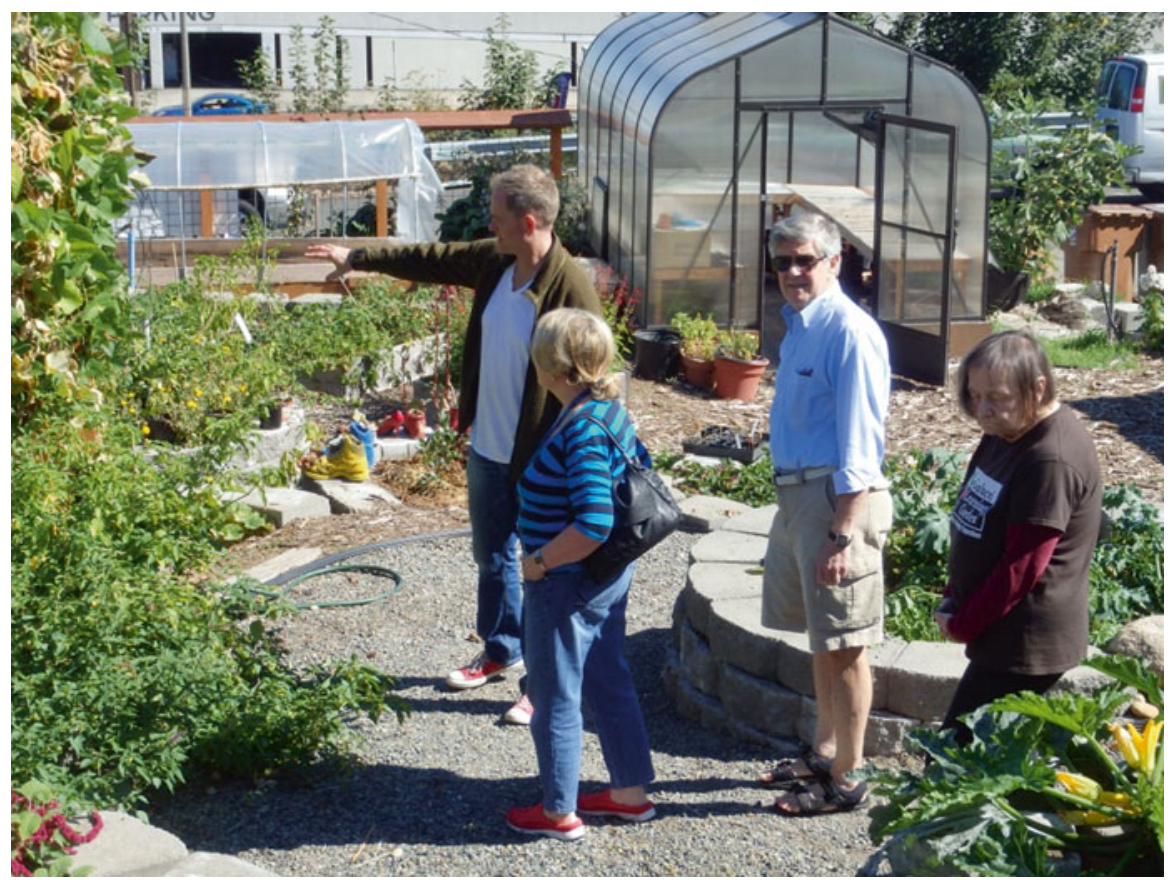

Fig. 14 Neighbors get a tour of the Gallucci Learning Garden after a workshop, in Tacoma, WA

\section{Transformative Action}

Integrating urban agriculture into the City of the Future will take a dramatic shift in the paradigm of urban planning and commitment from the city's residents. Even the simplest forms of urban agriculture - residential gardens - will require a shift in expectations. In some areas, neighborhood and city codes will need to be altered to allow lawns to be replaced with vegetable gardens, and to permit the keeping of chickens or other small animals.

Current zoning restrictions often do not facilitate multiple-use properties which might produce food, process wastewater, and generate energy in addition to serving a conventional residential, commercial, or industrial function. The City of the Future will have a code system that encourages a diversity of functions, while maintaining a safe and pleasant environment (Fig. 15).

Many of the urban spaces which could most readily be converted to food production are public property - parks, rights-of-way, and the landscaping of city-owned infrastructure and utilities. Making use of these areas requires action to prioritize urban agriculture at the local level, and outreach programs to communicate the benefits of such programs. In the City of the Future, city council members, community leaders, and urban planners will have the technical, economic, and social resources to maximize the production of food and other ecosystem services from public lands. 


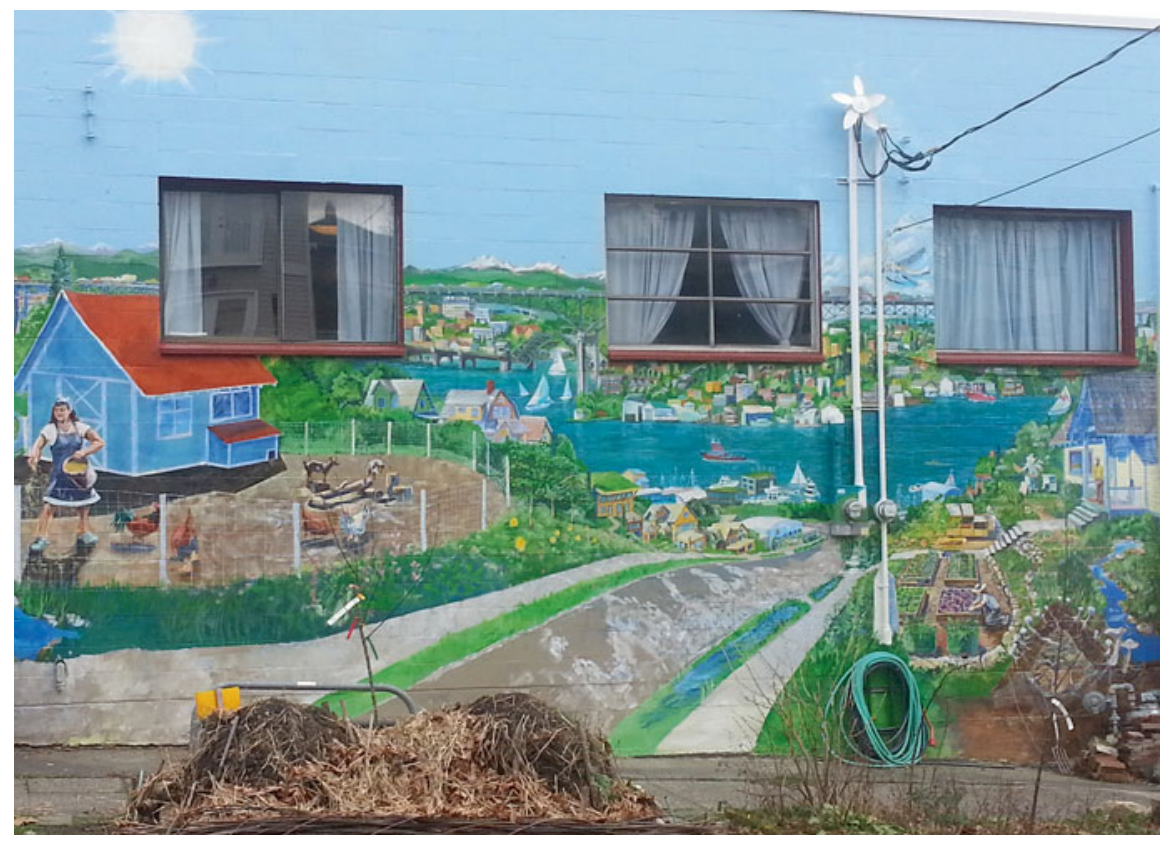

Fig. 15 One version of the city of the future- as depicted on a mural on the side of a building in Seattle, WA (Note that the curbside strip in front of the building are being used to compost and grow food. Photo by Sally Brown)

\section{Conclusion}

Urban agriculture shows tremendous promise. Current projects in cities across the globe have provided food, reduced stormwater, pollution, and heat island burdens, and improved the physical, mental, and social health of residents through urban agriculture. The economic success of private enterprises shows the potential to transform urban spaces into productive farms.

In the City of the Future, residents everywhere will have access to farm space on balconies, roofs, courtyards, or community plots. Homeowners with large backyard gardens will have easy access to the training and tools they need to produce a substantial fraction of their own food. Those uninterested in doing the work themselves can rent the space, or hire professional urban farmers to do all of the dirty work. These same farmers may also tend the fertile rights-of-way which connect neighborhood gardening districts, growing fruits and nut trees, berry-laden bushes, and tending grain crops.

Abandoned and disused lots do not stay empty for long. As more people move to the cities, towers rise to meet new demand, growing staple and luxury crops yearround in high-rise farms. Customers save money buying direct from a producer within walking distance, getting higher-quality produce and reducing the need for 
costly transportation. Utilities purchase electricity and integrate heating systems and wastewater treatment with compost and agricultural waste processing facilities, reducing their carbon footprint, increasing efficiency, and eliminating untreated overflows into nearby rivers. By reducing pressure on conventional farmers to maximize production in the face of uncertain weather, pests, and fuel prices, the City of the Future paves the way for greater protection of ecological resources around the world.

The urban farms in the City of the Future do much more than produce food. Tighter integration of food production with the rest of society allows effective cycling of nutrients, improving air and water quality; expanding urban green space brings cooler temperatures and happier, healthier citizens; reducing runoff lowers the cost of water treatment and risk of flooding; and finally, more closely connecting people with their food sources gives citizens greater understanding and control over their food, employing farmers who work directly with, and for, their neighbors.

\section{References}

Alaimo K, Packnett E, Miles RA, Kruger DJ (2008) Fruit and vegetable intake among urban community gardeners. J Nutr Educ Behav 40(2):94-101

Bakker N, Dubbeling M, Gundel S, Sabel Koschella U, de Zeeuw H (2000) Growing cities, growing food: urban agriculture on the policy agenda. A reader on urban agriculture. DSE, Feldafing

Bernholt H, Kehlenbeck K, Gebauer J, Buerkert A (2009) Plant species richness and diversity in urban and peri-urban gardens of Niamey, Niger. Agrofor Syst 77(3):159-179

Bhatti M, Church A (2001) Cultivating natures: homes and gardens in late modernity. Sociology 35(02):365-383

Blaine TW, Grewal PS, Dawes A, Snider D (2010) Profiling community gardeners. J Ext 48(6): 1-12.http://ohiostate.pure.elsevier.com/en/publications/profiling-communitygardeners(d5f06588640a-4f22-9d7a-29ca7f152428).html

Brown KH, Jameton AL (2000) Public health implications of urban agriculture. J Public Health Policy 21(1):20-39

Brummer EC, Barber WT, Collier SM, Cox TS, Johnson R, Murray SC, Olsen RT, Pratt RC, Thro AM (2011) Plant breeding for harmony between agriculture and the environment. Front Ecol Environ 9(10):561-568

Chiras DD, Reganold JP (2005) Natural resource conservation. Pearson Education, New York

Christin Z, Batker D, Harrison-Cox J (2011) Economic impact of metro parks Tacoma ecosystem services: economic impact study phase II. Earth Economics, Tacoma

City of Seattle (2013) P-patch community gardens. Retrieved December 8, 2013, from http://www. seattle.gov/neighborhoods/ppatch

Clark C, Adriaens P, Talbot FB (2008) Green roof valuation: a probabilistic economic analysis of environmental benefits. Environ Sci Technol 42(6):2155-2161

Delind LB (2006) Of bodies, place, and culture: re-situating local food. J Agric Environ Ethics 19(2):121-146

Despommier D (2010) The vertical farm: feeding the world in the 21st century. Picador, New York

Diaz RJ, Rosenberg R (2008) Spreading dead zones and consequences for marine ecosystems. Science 321(5891):926-929

Doron G (2005) Urban agriculture: small, medium, large. Archit Des 75(3):52-59 
EPA (2008) Heat island effect. Retrieved December 9, 2013, from http://www.epa.gov/hiri/

FarmedHere (2013) FarmedHere: sustainable indoor farming. Retrieved December 8, 2013, from http://farmedhere.com/2012/farmedhere-the-first-commercial-scale-indoor-vertical-farm-inchicagoland-receives-usda-organic-certification

Ferris J, Norman C, Sempik J (2001) People, land and sustainability: community gardens and the social dimension of sustainable development. Soc Policy Adm 35(5):559-568

Foley JA, DeFries R, Asner GP, Barford C, Bonan G, Carpenter SR, Chapin FS, Coe MT, Daily GC, Gibbs HK, Helkowski JH, Holloway T, Howard EA, Kucharik CJ, Monfreda C, Patz JA, Prentice IC, Ramankutty N, Snyder PK (2005) Global consequences of land use. Science 309(5734):570-574

Goddard MA, Dougill AJ, Benton TG (2010) Scaling up from gardens: biodiversity conservation in urban environments. Trends Ecol Evol 25(2):90-98

Grewal SS, Grewal PS (2012) Can cities become self-reliant in food? Cities 29:1-11

Holzschuh A, Steffan-Dewenter I, Tscharntke T (2008) Agricultural landscapes with organic crops support higher pollinator diversity. Oikos 117(3):354-361

ICIC (2013, July 29) Cleveland urban Ag zone breathes life into vacant land. ICIC Blog. Retrieved December 9, 2013, from http://www.icic.org/connection/blog-entry/what-works-clevelandsurban-ag-zone-breathes-life-into-vacant-land/bp

ILFI (2013) Living building challenge: site. Retrieved December 2, 2013, from http://living-future. org/node/137

Irvine M (2013, March 28) In a Chicago suburb, an indoor farm goes 'mega' The big story. Yahoo News. Retreived December 8, 2013 from http://news.yahoo.com/chicago-suburb-indoor-farmgoes-062525036.html

Kaplan R (1973) Some psychological benefits of gardening. Environ Behav 5(2):145-162

Konijnendijk CC (2008) The forest and the city: the cultural landscape of urban woodland. Springer, New York

Loram A, Tratalos J, Warren PH, Gaston KJ (2007) Urban domestic gardens (X): the extent \& structure of the resource in five major cities. Landsc Ecol 22(4):601-615

Malakoff D (1995) What good is community greening? ACGA Community Greening Rev 5:4-11

McLain R, Poe M, Hurley PT, Lecompte-Mastenbrook J, Emery MR (2012) Producing edible landscapes in Seattle's urban forest. Urban For Urban Green 11(2):187-194

Milligan C, Gatrell A, Bingley A (2004) Cultivating health: therapeutic landscapes and older people in northern England. Soc Sci Med 58(9):1781-1793

Patel IC (1991) Gardening's socioeconomic impacts. J Ext 29(4):7-8

Pudup MB (2008) It takes a garden: cultivating citizen-subjects in organized garden projects. Geoforum 39(3): 1228-1240

Redwood M (2009) Agriculture in urban planning: generating livelihoods and food security. Earthscan, Sterling

Rosenthal J (2013, July 12) 2013 farm report. Retrieved December 2, 2013, from http://www. uncommonground.com/pages/2013_farm_report/278.php

Sandhu HS, Wratten SD, Cullen R, Case B (2008) The future of farming: the value of ecosystem services in conventional and organic arable land. An experimental approach. Ecol Econ 64(4):835-848

Sandhu HS, Wratten SD, Cullen R (2010) Organic agriculture and ecosystem services. Environ Sci Pol 13(1):1-7

The Land Institute (2013) Developing a perennial solution. Retrieved December 9, 2013, from http://www.landinstitute.org

The Permaculture Association (2013) Principles. Retrieved December 9, 2013, from http://www. permaculture.org.uk/knowledge-base/principles

The World Bank (2013) Agricultural land (\% of Land Area). Data Catalog. Retrieved December 3, 2013, from http://data.worldbank.org/ 
USGBC (2005) LEED for new construction and major renovations version 2.2, United States Green Building Council, Washington, DC

Van Veenhuizen R (2006) Cities farming for the future: urban agriculture for green and productive cities. RUAF Foundation/IDRC/IIRR, Leusden

Viljoen A, Howe J (2005) Continuous productive urban landscapes. Routledge, London

Whelan A, Wrigley N, Warm D, Cannings E (2002) Life in a 'food desert'. Urban Stud 39(11):2083-2100 
Part I

Soil and Water Resources 


\title{
Soil Formation and Nutrient Cycling
}

\author{
Craig Cogger and Sally Brown
}

\section{Soil Development, Biological Physical and Chemical Properties including Nutrients}

\section{Soil Health and Ecosystem Services}

Soil is the foundation of terrestrial life - a complex ecosystem that supports plant growth and a living filter that binds and removes contaminants. Soil is also a fragile natural resource, and its mismanagement leads to lost productivity and a degraded environment. Soils play a critical role in a range of ecosystem services. These services include production of raw materials such as food and fiber, supporting natural processes including nutrient cycling, cultural services, and regulating services including waste treatment and air and water regulation (Costanza et al. 1997). Each of these can be related directly or indirectly to soil. A soils' ability to hold and store water, to transform wastes and nutrients, to store carbon (soil is the third largest carbon sink, behind oceanic reserves and fossil fuels), and to support plant growth are clear services attributed to soils (Clothier et al. 2009; Costanza et al. 1997; Doran 2002; Robinson et al. 2013). There have been recent efforts to quantify the value of soils in relation to these services. One study attributed $17 \%$ of the gross national product of New Zealand directly to soil resources (Kirkham and Clothier 2007). The value of macropores; the larger void spaces in soils that allow for movement of water and diffusion of gas to and from the atmosphere into the soil, in soils

\footnotetext{
C. Cogger $(\bowtie)$

Department of Crop and Soil Sciences, Washington State University, Pullman, WA, USA e-mail: cogger@wsu.edu

S. Brown

School of Environmental and Forest Sciences, University of Washington,

Seattle, WA, USA

e-mail: slb@uw.edu
} 
and the services associated with those pores was valued at $\$ 304$ billion annually (Clothier et al. 2008). Soil valuation has not progressed to the point where the value of a particular soil can be quantified. While tools like life cycle assessment have enabled a fuller understanding of the environmental ramifications of different systems, no comparable tools have been developed for soils and their associated services. Despite the growing recognition of the importance and value of soils for supporting ecosystem services, there are very few to no incentives in the US that encourage soil preservation and improvement. Currently the best tool available in the US for quantifying the value of soils is the USDA Conservation Reserve Program (CRP) that pays farmers to leave sensitive soils fallow in order to preserve and protect them. The program currently includes $140,000 \mathrm{~km}^{2}$ with annual payments of $\$ 1.8$ billion (Robinson et al. 2013). This is equivalent to a payment of $\$ 241,000$ to develop $15 \mathrm{~cm}$ of topsoil at a soil formation rate of $0.008 \mathrm{~cm}$ year (Brown et al. 2014).

\section{Current State of Soils}

The health of soils in the US has been declining. This decline has been accompanied by a decrease in functionality (Amundson et al. 2003; Banwart 2011). This decline has far reaching real world impacts. As we depend on soils to grow our food, declines in soil quality will impact both food quality and quantity. Lower quality soils will produce lower yields per acre, requiring more acreage in production to meet demands. Farmers currently exploit other available tools such as improved crop varietals and fertilizer inputs as a way to improve yields. It is not clear that sufficient additional tools are available to compensate for declining soil quality. The decline in soil quality is primarily the result of loses in soil carbon reserves ranging from about 30-40 tons of carbon per hectare (Lal et al. 2007).

Part of this loss of soil carbon and associated decline in soil quality can be related to conventional agricultural practices that result in erosion of between 0.2 and $1.67 \mathrm{~mm}$ per year (Montgomery 2007). This is far in excess of the rate of soil formation which is estimated as between 0.06 and $0.8 \mathrm{~mm}$ per year (Montgomery 2007). Tillage increases erosion in two ways. It allows excess oxygen to enter into the soil resulting in rapid mineralization of soil organic matter. The plow will also break up soil aggregates resulting in increased compaction. Large- scale reliance on synthetic fertilizers instead of manures or cover crops has also reduced soil organic matter and subsequently soil quality. In addition to providing fertility, cover crops and manures add organic matter to soils. Crop residues, organic material that has not had any commercial value is also traditionally left on the soil surface. These residues also help to maintain carbon concentrations in soils. Interest in crop residues as a feedstock for biofuels has the potential to further damage the health of agricultural soils as these materials would be removed from soils rather than being allowed to decay and increase soil organic matter.

Increasing the organic matter concentrations of soils is recognized as the most effective way to restore soil health and function (Doran 2002; Lal et al. 2007). 
Soils in urban areas tend to be degraded as well (Cogger 2005). Much of this degradation can be attributed to disturbance and lack of management. Soils in urban areas are often impacted by construction projects, impermeable surfaces, and altered soil-water relationships due to engineered storm water infrastructure. Soils may also be contaminated from historical industries and widespread use of lead in paints and auto exhaust. Some soils in urban areas are not degraded. In fact, well- tended soils in urban areas are likely more robust than corresponding agricultural soils. Soils under turf or landscape perennials that have been fertilized or mulched will likely have higher organic matter and improved soil properties in comparison to conventionally managed agricultural soils (Brown et al. 2012).

In order for urban agriculture to grow and flourish it is critical that the soils that support agriculture be healthy and productive. Even highly impacted soils can be restored to productivity through appropriate management. This section will provide an introduction to the basic science of soils. Methods to improve soil quality, primarily through addition of organic (meaning organic matter rather than certified organic) soil amendments will be discussed. Two case studies will be presented where residuals based soil amendments have been used to improve soils for urban agriculture.

\section{Soil Basics}

\section{Soil Components}

In the simplest terms soil consists of mineral matter, organic matter, and pore space (Fig. 1). Mineral matter comprises the bulk of the soil mass, and is made of weathered sediments and rock fragments. Organic matter is typically $1-10 \%$ of the soil mass, but its importance exceeds its proportions in soil. Organic matter contributes to the porosity of soil, supplies nutrients, binds contaminants, and supplies the energy needed to fuel the soil ecosystem.

Fig. 1 Soil components, showing approximate proportions of mineral matter, organic matter, and pore space in a typical soil

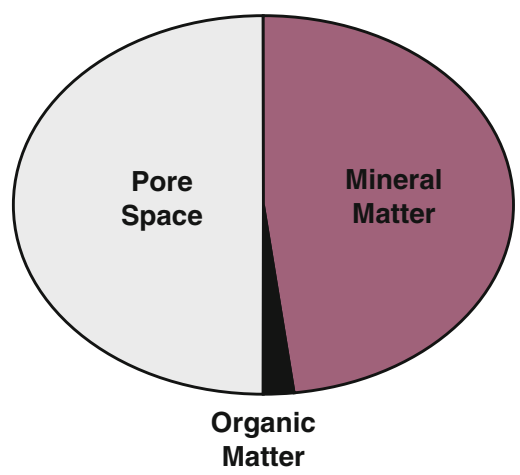


We often don't think about the third soil component - the pore space - but, it is vital to a healthy soil. The larger pores, or macropores, are conduits for water and air, allowing infiltration of rainwater, snowmelt, and irrigation water, and drainage of excess water and subsequent aeration of the soil. Smaller pores, called capillary pores, hold water like a sponge. This capillary water is the source of water for plants between rain or irrigation events. Micropores are the tiniest pores, and they hold water so tightly that it is not available to plants.

\section{The Soil Ecosystem}

This simple depiction of soil components is not complete, because soil is also an ecosystem. Most of the actors in the soil ecosystem are too small to be seen, but they play a remarkable role in the life of the earth (Fig. 2). A half teaspoon of garden soil can contain more than a billion microorganisms, and together they form nature's land-based recycling system (See chapter on soil microbiology). The soil ecosystem transforms the remains of plants, animals, and microbes, releasing energy, water, carbon dioxide, and plant nutrients, and producing humus, the stable organic matter of soil. Soil microbes can break down soil contaminants, including many pesticides, pharmaceuticals, and disease-causing pathogens. The soil ecosystem also includes earthworms, insects, and other larger creatures, who create macropores in the soil and render plant residues into forms that are more available to microorganisms. Plant roots are a vital part of the ecosystem, creating pores as they grow through the soil, and interacting with other soil organisms to obtain nutrients and fend off diseases.

The soil ecosystem is sometimes described as the "soil food web". Thinking of the ecosystem as a food web emphasizes the relationships among the different types of organisms as they decompose organic residues. Bacteria favor easily degradable substances in the residues, such as sugars, starch, and proteins, while fungi can digest woody materials. The bacteria and fungi incorporate nutrients from the residues into their bodies, and release any excess nutrients as soluble ions that can be taken up by plants. Mesofauna, such as nematodes, feed on bacteria and fungi, releasing more nutrients into available forms. Larger creatures, such as insects, work at both ends of the food web. Insects cut and chew leaves and other residues, increasing access for bacteria and fungi to continue the decomposition. Insects also feed on fungi and mesofauna, releasing nutrients held in their bodies. Adding organic matter to soils is a way to enrich the soil ecosystem. Organic amendments including composts and biosolids add a carbon or food source to soils as well as providing other nutrients. Studies are now starting to show how the soil microbial community responds to the addition of organic amendments (Alguacil et al. 2009; Cogger et al. 2013a, b; Park et al. 2013; Tian et al. 2009). In general, adding organic amendments is being shown to increase soil microbial populations and availability of soil nutrients. It is also a way to reduce stress to soil microbial populations (Park et al. 2013). 
Fig. 2 Examples of soil organisms. From top: fungi, bacteria, nematodes (mesofauna that eat bacteria, fungi, and other nematodes) and collembola (soil insects that eat fungi) (Photos by Doug Collins and Mary Fauci)
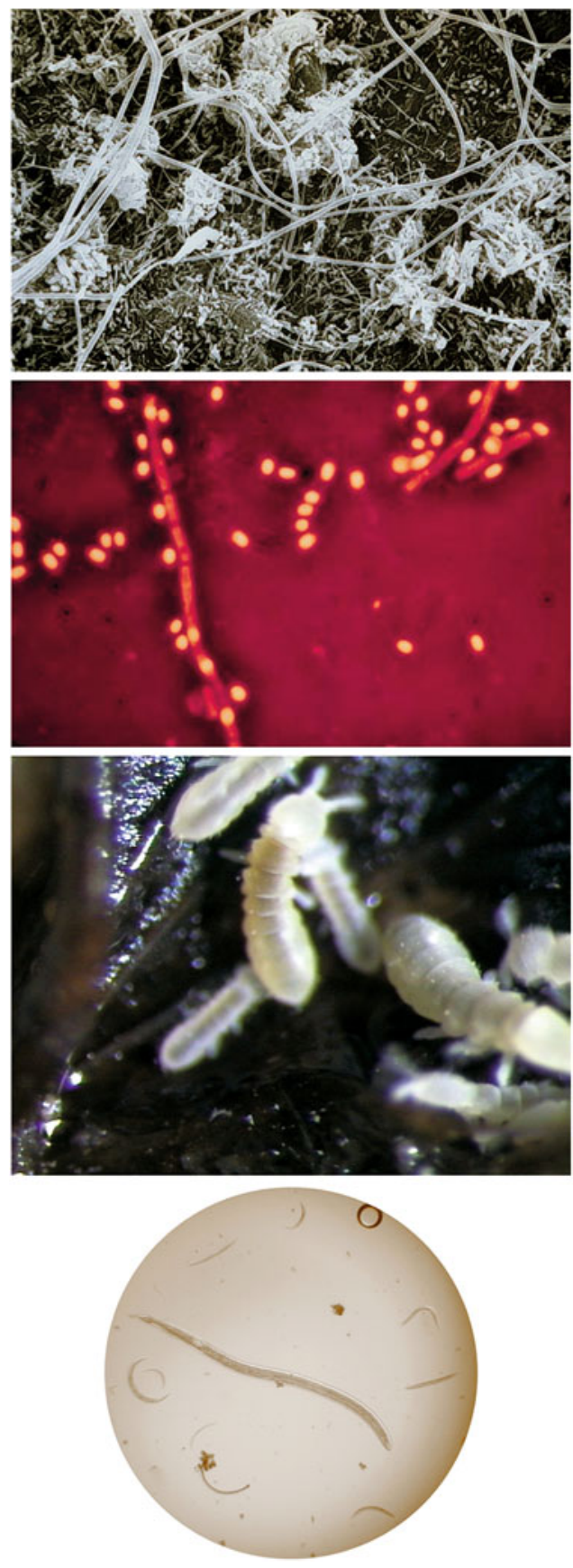


\section{The Soil Profile}

If you have observed an excavation or a road cut in soil, you have noticed that soils are not uniform, but vary with depth (Fig. 3). A soil horizon is a horizontal layer with appearance and properties that differ from any layers above and below it. Most soils have three or more main horizons (and may have sub-horizons as well) that differ from each other in color, texture, or other properties. These horizons are shaped by the soil forming factors (See Soil Formation below) and together they form the soil profile.

A typical soil has a dark-colored surface horizon (A horizon) that is enriched in organic matter, followed by a red, brown, yellow, gray, or mottled subsurface (B horizon). The B horizon has less organic matter than the A horizon, but it shows evidence of physical and chemical changes resulting from water movement and biological activity. Beneath the B horizon is a layer ( $\mathrm{C}$ horizon) that resembles the geologic parent materials from which the soil formed. Some soils have additional horizons as well, such as $\mathrm{O}$ horizons found on the surface of forest soils or in peat soils.

Fig. 3 A soil profile, showing dark A horizon, reddish $\mathrm{B}$ horizon, and coarse-textured $\mathrm{C}$ horizon of glacial outwash (Photo by Craig Cogger)

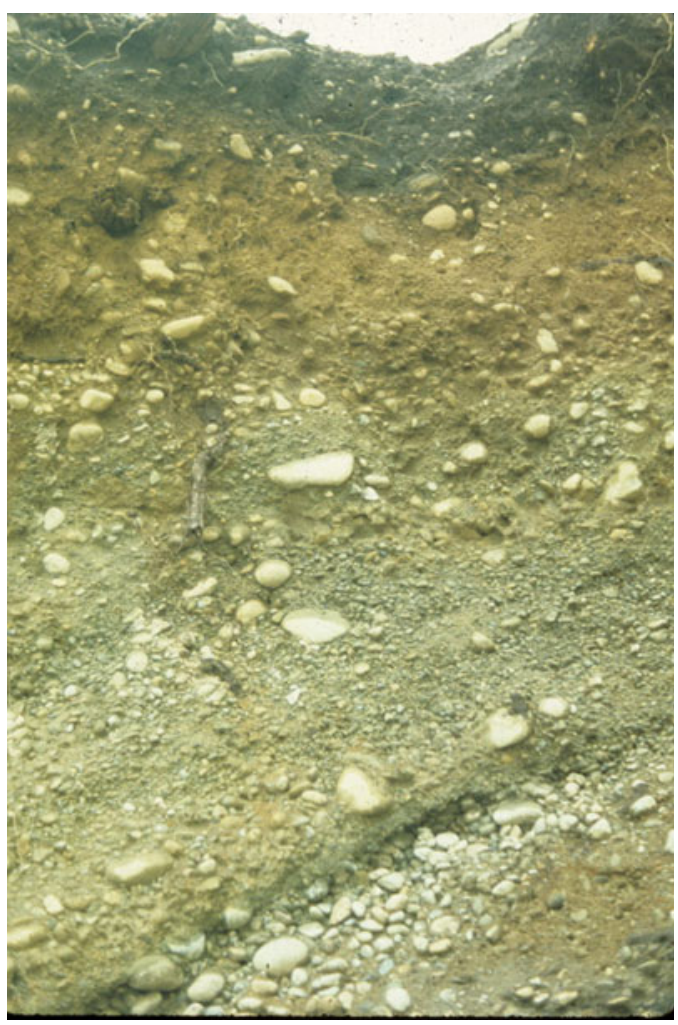


Table 1 Soilforming factors

\begin{tabular}{l}
\hline Parent material \\
\hline Topography \\
\hline Organisms \\
\hline Climate \\
\hline Time
\end{tabular}

\section{Soil Formation}

Soils form from geologic parent materials by the actions of organisms and water over time (Table 1). Parent materials include sediments and rocks, such as materials deposited by floods or glaciers, wind-blown silt and sand, materials exposed and moved by landslides, or simply rocks slowly weathered in place. Soils in warm climates have more year-round biological activity than soils in cold climates, which speeds soil development. Soils in wet climates have more water leaching through the profile than in dry climates, changing the chemical and physical nature of the soil.

Soils at the foot of hillslopes and in depressions collect water, saturating the pores, and excluding oxygen. This results in a different soil ecosystem, different chemistry, and different appearance from soil on higher ground, where excess water drains or runs off, maintaining air in the soil pores.

Soil is also shaped by its ecosystem. Most of the organic matter in forests is above ground, resulting in accumulation of organic litter on the soil surface. Soils in forests have a thin surface horizon rich in organic matter ( $\mathrm{O}$ horizon), but little organic matter in the underlying soil. Grasses have extensive, fibrous root systems, resulting in a deeper accumulation of organic matter in grasslands, as the roots decompose to humus. Soils in ecosystems with less vegetation, such as in deserts, typically accumulate little organic matter.

Soils change over time as minerals from the parent materials are transformed into clays and other minerals, and the more soluble elements leach from the soil profile. While humans become gray with age, soils often become rusty red, especially in well-drained environments, with the formation of rusty-colored iron oxides. These five soil forming factors - parent material, climate, topography, organisms, and time interact to form the vast array of soils we find in different landscapes, climates, and regions.

Humans are also a potent soil forming factor, often doing more harm than good. We excavate, cut, compact, level, and fill soils to construct buildings and roads and install utilities. Damage to the soil extends beyond the footprint of a building. As a result many urban soils do not support healthy growth of garden plants because of poor structure, compaction, shallow depth, and lack of organic matter. The soil has become dirt, with a disrupted ecosystem, reduced porosity, and a shrunken and damaged root zone (Fig. 4). Some damage to soil is reversible, given time and proper care. We can improve soils through addition of organic soil amendments to build organic matter and porosity, and through use of cover crops and judicious digging and tillage to reduce compaction (Fig. 5). 


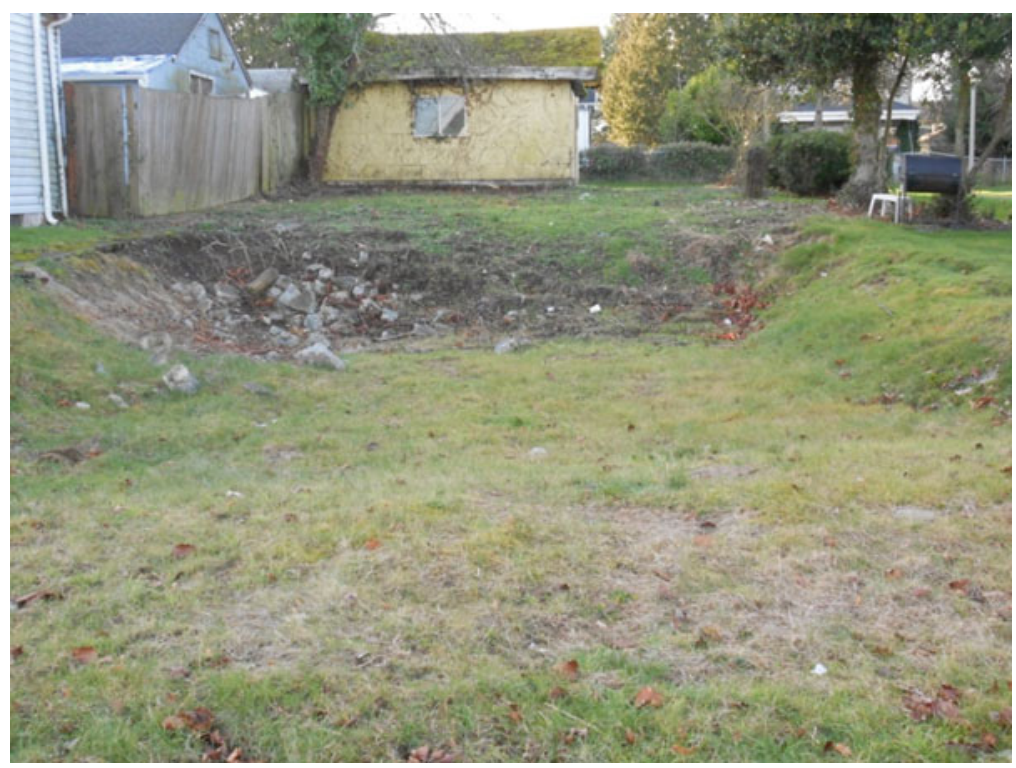

Fig. 4 Vacant urban lot on old house site, with cuts, debris, and compact soil (Photo by Craig Cogger)

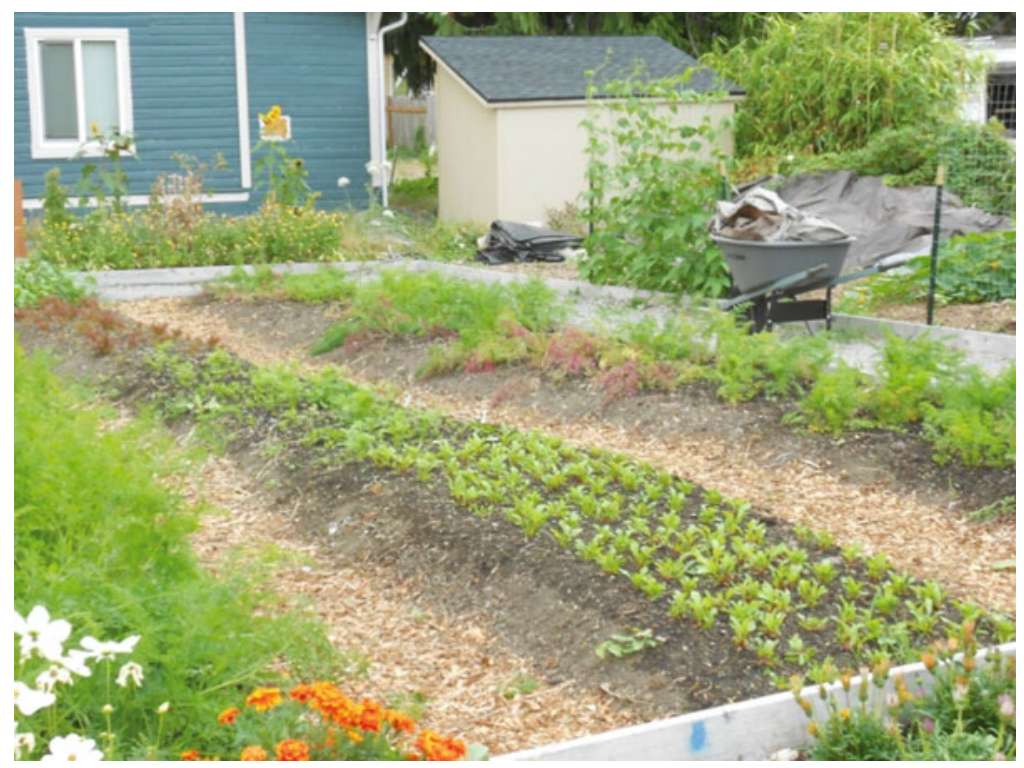

Fig. 5 Formerly vacant urban lot renovated for food production. Soil was amended with a Class A biosolids-wood product blend, and maintained as productive raised beds (Photo by Craig Cogger) 


\section{Soil Physical Properties}

Soil physical properties affect a soil's porosity, infiltration, rooting environment, and the exchange of air and water (Brady and Weil 2007).

Soil texture is the primary soil physical property. Soil texture describes the proportions of different size particles in soil, ranging from the tiniest clay particles to silt, sand, and coarse fragments such as gravel and rocks. When we feel a sample of soil in our hand, we can feel the different sized particles, hence the term texture to describe particle sizes in soil (Fig. 6). Farmers have long known that there is a connection between how a soil feels and how it is managed for best productivity.

Why is texture important? Particle size influences pore size, with sandy soils having mostly macropores, resulting in good drainage but poor water holding capacity. Soils containing mostly silt and clay have more capillary pores and micropores, increasing water holding capacity, but reducing infiltration and drainage. Texture also influences the amount of surface area in the soil, with sand contributing the least to surface area and clay the most. Soil surfaces are important in soils, because the surfaces are where the action is - holding nutrients and contaminants, and forming the physical support of the soil ecosystem. The range in the amount of surface area contributed by different sized particles is huge. A tablespoon of coarse sand particles has a total particle surface area equivalent to the top of a dollar bill. The same amount of fine clay particles has a surface area equivalent to the area of a football field. We can see that a little bit of clay in soil goes a long way to improve nutrient storage, contaminant binding, and water holding capacity. Soils with a large amount of clay, however, are difficult to manage, because they have slow infiltration

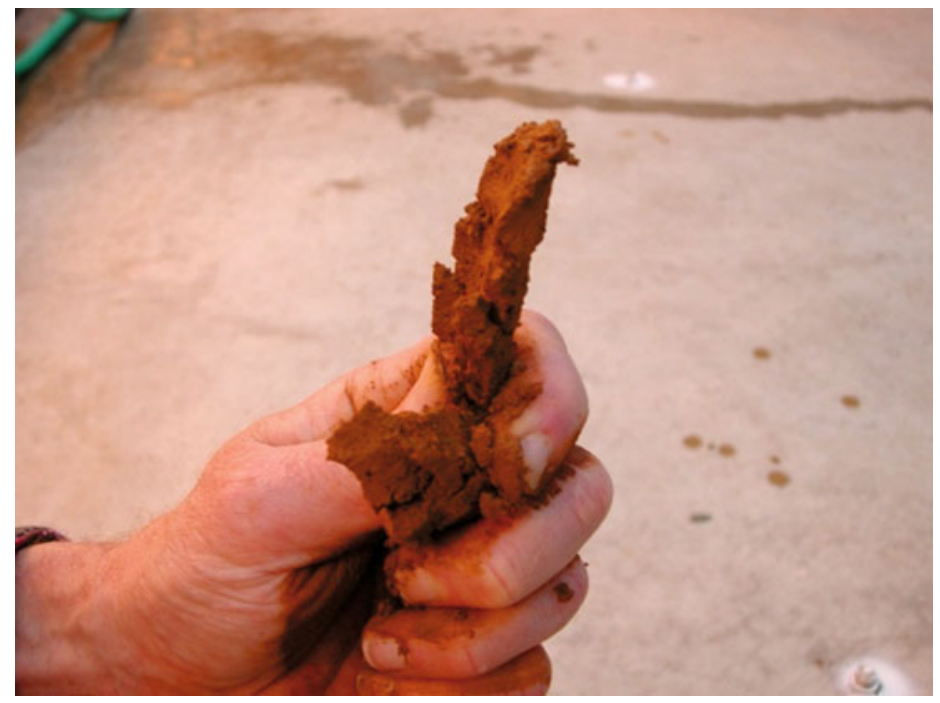

Fig. 6 Estimating soil texture by hand. The long soil ribbon shows that this sample is rich in clay (Photo by Andy Bary) 


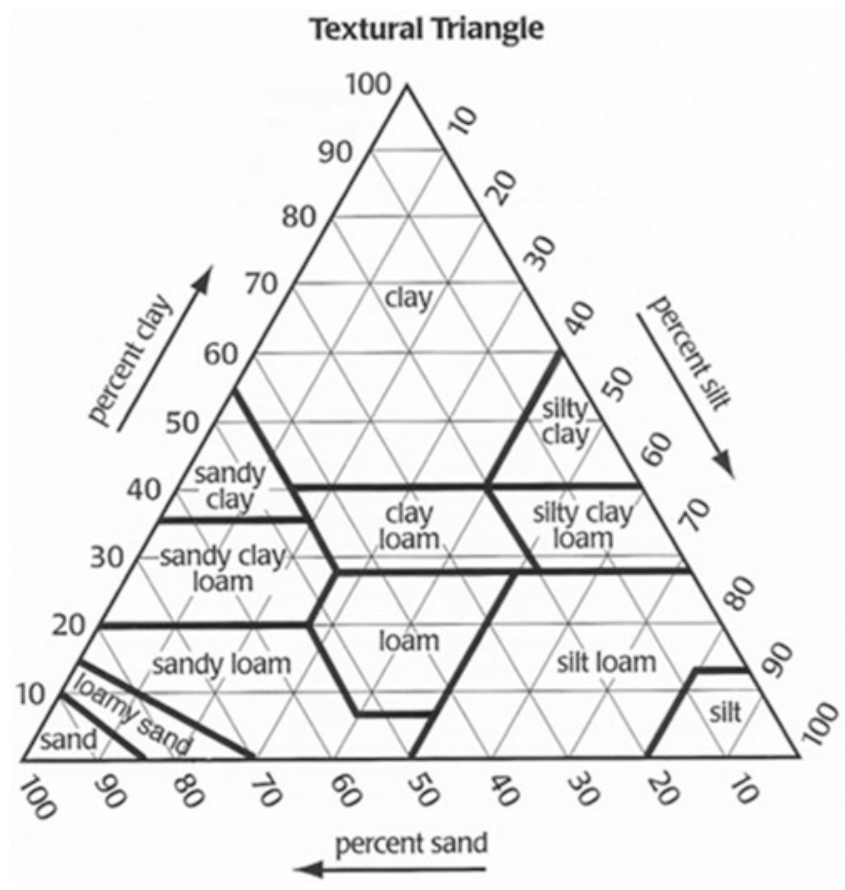

Fig. 7 The textural triangle, a graph showing the soil textural classes based on proportions of sand, silt, and clay

and drainage, and are often slow to warm during spring planting season. Once they become dry, the clay particles stick together, making the soil hard to dig.

Different soils have different proportions of sand silt and clay. Soils with a balanced influence of sand, silt, and clay are called loams. Loams generally have a good balance between drainage and water holding capacity, and are not hard to dig when dry. The textural triangle (Fig. 7) shows different textural classes based on proportions of sand, silt, and clay. Loam is in the lower middle of the triangle, containing roughly $10-25 \%$ clay, $30-50 \%$ silt, and $30-50 \%$ sand.

You can grow a garden in soils with a wide range of texture, from sandy to clayey, but management will differ, depending on texture. Soils rich in silt and clay will often be too wet and cold for early spring planting, but will need less intensive irrigation when it's dry. Sandy soils will be ready for planting earlier in the spring, but plants will need frequent irrigation to grow well during dry periods.

Soil texture is fixed, and is not affected by how we manage the soil. Individual sand, silt, and clay particles are like tiny rocks, resistant to change on human time scales. It is seldom practical to import materials to change the texture of a soil in an area larger than a raised bed.

Soil structure modifies texture and is influenced by our management. Structure is the aggregation of sand, silt, and clay particles into larger units called peds (Fig. 8). Structure is important because the spaces between peds are macropores. These are 
Fig. 8 Granular structure found in well-maintained topsoil (Photo by Andy Bary)

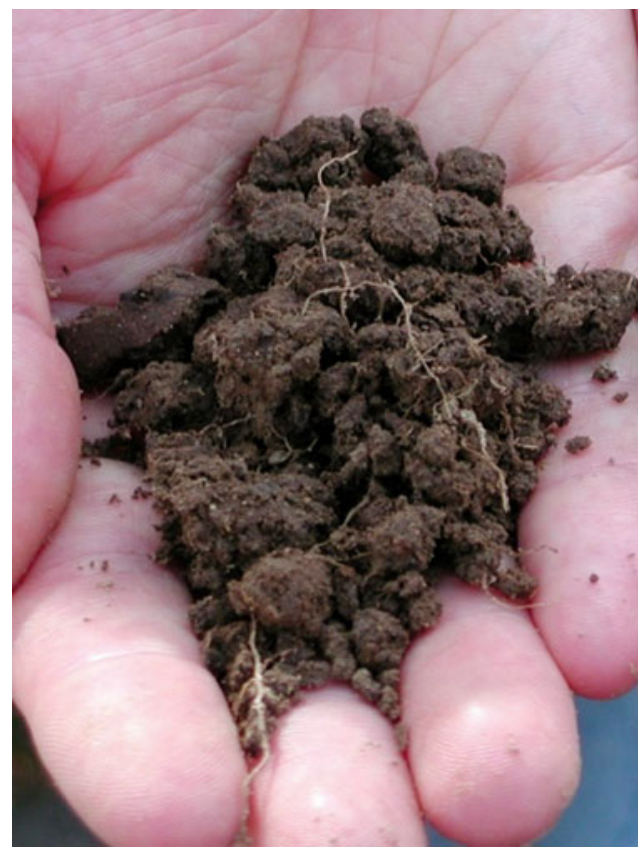

critical for improving infiltration, drainage, and aeration of medium and finetextured soils. Without structure, these soils are subject to runoff, prolonged wetness in the spring, reduced aeration, and poor root growth.

Soil organisms play a large role in the formation of soil structure. Earthworms create pores and aggregates as they burrow in the soil, passing soil through their bodies, and excreting them as earthworm castings. Plant roots also create pores as they grow through the soil. Soil bacteria produce glues that help bind smaller particles into aggregates, and fungal growth produces filaments that help hold the aggregates together. Humus, the stable organic matter that results from decomposition of organic residues, also helps strengthen aggregates.

Unlike texture, soil structure is fragile and is damaged by traffic, compaction, too much tillage, or tillage when soil is wet. Compacted urban soils have lost most of their structure, and take on a massive appearance. Because soil organisms are important agents in building soil structure, gardeners can help improve soil structure by improving the habitat for the organisms. Growing cover crops or adding amendments such as compost, manure, or biosolids products provide a food source for the organisms, resulting in their growth and eventual improvement of structure.

Increasing soil carbon concentration improves soil physical properties by increasing the number and stability of soil aggregates. Aggregates are conglomerations of small soil particles (typically loam and clay sized particles) that are held together usually by carbon 'glues'. When a soil is well aggregated it will typically also have lower bulk density. Many studies have reported on the ability of biosolids 
and composts to improve soil aggregation and/or reduce bulk density. For example Wallace et al. (2009) noted an increase in larger as well as water stable aggregates 4-5 years after surface application of 60 tons per ha of biosolids to rangeland. Aggelides and Londra (2000) also saw improvements in aggregate stability with application of a town waste and biosolids compost to loamy and clay soils in a semiarid environment. Decreases in bulk density and increases in porosity were also observed. Results were more pronounced for the loamy soil and at higher amendment loading rates. Similar results have been observed in a wide range of studies with different types of organic amendments (Albiach et al. 2001; Annabi et al. 2007; Bresson et al. 2001; Brown and Cotton 2011; Brown et al. 2011; Bulluck et al. 2002; Caravaca et al. 2001; Evanylo et al. 2008; Khaleel et al. 1981; ROU 2003).

\section{Water Relations}

Soil plays a critical role in the hydrologic cycle. Water travels through soil both to groundwater and to surface waters through subsurface flow. Flowing through soil water is filtered and is brought to an appropriate temperature. Water stored in soils is referred to as green water. Soil water also provides the primary source of water for plants. Soil water relations are generally a complicated interaction of a number of variables. Water enters the soil as a result of irrigation or rainfall events. The first stage of the interaction between water and soil relates to the speed at which water can infiltrate soils. This is referred to in the literature as the infiltration rate or hydraulic conductivity of the soil. Typically sandy soils will have much faster infiltration rates and conductivity rates than clayey soils. Organic amendments have been shown to increase water infiltration rates across different soil types and end uses (Brown and Cotton 2011; McFarland et al. 2007; McIvor et al. 2012).

The next factor for soil water relations is the ability of the soil to provide water for plants. Water that enters the soil will either drain through the soil or remain in the soil. Field capacity is the term used to describe the water that remains in the soil after a rain and after gravity flow has drained water from the larger pore spaces. This is an ideal condition for plant growth. Several studies have measured differences in total soil water concentration at field capacity or conditions of low moisture tension (readily available water for plant uptake). The soil will become increasingly drier as plants use the water. Water can also evaporate from the soil surface.

A final point in the soil water spectrum is referred to as the permanent wilting point. This is the level of dryness that results in sufficient drought stress that plants cannot recover. In some cases differences in plant available water is considered to be the differences in total water from field capacity to permanent wilting point. If a soil amendment results in increased total water at field capacity but also increased water at the tension equivalent to permanent wilting point, scientists will conclude that there is no increase in plant available water. Not all studies measure water at all tension levels or share the same perspective on plant available water. Amendments can alter soil water relations in several ways: 
- Increase the infiltration rate

- Reduce evaporation rate from soil surfaces

- Increase total soil water at field capacity

- Increase net water from field capacity to wilting point

Research results have generally identified increases in at least one of these parameters as a result of amendment addition. An early survey paper (Khaleel et al. 1981) looked at the impact of organic amendments on soil water holding capacity by reviewing previously published studies. They did not distinguish between municipal biosolids, animal manures, and composts. They found that $80 \%$ of the variability in soil water holding capacity at both field capacity and permanent wilting point varied based on soil texture and total $\mathrm{C}$ concentration. Changes in water holding capacity as a result of increases in soil $\mathrm{C}$ were much more pronounced for sandier soils.

A more recent survey paper quantified benefits for soil water associated with compost application (ROU 2006). Here, two types of applications were modeled: Compost used as a soil conditioner/fertilizer incorporated into the surface soils and compost added to the soil surface as a mulch. The authors then modeled predicted water savings for two crops grown in New South Wales, Australia. A 12 t/ha application of compost incorporated into the soil was predicted to result in water savings of $1.5 \%$ of the total quantity of irrigation water applied. For compost applied as mulch to a $10 \mathrm{~cm}$ depth (about 335 tons per hectare), water savings were predicted to be about $10 \%$ of the total irrigation water supplied. Brown and Cotton (2011) sampled a number of working farms with a history of compost application in California. Soil water holding capacity was measured at 1 bar $(100 \mathrm{kPa})$ of tension, or at the point where irrigation water would likely be applied. The sites that had received the highest loading rates (165 and $448 \mathrm{t} / \mathrm{ha}$ ) also saw the most significant increases in soil water. This difference was most pronounced for the two sites with sandier soils (loamy sand texture). The site with a silty loam soil that had received $224 \mathrm{t} /$ ha had only a minor increase in plant available water.

A study of long term biosolids and compost amended sites in Washington State also found significant increases in soil water for some of the sites (Brown et al. 2011). This was observed across different soil types, amendments and amendment loading rates, precipitation patterns, and cropping systems. Here increases were seen for compost added to irrigated fruit orchards, hops and turf, and biosolids to dryland wheat. The amendments for all sites were incorporated into the soil. The implications of the potential increase in water availability are discussed below.

At the fruit orchard site, the soil was a silt loam. The farmer had applied about 50 tons of compost to each acre over a several year period. A $50 \%$ increase in plant available water (the difference in total soil water between field capacity and 1 bar of moisture tension) was observed in the compost amended soils. Cherries in WA State are typically irrigated with 3.5 acre feet (an acre foot is equivalent to 325,850 gallons). Compost here should have reduced irrigation demand by about 1 acre foot per acre. 
Table 2 Plant nutrients

\begin{tabular}{l|l}
\hline $\begin{array}{l}\text { Major } \\
\text { nutrients }\end{array}$ & Micronutrients \\
\hline Nitrogen & Iron \\
\hline Phosphorus & Manganese \\
\hline Potassium & Boron \\
\hline Calcium & Zinc \\
\hline Magnesium & Copper \\
\hline Sulfur & Molybdenum \\
\hline & Chlorine \\
\hline
\end{tabular}

\section{Soil as a Source of Nutrients}

A major function of soil is to supply nutrients to plants. Nutrients are elements that are essential to plants, and are derived from soil. Plants require 13 essential nutrients (Table 2). The six major nutrients include nitrogen, phosphorus, potassium, calcium, magnesium, and sulfur. Plants need relatively large amount of the major nutrients. Plants require much smaller amounts of the micronutrients (Table 2), but all are essential. Each nutrient performs specific roles in plants. Nitrogen, for example, is a major constituent of chlorophyll, proteins, and DNA. Phosphorus is found in DNA, cell membranes, and molecules that capture and transfer energy. Potassium helps regulate the turgor (water pressure) in plant tissues, among other functions.

Both the mineral matter and organic matter in soil are storehouses of nutrients. Most of the nutrients are tied up in insoluble forms in mineral structures or complex organic molecules, and are not available to plants. The nutrients are slowly released into soluble, available forms through weathering of minerals and biological breakdown of organic matter (Fig. 9). The release of available nutrients from soil is sufficient to support native ecosystems, but rapidly growing plants in vegetable gardens need additional nutrients to meet their growth needs. Gardeners supply these nutrients though fertilizers, organic soil amendments, and cover crops.

\section{Nutrient Supply from Organic Matter and Organic Amendments}

Nutrients are stored in soil organic matter and organic amendments in complex organic molecules such as proteins and humus. As these molecules are broken down in the soil ecosystem, nutrients are released as simple, soluble ions that can be taken up by plants. The release of these nutrients depends on the activity of the ecosystem, which in turn depends on environmental conditions. When the soil is cold, biological activity is low, and nutrient release is slow or stopped. As the soil warms, biological activity increases, increasing the release of nutrients. If the soil becomes dry, biological activity again slows, reducing nutrient release. Plant growth and demand for nutrients is also sensitive to temperature and moisture, so there is a synchrony between nutrient release from organic matter and demand by plants. This results in efficient use and small losses of available nutrients in native ecosystems. 


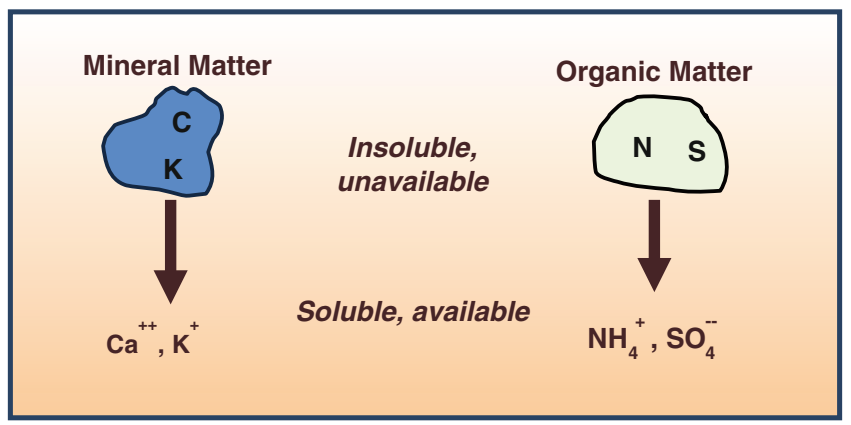

Fig. 9 Release of nutrients into soluble, plant-available forms (Figure by Craig Cogger)

Fig. 10 Nitrogen cycle (Figure by Craig Cogger)

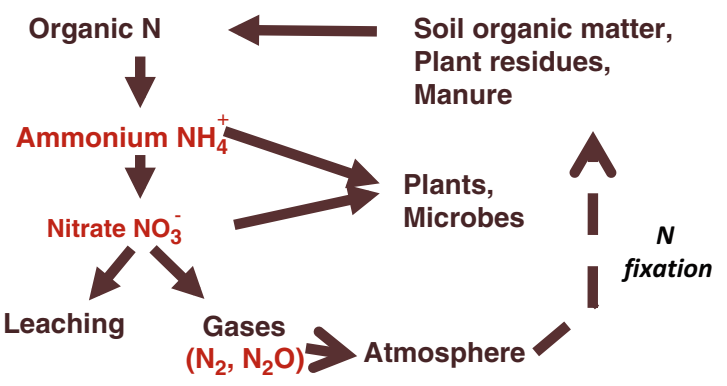

The nitrogen cycle is an important example of how nutrients are released and tied up by organic matter. Nitrogen is the nutrient that plants need in the largest quantities, and the one that gardeners most frequently need to apply for good growth and yields of fruits and vegetables. Applying too much nitrogen can harm plants and the environment, so it is important that we apply fertilizers and amendments at appropriate rates.

Most nitrogen in soil and soil amendments is in organic forms (such as proteins, DNA, and humus) and is not available to plants (Fig. 10). As the soil warms in the spring, soil microbes begin to feed on and decompose organic materials, taking nitrogen and other nutrients into their bodies, and releasing excess nitrogen as ammonium. Ammonium is a simple, soluble ion, and is available to plants. As the soil continues to warm, other bacteria, called nitrifiers, use ammonium as an energy source. They produce nitrate, another simple, soluble ion that is available to plants. Any nitrate remaining at the end of the growing season will leach during winter rains and snowmelt, or be converted to nitrogen gases. In humid and sub-humid climates nearly all of the available $\mathrm{N}$ will be lost during the winter. The leached nitrogen will wind up in ground water or surface water, where it can become an environmental or health problem.

We can use the nitrogen cycle to understand how fertilizers and soil amendments supply nitrogen to plants. An inorganic nitrogen fertilizer may contain nitrogen as 


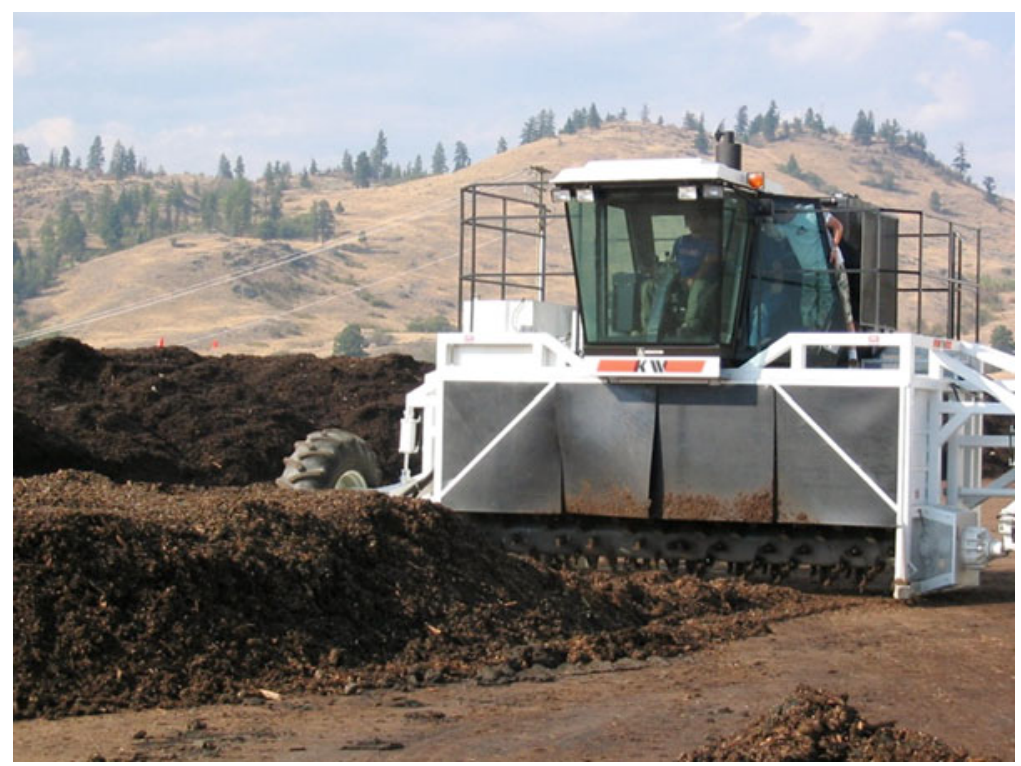

Fig. 11 Compost made from biosolids and yard debris is a slow-release source of nutrients

ammonium or nitrate. This nitrogen is immediately available to plants (fast-release), but is also subject to leaching loss. Nitrogen in soil amendments such as composts, manures, or biosolids products is mostly in complex organic forms, which are not immediately available to plants (Fig. 11). The nitrogen is released slowly as soil organisms break down the organic material and release excess nitrogen as ammonium. The rate of release of nitrogen from organic amendments depends on the amount of nitrogen in the amendment and the forms of nitrogen, as well as soil temperature and moisture. Uncomposted materials that are rich in nitrogen, such as grass clippings, and heat-dried biosolids or manure will release nitrogen more quickly than composted materials. Woody materials contain so little nitrogen that they do not meet the nutrient needs of the microbes decomposing them. The microbes then scavenge available nitrogen from soil, reducing the supply available to plants.

Another important piece of the nitrogen cycle is nitrogen fixation. Nitrogen is abundant in the atmosphere, but atmospheric nitrogen $\left(\mathrm{N}_{2}\right)$ is not available to plants. Certain microbes can "fix" $\mathrm{N}_{2}$, converting it into available forms. Rhizobia are microbes that form a symbiotic relationship with plants in the legume family to fix nitrogen (Fig. 12). Examples of legumes include clovers, vetches, peas, and beans. The legumes supply the Rhizobia with energy, and the Rhizobia supply the legumes with available nitrogen. When the legumes die and decompose, the fixed nitrogen is released into the soil in plant-available forms as described above. Growing legume cover crops is another source of nitrogen for urban gardeners. 


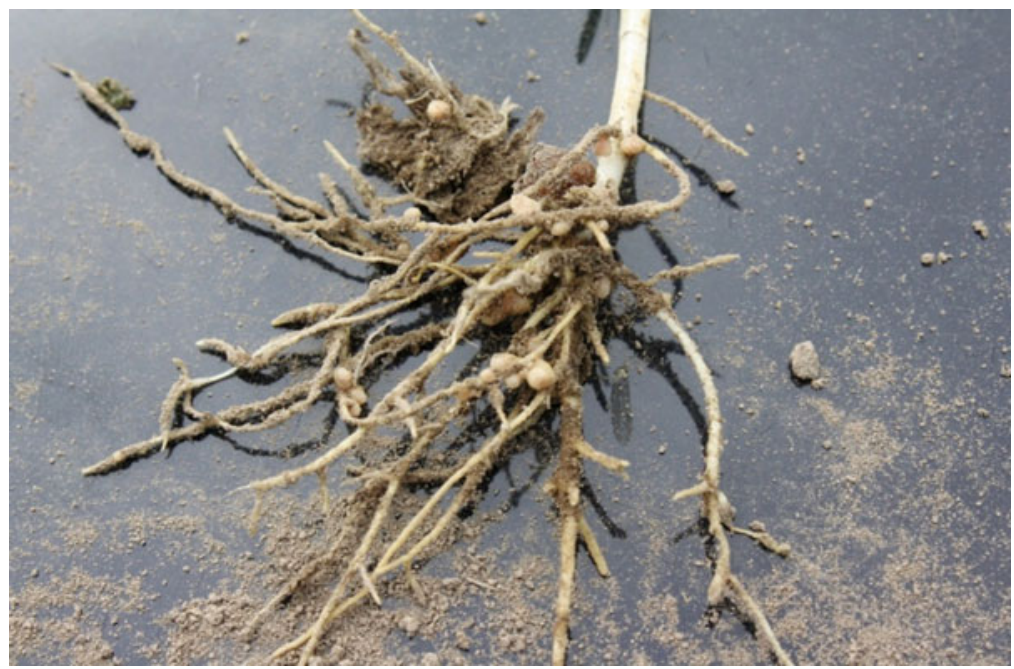

Fig. 12 Hairy vetch roots showing $\mathrm{N}$-fixing nodules that contain Rhizobia (Photo by Chris Benedict)

\section{Nutrient Supply from Soil Mineral Matter}

Most plant nutrients (potassium, calcium, magnesium and others) have positive charges when they are in soluble, available form. These positively charged ions are called cations. Clay surfaces are negatively charged and attract cations. This attraction reduces nutrient leaching loss, but it does not reduce availability of the nutrients. As plant roots take up nutrients from the soil solution, additional nutrients will exchange from the clay surfaces to replenish the soil solution. When we add fertilizers or soil amendments that contain these nutrients to the soil, the nutrients will exchange onto the clay surfaces. We can think of this as a "ready reserve" of nutrients. This ready reserve is called cation exchange capacity (or CEC). Organic matter also has negative charges, and holds nutrient cations in the same way that clay does. Soils that are rich in clay and/or organic matter have a greater CEC than sandy soils and soils with little organic matter.

Cation exchange is not the only way that nutrients are held in soil. For example, soil phosphorus is present as negatively-charged phosphate forms, which are not attracted to the negative charges on clay or organic matter surfaces. Phosphate ions do bind tightly to iron, aluminum, and calcium minerals on the surfaces of soil particles, which reduces risk of leaching, but also reduces phosphorus availability to plants. 


\section{Soil Amendments}

Gardeners and urban growers will typically add nitrogen, phosphorus and potassium to their soils. Other nutrients are rarely added. Deficiencies of other plant nutrients can and do occur, potentially limiting yields. Organic or residuals derived amendments such as composts, biosolids and manures, being derived from plant material and manures, will contain the full suite of required plant nutrients. Composts and biosolids can be added to soils to meet the nutrient needs of a crop. Composts can also be added to soils as a soil conditioner or as a mulch. Soil conditioners are typically incorporated into the surface $6^{\prime \prime}$ or $15 \mathrm{~cm}$ of the soil. Mulch is applied to the soil surface without incorporation. Conditioners are used to provide nutrients and organic matter to soils. Mulches are added to reduce evaporation from the soil and control weeds. They typically have low nutrient value. The nutrient availability of the amendment will depend on initial total nutrient concentrations and the rate at which these nutrients become plant available. In certain cases, amendments with a high Carbon: Nitrogen ratio can result in nitrogen immobilization (ROU 2006). Soil microbes use added carbon as a food source. A portion of this is used for energy with some used to build biomass. Much the same as people, they also require a certain amount of nutrients to be able to use the carbon to build biomass. If the added amendments are high in carbon and low in nitrogen and other nutrients, the microbes will use up all of the added $\mathrm{N}$ and render the soil nitrogen deficient for plant growth. This process is referred to as nitrogen immobilization. Because the nutrients in these materials are typically present in organic forms, they will function as a slow release fertilizer in soils. For example, in a study of food waste compost applied to turf grass in WA, a single application of compost provided $\mathrm{N}$ to the turf for the 7 year course of the study (Sullivan et al. 2002). Grass yield and total $\mathrm{N}$ uptake were increased in comparison to fertilizer addition. Studies have reported mineralization of about $35 \%$ of total $\mathrm{N}$ during a first cropping season after biosolids addition (Cogger et al. 2004) and average nitrogen recovery of $62 \%$ for repeated annual biosolids application to turfgrass in WA State (Cogger et al. 2001). Increases in phosphorus availability were also reported. Nitrogen uptake on the same plots continued for several years after the end of biosolids application with residual soil P remaining elevated 9 years after the cessation of amendment application (Cogger et al. 2013a, b). Other studies have also reported increase in soil fertility (using a range of indexes) for compost and biosolids amended soils in comparison to control soils (Brown et al. 2011; Brown and Cotton 2011; Christie et al. 2001; Evanylo et al. 2008; McIvor et al. 2012).

\section{Case Studies: Using Soil Amendments to Support Urban Agriculture}

The following case studies represent two examples where biosolids-based soil amendments are being used to support urban agriculture projects. The first (Tacoma) is a municipally supported program where the biosolids product has been integrated 
into the garden construction process and additionally as ongoing support of the gardens. The second (Seattle - Alleycat acres) details the start of a grassroots-based non-profit urban farm that

\section{Using Biosolids-Based Soil Amendments to Support Community Gardens in Tacoma, WA}

Tacoma, Washington has produced a pathogen free biosolids from their wastewater treatment plant since the early 1990s. As a result of the material being free of pathogens as well as meeting all of the EPA criteria for heavy metals, the biosolids are suitable for general use. The biosolids come out of the wastewater treatment process in a form that is not suitable for the home gardener. The material is primarily water, about $80 \%$ water and $20 \%$ solids. It is difficult to work with and has a distinct odor. The municipality recognized that direct sales of the biosolids would not be successful as a result of its objectionable odor and poor physical properties. As an alternative, the Wastewater Treatment division with the help of the Washington State University Extension, have designed a range of products that include the biosolids but are produced to be more appealing to the home grower. By adding washed sand and sawdust to the biosolids, they were able to create a customer product that proved to be an excellent soil amendment - this product is now marketed as "Tagro Mix". More recently, they developed a "Potting soil" that consists of biosolids and aged wood. All of these products are distributed under the brand name Tagro- short for Tacoma Grow (Fig. 13).

In their effort to develop a customer base in Tacoma, a garden was set up at the wastewater treatment plant (Figs. 14, 15, 16). Staff worked closely with local WSU Extension Master Gardeners to test the biosolids soil product. Vegetables from the garden were entered into the County fair, and produce from the garden was donated to local food banks. Tagro soil products were available to all residents at the treatment plant for no cost initially, now customers can also order larger quantities for home delivery. People coming to pick up Tagro are able to see the garden and talk to the staff who are all familiar with using the Tagro products. Over time, Tagro became an integral part of the gardening community in Tacoma with retail sales generating over $\$ 800,000$ annually. When the Tagro soil products were offered to gardeners at the Community Gardens, it was gratefully accepted by the vast majority of the growers because of their familiarity with the product.

As part of a deliberate decision made by the municipality to assure the continued growth and success of community gardens, the biosolids-based "Potting soil" is disturbed free to all community gardens in the City of Tacoma and surrounding Pierce County. The Potting soil is typically used to fill raised beds, although it can also be used to mulch existing plantings. It provides for excellent plant growth with all necessary plant nutrients. This has helped first time gardeners in that program to succeed. It is estimated about $80 \%$ of community gardeners in Tacoma are new to 


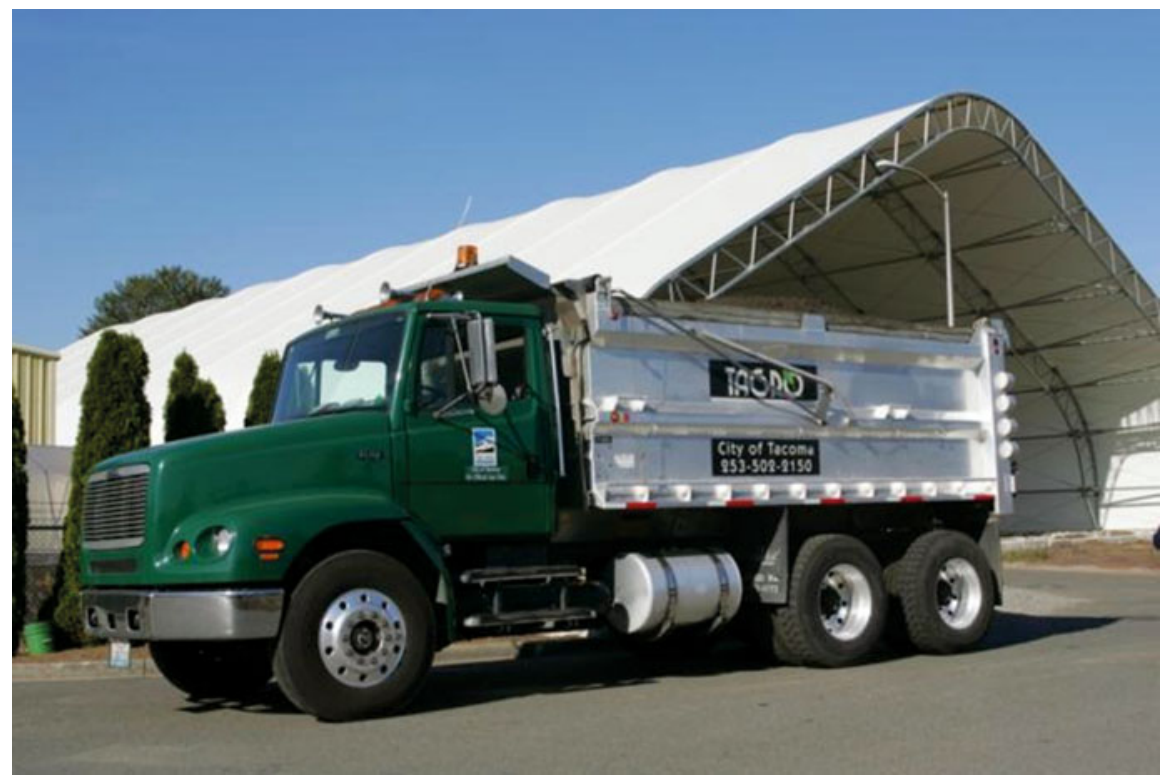

Fig. 13 Tagro truck delivering products

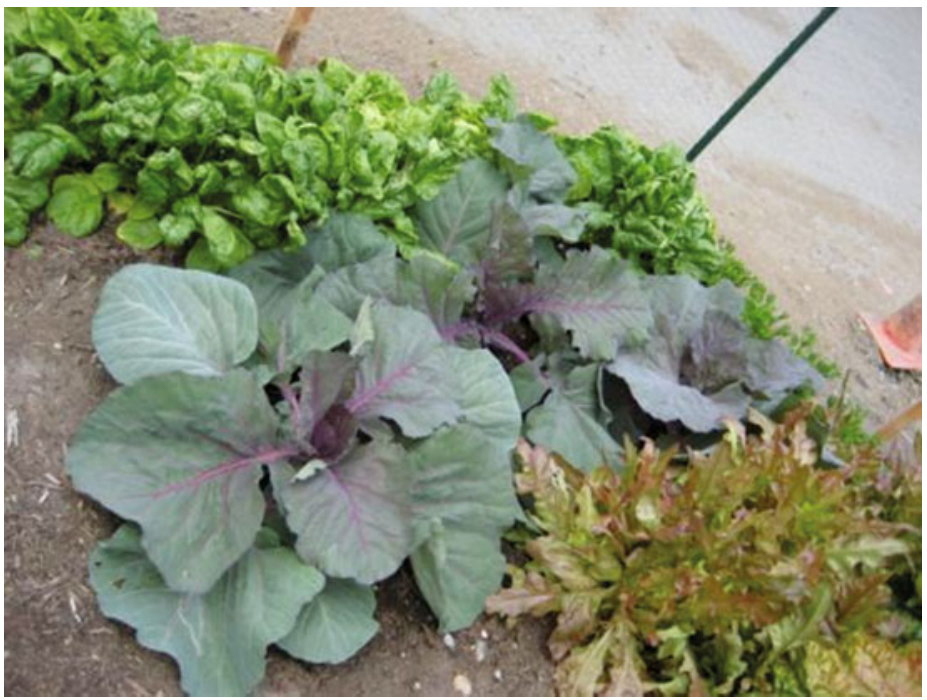

Fig. 14 Part of the garden at the waterwater treatment plant 
Fig. 15 Onions and salad greens growing at Tacoma's WWTP

Fig. 16 Salad greens growing in Tagro's Potting soil
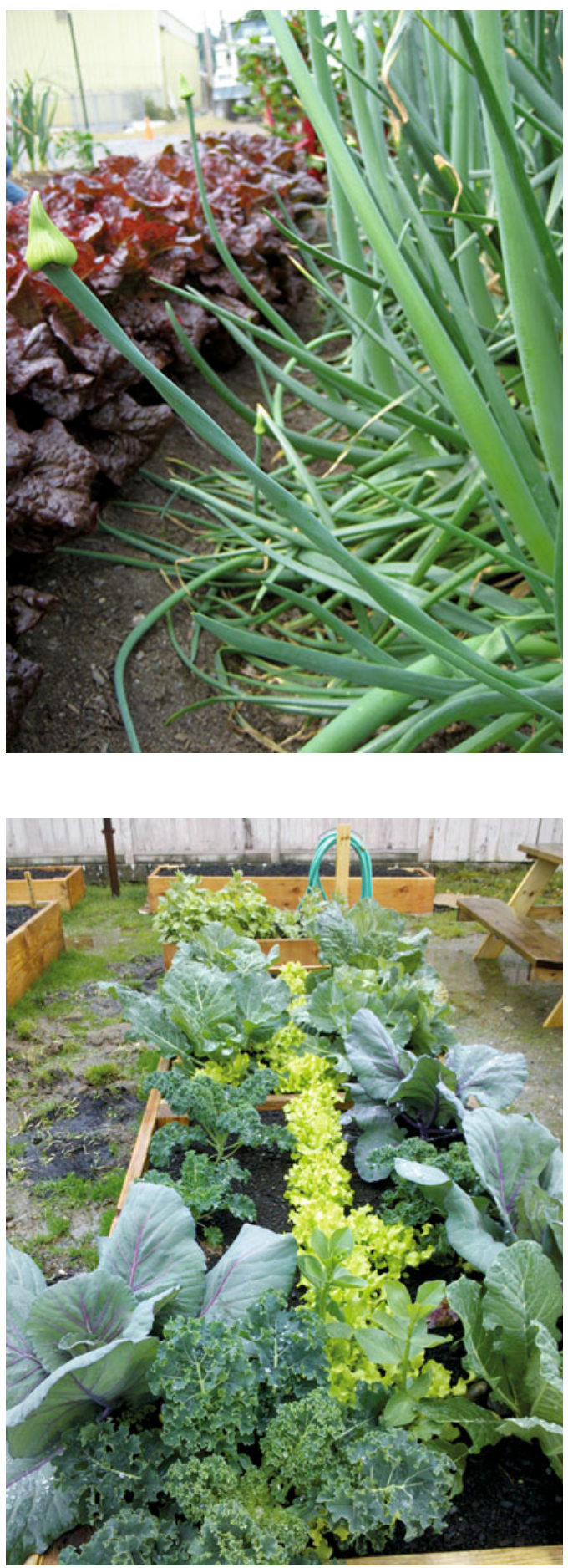
gardening. Urban soils are typically neglected with low nutrients and organic matter. They are also compacted. Without the potting soil, the potential for failure would be very high. Because of the potting soil, these gardeners and the community garden program are succeeding. At the same time, it also reduces concerns about growing food in contaminated soil.

There are many reasons to support the use of residuals based soil amendments in community gardens. These products are produced using materials that are typically landfilled. The feedstocks for these products - yard waste, food scraps and municipal biosolids - are derived either directly or indirectly from plants grown in soil. Beneficial use of these materials returns organic matter and nutrients to soils and so represents a high form of recycling. There are many greenhouse gas benefits associated with returning these materials to soil. These include methane avoidance, energy savings for replacing synthetic fertilizer and soil carbon sequestration. There are also benefits relating to soil health and sustainability. Many gardeners support the use of the Tagro products for these reasons. Providing these materials to gardeners free of cost has also generated support and good will. However, the primary reason that community gardeners in Tacoma and Pierce County welcome the biosolids based potting soil is because it is highly effective at growing plants. The Tagro enables gardeners to grow high volumes of fruits, flowers and vegetables in very small areas with very little effort. The key to acceptance and use of residuals-based soil amendments is the efficacy of the amendments for growing plants.

\title{
Case Study: Soil Amendments and Alleycat Acres
}

\author{
Kate Kurtz \\ Alleycat Acres Founding Board Member \\ Seattle, WA, USA \\ katkurtz@gmail.com
}

\begin{abstract}
Alleycat Acres is an urban farming collective that aims to connect people with food. We aim to do this by creating community-run farms on otherwise vacant lots in the city of Seattle, WA. By farming the cityscape, we are helping to create solutions that address a number of issues facing our communities, including providing access to fresh, healthy food and bringing neighbors together. We believe that food is more than what we eat; it's a medium through which we can forge intimate, meaningful relationships between people and place. Digging our hands in the soil and producing food is a medium that connects us, both mentally and physically, to our surroundings. Our urban farms lay the groundwork to enable anyone, from any background, to join in the process of local food production.

One big thing that makes Alleycat Acres unique is that unlike many community gardens where individuals or families get a plot of land to manage for themselves, the Alleycat Acres farms are managed collectively meaning that each farm has a cohesive planting plan that all community members involved work on together.
\end{abstract}




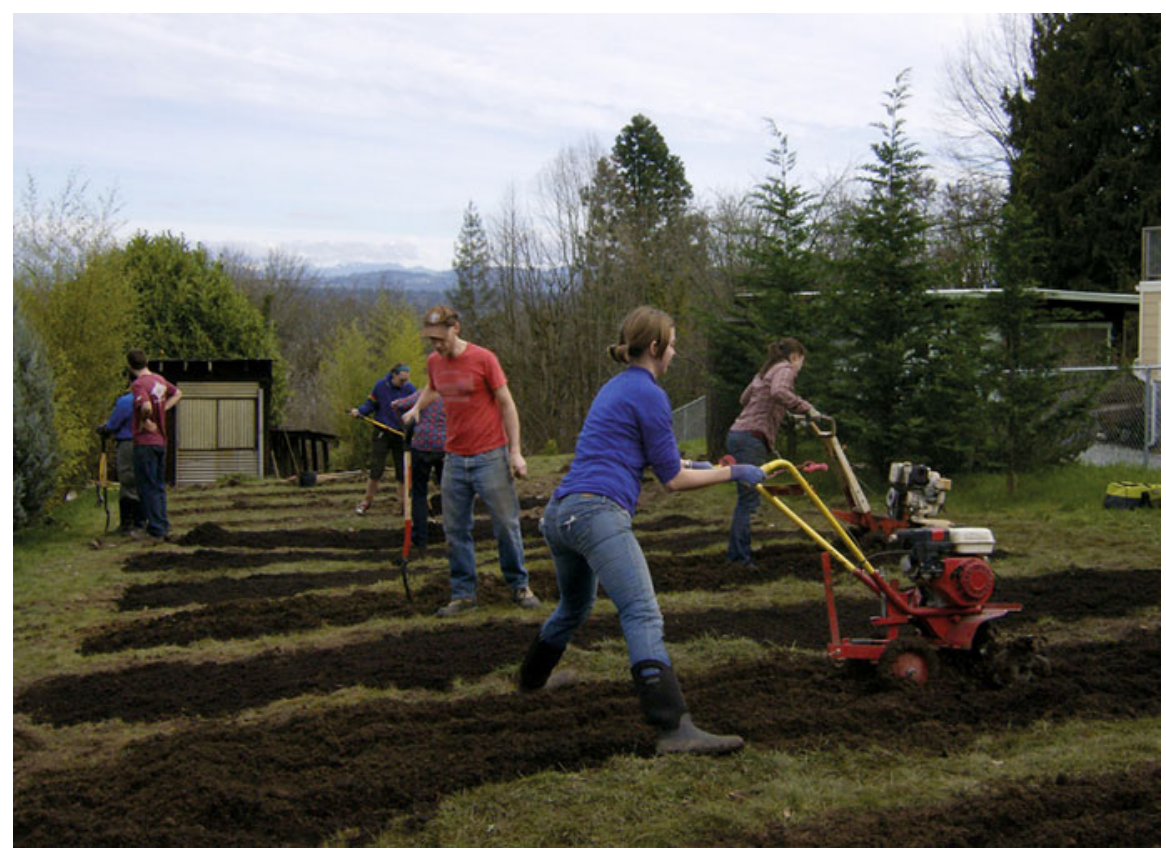

Fig. 17 Preparing beds for planting using biosolids compost

What and how we grow is a collaborative process. The interests of the different community members vary, so as a result each of the farms grows different crops, and in slightly different ways. All three farms grow annual vegetables and perennial berries, which grow well in the Pacific Northwest. One of the farms has several fruit trees and also laying hens. Two of the farms have honeybees, which are great for the honey and as well as the pollination benefits. The harvests are split between anyone who works on the farm, and extra produce goes to community partners like food banks and youth programs. There is no minimum number of work hours required to be eligible to take home a share of produce, nor is there a set share size. The amount of produce an individual takes home is based on his or her own needs and interests (Fig. 17).

A strong ethic of sustainability and social justice runs through how we operate our urban farms, and it is at the core of our values. In trying to strengthen the local food movement it only makes sense that we choose local and recycled farm inputs wherever possible. Inputs include soil amendments, seeds, pest management products, and hardscaping materials used to construct beds and greenhouses. We also encourage bicycle transportation to and from the farms, and our annual fundraiser is a bike ride through our scenic Puget Sound region.

Reducing our carbon footprint is very important to us. We have participated in events for 350.org to help bring awareness to climate change and global $\mathrm{CO}_{2}$ emissions. We also know that using compost, rather than fertilizer, is an excellent way to 


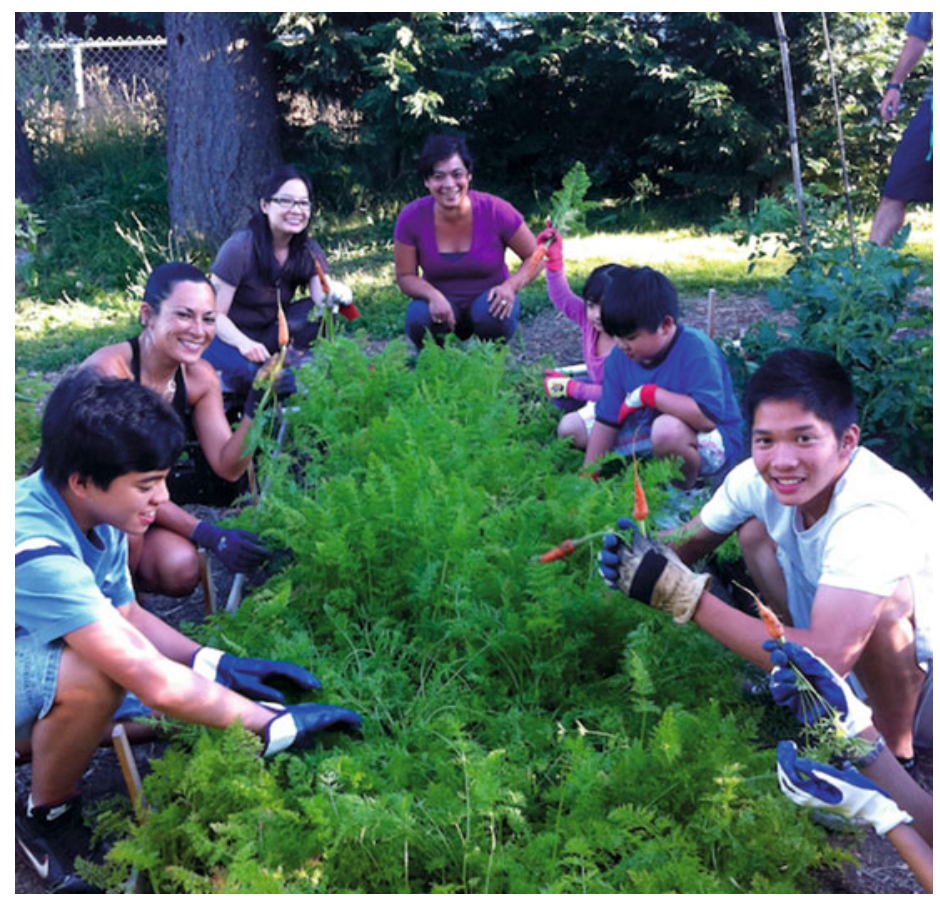

Fig. 18 Carrots at our Beacon Hill farm

not only create fertile soil with good tilth, but it is also a good way to avoid the $\mathrm{CO}_{2}$ emissions associated with fertilizer, and to sequester carbon in the soil. Choosing compost is an obvious choice (Fig. 18).

When we started our first farm in 2009 we had no budget and relied on donations. One of our cofounders was in graduate school for soil science at that time and she had a connection to a company that makes compost from the county's biosolids and sawdust from local lumber mills. Some of us had some questions about biosolids like heavy metals and pharmaceuticals, but she knew the science and explained that this product is as safe and clean as the local manure composts and the yard/food waste compost produced from the curbside collection. The company agreed to donate the material we needed to get going and we really liked it. The plants grew like crazy and we love the idea of recycling that waste back to the soil. The other thing that we really like is that it's sourced locally. The biosolids are our waste from the city. As an urban farming collective with a focus on the hyper-local, it only makes sense that we would choose an urban-derived soil amendment. We know that biosolids are not the most popular choice for people in the local food scene and are often downright controversial. That didn't matter to us though. We were excited about using this renewable resource and spreading the word.

In 2011, 2 years after we started our first farm the county gave us an award for being a leader in biosolids recycling. It felt good to be recognized for making the 


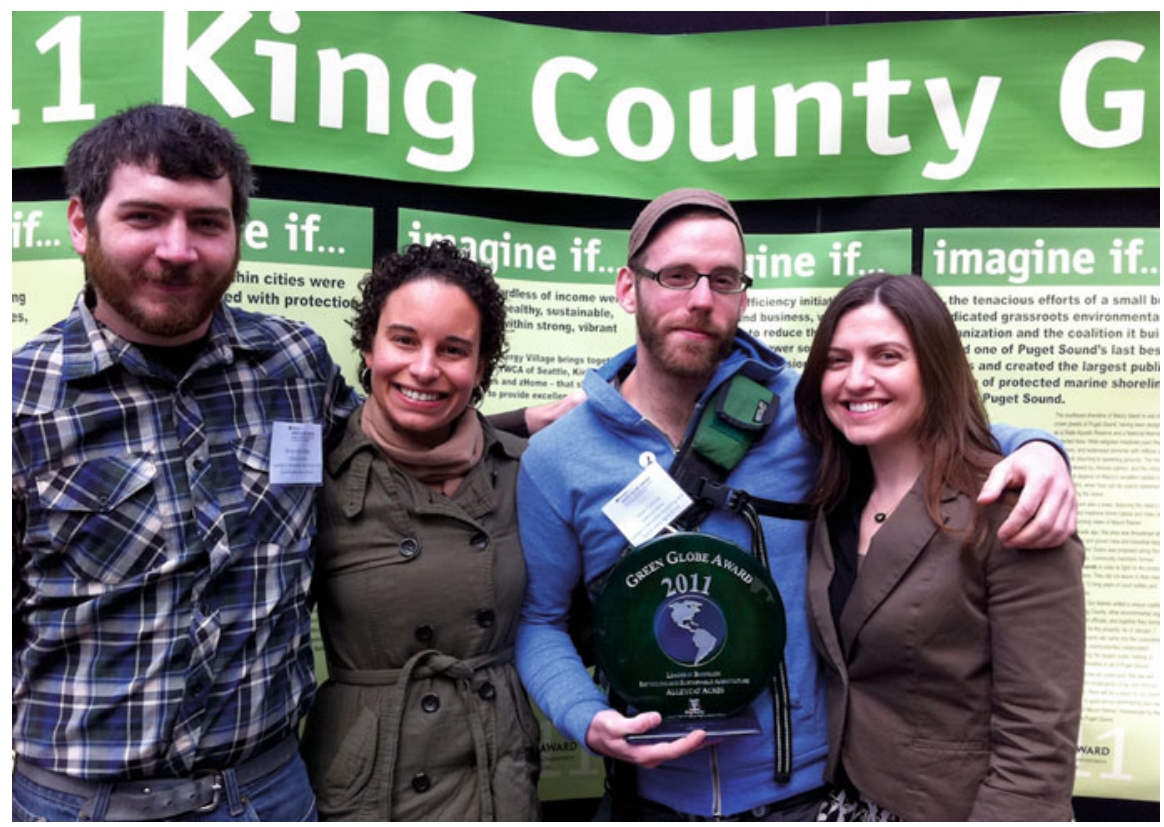

Fig. 19 Receiving the King County Green Globe award for use of biosolids compost in our farms

choice to use this local product and attempting to be a source of accurate information in the local food and urban agriculture worlds (Fig. 19).

During our second year we had funds from our annual bike ride and we bought more compost to use on our second farm, which was getting under way. Same thing for when we started our third farm the next year. After an initial heavy application in the first year of cultivation we add a little bit each year (half an inch to two inches) just to keep things going. One of the farms likes to use less compost and supplements quite a bit with a granular certified organic fertilizer blend consisting of things like seed and feather meal. Another farm likes to use heavy amounts of compost, practically planting directly into the compost alone, and also experiments with non-traditional techniques like hugelkultur, which involves constructing a raised bed from old logs and tree branches. The first farm takes a more traditional approach by applying an inch or so of compost each year, tilling it into the native soil, and only supplementing with amendments like lime and blood meal as needed based on a soil test. Each farm also uses a three bin composting system to handle the plant waste produced on site. That compost is used once it is mature. One of the farms has chickens, so a lot of the plant waste goes to the birds to eat, and then we compost the manure. The various techniques used by all three farms work great and we are happy that each farm decides how they would like to manage their soil. The main objective is that we are all directly involved with our food production and that we're doing it together.

We truly believe that every carrot we harvest together is a step toward creating a healthy, future-forward city. 


\section{Soil pH and Salts}

Soil $\mathrm{pH}$ affects the solubility and availability of both nutrients and toxic elements in soil. $\mathrm{pH}$ is a measure of the acidity or alkalinity, with $\mathrm{pH}$ less than 7 acid and $\mathrm{pH}$ greater than 7 alkaline. Most soils have a $\mathrm{pH}$ between 4 and 9. Soil $\mathrm{pH}$ tends to be higher in arid climates and lower in humid climates. Some fertilizers and soil amendments reduce soil $\mathrm{pH}$ over the long run. Depending on the history of a site, urban soils can have higher or lower $\mathrm{pH}$ than agricultural soils in surrounding areas.

Different nutrients are more soluble (and more plant-available) at different soil $\mathrm{pH}$. Phosphorus is most soluble in the 6-7.5 range, which partly explains why many plants grow best in that range. Iron and zinc are most soluble in acid soils. Zinc deficiencies in alkaline soils reflect low zinc availability, but not necessarily low levels of total zinc in the soil. Blueberries grow best in acid soils, which have high iron availability.

Many toxic elements are also more soluble in acid soils, and thus potentially more harmful to plants. Aluminum is naturally abundant in soils and toxic to plants, but it is not soluble enough to cause problems in most soils. As $\mathrm{pH}$ declines, however, aluminum solubility and availability increases to the point that it harms plants in strongly acid soils. Soil $\mathrm{pH}$ also affects the soil ecosystem, with more biological activity in the middle of the $\mathrm{pH}$ range, and less at the extremes. Soil acidity can be corrected by addition of lime (ground limestone), while elemental sulfur reduces alkalinity, lowering soil $\mathrm{pH}$.

Salts are added to soils in fertilizers, soil amendments, and irrigation water or seepage from irrigation water. De-icing salts can also affect soils adjacent to roads and sidewalks. Salts limit the ability of plants to take up water from the soil, which causes or exacerbates drought stress. Salts are seldom a problem in humid areas, because rainfall and snowmelt leach soluble salts through the soil profile. Salts can be a problem in arid regions with little natural leaching. If clean irrigation water is available, and the soil is well drained, salt levels can be reduced through controlled leaching.

\section{Soils and Plant Yield}

A low productivity soil will have low plant yields. As has been discussed, adding organic amendments to soils will typically improve soil physical properties such as aggregation. This will lower bulk density and increase soil water holding capacity. Amendments can also provide the full suite of nutrients required for plant growth. Studies have shown that use of organic amendments can also increase plant yields in comparison to conventional fertilizers. It is not always clear what factors relating 
to organic amendments are responsible for the observed yield increase. It may be availability of nutrients such as sulfur in the amendments. It can also be related to improved soil tilth or improved soil water relations. Reported yield increases have not been consistent across crops or years. For urban soils, adding organic amendments is a clear way to improve soil properties. These improvements will likely improve plant germination and yield. Understanding and tending to soils is the first critical step to a successful urban agriculture movement.

\section{References}

Aggelides SM, Londra PA (2000) Effects of compost produced from town wastes and sewage sludge on the physical properties of a loamy and a clay soil. Bioresour Technol 71(3):253-25

Albiach R, Canet R, Pomares F, Ingelmo F (2001) Organic matter components and aggregate stability after the application of different amendments to a horticultural soil. Bioresour Tech $76: 125-129$

Alguacil M, Díaz- Pereira E, Caravaca F, Fernández DA, Roldán A (2009) Increased diversity of arbuscular mycorrhizal fungi in a long-term field experiment via application of organic amendments to a semiarid degraded soil. Appl Environ Micro 75:4254-4263

Amundson R, Guo Y, Gong P (2003) Soil diversity and land use in the United States. Ecosystems 6:470-482

Annabi M, Houot S, Francou C, Poitrenaud M, LeBissonnais Y (2007) Soil aggregate stability improvement with urban composts of different maturities. Soil Sci Soc Am J 71:413-423

Banwart S (2011) Save our soils. Nature 474:151-152

Brady N, Weil R (2007) The nature and properties of soils. Prentice Hall, Upper Saddle River

Bresson LM, Koch C, LeBissonnais Y, Barriuso E, Lecomte V (2001) Soil surface structure stabilization by municipal waste compost application. Soil Sci Soc Am J 65:1804-1811

Brown S, Cotton M (2011) Changes in soil properties and carbon content following compost application: results of on-farm sampling. Compost Sci Util 19:88-97

Brown S, Cogger C, Miltner E (2012) Soil carbon sequestration potential in urban areas. In: Lal R, Augustin B (eds) Carbon sequestration in urban ecosystems. Springer, Berlin, pp 173-196

Brown S, Mahoney M, Sprenger M (2014) A comparison of the efficacy and ecosystem impact of residuals-based and topsoil-based amendments for restoring historic mine tailings in the TriState mining district. Sci Tot Environ 485-486:624-632

Brown S, Kurtz K, Bary A, Cogger C (2011) Long-term effects of organic amendments on soil carbon storage and physical properties. Environ Sci Tech. dx.doi.org/10.1021/es2010418

Bulluck LR, Brosius M, Evanylo GK, Ristaino JB (2002) Organic and synthetic fertility amendments influence soil microbial, physical and chemical properties on organic and conventional farms. Appl Soil Ecol 19:147-160

Caravaca F, Lax A, Albaladejo J (2001) Soil aggregate stability and organic matter in clay and fine silt fractions in urban refuse- amended semiarid soils. Soil Sci Soc Am J 65:1235-1238

Christie P, Easson DL, Picton JR, Love SCP (2001) Agronomic value of alkaline-stabilized sewage biosolids for spring barley. Agron J 93:144-151

Clothier BE, Green SR, Deurer M (2008) Preferential flow and transport in soil: progress and prognosis. Eur J Soil Sci 59:2-13. http://dx.doi.org/10.1111/j.1365-2389.2007.00991.x

Clothier B, Hall A, Deurer M, Green S, Mackay A (2009) Soil ecosystem services: sustaining returns on investment into natural capital. In: Proceedings of the OECD workshop on 'Sustaining soil productivity in response to global climate change-science, policy and ethics'. University of Wisconsin, Wiley Blackwell, June 29-July 1, 2009 
Cogger CG (2005) Potential compost benefits for restoration of soils disturbed by urban development. Sci Util 13(4):243-251

Cogger CG, Bary AI, Fransen SC, Sullivan DM (2001) Seven years of biosolids versus inorganic nitrogen applications to tall fescue. J Environ Qual 30:2188-2194

Cogger CG, Bary AI, Sullivan DM, Myhre EA (2004) Biosolids processing effects on first and second year available N. Soil Sci Soc Am J 68:162-167

Cogger CG, Bary AI, Kennedy AC, Fortuna AM (2013a) Long-term crop and soil response to biosolids applications in dryland wheat. J Environ Qual 42:1872-1880

Cogger CG, Bary AI, Myhre EA, Fortuna AM (2013b) Biosolids applications to tall fescue have long-term influence on soil nitrogen, carbon and phosphorus. J Environ Qual 42:516-522

Costanza R, d'Arge R, de Groot R, Farber S, Grasso M, Hannon B, Limburg K, Naeem S, O'Neill R, Paruelo J, Raskin R, Sutton P, vanden Belt M (1997) The value of the world's ecosystem services and natural capitol. Nature 387:253-260

Doran J (2002) Soil health and global sustainability: translating science into practice. Agric Ecosyst Environ 88:119-127

Evanylo G, Sherony C, Spargo J, Starner D, Brosius M, Haering K (2008) Soil and water environmental effects of fertilizer-, manure-, and compost- based fertility practices in an organic vegetable cropping system. Agric Ecosyst Environ 127:50-58

Khaleel R, Reddy KR, Overcash MR (1981) Changes in soil physical properties due to organic waste applications: a review. J Environ Qual 10:133-141

Kirkham MB, Clothier BE (2007) Loss and recovery of research investment for applied sciences: a salutary lesson from New Zealand. HortTechnology 17(1):9-13

Lal R, Follett RF, Stewart BA, Kimble JM (2007) Carbon sequestration to mitigate climate change and advance food security. Soil Sci 172:943-956

McFarland MJ, Vasquez IR, Vutran M, Schmitz M, Brobst RB, Greenhalgh L (2007) Rangeland restoration using biosolids land application. Water Pract 1:4. doi:10.2175/193317707X243382

McIvor K, Cogger C, Brown S (2012) Effects of biosolids based soil products on soil physical and chemical properties in urban gardens. Compost Sci Util 20:199-206

Montgomery DR (2007) Soil erosion and agricultural sustainability. Proc Natl Acad Sci U S A 104(33): 13268-13272

Park I, Zhang N, Ogunyoku TA, Young TM, Scow KM (2013) Effect of triclosan and biosolids on microbial community composition in an agricultural soil. Water Environ Res 85:2237-2242

Recycled Organics Unit (2006) Life cycle inventory and life cycle assessment for windrow composting systems. The University of New South Wales, Sydney, Australia. Available at http:// www.recycledorganics.com/publications/reports/lca/lca.htm

Robinson DA, Jackson BM, Clothier BE, Cominati EJ, Marchant SC, Cooper DM, Bristow KL (2013) Advances in soil ecosystem services: concepts models and applications for earth system life support. Vadose Zone J doi:10.2136/vzj2013.01.0027

Sullivan DM, Bary AI, Thomas DR, Fransen SC, Cogger CG (2002) Food waste compost effects on fertilizer nitrogen efficiency, available nitrogen and tall fescue yield. Soil Sci Soc Am J 66:154-161

Tian G, Granato TC, Cox AE, Pietz RI, Carlson CR Jr, Abedin Z (2009) Soil carbon sequestration resulting from long-term application of biosolids for land reclamation. J Environ Qual 38:61-74

Wallace BM, Krzic M, Forge TA, Broersma K, Newman RF (2009) Biosolids increase soil aggregation and protection of soil carbon five years after application on a crested wheatgrass pasture. J Environ Qual 38:291-298 


\title{
A Guide to Types of Non Potable Water and the Potential for Reuse in Urban Systems
}

\author{
Sally Brown
}

Agriculture in urban areas in the US and much of the developed world is protected by secure and reliable sources of water for irrigation. Garden hoses have always provided safe and potable water for plants and people. However, there are multiple reasons to look towards other sources in urban areas. Centralized systems have aging infrastructure. Leaks in pipes that both bring potable water to homes as well as collect used water from homes result in significant quantities of wasted water (Ghimire et al. 2014). Treating water to potable standards requires energy and depletes fossil resources. While this is necessary for potable water, water for irrigation does not need to meet the same rigorous standards. Decentralized water collection and use was once commonplace (Van Meter et al. 2014). It is again being looked at as a more sustainable alternative to centralized systems and groundwater irrigation around the world (Van Meter et al. 2014). While much of the focus has been on agricultural systems in rural areas, there are many reasons to apply these approaches for urban agriculture as well.

In large- scale agricultural systems, water is often the most limiting factor for plant growth. Worldwide, crop irrigation accounts for $70 \%$ of our freshwater usage. When rainwater is limiting or when aquifers dry up, our food supply is threatened.

Urban agriculture has additional sources of water that can be used for irrigation: grey water from homes (water from the home other than toilet water), reclaimed water (treated water from wastewater plants), as well as stormwater collected from roofs and streets. Use of each of these types of water has associated costs and benefits. For grey water and stormwater, there is also the potential for safety concerns. In fact, for some municipalities use of these waters is regulated or restricted. This chapter will focus on water sources for urban agriculture. Different types of water with associated risks and benefits will be discussed. Collection systems for the different

\footnotetext{
S. Brown $(\bowtie)$

School of Environmental and Forest Sciences, University of Washington, Seattle, WA, USA

e-mail: slb@uw.edu
} 
waters will be described. Examples of regulations covering use of alternative water sources will be provided. Finally, the potential environmental and economic impacts of use of potable and alternative sources of water for urban agriculture will be discussed.

It is also important to remember that use of alternative sources of water for urban agriculture is new and unexplored territory. Citizens in the US typically have affordable and unlimited access to strictly regulated potable water. Only recently have we recognized that dependence on potable water for a range of uses is not sustainable. Part of that realization includes understanding that alternative sources of water including stormwater, grey water and reclaimed water are good substitutes for potable water for certain uses. There are uncertainties associated with the use of alternative sources of water. These uncertainties are likely to result in some contradictory regulations and understanding of risks and benefits. The information presented in this chapter will reflect that uncertainty.

\section{Types of Water: Stormwater Basics}

Stormwater refers to water that falls from the sky. Stormwater can be a source of irrigation water for urban agriculture from water collected from roofs as well as water collected from streets. It is relatively simple for homeowners to install water collection equipment below rainspouts. Using water collection containers can provide significant quantities of water for irrigation (Fig. 1).

It is possible to estimate how much stormwater can be captured using a collection system. No stormwater collection system is $100 \%$ efficient. The efficiency of a system will depend on the type of surface that the water runs over before it is captured. Collecting stormwater from a metal or slate roof will yield more water, and porous roof surfaces like tiles will yield less water. Here is a tool for estimating how much water can be collected off of a surface. The equations are then used to estimate of how much water a roof system in an area with $100 \mathrm{~cm}$ of annual precipitation can collect in 1 year.

Annual rainfall (inches)* area of the collection surface (SF)* $144 \mathrm{sq}$ inches/SF* $0.00433 \mathrm{gal} /$ cubic inch $* 0.85$ collection efficiency $=$ water available for harvesting Annual rainfall $(\mathrm{cms}) *$ area of the collection surface (Square meters) $* 10,000 \mathrm{~cm}^{2} /$ $\mathrm{m}^{2 * 0.001 ~ l i t e r} / \mathrm{cm}^{2} * 0.85$ collection efficiency $=$ water available for harvesting If the surface area is $100 \mathrm{~m}^{2}$ and the annual rainfall in the area is $100 \mathrm{~cm}$ then: $100 \mathrm{~cm}$ rainfall $* 100 \mathrm{~m}^{2}$ collection area*10,000 $\mathrm{cm}^{2} / \mathrm{m}^{2} * 0.001$ liter $/ \mathrm{cm}^{2 *} 0.85$ efficiency $=85,000$ liters of water per year.

Water collected from roofs is typically clean and not subject to regulations (see regulatory section for additional information). Some cities have active programs to provide rainwater collection barrels to homeowners. Obstacles to rainwater use include having sufficient storage capacity and the necessity of connecting the storage to existing irrigation systems. Cisterns could be constructed to maximize 

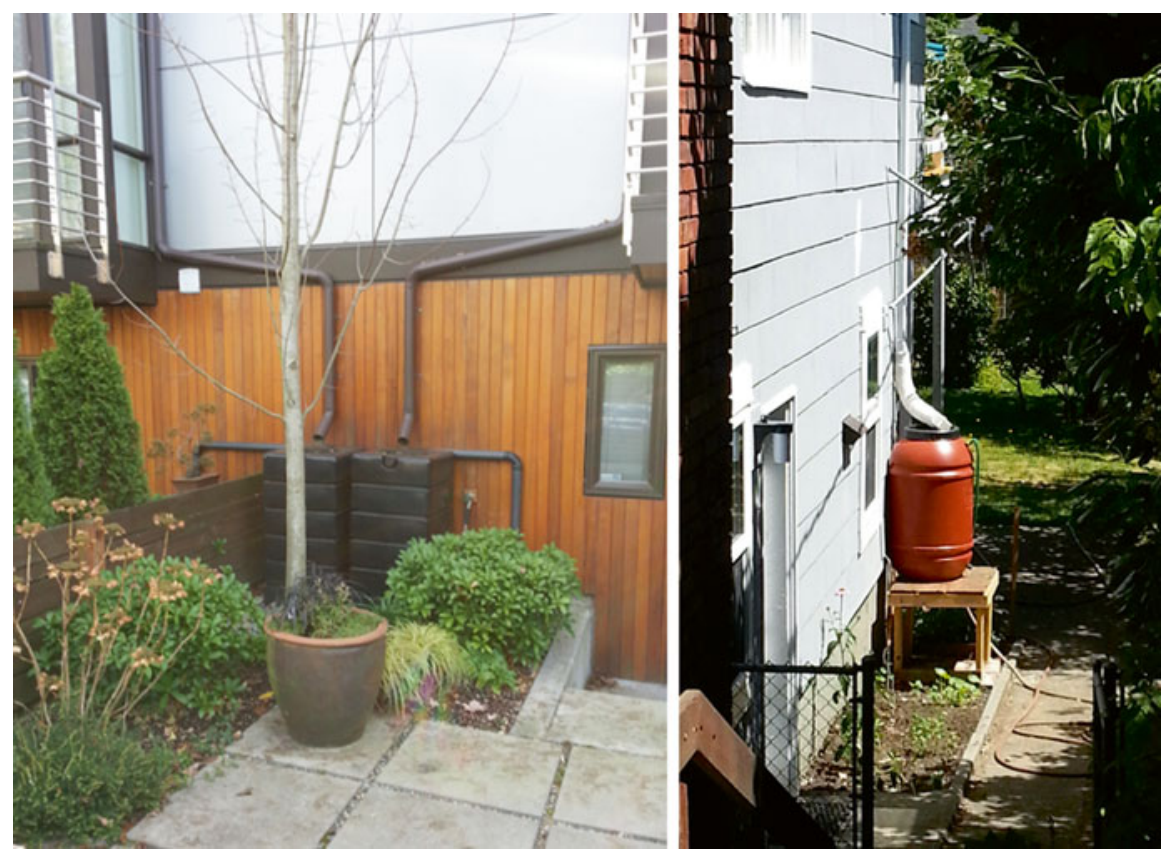

Fig. 1 Stormwater collection barrels in Seattle, WA. The newer home was designed to include a stormwater barrel while at the older home, the owners added the barrel. Seattle Public Utilities sells and delivers rain barrels to customers (http://www.seattle.gov/util/environmentconservation/ mylawngarden/rain_water_harvesting/buyrainbarrels/)

rainwater storage. However, these are costly and might require some type of municipal subsidy to gain wide spread use.

Water falling on streets could also be used for irrigation. Here collection is more problematic and there are concerns about contamination. In urban areas the focus on stormwater treatment has been to move the water away from streets as quickly as possible. Traditionally storm sewers or underground pipes were constructed to expedite water movement off streets and into existing natural water bodies. In many municipalities storm sewers and wastewater treatment piping are one and the same. For these combined systems, rainwater is directed to wastewater treatment plants where it is typically treated and released into natural water bodies. For large storm events, the quantity of precipitation entering these combined systems can overwhelm the ability of the treatment plant to effectively treat the water. When this happens, treatment plants will release excess stormwater mixed with untreated sewage. These releases are referred to as combined sewer overflows (CSO). The Washington, DC water management agency, DC Water has a description for its combined sewer system and the associated potential for overflows (http://www. dcwater.com/wastewater_collection/css/).

CSO releases are regulated under the National Pollutant Discharge Elimination System (NPDES). Municipalities are fined if they exceed a certain number of 
discharges per year (http://cfpub.epa.gov/npdes/home.cfm?program_id=5). As part of this regulatory framework, municipalities are currently working to reduce or eliminate CSOs. Strategies to eliminate or reduce CSOs have been developed using both grey (engineered) or green (natural) systems. For example, DC Water is currently constructing large underground storage tanks to store stormwater (http://www.dcwater.com/workzones/projects/anacostia_tunnel.cfm). This will allow the agency to treat the water gradually over time and will avoid discharges of untreated stormwater and wastewater. These types of solutions are very costly. Portland, OR has opted to integrate green stormwater infrastructure in combination with engineered systems as a way to reduce costs. The Tabor to the River project (http://www.portlandoregon.gov/bes/47591) has involved planting trees and rain gardens in addition to replacing sewer pipe. Including the green infrastructure in this effort has reduced the cost of the project from $\$ 144$ million for a fully engineered solution to $\$ 63$ million.

There is a potential for stormwater diverted from treatment plants to green infrastructure to be used for food production. It is easy to imagine for example, curbside or parking strip gardens receiving stormwater. However, there are concerns about contaminants in stormwater and the safety of using this water for food production. Contaminants in stormwater will originate from vehicular traffic and buildings (tires, brake pads, exhaust, and road building materials), soil and sediments and trash (Ingvertsen et al. 2011). Stormwater can also carry particles from dry deposition of particulates in urban air (Kabir et al. 2014). Pathogens from fecal material or dead animals may also be present.

Research has characterized contaminants in stormwater. Nutrients are often the primary contaminants of concern in stormwater due to their negative impacts on receiving fresh water bodies (Kabir et al. 2014). Both nitrogen and phosphorus are typically elevated in stormwater suggesting that use of green infrastructure for stormwater treatment will provide plants with a portion of their required nutrients. Stormwater will typically contain very low levels of metals, some organic contaminants, pathogens and dissolved organic matter (Kabir et al. 2014; McElmurry et al. 2014). The metals most commonly detected in stormwater are copper and zinc, both of which are necessary plant nutrients (Ingvertsen et al. 2011). Other metals including lead, cadmium, and chromium may also be detected, typically at low parts per billion concentrations (Kabir et al. 2014). Organic contaminants in stormwater are likely to consist of petroleum hydrocarbons, herbicide or pesticides and dissolved or suspended organic matter from soils (LeFevre et al. 2012). One study showed that dissolved organic matter in urban stormwater is similar in characteristics to suburban stormwater and water collected from parking lots (McElmurry et al. 2014). Although a study noted increased concentrations of hormones and wastewater micropollutants in CSOs, the observed increase was due to the release of untreated wastewater rather than elevated concentrations of these compounds in stormwater (Phillips et al. 2012).

There are currently no studies about the feasibility of using urban stormwater collected from streets for food production. There are also no regulations on use of these waters. As green infrastructure becomes more common in urban areas, there 
will likely be some evaluation of the potential for these waters to be used for some type of agricultural production. In the absence of regulations and based on information characterizing the contaminants in stormwater, it would seem advisable to limit use of street stormwater to irrigate crops that have no direct contact with soils. While previous work has suggested low availability of metal and organic contaminants from urban soils, the potential for pathogen transfer is likely the most significant concern with beneficial use of this water source (Attanayake et al. 2014). Tree fruits or bushes for example, could be grown using stormwater with minimal risk of pathogen transfer. Crops like carrots or potatoes would have a much higher risk due to the direct contact of the edible portion with the soil.

\section{Reclaimed Water Basics}

In urban areas, all wastewater flows through a centralized system of pipes to wastewater treatment plants. These plants have been designed to remove wastes (primarily dissolved carbon, nutrients, and pathogens) from the water through a combination of biological and chemical processes (Metcalf and Eddy 2003). The solids from these processes are typically treated to stabilize the organic matter and further reduce pathogens. These treated solids, termed biosolids, can then be used as a soil conditioner and fertilizer. Use of biosolids for urban agriculture is discussed in an upcoming chapter. The treated water from these facilities is typically discharged into a natural water body such as a river or lake. Most plants were constructed at low points in the topography so that water flow to the plants would be assisted by gravity. They are also typically located near water to facilitate discharge of the treated effluent. Most of the wastewater treatment plants in the US were constructed or last upgraded after passage of the Clean Water Act when concerns about water availability were much less pronounced then they are today. As a result, very few of these plants were constructed with the necessary infrastructure to divert the treated water from discharge into water bodies to beneficial use sites. Retrofitting these systems to facilitate beneficial use of the treated water involves constructing the necessary underground piping and pumping to deliver the treated water to end use points. Because of the expense associated with this type of capital project, it has typically only been done in areas where fresh water resources are scarce or when new plants and infrastructure are being constructed (http://www.kingcounty.gov/environment/ wastewater/ResourceRecovery/ReWater.aspx).

Currently, California, Florida, Texas and Arizona are the states with the most developed reclaimed water use infrastructure. End users are typically large-scale sites such as golf courses or commercial farms (US EPA 2012). Because of the high infrastructure costs, large-scale use of reclaimed water for urban agriculture may be limited. However, there is a potential for use in farms on the perimeter of cities or for larger farms in urban areas (Fig. 2).

Grey water basics are covered in a following chapter. 


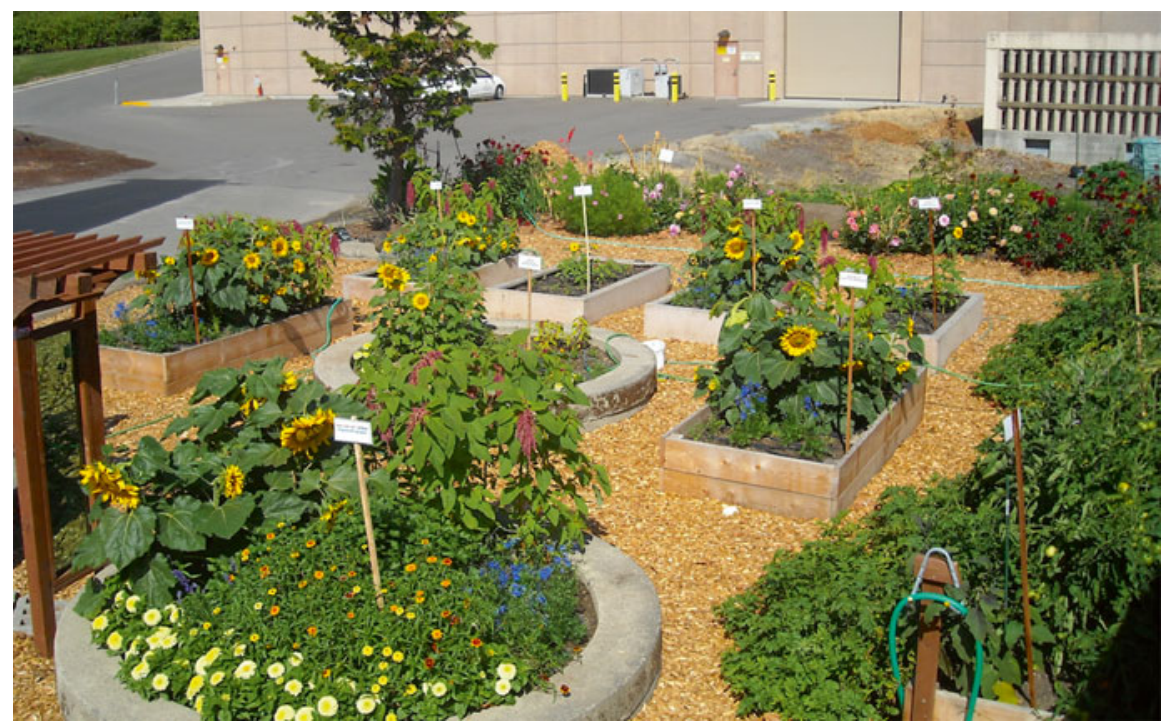

Fig. 2 A reclaimed water and biosolids compost demonstration garden at the South Treatment Plant operated by the King County Wastewater Treatment Division. The garden includes both edible and ornamental crops and is used as a way to educate potential customers and the general public about the benefits and safety of reclaimed water use. Picture Jo Sullivan

\section{Regulations on Potable Water Alternatives}

\section{Rainwater}

There are currently no regulations concerning use of rainwater for growing food crops. Summaries of rainwater regulations and guidance on a state by state basis can be found at the following websites: American Rainwater Catchment Systems Association (www.arcsa.org) and the National Conference of State Legislatures (http://www.ncsl.org/research/environment-and-natural-resources/rainwaterharvesting.aspx).

Many states have guidance on how to collect rainwater, likely quantities of rainwater that can be collected, how to store rainwater and how to filter and treat the collected water for different end uses. For example, Texas has a rainwater harvesting manual that includes a wealth of information on multiple aspects of rainwater harvesting (http://www.ecy.wa.gov/programs/wr/hq/pdf/texas_rw_harvestmanual_ 3rdedition.pdf). The manual includes information on types of collection systems, expected efficiencies of different systems, water quality and treatment, water balance and system sizing, best management practices, costs and available incentives for both individuals and municipal structures. According to the manual, it is important to consider the roofing material to determine both if a rainwater collection system is recommended and the expected efficiencies of different systems. For example, roofs made of clay or concrete tile are porous. While these materials will not impact 
water quality, they will reduce efficiency as a result of loss from texture, slower flow and increased evaporation. Roofs made from composite or asphalt are likely to leach toxins and so should not be used for collection of potable water but can be used for collection of irrigation water.

Multiple sources recommend that the 'first flush' of water, the first water collected after a dry spell, will likely have higher concentrations of particulates and contaminants than water collected from a primed surface. There is also information provided on how to filter particulates from collection systems and how to remove contaminants or pathogens from these systems. Most of these manuals were written with multiple uses of collected water as a focus. Specific consideration of use of the water for food crop irrigation is absent, however guidelines can be interpreted with this in mind.

\section{Grey Water}

Reuse of grey water is more heavily regulated than use of stormwater. In some cases reuse of grey water is prohibited while in others regulations governing reuse are in place or being established. The Washington State Department of Health recently codified regulations on grey water reuse for subsurface irrigation (http://www. thegreywaterguide.com/washington-state.html). These regulations separate grey water into two categories: light grey water and dark grey water. Light grey water originates from bathroom sinks, showers, and clothes washing machines. Dark grey water originates from kitchen sinks and dishwaters, non-laundry utility sinks, and any other water used in the home that has not come into contact with black water (water from toilets or urinals). There are specific regulations based both on the type of grey water and on the quantity of grey water that is generated (Table 1). This tiered system was put into place to require increasing levels of treatment and certain use restrictions based on the expected concentrations of hazardous materials

Table 1 Regulations on greywater use based on source of water and on size of system developed by the Washington State Department of Health and codified in Chapter 246-247 WAC

\begin{tabular}{|c|c|c|c|c|}
\hline $\begin{array}{l}\text { Project } \\
\text { type }\end{array}$ & $\begin{array}{l}\text { Source of } \\
\text { greywater }\end{array}$ & Storage & Quantity & Treatment and distribution \\
\hline Tier one & $\begin{array}{l}\text { Light } \\
\text { greywater }\end{array}$ & None & $\begin{array}{l}\text { Less than } 60 \text { gal per } \\
\text { day per irrigation } \\
\text { system- limit } 2 \text { per } \\
\text { building }\end{array}$ & $\begin{array}{l}\text { No treatment- gravity (exception: } \\
\text { treatment is required when used } \\
\text { in a public location such as a } \\
\text { playground, school, church or } \\
\text { park) }\end{array}$ \\
\hline Tier two & & $\begin{array}{l}\text { Less } \\
\text { than } 24 \mathrm{~h} \\
\text { per day }\end{array}$ & $\begin{array}{l}\text { Less than } 3500 \text { gal } \\
\text { per day }\end{array}$ & $\begin{array}{l}\text { No treatment- even distribution } \\
\text { (typically by pressure) }\end{array}$ \\
\hline Tier three & $\begin{array}{l}\text { Dark } \\
\text { greywater }\end{array}$ & No limit & $\begin{array}{l}\text { Less than } 3500 \text { gal } \\
\text { per day }\end{array}$ & $\begin{array}{l}\text { Treatment required- even } \\
\text { distribution (typically by } \\
\text { pressure) }\end{array}$ \\
\hline
\end{tabular}

The regulations were put into place in July, 2011 
in the grey water. For example, the Tier three system is required to treat dark grey water, light grey water stored for more than $24 \mathrm{~h}$ (time for pathogen and algal growth), or any water type to be used in a green roof or public environment (http:// www.doh.wa.gov/Portals/1/Documents/Pubs/337-063.pdf).

Arizona has similar but somewhat less restrictive regulations (http://www.azdeq. gov/environ/water/permits/download/graybro.pdf). While greywater may only be used for irrigation, both flood and subsurface irrigation are allowed. Reuse of greywater by homeowners is allowed without any permitting with the provision that homeowners follow recommended best management practices. In contrast, regulations in California are more complex and include a consideration of soil type in determining how much water a system can absorb. Permits are required for systems that reuse any water in addition to water generated by clothes washing machines (http://www.hcd.ca.gov/codes/shl/2007CPC_Graywater_Complete_2-2-10.pdf). Other states currently ban or severely restrict the use of greywater. In Florida, use of greywater is limited to flushing toilets and water must be treated before it can be used (http://edis.ifas.ufl.edu/ae453). However, this is likely to change as the environmental and economic benefits of greywater reuse are appreciated and the risks associated with use are better understood. For example, although greywater use is currently banned in most states, it is easy to find isolated examples of reuse for various purposes (http://blog.chicagolandh2o.org/2012/11/08/how-soon-is-now-the-future-of-water-reuse-becomes-reality-at-an-oak-park-home/). These examples are likely the first steps to more universal acceptance of greywater use including use for irrigating food crops.

\section{Laundry to Landscape- Greywater Use in Northern California}

Daily Acts is a nonprofit located in Petaluma, CA (http://dailyacts.org/ dao-home). It was founded in 2002 by Trathen Heckman with the goal of demonstrating how daily acts by families and individuals could both nurture community and have a positive environmental impact. Daily Acts is one of about 150 similar nonprofits in the US focused on building personal and community resilience (http://www.transitionus.org/). Daily Acts is currently working with a number of municipalities in Northern California to facilitate adoption of grey water diversion from wastewater to home lawns and gardens in a program that Heckman refers to as 'Laundry to Landscape'.

Although grey water use in California had been legal, it had not been widely adopted due to a very cumbersome permitting process along with high costs for system installation and restrictions on water end use. The push for broader acceptance of grey water reuse in California began as an environmental movement rather than as a municipal cost savings or water conservation initiative. For example, Greywater Action (http://greywateraction.org/) and the Greywater Guerrillas (http://www.nytimes.com/2007/05/31/garden/31 gre ywater.html?pagewanted=all) were two groups pushing for a regulatory structure 
that would promote grey water reuse. This has evolved and continues to evolve in Northern CA over time. A series of workgroups, combining a broad range of stakeholders has helped to engender confidence in the safety of less restrictive grey water use, which in turn has enabled broader adoption of Laundry to Landscape.

In 2008 the California State Senate Bill 1258 directed the Department of Housing and Community Development to develop revised standards for indoor and outdoor uses for residential grey water systems. An initial group was put together prior to the grey water bill revisions that took place in 2008 . Heckman was invited to participate in the process in preparation for the rewriting of the regulations. The group included a broad range of stakeholders who, through an iterative process, developed a white paper that provided the background for the revisions. A civil engineer was involved in the process and provided engineering approval to the suggested revisions. This was critical to public and regulatory acceptance of the more liberal rule that was developed. Also critical was a simple system, where a branched drain was used to divert water from home washing machines into yards. The system had been approved by the City of Berkeley. Having a model system to include in the discussion was also an effective tool to facilitate regulatory change.

It is now possible to install a greywater system in homes in a growing number of municipalities in Northern California without a permit. In some cases, the municipality will also provide subsidies for purchasing greywater systems and training for instillation and use. It is not permitted to use the greywater to grow crops that come into direct contact with soil. However, use of the water to irrigate fruit trees and other edibles that do not contact the soil is encouraged. Daily Acts held a first training workshop in Petaluma in 2010 with 5 systems installed. A neighboring town, Santa Rosa was also interested and so held a shorter weekend training, again led by Daily Acts with a total of 12 systems installed. In 2012 Daily Acts had a 100 Greywater Systems Challenge in partnership with four municipalities. A free workshop in Petaluma attracted 80 participants. For each family of four who does this conversion, 5000-8000 gal of water are diverted from centralized treatment facilities to soils.

Heckman considers himself to be a permaculture- ecological designer using a holistic perspective to apply the principles and functions of natural systems to homes and municipalities. Reuse of greywater fits directly into this vision. Conserving and catching water is one of the core elements of permaculture. He says that 'we can change the world in a garden'. A greywater system as part of a natural garden landscape with medicinal plants, edible plants, bees and chickens is a means to educate people. Heckman has seen that reconnecting people to the hydrological cycle through greywater diversion in their homes is a very powerful tool with broader implications. While Daily Acts did not set out to be greywater experts, he now recognizes that greywater is a perfect entry point into ecological design and a sustainable world (Fig. 3). 


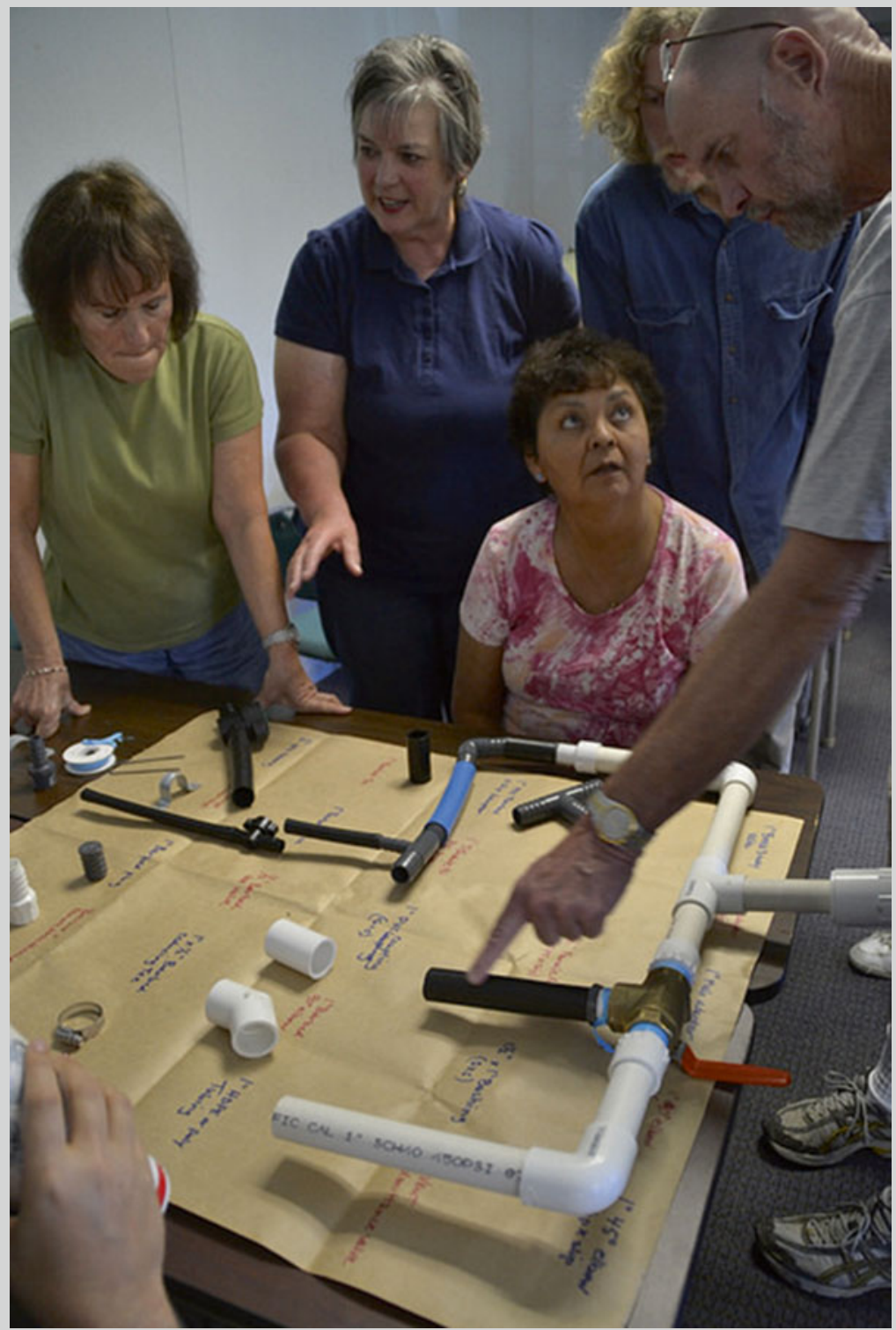

Fig. 3 A greywater workshop hosted by Daily Acts. The pictures show an indoor demonstration of the plumbing retrofit required, changing the plumbing on a washing machine, and installing the irrigation system outside a home (Photos Daily Acts) 


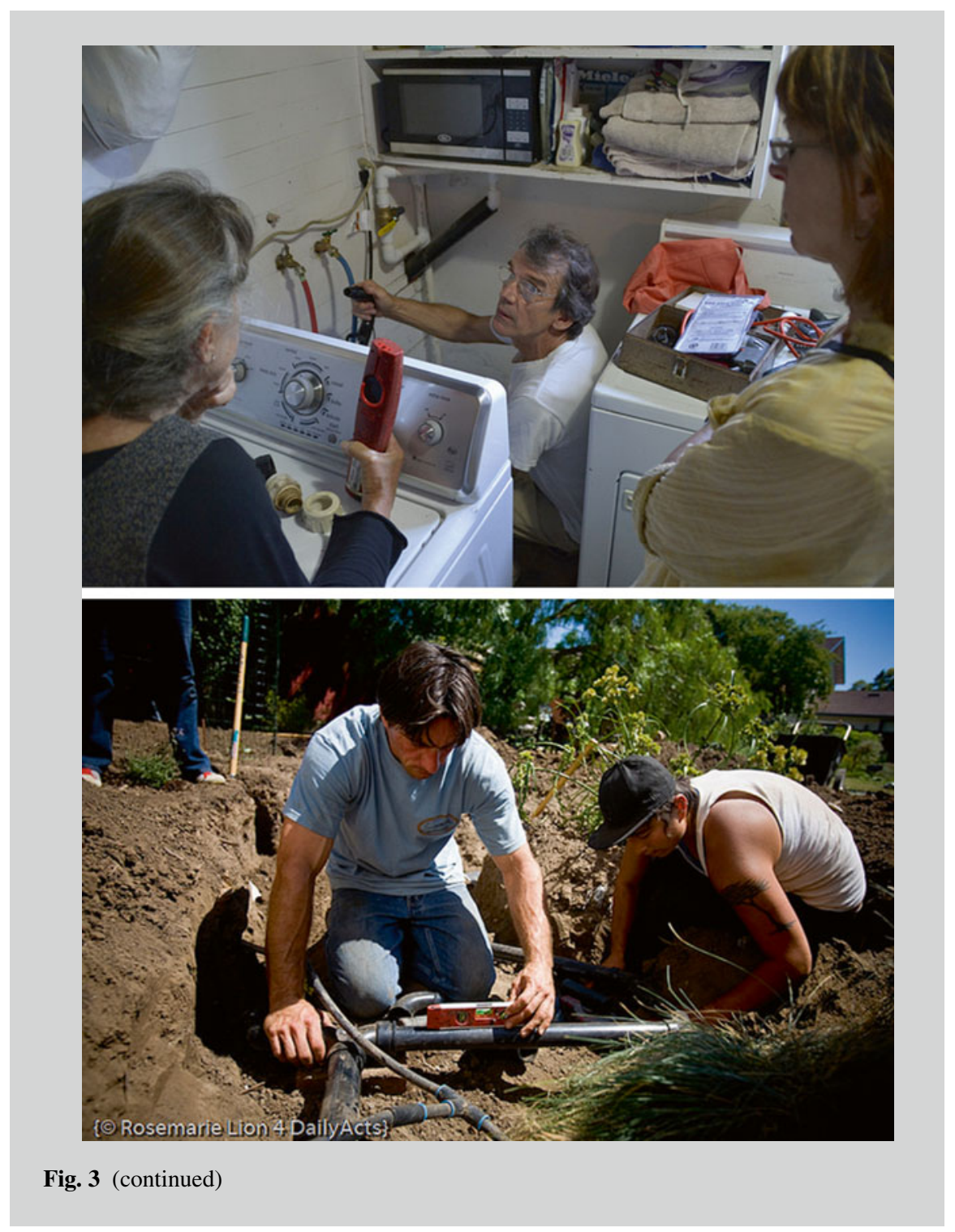

\section{Reclaimed Water}

Reclaimed water is effluent from municipal wastewater treatment plants that has been treated to a high enough standard to be suitable for different end uses. This water is very easy to regulate and very difficult to distribute. The water is generated by public facilities that are already subject to a range of regulatory requirements and oversight. 
Table 2 EPA guidelines for reclaimed water use for urban and agricultural uses

\begin{tabular}{|c|c|c|c|c|}
\hline & Treatment & \begin{tabular}{|l|} 
Reclaimed \\
water quality
\end{tabular} & $\begin{array}{l}\text { Reclaimed water } \\
\text { monitoring }\end{array}$ & Setback distances \\
\hline \multirow[t]{5}{*}{ Urban reuse } & Secondary & $\mathrm{pH}=6.0-9.0$ & pH- weekly & $\begin{array}{l}50 \mathrm{ft}(15 \mathrm{~m}) \text { to } \\
\text { potable water } \\
\text { supply wells; } \\
\text { increased to } 100 \mathrm{ft} \\
(30 \mathrm{~m}) \text { when } \\
\text { located in porous } \\
\text { media }\end{array}$ \\
\hline & Filtration & $\leq 10 \mathrm{mg} / \mathrm{l} \mathrm{BOD}$ & BOD- weekly & \\
\hline & Disinfection & $\leq 2 \mathrm{NTU}$ & Turbidity- continuous & \\
\hline & & $\begin{array}{l}\text { No detectable fecal } \\
\text { coliform } / 100 \mathrm{ml}\end{array}$ & Fecal coliform- daily & \\
\hline & & $\begin{array}{l}1 \mathrm{mg} / \mathrm{l} \mathrm{Cl} \mathrm{Cl}_{2} \\
\text { residual (min.) }\end{array}$ & $\begin{array}{l}\mathrm{Cl}_{2} \\
\text { residual- continuous }\end{array}$ & \\
\hline \multirow[t]{5}{*}{$\begin{array}{l}\text { Agricultural } \\
\text { reuse }\end{array}$} & Secondary & $\mathrm{pH}=6.0-9.0$ & pH- weekly & $\begin{array}{l}50 \mathrm{ft}(15 \mathrm{~m}) \text { to } \\
\text { potable water } \\
\text { supply wells; } \\
\text { increased to } 100 \mathrm{ft} \\
(30 \mathrm{~m}) \text { when } \\
\text { located in porous } \\
\text { media }\end{array}$ \\
\hline & Filtration & $\leq 10 \mathrm{mg} / \mathrm{l} \mathrm{BOD}$ & BOD- weekly & \\
\hline & Disinfection & $\leq 2 \mathrm{NTU}$ & Turbidity- continuous & \\
\hline & & $\begin{array}{l}\text { No detectable fecal } \\
\text { coliform } / 100 \mathrm{ml}\end{array}$ & Fecal coliform- daily & \\
\hline & & $\begin{array}{l}1 \mathrm{mg} / \mathrm{l} \mathrm{Cl} \mathrm{Cl}_{2} \\
\text { residual (min.) }\end{array}$ & $\begin{array}{l}\mathrm{Cl}_{2} \\
\text { residual- continuous }\end{array}$ & \\
\hline
\end{tabular}

The analysis conducted to meet these requirements is similar to what is required to test water to determine if it is acceptable for beneficial reuse. The US EPA has established guidelines for water reuse (Table 2). The guidelines, last issued in 2012, include recommendations for water quality standards for different types of reuse, a discussion of technical and legal issues associated with reuse along with examples (http://water.epa.gov/infrastructure/sustain/availability_wp.cfm).

Urban use is typically considered to be limited to landscape and golf course irrigation with no specific provisions for urban agriculture. The EPA recommended guidelines for unrestricted use of reclaimed water for urban irrigation and irrigation for food crops that may be eaten raw are shown in Table 2. Guidelines for both end uses are identical, suggesting that if reclaimed water meets standards for unrestricted landscape irrigation it would also be suitable for edible crop irrigation. EPA also has additional recommendations for water quality for crop irrigation. These recommendations are designed to protect the plants that are being irrigated rather than the people that would eat the plants. A portion of these are shown in Table 3. These guidelines focus on the potential for reclaimed water to increase soil salinity and the availability of certain inorganic ions to hinder plant growth. 
Table 3 Recommendations for reclaimed water characteristics to protect plant health from US EPA

\begin{tabular}{|c|c|c|c|c|c|c|}
\hline Potential problem & & Units & None & $\begin{array}{l}\text { Slight to } \\
\text { moderate }\end{array}$ & \multicolumn{2}{|l|}{ Severe } \\
\hline \multicolumn{7}{|l|}{ Salinity } \\
\hline & \begin{tabular}{|l|}
$\begin{array}{l}\text { Electrical } \\
\text { conductivity (EC) }\end{array}$ \\
\end{tabular} & $\mathrm{dS} / \mathrm{m}$ & $<0.7$ & $0.7-3.0$ & $>3.0$ & \\
\hline & $\begin{array}{l}\text { Total dissolved } \\
\text { solids (TDS) }\end{array}$ & $\mathrm{mg} / \mathrm{L}$ & $<450$ & $450-2000$ & $>2000$ & \\
\hline \multicolumn{7}{|l|}{ Infiltration } \\
\hline \multicolumn{7}{|l|}{$\begin{array}{l}\text { Sodium adsoprtion } \\
\text { ratio (SAR) }\end{array}$} \\
\hline & $0-3$ & & & $>0.7$ & $0.7-0.2$ & $<0.2$ \\
\hline & $3-6$ & & $\begin{array}{l}\text { And } \\
\mathrm{EC}=\end{array}$ & $>1.2$ & $1.2-0.3$ & $<0.3$ \\
\hline & $6-12$ & & & $>1.9$ & $1.9-0.5$ & $<0.5$ \\
\hline & $12-20$ & & & $>2.9$ & $2.9-1.3$ & $<1.3$ \\
\hline & $20-40$ & & & $>5.0$ & $5.0-2.9$ & $<2.9$ \\
\hline \multicolumn{7}{|l|}{ Specific ion toxicity } \\
\hline & Sodium $(\mathrm{Na})$ & & & & & \\
\hline & Surface irrigation & SAR & $<3$ & $3-9$ & $>9$ & \\
\hline & Sprinkler irrigation & meq/l & $<3$ & $>3$ & & \\
\hline & Chloride $(\mathrm{Cl})$ & & & & & \\
\hline & Surface irrigation & $\mathrm{meq} / \mathrm{l}$ & $<4$ & $4-10$ & $>10$ & \\
\hline & Sprinkler irrigation & $\mathrm{meq} / \mathrm{l}$ & $<3$ & $>3$ & & \\
\hline & Boron (B) & & $\mathrm{mg} / \mathrm{L}$ & $<0.7$ & $0.7-3.0$ & $>3$ \\
\hline
\end{tabular}

For both cases, concentrations are defined that will be acceptable for plants that are watered primarily using reclaimed water.

When reclaimed water meets required standards, use for food crop or landscape irrigation is generally broadly supported. In general, use of reclaimed water is increasing across the country. Different states have different regulations governing water quality for unrestricted irrigation of food crops as well as for urban use. Currently 32 States have water quality guidelines for urban irrigation water quality and 27 have guidelines for agricultural irrigation of food crops. As of 2011,29\% of the reclaimed water that was beneficially used was used for agricultural irrigation with $18 \%$ used for landscape or golf course irrigation. This is expected to increase rapidly (US EPA 2012).

\section{Environmental Benefits}

Watering a garden using a hose connected to the home's water supply uses water that has been treated to drinking water standards to grow food. With grey water or stormwater, water that would otherwise have required treatment is being used, 
while at the same time potable water is being conserved. Use of reclaimed water is using treated water, but also conserving potable water. There are multiple environmental benefits associated with using alternative water sources to irrigate a garden, but the primary benefits are linked to reducing the amount of water that requires treatment on either end of the pipeline. While these benefits will vary based on the source of the water that is used and the nature of the drinking water and wastewater infrastructure in a particular area, in general the practices prevent water from entering the stormwater or wastewater treatment systems and also reduces the quantity of water that needs to be treated to meet potable water standards.

Alternative water sources save both energy and money. The energy savings from diverting water from centralized treatment as well as the monetary savings from reduced infrastructure requirements and the associated capital costs for constructing that infrastructure can be estimated (Center for Neighborhood Technology 2010; Ghimire et al. 2014). A recent study quantified the benefits of domestic stormwater harvesting using life cycle assessment. The collected water was directed towards toilet flushing but benefits would likely be similar if the water was used for irrigation (Ghimire et al. 2014). The authors found that use of harvested rainwater conserved energy, and reduced fossil fuel use, eutrophication potential, and potable water use. Human health benefits (including cancer, non cancer, and health criteria air pollutants) also benefitted from domestic rainwater harvesting.

In a midsized city, the local wastewater utility uses about $343 \mathrm{kWh}$ to treat $1000 \mathrm{~m}^{3}$ of water. It is possible to calculate the fossil fuel use associated with that by using the specific $\mathrm{CO}_{2}$ equivalent for electricity in that region. Using the US EPA calculator, this amount of energy ( $343 \mathrm{kWh}$ ) is similar to that released by burning $27 \mathrm{gal}$ of gasoline. There is also an economic cost for stormwater treatment. For example, the City of Chicago spends $\$ 0.025$ for every cubic meter of stormwater it treats. For each $100 \mathrm{~m}^{2}$ roof in that city that installs a rainwater collection system (about the size of a single family home), the city saves about $\$ 2.09$ in treatment costs annually. If a new subdivision were constructed where all homes had stormwater collection, the city would also be able to reduce the size of the treatment facility. The City of Portland has estimated that the cost of grey or engineered infrastructure for each square meter of impervious surface is about $\$ 29.00$. If citizens harvest rainwater from the roof of their homes and used it to water their gardens, these emissions and dollar costs are avoided. If greywater is diverted from treatment and this is done on a large enough scale, similar savings are achieved.

\section{References}

American Rainwater Catchment Systems Association (www.arcsa.org)

Arizona Department of Environmental Quality. http://www.azdeq.gov/environ/water/permits/ download/graybro.pdf

Attanayake CP, Hettiarachchi GM, Harms A, Presley D, Martin S, Pierzynski GM (2014) Field evaluations on soil plant transfer of lead from urban garden soil. J Environ Qual 43:475-487

California http://www.hcd.ca.gov/codes/shl/2007CPC_Graywater_Complete_2-2-10.pdf 
Center for Neighborhood Technology (2010) The value of green infrastructure a guide to recognizing its economic, environmental and social benefits. www.cnt.org/.../gi-values-guide.pdf

Florida http://edis.ifas.ufl.edu/ae453

Ghimire SR, Johnston JM, Ingwersen WW, Hawkins TR (2014) Life cycle assessment of domestic and agricultural rainwater harvesting systems. Environ Sci Tech 48:4069-4077

Ingvertsen ST, Bergen Jensen M, Magid J (2011) A minimum data set of water quality parameters to assess and compare treatment efficiency of stormwater facilities. J Environ Qual 40:1488-1502

Kabir MI, Daly E, Maggi F (2014) A review of ion and metal pollutants in urban greenwater infrastructures. Sci Tot Environ 470-471:695-706

LeFevre GH, Novak PJ, Hozalski RM (2012) Fate of naphthalene in laboratory- scale bioretention cells: implications for sustainable stormwater management. Environ Sci Tech 46:995-1002

McElmurry SP, Long DT, Voice TC (2014) Stormwater dissolved organic matter: influence of land cover and environmental factors. Environ Sci Tech 48:45-53

Metcalf \& Eddy (2003) Wastewater engineering: treatment and reuse, 4th edn. Metcalf \& Eddy/ McGraw-Hill, New York

National Conference of State Legislatures http://www.ncsl.org/research/environment-and-naturalresources/rainwater-harvesting.aspx

Phillips PJ, Chalmers AT, Gray JL, Kolpin DW, Foreman WT, Wall GR (2012) Combined sewer overflows: an environmental source of hormones and wastewater micropollutants. Environ Sci Tech 46:5336-5343

Texas Rainwater Harvest Manual http://www.ecy.wa.gov/programs/wr/hq/pdf/texas_rw_ harvestmanual_3rdedition.pdf

US EPA (2012) Guidelines for Water Reuse. EPA/600/R-12/618. http://nepis.epa.gov/Adobe/PDF/ P100FS7K.pdf

Van Meter KJ, Basu NB, Tate E, Wyckoff J (2014) Monsoon harvests: the living legacies of rainwater harvesting systems in South India. Environ Sci Technol 48:4217-4225

Washington State Department of Health http://www.thegreywaterguide.com/washington-state.html 


\title{
Graywater Reuse for Irrigation: Benefits and Potential Hazards
}

\author{
Ian Pepper
}

\section{Definition of Graywater}

Graywater has been defined as all wastewaters generated in the household, except toilet wastes (Ingham 1980). A more recent definition is: "all flows exiting an urban building" (Winward et al. 2008a). Thus graywater includes wastewater from bathroom sinks, baths, showers, laundry facilities, dishwaters and sometimes, kitchen sinks. Due to the various household uses of water, graywater gets its name from its less than pristine appearance, and has led to an informal definition of water based on its appearance (Information Box 1).

Graywater can be further classified as "low load" and "high load" in terms of organic strength or concentration. Low load graywater does not contain kitchen and laundry wastewater which tends to have more organic contaminants than other household sources of graywater (Friedler 2004).

\section{Quantities of Graywater Generated by Households}

In terms of total water usage per person in a household, the amount of graywater produced vastly exceeds the amount of potable water consumed. Potable water consumption varies with a number of factors including gender, health, exercise and climate, but in general is between 2 and 41 of water per person per day.

The total water use for families also varies depending on a number of variables and can range from 20 to 301 per person per day in poorer areas, to over several

\footnotetext{
I. Pepper $(\bowtie)$

Director, Water \& Energy Sustainable Technology Center,

The University of Arizona, Tucson, AZ, USA

e-mail: ipepper@ag.arizona.edu
} 
Information Box 1 Colloquial definition of water based on its appearance

\begin{tabular}{l|l}
\hline Type of water & Colloquial name \\
\hline Potable water & White water \\
\hline Household wastewater & Graywater \\
\hline $\begin{array}{l}\text { Toilet waste/sewage } \\
\text { water }\end{array}$ & Blackwater \\
\hline
\end{tabular}

Table 1 Per capita in-house usage (Loh and Coghlan 2003)

\begin{tabular}{l|l|l}
\hline \multirow{2}{*}{ Appliance } & \multicolumn{2}{|l}{$\begin{array}{l}\text { Residential premise } \\
\text { (single household) }\end{array}$} \\
\cline { 2 - 3 } & $\begin{array}{l}\text { L/house/ } \\
\text { day }^{\mathrm{a}}\end{array}$ & $\begin{array}{l}\text { L/person/ } \\
\text { day }\end{array}$ \\
\hline Bath and shower & 198 & 66 \\
\hline Washing machine & 141 & 47 \\
\hline Sub-total graywater & 339 & 113 \\
\hline Toilet & 124 & 41 \\
\hline $\begin{array}{l}\text { Taps (includes } \\
\text { kitchen) }\end{array}$ & 140 & 47 \\
\hline Total in-house & 603 & 201 \\
\hline
\end{tabular}

${ }^{a}$ Based on 3 people per house

hundred liters per day for more wealthy individuals. However, an estimate of 120 2401 per day might be considered "normal" usage. The amount of graywater generated from various household practices is shown in Table 1. This data was generated in Sydney Australia, and is based on a household consisting of three people. In the scenario presented, 3391 of graywater were produced daily, whereas approximately 2231 per day of water were utilized for garden and lawn irrigation, car washing and swimming pools (Sydney Water 2005). Note that the largest source of graywater is from bathing and showers. Thus it is estimated that reusing graywater for irrigation could save between 50,000 and 100,000 1 of potable water per household annually (NSW Government 2008).

\section{Uses of Graywater}

For most homeowners, the obvious and most simple way to reuse graywater is to pipe it directly outside and use it for irrigation of gardens, lawns, ornamental plants or fruit trees. The mechanisms for moving graywater from the home to the targeted area for irrigation can be as simple as manual bucketing for small quantities of graywater, or as complex as the construction and use of sophisticated diversion systems (Fig. 1a, b, c). These systems are designed for immediate use of graywater, since graywater should not be stored for longer than one day prior to use. If graywater is to be utilized for purposes other than irrigation, such as toilet flushing, then additional treatment to improve the water quality is necessary prior to such usage. Note also that since using graywater for irrigation may be limited seasonally, then there 
a

\section{SAMPLE SYSTEMS}

The following graphics are provided to convey the wide variety of systems that can be designed for retrofitting a home and to help you design and install your own system.

\section{Gravity System}
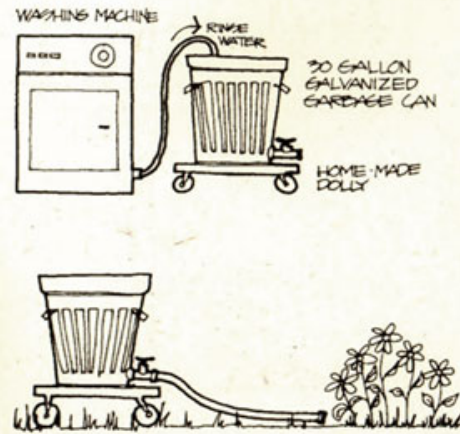

Gravity System with Portable Tank b

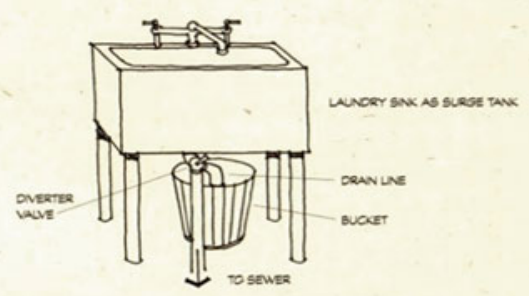

Bucket Graywater System

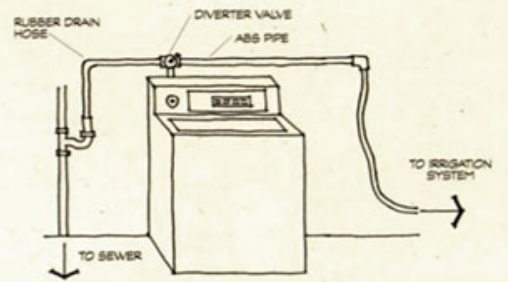

Hose Attachment Graywater System

c

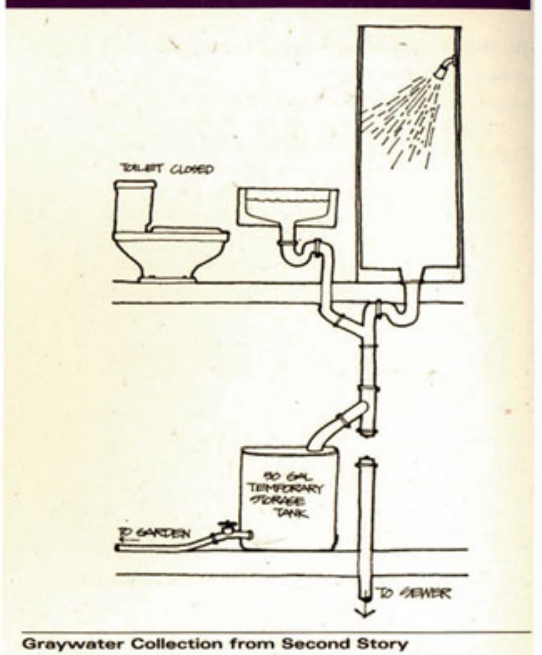

Fig. 1 Sample systems for diverting graywater: (a) gravity systems; (b) hose attachment system; and (c) collection from second story

must be easy mechanisms to cut off the graywater diversion systems, and resupply the graywater sources back into the sewer or septic system when necessary. When irrigating with graywater, the water can be supplied via flood irrigation or drip irrigation (surface or subsurface), but never via a sprinkler system. Basic guidelines for using graywater for irrigation are shown in Information Box 2. 
Information Box 2 Guidelines for safe use of graywater

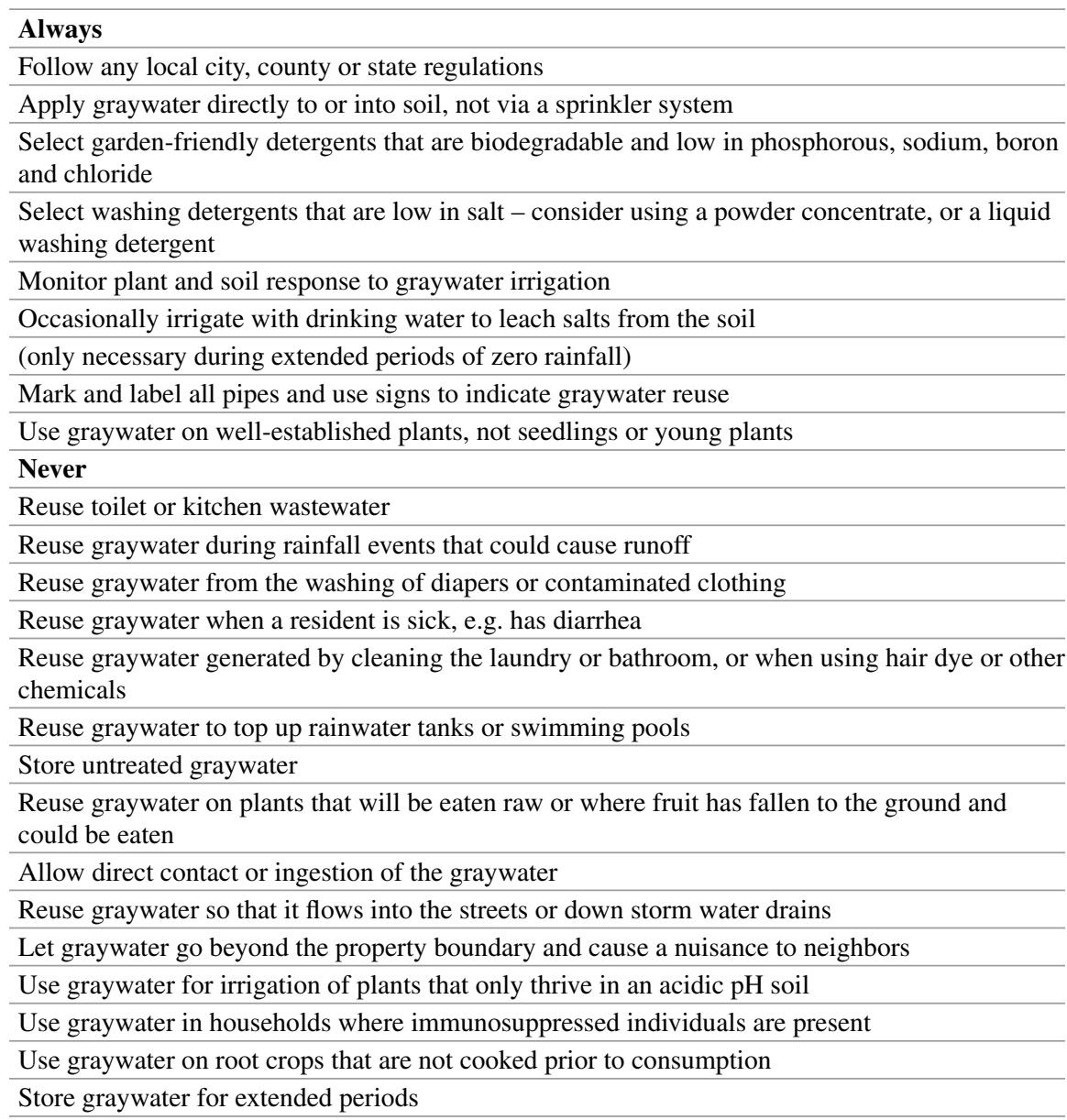

Adapted from NSW Government (2008)

\section{Microbial Content of Graywater}

The primary reason that there are regulations or concerns about using gray water is that gray water will contain small concentrations of pathogenic microorganisms. These organisms get into gray water when the potable water comes in contact with pathogens from hand washing, washing fruits and vegetables, and other household activities. It is difficult or impossible to test water for all potentially hazardous pathogens, both as a result of gaps in our ability to culture different organisms and the time and expense associated with testing. Instead, we generally test for indicator organisms. If these indicator organisms are not found, this typically means that other pathogens will also not be present. When graywater is collected and used 
without inputs of black water from toilet waste or sewage water, human pathogenic microorganisms are reduced in concentration but not totally eliminated. Several studies have shown that graywater may contain pathogens, as well as indicator organisms such as total and fecal coliforms. Graywater from kitchens in particular can be a source of bacterial pathogens such as Salmonella or Campylobacter that are frequently associated with meat products such as chickens (Ericksson et al. 2002). This is one reason why kitchen graywater should be excluded from graywater irrigation sources. However, shower or bath water can also be a source of microbial contamination, particularly for families with small children (Rose et al. 1991). Other sources of contamination can be the washing of soiled diapers, or hand washing after toilet use. The microbial content of graywater produced by a family of two adults is shown in Table 2. These data suggest that while indicator bacterial concentrations can be high, pathogenic bacterial concentrations are lower. A risk assessment of the hazards posed by microbes in graywater was conducted by Ottoson and Stenström in 2003. Their study concluded that risks were low, but that microbial risks from viruses, in particular rotavirus, posed the greatest hazard. Overall, to reduce the risk of illness from exposure to microbial pathogens, it would be prudent to restrict irrigation with graywater to non-food crops, to limit graywater irrigation to crops where the edible portion does not come into direct contact with soil, to stop graywater irrigation a week or two prior to harvesting crops, or treat graywater prior to use on food crops. Studies on reclaimed water (treated water from wastewater treatment plants) have shown rapid die off of pathogens when applied to soil surfaces (Hamilton et al. 2006; Manios et al. 2006; Sidhu et al. 2008). It may be that pathogens entering the soil system through graywater use may also experience rapid die off resulting in minimal risk.

Table 2 Microbial characteristics of graywater produced by a family of two adults

\begin{tabular}{l|l|l|l|l|l}
\hline & $\begin{array}{l}\text { Arithmetic } \\
\text { mean }\end{array}$ & $\begin{array}{l}\text { Geometric } \\
\text { mean }\end{array}$ & $\begin{array}{l}\text { Minimum } \\
\text { value }\end{array}$ & $\begin{array}{l}\text { Maximum } \\
\text { value }\end{array}$ & Range \\
\hline $\begin{array}{l}\text { Total coliforms } \\
(\mathrm{CFU} / 100 \mathrm{~mL})\end{array}$ & $8.03 \times 10^{7}$ & $2.39 \times 10^{7}$ & $6.60 \times 10^{5}$ & $2.10 \times 10^{8}$ & $2.09 \times 10^{8}$ \\
\hline $\begin{array}{l}\text { Fecal coliforms } \\
(\mathrm{CFU} / 100 \mathrm{~mL})\end{array}$ & $5.63 \times 10^{-5}$ & $6.95 \times 10^{4}$ & $3.20 \times 10^{3}$ & $8.56 \times 10^{6}$ & $8.55 \times 10^{6}$ \\
\hline $\begin{array}{l}\text { Fecal streptococci } \\
(\mathrm{CFU} / 100 \mathrm{~mL})\end{array}$ & $2.38 \times 10^{2}$ & $1.21 \times 10^{2}$ & $8.00 \times 10^{0}$ & $9.00 \times 10^{2}$ & $8.92 \times 10^{2}$ \\
\hline $\begin{array}{l}\text { S. aureus } \\
(\mathrm{CFU} / 100 \mathrm{~mL})\end{array}$ & 0 & 0 & - & - & - \\
\hline $\begin{array}{l}\text { P. aeruginosa } \\
(\mathrm{CFU} / 100 \mathrm{~mL})\end{array}$ & $1.99 \times 10^{4}$ & $2.92 \times 10^{3}$ & $2.00 \times 10^{2}$ & $1.57 \times 10^{5}$ & $1.57 \times 10^{-5}$ \\
\hline $\begin{array}{l}\text { Coliphages } \\
(\mathrm{PFU} / 100 \mathrm{~mL})\end{array}$ & $<1$ & $<1$ & - & - & - \\
\hline
\end{tabular}

From Casanova et al. 2001 


\section{Nutrient and Organic Content of Graywater}

Physical and chemical characteristics of a 'typical' graywater from a single household are shown in Table 3.

The second concern about using graywater for irrigation is its' effect on soils and plants. In terms of plant nutrients, graywater contains useful amounts of essential elements including nitrogen and phosphorus, as well as magnesium and calcium. By knowing the approximate nutrient concentrations and the volume of graywater applied, the amount of added nutrients can be calculated, and taken into account if additional fertilizers are added. However, graywater will also typically contain salts such as sodium that can build up in soil following long term continuous irrigation with gray water. Sodium in particular is a potential hazard for long term use of graywater due to its high content in laundry detergents (Information Box 3). In soils, excess sodium expressed as the sodium adsorption ratio (SAR) can lead to poor plant growth as well as soil structure problems that reduce water infiltration. Water with $\mathrm{SAR}$ values $>6$ can cause increased soil sodicity.

The organic content of graywater is not normally a problem unless kitchen sink graywater sources are also included in the irrigation water. Such organic content arises from food waste and greases, and ideally should not be utilized for graywater irrigation.

Table 3 Physical and chemical characteristics of a 'typical' graywater from a single household

\begin{tabular}{l|l|l}
\hline Parameter & Mean value & Range \\
\hline $\mathrm{pH}$ & 7.5 & $5-8$ \\
\hline Turbidity (NTU) & 76 & $20-140$ \\
\hline Biological Oxygen Demand (BOD) (mg/L) & 65 & $41-85$ \\
\hline Total Organic Carbon (TOC) (mg/L) & 49 & $30-65$ \\
\hline Total dissolved salts (mg/L) & 35 & $15-112$ \\
\hline Hardness (mg/L) & 144 & $112-152$ \\
\hline Alkalinity (mg/L) & 158 & $149-198$ \\
\hline Phosphate (mg/L) & 9 & $4-35$ \\
\hline Sulfate (mg/L) & 23 & $12-40$ \\
\hline Ammonium-N (mg/L) & 0.75 & $0.1-3.2$ \\
\hline Nitrate (mg/L) & 1 & $0-5$ \\
\hline Total N (mg/L) & 1.7 & $0.6-5.2$ \\
\hline Chloride (mg/L) & 9 & $3-12$ \\
\hline Adaptedfom Ros & &
\end{tabular}

Adapted from Rose et al. (1991), Casanova et al. (2001), NSW Government (2008), Winward et al. (2008a, b) 
Information Box 3 Typical sodium adsorption ratios of detergents

\begin{tabular}{l|l|l}
\hline \multirow{2}{*}{ Graywater type } & \multicolumn{2}{|l}{ Sodium adsorption ratio (SAR) } \\
\cline { 2 - 3 } & Mean & Range \\
\hline Laundry (powder detergent) & 9.2 & $1.2-52.1$ \\
\hline Laundry (liquid detergent) & 1 & $0.02-4$ \\
\hline
\end{tabular}

Higher ratios mean that a higher percentage of soil adsorption sites are filled with sodium Adapted from NSW Government (2008)

\section{Management of Soils Irrigated with Graywater}

The key potential hazards of using graywater for long term continuous irrigation are soil build up of salts and sodium. There are two ways to reduce the potential for excess salts to build up in soils irrigated with gray water: salt leaching and use of soil amendments. Salt leaching involves inputs of water other than graywater to flush excess salts and sodium through the soil root zone. In areas with seasonal rainfall, the rain itself may be sufficient for the leaching process. In arid regions, occasional irrigation with fresh water can be used to reduce salt concentrations. If symptoms of plant stress occur, such as loss of tree leaves, you should water soil thoroughly with fresh water. Tap water is generally much lower in salts than gray water and can be used to flush excess salts through the soil profile. Soil amendments are also excellent tools to reduce soil sodium and alkalinity issues. These include the use of gypsum, calcium sulfate, or elemental sulfur that becomes oxidized and reduces the soil $\mathrm{pH}$. The addition of an organic mulch or compost can also be beneficial in reducing these problems.

\section{Treatment of Graywater}

Many states prohibit graywater use (see regulatory section). Some, such as California, allow it for only certain applications. If homeowners chose to treat graywater to reduce risks from disease-causing microorganisms, a variety of techniques can be utilized that vary greatly in terms of their complexity and sophistication. Ultimately the choice of treatment may be determined by the answer to issues and questions shown in Information Box 4.

For single- family homeowners, treatment technologies tend to be relatively simple. For multiple-owner complexes such as an apartment complexes, larger volumes of graywater can be collected and subjected to more complex technologies. Simple technologies typically consist of settling tanks, or filtration units.

Settling tanks, as the name implies allow for collection of graywater, from which solids and large particles settle out, while greases, oils and small particles float to 
Information Box 4 Issues to consider prior to designing and building graywater treatment technologies

\begin{tabular}{l|l}
\hline Issue: & Quantity of greywater to be treated? \\
\hline Response: & Smaller volumes need simple technologies to be cost effective \\
\hline Issue: & Types of contaminants within the greywater? \\
\hline Response: & Disinfecting bathroom graywater may not be a critical as kitchen graywater \\
\hline Issue: & Planned use of the graywater \\
\hline Response: & $\begin{array}{l}\text { Greywater irrigation of food crops will require more treatment than for trees or } \\
\text { ornamentals }\end{array}$ \\
\hline
\end{tabular}

the surface and can be skimmed off. To do this, 55 gallon plastic garbage bins can be used. Chlorine granules can be added to the graywater as a microbial disinfectant, and the chlorine level checked using simple kits provided by swimming pool supply stores.

Filtration can be as simple as a cloth mesh bag tied over the end of a hose, which will filter out lint and hair. Commercial filters are also available utilizing activated charcoal or cellulose. These can be gravity fed or pressurized. Slow sand filtration units can also be easily built using sand within a 55 gallon drum. Essential features of the unit include: (i) a perforated plate on top of the sand to ensure even distribution of greywater over the sand; (ii) a drain pipe at the bottom of the drum connected to a concrete funnel at the bottom of the drum; and (iii) large stones at the bottom of the filter to encourage drainage. Typically a slow sand filter unit will consist of a two feet depth of sand, beneath which are shallow layers of the stone, followed by medium gravel and pea gravel. Slow sand filtration will remove pathogens, suspended solids, organics and turbidity. Maintenance of such units includes periodic removal of the top most portion of the sand (one to two inches).

For treatment of large quantities of graywater very sophisticated technologies can be utilized including constructed wetlands or membrane bioreactors. Of these, membrane bioreactors have been shown to produce the highest quality water for irrigation (Winward et al. 2008b).

\section{Summary}

The safe use of graywater for irrigation of food and non-food crops is cost-effective and environmentally sound, provided appropriate guidelines are followed. Large scale use of graywater, particularly in communities in arid regions has the potential to save millions of gallons of potable water, while also supplying nutrients essential for plant growth. In an urban setting, graywater use for irrigation is an effective water conservation practice. 


\section{References}

Casnova LM, Gerba CP, Karpiscak M (2001) Chemical and microbial characterization of household greywater. J Environ Sci Health A36(4):395-401

Eriksson E, Auffarth K, Henze M, Ledin A (2002) Characteristics of grey wastewater. Urban Water 4:85-104

Friedler E (2004) Quality of individual domestic greywater streams, and its implication for on-site treatment and reuse possibilities. Environ Sci Technol 25:997-1008

Hamilton AJ, Stagnitti F, Premier R, Boland A, Hale G (2006) Quantitative microbial risk assessment models for consumption of raw vegetables irrigated with reclaimed water. Appl Environ Microbiol 72(5):P3284-P3290

Ingham AT (1980) Residential greywater management in California. California State Water Resources Control Board, Sacramento

Loh M, Coghlan P (2003) Domestic water use study: in Perth Western Australia 1998-2001. Water Corporation, Perth

Manios T, Moraitaki G, Mantzavinos D (2006) Survival of total coliforms in lawn irrigated with secondary wastewater and chlorinated effluent in the Mediterranean region. Water Environ Res 78(3):330-335

NSW Government (2008) NSW guidelines for greywater reuse in sewered single household residential premises. Water for Life, NSW Government, Sydney, Australia

Rose JB, Sun G-S, Gerba C, Sinclair NA (1991) Microbial quality and persistence of enteric pathogens in greywater from various household sources. Water Res 25:37-42

Sidhu JPS, Hanna J, Toze SG (2008) Survival of enteric microorganisms on grass surfaces irrigated with treated effluent. J Water Health 06(2):255-262

Sydney Water Corporation (2004-2005) Water conservation and recycling implementation report 2004-2005. Sydney Water Corporation, Sydney

Winward GP, Avery LM, Stephenson T, Jefferson B (2008a) Chlorine disinfection of greywater for reuse: effect of organics and particles. Water Res 42:483-491

Winward GP, Avery LM, Frazer-Williams R, Pidou M, Jeffrey P, Stephenson T, Jefferson B (2008b) A study of the microbial quality of greywater and an evaluation of treatment technologies for reuse. Ecol Eng 32:187-197 


\title{
Planting Abundance: Alternative Water Sources for Urban Farms
}

\author{
Brad Lancaster
}

We live in a natural abundance. If you can see it, you can plant it, and grow its potential!

Here in the desert community of Tucson, Arizona, as is the case with most communities in the U.S. and the world, in an average year of rainfall more rain falls on the surface area of the community than all its citizens consume of utility water in that same year.

This rainwater is the best water for our plants and soil. It is salt-free (salts common in our groundwater and imported surface waters such as those from the Colorado River can build up in irrigated soil and impede plants' ability to photosynthesize and utilize water) (Clevelend and Soleri 1991). Rainwater is a natural fertilizer (containing sulfur, beneficial microorganisms, mineral nutrients, and nitrogen) (Begeman 1998).

And it's free.

Nonetheless, we drain the vast majority of that high-quality rainwater out of our communities almost as quickly as it arrives via mound-like landscapes, soil scraped and raked bare, excessive paving, and our streets and stormdrains. This practice then grows the perceived "need" to import more-distant waters at greater cost.

In fact, 30-50\% of the drinking water consumed by the average single-family U.S. household is used to irrigate their landscape (Vickers 2001). In hot Las Vegas, Nevada; southern California; and Phoenix, Arizona, the amount of drinking water put right into the dirt is up to $70 \%$ of the household's consumption of water (which they purchase from their water utility, which had to purchase and import much of its water from elsewhere) (Vickers 2001).

As to the water consumed within the home, much could be recycled onsite for irrigation rather than drained offsite after just one use. The volume of greywater running down the drain of the average single-family Arizona household is enough

\footnotetext{
B. Lancaster $(\bowtie)$

Rainwater Harvesting for Drylands and Beyond, Tucson, Arizona, USA

e-mail: admin@HarvestingRainwater.com; http://www.harvestingrainwater.com/
} 
to meet about half of the average family's landscape-irrigation demand. Greywater is the drainwater from household bathroom sinks, showers, bathtubs, and washing machines, and can be safely used for irrigation if correct soaps and detergents are used.

Still more water is lost due to the unnaturally exposed soil and pavement of our landscapes, along with the sun-baked exterior walls of our homes, schools, and other buildings that drain still more water by absorbing the heat of the sun during the day and reradiating that heat back out at night, increasing temperatures up to 10 ${ }^{\circ} \mathrm{F}$, which leads to more water loss to evaporation and evapotranspiration.

In dryland environments, and the dry seasons in wetter environments, this potential evaporative loss can be extreme-exceeding the amount of water gained by precipitation. For example, the average annual rainwater income/gain in Tucson, Arizona, is about 11 in. of rain a year. But our potential water loss to evaporation is about 100 in. per year (One-Page Place Assessment, Tucson, Arizona).

\section{Watergy Sidebar}

Water consumption leads to energy consumption if that water has been mechanically treated and/or pumped. If the energy used to pump the water comes from thermoelectric power plants, then even more water is used, as those power plants use water to generate steam or cool the power plant as they produce electricity. The greater the distance or height we pump the water, and the more we treat it - the greater the energy and water consumption.

The table shows the energy costs of different sources of water. The ranges are for U.S. averages of $\mathrm{kWh}$ of energy consumed per given amount of water consumed, not extremes. Energy use is zero for gravity-fed, naturally filtered rainwater and greywater systems. High ends of ranges include power consumption of pumps (and in the case of rainwater, UV filtration) (Lancaster 2013).

\begin{tabular}{l|l|l}
\hline Water source & $\mathrm{kWh} /$ gallon range & $\mathrm{kWh} / \mathrm{month}$ range \\
\hline & $\begin{array}{l}\text { per } 100,000 \text { households water } \\
\text { consumption }\end{array}$ \\
\hline On-site rainwater & $0.0000-0.0007$ & $0-540,120$ \\
\hline On-site greywater & $0.0000-0.0002$ & $0-154,320$ \\
\hline Groundwater & $0.0006-0.0020$ & $478,392-1,543,200$ \\
\hline Wastewater & $0.0010-0.0030$ & $771,600-2,314,800$ \\
\hline Central Arizona Project & $0.0126-0.0152$ & $9,738,209-11,745,049$ \\
\hline Desalinated sea water & $0.0087-0.0882$ & $6,712,920-68,055,120$
\end{tabular}


Use this information to act, and enhance life, with six simple steps:

\section{Plant the Rain}

Improve your water gain by planting the mother of all waters - rain - before you plant any vegetation. (Or plant the rain beside vegetation if the plants are already in the ground.) Plant the rain within bowl-like, as opposed to mound-like, shapes in your landscape to capture and infiltrate, rather than drain, the rain. These basinshaped rain gardens are ideal for passively/freely irrigating perennial food plants.

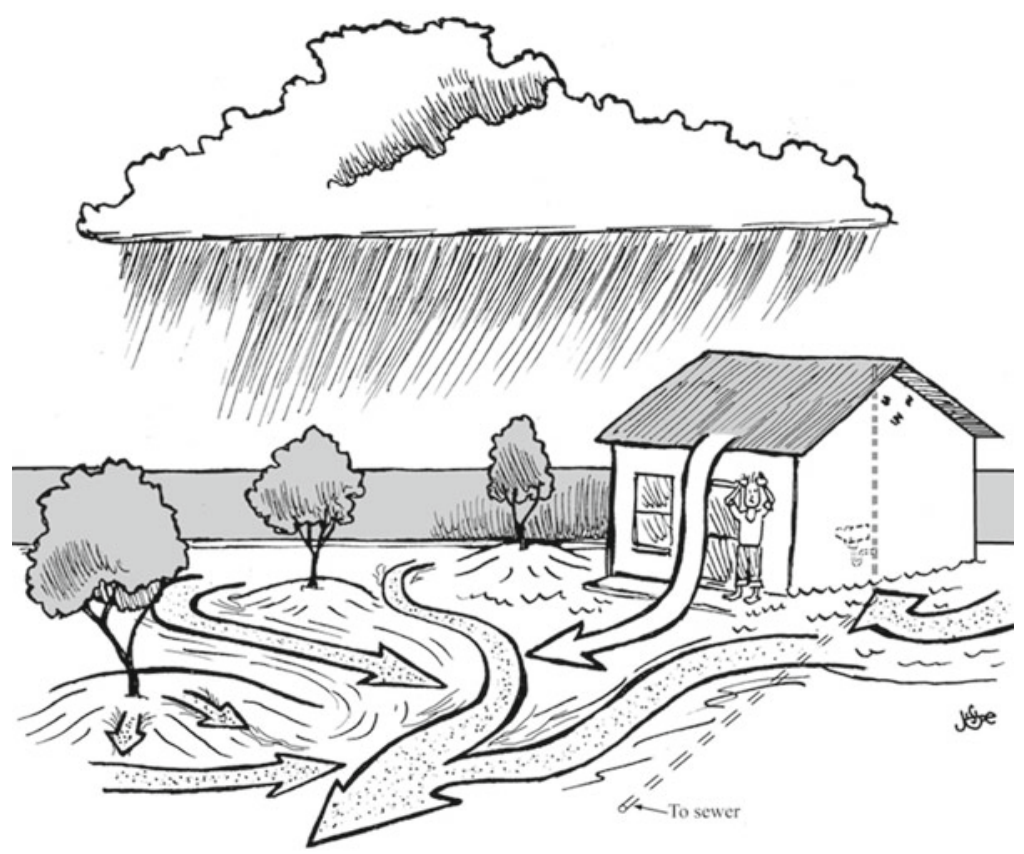

Fig. 1 The wasteful path to scarcity. The site rapidly dehydrates itself by erosively draining rainwater and runoff to flood downslope areas and contaminate surface water with sediment. Greywater is lost to the sewer. Costly municipal or well water is pumped in to replace the free water that was drained away. Leaf drop/mulch is also raked/drained away, further reducing fertility and waterholding capacity. This leads to a depletion of resources and feeling "scared in the city" due to the resulting scarcity (Illustration by Joe Marshall and reproduced with permission from Rainwater Harvesting for Drylands and Beyond, Volume 2, by Brad Lancaster) 


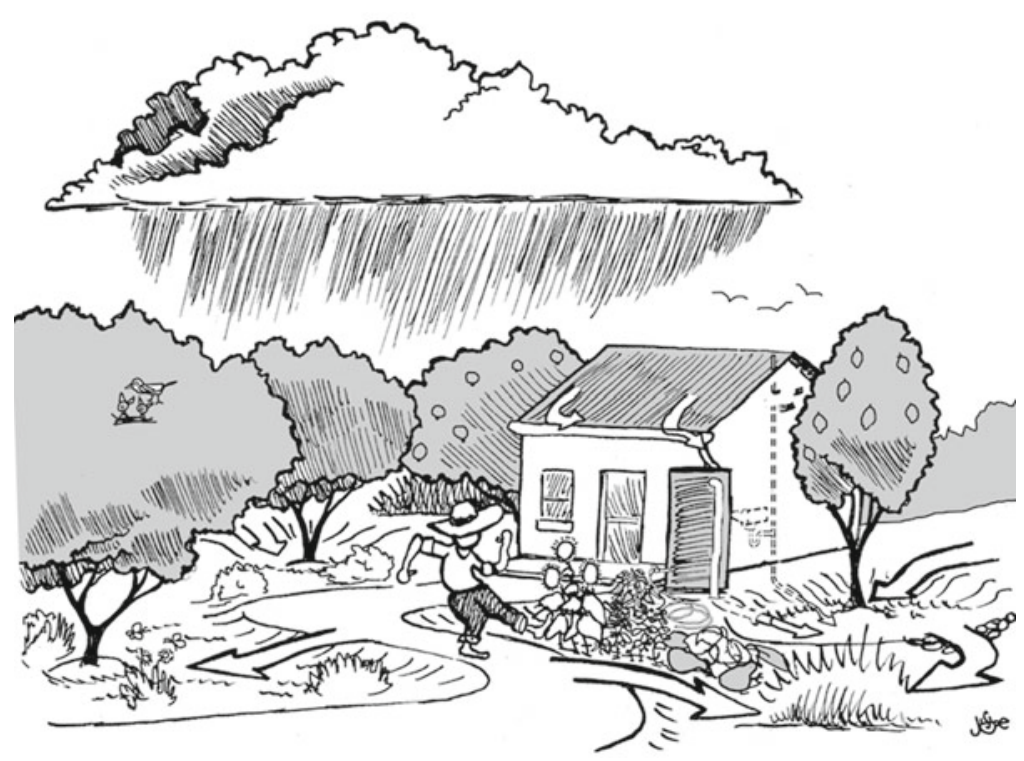

Fig. 2 The stewardship path to abundance. This site passively hydrates itself by harvesting and infiltrating rainwater, runoff, and greywater on site, reducing downslope flooding and overall water consumption and contamination. The need to pump in water is greatly reduced or eliminated. Leaf drop/mulch is also harvested and cycled back into soil and plants, further increasing fertility and water-holding capacity. This leads to an enhancement of resources and "a bun dance" of celebration due to the resulting abundance (Illustration by Joe Marshall and reproduced with permission from Rainwater Harvesting for Drylands and Beyond, Volume 2, by Brad Lancaster)

Over a 16-year period of annual tree planting projects in my neighborhood (during which over 1,300 trees have been planted), we found that trees planted within, or directly beside, water-harvesting basins had more than a $50 \%$ greater chance of survival than the trees that were not planted in association with such basins. This is because due to forgetfulness, laziness, etc. many trees were rarely, if ever, watered after planting day. The passively harvested rainfall ensured all trees got some irrigation, and provided more water for those trees that were regularly irrigated during establishment. In addition, the rainwater gave all trees a nutrient boost, while flushing salts from the trees' root zones.

The trees accessing harvested rainwater also grew faster and larger than those not harvesting the rain. These differences are even more pronounced when the trees' basins harvest runon and/or greywater in addition to rainfall. 


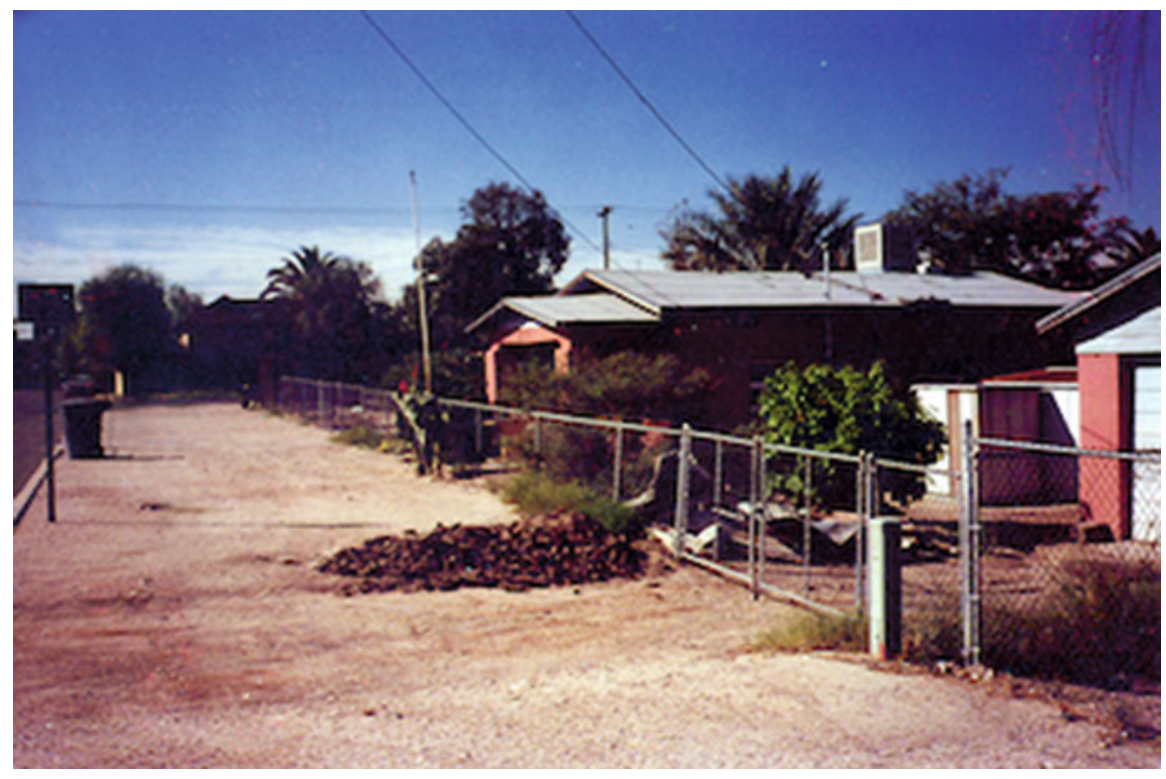

Fig. 3 Before the 1996 planting of rain and trees. Public right-of-way adjoining property, with asphalt driveway freshly removed, 1994 (Reproduced with permission from Rainwater Harvesting for Drylands and Beyond, Volume 1, 2nd Edition, by Brad Lancaster)

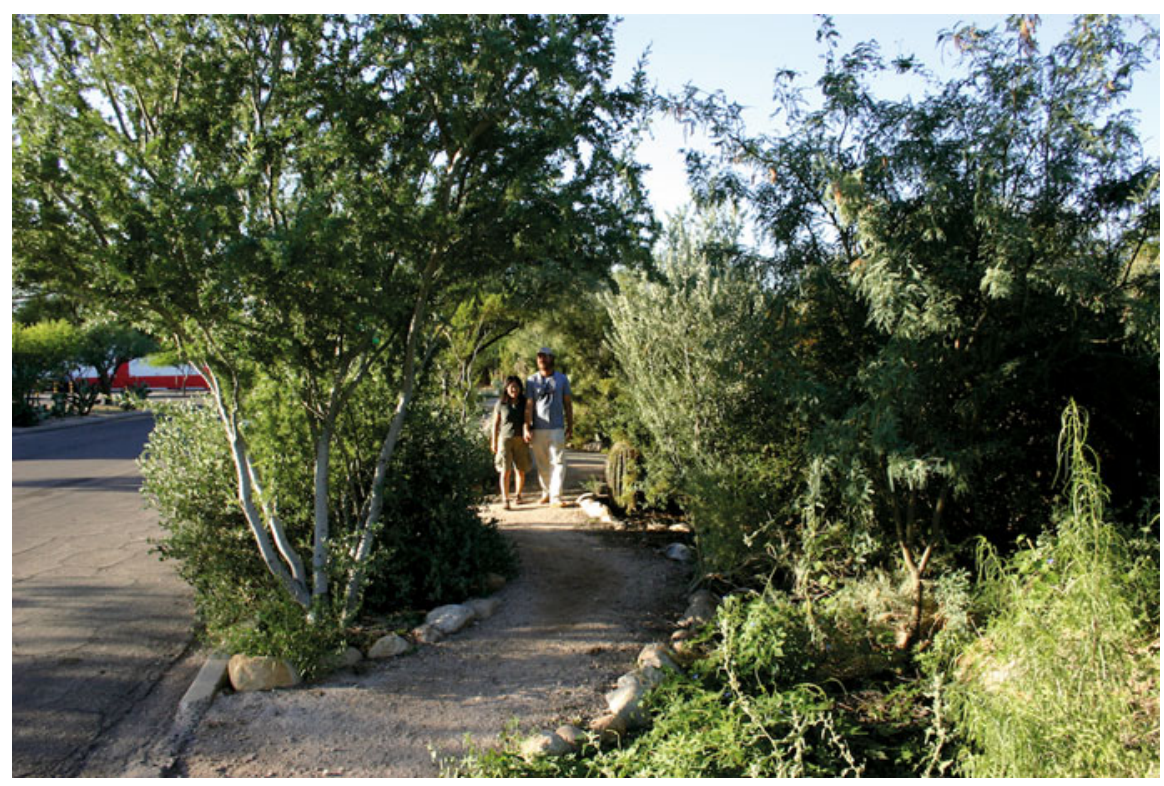

Fig. 4 After planting of rain and trees. Tree-lined footpath reviving the once-sterile right-of-way, 2006. Plants are irrigated solely with passively harvested rainwater and street runoff in Tucson, Arizona, where annual rainfall averages 11 in. (Reproduced with permission from Rainwater Harvesting for Drylands and Beyond, Volume 1, 2nd Edition, by Brad Lancaster) 


\section{Start Where You Have More Rain-Those Areas Where You Can Turn Runoff Into Runon}

Emphasize the placement of these basin-shaped rain gardens next to and below impervious surfaces like roofs, roads, and patios from which water runs off. That way you can double or even triple the available rainfall in the basins by capturing both rainfall and runoff, which becomes runon, and that's right on!

For example, if the amount of roof or patio area draining to a rain garden in the yard is two times the area of the rain garden, then the amount of available rainfall is tripled. You get all the rain falling on the rain garden (none drains away) - plus the runoff from the roof or patio. Planning and installing an overflow route ensures you don't get too much water in really big rain events.

Rainwater runoff from roofs is an excellent source of irrigation water, and can be stored in tanks for later use in vegetable gardens.

Street runoff can also provide a substantial volume of water. In an average year of rainfall (11 in. or $279 \mathrm{~mm}$ ), the runoff from rain falling on my neighborhood's 36-ft wide streets equals over 1.25 million gallons per mile (or 3.46 million liters per kilometer) (Lancaster 2008)! In my climate, that's enough runoff to provide all the irrigation needs of over 400 established $20-\mathrm{ft}(6-\mathrm{m})$ tall native food-bearing trees per mile $(1.6 \mathrm{~km})$, or a tree every $25 \mathrm{ft}(7.5 \mathrm{~m})$ lining both sides of the street (Lancaster 2008).

So we've started to tap that runoff to passively and sustainably irrigate street-side shade trees, which are turning hot and sterile strips of asphalt into cool and beautiful greenways that solve flooding and water-quality problems instead of creating them.

For every inch of rainfall...

A 10-ft wide paved street will drain 27,000 gallons of runoff per mile A 20-ft wide paved street will drain 55,000 gallons of runoff per mile A 30-ft wide paved street will drain 83,000 gallons of runoff per mile

\section{Plant Living "Pumps" of Vegetation to Shade and Cool Your Runoff Hotspots Where Needed}

Decrease potential water loss to evaporation by planting shading vegetation, ideally low-water-use, native, food-producing trees that will then grow to shade and cool roads, patios, and the east-, west-, and even north-facing walls of adjoining buildings. This will reduce unwanted sun exposure on our buildings' walls and windows in the mornings and afternoons of the hot months. (But leave the winter-sun/ south-facing wall, beneath an appropriately sized roof overhang or awning, open to the winter sun low in the southern sky, so you can get free heat, light, and solar power when you need it most.) The runoff from the buildings and paved surfaces then freely runs into the rain gardens to irrigate the trees, while the trees passively 


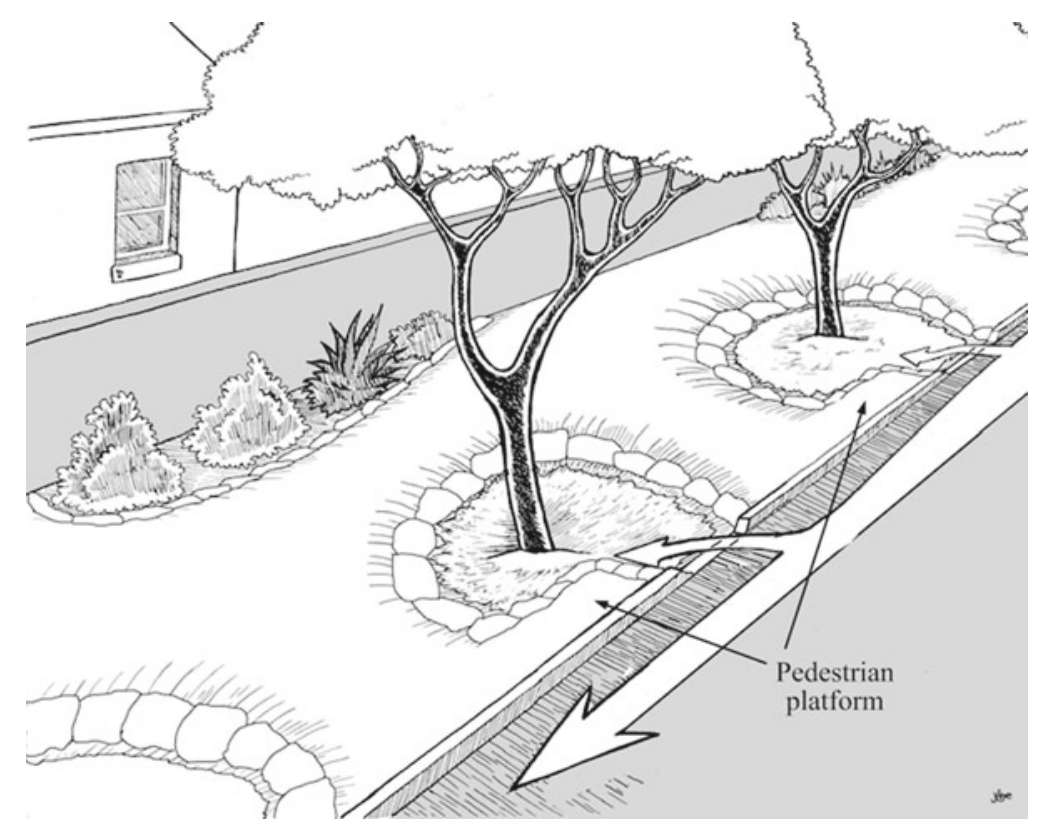

Fig. 5 Street runoff is directed into backwater or eddy-like basins via curb cuts . Once the basins are full, surplus water just continues down the street (Illustration by Joe Marshall and reproduced with permission from Rainwater Harvesting for Drylands and Beyond, Volume 2, by Brad Lancaster. For more curb-cut-basin details, see the Street-Runoff Harvesting page at www. HarvestingRainwater.com)

shade and cool the pavement-reducing water loss to both wasteful runoff and evaporation.

Food-producing shade trees planted on the east, northeast, northwest, and west sides of buildings can result in up to a $40 \%$ reduction in energy costs compared to same building without such shade trees (Simpson and McPherson 1996).

Such strategic shade-tree planting will also reduce water consumed to generate power. For example, electricity produced from burning coal consumes just under a half gallon of water per kWh of power produced (Lancaster 2013). The average U.S. household consumes about 1,000 kWh of electricity a month, and thus about 500 gallons of water per month for the electricity if provided by a coal-burning power plant. Increase that number to 100,000 households, and the monthly water consumption to generate the homes' power jumps to over 51 million gallons of water a month (Lancaster 2013). Using less power, by providing more of your home's cooling and heating with the passive harvest of summer shade and winter sun, will reduce this water consumption/loss.

See the Water-Energy-Carbon Nexus charts in "Rainwater Harvesting for Drylands and Beyond, Volume 1, 2nd Edition," for the water costs of other energy sources. 


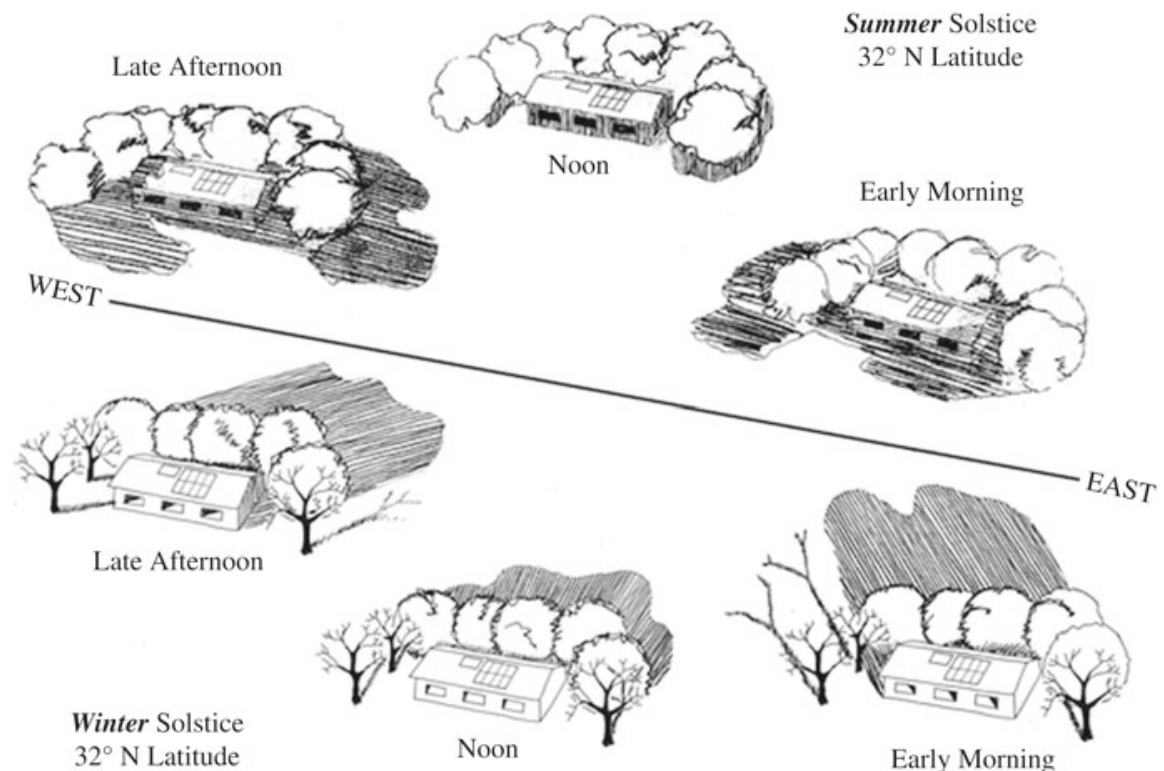

Fig. 6 Ideal orientation to the sun of building and landscape for free summer shading/cooling and winter heating and light. The trees that shade the building in summer are passively irrigated by the runoff from the building's roof and its greywater (Illustration by Silvia Rayces and reproduced with permission from Rainwater Harvesting for Drylands and Beyond, Volume 1, 2nd Edition, by Brad Lancaster)

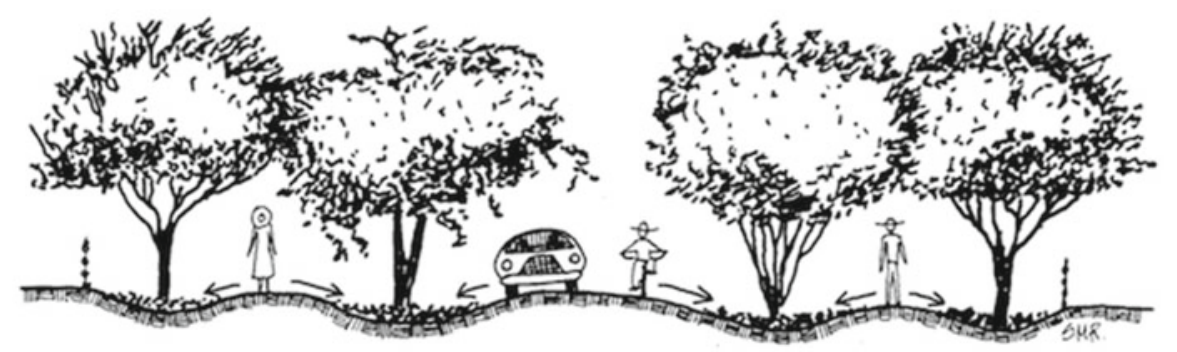

Fig. 7 Raise pathways, and sink mulched and vegetated basins (Illustration by Ann Audrey and reproduced with permission from Rainwater Harvesting for Drylands and Beyond, Volume 1, 2nd Edition, by Brad Lancaster)

Note that in 2013 the City of Tucson passed a green-streets policy that all new city streets must be designed and built to harvest at least a half-inch rainstorm's worth of water to freely irrigate street-side vegetation shading and cooling the street and walkways. This is a major shift! This policy transforms the conventional way of building streets - acting as a drain of $100 \%$ of the rain falling on the streets, to a 
new way of building streets - acting as a harvesting strategy to utilize the majority of the rain as close as possible to where it falls in a way that generates more life and resources (Mayor Rothschild).

\section{Maximize the Living Sponge}

Mulch the surface of the soil to make it more porous or sponge-like to speed up the rate at which water infiltrates, while reducing the loss of soil moisture to evaporation. Compost and woody organic matter are the best mulch as they increase the fertility of the soil and plant growth. Furthermore, this mulch feeds beneficial soil microorganisms, such as mycorrhizal fungi, which tap into and expand the surface area of associated plants' roots (Lowenfels and Lewis 2010). The plants can then more efficiently uptake the harvested water, as the fungi give the plants water and minerals, while the plants give the fungi carbohydrates and sugars. At the very least, don't rake up and throw away your fallen leaves. They are called "leaves" because you are supposed to leave them as mulch beneath your plantings.

Research in Tucson by Mitch Pavao-Zuckerman, PhD, has found that within just a few years, the application of organic mulch, coupled with passively harvested water and newly planted multi-use perennial vegetation, has transformed oncedegraded urban soils into rich soil ecologies equivalent to those found in healthy regional forests (Pavao-Zuckerman 2014).

In addition it has been found that:

- Trees associated with mulched water-harvesting earthworks are able to grow $33 \%$ larger than those without, more than doubling the trees' potential sequestration of atmospheric carbon (Pavao-Zuckerman 2013),

- The presence of more organic matter in the soil enables the soil itself to sequester more carbon (Sundermeier et al.), and

- The natural pollutant-filtering/bioremediation ability of the soil mulched with organic material was ten times greater than that of rock- or gravel-mulched soil (Pavao-Zuckerman 2014).

\section{Augment the Free Irrigation of Higher-Water-Use Plantings Such as Fruit Trees by Planting Greywater Before You Plant the Trees}

If you want any higher-water-use perennial plantings such as fruit trees, be sure to plant your greywater before you plant your fruit tree(s). (Or if your fruit tree is already planted, then plant the greywater next to the fruit tree.) Greywater is the drainwater from household bathroom sinks, showers, bathtubs, and washing machines. The volume of greywater running down the drain of the average Arizona family household is enough to meet about half of the average family's 


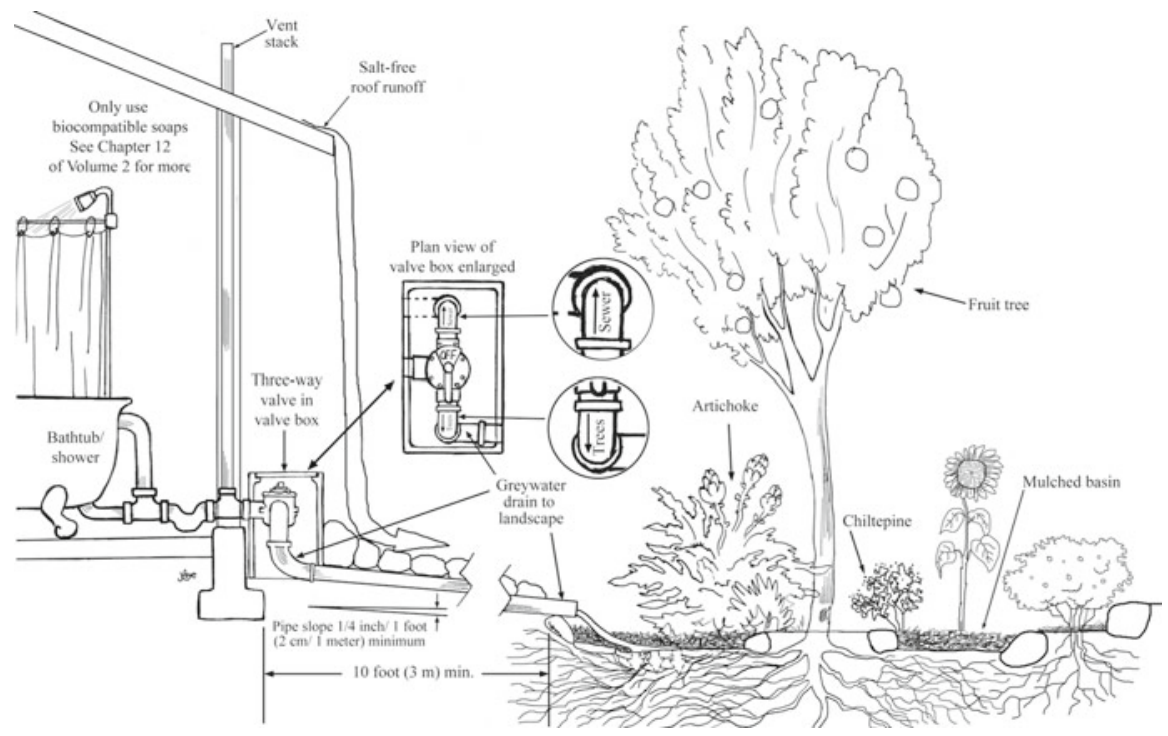

Fig. 8 Roof runoff and bathtub/shower greywater directed to a well-mulched and vegetated infiltration basin. A three-way valve (in valve box) allows for distribution of greywater to either landscape or sewer. End of greywater pipe discharges a few inches above the mulch in the basin to prevent roots growing into pipe and solids from backing up and clogging pipe. Greywater immediately infiltrates beneath the surface of the mulch to be used by plants. Illustration by Joe Marshall and reproduced with permission from Rainwater Harvesting for Drylands and Beyond, Volume 1, 2nd Edition, by Brad Lancaster.

landscape-irrigation demand. If you use the correct non-toxic, salt-free soaps and detergents, your greywater can be directed to and planted within the same mulched basins that capture your rainwater. In times of rain the basins act as rain gardens. In times of no rain, they act as greywater gardens. As long as you are home, that greywater flow to your plants can be perennial-even in the driest of times.

\section{Greywater-Harvesting Principles}

1. Use correct soaps/detergents and avoid products that could damage or kill soil microorganisms or plants. See the "Greywater Harvesting" page at www.HarvestingRainwater.com for "Soap and Detergent Info" on what ingredients and products are good or bad to use. At the very least, avoid products containing sodium, salt, boron, or chlorine. Don't trust the marketing label-read the ingredients.

2. Simplify and use gravity-fed distribution or a Laundry to Landscape (L2L) system (either of which require no extra tanks or pumps) whenever possible. (A L2L system is only for washing machines, and uses the pump already in the washing machine to pressurize the greywater it distributessee www.OasisDesign.net for more info.) 
This will reduce costs and maintenance. For example, I do not advocate the storage of greywater in tanks, because this can lead to bad odors and a worsening of the greywater's quality. Pumps used in tanked greywaterharvesting systems typically need to be replaced every 3 years.

3. Discharge greywater as high as possible in soil profile to take advantage of the greatest possible number of beneficial soil microorganisms. Adding the water to the subsoil will minimize its benefits. The surface 6 " or $15 \mathrm{~cm}$ of soil have the greatest microbial activity.

These soil microorganisms help naturally filter the greywater, and as there are more roots in the upper level of the soil, more of the greywater is then utilized by the associated plants.

4. Distribute greywater to multiple points, rather than concentrate it, to ensure soil stays aerobic. If too much greywater is continuously directed to one spot there is the potential of the soil becoming oversaturated, leading to anaerobic conditions and bad odors.

5. Have the option of sending greywater to sewer or septic if needed. Greywater can be sent to sewer or septic if soils are saturated from excessive rainstorms, or if products are used that would damage your soil or plants.

6. Use AC condensate rather than wasting this water. If you have an airconditioner, direct its salt-free condensate water to rain gardens instead of to the sewer. You'll get only about a $1 / 4$ gallon per day of condensate from a home air conditioner in the dry season/climate, but it can be as much as 18 gallons a day in the humid season/climate. Condensate from commercial air conditioners equals hundreds of gallons a day.

The College of Architecture and Landscape Architecture (CALA) building at the University of Arizona harvests about 95,000 gallons of airconditioning condensate per year from the 3 HVAC systems on its roof. That water is then used (along with roof runoff, and drinking- fountain greywater) to irrigate the building's award-winning landscape (University of Arizona).

Watergy of AC condensate. Energy use of passive harvest (secondary to normal operation of air conditioner (AC)) could be considered zero. But cost rises dramatically for active harvest (if AC is installed or run primarily for condensate), in which case an average of $360 \mathrm{kWh}$ of energy would be consumed for each gallon of condensate produced (Lancaster 2013).

Taking these steps which harvest, rather than drain free, local waters transform dehydrating landscapes into rehydrating landscapes that provide myriad additional benefits such as more local food, enhanced flood control, diverse wildlife habitat, beauty, and more life which can potentially also lead to more rain.

This is because clouds are more likely to form from cooled atmospheric moisture evapotranspired through plant leaves than the warmer moisture evaporated from bare soil. In addition, raindrops are more likely to condense around tiny, richly-textured, air-borne particles of organic matter generated by the vegetation (Pöhlker et al. 2012). 
We can choose to work with these natural systems or against them.

I think you'll find going with the flow by naturally harvesting/upcycling free, on-site resources is always the most sustainably abundant path.

\section{References}

Begeman J (1998) Thanks to storms, rain delivers more than water to desert, Arizona Daily Star, 2 August 1998, Home Section, p. 1

Cleveland DA, Soleri D (1991). Food from dryland gardens: an ecological, nutritional, and social approach to small-scale household food production. xiii, Center for People, Food and Environment, Tucson, $387 \mathrm{pp}$

Lancaster B (2008) Rainwater harvesting for drylands and beyond, vol 2. Rainsource Press, Tucson, $336 \mathrm{pp}$

Lancaster B (2013) Water costs of energy chart, rainwater harvesting for drylands and beyond. In: Guiding principles to welcome rain into your life and landscape, vol 1, 2nd edn. Rainsource Press. Tucson. ISBN-10: 0977246434

Lowenfels J, Lewis W (2010) Teaming with microbes: the organic gardener's guide to the soil food web, rev edn. Timber Press, Portland, Oregon

Mayor Rothschild. Website: http://www.mayorrothschild.com/2013/05/29/tucson-to-capturestormwater-for-irrigation-of-roadway-vegetation/

One-Page Place Assessment, Tucson, Arizona, http://www.harvestingrainwater.com/wp-content/ uploads/2009/10/One-Page-Place-Assessment-Tucson-AZ-130108-Web.xlsx.pdf

Pavao-Zuckerman MA (2013) Soil's role in processing pollutants fro air and water: case studies of green infrastructure and carbon sequestration. Watershed management group. http://watershedmg.org/webinars/soils

Pavao-Zuckerman MA (2014) Hot spots in urban social-ecological systems: streetscape green infrastructure in a desert city. Soils in the city conference, Chicago, June 29-July 2, 2014

Pöhlker C, Kenia T, Wiedemann BS, Shiraiwa M, Gunthe SS, Smith M, Su H, Artaxo P, Chen Q, Cheng Y, Elbert W, Gilles MK, Kilcoyne ALD, Moffet RC, Weigand M, Martin ST, Pöschl U, Andreae MO (2012) Biogenic potassium salt particles as seeds for secondary organic aerosol in the Amazon. Science 337(6098):1075-1078

Simpson JR, McPherson EG (1996) Potential of tree shade for reducing residential energy use in California. J Arboricult 22(1):10-18

Sundermeier A, Reeder R, Lal R. Soil carbon sequestration fundamentals. Ohio State University Extension Fact Sheet, AEX-510-05. http://ohioline.osu.edu/aex-fact/0510.html

University of Arizona. Underwood Family Sonoran Landscape Laboratory http://architecture.arizona.edu/facility/other/underwood-family-sonoran-landscape-laboratory?destination $=\mathrm{n}$ ode/1013

Vickers A (2001) Handbook of water use and conservation. WaterPlow Press, Amherst, 464 pp

Brad Lancaster is the author of the best-selling, award-winning books "Rainwater Harvesting for Drylands and Beyond, Volumes 1 and 2" (the newly revised and greatly expanded 2nd edition of Volume 1 having been released in 2013), and www.HarvestingRainwater.com, which show you how to make the most of the above six steps and a whole lot more-even if you are renting your home and don't have a yard. 


\section{Part II \\ Ecosystem Services - Waste Treatment}




\title{
The Role of Organic Residuals in Urban Agriculture
}

\author{
Sally Brown and Nora Goldstein
}

\section{Introduction}

Urban agriculture offers the opportunity to restore soil treatment of wastes as an urban ecosystem service. While direct deposition and treatment of wastes on soil may not be feasible, using soils as a receiving medium for fully or partially treated wastes is. Residuals pertinent to urban agriculture include recycled water, yard wastes, food scraps, and municipal biosolids, the solid residual from wastewater treatment. Benefits associated with use of these materials on urban lands cover multiple categories. Resource conservation, greenhouse gas mitigation, improved soil tilth, higher net primary productivity, reduced infrastructure costs, and increased environmental literacy and awareness are some of the benefits (see soils section). This section will provide a basic background on waste treatment and describe types of organic residuals available in all urban areas. Composting is the most common means to stabilize organic wastes to make them suitable for use on urban soils. Composting can occur in a decentralized manner or as a municipal alternative to landfilling. A case study describes how food scraps were diverted from landfills to composting in Seattle. This is presented both from a political perspective and from the composter's perspective. Small scale decentralized composting is also discussed. A final section will compare the environmental and economic costs of different waste treatment options.

\footnotetext{
S. Brown $(\square)$

School of Environmental and Forest Sciences, University of Washington, Seattle, WA, USA

e-mail: slb@uw.edu

N. Goldstein

Biocycle Magazine, Emmaus, PA, USA

e-mail: noragold@jgpress.com; http://www.biocycle.net/
} 


\section{Waste Conversion}

Waste treatment is one of the ecosystem services associated with soils (Constanza et al. 1997). Through chemical, physical and biological processes, soils can convert a range of organic (carbon based) and inorganic (metal or metalloid based) wastes into components of the soil. The transformations involve stabilization of organic matter, nutrient release to the soil solution and nutrient retention in stabilized organic matter. Pathogens in the added organic matter are also inactivated over time as a result of competition from the native soil fauna. The vast majority of the carbonbased wastes converted by soils in natural or agricultural systems consist of dead plant materials such as leaves, roots, woody branches and fruits. In an urban environment, this category would correspond to food scraps and yard waste. In natural or agricultural systems, animal manures including liquid and solid wastes from wild and domesticated animals are also converted by soils into components of soil organic matter. The urban equivalent would be biosolids, the residual product from municipal wastewater treatment.

Soil processes convert these materials into soil organic matter, plant nutrients and $\mathrm{CO}_{2}$. In certain and typically limited categories, other organics such as anthropogenically produced chemicals and herbicides can also be transformed by the soil into soil organic matter and $\mathrm{CO}_{2}$ (i.e. Alexander 2000; Chen et al. 2003; Puglisi et al. 2007). This decomposition process is a critical way to recycle organics and nutrients. It is both a waste treatment process and a soil enrichment process. Soils can also absorb a range of inorganic wastes. Typically, many of the elements in wastes are plant nutrients. When introduced to a soil system they will bind to soil surfaces and become gradually available to plant roots. In other cases, residuals with a high calcium carbonate equivalence can be used in lieu of commercial limestone to neutralize soil acidity. Finally soils can destroy pathogens in different waste materials (Gerba and Smith 2005). This soil transformation process occurs to materials added as liquids and as solids. Water filtration and purification by soils is one example of these processes. With sufficient retention time, pathogens in water are destroyed by soil microorganisms. These same microorganisms use the organic matter carried by or dissolved in the water as a food source. Inorganic compounds in the water such as nutrients are absorbed onto charged soil particles as the water passes through the soil.

Soil has been the most efficient way to both treat wastes and recycle organic matter and nutrients in natural systems. However, if too much of a particular residual is added to soil, the ability of the soil to 'treat' the residual becomes overtaxed. This can result in incomplete waste treatment and damage to the soil's ability to function as a living system. For example, if too much manure is added to soils, the soil will not be capable of destroying all pathogens, absorbing all nutrients, and transforming all organic matter. Examples of this overtaxing of a soil's ability to treat waste can be seen in confined animal feeding operations where nutrients, organic matter and pathogens are able to flow through soil to groundwater (Gagliardi and Karns 2000; Vaillant et al. 2009). Superfund sites, the most contaminated sites in the US that are 
included on US EPA National Priorities List (NPL), are another example. In these cases, too much of a particular contaminant or suite of contaminants have been added to soils. As a result, the biological or living components of the soil system are no longer able to function. The alluvial tailings deposits along the Upper Arkansas River in Leadville, $\mathrm{CO}$ are an example. Historic mining of acid bearing metal ores that were rich in lead, zinc and cadmium produced tailings that were released into the Arkansas River. Alluvial tailings deposits along the river created dead zones that were devoid of plant life and had reduced microbial activity (Brown et al. 2005).

Because of the high concentrations of wastes in urban areas and the understanding that use of soils to treat wastes is not feasible with the quantities involved, wastes are typically collected and removed from urban areas. Wastes in urban areas can be divided into two basic categories: solid and liquid. Solid waste is what is put in cans and bins for centralized pick up on select days of the week. Liquid waste is what goes down pipes, toilets and storm sewers. Historically solid wastes were disposed of in landfills. Liquid wastes flow to centralized treatment plants where the partially treated water was released to natural water bodies and the solids were landfilled, incinerated, or applied to agricultural lands outside of urban areas (Metcalf and Eddy 2003). In both cases, although biological processes can be part of the treatment process, these would be considered engineered treatment systems.

Much of the emphasis on engineered waste treatment has been protection of public health and efficiency. With public health and efficient waste disposal as the main goals, sanitary landfills became the repository of choice for yard waste and food scraps for most of the twentieth century. Only recently has resource recovery entered into discussions of appropriate ways to manage residuals (Penninsi 2012). One early example of this is recycling of cans and bottles. We are now seeing increasing examples of organics being considered as a resource that merits recycling. This started with yard waste bans in the 1980s-1990s and is now increasingly focusing on food scraps with several states offering diversion options or requiring that these materials be diverted from landfills (Platt and Goldstein 2014). Food waste collection and reuse as a soil amendment is still in its infancy across the US. Food waste presents a potentially excellent feedstock for compost production and use as an urban soil amendment (Fig. 1). The percent of total food and yard waste collected per capita for select states is shown in Table 1.

Urban agriculture offers another opportunity to restore soil treatment of wastes as an urban ecosystem service. While direct deposition and treatment of wastes on soil may not be feasible for most cases, using soils as a receiving medium for fully or partially treated wastes is. Residuals pertinent to urban agriculture include a range of types of water, yard wastes, food scraps, wood waste, soiled paper, and municipal biosolids, the solid residual from wastewater treatment. A description of the quantities, concerns, regulatory restrictions, stabilization processes and benefits for different urban residuals is shown in Table 2 . These materials are typically composted with the finished product available for a range of land based uses. There are also cases where municipal biosolids are treated to reduce all pathogens and made available to urban gardeners and growers (McIvor et al. 2012). 


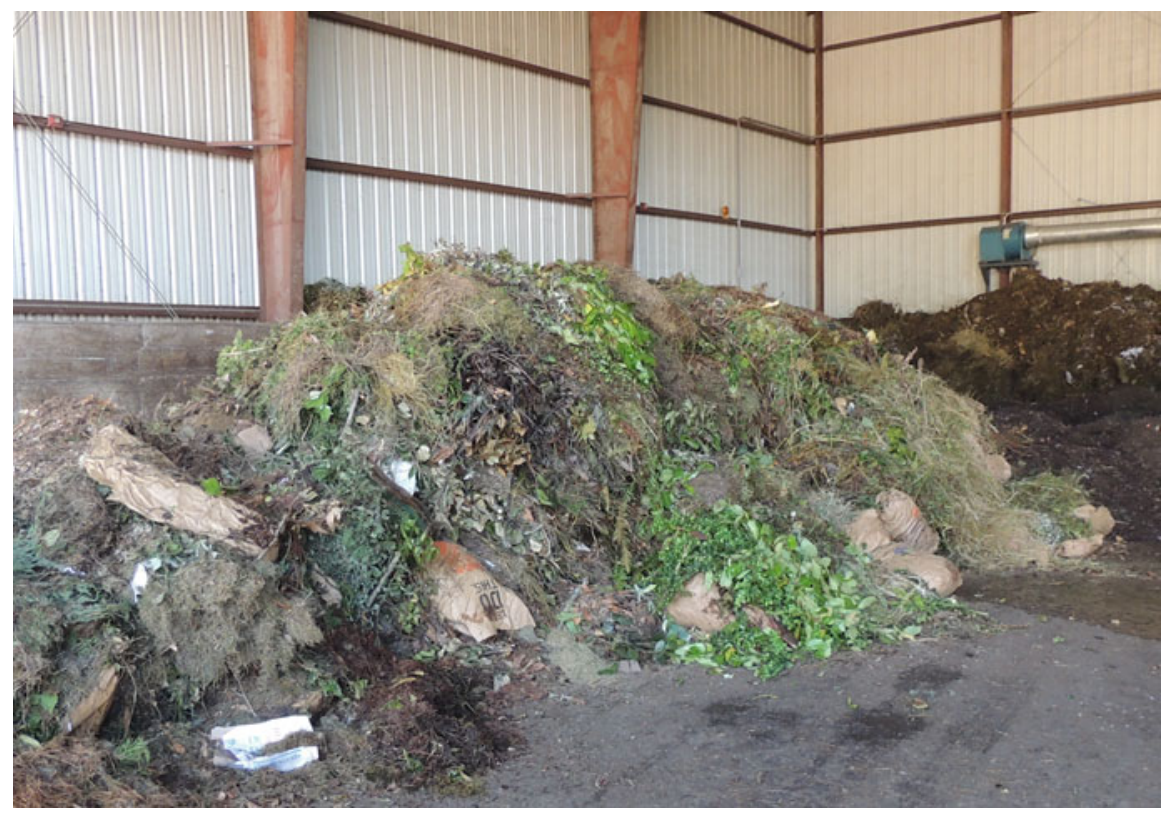

Fig. 1 Combined food and yard waste collected from private homes that will be composted to produce a soil amendment

Table 1 Total organics (food scraps and yard waste) diverted to composting for select states

\begin{tabular}{l|l|l|l|l|l}
\hline & $\begin{array}{l}\text { Total organics } \\
\text { diverted to } \\
\text { composting (tons) }\end{array}$ & $\begin{array}{l}\text { Diverted organics } \\
\text { as a percent } \\
\text { of total MSW }\end{array}$ & $\begin{array}{l}\text { State } \\
\text { population } \\
\text { (million) }\end{array}$ & $\begin{array}{l}\text { Per capita } \\
\text { diverted } \\
\text { (kg) }\end{array}$ & $\begin{array}{l}\text { \% Diverted } \\
\text { of total } \\
\text { generated }\end{array}$ \\
\hline California & $5,900,000$ & 8.6 & 38.33 & 140 & 68.51 \\
\hline Colorado & 263,549 & 3.2 & 5.27 & 45 & 22.26 \\
\hline Florida & $1,450,757$ & 5 & 19.55 & 67 & 7.27 \\
\hline Maine & 27,944 & 1.6 & 1.328 & 19 & 9.37 \\
\hline New Jersey & 535,176 & 4.2 & 8.9 & 55 & 26.76 \\
\hline Washington & $1,211,805$ & 13.7 & 6.97 & 158 & 77.38 \\
\hline
\end{tabular}

State population, per capita diverted and \% diverted of total generated. Data on total waste generated from http://www.epa.gov/epawaste/nonhaz/municipal/, data on total diverted from Platt and Goldstein (2014)

\section{Compost}

Composting is a process where different carbon based feedstocks are combined and decompose producing a stable soil conditioner that is high in organic matter and is also a source of nutrients. Feedstocks for composting often include a wet and high nitrogen material such as food scraps, municipal biosolids, or animal manures and 


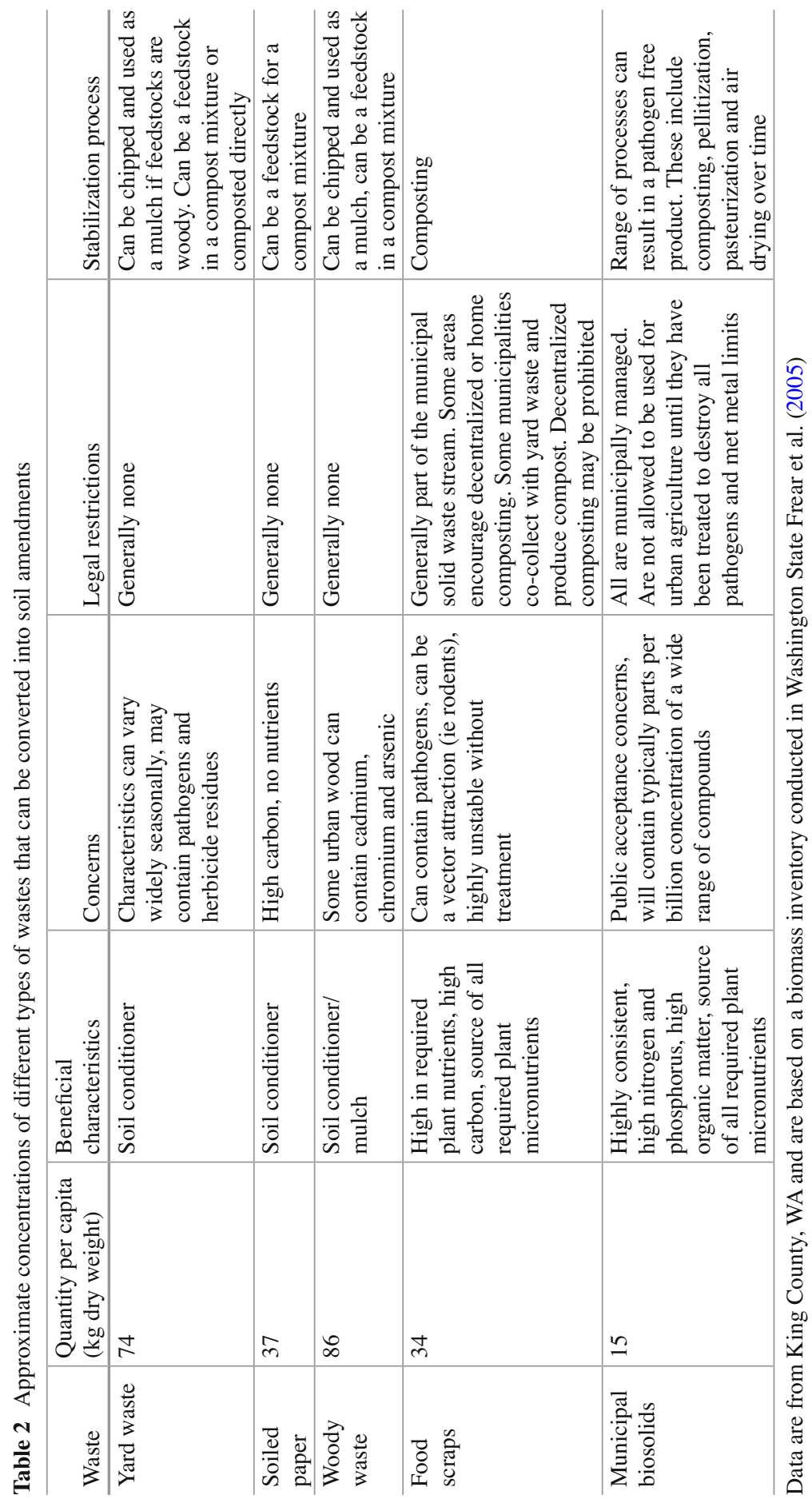




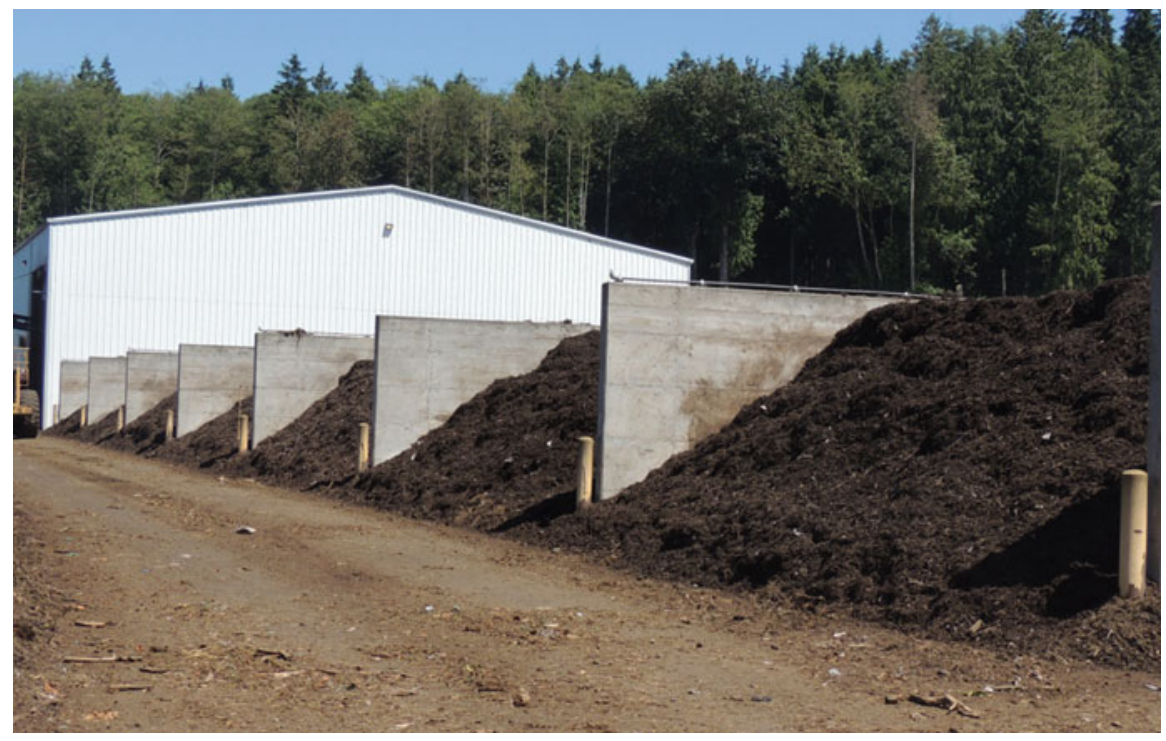

Fig. 2 Co-composting composting food and yard waste at the Lenz Enterprises compost facility north of Seattle, Washington

a dryer high carbon material such as woody debris, soiled paper, and yard waste. Washington State University has developed a spreadsheet to help determine appropriate mixtures of feedstocks for producing compost (Compost Mixture Calculator version 2.1).

Composting, more appropriately stabilization, will occur over time when materials are allowed to decompose and stabilize naturally. This process will typically occur over months or years. Controlled composting is a way to accelerate the stabilization process. Controlled composting is typically carried out in an aerobic environment. If provided with sufficient oxygen, a compost pile will heat to about $55^{\circ} \mathrm{C}$ (Fig. 2). If this temperature is maintained for a sufficient period, all pathogens and weed seeds in the pile will be destroyed. This is referred to as the active stage of composting. After reaching and maintaining temperature for the required time, most of the rapid decomposition will have finished. Compost is then typically allowed to cure for weeks to months before it is used. An ideal compost pile should start with a carbon: nitrogen ratio of 20-40:1 and a moisture content between 40 and $60 \%$. This process is typically carried out in windrows; long rows of material, with or without forced aeration or turning, and with or without surface covers. There are a number of organizations that provide training for composters and labs that test compost to make sure that it is sufficiently cured and is a suitable soil amendment.

Links:

- What Does Compost Analysis Tell You About Your Compost? http://puyallup. wsu.edu/soilmgmt/Pubs/Poster-CompostAnalysis.pdf (sampling, labs, results.)

- Washington State University http://puyallup.wsu.edu/soilmgmt/Composts.html 
- The Art and Science of Composting, http://www.cias.wisc.edu/wp-content/ uploads/2008/07/artofcompost.pdf (pdf) Univ. Wisconsin-Madison

- Cornell Composting, http://compost.css.cornell.edu/ educational materials, programs, links.

- US Composting Council, education materials, testing information, links

- http://compostingcouncil.org/

- BioCycle, published since 1960 (originally as Compost Science); archives accessible electronically starting in 2004; www.biocycle.net

\section{Municipal Biosolids}

Biosolids are the semi solid material produced by wastewater treatment plants when they treat wastewater. Biosolids typically contain high concentrations of nitrogen and phosphorus and all other required plant micronutrients. They are also high in organic matter, making them useful as a soil conditioner in addition to having fertilizer value. As they are produced from a predictable and consistent waste stream and as they are required to be tested and monitored, biosolids quality is consistent and predictable. The influent into a wastewater plant consists primarily of household waste, including water from showers, sinks and toilets. Most cities also have some influent from industries entering the municipal system. These include commercial food processing wastes and distillery waste in addition to what are typically thought of as industries. An industry wishing to use the municipal system must first apply for and be granted a permit to use that system. The permit will require the industry to provide expected characteristics of the wastewater it intends to discharge and can also require the industry to pre-treat the wastewater to reduce contaminant concentrations to acceptable levels prior to discharge. In cities with older wastewater infrastructure stormwater and wastewater pipes are combined and stormwater enters the treatment plant during storm events.

Wastewater treatment is a municipal service. Treatments to stabilize biosolids and reduce pathogen concentrations are described in regulations promulgated by the US EPA (US EPA 1993, 1994). US EPA has also done an extensive risk assessment to develop acceptable concentrations for contaminants in metals. This process included a consideration of heavy metals and toxic organics. Biosolids that are available for urban agriculture must fall within these regulatory limits and must not contain any pathogens (US EPA 2011). Research has also shown that plants grown in biosolids amended soils have no detectable concentrations of common household chemicals including pharmaceuticals and personal care products (Gaylor et al. 2014; Gottschall et al. 2012; Hale et al. 2012; Sabourin et al. 2012). Characteristics of biosolids and composts are shown in Table 3.

Benefits associated with use of composts and biosolids soil products on urban lands cover multiple categories (Fig. 3). Resource conservation, greenhouse gas mitigation, improved soil tilth, higher net primary productivity, reduced infrastructure costs, and increased environmental literacy and awareness are some of the benefits. 
Table 3 Characteristics of biosolids and compost

\begin{tabular}{|c|c|c|c|c|c|c|c|c|c|}
\hline & $\begin{array}{l}\text { Total } \\
\text { Carbon } \\
\left(\mathrm{g} \mathrm{kg}^{-1}\right)\end{array}$ & $\begin{array}{l}\text { Total } \\
\text { Nitrogen } \\
\left(\mathrm{g} \mathrm{kg}^{-1}\right)\end{array}$ & $\begin{array}{l}\text { Total } \\
\text { Phos- } \\
\text { phorus } \\
\left(\mathrm{g} \mathrm{kg}^{-1}\right)\end{array}$ & $\begin{array}{l}\text { Total } \\
\text { Potassium } \\
\left(\mathrm{g} \mathrm{kg}^{-1}\right)\end{array}$ & \begin{tabular}{|l|}
$\begin{array}{l}\text { Total } \\
\text { Copper } \\
(\mathrm{mg} \\
\left.\mathrm{kg}^{-1}\right)\end{array}$ \\
\end{tabular} & $\begin{array}{l}\text { Total } \\
\text { Zinc } \\
(\mathrm{mg} \\
\left.\mathrm{kg}^{-1}\right)\end{array}$ & $\begin{array}{l}\text { Total } \\
\text { Arsenic } \\
(\mathrm{mg} \\
\left.\mathrm{kg}^{-1}\right)\end{array}$ & $\begin{array}{l}\text { Total } \\
\text { Cadmium } \\
\left(\mathrm{mg} \mathrm{kg}^{-1}\right)\end{array}$ & $\begin{array}{l}\text { Total } \\
\text { Lead } \\
(\mathrm{mg} \\
\left.\mathrm{kg}^{-1}\right)\end{array}$ \\
\hline $\begin{array}{l}\text { Pelletized } \\
\text { biosolids } \\
\text { Cogger } \\
\text { et al. (2013) }\end{array}$ & 44.8 & 16 & 1.4 & & & & & & \\
\hline $\begin{array}{l}\text { Composted } \\
\text { biosolids }\end{array}$ & 455 & 19 & 8.9 & & 143 & 169 & 0.26 & 0.8 & 20 \\
\hline $\begin{array}{l}\text { Biosolids } \\
\text { based } \\
\text { potting soil }\end{array}$ & 173 & 12.5 & 6.9 & & 133 & 212 & 3.2 & 0.5 & 14 \\
\hline $\begin{array}{l}\text { Food/yard } \\
\text { compost } \\
\text { Sullivan } \\
\text { et al. (2002) }\end{array}$ & 11.7 & 2.6 & 10.5 & 54 & 233 & & & & \\
\hline $\begin{array}{l}\text { Yard waste } \\
\text { compost } \\
\text { Barker (2001) }\end{array}$ & 7 & 1.6 & 2.6 & 310 & 162 & & 2 & 130 & \\
\hline
\end{tabular}

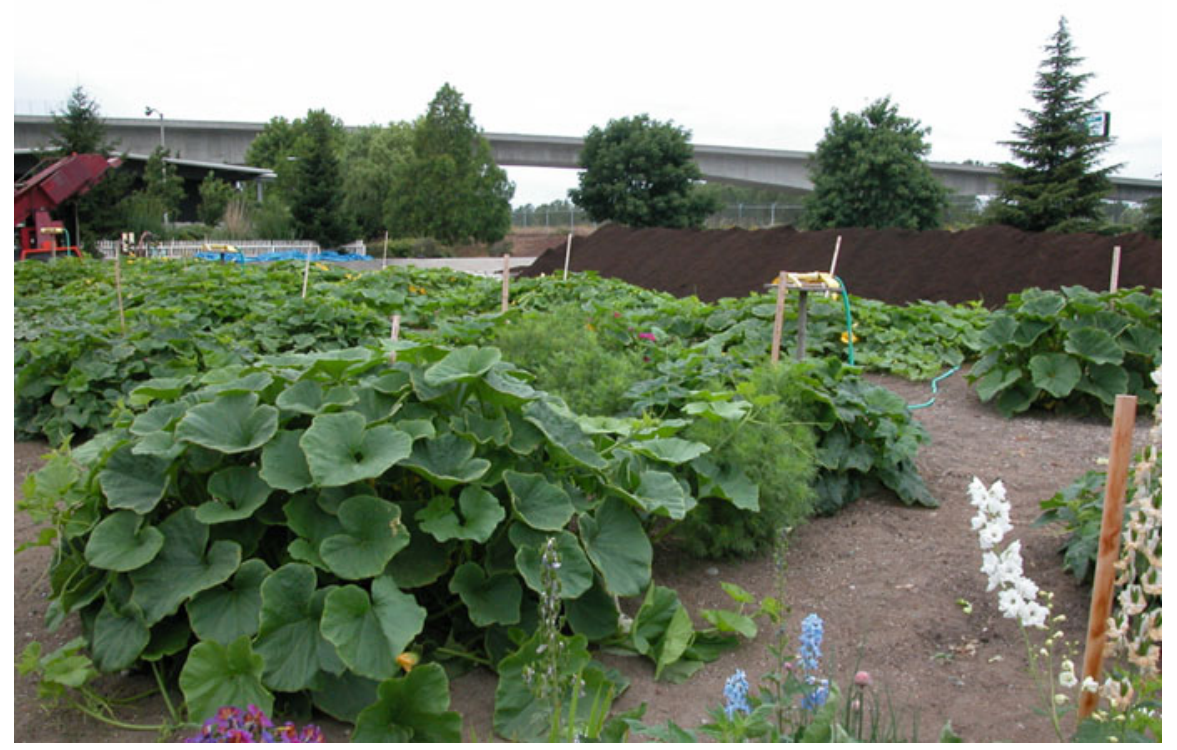

Fig. 3 The garden at the Tacoma, Washington wastewater treatment plant. The plant produces a biosolids based potting soil that is available free to all community gardens 
The Water Reuse chapter provides details on types of water for urban agriculture, safety and regulations governing use of non potable water for irrigation and benefits of using non potable water. The Soil Amendments chapter provides a discussion on residuals as soil amendments including a description of the benefits associated with adding treated organics to soils. Before these materials can be returned to soils in urban areas they must be stabilized. As stated, composting is perhaps the most common way to stabilize organic residuals so that they are appropriate for use on urban soils. For municipalities that have traditionally landfilled these materials, the decision to divert wastes from landfills to compost piles can be difficult. More and more municipalities are starting to do this. It can be done on a local level by private citizens and nonprofits. It can also be done on a municipal level. A discussion of decentralized composting follows. This section also includes information on broad scale food scrap diversion in Seattle, Washington from both the composter's perspective and a political perspective, and a comparative cost and environmental analysis of different residual management options.

\section{Decentralized and Small Scale Composting}

Composting can take place in backyards, in community gardens and in vacant lots. In the absence of centralized collection systems, many municipalities, gardeners and organizations support, encourage and participate in decentralized, small scale composting. While centralized collection and composting of municipal yard waste and food scraps is becoming more common, it is by far the exception rather than business as usual. Smallscale composting can provide a viable substitute. The benefits for small scale or decentralized operations are multiple. Waste is diverted from landfills, resulting in reduced fugitive greenhouse gas emissions, recycling of plant nutrients, and production of compost that is an essential tool for making urban soils suitable for food production. However, many of the challenges that larger, centralized systems experience, can also apply to smaller scale sites.

Backyard composting is the simplest version of a decentralized system. Many communities offer bins as well as classes on how to make compost that are geared to individual homeowners. For example, the city of Fort Collins, CO offers information on backyard composting on their municipal website (http://www.fcgov.com/ recycling/composting.php). A link to composting resources, information on a backyard composting demonstration site, as well as links to access worms for vermicomposting are offered. Backyard systems offer the general benefits of reduced volumes of waste to handle for municipalities and relatively small volumes of wastes to compost for non professionals. As these composting systems are small and located in private yards, there is also a very small potential for composts to generate odors that irritate neighbors. There is also a pre-existing market for use of the finished compost - in the yards where it was produced. Home composting however, is unlikely to result in large-scale diversion of waste from landfills and in production of sufficient volumes of compost for the multiple potential uses within a city. 
Community-based composting is a next step, in between backyard composting and centralized collection and large-scale systems. Community based composting operations typically accept food scraps from a mixture of commercial and residential sources and compost them using a mixture of techniques. These composters typically include a mixture of salaried employees and volunteers. Sufficient compost is produced that there is enough material for use on community gardens with the potential to have supplemental material. A recent survey identified 43 community based compost sites in the US (Brenda Platt, Institute for Local Self-Reliance). Because of the selection criteria used the survey only accounted for a portion of the community based composting sites in operation. Despite that, the results can be viewed as a lens on these programs. Of these, 24 responded to a survey on different aspects of their operations. The compost produced by $96 \%$ of those responding was used in home and community gardens. A majority of those responding accepted material to compost from offsite, were located in urban areas, and were operated by non-profits, with about $40 \%$ of those responding also involved in food production. A smaller percentage $(23 \%$ ) classified themselves as farms. A range of composting methods were used including windrows $(50 \%)$, vermicomposting and bins (each at $42 \%$ ) and static piles (31\%). A smaller percentage (27\%) used forced aeration, a system that requires more infrastructure investment.

Community composting operations can result in cost savings for municipalities, and in some cases they can also generate revenue. Of those responding to the survey $43 \%$ relied on governments for use of land and $62 \%$ received government grants to support their operations. A majority generated revenue $(63 \%)$ with revenue coming from a range of sources including charging tip or collection fees for feedstocks and income from sales of compost or other soil products. Although a majority generated revenue, only $28 \%$ of those surveyed generated sufficient revenues to sustain operations while $72 \%$ were operating in the red. Most of the sites were staffed by a mixture of volunteers and paid employees. Volunteers participated in the composting process at varying levels depending on the site, but were involved in the process at all sites (Fig. 4).

Another feature of community composting operations is that composting is typically only a part of what occurs at each site. A description of a community composting operation, located in Brooklyn, NY illustrates this point. The operation is funded at least in part by the New York City Department of Sanitation. The Department of Sanitation began an effort to promote community and local composting in 1993. Currently, the program supports 200 smaller sites and eight to ten mid sized sites in the five boroughs (Goldstein 2013; https://sites.google.com/site/communitycompostnyc/home). The program has also worked with the New York City Botanical Gardens to provide educational material and demonstration sites (for example: http://www.bbg.org/gardening/nyc_compost_project_in_brooklyn). The Botanical Gardens also teaches a Master Composter Certificate Course which certifies about 60 people per year. Added Value Community Farm, located in Red Hook, a low income neighborhood in Brooklyn is one of the composting operations that the 
Department of Sanitation funds (http://added-value.org/). Founded in 2000, their primary goal as a non-profit is to 'promote the sustainable development of Red Hook by nurturing a new generation of young leaders'. The organization works with teens between the ages of 14 and 19 as well as local elementary school students. The organization has revitalized local parks, turned vacant lots into farms, and started a local farmers market. With this, they have increased access to local and healthy
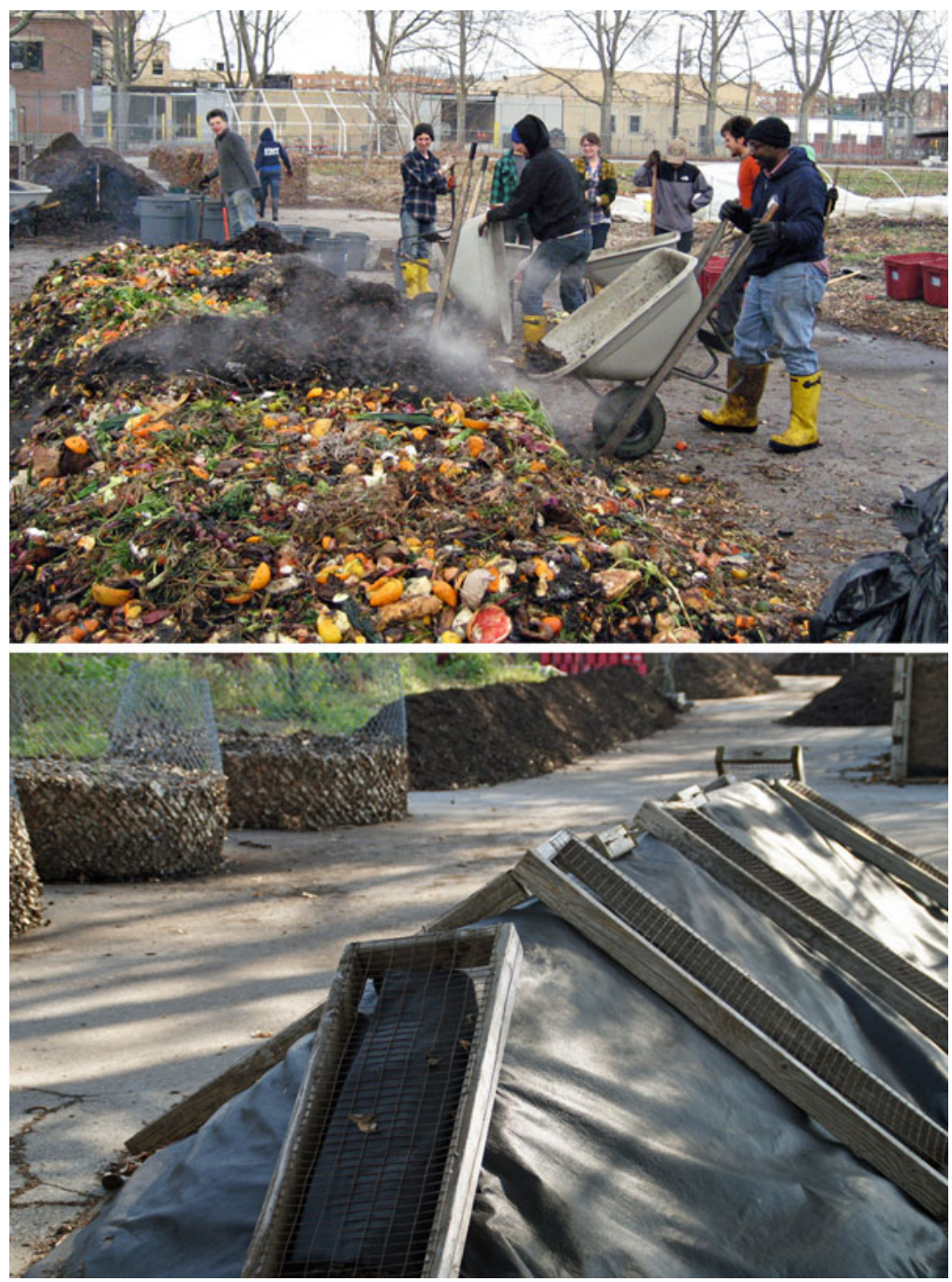

Fig. 4 Community composting at Added Value Community Farm in Redhook, Brooklyn (Photos by Terry Kaelber) 

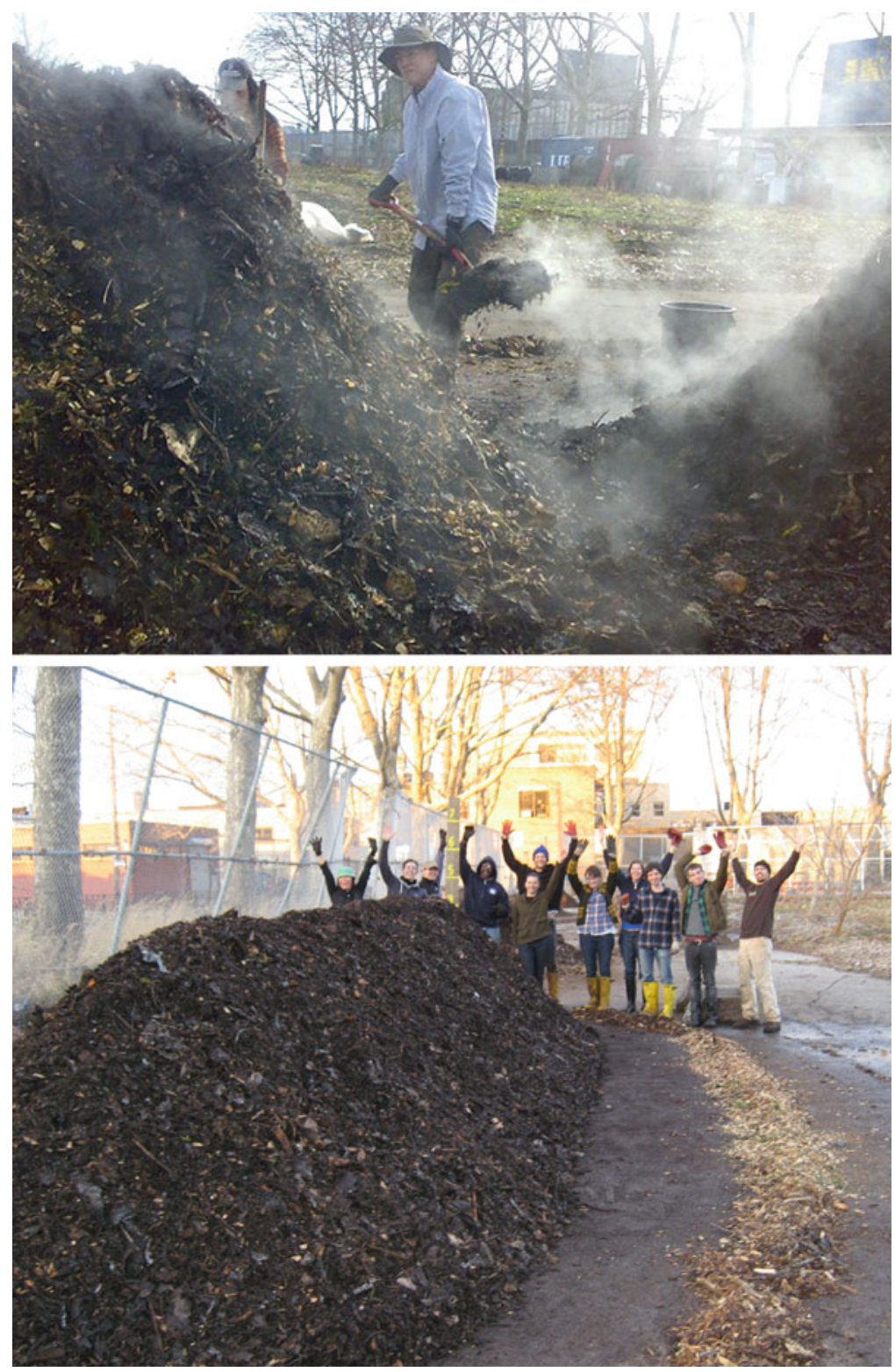

Fig. 4 (continued)

foods and helped the local economy. They also produce compost from plant material from the farm as well as locally collected food scraps in windrows that are set up and maintained by hand. Peak capacity is about 225 tons of compost feedstocks per year. The composting program is run entirely on sustainable resources: solar power 
and people power and is the largest such program in New York City. Links to other programs in New York are provided below.

http://www.lesecologycenter.org/index.php/composting.html

https://dl.dropboxusercontent.com/u/87688134/Public Files Folder/UrbanFarming

Magazine4-13.pdf

http://www.bignyc.org/compost

http://www.queensfarm.org/sustainable_agriculture.html

http://added-value.org/growing-a-just-food-system

http://www.earthmatter.org

http://www.nyc.gov/html/nycwasteless/html/compost/operations_community.shtml http://gowanuscanalconservancy.wordpress.com/category/composting-gowanus/

\section{Conclusion}

Waste conversion is an essential ecosystem service that is provided by soils in natural systems. In urban areas a broad range of feedstocks can, with proper treatment, be transformed into valuable soil amendments. However, the quantities that are produced along with the limited amount of soil within a municipality means that these transformations have to occur with some oversight in dedicated facilities. Dedicated facilities can range from backyard composters to centralized wastewater treatment facilities. In all cases, with proper treatment, these residuals can be transformed into excellent soil amendments for urban agriculture.

\section{References}

Alexander M (2000) Aging, bioavailability, and overestimation of risk from environmental pollutants. Environ Sci Technol 34:4259-4265

Barker AV (2001) Evaluation of composts for growth of grass sod. Commun Soil Sci Plant Anal 32:1841-1860

Brown S, Sprenger M, Maxemchuk A, Compton H (2005) An evaluation of ecosystem function following restoration with biosolids and lime addition to alluvial tailings deposits in Leadville, CO. J Environ Qual 34:139-148

Chen YC, Banks MK, Schwab AP (2003) Pyrene degradation in the rhizosphere of tall fescue (Festuca arundinacea) and switchgrass (Panicum virgatum L). Environ Sci Tech 37:5778-5782

Cogger CG, Bary AI, Myhre EA, Fortuna AM (2013) Biosolids applications to tall fescue have long-term influence on soil nitrogen, carbon, and phosphorus. J Environ Qual 42:516-522

Costanza R, d'Arge R, de Groot R, Farber S, Grasso M, Hannon B, Limburg K, Naeem S, O’Neill R, Paruelo J, Raskin R, Sutton P, Vanden Belt M (1997) The value of the world's ecosystem services and natural capitol. Nature 387:253-260

Frear C, Zhao B, Fu G, Richardson M, Chen S, Fuchs MR (2005) Biomass inventory and bioenergy assessment: an evaluation of organic material resources for bioenergy production in Washington State. Washington Department of Ecology Publication No. 05-07-047 http://www. pacificbiomass.org 
Gagliardi JV, Karns JS (2000) Leaching of Escherichia coli O157:H7 in diverse soils under various agricultural management practices. Appl Environ Microbiol 66(3):877-883

Gaylor MO, Mears GL, Harvey E, LaGuardia MJ, Hale RC (2014) Polybrominated diphenyl ether accumulation in an agricultural soil ecosystem receiving wastewater sludge amendments. Environ Sci Tech 48:7034-7043

Gerba C, Smith JE (2005) Sources of pathogenic microorganisms and their fate during land application of wastes. J Environ Qual 34:42-48

Goldstein N (2013) Community composting in New York City. Biocycle 54:11-22

Gottschall N, Topp E, Metcalfe C, Edwards M, Payne M, Kleywegt S, Russell P, Lapen DR (2012) Pharmaceutical and personal care products in groundwater, subsurface drainage, soil, and wheat grain, following a high single application of municipal biosolids to a field. Chemosphere 87:194-203

Hale RC, LaGuardia MJ, Harvey E, Chen D, Mainor TM, Luellen DR, Hundal LS (2012) Polybrominated diphenyl ethers in U.S. sewage sludges and biosolids: temporal and geographical trends and uptake by corn following land application. Environ Sci Tech 46:2055-2063

McIvor K, Cogger C, Brown S (2012) Effects of biosolids based soil products on soil physical and chemical properties in urban gardens. Compost Sci Utiliz 20:199-206

Metcalf \& Eddy (2003). Wastewater engineering: treatment and reuse, 4 ed. McGraw-Hill, New York

Penninsi E (2012) Water reclamation going green. Science 33:674-676

Platt B, Goldstein N (2014) State of composting in the U.S. Biocycle 55(6):19-26

Puglisi E, Cappa F, Fragoulis G, Trevisan M, Del Re A (2007) Bioavailability and degradation of phenanthrene in compost amended soils. Chemosphere 67:548-556

Sabourin L, Duenk P, Bonte-Gelok S, Payne M, Lapen D, Topp E (2012) Uptake of pharmaceuticals, hormones and parabens into vegetables grown in soil fertilized with municipal biosolids. Sci Total Environ 431:233-236

Sullivan DM, Bary AI, Thomas DR, Fransen SC, Cogger CG (2002) Food waste compost effects on fertilizer nitrogen efficiency, available nitrogen and tall fescue yield. Soil Sci Soc Am J 66:154-161

US EPA (2011) Growing gardens in urban soils. EP A/542/F- 10/011. Retrieved from http://www. clu-in.org/eco- tools/urbangardens.cfm

USEPA (1993) 40 CFR Part 503 - Standards for the use and disposal of sewage sludge: final rule. Fed Regist 58:9248-9415

USEPA (1994) A plain English guide to the part 503 biosolids rule. EPA/832/R-93/003. USEPA Office of Wastewater Management, Washington, DC

Vaillant G, Pierzynski GM, Ham JM, DeRouchey J (2009) Nutrient accumulation below cattle feedlot pens in Kansas. J Environ Qual 38:909-918 


\title{
Municipal Food Waste Management Options: Climate and Economic Impacts
}

\author{
David Parry
}

\section{Introduction}

This section summarizes and expounds on work performed in a 2012 study of sustainable food waste management alternatives published by the Water Environment Research Foundation (WERF 2012). The study evaluated economic, environmental, social, and operational impacts associated with food waste management options for a hypothetical community of 100,000 residents. The reader is referred to the original study for more detail on the assumptions and approach used in the evaluation described in this section. An additional option-de-centralized composting-is included below for the purposes of this publication.

According to the United States Environmental Protection Agency (EPA), the United States generates over 34 million tons of food waste annually (U.S. EPA 2011). Almost all of this waste is landfilled. Food waste is the second greatest category of waste generated in the United States, exceeded only by paper products. However, the EPA's estimates may be underreporting the total generation of food waste as it is unclear if they are including food waste that is generated and processed in food waste disposers, or by other means, such as backyard composting. Given the mass of food waste generated, determining the multiple impacts of different food waste management methods will provide valuable guidance in decisions related to solid waste and wastewater treatment policies.

D. Parry, Ph.D., P.E., BCEE ( $\square)$

Water Business Group, CH2M, 1100 112th Avenue NE, Bellevue 98004-5118, WA, USA

e-mail: David.Parry@ch2m.com 


\section{Research Objectives}

This study examined food waste management techniques at commonly configured landfills, wastewater treatment plants (WWTP), and composting facilities. The study assessed the economic, environmental, social, and operational impacts of food waste management. To maintain consistency throughout the analysis, assumptions that impacted multiple alternatives (e.g., equipment demands, fuel characteristics, general costs, etc.) were made common to all the alternatives. In order of preference, assumptions were based on manufacturers' data, literature values, and professional experience of the researchers.

All of the food waste management scenarios were based on a representative community located in North America. Although the focus of the research was on residential food waste generation, several of the concepts and the general approach could broadly be applied to commercial or industrial food waste applications. However, unlike residential, it is unlikely that commercial or industrial food waste management would include using the wastewater collection system for conveyance. The research focused on quantifying impacts - i.e., costs, energy demands, renewable energy production, greenhouse gas emissions, footprint requirements, worker staffing requirements, water demands - of the following food waste management methods:

- Landfilling (Landfill). Curbside collection of commingled food waste with other residential municipal solid waste and processing in a landfill.

- Sewered Conveyance to the Wastewater Treatment Plant (WWTP/Sewer). Food waste processing in a residential food waste disposer and conveyance via the existing sewer infrastructure to the wastewater treatment plant operating with primary treatment, aerobic secondary treatment and anaerobic digestion.

- Direct Anaerobic Digestion (WWTP/Hauled). Curbside collection of sourceseparated food waste, transportation via truck hauling to the wastewater treatment plant, and direct beneficial use in the treatment plant anaerobic digesters.

- Centralized Composting (Centralized Compost). Curbside collection of sourceseparated food waste with green waste and beneficial use in a large-scale composting facility.

- De-Centralized Composting (De-Centralized Compost). Curbside collection of source-separated food waste only and beneficial use in several small-scale community composting facilities.

For the Landfill alternative, it was assumed that commingled food waste was first collected from the residence and trucked to a transfer station. After the transfer station, food waste was hauled to the landfill for processing and disposal. The landfill operations were assumed to use soil for daily cover and compactors to spread and compact the waste. Leachate was assumed to be trucked and treated offsite at a WWTP, as this is the most common form of leachate management for municipal solid waste landfills. The moisture content of food waste is more than adequate to allow for biological decomposition; therefore, biological degradation of food waste 


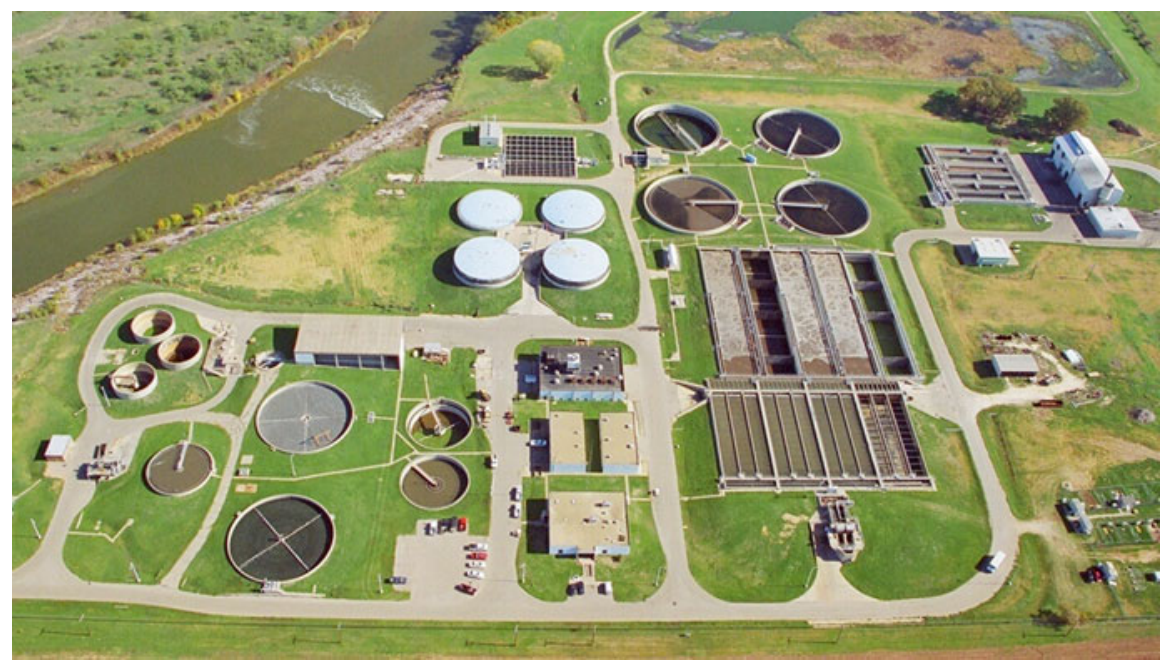

Fig. 1 The Waco Metropolitan Area Regional Sewerage System (WMARSS) Wastewater Treatment Plant (WWTP) serving the City of Waco, TX. The plant uses aerated secondary treatment and anaerobic digestion to stabilize wastewater (Photo from Michael Jupe)

within the landfill was assumed to proceed spontaneously. Biogas produced from the decomposition of landfilled food waste was assumed to be captured and combusted in an internal combustion engine-driven generator to produce electricity only, as that is the most common landfill gas utilization method and the presence of local heat demands are improbable.

The WWTP/Sewers analysis focused on a single common WWTP that uses raw wastewater screening and grit removal, primary clarification, activated sludge treatment for carbonaceous BOD removal, hypochlorite disinfection of treated effluent, solids thickening, anaerobic digestion with combined heat and power (CHP), biosolids dewatering, and biosolids land application. The increased energy demand for additional aeration resulting from the increased BOD load on the activated sludge treatment system was taken into account (Fig. 1).

The WWTP/Hauled alternative was based on source-separated residential food waste being collected curbside, screened at a solid waste facility, and the preprocessed food waste transported to a local WWTP. At the WWTP, the food waste was further screened and pumped directly into an anaerobic digester (Fig. 2). The design of the digester was the same as that used in the WWTP/Sewers alternative, with the exception that a sludge screen was installed on a circulation loop to further reduce particle size and remove inert materials. Biogas produced from the digestion process was collected and utilized in an internal combustion engine CHP facility and biosolids were hauled offsite for land application.

For the Centralized Compost alternative, source-separated residential food waste was assumed to be collected curbside with green waste and transported to a single, large-scale compost facility. Because the compost product requires a substantial 


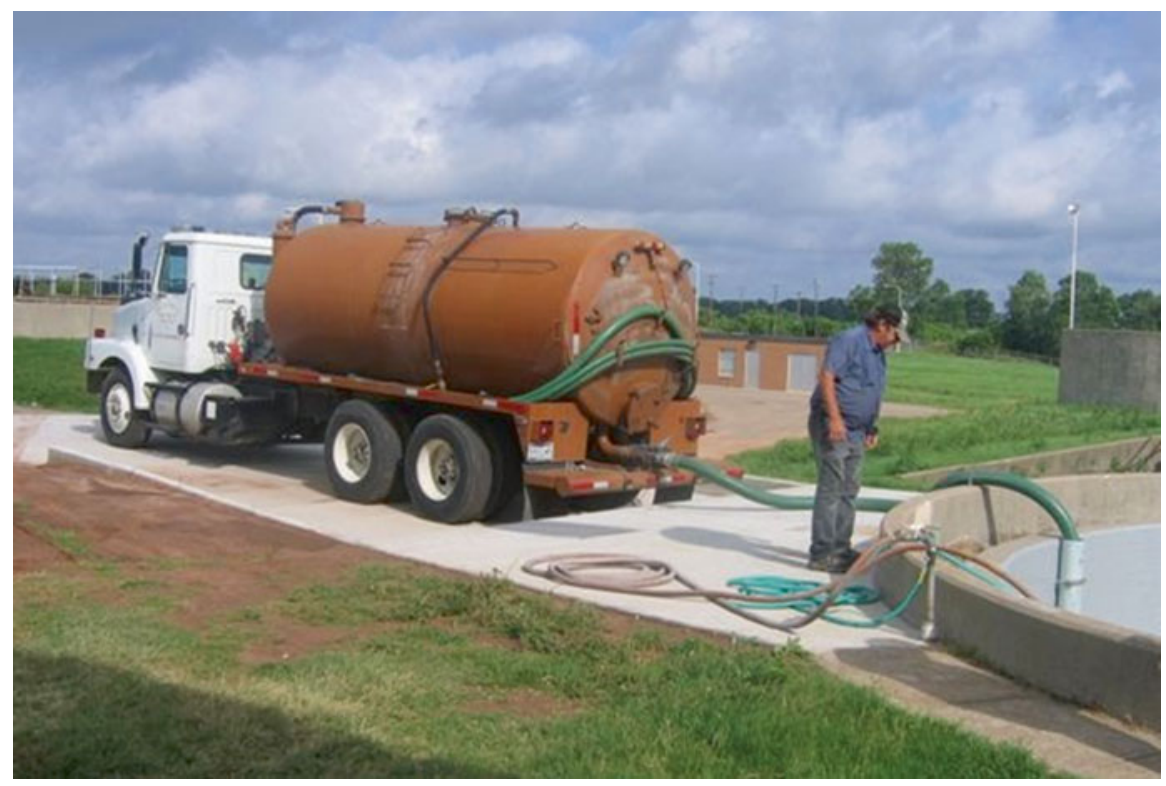

Fig. 2 High strength organic wastes from food processing being delivered to a wastewater treatment plant for direct anaerobic digestion (Photo from Michael Jupe, Waco, TX)

amount of addition bulking agent, the costs and labor required to process the additional bulking agent were also taken into account; however, the bulking agent was assumed to be produced onsite as a waste product, so the cost of transporting the raw bulking agent was neglected. The round-trip haul distance to the compost facility was assumed to be 45 miles. It should be noted that emissions and costs for collecting and processing food waste depend on a several factors, including the type of collection vehicle, local traffic conditions, public or private collection programs, and the distance to the compost facility.

The De-Centralized Compost alternative was based on professional experience and data reported in Rothenberger et al. 2007. The alternative assumed that sourceseparated residential food waste was collected curbside and transported to one of four small-scale community compost facilities (Fig. 3). Because the compost product required a substantial addition of bulking agent, the costs and labor required to transport and process the additional bulking agent were also accounted for in this step, but the bulking agent (leaves, paper, coffee grounds, etc) could be sourced nearby. The average round-trip haul distance to the compost facility was assumed to be 15 miles. Although a de-centralized compost facility is typically a simple, lowtechnology operation, it was assumed that each facility would require a frontloading excavator for moving and processing food waste and a grinder for reducing material size. All other material processing needs were assumed to be performed by facility personnel. New rear-loading haul trucks were also assumed because most municipalities with compost operations do not require separation of food waste from 


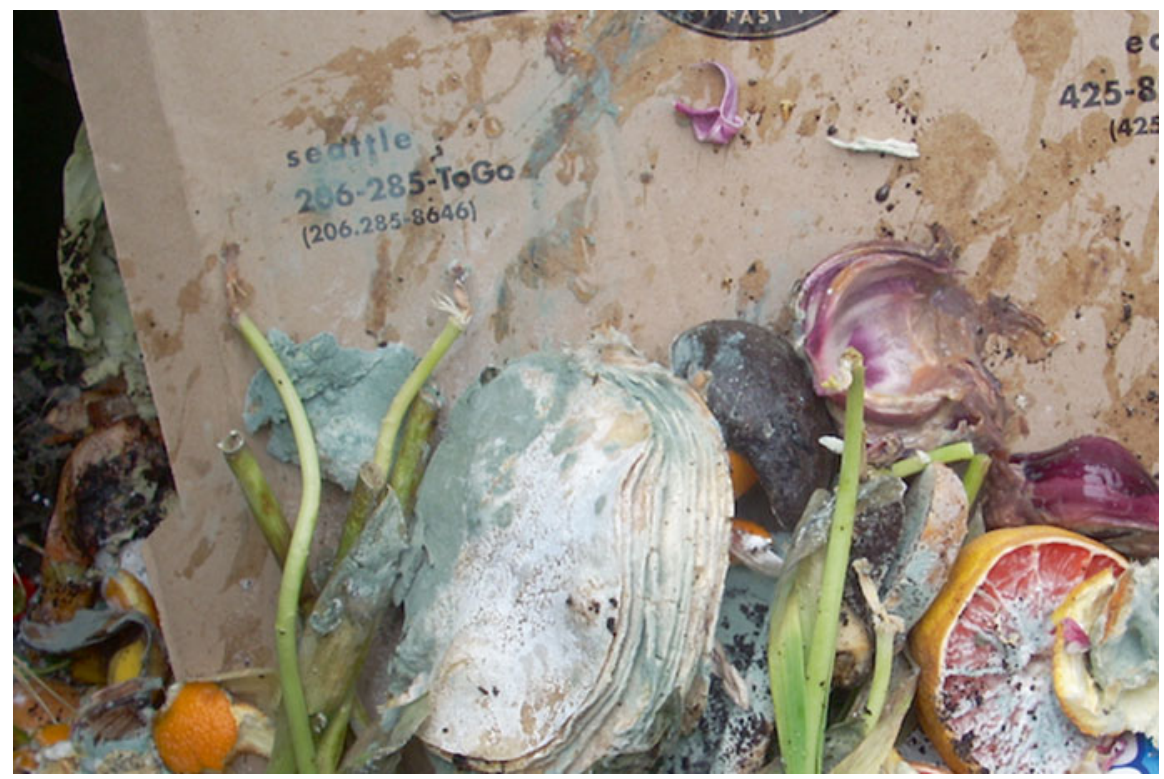

Fig. 3 Co collected residential food waste and yard waste in Seattle, WA (Photo Sally Brown)

other green waste. A de-centralized system would rely on the public to source-separate food waste only; then deposit the food waste into dedicated bins or trucks for the community compost operation (Fig. 4). The greater quantities of green waste would be handled at larger central composting facilities. It was assumed that land requirements for de-centralized compost operations would be provided free of charge by governmental or community organizations.

\section{Food Waste Sustainability Results}

Each food waste analysis was developed based on common assumptions. The major assumptions common to all food waste management alternatives are as follows:

- Mass of food waste is based on a city of 100,000 people, resulting in food waste production of 3930 tons per year

- Food waste is composed of $69 \%$ water

- The chemical composition of the dry fraction of food waste was approximated by $\mathrm{C}_{21.5} \mathrm{H}_{34.2} \mathrm{O}_{12.7} \mathrm{~N}_{1}$

- Annual food waste generation rates:

- 1870 ton/year COD

- 1530 ton/year biodegradable COD

- 1220 ton/year total solids 


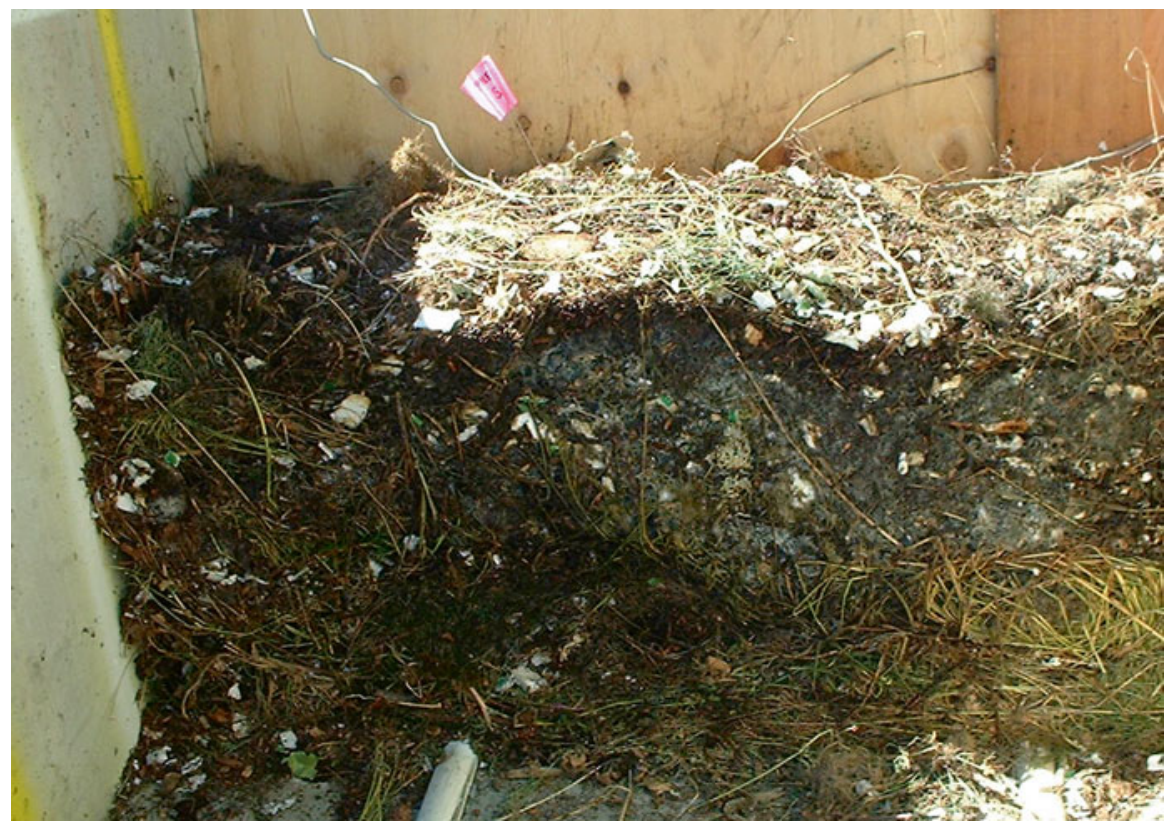

Fig. 4 Small scale composting. This unit would be appropriate for multiple households (Photo from Sally Brown)

This analysis was not tailored to a specific application or even a general region, thus every effort was made to generalize and simplify the assumptions used in this report to the extent possible. This analysis is therefore non-specific and was meant to serve as a comparative study or provide some general guidance regarding sustainable food waste management alternatives. Because of its broad nature, this report should be seen as a template for future site-specific studies, and should not be viewed as a comprehensive characterization of food waste management alternatives.

\section{Greenhouse Gas Emissions}

The emissions from fugitive methane, combustion of fuels and the use of electricity contribute to the overall carbon footprint of an alternative through the emission of greenhouse gas (IPCC AR4 2007). This analysis quantified the direct and indirect emissions of greenhouse gases; then calculated the carbon footprint as a result of food waste processing in each alternative.

The greenhouse gas pollutants quantified in this analysis were carbon dioxide $\left(\mathrm{CO}_{2}\right)$, methane $\left(\mathrm{CH}_{4}\right)$, and nitrous oxide $\left(\mathrm{N}_{2} \mathrm{O}\right)$. These gases are generally considered to be the most important greenhouse gases. The atmospheric chemistry of each of these gases differs. The greenhouse gas emissions were normalized to a 
"carbon dioxide equivalent" or $\mathrm{CO}_{2} \mathrm{e}$, using the global warming potentials of each gas. The global warming potential is a measure of the global warming effect of each gas relative to carbon dioxide over a 100-year timeframe. By convention, the global warming potential of carbon dioxide is equal to 1 , while the global warming potentials of $\mathrm{CH}_{4}$ and $\mathrm{N}_{2} \mathrm{O}$ are 25 and 298 ton $\mathrm{CO}_{2} \mathrm{e} /$ ton, respectively. The global warming potentials imply that 1 ton of $\mathrm{CH}_{4}$ emitted to the atmosphere has the same global warming impact as 25 tons of $\mathrm{CO}_{2}$, and 1 ton of $\mathrm{N}_{2} \mathrm{O}$ has the same impact as 298 tons of $\mathrm{CO}_{2}$. Therefore, $\mathrm{CH}_{4}$ and $\mathrm{N}_{2} \mathrm{O}$ emissions incurred throughout this analysis were multiplied by 25 and 298, respectively, to normalize those emissions to carbon dioxide equivalents and compare the greenhouse gas emissions of each alternative on an equal basis. Unless otherwise noted, all greenhouse gas emissions reported in this study are in tons of $\mathrm{CO}_{2} \mathrm{e}$ per year.

In this analysis, emissions of greenhouse gases were separated into non-biogenic and biogenic sources. Non-biogenic sources included emissions from electrical use, fossil fuel (diesel, gasoline, or natural gas) combustion, and any emission of methane and nitrous oxide, regardless of the source of the emissions. Average U.S. power utility data were used to calculate the greenhouse gas emissions from electrical use. According to the U.S. EPA eGRIDweb (U.S. EPA 2011), national greenhouse gas emissions of $\mathrm{CO}_{2}, \mathrm{CH}_{4}$, and $\mathrm{N}_{2} \mathrm{O}$ from electricity production are $1330,0.0273$, and $0.0206 \mathrm{lb} / \mathrm{MWh}$ produced, respectively. These greenhouse gas emission factors were used to calculate a net carbon dioxide equivalent emission factor of 1.34 pounds of $\mathrm{CO}_{2} \mathrm{e}$ per kWh electricity consumed or offset. The analysis assumes that electricity produced onsite by combined heat and power equipment would result in a commensurate decrease in electrical demand on the local power utility. Therefore, the $\mathrm{CO}_{2} \mathrm{e}$ credit from electrical production was equal to $\mathrm{CO}_{2} \mathrm{e}$ emissions from a corresponding amount of electricity purchased from the local utility.

Indirect environmental impacts from the manufacture of chemicals, namely synthetic fertilizer, were also evaluated. The manufacture of synthetic fertilizers is energy-intensive due to the need to fix atmospheric nitrogen to produce ammonia nitrogen. Using biosolids in lieu of synthetic fertilizers results in an avoidance of the demand for those products and an indirect reduction in energy and non-biogenic carbon emissions. This report used a carbon offset of $4 \mathrm{~kg}$ of $\mathrm{CO}_{2} \mathrm{e} / \mathrm{kg}$ of N applied via compost or biosolids to a land application site (Brown et al. 2010).

Biogenic carbon dioxide equivalent emissions included any $\mathrm{CO}_{2}$ emissions resulting from the aerobic or anaerobic decomposition of food waste (or other renewable resources required in the process), or the combustion of biogas methane. A biogenic $\mathrm{CO}_{2} \mathrm{e}$ credit was also included for carbon sequestration from land applying organic matter. Landfilling or land applying organic material acts as a carbon sink by converting some of the carbon into refractory forms that are retained at the point of application.

It was assumed that all of the trucks and other heavy machinery used in the alternatives were conventional vehicles using internal combustion diesel engines (Fig. 5). Where food waste was hauled within city limits, an eight-ton vehicle with an average mileage of three miles per gallon was assumed. When larger volumes of materials were hauled (e.g., during biosolids management or food waste transport 


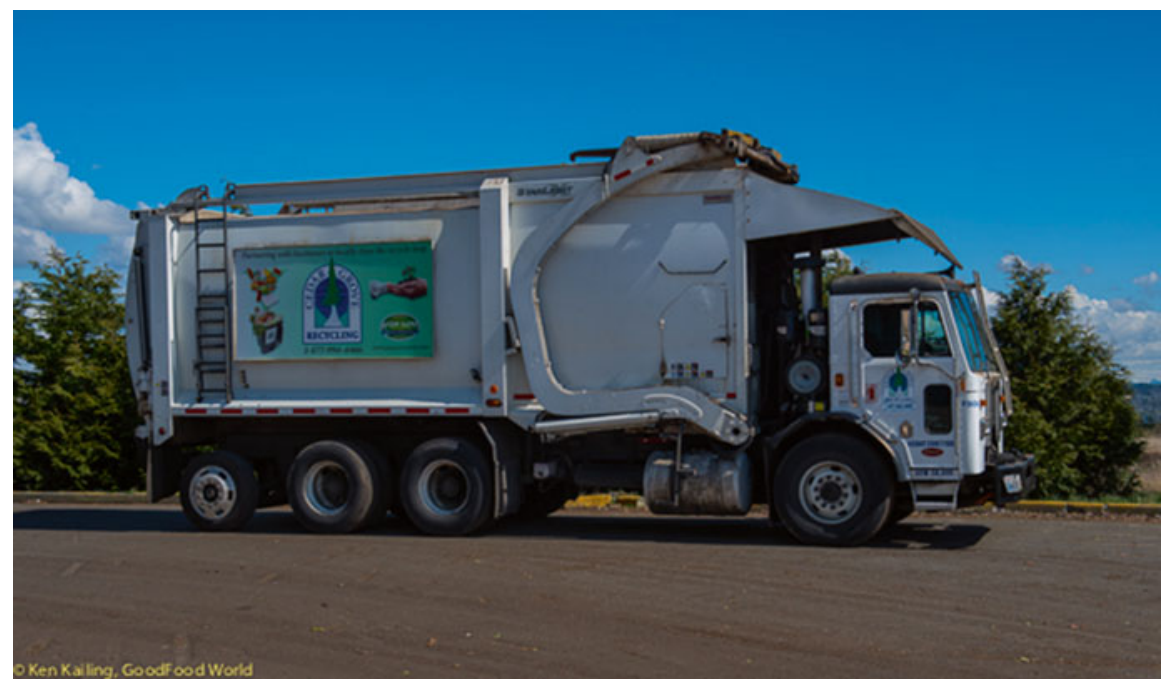

Fig. 5 A collection vehicle used to collect combined yard and food waste (Photo by Ken Kailing)

after processing at a transfer station), a 22 -ton vehicle with a mileage of 5.8 miles per gallon was estimated, which is typical of highway haul trucks [The Climate Registry (2008) and professional experience]. Where diesel consumption data was unavailable for processing equipment and heavy machinery, a consumption rate of $0.04 \mathrm{gal} / \mathrm{hp}$-h was assumed (based on professional experience). Once the total fuel use for each alternative was calculated, the greenhouse gas emissions were calculated using an emissions factor of 22.2 pounds of carbon dioxide equivalents per gallon of diesel combusted (U.S. EPA Emission Facts 2005).

A summary of $\mathrm{CO}_{2} \mathrm{e}$ emissions from the food waste management alternatives are presented in Fig. 6. Because biogenic $\mathrm{CO}_{2} \mathrm{e}$ emissions were based on the biological degradation of a consistent mass of food waste, the biogenic $\mathrm{CO}_{2} \mathrm{e}$ emissions were relatively consistent throughout the alternatives. Minor variations in biogenic $\mathrm{CO}_{2} \mathrm{e}$ emissions across alternatives can be attributed to differences in biogas utilization or carbon sequestration rates. The Landfill alternative had the highest non-biogenic $\mathrm{CO}_{2} \mathrm{e}$ emissions because of the relatively high proportion of unrecovered methane produced by biological degradation of food waste within the landfill. The WWTP/ Sewers alternative had moderately high greenhouse gas emissions associated with fugitive methane release in the sewers. There is little data available regarding the extent of food waste degradation in sewers. The researchers assumed $5 \%$ aerobic and $10 \%$ anaerobic degradation of chemical oxygen demand (COD), for a total degradation of $15 \%$. It should be noted that the assumption is arbitrary, because of the variability of sewer length and wastewater temperature. There is limited information on the characterization of food waste in the sewers. Further research is needed to characterize the type and extent of food waste decomposition in sewers. 


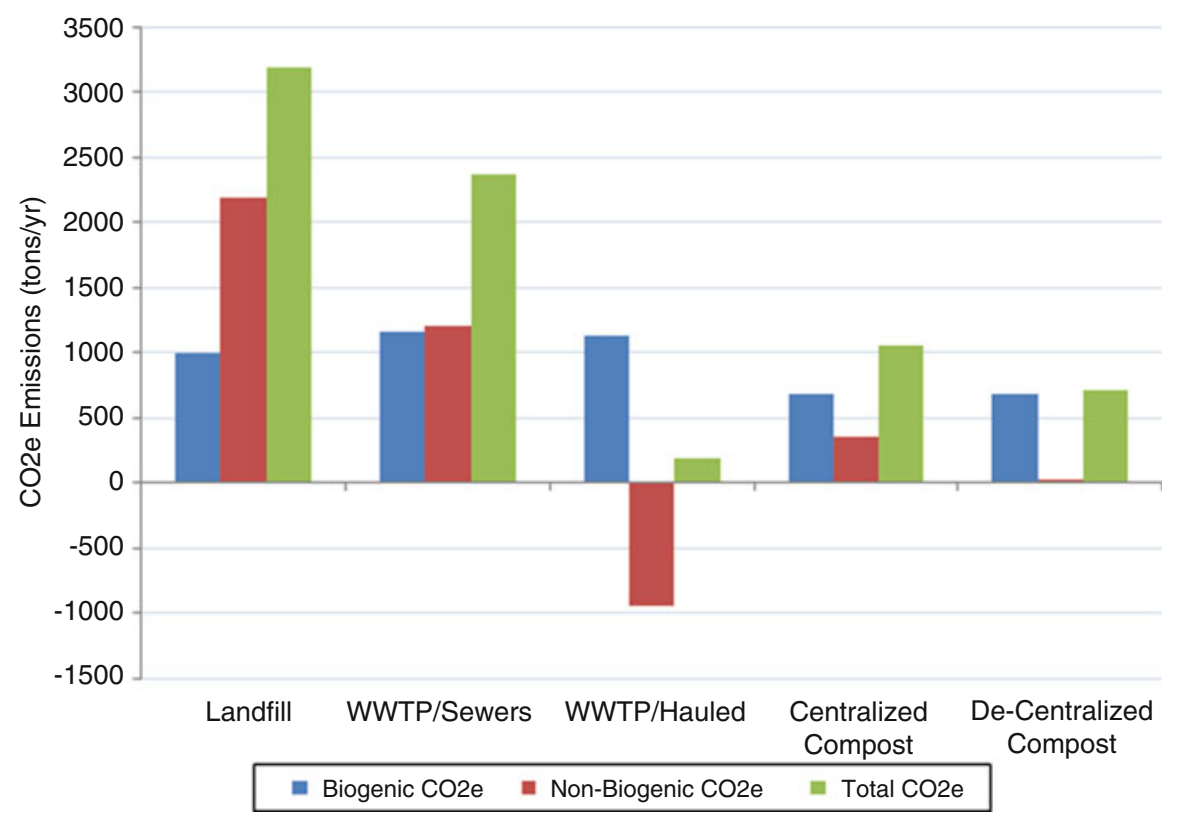

Fig. 6 Comparison of greenhouse gas emissions $\left(\mathrm{as}^{\mathrm{C}} \mathrm{CO}_{2} \mathrm{e}\right)$ from food waste management options. Biogenic carbon is not typically considered in carbon accounting. The benefits associated with land application of the final product (soil carbon presentation and fertilizer avoidance) are not considered in this summary

Thus, the impact of this assumption is large and provides a high degree of uncertainty to the results of carbon dioxide equivalent emissions for the WWTP/sewers alternative. The WWTP/Hauled alternative showed negative non-biogenic $\mathrm{CO}_{2} \mathrm{e}$ emissions because more organics are broken down anaerobically and more methane is recovered for beneficial use in combined heat and power equipment. A negative result implies a net offset of non-biogenic $\mathrm{CO}_{2} \mathrm{e}$ emissions for the alternative. As a result of the net negative non-biogenic $\mathrm{CO}_{2} \mathrm{e}$ emissions, the WWTP/Hauled alternative also showed the lowest total $\mathrm{CO}_{2} \mathrm{e}$ emissions. The Centralized and De-Centralized Compost alternatives showed a relatively small carbon footprint and benefited from a high degree of carbon sequestration. The sequestered carbon included the carbon in both the food waste and the composting amendment. Because the composting process in both centralized and de-centralized composting operations is similar, the biogenic $\mathrm{CO}_{2} \mathrm{e}$ emissions from both composting alternatives were also the same. However, de-centralized composting relies more heavily on facility staff to maintain the process, rather than heavy machinery, thus the non-biogenic $\mathrm{CO}_{2} \mathrm{e}$ emissions from the De-Centralized Compost alternative were lower. In general, $\mathrm{CO}_{2} \mathrm{e}$ emissions from hauling were relatively minor compared to other process steps, particularly the biological degradation of the food waste itself. 


\section{Costs}

The capital, annual, and present costs of each alternative were calculated based on a 20-year life cycle cost and a discount rate of $6 \%$. The discount rate was assumed to include inflation. Where possible, capital and operating costs were based on typical industry values and literature cost curves. The Engineering News-Record construction cost index was used to inflate costs to 2012 dollars (USD). If general cost guidance was not available, estimations were made based on labor costs for new assets, energy costs, and other operational and maintenance costs. Unless otherwise noted, all operating and maintenance costs reported in this study were assumed to be constant over the 20-year lifespan of the analysis.

Material hauling costs were broken into two categories for this analysis: in-town hauling and highway hauling. In-town hauling was defined as the pickup and transport of material within city limits, and thus involves significantly more stop-and-go traffic, manual labor, and management oversight than highway hauling. Similarly, the infrastructure and operation of a source-separated waste pickup program is different from that of a commingled waste pickup program, resulting in different costs for each hauling method.

The cost of electricity was based on average national values obtained from the U.S. Energy Information Administration. An electrical cost of $\$ 0.1$ per kWh consumed was assumed, but it should be noted that this value can change significantly depending on local conditions. The electrical cost is higher than the wholesale cost of electricity from the local utility and includes indirect costs such as utility transmissions, distribution, and hookup fees. Therefore, only electrical production that directly offsets electricity that would otherwise be purchased from the local utility was valued at $\$ 0.1$ per $\mathrm{kWh}$. For example, most WWTPs use two to three times more power than is generated from onsite combined heat and power units (if applicable), thus the assumption that power costs would be offset at $\$ 0.1$ per $\mathrm{kWh}$ cost is reasonable. For a landfill, however, electricity produced from landfill gas utilization would most likely be sold back to the local utility because there are few local demands that consume the electricity onsite. Selling power back to the local utility will result in lower revenues than cost offsets incurred by using the electricity onsite. In those cases, a buyback rate of $\$ 0.03 / \mathrm{kWh}$ was assumed.

Estimated costs for each alternative are shown in Fig. 7. The WWTP/Sewers alternative had the highest capital cost because the most incremental infrastructure is required. Conversely, the Centralized Compost alternative showed the lowest expected capital cost because minimal infrastructure is required. The Landfill alternative showed the highest annual O\&M cost primarily due to haul costs and processing fees, while the WWTP/Sewers alternative had the lowest annual O\&M costs due to minimal processing fees. The De-Centralized Compost alternative showed a significantly higher capital cost than the Centralized Compost alternative because more facilities would be required to process the same amount of food waste. Although the technology used in de-centralized facilities is simpler and requires less equipment, there is a much greater reliance on personnel, which 


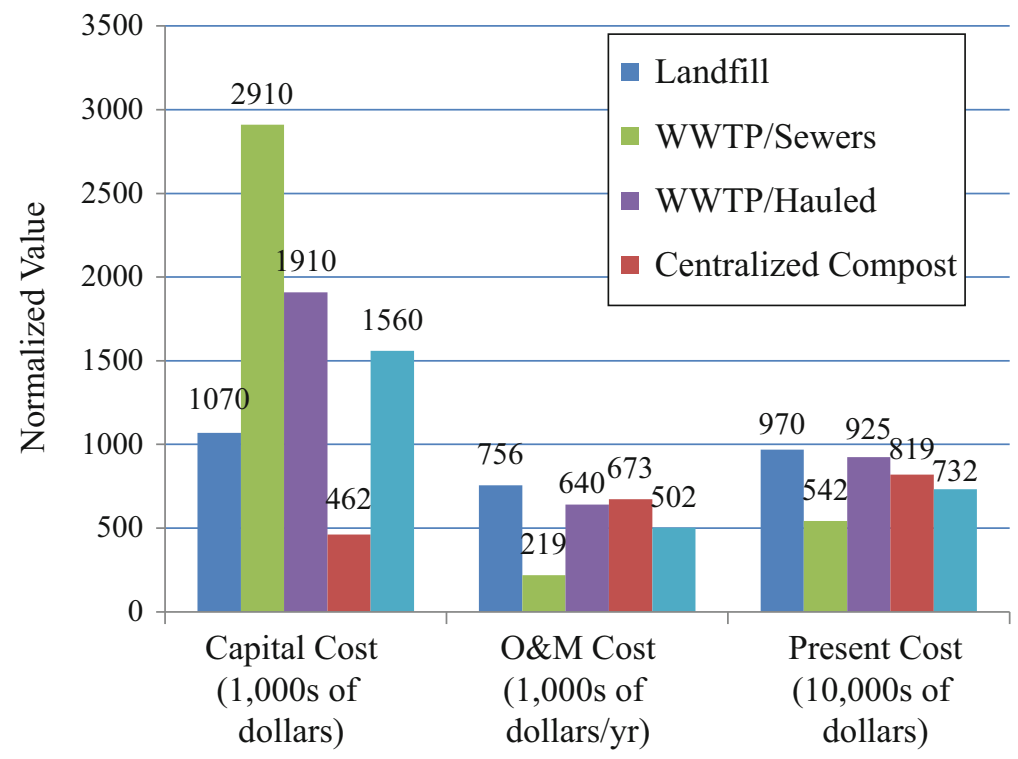

Fig. 7 Estimated costs for different food waste management methods including de-centralized compost

increases the annual operating costs substantially. If the de-centralized composting facility was operated by volunteers or the cost of local labor is exceptionally low, the annual cost of de-centralized composting could be substantially reduced. The Landfill and WWTP/Hauled alternatives had the highest net present costs, and the WWTP/Sewers had the lowest net present costs.

\section{Other Quantitative Results}

This study also examined water usage, footprint requirements for treatment, staffing demands, diesel usage, and net electricity usage. A summary of the research findings related to these topics is shown in Table 1. The composting alternatives showed the highest footprint requirements, although as noted above, the land used by composting and WWTPs can be re-used indefinitely compared to landfills which permanently prevent the land from being re-used. The composting alternatives also require the most labor. The Centralized Compost alternative required significantly more fuel than the other alternatives because of the heavy equipment demands during transport and processing. Both the Landfill and WWTP/Hauled alternatives were net producers of electricity due to the high volume of methane collected and beneficially used in combined heat and power equipment, while the other alternatives had relatively low electricity demands due to minor power demands for buildings and equipment. Water demand for the WWTP alternatives was due primarily to the need 
Table 1 Other quantitative impacts of food waste handling alternatives. The footprint required for landfill would increase over time. It would not be expected to change over time for the other alternatives without an increase in population

\begin{tabular}{l|l|l|l|l|l}
\hline & Landfill & $\begin{array}{l}\text { WWTP/ } \\
\text { Sewers }\end{array}$ & $\begin{array}{l}\text { WWTP/ } \\
\text { Hauled }\end{array}$ & $\begin{array}{l}\text { Centralized } \\
\text { compost }\end{array}$ & $\begin{array}{l}\text { De-centralized } \\
\text { compost }\end{array}$ \\
\hline Footprint (acres) & 0.70 & 0.01 & 0.01 & 1.36 & 5 \\
\hline Labor (staff/day) & 2.30 & 0.10 & 2.00 & 6.10 & 19.6 \\
\hline Fuel use (gals/year) & 5600 & 1200 & 6100 & 30,000 & 5380 \\
\hline $\begin{array}{l}\text { Net electrical use } \\
\text { (MWh/year) }\end{array}$ & -770 & 340 & -1300 & 150 & 46 \\
\hline $\begin{array}{l}\text { Water demand } \\
\text { (gals/year) }\end{array}$ & Negligible & 9.71 million & 197,000 & Negligible & Negligible \\
\hline
\end{tabular}

to convey processed food waste in a slurry. The WWTP/Sewers would require potable city water, but the WWTP/Hauled alternative could use plant process water for this demand.

\section{Non-Economic Considerations}

Notwithstanding costs and the quantifiable environmental considerations, success of a food waste handling method depends on many other factors. A successful program needs to be accepted by consumers and address concerns associated with odors, pests, traffic, aesthetics, and cleanliness. Programs could also improve operations, or even have impacts that are currently unknown (i.e., unintended or unanticipated consequences).

\section{Consumer Acceptance of Collection Methods}

Consumer acceptance is potentially the most important factor in food waste management. Food waste is most commonly handled through commingled collection of food waste with municipal solid waste and then landfilled. This method is easy for the consumer as they do not need to distinguish and sort food waste from other wastes. Many municipalities are now requesting that consumers begin source separating food waste from other municipal solid wastes and recycling. Most often the municipalities request that food waste be separated and collected with green waste. This allows for the potential to compost the food waste and if collected separately from green waste it could potentially allow for direct digestion of food waste. Although this adds a new burden to the consumer, many consumers are willing to assume this extra responsibility for the benefit of the environment. However, there are problems with source separation. Some consumers do not want the additional 
responsibility or may not properly separate all the different materials. The cost of biodegradable bags or separate containers can also be a burden for consumers. Therefore, it is believed that source separation of food waste will likely only be able to achieve a maximum participation threshold that is less than $100 \%$. In most cases, communities that participate in small-scale de-centralized composting operations will more effectively separate food waste, creating a higher value product.

\section{Consumer Acceptance of Food Waste Products}

Food waste management methods produce different products. When treated at a wastewater treatment plant, the ultimate product is biosolids. Biosolids are often used as a soil amendment or as a fertilizer. Land application of biosolids is an acceptable means for handling biosolids and has benefits to farmers and other land managers. However, there is a small segment of the public that opposes biosolids due to unsupported concerns of pathogen exposure or other reasons.

Composting produces a product that is similar to soil. Like biosolids management programs, composting is a well-accepted practice. In general, however, composted products that do not contain biosolids do not raise the same concerns compared to biosolids. When compost products contain municipal biosolids they are regulated by EPA 503 regulations. Composting of food waste (with or without biosolids) can be regulated by a solid waste authority. Additionally, neighborhood composting centers similar to that envisioned in the De-Centralized Compost alternative tend to enhance community involvement and interaction with the composting process. However, food waste compositing can be regulated which adds to the cost and reduces the potential for decentralized neighborhood compositing centers to be organized.

\section{Potential for Odors and Pests}

One of the advantages of food waste disposers is the ability to keep a cleaner garbage bin. This reduces the likelihood of odors developing under the kitchen counter and at the road. It also removes food waste from garbage bins that may attract raccoons, dogs, rats, and other pests.

Source separation of food waste is similar to commingled collection of food waste in that the food waste must be temporarily stored in the home and then taken out to the roadside for collection. Thus, there is potential for both odors and pests. Most municipalities with source separated food waste collection provide consumers with robust sealable containers to store the food waste curbside, but consumers may need to provide storage within the home. These containers work well to capture odors and prevent most large pests from gaining access. However, when there are 
lengthy periods between collection, source separated food waste may allow maggots and other small pests to grow within the food waste bins.

The proximity of de-centralized composting operations may also present problems for local residents if the composting operating is not maintained properly. Poorly maintained compost operations can cause problems such as odor, leachate, or pest attraction. Offsite centralized composting facilities tend to avoid this issue by using more skilled personnel and by increasing the distance between odor source and receptor.

\section{Truck Traffic}

Garbage collection trucks have been operating in residential neighborhoods for a long time. Increased separation of food waste vessels means that more trucks will be required to operate within neighborhoods. Municipalities can reduce the truck impact by providing dual purpose trucks that have separate bins to handle different products or by commingling similar materials, e.g. food waste and green waste.

There is little known evidence of residential consumers becoming concerned with the number of collection vehicles, particularly when the additional trucks are needed to provide a beneficial use for product (when compared to landfilling). However, public opposition remains a possibility if more collection vehicles are needed. There is also a potential to reduce the frequency of residual MSW pickups because of the food waste being handled separately. For example, MSW pickups could change from once a week to once every other week pickups and reduce truck traffic.

\section{Use of Existing Infrastructure}

All food waste management methods use existing infrastructure, whether it is trucks, landfills, composting facilities, sewers, or wastewater treatment plants. However, composting facilities and wastewater facilities are different than landfills. Landfills have finite volumes and are capped and closed when filled. Thus, food waste disposed in landfills has a direct impact on the life of a landfill.

Wastewater treatment plants and composting facilities are processes that treat the waste and process it continuously. When the waste is treated, the space or capacity is available for additional waste. Thus, capacity of these processes is limited by a loading rate rather than by an overall capacity. As long as the loading rate of the process is not exceeded, the process has the ability to continue treating waste indefinitely. Due to this difference, the capital costs reported above may be overstated for individual municipal facilities where capacity is in excess of current operations. That is, if an individual facility has sufficient excess capacity, the impact of additional food waste would not cause an overload of the existing treatment capac- 
ity and would likely not decrease the useful life of the facility. In this case the capital costs could be assumed to be negligible for the wastewater collection and treatment systems. It is also important to note that if a municipality already has a large number of residential food waste disposers installed in its service area and adds curb side pickup of food waste, it will effectively be adding capacity to its wastewater collection system.

\section{Variability of Infrastructure}

This model was limited in scope. As a result, only a select installation type was evaluated for a food waste management method. For the landfill, it was assumed that biogas was collected and used to generate power. However, many landfills do not have this capability. Similarly, the wastewater treatment alternative was based on a treatment plant with primary clarification, a secondary system with a short mean cell residence time, anaerobic digestion, and biogas collection for power and heat generation. This is a typical treatment plant for many large municipalities. However, most smaller municipalities would not have this type of treatment system and thus the likely operational costs as well as the carbon dioxide equivalent emissions would be greater.

The availability of land is a key consideration when evaluating composting alternatives. Because a relatively large amount of land is required for composting, a community or municipality without available land would likely not benefit from a composting alternative, and should likely consider a WWTP or another alternative such as a high-tech composting alternative with covered and ventilated windrows. Conversely, an area with sufficient land may provide environmental and economic benefits by encouraging a compost operation.

\section{Side Stream Impacts}

Side streams are specific to the food waste management methods at the wastewater treatment plant. The addition of food waste will change the characteristics of the centrate or filtrate produced in dewatering. Predictions of changes to the side streams were not determined in this study.

\section{Carbon Source for Biological Nutrient Removal}

Nutrient limits for wastewater treatment plants are becoming more prevalent. Due to the scope of this study, the impact on food waste on a treatment plant with nutrient limits was not researched. However, food waste has the potential to bring in 
an increased mass of nitrogen to be removed. However, the increased organics associated with the food waste has the potential to improve biological nutrient removal by reducing the amount of supplementary carbon required for the process.

\section{Conclusions}

Over 34 million tons of food waste is generated annually in the United States. This study looked at five different methods for handling food waste to assess the costs and environmental impacts of each method.

Landfilling is currently the most prevalent means of handling food waste. The study results show that the landfill results in the highest emission of greenhouse gases and requires a relatively large amount of land to implement. Further, landfilling costs appear to be among the highest of the food waste management methods.

Use of a food waste disposer for handling food waste and the existing sewer system for transport to and treatment at the wastewater treatment plant had the lowest net present cost. The method also has minimal footprint requirements, staffing, and other infrastructure requirements. The alternative, however, requires water to convey the food waste into the sewers and showed a high electricity demand for secondary treatment. Food waste disposers have been successfully installed in residential homes for many years and have achieved $68 \%$ usage by residential consumers in the West of the United States.

Curbside pickup of source-separated food waste with trucked conveyance to the wastewater treatment plant and direct feed to the digesters had many advantages over other management methods. This method had the lowest carbon dioxide equivalent emissions and was a net electricity producer. However, source-separated collection of food waste for direct injection into a wastewater treatment plant anaerobic digester could potentially have the lowest consumer acceptance of the alternatives. The method would require a new bin in addition to the garbage container, recycling container, and green waste bin. Since very few municipalities have four separate collection bins, it is unknown how consumers would receive this additional separation requirement and what types of contamination would be created with the new bin. Source separated trucking of organic wastes may be more applicable in industrial food processing operations where a waste compatible with anaerobic digestion is produced. Targeted commercial collection of wastes with a high fraction of food waste (e.g., restaurants and grocery stores) may also be more applicable for trucking food waste to be fed to anaerobic digesters.

Both centralized and de-centralized composting was shown to have low carbon dioxide equivalent emissions and low net present costs. However, the footprint and staffing requirements were highest of all the management methods. In some areas, increased staffing requirements may be viewed as a positive for a source of employment and "green jobs." Centralized composting of food waste is becoming more common as it is often collected with green waste, whereas de-centralized composting is much less common in the United States. De-centralized composting operations may also 
enhance public acceptance of source-separating food waste because it involves the community more efficiently.

A community may actually have several or all of the food waste management methods evaluated here. The results of this evaluation quantify some of the economic, environmental, social and operational impacts of food waste management methods. The convenience to the residents and the operating requirements of the different methods must also be considered. The preferred food waste management method is dependent on the goals of the community and site-specific conditions. If cost and convenience is a major driver, a food waste disposer method is preferred. If energy efficiency and low carbon foot print are the drivers, then a direct anaerobic digestion method is preferred. If cost and carbon footprint are priorities and space is available, a compost approach should be encouraged. By providing several options for food waste management, higher diversion rates and greater beneficial use can be realized from food waste.

\section{References}

Brown S, Beecher N, Carpenter A (2010) Calculator tool for determining greenhouse gas emissions for biosolids processing and end use. Environ Sci Tech 44:9509-9515

IPCC AR4, Forster P, Ramaswamy V, Artaxo P, Berntsen T, Betts R, Fahey DW, Haywood J, Lean J, Lowe DC, Myhre G, Nganga J, Prinn R, Raga G, Schulz M, Van Dorland R (2007) Changes in atmospheric constituents and in radiative forcing. In: Solomon S, Qin D, Manning M, Chen Z, Marquis M, Averyt KB, Tignor M, Miller HL (eds) Climate change 2007: the physical science basis. Contribution of working group I to the fourth assessment report of the intergovernmental panel on climate change. Cambridge University Press, Cambridge/New York

Rothenberger S, Zurbrugg C, Muller C (2007) Does decentralized composting make economic sense? Eawag New 62e. http://www.eawag.ch/medien/publ/eanews/archiv/news_62/en62e_ rothenberger.pdf

The Climate Registry (2008) General reporting protocol: chapter 13, p 86

U.S. EPA (2011) Basic information about food waste, July 26. Retrieved from: http://www.epa. gov/osw/conserve/materials/organics/food/fd-basic.htm

U.S. EPA Emission Facts (2005) Emission facts: average carbon dioxide emissions resulting from gasoline and diesel fuel. Office of transportation and air quality. EPA420-F-05-001. http://www.epa.gov/otaq/climate/420f05001.pdf

Water Environment Research Foundation (2012) Sustainable food waste evaluation: OWSO5R07e. IWA Publishing. www.werf.org/c/_FinalReportPDFs/OWSO/OWSO5R07e.aspx 


\title{
Food Waste Composting in Seattle: The Political Perspective
}

\author{
Alexis Schulman
}

Over the course of two decades, organics collection in Seattle (population 620,778) evolved from a limited yard waste collection service initiated in 1989 to a comprehensive and mandatory residential curbside food and yard waste collection system established in 2011. This development was not the result of state pressure, as the State of Washington has no waste reduction mandate. Instead curbside compostables collection in Seattle was propelled by the skyrocketing landfill disposal costs and bolstered by elected officials and city staff who were committed to waste reduction. Also working in its favor, Seattle had a local yard waste processing plant that was able to integrate food waste, as well as a solid waste utility supported by a PAYT (pay as you throw) system. Trash disposal fee-based incentives, paired with a zero waste resolution and a participation mandate for single- and multi-family residences, have increased Seattle's composting levels and helped the city achieve one of the highest per capita compostables collection rates in the nation.

\section{Program Origins and Implementation}

Collection of food and yard waste and other compostables is one of several approaches Seattle has adopted over the years in response to a waste disposal crisis it faced in the 1980s. By 1987, the city had closed its last two remaining local landfills,

This was adapted from Judith A. Layzer and Alexis Schulman. (2014). "Municipal Curbside Compostables Collection: What Works and Why?" Work product of the Urban Sustainability Assessment (USA) Project, Department of Urban Studies and Planning, Massachusetts Institute of Technology.

\author{
A. Schulman $(\square)$ \\ Department of Urban Studies and Planning, \\ Massachusetts Institute of Technology, Cambridge, MA, USA \\ e-mail: alexiss@mit.edu
}


both of which had been designated as Superfund sites and required more than $\$ 90$ million in cleanup to become operable again (Bagby 1999). Exacerbating an already difficult situation, the substitute destination for Seattle's waste - a landfill in King County - raised its tipping fees dramatically, requiring Seattle's solid waste utility to raise its customer rates by more than 80 \% (Bagby 1999; Seattle Public Utilities 2011). The county further required Seattle to enter into a 40 -year solid waste management contract or find an alternative disposal site (Bagby 1999). Seattle leaders chose to use the crisis as an "opportunity for an experiment in waste reduction and recycling that had never been attempted on such a large scale" (Bagby 1999). After an intensive modeling process, the city opted out of the county system and produced its first integrated solid waste master plan, called On the Road to Recovery. That plan advocated an approach of waste reduction and diversion, establishing a $60 \%$ diversion target for the year 1998 (Seattle Public Utilities 1989).

The plan led to two critical developments. First, in 1989 the city passed a ban on landfilling yard waste, which represented $17 \%$ of the city's residential waste stream, and initiated a residential curbside yard waste collection service through its contracted haulers (Seattle Public Utilities n.d.). As per an earlier negotiation with the city, that same year Cedar Grove, a local hauler, brought online an organics processing plant to handle the city's new yard waste stream (Bartlett 2013). Processing organics locally was far more economical than hauling it by rail to landfills in eastern Washington and Oregon state, as Seattle had been doing since leaving the county system. The second important development was the establishment of a new rate structure for the city's contracted waste haulers to encourage recycling. The mayor and city council approved the new rates, raising collection fees for the first 32-gallon can from $\$ 13.55$ to 13.75 per month, while increasing the cost of a second can by significantly more: from $\$ 5.00$ to $\$ 9.00$ (Seattle Public Utilities n.d.). Seattle Public Utilities also introduced a new 19-gallon can size (the minican). Twice-monthly recycling pickup was included in the refuse collection cost for both residential and commercial customers. The charge for yard waste pickup was a fraction of the refuse fees. The new rate structure immediately altered citizen's behavior. In 1988, $40 \%$ of residential customers had subscriptions for two or more 32-gallon bins. By 1990, only $10 \%$ of citizens subscribed to two or more standard cans, and $20 \%$ subscribed to minican service. Overall, $90 \%$ of Seattle's residents subscribed to one 32-gallon can or smaller (Bagby 1999) (Fig. 1).

Nevertheless, by 1998 Seattle had barely reached its $60 \%$ diversion goal among single-family residences, with no other sectors in compliance (Bagby 1999). In light of these findings, Seattle undertook a new planning effort that resulted in the city's 1998 waste management plan, On the Path to Sustainability (Seattle Public Utilities 1998). That plan reaffirmed Seattle's $60 \%$ goal, while extending the deadline for meeting it to 2008. The city also adopted "zero waste" as a guiding principle and advocated the "addition of food waste to the city's recycling programs" to meet the city's ambitious diversion targets (Bagby 1999).

Seattle already had a long history of supporting backyard composting and had even piloted curbside food waste collection in the 1990s (Cascadia Consulting Group 2001). In 2000, the city hired a consultant to compare the results of its earlier 


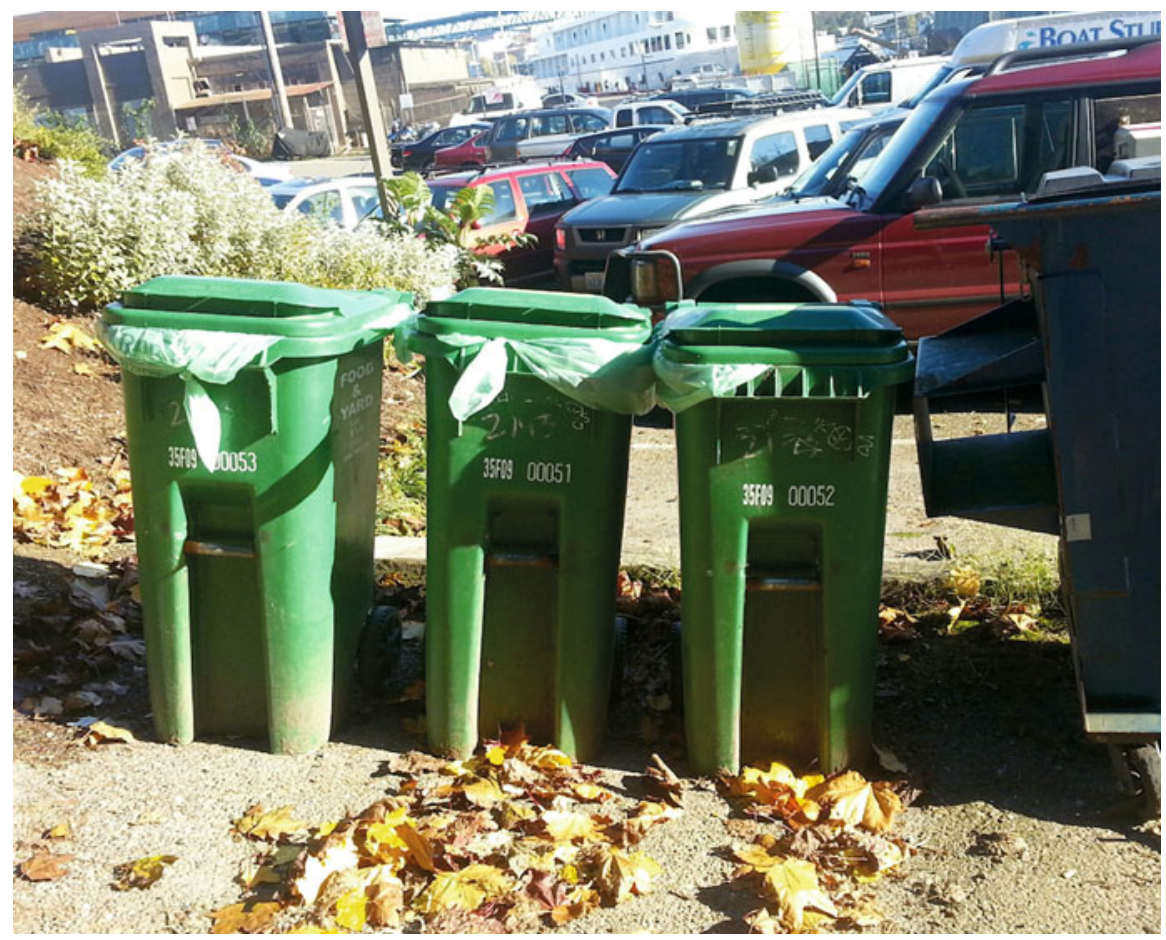

Fig. 1 Food/yard waste toter bins at a multiple family residence in Seattle

pilot-in which food scraps were collected in a separate container from yard waste - with a new curbside system in which food scraps would be collected along with yard waste in a single 96-gallon, aerated bin (Cascadia Consulting Group 2001; Lilly 2011). In addition to addressing concerns about insects, odors, and animals voiced by the city's health department, which has regulatory authority over composting, the new pilot sought to better gauge participation rates, get feedback from the city's private collection companies, and understand "potential operational issues" at the city's transfer stations or the Cedar Grove processing facility (Anon 2010; Cascadia Consulting Group 2001). The resulting analysis found "no critical barriers to implementation" of curbside compostables collection and hailed the combined organics collection system as more effective than the city's earlier pilot (Cascadia Consulting Group 2001). In 2004, Cedar Grove completed construction on a second, larger processing facility in Everett Washington, allowing Seattle to begin offering twice-monthly yard waste plus vegetative food scrap collection citywide (Bartlett 2013) (Fig. 2).

Mandatory, comprehensive organics collection (including meats, dairy and soiled paper) did not arrive in Seattle until 2009, and was preceded by a solid waste logjam. 


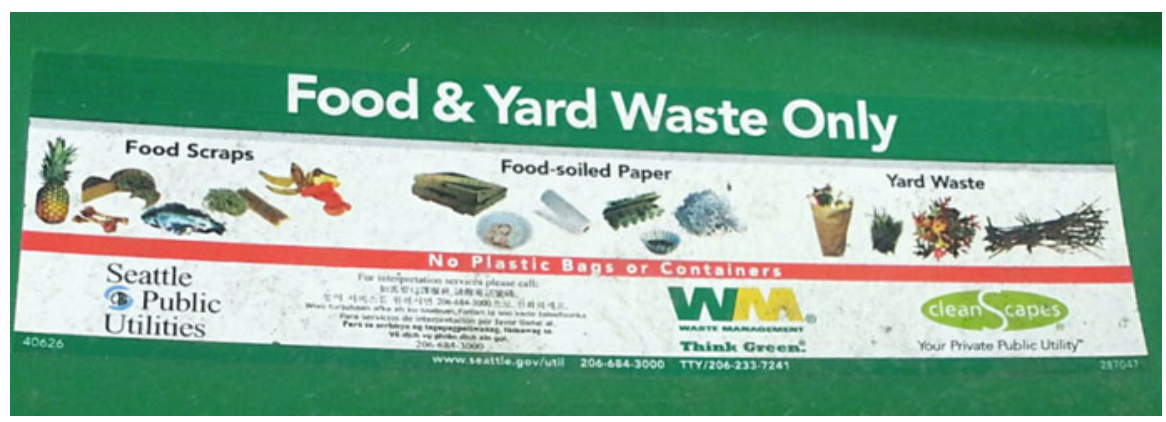

Fig. 2 Signage on a food/yard waste bin detailing what is acceptable to compost

In 2003, Seattle Public Utility found its transfer system working at capacity and recommended the construction of a new facility (Seattle Public Utilities 2004). The city council resisted, requesting a jointly funded study to examine alternative solutions. Completed in 2007, the zero waste study, corroborated the Seattle Public Utilities' solid waste facilities plan, but also laid out a detailed strategy for Seattle with the "potential to divert significant tonnage away from landfill disposal" (Seattle Public Utilities 2004). Following the report's release, the city council indefinitely postponed the construction of a new transfer station, opting instead to replace existing facilities and more aggressively pursue the strategy advocated in its zero waste study. On July 16, 2007, the city council passed its landmark Zero Waste Resolution, establishing new diversion benchmarks (60\% by 2012 and $70 \%$ by 2025) and mandating that all single-family residences subscribe to organics collection by 2009 (City of Seattle 2007).

Consistent with this requirement, on April 1, 2009, Seattle Public Utilities began providing weekly, curbside organics collection for all single-family residences. Each household is required to subscribe to the service, unless it can demonstrate that it composts on site. All kinds of food waste are permitted in the organics bins, which range in size from 13 gallons to 96 gallons. As of 2013, monthly collection rates range from $\$ 4.95$ for a 13 -gallon bin to $\$ 9.50$ for a 95 -gallon bin (Seattle Public Utilities 2013). The city unveiled a similar model for multiunit buildings, rolling out a pilot in 2007 and 2009 before issuing a multifamily participation mandate in late 2011 (Lilly 2011). As of 2013, commercial entities can pay to have compostables collection, but only restaurants and other food service establishments are required to compost (Stav 2013). Rates for commercial organics, which are $30 \%$ lower than those for garbage, are used to encourage participation. As it has already done with recyclables and yard waste, the city's next step may be to ban food waste from landfills entirely, thereby forcing residents to dispose of organics in the proper bin (Conlin 2011). 


\section{Challenges}

Seattle faced its largest challenge after implementing its recycling-friendly variable rates in the late 1980s. The rate change was unexpectedly successful in prompting residents to reduce or divert their waste, and the city saw its revenue drop precipitously after a majority of customers switched their service from two refuse bins to one. As many other cities have found, a collection system founded on zero waste principles whose revenue is drawn strictly from landfill-bound waste can be financially unstable. Seattle has dealt with this risk by examining its finances every quarter so that it can make real-time adjustments, as well as by charging for organics collection (Seattle Public Utilities n.d.).

Aside from these early issues, the city faced no major challenges related to implementing curbside organics collection (Conlin 2011). Seattle's composting program developed gradually; according to former city council president Richard Conlin, this accounts for the city's success. Brett Stav, of Seattle Public Utilities, believes that other cities can accomplish what Seattle did if they take a similarly methodical approach: begin with a pilot and make adjustments before rolling out the program on a larger scale (Stav 2013).

That said, minor issues have arisen. They include concerns by some residents about changes to garbage service or the possibility of attracting vermin and causing odors. The city addressed such worries by holding public meetings, shifting organics collection service from every other week to weekly, and boosting public outreach (Stav 2013). A remaining challenge is to increase participation in multiunit buildings, where residents tend to be more transient, waste collection areas are often difficult for the hauler to access or have limited space, and building managers are reluctant to encourage composting because they fear it will make a mess. Seattle Public Utilities has addressed these issues by providing free educational materials to help inform inhabitants, providing a two-hour training for one person to serve as an advocate in each building, distributing free kitchen containers that residents can use to transfer scraps from their unit to the main bins, and offering discounts on garbage bills.

\section{Effectiveness}

By 2010, with an overall recycling rate of $53.7 \%$, Seattle was close to reaching its diversion goal. After organics collection became weekly and mandatory for singlefamily residences in 2009, organics tonnage in this sector tripled-from 11,200 tons collected in 2009 to 35,000 tons in 2010 (City of Seattle 2010). Following the multifamily organics mandate in 2011, total residential curbside tonnage reached an all-time high of 83,666 tons in 2012 (Seattle Public Utlities 2013). In 2012, haulers collected more than 130,000 tons of organics from all sectors, or approximately 390 pounds per capita. Richard Conlin notes that the city has begun to shift its focus 
away from diversion percentage toward the tonnage of waste produced: the city has seen a reduction in total waste tonnage of about $10 \%$ every year since it adopted the zero waste strategy in 2007 (Conlin 2011). The composting program is a major reason for this reduction.

\section{References}

Anon (2010) Superhero profile: Josh Marx, King County, Washington. Harvest Blog, September 13. http://blog.harvestpower.com/superhero-profile-josh-marx-king-county-washington/

Bagby J (1999) City of Seattle: past, present and future and the role of full cost accounting in solid waste management. Seattle Public Utilities, March.http://www.seattle.gov/util/groups/public/@ spu/@garbage/documents/webcontent/theroleo_200312021029055.pdf

Bartlett D (2013) Manager, organic soil solutions (Cedar Grove). Phone interview by Alexis Schulman. September 6

Cascadia Consulting Group (2001) Food waste collection pilot project: summary report, July. http://www.seattle.gov/util/groups/public/@spu/@garbage/documents/webcontent/foodwaste_ 200312021402223.pdf

City of Seattle (2007) Zero waste resolution (30990), July 16. http://www.seattle.gov/util/groups/ public/@spu/@garbage/documents/webcontent/02_015860.pdf

City of Seattle (2010) 2010 recycling rate report. http://www.seattle.gov/util/groups/public/@ spu/@garbage/documents/webcontent/01_013797.pdf

Conlin R (2011) President, Seattle City Council. Phone interview by Keith Tanner. August 29, 2011

Lilly D (2011) Business area manager for waste prevention \& product stewardship, Seattle Public Utilities. Phone interview by Keith Tanner, August 15, 2011

Seattle Public Utilities (1989) On the road to recovery: Seattle's integrated solid waste management plan

Seattle Public Utilities (1998) Solid waste management plan: on the path to sustainability

Seattle Public Utilities (2004) Solid waste facilities plan. http://www.seattle.gov/util/Documents/ Plans/SolidWastePlans/Solid_Waste_Facilities_Plan/index.htm

Seattle Public Utilities (2011) Seattle solid waste plan: 2011. http://www.seattle.gov/util/groups/ public/@spu/@garbage/documents/webcontent/02_015213.pdf

Seattle Public Utilities (2013) Organics report: 4th quarter 2012, January 31. http://www.seattle. gov/util/groups/public/@spu/@garbage/documents/webcontent/01_016690.pdf

Seattle Public Utilities (n.d.) History of variable can rates. http://www.seattle.gov/util/MyServices/ Garbage/AboutGarbage/SolidWastePlans/AboutSolidWaste/HistoryofVariableCanRate/ index.htm

Stav B (2013) Senior planning and development specialist, Seattle Public Utilities. Phone interview by Yael Borofsky. March 6 


\title{
Cedar Grove Compost: Developing a Combined Food-Yard Waste Centralized Composting Program
}

\author{
Denise Bartlett
}

Cedar Grove Composting started in 1989 in Maple Valley, WA (in King County, approx. 25 miles SE of Seattle). The company is a private, family-owned business that also has sister companies that collect and process used oil, wastewater, solvents, and hazardous waste. The family business, Seattle Disposal, started collecting Seattle's garbage with horse and buggy in 1938. In 1989, the city of Seattle approached Seattle Disposal about composting grass clippings and yard prunings (i.e. yard waste) instead of landfilling. A third collection bin was added for the yard waste, in addition to the garbage and recycling bins, for residential collection. All the material that was collected by the two city haulers was taken to the one of the two city transfer stations, then hauled by the city to Cedar Grove. Cedar Grove Composting was formed (it's named originated from being located on Cedar Grove Rd.) and began its windrow operation. Volumes quickly grew and other, higher control, composting technologies were employed over time: Open windrows gave way to static piles, then to negatively-aerated static piles that vented to biofilters, and multi-phased large piles.

In the mid 1990s vegetative, pre-consumer food waste material was added to the feedstock. Including post-consumer food scraps required a change to composting inside a building or in-vessel. When the city of Seattle wanted to look at higher organics diversion to include all food scraps, pre and post-consumer, including meats and cheeses, the King County Health Department had concerns regarding collection frequency, vectors, and odors. Cedar Grove had had odor complaints when composting yard waste. The addition of more putrescibles was expected to increase the potential for malodors during the composting process. Due to odor concerns and the Health Department's other concerns, the company decided to explore what other countries were doing to incorporate these higher putrescible organics into their composting process. Europe has been a leader in organics and

D. Bartlett $(\bowtie)$

Bartlett Ventures LLC, Seattle, WA, USA

e-mail: Bartlettventures@gmail.com 


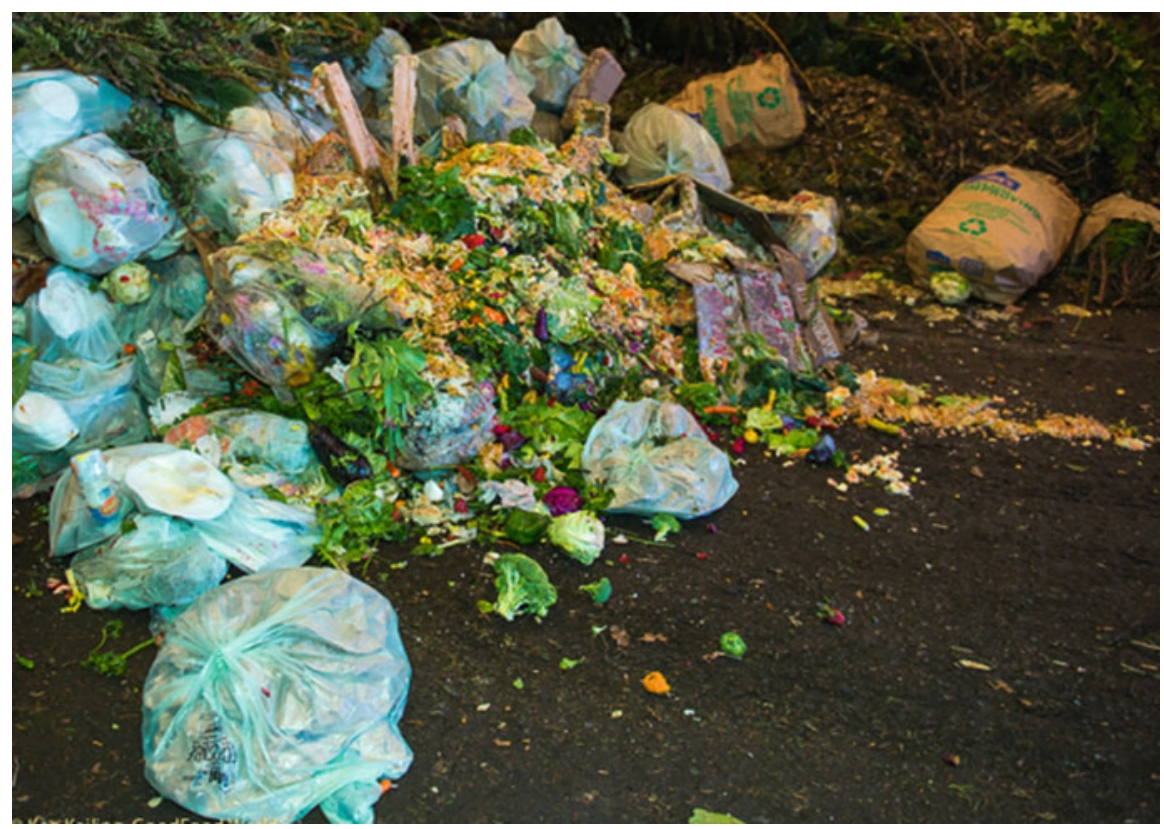

Fig. 1 Compost feedstocks at the Cedar Grove facility. The company currently co-compost food scraps and yard waste

alternative energy production for many decades due to higher landfill costs/reduced available capacity and higher energy costs. After considerable research into composting technologies and site visits to facilities overseas, Cedar Grove selected GORE® Cover technology (more information below) due to the fact that the system was proven to work with our yard debris and food scraps feedstock, had been operating at numerous facilities worldwide for at least 5 years, and was financially backed and guaranteed by W.L. Gore and Associates (Fig. 1).

\section{Composting Technologies}

\section{GORE ${ }^{\circledR}$ Cover System}

Cedar Grove uses a GORE® Cover system to compost the combined food and yard waste. The system is centered on membrane laminate technology similar to that of its GORE-TEX ${ }^{\circledR}$ fabrics used for outerwear and footwear. The integrated system includes the GORE® Cover, positive in-floor aeration, aeration blowers, oxygen and temperature sensors, controllers, computers, software, cover handling systems; along with training, engineering guidance, and installation support. The GORE® Cover heap model is currently categorized as a covered aerated static pile (ASP). 


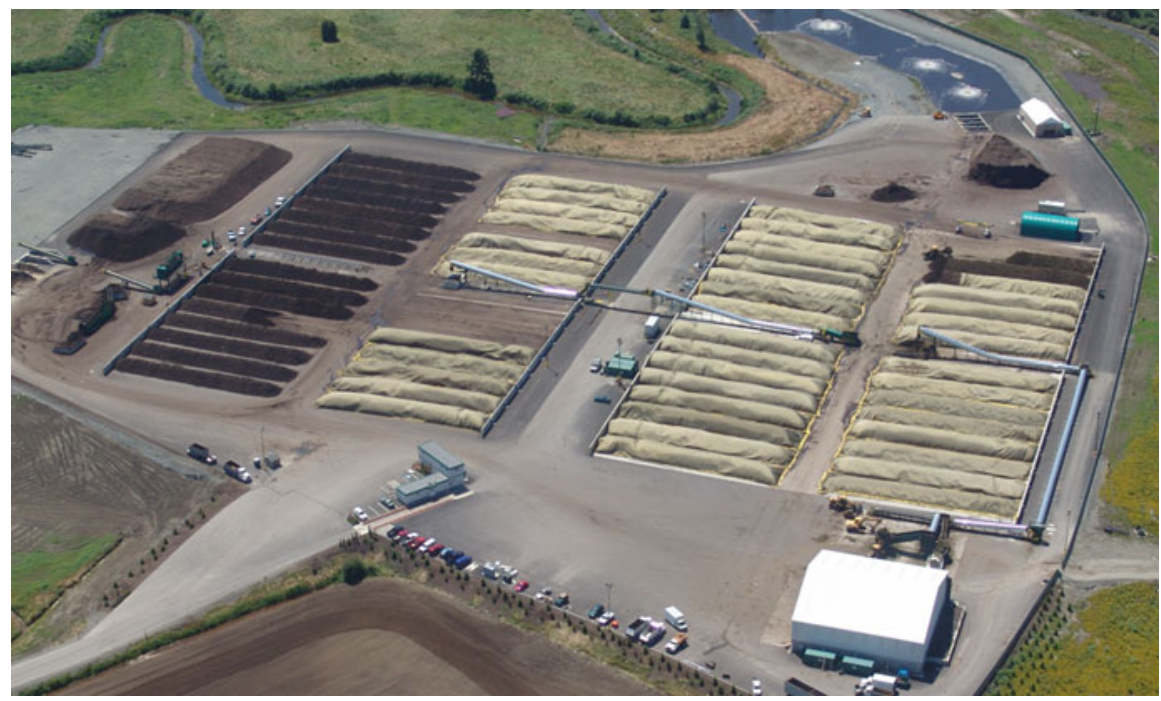

Fig. 2 An aerial view of the Cedar Grove composting facility in Everett, WA. The Gore covers are visible on the actively composting windrows. The curing piles are open to the atmosphere. The feedstock receiving building is shown on the bottom right of the photo

The cover membrane has a pore structure sized to selectively influence the composting process. The system allows carbon dioxide to pass through the membrane but prevents odor from escaping. Odorous compounds are much larger molecules than carbon dioxide and are not able to pass through the membrane. The membrane will also not allow rainwater to pass through to the curing compost. Composting is done in 3 phases over 8 weeks.

In 2003, Cedar Grove constructed a 40,000 tons per year GORE® Cover system at the Maple Valley site and started processing yard debris and food scraps in this system. With higher demand for post-consumer organics diversion in the region, Cedar Grove decided to expand their operations north. In late 2004, property in Everett, WA (40 miles north of Seattle) was purchased and over the next year, a 164,000 tons per year all GORE® Cover system was constructed. Food scrap feedstocks expanded throughout the mid-late 2000s to include meats and cheeses, fish, soiled paper, along with new manufactured "compostable" food service items, such as bags, plates, cups, etc. In 2009, with higher landfill diversion rates being sought by the city of Seattle, and at the Health Department's urging, curbside collection of food scraps went from every other week to weekly (Fig. 2). 


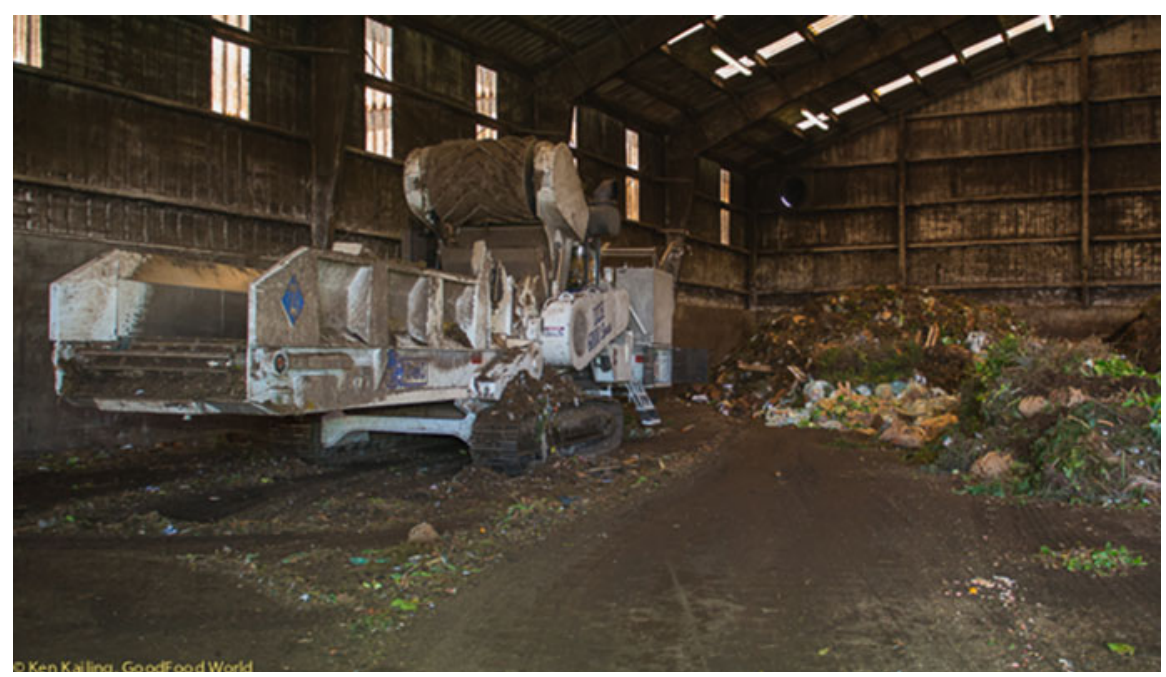

Fig. 3 A grinder inside the receiving facility. The grinder grinds feedstocks to fixed particle sizes allowing for rapid composting

\section{Other Equipment}

Producing a high-quality compost from co-collected yard waste and food scraps has required investment into a range of equipment. In addition to the GORE® Cover composting technology, Cedar Grove has invested in grinders, conveyers, front loaders, and screeners. It also constructed an enclosed delivery building to allow trucks to dump their loads in an enclosed space. Air in the delivery building is treated through a biofilter. The GORE $®$ Cover system is a batch system that is selfregulating with oxygen controls and safety features to ensure the pile has adequate aeration and does not go anaerobic. Anaerobic conditions slow the composting process and generate odors. Having quality, reliable grinding (and manufacturer warranties) equipment ensures feedstocks will be ground to an ideal size to allow adequate porosity/air flow throughout the heap; in addition to the right recipe this is also necessary to provide sufficient microbial activity to achieve the temperatures required for pathogen kill. Cedar Grove uses conveyers after grinding to move the material before building the composting heaps. Spray bars set on the conveyor moisturize the material; magnets pull out any metals, such as nails, clippers, forks, etc. from the material before hitting a set drop point. Uniform-sized front loaders ensure known quantities of material are being loaded/unloaded at all times. Stateof-the-art screening equipment is used to remove film plastic, rocks, and other contaminates in the finished product. All the movement at the facility is orchestrated (Fig. 3).

Each new heap is tested after initial building for $\mathrm{pH}, \mathrm{C}: \mathrm{N}, \%$ moisture, and bulk density; it is tested a second time before final moving after active composting to 


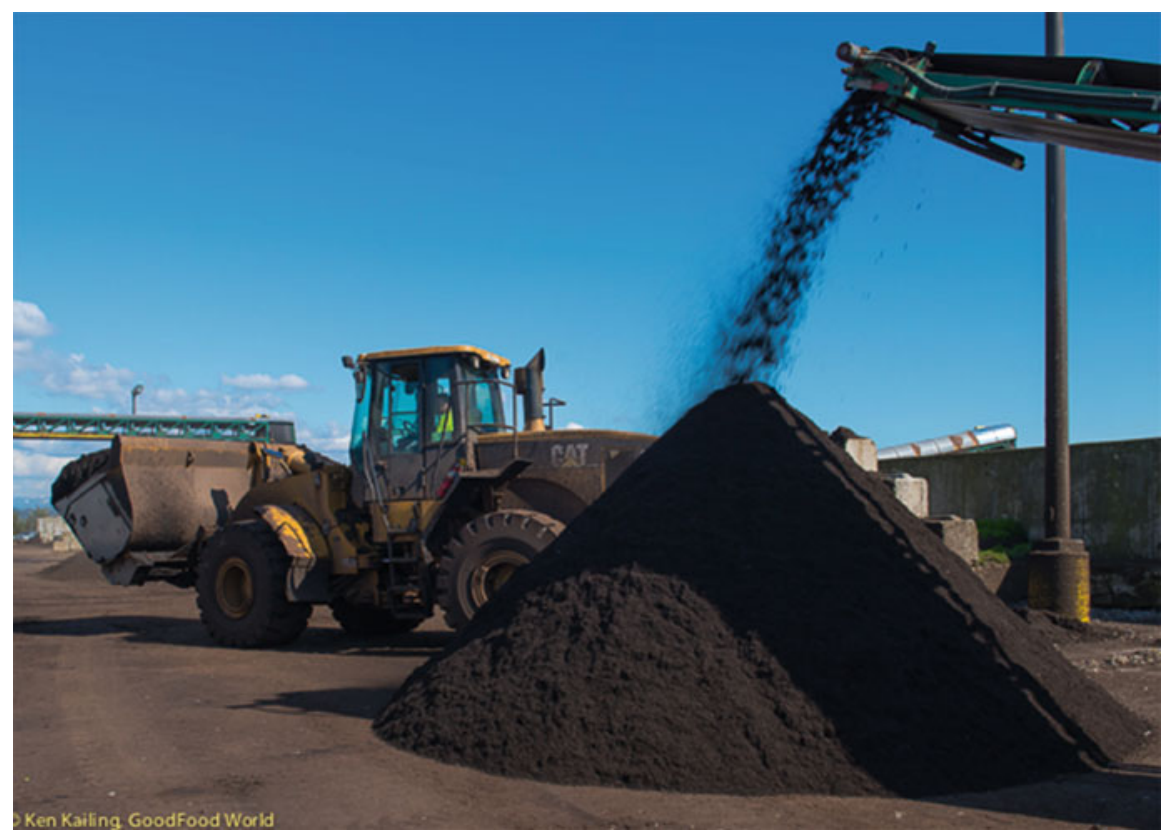

Fig. 4 Screening the finished compost product. Screening to different particle sizes allows us to develop products for different markets. It also assures the consistency of the product

demonstrate meeting WA state standards for finished compost, and again, after aging (which can be anywhere from 6 months to a couple years) prior to selling. The product is very consistent. Testing frequency requirements are determined by volume by the WA Department of Ecology, but jurisdictional health departments can modify frequencies based on facility history (Fig. 4).

\section{Commercial Organics}

Commercial separation and collection of food scraps is currently now mandatory in Seattle and the collection business of these organics, like other traditional recyclables, is an open market in WA State. The regional commercial collection haulers were slow to offer food scrap collection as part of their service since this meant an additional bin for the customer and an additional collection (and haul) for the hauler. Since Cedar Grove's founder had roots in the garbage collection business, and tipping fee rates were roughly half of the garbage transfer station rates, Cedar Grove started a commercial organics collection business in 2007. Cedar Grove Organics Recycling today has over 2000 customers. Other regional haulers have started offering this service as part of their service packages. As part of the program to develop a successful commercial organics pick up service, Cedar Grove Organics Recycling 
provides consultation to customers on container sizes, collection frequencies, training, signage, as well as on-going support.

\section{Importance of Education Outreach}

Educational outreach has been critical to Cedar Grove over the years. There can never be too much education! The education on the front end or collection side of the process affects the end compost product. Contamination in equals contamination out (not all can be screened out). Residential customers for the city of Seattle receive a yearly schedule of collection days with visual and worded accepted items for yard trimmings and food scraps collection, along with accepted items for traditional, mainstream recyclables. This information is also available on-line and in several languages. Other areas outside the city have similar programs. Cedar Grove's website also provides specific information about acceptable and nonacceptable items (http://cedar-grove.com/).

Commercial collection education is the most challenging. Restaurants and grocery stores are the most challenging due to higher employee turnover, uncertainty of acceptable items, higher percentages of food stickers, ties and plastic wrappings, and laziness ("it's not my restaurant" or "they'll just screen out the stuff they don't want"). In addition, since average collection and tipping rates for organics are substantially less than landfill rates in the Seattle area, some businesses see this as a significant yearly cost savings as well as benefiting the environment. Once large bins are full or material is placed in acceptable compostable bags, it is difficult to see contaminants until the material is offloaded or ground at the compost facility. This material can then make its way through the entire composting process and result in contaminants in the finished compost.

In addition to the above issues with contamination, Cedar Grove has moved to an enforcement component as a last resort. Each facility has a building monitor that watches unloading of trucks in the receiving buildings. As previously mentioned, all contamination is not always visually apparent, especially when loads contain acceptable compostable bags. However, large or heavily noticeable unaccepted items are photographed, documented, and ultimately upcharged to the customer or hauler, depending on the source of the load.

There can never be too much education!

\section{Compost Marketing}

Educational outreach on the compost product is also critical to Cedar Grove's success. In order for the Seattle community to be involved, the importance of understanding their role in the closed loop composting process is crucial. Cedar Grove takes in organic curbside collection from over 1.2 million households or 2.7 million 
people in the Seattle region and wants them all to replenish their yards and gardens with the products they help make. Outreach comes in forms such as local gardening TV and radio programs, community gardens, mailers, coupons, Earth Day celebrations, "Compost Days", master gardeners, and more. Education in schools is also critical. Grade schools are great because children listen and want to do the right thing. They bring this knowledge home with them and can (hopefully) be champions for their family's recycling efforts now and in the future. The overall goal is to relay what compost is, how to use it, what it can do, what it can replace or reduce what is used, and why it matters.

\section{Challenges in Collection/Composting}

\section{Regulations and Permitting}

Composting as a business in Washington State, specifically in the Puget Sound region is also a challenge from a regulatory perspective. The State-wide regulations are written by the Washington State Department of Ecology which also issues stormwater permits. The local health departments implement those solid waste rules and issue permits and approve individual operation plans. Regional air agencies review and permit plans to construct, operate and/or modify a facility, air exhaust devices, and any other on site equipment; as well as responding to any odor complaints. In some cases, these agencies are overlapping in what they feel they should have authority over and one agency permit may be in conflict with what another agency would like to implement.

\section{Staffing}

An operational challenge in composting is getting, training, and keeping experienced and knowledgeable operators. Composting is simple in concept; however, it is a manufacturing process and requires, conscientious on-the-ground operators to get the recipe right, build and maintain the compost heaps, operate and maintain the equipment properly, and ultimately care about the company and the finished product they are making. Because of our Pacific Northwest location, Cedar Grove has seasonal feedstock, which leads to seasonal compost recipes; yet it wants a consistent end product. This is achieved by keeping with a starting 30:1 carbon to nitrogen ratio recipe. When it's spring heavy grass (nitrogen) season, operators need to add a lot more wood (carbon) to the ideal recipe. In the fall, the recipe is modified due to less grass and more leaves, and so on year round. 


\section{Neighbors}

A challenge to the composting industry as a whole is with a few local neighbors not wanting a facility anywhere near where they work or live. In the case of the Cedar Grove Maple Valley location, when the facility was first started in 1989, this area was considered rural agriculture land and built next to a local county landfill. Over the years, urban growth boundaries have expanded and expensive homes have been built near the facility. These new neighbors come with a very low tolerance for odors and other disturbances such as truck traffic. This is an ever growing issue for any would-be composting operation these days. With the internet and no-filter comments, stories of siting composting facilities, especially food scraps composting, is a hot topic and opposition groups form before any plans are even established.

\section{Contamination}

When people think of contaminants in compost, most consider things like heavy metals and herbicides. These are regulated and are regularly measured in Cedar Grove's products. The company's s largest concern is with physical contaminants that affect our product appearance and so quality. As discussed previously, contamination is an ongoing concern. Besides the routine plastic and glass bottles, plastic bags, dog toys, milk carton, cans, etc., "compostable" food service items are all contaminants that are seen daily. With the desired increase of food scraps collection for composting, Cedar Grove noticed a new breed of contaminants, namely "compostable" food service items. To this day, this newer industry is not regulated, so any manufacturer can label a product as "compostable" even though it may be made with materials or resins that are not truly compostable as defined by ASTM (American Society for Testing and Materials) standards.

With these new items showing up in the feedstock, in the early 2000s, Cedar Grove embarked on in-house compostability testing of these products in the facility compost heaps. Most outside testing of these items is performed in laboratory, bench-scale size batches, which may or may not reflect real world performance of the products. In Cedar Grove's compostability testing program, products must meet certain criteria and are processed though the company's actual on-site composting process (http://cedar-grove.com/commercial/compostability-testing). To date, thousands of products have been tested and a list of the approved or passed items are routinely updated and posted on the Cedar Grove web site (http://cedar-grove. com/commercial/accepted-items/). For Cedar Grove's in the city of Seattle and other collection areas, only those items on its Commercially Acceptable Items list are allowed to be purchased and used. This system is not fool proof since manufacturers still manage to sell into the regional market even though they are aware of the program and approval process. Since the "compostable" food service industry has grown 10 -fold in the last five or so years, the sheer increase in overall volume of 


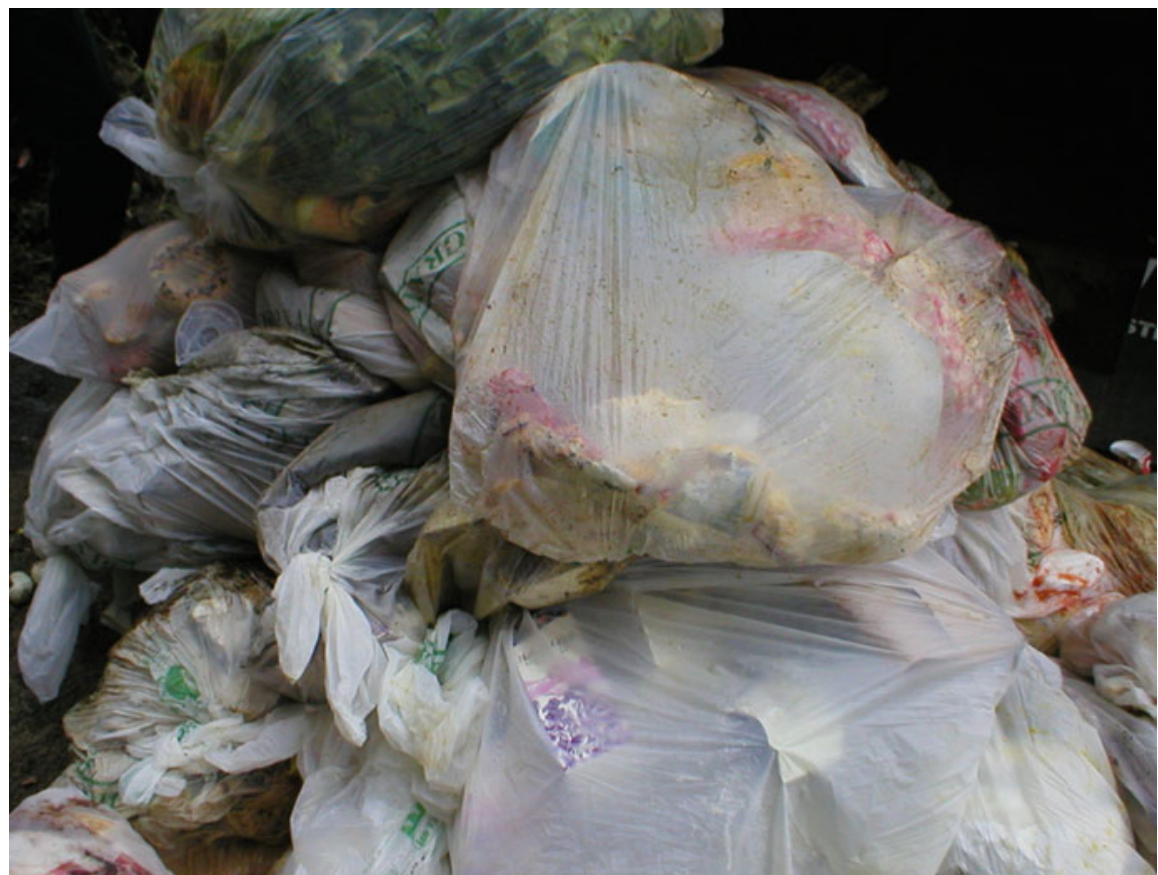

Fig. 5 Contaminants in the compost feedstocks can include drink and beverage containers and lids

these products has led to an increase in end product contamination for Cedar Grove (Fig. 5).

\section{Developing a Market for Compost}

In 1989, Cedar Grove's first year of composting, the company had a hard time selling product. Most people didn't know what compost was, how to use it, etc. A marketing person was hired to get the awareness and education components of the business going.

People didn't want to pay for product, so, Cedar Grove started bagging and selling the compost product (at a loss) in the early 1990s. Cedar Grove was one of the first companies in the country to bag compost for sale. The bags were used as a marketing tool, with the back of the bag listing the uses, benefits, etc. to get folks to buy more and buy in bulk. Profits from bag sales were being realized in the early 2000s and Cedar Grove updated the bag labeling to include new artwork along with a quality guarantee for the compost. The prices of bagged compost were also raised at this time. New product blends made from compost were added to the bagged line (Fig. 6). 


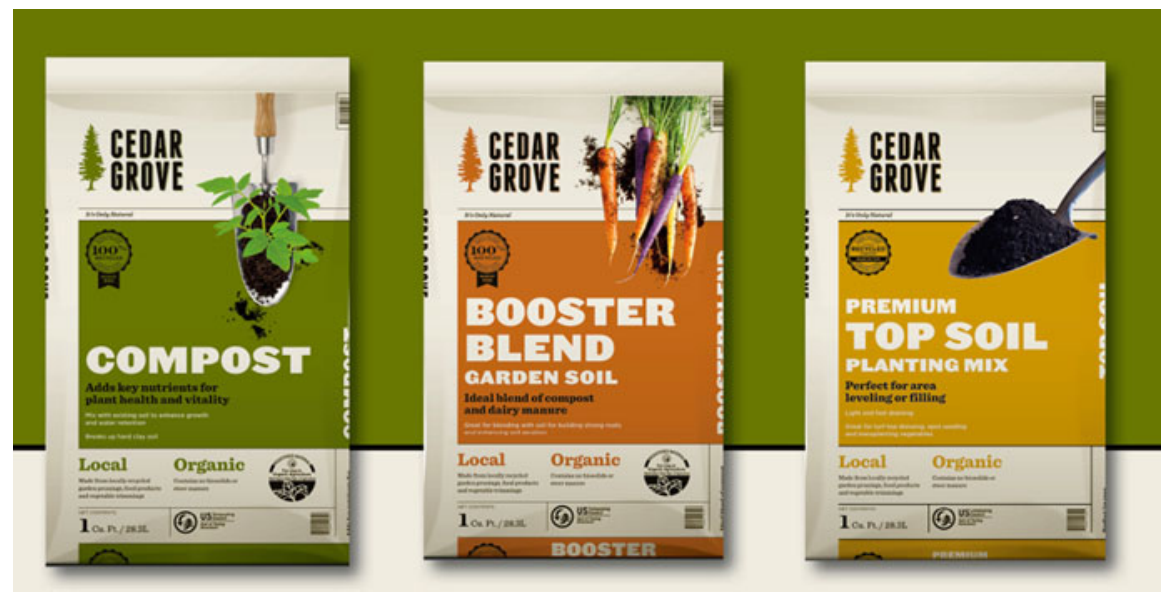

Fig. 6 Cedar Grove compost products developed for urban food production

In addition to homeowners, Cedar Grove established bulk dealers in the region. These dealers purchase bulk quantities of products, are supplied signage and are able to price and sell the products from their retail locations. This is win-win situation in that consumers can buy smaller bulk quantities closer to home without a higher transportation fee from a Cedar Grove facility and the bulk dealers can price the products at a profit while also potentially selling additional gardening products or supplies. Cedar Grove purchased blower trucks in the past and offered these services as a way for homeowners, businesses, and roadside construction to more easily place bulk compost in specific or hard to access areas.

Through continuous presence in the community since its start in 1989, Cedar Grove has maintained and grown the number compost users and affiliate product businesses in the region. Community outreach has been an important component of the company's program. Community outreach includes over 10,000 cubic yards per year of donated compost to community gardens, schools, and churches. Additional outreach extends to master gardeners programs, SeattleTilth, a local nonprofit that works to support urban agriculture, local extension services, classes, and facility tours.

Cedar Grove was an original participant in the US Composting Council's Seal of Testing Assurance (STA) program. The STA is a compost testing, labeling and information disclosure program designed to give composters the information needed to get the maximum benefit from the use of their compost products. The program was created in 2000 with specific test methods (TMECC) for compost. These include a suite of physical, chemical and biological tests selected to help both the compost producer and purchaser to determine if the being considering is suitable for the use that they are planning, and to help them compare various compost products using a testing program that can be performed by a group of independent, certified labs across the country and in Canada. The Washington State Department 
of Transportation and other county programs now require compost producers to be members of STA and provide STA data as part of doing business.

Compost use in agriculture has been a recurring focus for Cedar Grove. Various trials and demonstrations have been done and are continuing in collaboration with multiple Washington State University extensions and counties since the early 2000s. Cedar Grove has donated over 20,000 cubic yards of compost for research focusing on apples, wine grapes, triticale, pumpkins, field corn, sweet corn, various trees, pasture, wheat hay, silage, blueberries, raspberries, potatoes, beans, beets, strawberries, carrots, squash, broccoli, kale, lettuce, cover crops, flowers, and more.

\section{Obstacles}

Cedar Grove has experienced its share of marketing obstacles over the years. In the late 1990s, when the incoming feedstock material was only yard debris and prior to implementation of the higher controlled, forced aeration composting technologies, Cedar Grove experienced a problem with weed seeds. WA State composting requirements did not require green or yard waste to meet certain time and temperature criteria, known in the industry as PFRP (process to further reduce pathogens). This problem was resolved with the advanced composting technologies that employed more air into the process, which increased and maintained temperatures as well as better microbial activity. Meeting time and temperature requirements kills pathogens and also kills weed seeds.

In 2000, clopyralid, a selective herbicide used for control of broadleaf weeds, especially thistles and clovers entered Cedar Grove's world. Clopyralid is now known for its ability to persist in dead plants and compost, which can be particularly damaging to peas, tomatoes and sunflowers and can render potatoes, lettuce and spinach and other crops inedible. The first case of this chemical being a problem in compost was in Washington State. Residues of clopyralid were detected in Cedar Grove and other commercial composts. Damage was wide spread on tomatoes and other garden plants planted in compost. Word quickly spread to other local and state governments and in 2002 the state of Washington deregistered the product for residential use. DowAgro, the manufacturer of clopyralid, then voluntarily deregistered it for use on domestic lawns in the US. Cedar Grove, amongst other composters spent years in a legal battle to recoup damage to product and lost revenue. In the end, composters settled for pennies on the dollars of damages rather than extend the already 8-year battle. Since Cedar Grove only accepts feedstock from urban sources, chlopyralid and other similar problem herbicides, have not been an issue in the end product. Routine outside lab testing and in-house bioassay growth tests are still performed.

Economic downturns have a significant impact on the commercial composting industry and Cedar Grove especially since it produces over 300,000 cubic yards of finished product per year. Construction projects and WDOT projects are large 


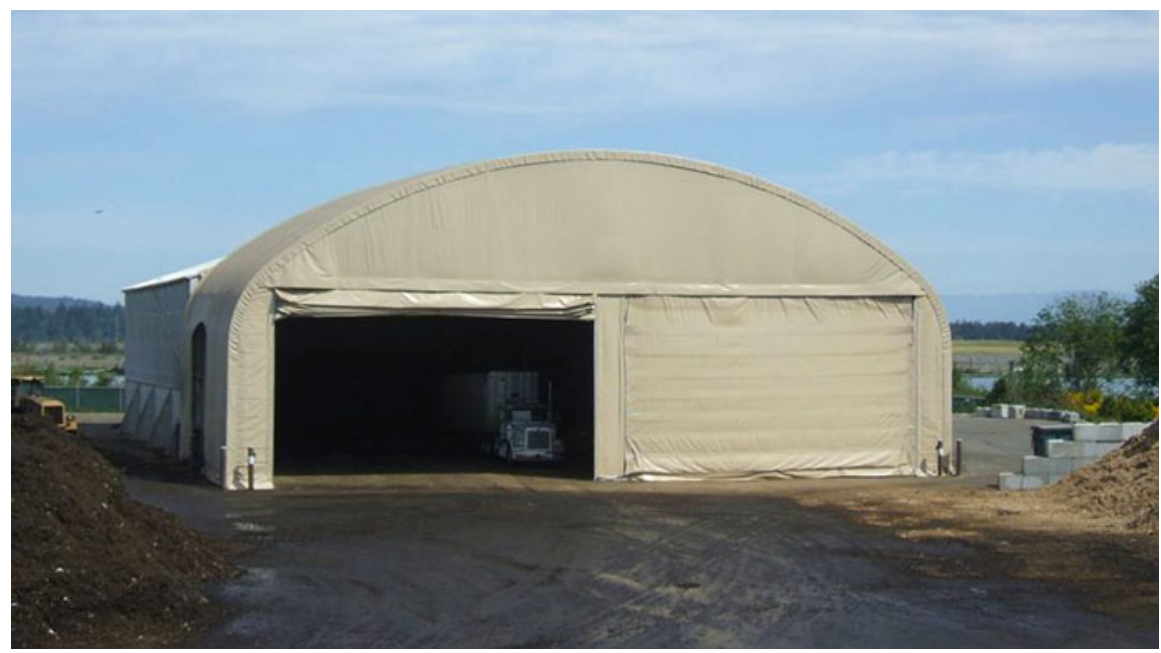

Fig. 7 The receiving building at the Everett compost facility. Enclosing the receiving area was done as a way to mitigate odors. Delivery of feedstocks is the greatest source of odor at our facility

volume users of compost. In addition, home gardeners tend not to spend as much money during recessions.

Compost quality with the addition of the "non-compostable" food service items and other contaminants such as plastics, glass, etc. as previously discussed has had a negative impact on compost product sales for Cedar Grove. For example, WDOT prefers to have a coarser, woodier product to use for erosion control projects; however, the larger the screening size of the finished product, the more of these contaminants remain in the end product. This is a downside of accepting food scraps as well as the "non-compostable" packaging that comes along with this feedstock.

Odors, real or perceived, have had a definite impact on Cedar Grove and other composting operations, which affects product sales in some cases. Instituting best available control technologies along with continuous community outreach has been a staple for Cedar Grove over the years. As the Seattle region has grown and expanded, more cities and residents are participating in landfill diversion, which increases inbound organic volumes for Cedar Grove. New alternative energy technologies, such as anaerobic digestion, and diversion to other composting operations that are newer to the region are ways to process the additional organics in the future (Fig. 7). 
Part III

Ecosystem Services - Climate Regulation 


\title{
Soils and Climate Change
}

\author{
Sally Brown
}

\section{Soils and Carbon Sequestration}

Increasing soil carbon storage has been advocated as a means to both reduce net $\mathrm{C}$ emissions and increase the resiliency of soils for climate change (Lal 2004a, b; Lal et al. 2007). In fact, emissions of $\mathrm{CO}_{2}$ from soils since 1850 total approximately $78 \pm 12$ giga tons $(1 \mathrm{Gt}=1$ billion tons $)$ of $\mathrm{CO}_{2}$. In comparison emissions related to fossil fuel use over the same time frame total $270 \pm 30 \mathrm{Gt}$ of $\mathrm{CO}_{2}$. Considering only cropland, total soil organic carbon sequestration potential in the US is $45-98 \mathrm{Mt}$ ( $1 \mathrm{Mt}=1$ million tons) (Lal et al. 2007). Soil carbon storage is complicated by the fact that increased soil carbon is not simply a case of adding carbon to soils and having that carbon remain in place for decades. Organic matter in soils is part of the annual cycle of growth and decay. At the same time that a portion of the existing carbon in soils is mineralized by soil microbes, more carbon is being added via plant growth and decay. Increasing carbon will result in net increases in primary productivity (plant growth) (Fig. 1). This increase in productivity will result in increased carbon inputs into soil. A portion of this increased productivity will remain in the soil as detritus from above and below ground plant biomass. While a fraction of this added carbon decomposes and returns to the atmosphere as $\mathrm{CO}_{2}$, a portion becomes incorporated into soil organic matter.

When soil carbon reserves are increasing the rate of mineralization of carbon (carbon returning to the atmosphere as $\mathrm{CO}_{2}$ ) is less than the total carbon input into soil. So even though adding more carbon to soil will increase mineralization, this mineralization is considered to come from the short-term carbon cycle and so does not count as a carbon emission. The rate of $\mathrm{C}$ mineralization will also be lower than the total rate of carbon addition (amendment application rate + increase in primary

\footnotetext{
S. Brown $(\bowtie)$

School of Environmental and Forest Sciences, University of Washington, Seattle, WA, USA

e-mail: slb@uw.edu
} 

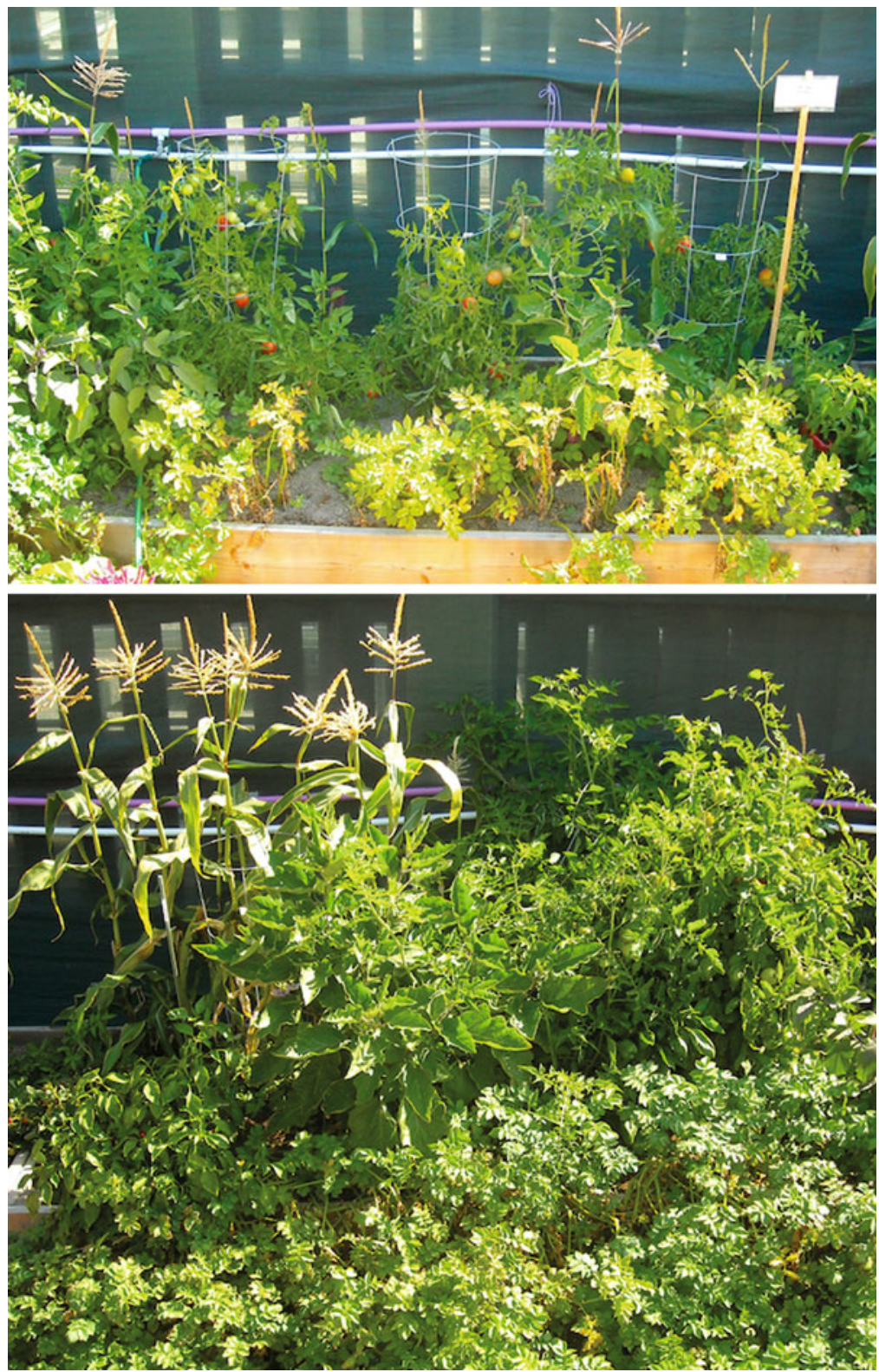

Fig. 1 Two garden plots, planted with the same plants at the same time. The upper plot was planted into commercial topsoil. The lower plot was planted into commercial topsoil and a biosolids compost. Adding the soil amendment increased soil carbon and also resulted in higher productivity. Higher productivity results in continued additions of carbon to soil from roots and dead plant tissue (Photos Kristen McIvor) 
Fig. 2 A former coal mine site restored to forestry in Centralia, WA. Soils were amended with biosolids to increase productivity and have served as a carbon sink

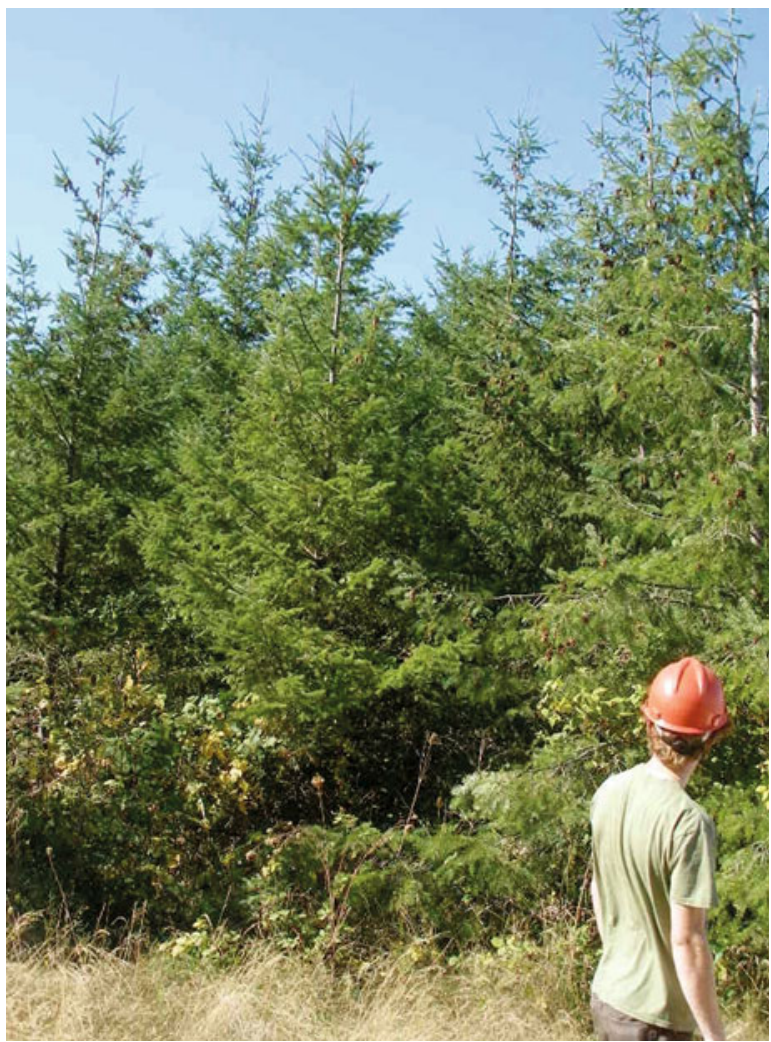

productivity). For example, one study on strip -mined land amended with biosolids saw a stable increase in soil carbon over time, even after biosolids amendments had ceased (Fig. 2). The authors attempted to differentiate between the portion of applied carbon from the biosolids that remained and the new carbon added to soil as a result of higher plant productivity (Tian et al. 2009). Carbon will continue to accumulate in soils until equilibrium conditions are reached. For healthy and undisturbed soils, it is likely that this balance between carbon inputs and carbon mineralization is already in equilibrium. For disturbed soils, however, it is likely that net carbon accumulation can occur for several decades (Brown et al. 2011; Lal 2004a, b; Lal et al. 2007; Trlica and Brown 2013). Agriculture is a significant type of soil disturbance. Research has shown similar rates of carbon accumulation for agricultural and mined soils as a consequence of organic amendment addition (Brown et al. 2011; Trlica and Brown 2013). 


\section{Carbon Storage Versus Carbon Concentration}

Soil carbon concentrations are typically measured as the \% of carbon in the soil. This can be converted to the total carbon stored in a soil (tons per acre) by multiplying the $\%$ concentration by the weight of the soil (bulk density). Changes in soil carbon can be reported as increases or decreases in \% carbon or as differences in the quantity of carbon stored in soils (tons per hectare). The latter takes into account the bulk density or weight of the soils. It is more commonly used when soil carbon storage is a focus of the work. For example an early review by Khaleel et al. (1981) noted changes in soil $\mathrm{C}$ concentration in response to addition of biosolids, composts and manures. These were observed across a range of amendment loading rates, different soil types, and over different time periods. Increases (reported as \% net increase in soil C) ranged from 0.03 for annual application of manure at $4.7 \mathrm{t} / \mathrm{ha}$ over 18 years to silt loam soil to 4.65 after annual applications of manure at $125 \mathrm{t} /$ ha over 3 years to a silty clay loam. Changes in soil carbon storage were not reported. As more researchers understand the importance of soil carbon sequestration, more studies report changes in soil carbon as tons per hectare or acre rather than as $\% \mathrm{C}$ in soils.

\section{Understanding Soil Carbon Sequestration}

Low carbon or disturbed soils will have higher rates of net $\mathrm{C}$ sequestration than less disturbed soils. This will continue until these soils approach equilibrium $\mathrm{C}$ concentrations (Lal 2004a; Powlson et al. 2012). Much of the focus on carbon storage has been on wildland or agricultural soils. Deforestation disturbs soils as well as trees and has resulted in significant soil carbon loss (Lal 2004a, b). Conventional tillage in agricultural soils results in soil loss at a rate that is 1-2 orders of magnitude greater than soil formation (Montgomery 2007). Losing soil also means losing soil carbon reserves. Typically soils in urban areas have not been considered in these discussions. Soils in urban areas are often disturbed as a result of neglect or construction. Urban areas, as a result of being population centers are also centers for residuals such as food scraps, yard waste and municipal biosolids. These residuals have value as soil amendments. The value comes from nutrient content and organic matter. Restoring these soils to productivity through the use of soil amendments will likely result in soil carbon storage similar to what has been observed for mined lands and agricultural lands that are degraded (Brown et al. 2011). One estimate suggests that urban soils are capable of sequestering 0.22 tons of carbon per hectare per year (Brown et al. 2011). 


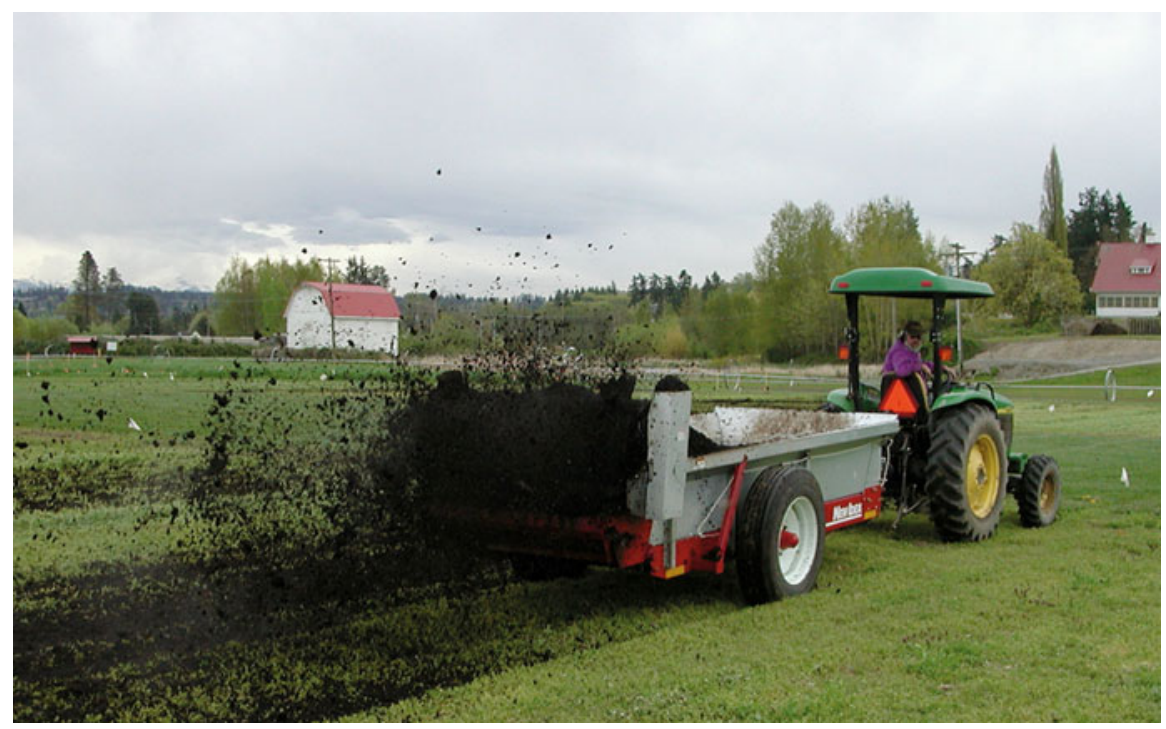

Fig. 3 Applying mixed waste (yard waste, manure, pre-consumer food waste) compost to cropland in Puyallup, WA (Craig Cogger)

Table 1 Rates of soil carbon sequestration for soils under no till and for soils receiving a 4 ton per hectare annual application of compost or biosolids

\begin{tabular}{l|l}
\hline & C sequestration \\
\hline & kg C per ha per year \\
\hline No till & $30-35$ \\
\hline $\begin{array}{l}\text { Residuals } \\
\text { use }\end{array}$ & $400-1600$ \\
\hline
\end{tabular}

\section{No Till Versus Amendments}

Eliminating or minimizing tillage has been the focus of attempts to restore soil productivity and increase soil carbon reserves. However, studies have shown that using organic (high carbon) soil amendments is a much more effective way to rapidly increase soil carbon (Trlica and Brown 2013; Brown et al. 2011; Lal 2004a, b; Spargo et al. 2008; Trlica and Brown 2013) (Fig. 3). Typical rates for C accumulation in soils as a result of conversion to no till farming are $30-35 \mathrm{~kg} \mathrm{C}$ per hectare per year (Lal 2004b). In comparison, studies of long-term sites where composts or municipal biosolids have been applied are typically at least an order of magnitude higher (Table 1). Using an annual loading rate of 4 tons per hectare, studies have shown carbon sequestration rates ranging from $400 \mathrm{~kg}$ to over $1600 \mathrm{~kg}$ C per hectare per year (Brown et al. 2011; Trlica and Brown 2013). 


\section{Mechanisms}

Researchers have attempted to understand the processes that result in increased soil carbon concentrations for sites where amendments have been added. A recent study used X ray adsorption spectroscopy to determine forms of carbon in soils that had historic applications of biosolids or composts (Li et al. 2013). The authors saw increased evidence of more weathered carbon compounds in the amended soils and suggest that the formation of more stable, weathered $\mathrm{C}$ compounds in the amended soils was partially responsible for the increased $\mathrm{C}$ concentrations in those soils. A study on California rangelands receiving a single compost application confirmed these results (Ryals et al. 2013). Another study looked at soil carbon storage and associations as a function of tillage and biosolids application (Stewart et al. 2011). Biosolids had been applied once 3-5 years prior to sampling at agronomic rates (8-14 t/ha). The authors noted increased soil $\mathrm{C}$ storage in the biosolids amended soils compared with the fertilized soils (33.1 \pm 1.8 vs. $28.4 \pm 1.1$ t C ha ${ }^{-1}$ ). Fractionation of the soils indicated that organic matter associated with silt and clay particles was near saturation but that particulate organic matter could adsorb additional carbon. Another study looked at carbon accumulation in soils amended with compost or fertilizer and then evaluated $\mathrm{C}$ mineralization rates from micro and macro aggregates (Yu et al. 2012). Eighteen years of compost application increased soil $\mathrm{C}$ by $71-122 \%$. While compost increased mineralization in comparison to the control, this increase was less than the rate of carbon accumulation. The authors found that compost amendment also decreased the rate of $\mathrm{C}$ mineralization in soil micro-aggregates and silt and clay fractions in comparison to the control and fertilized soils.

\section{Long Term Studies}

Other studies have reported changes in soil carbon on a ton of $\mathrm{C}$ stored per hectare basis. In some cases, carbon storage efficiency, or carbon stored per unit of amendment applied is reported. A summary of papers showing $\mathrm{C}$ storage per ton of amendment applied is shown in the table below (Table 2).

In general, carbon storage per ton of amendment added is higher in sites with initially lower carbon concentrations. For example, total $\mathrm{C}$ concentration in two of the sites reported in Brown et al. (2011) that showed low C storage efficiency had carbon storage ranging from 30 to 40 tons per hectare in the control sites. Areas that showed increased carbon storage efficiency had initial carbon storage ranging from 13 to 25 tons per hectare. The data also suggests that there is likely a potential to over apply amendments. Carbon storage efficiency ranged from 0.15 to 0.28 in mine sites restored with biosolids or composts (Trlica and Brown 2013). In a site where 560 tons/ha of biosolids was added to a site that had also received over a meter of topsoil, this rate fell to 0.03 tons $\mathrm{C}$ per ton amendment. 
Table 2 A summary of studies showing rates of soil carbon accumulation per ton of amendment applied

\begin{tabular}{|c|c|c|c|c|}
\hline Study & Amendment & $\begin{array}{l}\text { Cumulative } \\
\text { application rate } \\
\left(\text { tons } \mathrm{ha}^{-1}\right)\end{array}$ & $\begin{array}{l}\text { Net } \mathrm{C} \text { per } \\
\text { ton } \\
\text { amendment } \\
\text { (tons) }\end{array}$ & Notes \\
\hline ROU, 2006 & Compost & & 0.07 & $\begin{array}{l}\text { Modeled value after } \\
\text { US EPA }\end{array}$ \\
\hline \multirow[t]{4}{*}{$\begin{array}{l}\mathrm{Li} \text { and Evanylo } \\
\text { (2013) }\end{array}$} & Biosolids & $42-210$ & $0.04-0.075$ & $\begin{array}{l}\text { Study conducted } \\
\text { on VA soils }\end{array}$ \\
\hline & Biosolids & $14-98$ & $0.03-0.12$ & $\begin{array}{l}\text { Decreasing efficiency } \\
\text { with increased } \\
\text { application rate }\end{array}$ \\
\hline & Compost & 126 & 0.11 & \\
\hline & & 202 & 0.1 & \\
\hline \multirow[t]{9}{*}{$\begin{array}{l}\text { Brown et al. } \\
\text { (2011) }\end{array}$} & & & & $\begin{array}{l}\text { Study conducted on } \\
\text { WA sites }\end{array}$ \\
\hline & Compost & 134 & 0.54 & Orchards \\
\hline & Compost & $84-140$ & $0.12-0.24$ & Orchards \\
\hline & Compost & 157 & 0.06 & Turf \\
\hline & Compost & 224 & 0.08 & Landscape \\
\hline & Compost & 150 & 0.35 & Highway \\
\hline & \begin{tabular}{|l|} 
Biosolids \\
\end{tabular} & $67-202$ & $0.04-0.09$ & Turf \\
\hline & Biosolids & $18-40$ & $0.34-0.43$ & Wheat \\
\hline & Biosolids & 147 & 0.47 & Highway \\
\hline \multirow{3}{*}{$\begin{array}{l}\text { Powlson et al. } \\
\text { (2012) }\end{array}$} & & & & Review of UK sites \\
\hline & Compost & & 0.06 & \\
\hline & Biosolids & & 0.18 & \\
\hline \multirow{5}{*}{$\begin{array}{l}\text { Trlica and } \\
\text { Brown (2013) }\end{array}$} & & & & Mine sites \\
\hline & Biosolids & 135 & 0.28 & \\
\hline & $\begin{array}{l}\text { Biosolids/pulp } \\
\text { sludge }\end{array}$ & $50-486$ & 0.31 & \\
\hline & Biosolids/compost & $128-337$ & 0.15 & \\
\hline & Biosolids & 560 & 0.03 & \\
\hline
\end{tabular}

\section{Conclusions}

Urban soils can serve as an effective sink for carbon. While the acreage of soils in urban areas is much lower than soils in agricultural areas, the proximity to a range of residuals based soil amendments can help to accelerate soil carbon storage. This rapid rate of building carbon stores in soils will provide a greenhouse gas reduction. It will also increase productivity of the soils and potentially the productivity of urban agriculture. 


\section{References}

Brown S, Kurtz K, Bary A, Cogger C (2011) Long-term effects of organic amendments on soil carbon storage and physical properties. Environ Sci Technol. dx.doi.org/10.1021/es2010418

Khaleel R, Reddy KR, Overcash MR (1981) Changes in soil physical properties due to organic waste applications: a review. J Environ Qual 10:133-141

Lal R (2004a) Soil carbon sequestration to mitigate climate change. Geoderma 123:1-22

Lal R (2004b) Soil carbon sequestration impacts on global climate change and food security. Science 304(5677): 1623

Lal R, Follett RF, Stewart BA, Kimble JM (2007) Carbon sequestration to mitigate climate change and advance food security. Soil Sci 172:943-956

Li J, Evanylo GK (2013) The effects of long-term application of organic amendments on soil organic carbon accumulation. Soil Sci Soc Am J 77:964-973

Li J, Evanylo GK, Xia K, Mao J (2013) Soil carbon characterization 10 to 15 years after residual application: carbon (1s) K-edge near- edge, X-ray adsorption fine- structure spectroscopy study. Soil Sci 178:453-464

Montgomery DR (2007) Soil erosion and agricultural sustainability. Proc Natl Acad Sci 104(33):13268-13272

Powlson DS, Bhogal A, Chambers BJ, Coleman K, Macdonald AJ, Goulding KWT, Whitmore AP (2012) The potential to increase soil carbon stocks through reduced tillage or organic material additions in England and Wales: a case study. Agric Ecosyst Environ 146:23-33

Ryals R, Kaiser M, Torn MS, Berhe AA, Silver WL (2013) Impacts of organic matter amendments on carbon and nitrogen dynamics in grassland soils. Soil Biol Biochem 68:52-61

Spargo JT, Alley MM, Follett RF, Wallace JV (2008) Soil carbon sequestration with continuous no-till management of grain cropping systems in the Virginia coastal plain. Soil Tillage Res 100:133-140

Stewart CE, Follett RF, Wallace J, Pruessner EG (2011) Impact of biosolids and tillage on soil organic matter fractions: implications of carbon saturation for conservation management in the Virginia Coastal Plain. Soil Sci Soc Am J 76:1257-1267

Tian G, Granato TC, Cox AE, Pietz RI, Carlson CR Jr, Abedin Z (2009) Soil carbon sequestration resulting from long-term application of biosolids for land reclamation. J Environ Qual 38:61-74

Trlica A, Brown S (2013) Greenhouse gas emissions and the interrelation of urban and forest sectors in reclaiming one hectare of land in the Pacific Northwest. Environ Sci Technol 47(13):7250-7259

Yu H, Ding W, Luo J, Geng R, Ghani A, Cai Z (2012) Effects of long-term compost and fertilizer application on stability of aggregate- associated organic carbon in an intensively cultivated sandy loam soil. Biol Fertil Soils 48(3):325-336 


\title{
Soil Carbon Sequestration and Organic Wastes
}

\author{
Andrew Trlica
}

\section{Organic Residuals, Urban Agriculture, and Greenhouse Gases}

In cities there is a special nexus between urban waste management, climate change mitigation, and urban agriculture. Urban areas contain under-utilized vacant land in a degraded state with poor topsoil, as for instance in a vacant lot. Urban soil improvements, to enhance the quality of public greenspace or to support urban agriculture, are often most quickly and dramatically achieved by adding significant amounts of organic soil amendments. Urban areas are also themselves the source of large amounts of organic residuals well suited for use as soil amendments: Biosolids from wastewater treatment, and compost derived from urban wastes such as yard- and garden wastes and pre- and post-consumer food wastes. Finally, activity in urban areas is a source of increasingly large greenhouse gas (GHG) emissions, and urban areas must also cope with increasingly large waste management demands (themselves a potentially large GHG source). As the following discussion will show, beneficially re-using urban organic residuals as soil amendments may allow urban areas to realize increased local food production along with greater soil carbon storage, while avoiding more GHG-intensive pathways for managing urban wastes.

Urban areas are major sources of GHG emissions owing mainly to activities like power generation, vehicle transportation, and demand for manufactured materials. Urban waste management also tends to be a significant GHG source. Landfill disposal and trash incineration have historically been the most common waste disposal approaches, but can come with a relatively high GHG burden. Organic wastes buried in landfills break down in the absence of oxygen and release, among several potentially harmful liquid and gaseous by-products, methane $\left(\mathrm{CH}_{4}\right)$ and nitrous oxide $\left(\mathrm{N}_{2} \mathrm{O}\right)$. These gases have global warming potentials of 21 and 310 times the

\footnotetext{
A. Trlica $(\bowtie)$

Department of Earth and Environment, Boston University, Boston, MA, USA

e-mail: andrewtrlica@gmail.com
} 
same amount of $\mathrm{CO}_{2}$, respectively. In addition, as urban areas continue to expand space available for use as landfill has becoming increasingly scarce, requiring long truck or train hauling of wastes to distant outlying facilities. The $\mathrm{CO}_{2}$ released due to fuel consumption in hauling waste to landfills contributes to the net climate change impact of urban waste management. Alternatively, disposing of organic wastes through incineration can produce high emissions of nitrous oxide, with a similarly outsized effect on climate change impact (Brown et al. 2010; Suzuki et al. 2003). Because of the high moisture content of most urban residuals, combustion as a means of disposal can use energy rather than generate energy. Incinerators also tend to consume large quantities of fuel such as natural gas, and still may require long-distance hauling for disposal of the resulting ash.

In contrast, utilizing urban organic residuals to improve soil may help store carbon. Composting organic residuals tends to result in substantial reductions in methane emissions compared to landfilling or lagoon treatment (Brown et al. 2010, 2011) and can offer reduced need for long-distance hauling, particularly for residuals managed for re-use within the urban area. Furthermore, the use of these soil amendments to support crop production can help to avoid the need for manufacturing of synthetic fertilizers with large energy requirements and resulting GHG emissions.

\section{Comparative GHG Emissions for Organic Residuals Management Seattle}

The management of biosolids in the city of Seattle offers an example of the comparative GHG trade-offs that can arise from different residuals management scenarios available in an urban area. The following study compares the net GHG balance of different management options available for Seattle biosolids, based on an approach adapted from the life cycle assessment technique. This technique tracks the necessary inputs and environmental outputs of each stage of a production or activity cycle to estimate the net environmental impact of the process or activity in question. In the following study a multi-part mathematical model was used to estimate the net GHG impact arising from different management routes applied to a single metric ton of biosolids in Seattle from the time the material leaves the wastewater facility to its final disposal or use point. The model estimate for net GHG balance for each management route allows for comparison of relative impacts between different options. This work was based on previous research and modeling studies of life-cycle GHG emissions associated with biosolids management (Brown et al. 2010; Trlica and Brown 2013).

In the Seattle example, the city could plausibly choose to manage its biosolids by landfill disposal, direct land application to distant agricultural lands, or composting of the material followed by local distribution and use on urban land. (Incineration was not considered since this approach is not practiced widely in the region and is unlikely to become available in the near future). Each scenario below considers the 
relative haul distances, fuel and energy requirements, direct GHG emissions, soil C sequestration and useful outputs for each management pathway, and the GHG emissions or offsets that result from each. The model used to produce the GHG estimates is available as a spreadsheet calculator through the Canadian Council of Minister of the Environment (Biosolids Emissions Assessment Model, BEAM), and has been adapted for conditions appropriate to Washington State and the Seattle region. The model output gives a generalized estimate of the expected GHG balance of the above management scenarios in terms of $\mathrm{CO}_{2}$-equivalents $\left(\mathrm{CO}_{2} \mathrm{e}\right)$, which takes into account the varying climate change effects of different GHGs. A separate GHG intensity was estimated for each scenario, providing an idea of the amount of GHG released per kilogram of biosolids managed.

To prepare the model calculations, biosolids properties were input based on average measurements from the two main wastewater treatment plants in operation for the Seattle metropolitan area, current to 2011. The model takes into account GHG emissions for electricity production (based on the Canadian province of British Columbia, with similar low GHG intensity as in Washington state) as well as for electricity offsets for energy captured. Fuel use during transportation and in machinery for handling materials is also accounted for. Manufacturing offset credits are given for any nitrogen and phosphorus that is recycled back to land that would otherwise have required synthetic fertilizer inputs.

A Composting + Urban Use scenario was prepared which assumed windrow composting of dewatered biosolids similar to a process currently used on a small scale to compost biosolids produced in Seattle. Haul distance of biosolids for composting (including back haul of finished compost to the urban core) was based on the assumption that composting would take place at a large-scale facility in the nearby city of Everett, Washington, which has previously composted food and yard waste collected in Seattle.

A Rural Agriculture scenario was modeled after management practice currently used for the bulk of biosolids now generated in the city of Seattle. In this scenario biosolids are hauled and directly applied to farm fields in eastern Washington to replace fertilizer required for dryland wheat production.

Two Landfill scenarios were modeled assuming disposal of biosolids in the available facility nearest to Seattle. The landfill scenarios consider the fugitive methane and nitrous oxide generated from anaerobic decay of biosolids over the course of long-term burial. One scenario assumes no effective capture or destruction of these emissions ("no capture"), as this represents the upper end of the potential emissions profile and remains an operating condition of some landfills in the U.S. The other scenario ("80\% capture + electricity") assumes the facility operates an advanced landfill gas capture system with high methane capture efficiency. This captured methane is then assumed to power on-site electricity generation for export to the regional grid. The capture model represents an optimistic scenario (Fig. 1).

Recent revisions of the US EPA WARM model show variability in landfill gas capture efficiency based on design of the landfill, age of the landfill and operating efficiency (Table 1) (US EPA 2014). The climate in the area of the landfill will also impact methane generation and release with much faster decay rates seen in wet versus dry climates. A faster decay rate means that methane will be released more 


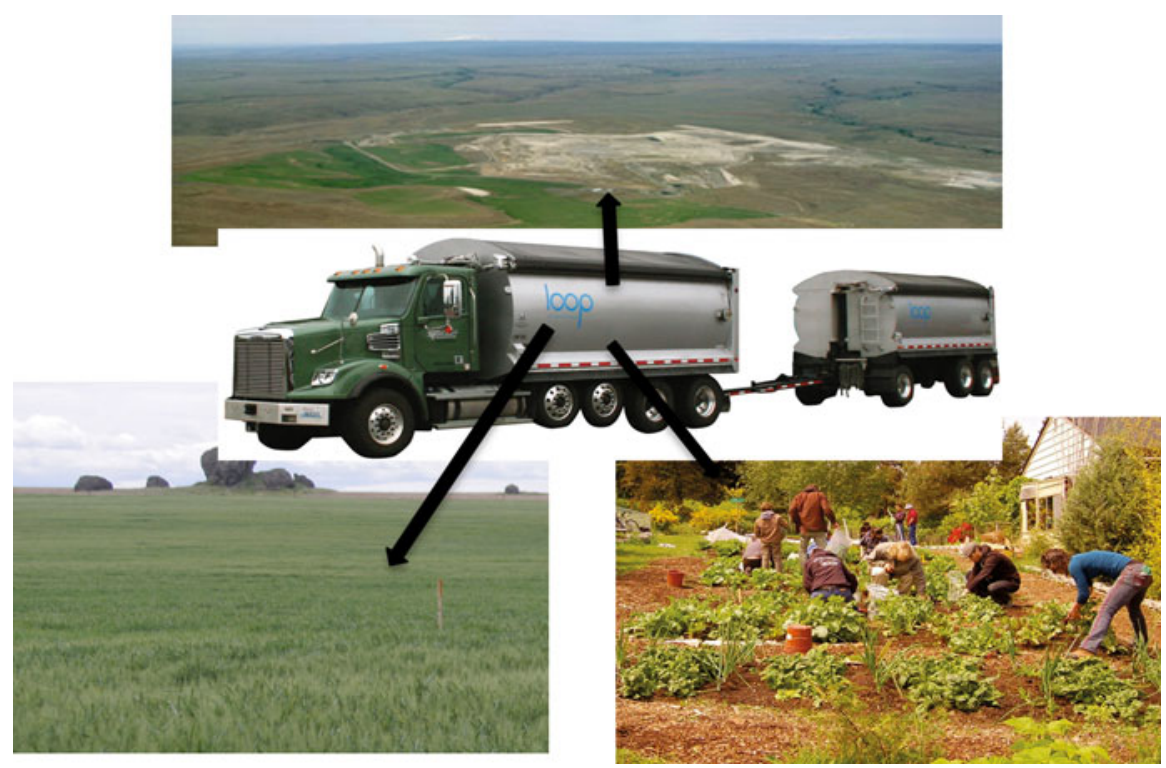

Fig. 1 Three options modeled for municipal biosolids include landfilling, use as a fertilizer substitute for dryland wheat and composting, and use in urban agriculture

Table 1 Variation on landfill gas collection efficiency as a result of time and of individual landfill characteristics

\begin{tabular}{|c|c|c|c|c|}
\hline \multirow[b]{3}{*}{ Scenario description } & \multirow{3}{*}{$\begin{array}{l}\text { Gas collection } \\
\text { Scenario }\end{array}$} & \multicolumn{3}{|c|}{ MSW decay rate (per year) } \\
\hline & & 0.02 & 0.12 & $\begin{array}{l}\text { National } \\
\text { average }\end{array}$ \\
\hline & & \multicolumn{3}{|c|}{ Total collection efficiency $(\%)$} \\
\hline \multirow{3}{*}{$\begin{array}{l}\text { Typical collection, representative of an } \\
\text { average landfill }\end{array}$} & Year 0-1: $0 \%$ & \multirow[t]{3}{*}{68.2} & \multirow[t]{3}{*}{60.6} & \multirow[t]{3}{*}{64.8} \\
\hline & Years 2-4: $50 \%$ & & & \\
\hline & Years 5-14: $75 \%$ & & & \\
\hline \multirow[t]{3}{*}{ Worst case collection } & Years 0-4: $0 \%$ & \multirow[t]{3}{*}{66.2} & \multirow[t]{3}{*}{50.6} & \multirow[t]{3}{*}{60.3} \\
\hline & Years 5-9: 50\% & & & \\
\hline & Years $10-14: 75 \%$ & & & \\
\hline \multirow[t]{3}{*}{ Aggressive gas collection } & Year 0: $0 \%$ & \multirow[t]{3}{*}{68.6} & \multirow[t]{3}{*}{63.9} & \multirow[t]{3}{*}{66.4} \\
\hline & Years $0.5-2: 50 \%$ & & & \\
\hline & Years 10-14: $75 \%$ & & & \\
\hline
\end{tabular}

Data is from the US EPA WARM model

quickly than with a slower decay rate. Fast decay rates coupled with low initial gas collection efficiency will result in high rates of methane emissions. The revised WARM model shows different decay rates for food scraps and yard waste (Table 2). Biosolids decay rates are not provided. The model also estimates the amount of biosolids-derived carbon expected to remain buried in the landfill for the long-term. Though landfilling of biosolids from Seattle is not commonly practiced, the option remains in place as a contingency management pathway. 
Table 2 Potential methane release from food scraps and yard trimmings from landfills. The different decay rate constants reflect how quickly these materials will decay in landfills in different climates and management practices

\begin{tabular}{l|l|l|l|l|l|l}
\hline & $\begin{array}{l}\text { Methane } \\
\text { generation } \\
\text { potential }\end{array}$ & & & $\begin{array}{l}\text { Decay rate } \\
\text { constants }\end{array}$ & & \\
\hline & $\begin{array}{l}\text { Tons } \mathrm{CO}_{2} \text { e per } \\
\text { wet ton }\end{array}$ & Dry & Moderate & Wet & Bioreactor & $\begin{array}{l}\text { National } \\
\text { average }\end{array}$ \\
\hline Food scraps & 1.575 & 0.07 & 0.14 & 0.22 & 0.43 & 0.19 \\
\hline $\begin{array}{l}\text { Yard } \\
\text { trimmings }\end{array}$ & $0.51-0.77$ & 0.1 & 0.2 & 0.29 & 0.59 & 0.26 \\
\hline
\end{tabular}

Data is from the US EPA WARM model

Table 3 Results of GHG modeling of for management of 1 dry ton of biosolids under different management scenarios in Seattle, Washington

\begin{tabular}{l|l|l|l|l}
\hline & $\begin{array}{l}\text { Landfill (no } \\
\text { capture) }\end{array}$ & $\begin{array}{l}\text { Landfill }(80 \% \\
\text { capture+electricity) }\end{array}$ & $\begin{array}{l}\text { Rural } \\
\text { agriculture }\end{array}$ & $\begin{array}{l}\text { Composting }+ \\
\text { urban use }\end{array}$ \\
\hline $\begin{array}{l}\text { Transport distance }(\mathrm{km}, \\
\text { round trip) }\end{array}$ & 800 & 800 & 600 & 200 \\
\hline Transport & 166.9 & 166.9 & 125.2 & 41.7 \\
\hline Handling machinery & 0 & 0 & 7.5 & 86 \\
\hline Electricity production & 0 & -29.6 & 0 & 32.1 \\
\hline Fugitive methane & 3586.4 & 2888.8 & 21.8 & 0 \\
\hline Fugitive nitrous oxide & 481.7 & 481.7 & 15.2 & 0 \\
\hline Soil C sequestration & -282.1 & -282.1 & -246 & -246 \\
\hline N fertilizer offset & 0 & 0 & -263.7 & -263.7 \\
\hline P fertilizer offset & 0 & 0 & -39.8 & -39.8 \\
\hline Net GHG balance & 3952.9 & 3225.7 & -379.8 & -389.7 \\
\hline $\begin{array}{l}\text { GHG intensity (kg } \\
\text { CO }{ }_{2} \text { e/kg biosolids) }\end{array}$ & 3.95 & 3.23 & -0.38 & -0.39 \\
\hline
\end{tabular}

Negative figures indicate GHG offsets. All figures are given in $\mathrm{kg} \mathrm{CO}_{2} \mathrm{e}$

The estimates for each scenario show clear differences in the GHG output for each biosolids management scenario (Table 3). The two landfill scenarios are both estimated to result in relatively high net GHG emissions, primarily due to high emissions of fugitive methane. Capture of methane and offsets for electricity production would be expected to do little to moderate the overall net GHG emissions of landfill disposal of biosolids.

In contrast, the two scenarios in which biosolids were recycled to land as soil amendment (either directly to wheat fields or in urban-use compost) showed netnegative GHG emissions, meaning net carbon sequestration. While transport and handling machinery fuel use produced considerable emissions, these emissions were more than offset by the soil $\mathrm{C}$ sequestration and fertilizer replacement offsets predicted by the model. Fugitive methane and nitrous oxide emissions from 
temporary storage of biosolids on-site and greater fuel use due to longer transportation distance added to emissions in the Rural Agriculture scenario. In the Composting scenario there were comparatively higher emissions due to greater fuel use in handling machinery. Net GHG draw-down was similar for both landuse scenarios.

Greenhouse gas emissions intensity for each scenario, expressed in terms of GHG impact per $\mathrm{kg}$ of biosolids managed, showed the same small net drawdown for each ton of biosolids managed through land-use. In contrast, emissions intensity for both landfill scenarios showed relatively high net GHG emissions for every $\mathrm{kg}$ of biosolids managed - exceeding a complete "conversion" of each kg of biosolids to $1 \mathrm{~kg} \mathrm{CO}_{2} \mathrm{e}$ of global warming impact. Along with the GHG liabilities landfilling can be expected to incur, the opportunity for soil improvement and re-capture of valuable nutrients would also be lost in either of the landfill management routes.

The results of this modeling show that different organic waste management options available to the city of Seattle can have widely different GHG emissions outcomes. While Seattle currently utilizes a generally GHG-negative management approach for most of its biosolids (dryland wheat fertilization), diversion of biosolids to support local urban agriculture would likely have a similar GHG benefit. The modeling study therefore shows that diversion of biosolids from dryland wheat to composting and urban soil improvement would not involve significant tradeoffs in GHG balance. In contrast, disposal of locally produced biosolids to landfill would likely create new GHG liabilities, as well as forgo other environmental benefits due to soil improvement and opportunities for greater regional food production.

The modeling results also suggest general guidelines for minimizing GHG emissions with urban residuals management. Greater hauling distances, more intensive machinery and electricity use during processing, and longer storage time prior to use on land can all be expected to increase GHG emissions associated with residuals management. On the other hand, maximizing nutrient recovery and soil $\mathrm{C}$ enhancement was estimated to improve the overall GHG profile of a given residuals management route. By far the greatest GHG emissions reductions were estimated to accrue by diverting urban organic residuals like biosolids, yard and food scraps from landfill disposal to use as a soil amendment, either within the urban core or on its periphery.

The example of residuals management in Seattle provides an illustration of the links between soil carbon sequestration, GHG emissions, and urban agriculture. The modeling results show that urban waste management options that recycle organic residual back to soil should generally help avoid high GHG emissions from landfill burial, reduce the need for production of GHG-intensive fertilizers, and increase soil carbon storage. Urban agriculture, and the need for fertilizer and soil improvement that go with it, therefore has a role to play in helping cities reduce urban GHG emissions while sustainably managing their organic wastes. 


\section{References}

Brown S, Carpenter A, Beecher N (2010) Calculator tool for determining greenhouse gas emissions for biosolids processing and end use. Environ Sci Technol 44(24):9505-9515

Brown S, Kurtz K, Bary A, Cogger C (2011) Quantifying benefits associated with land application of organic residuals in Washington state. Environ Sci Technol 45(17):7451-7458

Suzuki Y, Ochi S, Kawashima Y, Hiraide R (2003) Determination of emission factors of nitrous oxide from fluidized bed sewage sludge incinerators by long-term continuous monitoring. J Chem Eng Jpn 36:458-463

Trlica A, Brown S (2013) Greenhouse gas emissions and the interrelation of urban and forest sectors in reclaiming one hectare of land in the Pacific Northwest. Environ Sci Technol 47(13):7250-7259

US EPA (2014) Waste Reduction Model (WARM) solid waste management and greenhouse gasses. http://www.epa.gov/epawaste/conserve/tools/warm/SWMGHGreport.html 


\title{
Lettuce to Reduce Greenhouse Gases: A Comparative Life Cycle Assessment of Conventional and Community Agriculture
}

\author{
Isaac Emery and Sally Brown
}

\section{Introduction}

One of the most frequently touted benefits of community gardens and the local food movement is the potential to reduce greenhouse gas emissions through local low input production. Commercially grown foods, grown as monocultures on large acreage typically require large inputs of fertilizers, water and pesticides along with long transport distances and refrigerated storage to reach consumers. What impact can we have when labor, water, and nutrients are supplied locally? To evaluate this, we used life cycle assessment to compare the greenhouse gas emissions of supplying lettuce to customers in Seattle with either conventionally grown lettuce from central California or with lettuce grown in a community garden (Figs. 1 and 2).

Life cycle assessment is a tool that can be used to calculate the different costs and benefits for centralized cultivation in comparison to local production by considering all factors and inputs required in getting a product, in this case a head of lettuce, to the consumer. Life cycle assessment can include a range of end points such as air and water pollution potential to determine the environmental impacts of different activities. It can also be used to evaluate the carbon emissions of different activities. A critical component of life cycle assessments are the baseline assumptions used to define each activity. For our analysis, the urban farm, much like a home garden relies on manual labor for preparing soil, planting, weeding, and other farm operations.

\footnotetext{
I. Emery $(\square)$

School of Forest Resources, University of Washington, Seattle, WA, USA

Department of Systems Engineering and Management, Air Force Institute of Technology,

Wright-Patterson Air Force Base, OH, USA

e-mail: isaac.emery@gmail.com

S. Brown

School of Environmental and Forest Sciences, University of Washington, Seattle, WA, USA

e-mail: slb@uw.edu
} 
Fig. 1 Lettuce grown in a raised bed in a garden in Seattle
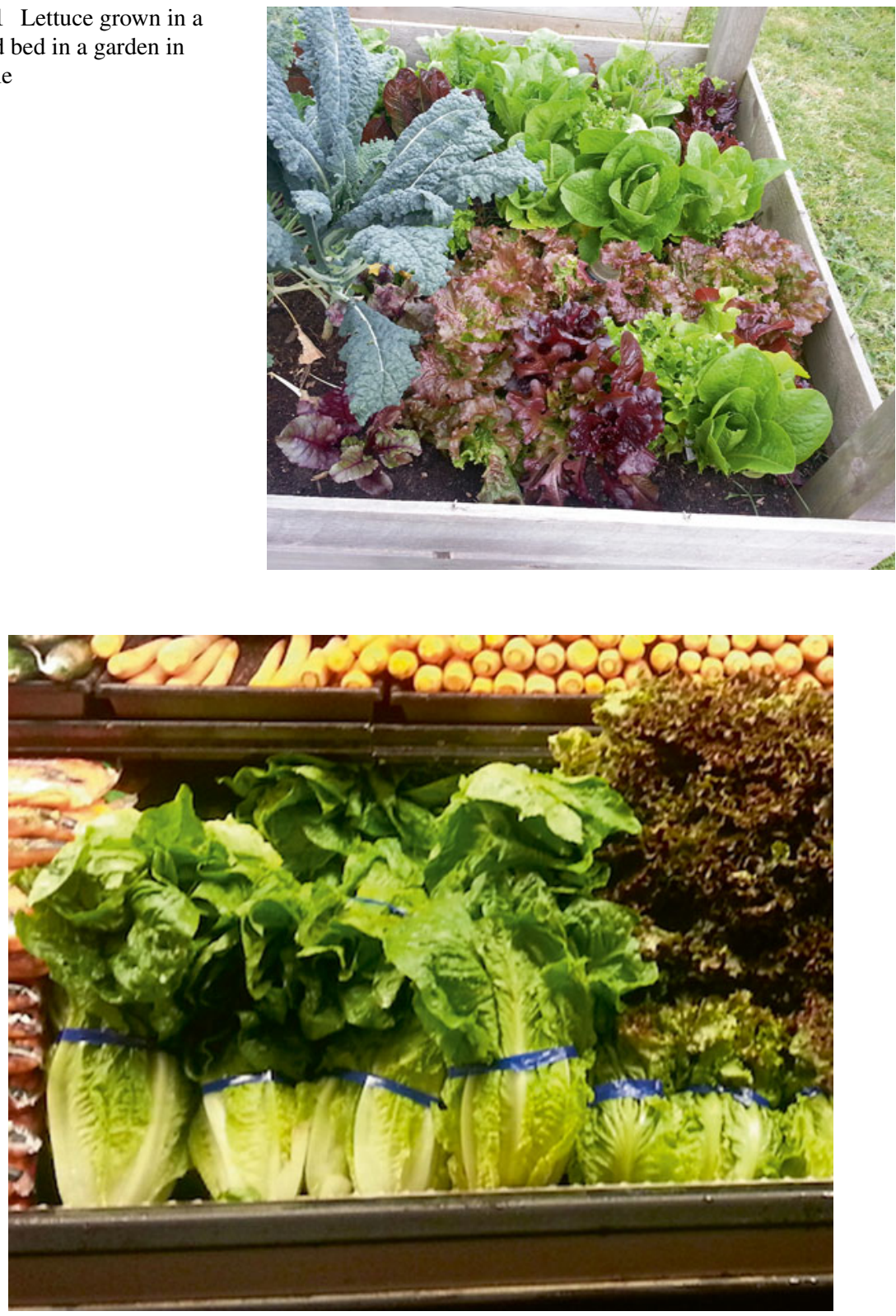

Fig. 2 Supermarket lettuce in Seattle

We have also assumed that the urban farm uses locally produced composts for soil conditioning and fertility. Irrigation for the urban farm is supplied in part by collected rainwater in recycled plastic rain barrels, with the remainder coming from the city water supply. We focus on a single lettuce crop planted in late spring and 
harvested mid-summer, assuming that the land (Californian and in Seattle) is put to other uses the rest of the year. More detailed data and assumptions are listed at the end of this report.

\section{Results}

Conventional Californian lettuce production emits about $0.7 \mathrm{~kg}$ of $\mathrm{CO}_{2}$-equivalent emissions (including other greenhouse gases like $\mathrm{N}_{2} \mathrm{O}$ and $\mathrm{CH}_{4}$ ) per $\mathrm{kg}$ lettuce. Most of this comes from irrigation and transportation. Fertilizer, farming operations, and retail contribute much smaller fractions of the total.

Our hypothetical community garden may actually reduce emissions, preventing $0.35 \mathrm{~kg} \mathrm{CO}$ e per kg lettuce. Since we assume that no one burns fuel to deliver lettuce from the urban farm, there are no transportation or retail emissions. Instead, the biggest factor is the use of compost instead of synthetic fertilizer - everything else is small potatoes in comparison (Fig. 3, Table 1).

\section{Transportation}

Transportation related emissions are generally perceived to be the largest source of emissions related to eating food grown in far away places. For this analysis, transportation is the biggest source of emissions for conventional lettuce trucked from California to Seattle. This was the case for both high and low efficiency distance transport. Low efficiency transport was modeled based on two sources

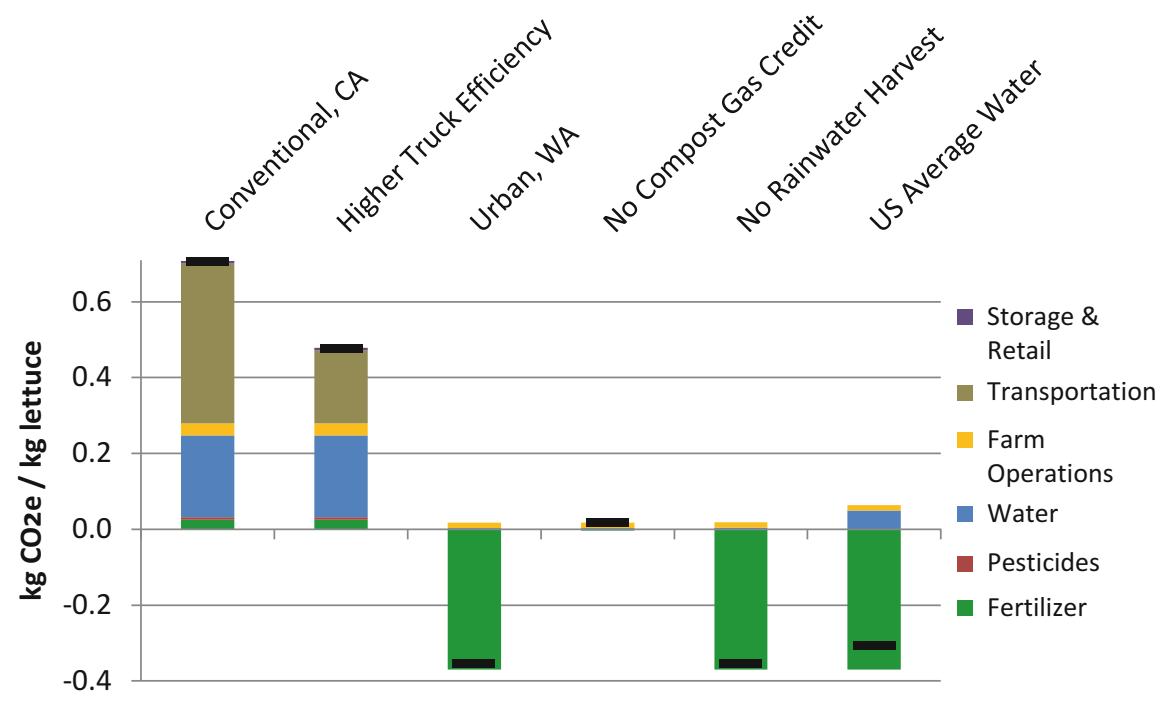

Fig. 3 Greenhouse gas emissions from each lettuce farming scenario 
Table 1 Greenhouse gas emissions from each major category of lettuce farming and supply in $\mathrm{kg}$ $\mathrm{CO}_{2}$ equivalent emissions per $\mathrm{kg}$ of lettuce $\left(\mathrm{kg} \mathrm{CO}_{2} \mathrm{e} / \mathrm{kg}\right.$ lettuce $)$

\begin{tabular}{l|l|l|l|l|l|l|l|l}
\hline & Fertilizer & Pesticides & Water & $\begin{array}{l}\text { Farm } \\
\text { operations }\end{array}$ & Transportation & $\begin{array}{l}\text { Storage } \\
\& \text { retail }\end{array}$ & Total \\
\hline \begin{tabular}{l} 
Conventional, CA \\
\hline Baseline
\end{tabular} & 0.025 & 0.007 & 0.215 & 0.032 & 0.421 & 0.007 & 0.707 \\
\hline $\begin{array}{l}\text { Higher truck } \\
\text { efficiency }\end{array}$ & 0.025 & 0.007 & 0.215 & 0.032 & 0.192 & 0.007 & 0.478 \\
\hline \begin{tabular}{l} 
Urban, WA \\
\hline Baseline
\end{tabular} & -0.370 & - & 0.004 & 0.014 & - & - & -0.352 \\
\hline $\begin{array}{l}\text { No compost } \\
\text { gas credit }\end{array}$ & -0.003 & - & 0.004 & 0.014 & - & - & 0.015 \\
\hline $\begin{array}{l}\text { No rainwater } \\
\text { harvest }\end{array}$ & -0.370 & - & 0.005 & 0.014 & - & - & -0.351 \\
\hline $\begin{array}{l}\text { US average } \\
\text { water }\end{array}$ & -0.370 & - & 0.049 & 0.014 & - & - & -0.307 \\
\hline
\end{tabular}

(Davis et al. 2007; Weber and Matthews 2008). Because transportation has such a dramatic impact on the results, we used another method to calculate truck fuel use. In the high efficiency scenario, a semi truck at $5.3 \mathrm{mpg}$ carrying a full load of lettuce from California to King County, WA would emit about half the greenhouse gases as we estimated below, $0.19 \mathrm{~kg}$ rather than $0.42 \mathrm{~kg} \mathrm{CO}_{2} \mathrm{e} / \mathrm{kg}$ lettuce (USDA).

This certainly is a major benefit of local community gardens. When people get their lettuce from their backyard instead of a supermarket that has in turn gotten it from a distant source, it is clear that fewer transport emissions are required to make a salad. This is also the case when people can walk, bus, or bicycle to pick up or deliver their produce from a farm literally down the street. Locally grown lettuce, because of reduced transportation emissions benefits from a carbon perspective. But this may be an extreme example. Other scientists have found that transportation is only a small part of all food-related emissions (Weber and Matthews 2008), and that driving even just $7 \mathrm{~km}$ (4.3 miles) to a farm or market to buy locally-grown vegetables can outweigh all of the greenhouse gas emissions of more efficient longdistance transportation of food (Coley et al. 2009). The impact of driving to a farm or market in comparison to long-distance haul will depend on how often car trips are taken and how many other tasks are combined with picking up the lettuce. For home grown or community garden plot lettuce, within walking or biking distance of the kitchens where the lettuce will be used, transportation is clearly a major opportunity for emissions reduction.

\section{Water}

For the boundaries we set for this LCA, energy associated with irrigation was a major source of GHG emissions, up to $0.22 \mathrm{~kg} \mathrm{CO}_{2} \mathrm{e} / \mathrm{kg}$ lettuce. This is due to multiple factors. Lettuce is grown using irrigation water rather than rainfall in California. 
Irrigation water has to be pumped from the ground to water a crop. The high $\mathrm{CO}_{2} \mathrm{e}$ for electricity needed for pumping water in California is largely responsible for the high emissions associated with providing water for the crop. In contrast, emissions for locally grown lettuce are much lower. This was the case for many reasons, including smaller water demand in the cooler climate, lower energy requirements and lower $\mathrm{CO}_{2} \mathrm{e}$ for energy in Seattle, and use of rainwater. The water supply for our urban farm emits only $0.004 \mathrm{~kg} \mathrm{CO}_{2} \mathrm{e} / \mathrm{kg}$ lettuce.

\section{No Rainwater Harvest Scenario}

What if the urban farm relies completely on the city's municipal water supply to irrigate the lettuce? As it turns out, it makes little difference. Water-related emissions increase $30 \%$, from 3.6 to $4.7 \mathrm{~g} \mathrm{CO}_{2} \mathrm{e} / \mathrm{kg}$ lettuce. This is primarily due to the low carbon footprint of electricity in the Pacific Northwest, which relies more on hydropower and less on coal than most of the U.S.

\section{US Average Water Scenario}

If we use the average carbon cost of municipal tap water in the U.S. (Ghimire et al. 2014), emissions jump $1270 \%$ to $0.049 \mathrm{~kg} \mathrm{CO}_{2} \mathrm{e} / \mathrm{kg}$ lettuce (Ghimire et al. 2014). This is still less than the $0.22 \mathrm{~kg} \mathrm{CO} \mathrm{CO}_{2} \mathrm{e} / \mathrm{kg}$ lettuce needed to irrigate the average Californian lettuce crop, mostly because the Californian fields simply require more water (24 versus 12 in. over the growing period of each crop) and because irrigation water must be brought further or pumped from deeper wells in California than in Western Washington (Burt et al. 2003; Hemphill 2010; Reed et al. 1986; Smith et al. 2011).

\section{Compost}

Conventional and compost fertilizers are backed by completely different industrial systems. Conventional fertilizers, from the stuff in bags at the local garden store to that applied to corn, soybean, and vegetable fields across the country, are the product of globe-spanning mining and chemical industries. Compost, like the municipal food waste compost we assume in this study, recycles nutrients that would otherwise be headed for an incinerator or a landfill. Nitrogen fertilizer is produced by converting nitrogen gas into ammonia. This is an energy intensive process that uses about $4 \mathrm{~kg} \mathrm{CO}$ for each $\mathrm{kg}$ of $\mathrm{N}$ converted to fertilizer. Other nutrients also require energy to convert into plant available form. For example, phosphorus fertilizer is produced from phosphate rock in an industrial process that requires about $2 \mathrm{~kg} \mathrm{CO}_{2}$ 
for each $\mathrm{kg} \mathrm{P}$. Emissions from $\mathrm{N}$ and P fertilizers totaled $0.025 \mathrm{~kg} \mathrm{CO}_{2} \mathrm{e} / \mathrm{kg}$ lettuce in the Californian scenario. In contrast, compost production is typically associated with carbon sequestration as a result of diverting the feedstocks for producing compost from garbage and turning them into soil amendments. Both municipal food waste and biosolids can be made into compost for growing lettuce. In both cases, the high nutrient feedstocks are typically combined with higher carbon materials such as yard waste to produce compost. Keeping food waste out of the landfill prevents methane production and gives a big greenhouse gas credit to the lettuce $(0.37 \mathrm{~kg}$ $\mathrm{CO}_{2} \mathrm{e} / \mathrm{kg}$ lettuce). Similar reductions in emissions are seen when biosolids are diverted from landfills or from incinerators. Supplying all of the necessary nutrients on the urban farm requires about $470 \mathrm{~kg}$ of compost - under $1 \mathrm{~m}^{3}$ or cubic yard - for an average urban lot.

\section{No Compost Gas Credit Scenario}

The biggest emissions factor on the urban farm is food waste compost. But what if the food waste hadn't been destined for a landfill? If we do not credit the lettuce with the methane reduction from the compost, the overall emissions from the urban farm become positive - just barely, $0.01 \mathrm{~kg} \mathrm{CO}_{2} / \mathrm{kg}$ lettuce. The biggest contributor to urban emissions is now the fuel used in supply trips $\left(0.014 \mathrm{~kg} \mathrm{CO}_{2} \mathrm{e} / \mathrm{kg}\right.$ lettuce $)$.

\section{Other Factors}

Pesticides and lettuce storage at retail stores contributed relatively little to Californian lettuce emissions. Although pesticides require large energy and have large carbon footprints (up to ten times fertilizer production energy), even conventional lettuce farms use them in small quantities. Total emissions from pesticides and other chemicals were about $1 / 4$ fertilizer emissions, $0.007 \mathrm{~kg} \mathrm{CO}_{2} \mathrm{e} / \mathrm{kg}$ lettuce. Storage at retail stores requires energy use to keep the lettuce cool and prevent it from drying out. The carbon footprint of that electricity is also fairly small, about $0.007 \mathrm{~kg} \mathrm{CO}_{2} \mathrm{e} / \mathrm{kg}$ lettuce. Because we assume the urban farm uses manual labor for weeding and pest control, and that harvested lettuce is refrigerated at home by consumers, these emissions are only added to the conventional Californian operation.

\section{Conclusions}

This case study highlights the potential benefits of a well-tended urban community garden. In addition to other benefits, closing the loop on nutrients and eliminating long-distance trucking can lead to big reductions in greenhouse gas emissions. 
The exact difference between conventional Californian produce and lettuce from a local garden will vary depending on many factors, including the season, truck fuel efficiency, local composting system, and whether community members drive to tend or harvest the urban farm. But if we take care to establish urban gardens with these factors in mind, we can make substantial differences in the environmental impacts of our food.

\section{Data \& Sources}

Greenhouse gas emissions from materials, energy, and fuel use throughout lettuce production and the supply chain were combined using a life cycle assessment methodology, based on a functional unit of one kilogram of lettuce delivered to a consumer.

Conventional Californian lettuce production is based on the average head lettuce yield in California of 41,600 kg/ha (2007-2013, USDA NASS Data) (USDA-NASS 2014). Fertilizer application rates used were $184 \mathrm{~kg} / \mathrm{ha}$ Nitrogen, $22 \mathrm{~kg} / \mathrm{ha}$ Phosphorous, and $62.1 \mathrm{~kg} / \mathrm{ha}$ Potassium (average of USDA NASS data from 2002 to 2010) (Geisseler and Horwath 2013; Smith et al. 2011; USDA-NASS 2014). The carbon footprint of fertilizer production and application was 4.0, 2.0, and $1.2 \mathrm{~kg}$ $\mathrm{CO}_{2} \mathrm{e} / \mathrm{kg} \mathrm{N}$, P, and K, respectively (Brown et al. 2010; Kool et al. 2012). Pesticide application rates were averaged from USDA-NASS survey data from 2000 to 2010 , while the greenhouse gas emissions from chemical application were taken from Audsley et al. (2009). We assume 37.3 L/ha gasoline and $345 \mathrm{~L} / \mathrm{ha}$ diesel use on the farm (Takele 2000), using greenhouse gas intensity of $94 \mathrm{gCO}_{2} \mathrm{e} / \mathrm{MJ}$ for gasoline and $81 \mathrm{gCO}_{2} \mathrm{e} / \mathrm{MJ}$ for diesel from the Greenhouse gas, Regulated Emissions, and Energy use in Transportation (GREET) model (Wang et al. 2012). Californian lettuce requires an average of 2 acre-feet (nearly 6.1 million liters per hectare) of irrigation (Smith et al. 2011), with a carbon footprint of $1.2 \mathrm{gCO}_{2} \mathrm{e} / \mathrm{L}$ (California Air Resources Board 2011; Smith et al. 2011). Transport and retail of conventional lettuce from California to King County, WA requires fuel use up to 2.7 MJ diesel per ton-km over $1662 \mathrm{~km}$ (Davis et al. 2007; Weber and Matthews 2008), and retail electricity use of $0.16 \mathrm{MJ} / \mathrm{kg}$ lettuce (Canals et al. 2008).

Urban lettuce production takes place in a hypothetical community garden in King County, Washington. The farm, on a typical $15 \times 30 \mathrm{~m}$ urban lot, has $60 \%$ of its area devoted to food production and $40 \%$ to access paths, tool storage, etc. Farm work is done by hand, with no herbicides or insecticides used. Fertilizer is supplied using food waste compost, assumed to be part of a large-scale collection and composting operation. Emissions $\left(0.26 \mathrm{~kg} \mathrm{CO}_{2} \mathrm{e} / \mathrm{kg}\right)$ and offsets $\left(0.28 \mathrm{~kg} \mathrm{CO}_{2} \mathrm{e} / \mathrm{kg}\right)$ from compost production and application (California Air Resources Board 2011) were combined with a credit for avoided methane production from landfilled food waste (1.4 kg CO $2 \mathrm{e} / \mathrm{kg}$ ) (US EPA 2009). Compost delivery by truck adds only slightly to emissions $\left(0.0013 \mathrm{~kg} \mathrm{CO}_{2} \mathrm{e} / \mathrm{kg}\right.$ compost). Half of irrigation needs $(30.5 \mathrm{~cm}$, or 12 in.) is supplied by rainfall collected in plastic rain barrels (Hemphill 2010). 
Barrels made from recycled plastic are assumed to reach $80 \%$ of full ten times during the growing season (Keoleian et al. 2011; Plastics Recycling 2014). A total of 27,200 L barrels each containing $10 \mathrm{~kg}$ plastic would be needed to supply half of water needs. We assume $10 \mathrm{~kg}$ of plastic hose and other tools at the farm as well. We also assigned an emissions credit to collected rainwater based on avoided municipal water treatment (Brown et al. 2010). The remaining half of irrigation comes from the municipal water supply (US Energy Information Administration 2013; Pabi et al. 2013). Lettuce harvest and distribution from the urban farm are done by hand, without additional fuel or electricity use.

Food waste factors were used to generate parameters for each stage of urban and conventional lettuce production (Gustavsson et al. 2011). Multiplying the greenhouse gas emissions at each stage by these parameters brings all of the data in line with the functional unit of $1 \mathrm{~kg}$ lettuce in the hands of a consumer.

\section{References}

Audsley E et al (2009) Estimation of the greenhouse gas emissions from agricultural pesticide manufacture and use. Cranfield University, Cranfield/Bedford, p 24

Brown S, Beecher N, Carpenter A (2010) Calculator tool for determining greenhouse gas emissions for biosolids processing and end use. Environ Sci Technol 44(24):9509-9515

Burt C, Howes D, Wilson G (2003) California agricultural water electrical energy requirements. In: Public interest energy research program. Irrigation Training and Research Center, San Luis Obispo, pp 1-47

Canals LMI et al (2008) Life cycle assessment (LCA) of domestic vs. imported vegetables. In: Case studies on broccoli, salad crops and green beans. Centre for Environmental Strategy, Guildford, $\mathrm{p} 46$

CARB (2011) Method for estimating greenhouse gas emission reductions from compost from commercial organic waste. California Air Resources Board, Sacramento, CA, p 24

Coley D, Howard M, Winter M (2009) Local food, food miles and carbon emissions: a comparison of farm shop and mass distribution approaches. Food Policy 34(2):150-155

Davis S, Diegel S, Boundy R (2007) Transportation energy data book: Edition 26. Oak Ridge National Laboratory. ORNL, Oak Ridge, TN, 6978

Geisseler D, Horwath WR (2013) Lettuce production in California. Fertilizer Research and Education Program, p 4

Ghimire SR et al (2014) Life cycle assessment of domestic and agricultural rainwater harvesting systems. Environ Sci Technol 48(7):4069-4077

Gustavsson J et al (2011) Global food losses and food waste: extent, causes and prevention. Food and Agriculture Organization of the United Nations, Rome

Hemphill D (2010) Lettuce. Oregon vegetables 2010. February 11, 2010 [cited 2014 June 18, 2014]. Available from: http://horticulture.oregonstate.edu/content/lettuce-0

Keoleian $\mathrm{G}$ et al (2011) Life cycle material data update for the GREET model. Argonne National Laboratory, Darien

Kool A, Marinussen M, Blonk H (2012) LCI data for the calculation tool feedprint for greenhouse gas emissions of feed production and utilization: GHG emissions of $\mathrm{N}$, P, and $\mathrm{K}$ fertilizer production. Blonk Consultants, Gouda, p 15

Pabi S et al (2013) Electricity use and management in the municipal water supply and wastewater industries. Electric Power Research Institute, Palo Alto, p 194

Plastics E (2014) Plastics Recycling FAQ. [cited 2014 May 16, 2014]. Available from: http:// envisionplastics.com/faqs/ 
Reed W, Geng S, Hills FJ (1986) Energy input and output analysis of four field crops in California. J Agron Crop Sci 157(2):99-104

Smith R et al (2011) Leaf lettuce production in California. In: Mitchell J (ed) Vegetable produciton series. University of California Vegetable Research and Information Center, Richmond, p 6

Takele E (2000) Loose-leaf lettuce production: sample costs and profitability analysis. University of California Division of Agriculture and Natural Resources, Oakland, p 19

US EIA (2013) State-level energy-related carbon dioxide emissions, 2000-2010. U.S. Energy Information Administration, Washington, DC, p 16

US EPA (2009) Opportunities to reduce greenhouse gas emissions through materials and land management practices. United States Environmental Protection Agency, Washington, DC, p 28

USDA, Truck transportation, USDA. pp 403-438

USDA-NASS (2014) Head Lettuce, Yield, CA. National Agricultural Statistics Service. [cited 2014 April 20, 2014]

Wang $\mathrm{M}$ et al (2012) Well-to-wheels energy use and greenhouse gas emissions of ethanol from corn, sugarcane, and cellulosic biomass for US use. Environ Res Lett 7(4):045905

Weber CL, Matthews HS (2008) Food-miles and the relative climate impacts of food choices in the United States. Environ Sci Technol 42(10):3508-3513 


$$
\begin{array}{r}
\text { Part IV } \\
\text { Ecosystem Services - Habitat }
\end{array}
$$




\title{
Basics of Microbial Ecology and Function in Urban Agriculture
}

\author{
Karl A. Wyant
}

\section{Chapter Objectives}

In this chapter, we will explore the following topics:

- Soil as a complex multiphasic habitat for growing crops

- The form and function of soils microbes

- The connection between soil microbes, soil fertility, and plant health

\section{Introduction to Urban Soils - The Physical Setting}

Imagine a type of environment on Earth characterized by immense empty spans, rivers and oceans that drain and fill daily, and massive boulder-sized solids perched precariously against one another. Now imagine a suite of organisms, interacting in complete darkness, going about their lives in the environment described above. Does the image of an eight-legged animal quietly stalking its prey come to mind or a population density of organisms that reaches over a million in one single spoonful?

Are you intrigued? You might be wondering where this strange place is and how you might be able to visit. Good news! This world exists right below your feet. Soil is a highly complex habitat, filled with all the biological drama of your favorite soap opera, but it largely goes ignored due to the small size of the organisms and soil particles. Learning about the organisms in the soil is crucial to a gardener's success and in this chapter we will explore the role of soil microbes in the urban garden.

K.A. Wyant $(\square)$

School of Life Sciences, Arizona State University, Tempe, AZ 85287, USA

e-mail: kawyant@asu.edu 


\section{Physical Properties of Soil}

Soil is unique in the fact that it exists as three different material states, all at once. The term we use to describe this property is multiphasic (Brady and Weil 1999). Soils are roughly characterized as $50 \%$ soil material (e.g., rock minerals and organic matter), $25 \%$ gaseous voids or pores, and $25 \%$ water. Of course, these percentages change from soil to soil, as some are much drier or wetter than others. The almost infinite combination of these percentages allows for a surprising number of unique habitats for belowground microbes and animals. Furthermore, these habitats are home to two very important resources for the soil microbes in your garden: organic matter and soil moisture.

\section{Organic Matter}

Organic matter initially enters the soil system as detritus. Detritus refers to any former biologically active organic material that is now non-living (Moore et al. 2004). Examples of detritus include fallen leaves, carcasses, and compounds that leak from plant roots. Roughly $90 \%$ of the biological materials produced by a plant become detritus at some point in time (Lavelle 2012). Soil organic matter is the energy source and nutrient source, or food, for soil microbes. In short, the leaves that fall on to your lawn in autumn "fuel" microbial activity. Too little food and your microbes will starve (Fig. 1).

Complex biological materials are decomposed by soil microbes and animals, broken down into simpler structures, and remain in the soil as a complex mixture of carbon-rich compounds referred to generally as organic matter. Organic matter can range from $<1 \%$ in desert soils to $>25 \%$ in tundra and bog soils. Organic matter has properties that warrant the attention of any serious urban gardener. For example, organic matter can greatly increase the water holding capacity of a soil, via charge interactions between water molecules and the surfaces of organic matter particles.

Soil organic matter is also a critical factor for soil nutrients, or elements that are crucial to plant growth, production, and survival (Table 1). Soil organic matter is explicitly connected with the supply of the mineral nutrients, which come from the soil and are absorbed by the plant roots. The most important of these types are referred to as macronutrients and include nitrogen $(\mathbf{N})$, phosphorus $(\mathbf{P})$, and potassium (K). Macronutrients are contained in detritus and are released when dead plant and animal materials are decomposed in the soil environment. Soil organic matter, thus, can serve as a source (when decomposed) of nutrients and a sink (nutrient storage) where $\mathrm{N}, \mathrm{P}$, or $\mathrm{K}$ remain bound to carbon chains and unavailable for plant uptake. The non-mineral nutrients: carbon, oxygen, and water, are derived from the atmosphere or soil and are critical for plant photosynthesis. 
Too little organic matter will starve your microbes!

Signs to look for:

- Soil feels sandy or clay-like

-Soil dries quickly

High Plants are not performing as expected
Too much organic matter?

\section{Signs to look for:}

- Adding too much organic matter will not hurt your microbes but they may become nutrient limited. Make sure that airflow is not compromised.
Solution:

Lightly mix well-aged manures (e.g., cattle and chicken) or compost into soils

(

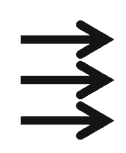

\section{Solution:}

Just wait until next gardening season to add more organic matter

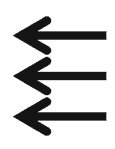

Low

Low

Soil Organic Matter

High

Fig. 1 The relationship between soil organic matter and microbial health. The arrows represent directions that soil organic matter content can be "pushed" for optimized soil microbial activity

Table 1 Essential mineral and non-mineral nutrients and their use in plants

\begin{tabular}{l|l|l|l}
\hline Nutrient name & $\begin{array}{l}\text { Chemical } \\
\text { symbol }\end{array}$ & Plant use & Typical sources \\
\hline $\begin{array}{l}\text { Nitrogen } \\
\text { (mineral) }\end{array}$ & $\mathrm{N}$ & $\begin{array}{l}\text { Needed by all plants for } \\
\text { structural, genetic, and metabolic } \\
\text { compounds in plant cells }\end{array}$ & $\begin{array}{l}\text { Pellet and liquid fertilizers - } \\
\text { both organic and inorganic } \\
\text { formulations; naturally found } \\
\text { in soil and released by } \\
\text { microbes, found in manures } \\
\text { and plant composts }\end{array}$ \\
\hline $\begin{array}{l}\text { Phosphorus } \\
\text { (mineral) }\end{array}$ & $\mathrm{P}$ & $\begin{array}{l}\text { Important for the construction of } \\
\text { genetic materials, energy storage, } \\
\text { and protein synthesis }\end{array}$ & $\begin{array}{l}\text { Important for protein synthesis } \\
\text { and photosynthesis }\end{array}$ \\
\hline $\begin{array}{l}\text { Potassium } \\
\text { (mineral) }\end{array}$ & $\mathrm{K}$ & $\begin{array}{l}\text { Allows for uptake of nutrients in } \\
\text { soil, serves as electron source for } \\
\text { photosynthesis }\end{array}$ & $\begin{array}{l}\text { Found in soil; falls as } \\
\text { precipitation, comes out of } \\
\text { your hose }\end{array}$ \\
\hline $\begin{array}{l}\text { Water } \\
\text { (non-mineral) }\end{array}$ & $\mathrm{H}_{2} \mathrm{O}$ & Energy source for photosynthesis & The Sun! \\
\hline $\begin{array}{l}\text { Sunlight } \\
\text { (non-mineral) }\end{array}$ & - & $\begin{array}{l}\text { Source of carbon to build organic } \\
\text { molecules }\end{array}$ & Atmosphere \\
\hline $\begin{array}{l}\text { Carbon dioxide } \\
\text { (non-mineral) }\end{array}$ & $\mathrm{CO}_{2}$ & &
\end{tabular}




\section{Soil Moisture}

As we reviewed earlier, soils is roughly $25 \%$ water, give or take a bit depending on climate and landscape position of your soil sample. Water is critical to all life on earth, including the microbes that inhabit your vegetable patch. Water provides a habitat to live in, a "lab bench" on which to perform chemical reactions, and a solution that can move nutrients towards plant roots. While many gardeners intuitively understand that their vegetation need water; they have often not thought of how their watering practices affect the microbes associated with their favorite plants. Water, shown here as soil moisture, has a convex relationship with microbial activity (Fig. 2).

Too little water and your microbes cannot function properly because they are dried out. Too much water and you are essentially drowning them. These same effects can be observed with plant roots. Many gardeners are guilty of overwatering or, in some case, of ignoring their plots for too long between watering intervals. Many troublesome plant problems are associated with the dry soil/wet soil interval flip-flop, including blossom end rot. Blossom end rot is familiar to gardeners who
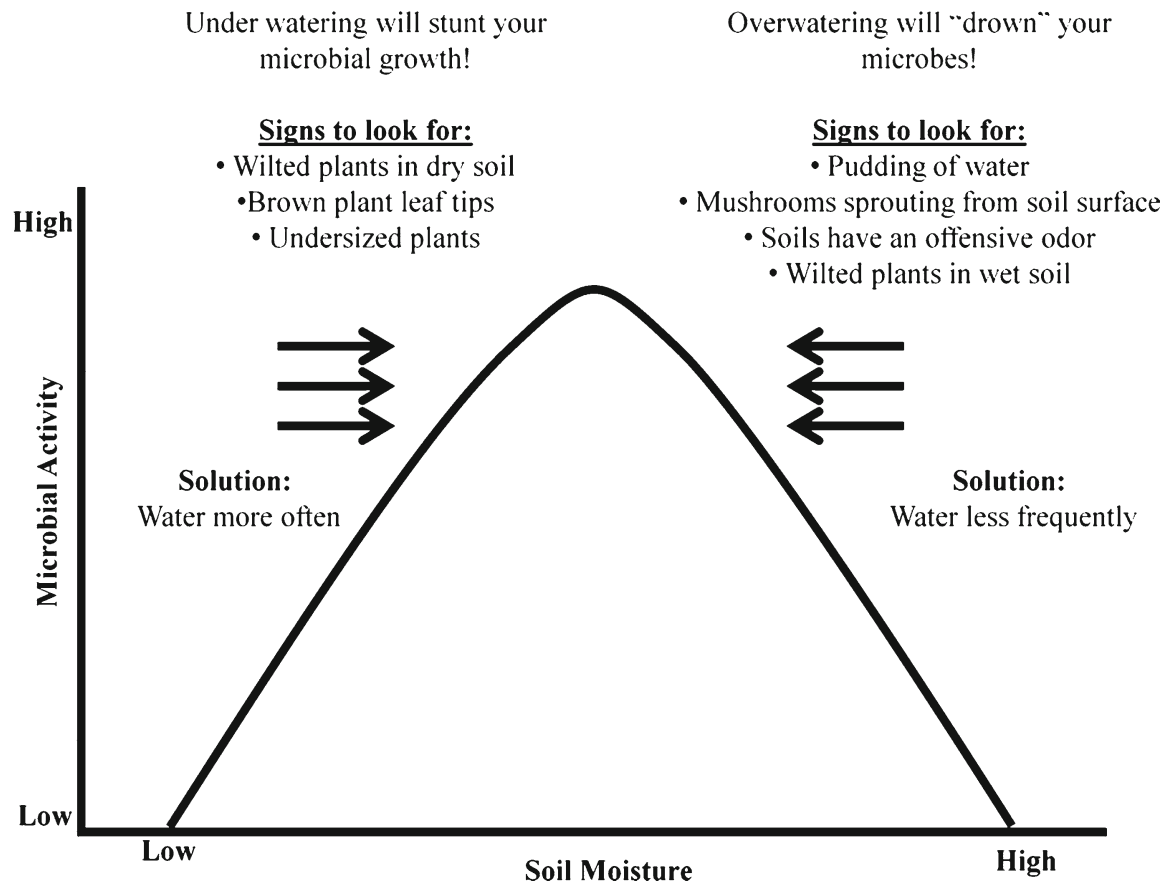

Fig. 2 The relationship between soil moisture and microbial health. The arrows represent directions that soil moisture content can be "pushed" for optimized soil microbial activity 


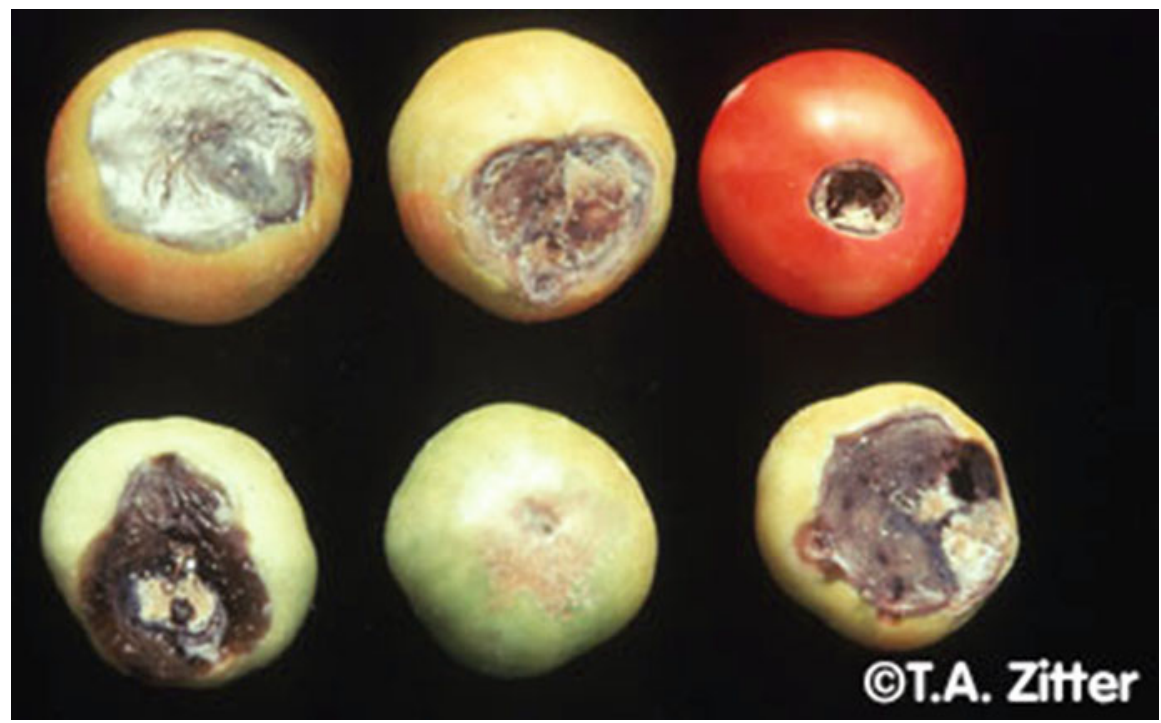

Fig. 3 Blossom end rot symptoms on a tomato plant (Photo courtesy of T.A. Zitter, Cornell University, Ithaca, NY)

have grown tomatoes (Fig. 3) in soils with low calcium supply and irrigation issues. Symptoms include dark spots on the end of the fruit before they are fully ripe.

The key to a successful microbial community and garden is to water at regular intervals suitable to your climate and to the right depth. You can check soil moisture levels by feeling the soil by hand. Furthermore, you can check for moisture at depth by using a long, flat head screwdriver. Dry soils will resist penetration by the screwdriver and this will help you determine if your watering efforts are acutally travelling below the soil surface and into the rooting zone. Proper oversight of both organic matter and moisture will promote a healthy microbe population. With that being said, we now turn our attention to the "middle men" that link detritus and the supply of nutrients that your plants need to grow.

\section{Soil Microbes - The Unseen Heroes of Your Garden!}

When one hears them term soil microbes, you should know that we are talking about three separate and very different groups of organisms (Fig. 4). The commonalty between all three is the habitat they share (soil) and their important role in your garden (decomposition and plant nutrient supply). 
Fig. 4 Soil microbes are a diverse group. Here bacteria dot the surface of strands of fungal hyphae (Photo Courtesy:

R. Campbell. In

R. Campbell. 1985. Plant Microbiology. Edward Arnold; London. P. 149. Reprinted with the permission of Cambridge University Press)
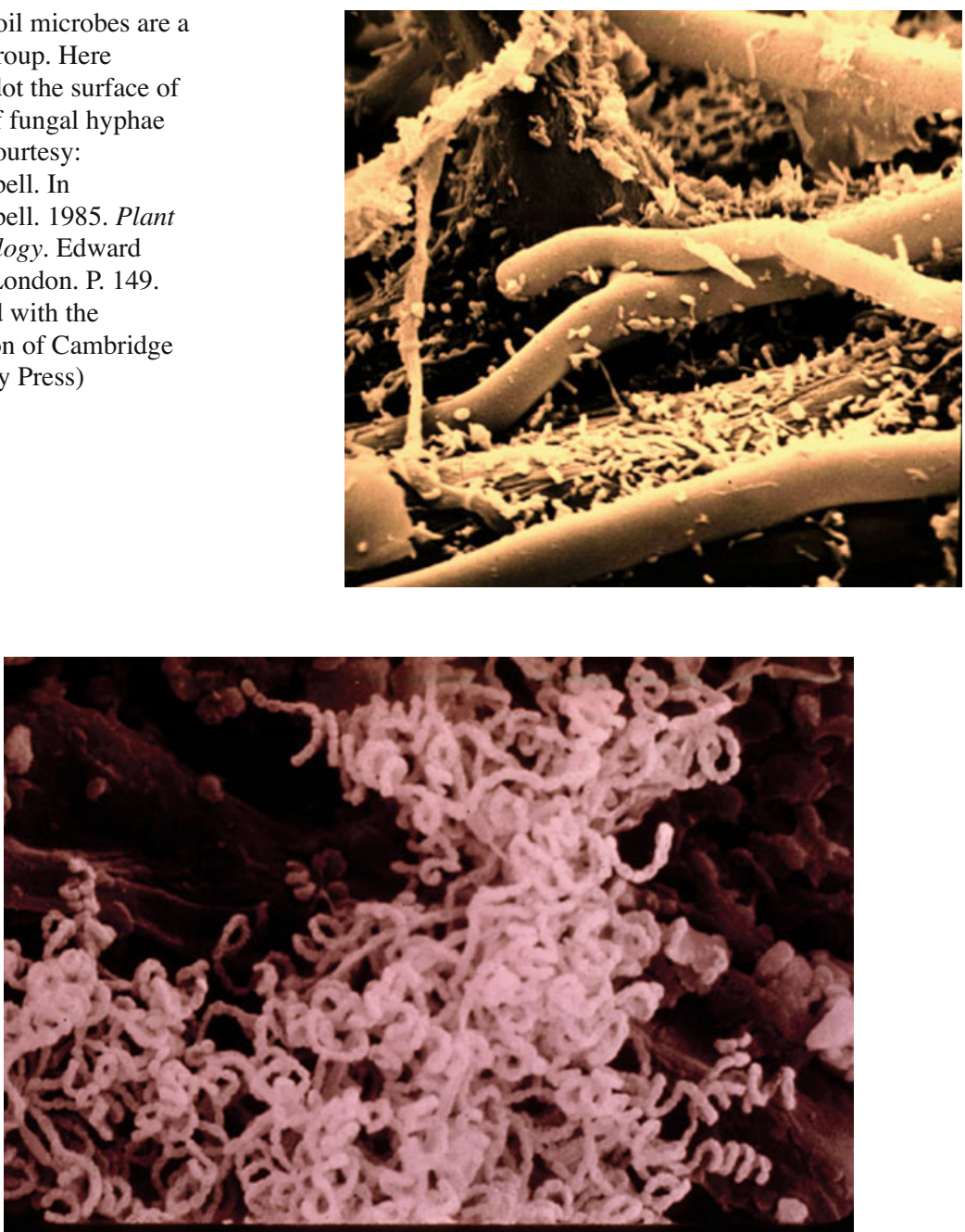

Fig. 5 Actinomycetes give soil its pleasant "earthy" smell (Photo Courtesy: No. 14 from Soil Microbiology and Biochemistry Slide Set. 1976. J.P. Martin, et al., eds. SSSA, Madison, WI)

\section{Bacteria}

The Bacteria, are organisms that do not have a nucleus (membrane-bound "library" for genetic material), nor do they have large organelles (specialized cellular machinery), (Fig. 5). Despite this seemingly simple structure, bacteria are incredibly diverse in terms of their roles they play in an ecosystem.

They are also incredible abundant in soil. To illustrate how many bacteria you can find in an area, consider a teaspoon used for baking. If you were to fill this tea- 


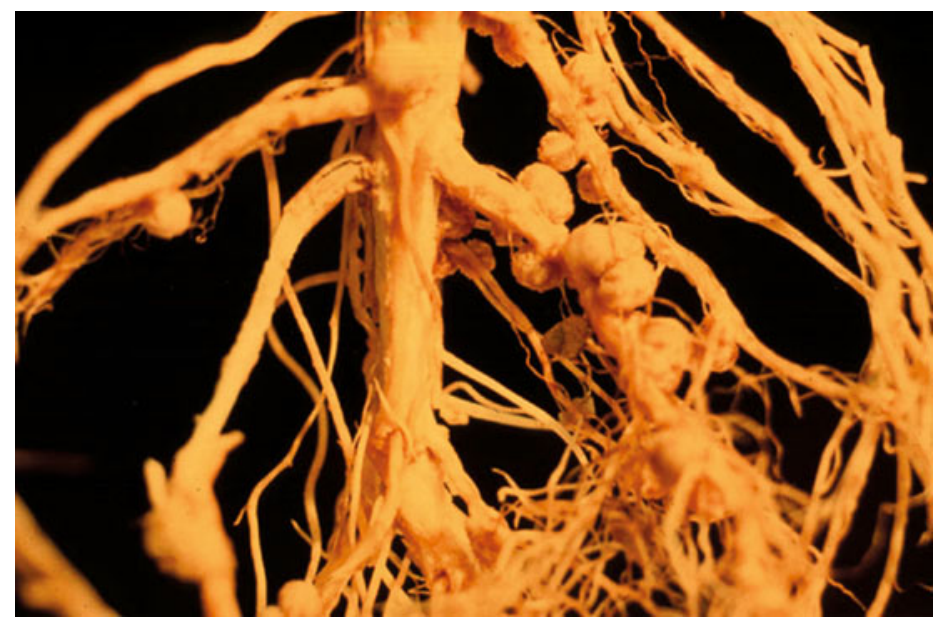

Fig. 6 Nodules formed where Rhizobium bacteria infected soybean roots. The bacteria can now turn gaseous nitrogen into something biologically useful (Photo Courtesy: Stephen Temple, New Mexico State University)

spoon with soil, it would hold between 100 million and 1 billion soil bacteria (Tugel et al. 2000). If you were to weigh all the soil bacteria beneath your feet, there would be enough mass to equal about two cows per acre. However, despite their abundance, you will not be able to see the soil bacteria, as they are very small $(1 \mu \mathrm{m})$.

I mentioned the numerical abundance of soil bacteria and, as you might have guessed, this group plays many different roles in the soil environment. For simplicity, we will only discuss the three major roles relative to urban gardening. The decomposer group are critical for turning previously living stuff (e.g., old seed husks, corn tassels, watermelon rinds, etc.) back into their simpler forms. Decomposer bacteria use the energy stored in complex substances by breaking the chemical bonds that hold the molecule together. Essential nutrients, such as nitrogen and phosphorus, are also "liberated" this way and reincorporated into the living biological structures inhabiting the soil matrix, including plant roots.

The mutualism group are perhaps the most famous bacteria in the gardening world. The members of this group are why we plant beans, cowpeas, soybeans, etc. in our garden, especially after growing things like squashes and zucchini. We are essentially repaying a "debt" by following this strategy. The squash, like many plants, use nutrients found in soil, particularly nitrogen, to create biomass and, hopefully, a nice delicious fruit for your table. However, we are now facing a state of localized $\mathrm{N}$ depletion. By exploiting the relationship between bacteria, particularly the genera Rhizobia, and plants, we can repay our $\mathrm{N}$ debt. Rhizobia have the unique ability to turn $\mathrm{N}$ gas $\left(\mathrm{N}_{2}\right)$ into a more biologically useful form called ammonia $\left(\mathrm{NH}_{3}\right)$, thus adding $\mathrm{N}$ back to the soil (Fig. 6). 
Fig. 7 Bacterial leaf spot on cauliflower is caused by a pathogen that can be transmitted to crops by the splashing of water on the soil surface (Photo Courtesy: T.A. Zitter, Cornell University, Ithaca, NY)

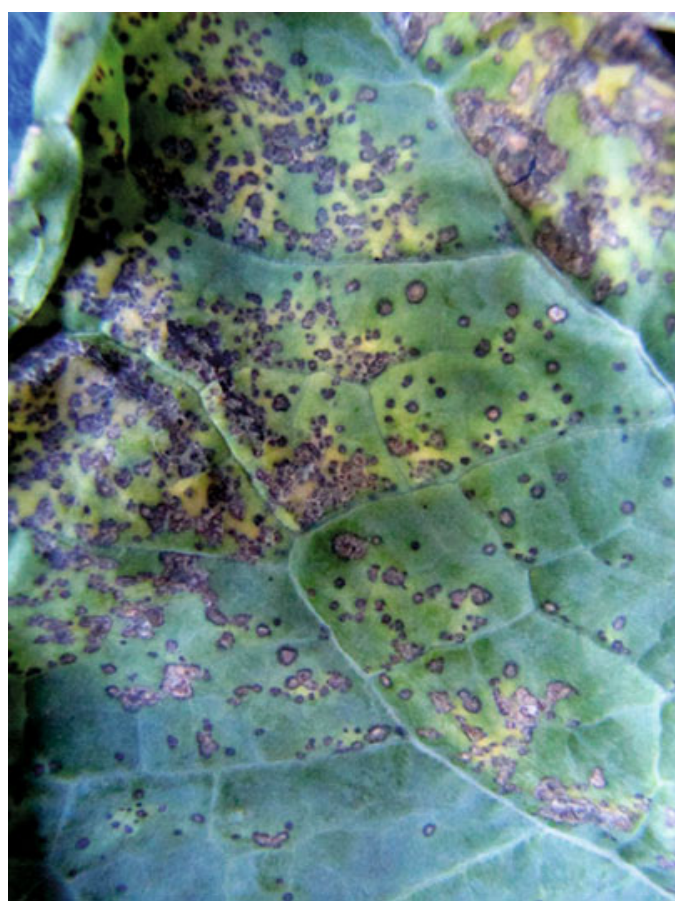

However, this process must occur and can only occur in the roots of a plant capable of supporting this relationship (e.g., plants in the bean family) and thus most garden stalwarts cannot support populations of Rhizobia, such as tomatoes and squash, are not able to replenish your soil of lost $\mathrm{N}$.

The last group of important soil bacteria are the pathogens. These are the more nefarious members of the bacteria group that a gardener can come across. Bacteria pathogens can cause diseases in your favorite vegetables such as bacteria blight, soft rot, ring rot, spot, and wilt (Fig. 7).

One wishes that controlling the spread of pathogens were as simple as weeding, but you can try to prevent conditions that promote bacterial growth. If one avoids overly damp soil conditions, uses clean equipment, and stays away from dense plantings, the transfer of harmful bacteria, between plants, can be reduced substantially. Another approach to controlling soil borne pathogens is to promote a healthy microbial population. Scientists have recently discovered that a diverse community of soil microbes can actively suppress plant pathogens and improve plant yields. For example, researchers found that sugar beet fields exhibiting active suppression of a deadly root pathogen also had the largest abundance of 17 unique types of pathogen fighting bacteria when compared to control plots (Mendes et al. 2011). 


\section{Archaea}

The Archaea resemble the bacteria in terms of appearance and size but also share some commonalties with the more familiar Eukaryotic relatives (e.g., plants, animals, fungi, and protists) at the molecular level. However, this group is poorly known as a whole, relative to the bacteria and fungi, and their role in urban agriculture is not well understood. Recent evidence suggests that the Archaea play a large role in biogeochemical cycles, especially in dry, arid regions, and can decompose a variety of different chemicals, including oils, acidic mine tailings, and sulfur containing compounds (Offre et al. 2013). Work has also shown that Archaea play a role in the nitrogen cycle- converting ammonia into nitrate, the preferred version of this nutrient for plants. Stayed tuned for future news about how this group might connect to your gardening efforts.

\section{Fungi}

The Fungi are the last of the soil microbes that we will consider and are of interest to many gardeners (Fig. 8). Fungi belong to the group of organisms that have a nucleus and membrane bound organelles called the Eukaryotes.

Plant, animals, and protists are also in this large group. Relative to Bacteria and Archaea, the Eukaryotes are much larger and a single cell can be seen easily by the naked eye. Most gardeners have experienced the fungi in one of two ways: the

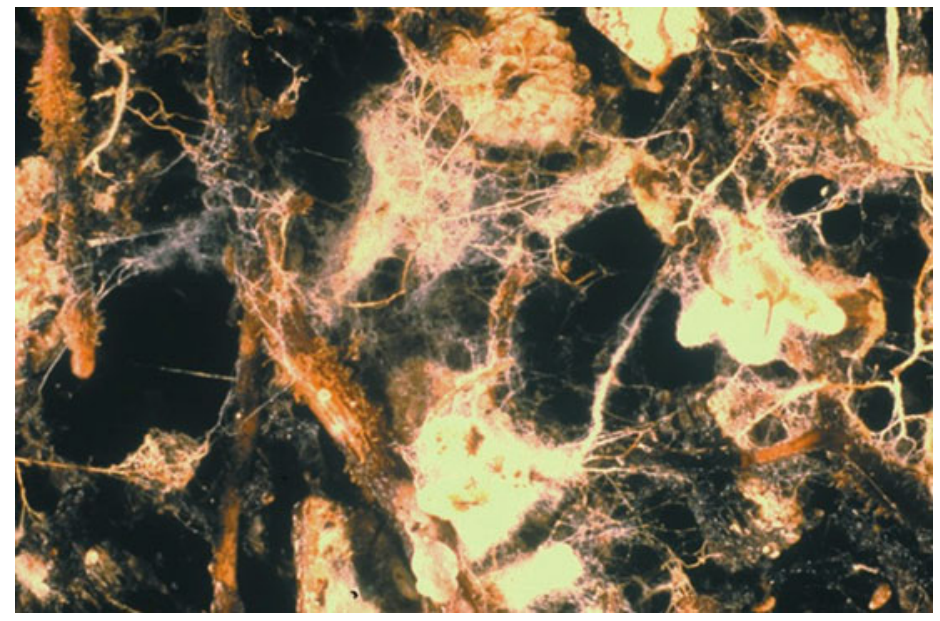

Fig. 8 Many plants depend on fungi to help extract nutrients from the soil. Roots are connected to the fungal hyphae (thin white strands) extending outward into the soil (Photo Courtesy: Randy Molina, Oregon State University, Corvallis) 
aboveground reproductive structure that we refer to colloquially as the mushroom and the white, web-like netting found in moist garden soil and often under potted flowers. The two structures previously mentioned are not separate entities but rather a continuous extension of a unique network of tissues called the hyphae. Hyphae is characterized as a multicellular, thread-like filament that is strong, yet flexible. The cells that make up the hyphae are interlinked with pores and these openings allow for a variety of cellular materials to move unhindered between cells and even across long distances. A network of multiple hyphae is called the mycelium. The mycelium usually escapes our eye because much of it lies underground, intermingling and networking extensively throughout the soil profile, binding particles together and limiting soil erosion. Amazingly, scientists have found a single fungal mycelium network that covers roughly $\sim 3.5$ miles in diameter and weighs into the hundreds of tons!

If one were to measure the distance of a mycelium network in a bucketful of soil, you would tally roughly a kilometer of individual threads (hyphae) at the end of your arduous experiment. Interestingly, when it comes time for reproduction, some fungi push their mycelium upward through the soil and forms the familiar sight of a mushroom (Fig. 9).
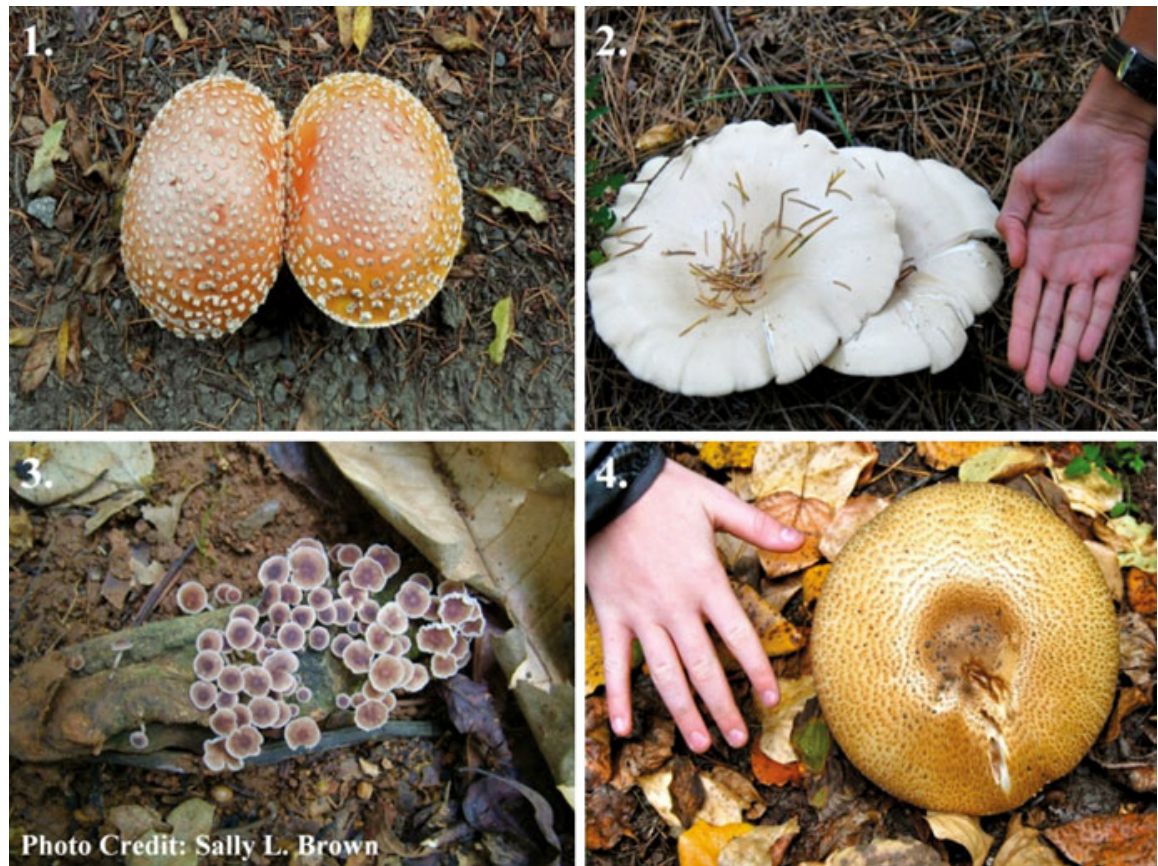

Fig. 9 Various types of mushrooms that you might encounter. Most garden soil mushrooms resemble those pictures in image three and are an indicator of chronic overwatering (Photo Courtesy: Sally J. Brown, University of Washington, Seattle, WA) 


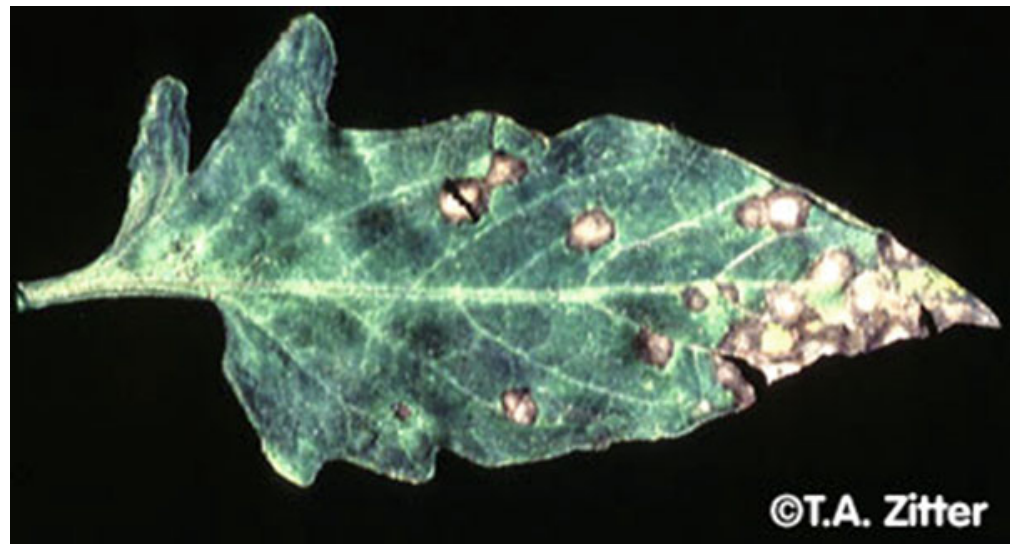

Fig. 10 Septoria Leaf Spot symptoms on a tomato plant (Photo Courtesy: T.A. Zitter, Cornell University, Ithaca, NY)

The mushroom's sole job is to release fungal spores on air currents and spread the fungi elsewhere. That's right, when you eat mushrooms, you are eating reproductive parts. Think about that next time you have them on your pizza.

Fungi, similarly to the bacteria involved in decomposition, degrade a variety of non-living biological compounds and gain both energy and nutrients from this process. An interesting and intriguing aside about fungi is the way they go about decomposing these biological compounds. Fungi acquire their energy and nutrients via adsorption. In this process, fungi release digestive chemicals into the surrounding soil matrix and the fungi then absorbs the simpler organic materials into the hyphal tissue.

Not all fungi are a friend to the gardener and they can take considerable toll on your crop yields. For example, another scourge of the garden superstars - the tomatoes, include early blight and Septoria leaf spot (Fig. 10).

These diseases can appear any time during the growing season but often show up after the flowers appear (Kennelly 2009). For Septoria leaf spot, symptoms include dark lesions and reproductive structures on the lower leaves, working their way upward as the plant grows. Early blight can be recognized by light brown, irregularly shaped lesions that can be up to $1 / 2$ in. wide and are marked by concentric rings. If you are constantly plagued by sick plants, you might have a fungus problem (Table 2).

Instead of reaching for a fungicide, double-check your watering habits. Most pathogenic fungi can be controlled by following the old gardening axiom, "Water the soil, not the foliage". Keeping the leaves dry will keep most fungal spores from growing on the plant where they can cause extensive damage. Furthermore, staking sprawling plants, such as indeterminate growing tomatoes, will increase airflow around the plant and will help keep fungal pests at bay (Fig. 11). 
Table 2 A list of plant diseases caused by soil-borne fungi

\begin{tabular}{l|l|l|l}
\hline Disease type & $\begin{array}{l}\text { Plant structures } \\
\text { targeted }\end{array}$ & Symptoms & Solutions \\
\hline $\begin{array}{l}\text { Mildews - Leaves } \\
\text { and stems }\end{array}$ & $\begin{array}{l}\text { Leaves and stems } \\
\text { of roses and spinach } \\
\text { relatives }\end{array}$ & $\begin{array}{l}\text { Powdery (usually) } \\
\text { white substance on } \\
\text { leaves and stems }\end{array}$ & $\begin{array}{l}\text { Keep plants well watered } \\
\text { and avoid wetting leaves } \\
\text { and stems. Avoid watering } \\
\text { in damp, cold conditions. } \\
\text { Increase airflow around } \\
\text { plants }\end{array}$ \\
\hline $\begin{array}{l}\text { Rusts/Smuts - } \\
\text { Leaves and stems }\end{array}$ & $\begin{array}{l}\text { Many ornamental } \\
\text { plants - usually } \\
\text { appear on the leaves }\end{array}$ & $\begin{array}{l}\text { Round, blister-like } \\
\text { blotches of a variety } \\
\text { of colors }\end{array}$ & $\begin{array}{l}\text { Remove infected plant and } \\
\text { avoid area for season. } \\
\text { Varieties of chemical } \\
\text { treatments are available } \\
\text { including Bordeaux mixture }\end{array}$ \\
\hline $\begin{array}{l}\text { Rots - Leaves } \\
\text { and stems }\end{array}$ & $\begin{array}{l}\text { Leaves, stems, and } \\
\text { flowers die off. } \\
\text { Eventual death of } \\
\text { entire plant }\end{array}$ & $\begin{array}{l}\text { Unexpected } \\
\text { withering and death } \\
\text { of plant structures }\end{array}$ & $\begin{array}{l}\text { Only plant healthy looking } \\
\text { vegetables. If in doubt, } \\
\text { throw it out! Discard } \\
\text { infected plants immediately. } \\
\text { Avoid overwatering and } \\
\text { increase airflow in garden. } \\
\text { Chemical treatments are } \\
\text { available }\end{array}$ \\
\hline $\begin{array}{l}\text { Rots/Moulds - } \\
\text { Flowers } \\
\text { and fruits }\end{array}$ & $\begin{array}{l}\text { Soft tissues in fruits } \\
\text { and flowers }\end{array}$ & $\begin{array}{l}\text { Grey-white furry } \\
\text { mold }\end{array}$ & $\begin{array}{l}\text { Treat with fungicide and } \\
\text { avoid overly damp } \\
\text { conditions. Removed } \\
\text { infected plant material as } \\
\text { soon as possible }\end{array}$ \\
\hline Rots - Roots & $\begin{array}{l}\text { Root structures } \\
\text { abe affected first. } \\
\text { structures are } \\
\text { affected second }\end{array}$ & $\begin{array}{l}\text { Change in color of } \\
\text { vegetative structures, } \\
\text { sparse foliage, } \\
\text { premature death } \\
\text { of plant }\end{array}$ & $\begin{array}{l}\text { Remove infected plants. } \\
\text { Avoid planting in area } \\
\text { for a few months. Improve } \\
\text { drainage of soil in garden }\end{array}$ \\
\hline
\end{tabular}

\section{Soil Microbes, Nutrients, and Plant Health}

\section{The Connection Between Organic Matter and Soil Microbes}

We have now established the physical habitat and the main agents of decomposition and nutrient cycling (soil microbes). In this section, we will discuss the connection between soil and the microbes that inhabit it and also broader issues of nutrient availability and how plant health is affected. Decomposition and nutrient liberation is an ecosystem service that microbes perform free of charge. However, you must keep the microbes happy, via organic matter and moisture inputs, so they decompose materials at a proper rate. This ecosystem service is critical for vegetable growth.

Interestingly, plants can only take up nutrients that are dissolved in the soil water that surrounds plants roots. However, most nutrients are not available in this form and are instead locked up tight in soil organic matter and detritus. Microbes (bacteria 


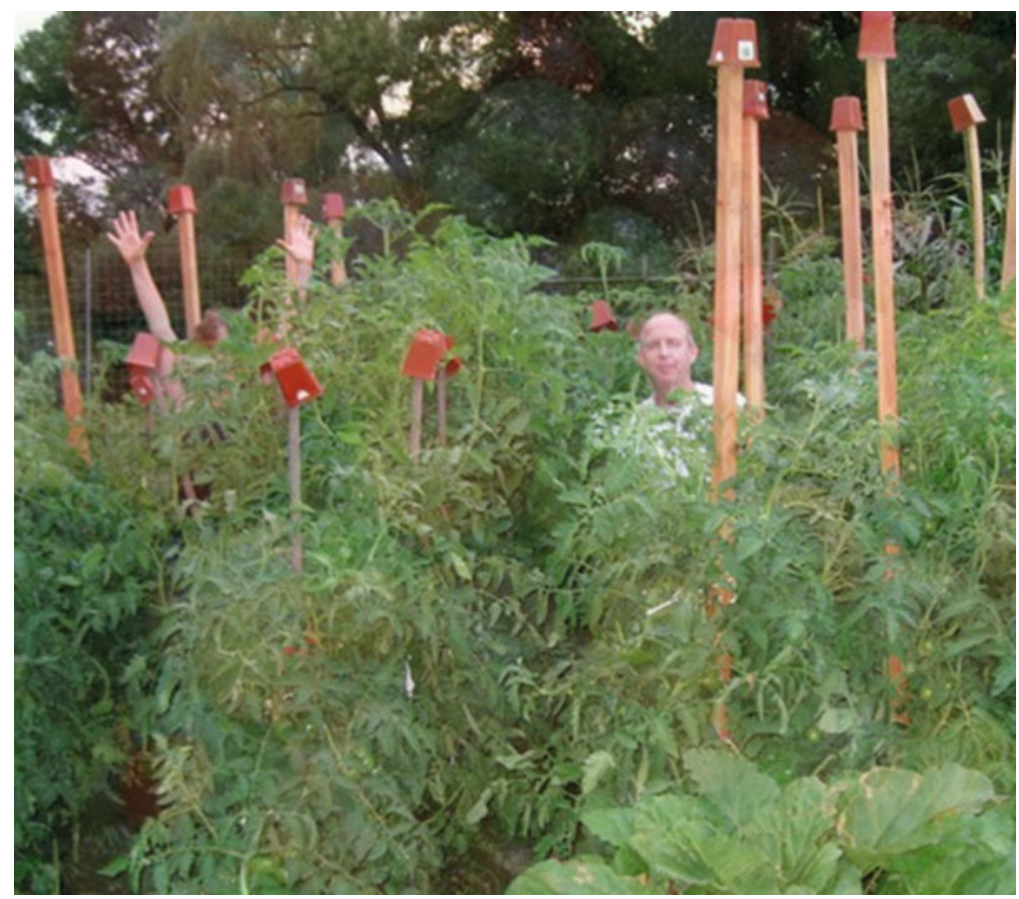

Fig. 11 An intrepid urban gardener poses near his tomatoes. Staking the plants allows for increased airflow, which helps reduce microbial pathogens and increases plant health (Photo Courtesy: Vicky Zeph)

and fungi), via decomposition of organic materials, release bound nutrients from more complex molecules, and thus largely control the supply of nutrients available for plants. As such, microbes are critical for gardening success and annual yields and should be treated as a "silent partner" in your growing operation.

\section{How Microbes Control Nutrient Supply}

As we have discussed previously, soil microbes (bacteria and fungi) decompose organic materials in soils and release important nutrients for plant uptake. However, it important to note that microbes are not simply providing a free service for the gardener at their own expense. Bacteria and fungi only release nutrients to plants once they meet their own personal Nitrogen $(\mathrm{N})$ and Phosphorus $(\mathrm{P})$ demands. Soil microbes decompose materials in order to gain energy, by breaking the carboncarbon bonds, to fuel biological activities such as reproduction, tissue maintenance, etc. Along with energy demands, nutrients, such as $\mathrm{N}$ and $\mathrm{P}$, are assimilated into biomass and form the base components of most proteins, DNA, and other cellular structures. 


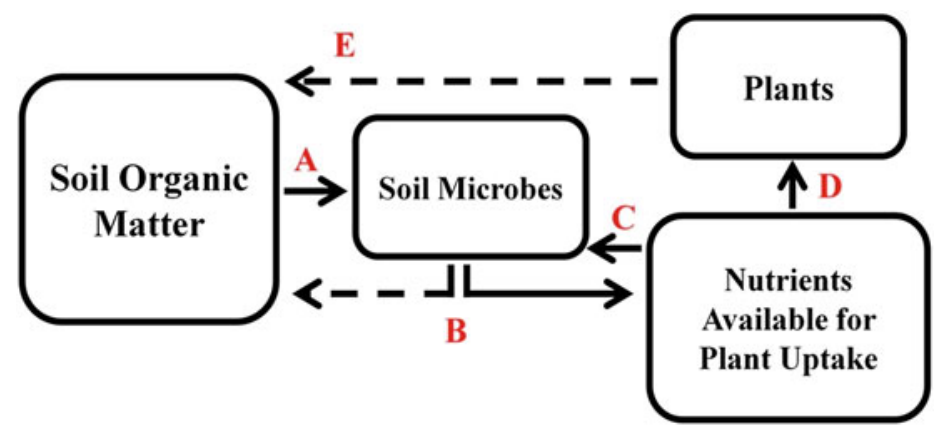

Fig. 12 The mineral nutrient cycle in gardens. (a) Microbes decompose the detritus in the soil; (b) Soil microbes excrete excess nutrients into soil solution and return to the organic matter pool upon death; (c) Microbes can also assimilate nutrients from the soil pool that plants use; (d) Plant roots can only take up nutrients in soil solution; (e) Plant materials are returned to the soil organic matter pool upon death. This might be the most successful recycling program on Earth!

After soil microbes use the nutrients for their own purposes, the excess is excreted back into the soil environment or released when they die. These leftover nutrients are how plants meet their biological demand for nutrients. Microbes serve as the "middle man" between the nutrients locked in organic materials and the nutrients, held in soil water, being absorbed by the plant root. Thus, microbes and plants are interlinked in a nutrient cycle. Plant materials are created from the nutrients absorbed in the soil and carbon dioxide from the air and, when these materials die, are returned to the soil to fuel the microbial activity that releases nutrients for plants (Fig. 12).

\section{Managing Microbes in Your Garden}

I hope you are now convinced of the role soil microbes can play in your gardening success. A practical gardener might wonder how to best manage soil microbial populations and thus maintain a healthy nutrient cycle. An important part of managing microbes is to consider their needs from a biological perspective. You can promote healthy microbial populations by adding extra organic matter to your soil. Common types of organic matter available to the gardener are manure inputs from cows and chickens, composts from food (no meats or fats!) and yard plant clippings, and soil products from municipal biosolids. If you live in an area with an annual leaf fall, you can add your leaf piles to your garden and later incorporate it into your garden soil. Organic matter will serve as a food source (carbon) for soil microbes, thus promoting a healthy population in your garden.

Organic matter has a myriad of other benefits besides serving as a food source for microbes. Organic materials will help moderate the effects of low $\mathrm{pH}$ in acidic soils and will help hold onto soil moisture during dry periods. Furthermore, the electrical 
charges on decaying organic matter will provide sites for excess soil nutrients to "hang out". This will serve as a future source of soil fertility akin to a bank savings account. Other benefits of adding organic matter included reduced compaction and better water and oxygen infiltration around plant roots.

\section{Disturbances to Soil Microbes}

Disturbance to the soil in your garden can severely disrupt the life cycle of microbes. Common disturbances include tilling the soil in excess, compaction due to foot traffic, and watering practices that promote erosion. Gardeners often till their plots in order to break up tough soil, incorporate organic matter throughout the soil profile, and reduce the infiltration of weeds. However, tilling can upset the activities of soil microbes, particularly the fungi. If you recall from the previous section, fungi are made up of an extensive belowground network called the mycelium. When you till, you sever this network and compromise the function of fungi in your garden. Thus, by supposedly helping your garden, you can actually limit nutrient availability in your soils for future growing seasons. In order to reduce the effects of tilling, try to only till as minimally as possible and on the extreme bookends of your growing season.

\section{Compaction}

Soil compaction in the garden is primarily caused by foot or tire traffic. These forces compress the large pores in your soil. If you recall from our description of the physical nature of soil, pore spaces are crucial for moving both gasses and water throughout the soil profile. This can result in hypoxic conditions, which can essentially starve important microbes of oxygen. In order to reduce compaction, one should take great care to not step on the soils in which you will be growing plants. Establish paths for foot traffic in your garden that allow you ease of access to all sides of your plot. If you must walk in your plots, try to keep your weight spread out on a wooden board to reduce soil compaction.

Watering, although obviously helpful in the garden, can be detrimental to your success. Many gardeners, the author included, are guilty of overwatering. Overwatering, similar to soil compaction, displaces the oxygen gas in the soil and will prevent beneficial microbes from carrying out biological functions. Also, if you apply your water in a rough matter (e.g., with a jet nozzle or straight from the hose), you can physically tear apart soil and promote needless erosion, in a manner similar to tilling. Watering in this manner, not surprisingly, will disrupt the life cycle of soil fungi in a manner disproportionate to soil bacteria. In order to avoid problems associated with water application; make sure you apply water gently and only when the plants need it according to your local climate. 


\section{Chapter Summary}

In this chapter, we established the following:

- Soil is a complex, multiphasic habitat that is crucial for gardening success.

- Microbes serve as the middle-man between soil organic matter and plant available nutrients.

- The connection between soil microbes, soil health, and gardening success cannot be ignored and soils should be managed to maximize microbial populations.

- Adding organic matter to soils is the best way to support a healthy soil microbial population.

- Be aware of compacting soil and overwatering, both will be detrimental to soil microbes.

\section{Suggested Readings and Online Resources for the Urban Gardener}

1. Tugel AJ, Lewandowski AM, Happe-vonArb D (eds) (2000) Soil biology primer. Soil and Water Conservation Society, Ankeny

2. Pavao-Zuckerman MA (2012) Urbanization, soils, and ecosystem services. In: Wall DH (eds) Soil ecology and ecosystem services. pp 270-278

3. Directory of Cooperative Extension Services - http://www.csrees.usda.gov/ Extension/

4. Hoorman JJ, Islam R (2010) Understanding soil microbes and nutrient recycling. Fact Sheet SAG-16-10. The Ohio State University Cooperative Extension Service

5. Hoorman JJ (2011) The role of soil bacteria. Fact Sheet SAG-13-11. The Ohio State University Cooperative Extension Service

6. Hoorman JJ (2011) The role of soil fungi. Fact Sheet SAG-14-11. The Ohio State University Cooperative Extension Service

7. Mazza CP, Cunningham SK, Harrison EZ (2001) Using organic matter in the garden. Soils and Composting Fact Sheets. Cornell University. Department Of Horticulture

\section{Glossary}

Adsorption the adhesion of atoms, ions, or molecules from a gas, liquid, or dissolved solid to a surface

Archaea a domain of single-celled Prokaryote microorganisms

Assimilation the conversion of nutrients into biological mass

Bacteria a domain of single-celled Prokaryote microorganisms

Biogeochemical Cycles the pathway of a chemical substance as it moves through living and non-living components in an ecosystem 
Compaction an increase in the solid density of a volume of soil and displacement of water and gas from soil pores

Decomposer organisms that break down dead or decaying organisms

Decomposition the biotic and abiotic process of decay

Detritus non-living biological materials

Ecosystem Service a benefit provided to humankind from the normal functioning of an ecosystem

Erosion the process by which soil and rock are removed from the Earth's surface

Excretion the act of eliminating biological waste from an organism

Fungi single or multicellular Euklaryotic organisms

Hyphae multicellular, thread-like filaments made of chitin

Mineral Nutrients chemical elements that are known to be important to a plant's growth, which come from the soil, are dissolved in water, and absorbed through a plant's roots

Multiphasic consisting of three states (solid, gas, liquid)

Mutualists a biological relationship in which both entities derive benefit

Mycelium vegetative part of a fungus, consisting of a mass of branching hyphae

Nitrogen (N) essential macronutrient needed by all plants for structural, genetic and metabolic compounds in plant cells. It is also one of the basic components of chlorophyll.

Non-Mineral Nutrients known to be important to a plant's growth and derived from air and water

Overwatering the application of water in a manner that promotes anoxia and waterlogging

Pathogens an infectious agent that can produce disease

Phosphorus (P) macronutrient important for the construction of genetic materials, energy storage, and protein synthesis

Potassium (K) macronutrient important for protein synthesis and photosynthesis

Soil Microbes community of Bacteria, Archaea, and Fungi that lives belowground Soil Nutrients mineral elements that are critical for successful plant production

Soil Water water held in soil pores

Tilling the breaking up and cultivating of soil for agricultural use

\section{References}

Brady NC, Weil RR (1999) The nature and properties of soils. Prentice Hall, Upper Saddle River. $881 \mathrm{p}$

Kennelly M (2009) Tomato leaf and fruit diseases and disorders. Kansas State University Agricultural Experiment Station and Cooperative Extension Service (L-721), Manhattan, KS, pp 1-8

Lavelle P (2012) Soil as a habitat. In: Wall DH (ed) Soil ecology and ecosystem services. Oxford University Press, Oxford, UK, pp 7-21 
Mendes R, Kruit M, de Bruijn I, Dekkers E, van der Voort M, Schneider JHM, Piceno YM, DeSantis TZ, Andersen GL, Bakker PAHM, Raaijmakers JM (2011) Deciphering the rhizosphere microbiome for disease-suppressive bacteria. Science 332:1097-1100

Moore JC, Berlow EL, Coleman DC, de Ruiter PC, Dong Q, Hastings A, Johnson NC, McCann KS, Melville K, Morin PJ, Nadelhoffer K, Rosemond AD, Post DM, Sabo JL, Scow KM, Vanni MJ, Wall DH (2004) Detritus, trophic dynamics, and biodiversity. Ecol Lett 7:584-600

Offre P, Spang A, Schleper C (2013) Archaea in biogeochemical cycles. Annu Rev Microbiol 67:437-457

Tugel AJ, Lewandowski AM, Happe-vonArb D (eds) (2000) Soil biology primer. Soil and Water Conservation Society, Ankeny 


\title{
Urban Microbiomes and Urban Agriculture: What Are the Connections and Why Should We Care?
}

\author{
Gary M. King
}

A large percentage $(\sim 50 \%)$ of the global human population lives in urban systems. The transition from largely rural to urban lifestyles began gradually, but has accelerated. Given the magnitude of anthropogenic changes in the Earth system as a whole and concerns about resource availability and continued population growth, questions about the sustainability of urban systems have become a focal point for a variety of research and civic efforts, including programs promoting urban agriculture as a means to provide local food sources and to better manage critical nutrients such as nitrogen and phosphorus. The last decade or so has also witnessed a remarkable transformation in our understanding of the centrality of microbes for virtually all aspects of human life and wellbeing. However, this transformation has not yet been incorporated into a fuller understanding of the biology and ecology of urban life. Research on microbial assemblages (or microbiomes) in the built environment, particularly building interiors, has provided compelling examples of the importance of microbes, but these results provide at most an incomplete picture of microbial distribution and activity in urban systems. For example, though very little is known about microbial interactions with urban agriculture, the success of urban agriculture and its potential to contribute to urban sustainability will depend in part of incorporating new knowledge about soil and plant microbiomes to optimize production and to minimize some of the adverse effects of agriculture in traditional settings (e.g., greenhouse gas emission, nitrogen and phosphorus eutrophication). To that end, this review defines and provides examples of the microbiome concept and the significance of microbiomes in urban systems; it also identifies large knowledge gaps and unanswered questions that must be addressed to develop a robust and predictive understanding of urban biology and ecology.

G.M. King $(\bowtie)$

Department of Biological Sciences, Louisiana State University,

Baton Rouge, LA 70803, USA

e-mail: gkingme@gmail.com 


\section{Introduction and Definitions}

Microbes in natural and managed systems have long been recognized for their critical biogeochemical functions, e.g., decomposition and nutrient cycling (Fenchel et al. 2012). These functions are among numerous diversity-dependent "ecosystem services," many of which provide benefits for humans at little or no cost (Bell et al. 2005; Balvanera et al. 2006; Langenheder et al. 2010). Indeed, some services, e.g., nitrogen fixation, have been exploited to improve soil fertility and food production resulting in substantial economic benefits (Fig. 1).

The services provided by microbes result from the activities of individual populations or groups of populations (i.e., guilds) acting in complex assemblages, or communities. Many microbial communities (e.g., those in soils) harbor thousands of populations (or "species") that form interacting and interdependent networks. These networks and their services are sensitive to natural and anthropogenic disturbances, which elicit a variety of responses that depend in part on community composition, species richness and evenness (Yeager et al. 2005; Wittebolle et al. 2009).

Fig. 1 Using a winter cover crop of crimson clover to fix nitrogen in a raised bed curbside garden in Seattle, WA (Photo by Sally Brown)

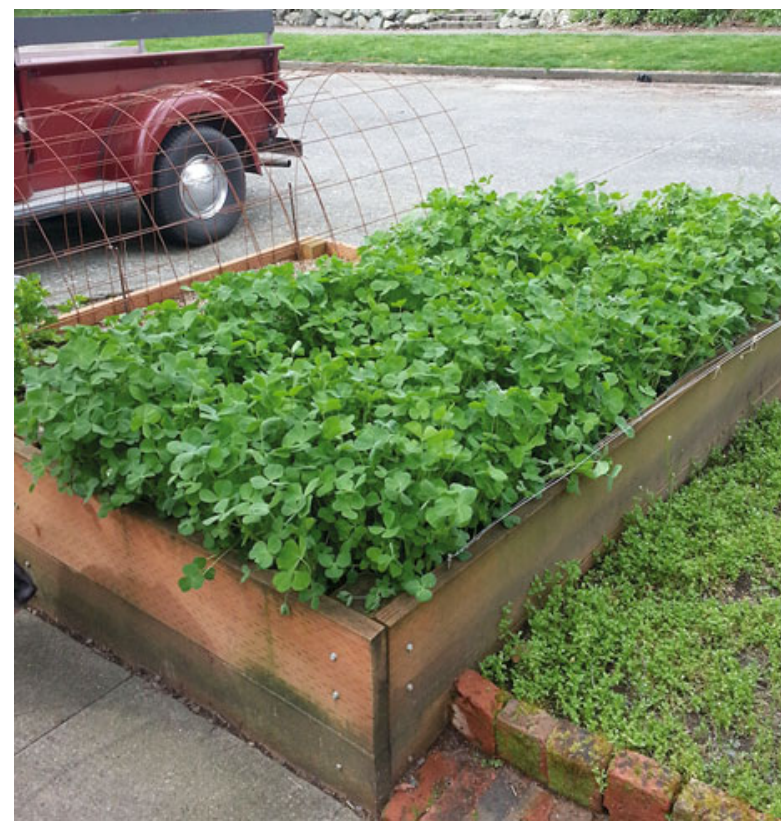




\section{Microbiome Definition and Examples}

Although the term "microbial community" remains widely used when referring to assemblages of microbes, the term "microbiome" has been used synonymously to refer to assemblages associated with macroorganisms. More specifically, it has been used to refer to members of the domains Bacteria and Archaea associated with organs (e.g., rumen, colon, vagina), surfaces of organisms (e.g., epithelia), or in some cases organisms as a whole. This usage has been credited to Joshua Lederberg, a 1958 Nobel Laureate in Physiology, who described the intimate relationships between humans and microbes, stressing their profound importance and mostly beneficial service roles in human health (Relman et al. 2009).

Recognition of the importance of microbes in the human gut stimulated a major investment in the Human Microbiome Project, which has established biogeographic maps of microbial communities on and within humans of different age, ethnicity, gender and geography (Sears 2005; Gill et al. 2006; Diaz et al. 2012; Fierer et al. 2012; Faith et al. 2013). Numerous related studies have developed strong linkages between microbiome composition and activity, and diseases including certain cancers, diabetes and obesity (Armougom et al. 2009; Larsen et al. 2010; Hu et al. 2011). These studies have not simply documented relationships between microbes and disease states; rather they have shown that some members of the human microbiome contribute beneficially to health in a variety of ways (Fierer et al. 2012).

In parallel, a large number of studies have explored microbial associations with plants and animals (e.g., Rawls et al. 2004; Thompson et al. 2010; Kelley and Dobler 2011; Yashiro et al. 2011; King et al. 2012). Some of the latter have helped inform human studies. Collectively, they have transformed our understanding of organismal biology by illustrating the extent to which multicellular organisms depend on bacterial associates or symbionts to function optimally.

Microbiome research has also expanded beyond organisms to consider assemblages of microbes that are resident on or in inanimate objects with which specific organisms interact. Thus, the microbiomes of cleaning sponges, shower curtains, kitchen and bathroom surfaces, cell phones, and computers have all been analyzed to better understand the microbial populations with which humans come in contact (Feazel et al. 2009; Corsi et al. 2012; Hospodsky et al. 2012; Kelley and Gilbert 2013; Berg et al. 2014; Fujimura et al. 2014; Kembel et al. 2014; Meadow et al. 2014). Results from these studies have revealed a surprising level of diversity in the "built environment" (referring to human-produced structures), and documented reservoirs of pathogens in sometimes surprising contexts (Feazel et al. 2009).

The microbiome concept is extended here beyond individuals and the objects and structures with which they interact in an immediate sense to the urban scales that define the geographic boundaries within which most people currently spend most of their time. The urban scale is increasingly important due to the ongoing worldwide urbanization of human populations, and growing concerns about urban sustainability. Extension of the microbiome concept to this scale draws from a rich literature that recognizes urban environments as distinct, complex ecosystems, 
which necessarily include important, but mostly underappreciated roles for microbes (Groffman et al. 2002; Kaye et al. 2006; Pickett et al. 2008; Pouyat et al. 2010; King 2014).

\section{Urban Microbiomes}

What then are urban microbiomes? In what ways do they matter? What do we need to know about them? Questions such as these were not asked a mere decade ago, and for all practical purposes, they could not have been answered if they had been asked. Methodological and conceptual limitations constrained studies on microbes in urban environments largely to pathogens, pathogen indicators, bio-threat agents and waste treatment (e.g., Werner et al. 2011; Dobrowsky et al. 2014). Exceptions include studies that have addressed biogeochemical processes in urban settings (Milesi et al. 2005; Groffman and Pouyat 2009; Harrison et al. 2011; Bettez and Groffman 2012), and that have addressed the role of microbes in the degradation of culturally or artistically valuable sculpture and building surfaces (Saiz-Jimenez 1997; Papida et al. 2000; Herrera and Videla 2004; Herrera et al. 2004; Webster and May 2006; Fujii et al. 2010). However, most urban microbe studies have focused on individual populations and their effects; few studies have been integrative, and those have been eclectic in nature (Braun et al. 2006; Knapp et al. 2009; Hou et al. 2013).

At present, only limited information exists about urban microbiomes, and most of the recent observations have emphasized interiors of the built environment. However, urban microbiomes not only encompass microbial assemblages within buildings, they also include assemblages associated with the highly diverse exterior environments that characterize urban systems (e.g., Ramirez et al. 2014). Among many others, the latter include building surfaces, roads, streets and other passages; surface and sub-surface soils; the phyllosphere of plants; animal and human waste; water distribution systems, streams, drainage systems and other aquatic habitats.

The atmosphere of urban environments also harbors microbes, even if its populations are transient (Brodie et al. 2007). Because the urban atmosphere can exchange microbes with both the physical and biological components of urban systems, it contributes to the collective urban microbiome. The atmosphere also represents a medium or "teleconnection" for exchange of microbes between urban and rural systems, and provides a pathway for the introduction of microbes from distant or remote systems (Bowers et al. 2011). For example, in March 2013, a dust storm originating in China's Gobi Desert deposited sand with associated microbes in Los Angeles, California, more than $10,000 \mathrm{~km}$ away. The extent to which such events impact urban systems is essentially unknown, though a variety of consequences can easily be imagined.

Urban microbiomes are thus comprised of the vast and diverse assemblages of microbes that occur as resident or transient members of numerous habitats within urban systems. Today detailed characterizations are conceivable using "next gen" approaches for metagenetic and metagenomic sequencing. However, this capability 
begs important questions: Why do urban microbiomes matter? Why would one want to characterize them in the first place? Are there connections with new initiatives in urban sustainability, i.e., urban agriculture?

\section{Urban Microbiomes: Why Do They Matter?}

Urban microbiomes are important for numerous reasons, some of which directly involve human wellbeing. For example, microbial communities in waste treatment systems have contributed greatly to improvements in public health. Urban microbiomes also indirectly affect human wellbeing. For instance, certain microbial biogeochemical transformations produce greenhouse gases (e.g., nitrous oxide, $\mathrm{N}_{2} \mathrm{O}$ ) that contribute to global warming and its adverse impacts (Kaye et al. 2004; Townsend-Small et al. 2011), while other processes contribute beneficially to pollutant detoxification (Kolvenbach et al. 2014). Human life in urban systems is inextricably linked to microbes. Several examples of the importance of urban microbiomes are summarized briefly below.

\section{Microbial Biomass and Diversity}

In undisturbed terrestrial systems, microbial biomass, largely found in soils, typically accounts for a substantial fraction of total non-plant biomass (Tate 2000). Although biomass inventories have not been reported for urban systems, the relatively small amount of exposed soil surface suggests that microbial biomass might be modest at most, and distributed very differently than in undisturbed systems. The consequences of different distributions are unknown; similarly unknown is the extent to which soil beneath built surfaces contributes to the biogeochemical "footprint" of urban systems.

Nonetheless, with thousands of microbial species per gram of soil, microbes undoubtedly constitute the greatest reservoir of urban species and genetic biodiversity, exceeding the diversity of all urban plants and animals combined, and this does not even consider microbes that colonize or are otherwise associated with plants and animals themselves. Urban microbial diversity includes species that contribute important ecosystems services (e.g., waste treatment, pollutant biodegradation, nitrogen fixation) from which humans benefit, as well as species that have adverse impacts (e.g., plant and animal pathogenesis and building deterioration). Reasonably complete inventories exist for plant and animal diversity in urban systems, but comparable assessments for microbes are lacking.

Regardless, a recent survey of in soils of Central Park, New York City revealed a level of microbial diversity similar to that observed in natural (i.e., unmanaged) soils across the globe (Ramirez et al. 2014). Not only were the numbers of microbial species in Central Park soils equivalent to numbers in other soils, the composition 
of the soil communities were similar; this was true both for bacteria (domains Bacteria and Archaea) and fungi (Fig. 2a, b). Although more comprehensive analyses of urban soils are needed, initial results confirm that they are a major reservoir of species and genetic diversity.

\section{Microbial Interactions with Plants}

Irrespective of their biomass, soil microbes play profoundly important roles in plant production, and thus must be considered in the development of sustainable urban agriculture. Soil microbes complete with plants for nitrogen and other nutrients, but they also promote plant growth by facilitating nutrient uptake through a variety of symbiotic or associative relationships that have been thoroughly documented for many natural and agricultural systems (Tate 2000). Plant growth-promoting rhizobacteria (PGPR) also aid in plant defenses against disease by regulating some plant pathogen populations and contributing to "induced systemic resistance" (Faure et al. 2008; Belimov et al. 2009; Doornbos et al. 2011; Hassan and Mathesius 2012; Carvalhais et al. 2013) (Fig. 3).

In addition, urban soils are often degraded relative to managed agricultural and unmanaged natural soils, usually due to elevated toxic metals and organics (e.g., copper, lead, polycyclic aromatic hydrocarbons - PAH), which can limit their productivity. In some cases, soil microbes have been successfully exploited to enhance metal and organic phytoremediation in brownfield and other contaminated soils (Di Gregorio et al. 2006; Gerhardt et al. 2009). Microbially-enhanced phytoremediation might thus prove generally useful as a pre-treatment to improve urban soil quality for agricultural applications. Targeted selection of plants and bacterial inoculants, along with strategies to enhance naturally-occurring microbial biodegradation, could increase the inventory of agriculturally suitable soils with little to moderate cost. Similar approaches could also be used to "condition" microbial communities to optimize and sustain urban production, but this will require new knowledge about urban soil microbes.

\section{Microbes and Biogeochemical Transformations}

In addition to their interactions with plants, urban microbes mediate a variety of biogeochemical processes that affect mass and energy flows within urban systems, and exchanges of mass and energy between urban systems and their surroundings. Some of these processes occur within waste treatment systems, which affect forms and masses of carbon, nitrogen, phosphorous, trace metal and pollutant exchanges.

Other processes associated with urban soils, riparian systems and structures engineered for controlling water movement (e.g., storm runoff) are also important (Arango et al. 2008; Cadenasso et al. 2008; Harrison et al. 2011; Li et al. 2014). 

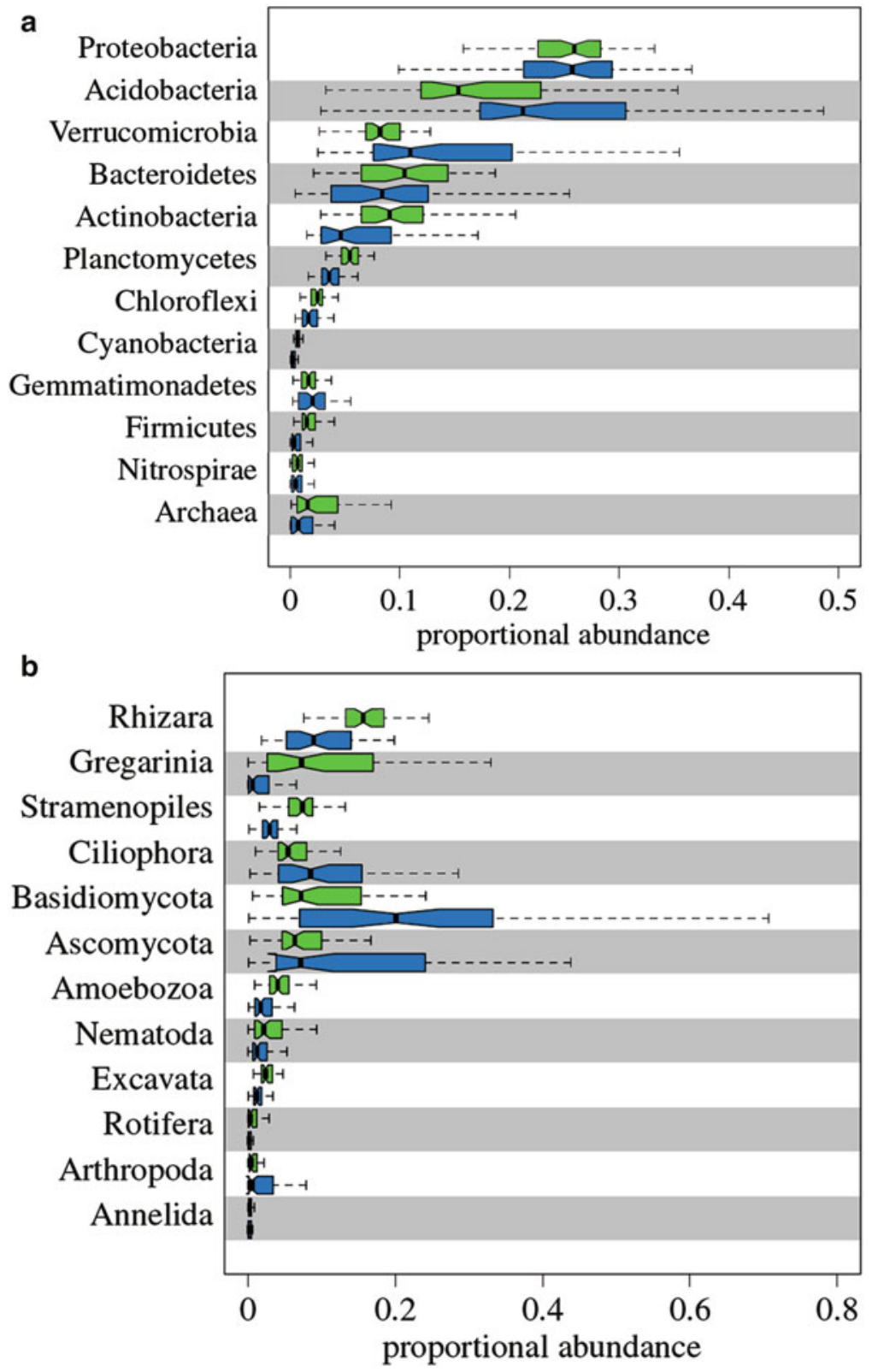

Fig. 2 (a) Relative abundances of common bacterial phyla and Archaea in Central Park, New York City soils. Box and whisker plots show average abundances (bar) and upper and lower limits (dashed lines) for Central Park (green) and a global soil inventory (blue). (b) As for (a), but illustrating relative abundances of fungi and other eukaryotes (From Ramirez et al. (2014)) 


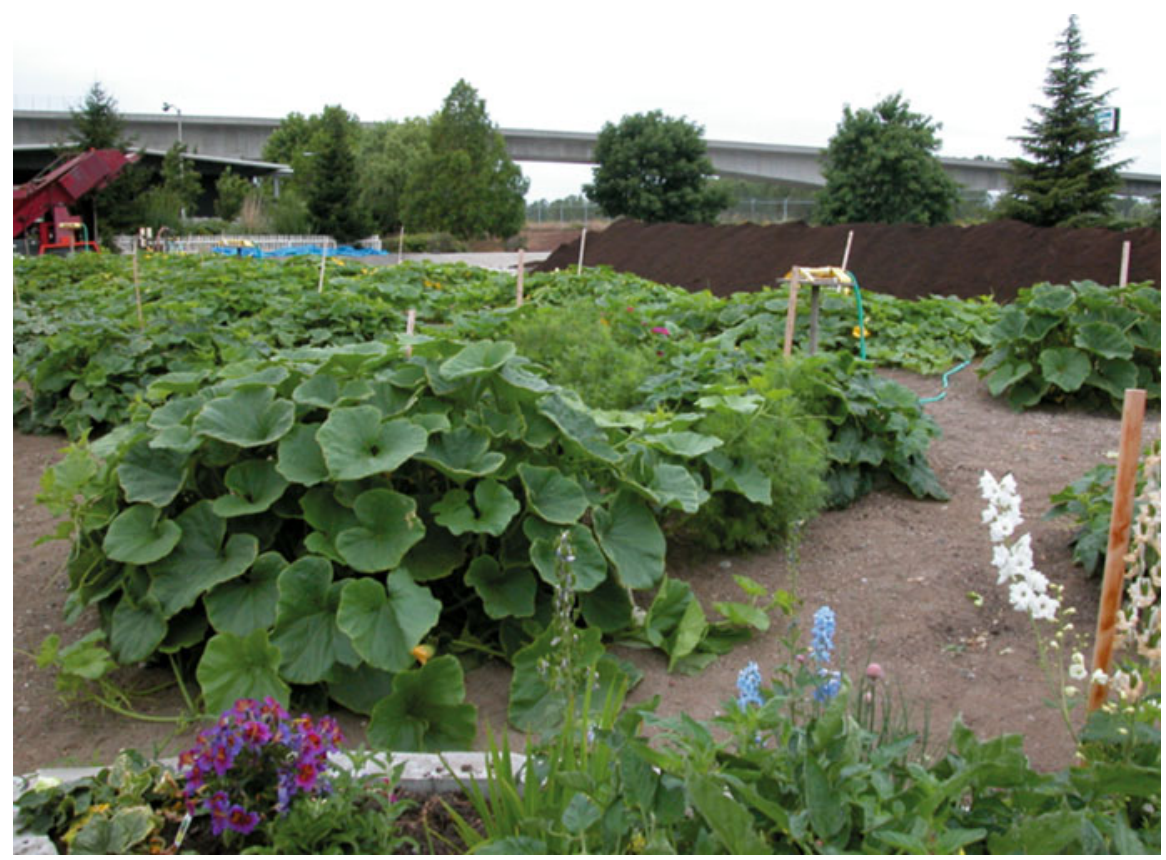

Fig. 3 A garden constructed using municipal biosolids at a wastewater treatment plant in Tacoma, WA (Photo by Dan Eberhart)

Denitrification rates, which are elevated in urban systems, are particularly significant, because denitrification can limit nitrogen (nitrate) exports to receiving systems, such as inland and coastal waters (Klocker et al. 2009; Harrison et al. 2011). However, denitrification can also contribute to $\mathrm{N}_{2} \mathrm{O}$ formation. Denitrification and the coupled process of nitrification are both stimulated by nitrogen fertilization, whether fertilizers are applied for lawns or crop and vegetable production. $\mathrm{N}_{2} \mathrm{O}$ formation from these processes, and fluxes from urban agriculture, must be considered carefully and controlled to the extent possible, since $\mathrm{N}_{2} \mathrm{O}$ emissions can potentially vitiate any benefits from carbon storage (sequestration) or reduced $\mathrm{CO}_{2}$ emissions accompanying urban agriculture (Livesley et al. 2010). While rigorous management of nitrogen fertilization might represent the primary mechanism for controlling urban $\mathrm{N}_{2} \mathrm{O}$ emissions, a deeper understanding of the relevant microbial populations, their activities and controls is also essential.

\section{Microbes and Water Distribution Systems}

The role of microbial communities in water distribution systems has been a subject of increasing attention, largely due to the recognition that "premise plumbing" systems (i.e., the water distribution systems of buildings) harbor distinct microbiomes 
(Wang et al. 2013). A variety of opportunistic pathogens, including various mycobacteria, Pseudomonas, Legionella and protozoans such as Acanthamoeba, occur in these assemblages, and can contribute to disease outbreaks. Recently, for example, the protist Naegleria fowleri, which causes a nearly always-fatal primary amebic meningoencephalitis, has been found in premise plumbing at two locations in Louisiana, USA.

While much remains unknown about premise plumbing microbiomes, it has been suggested that they might be manipulated using a form of probiotic treatment to limit opportunistic pathogens (Wang et al. 2013). To accomplish this successfully will require a level of understanding comparable to that now emerging for the human gut microbiome. Success will also hinge on a new recognition of the integral role microbes play in all built systems, and our routine and intimate associations with those microbes.

\section{Exposures to Microbes and Consequences}

Because they are ubiquitous, humans interact directly and indirectly with microbes in the urban environment, as do all urban plant and animal populations. These interactions occur routinely and often with no obvious consequences. However, recent results suggest that some exposures to airborne microbes can have beneficial consequences for immunological fitness. In particular, exposures to microbes in rural atmospheres have been associated with lower incidences of asthma than exposures to microbes in urban atmospheres (Riedler et al. 2001; Ege et al. 2011; Illi et al. 2012). This difference might be due to a number of factors, including the concentration and diversity of airborne microbes and durations of exposure. In addition, the results indicate that increased urbanization could be associated with future increases in asthma incidence. Interestingly, the protective benefit of rural atmospheres has been attributed to farming environments and activities. This intriguing observation suggests that urban agriculture could provide similar protective benefits if agricultural activity is incorporated appropriately within urban systems (Brown and Jameton 2000).

\section{Urban Microbiomes: What Do We Need to Know?}

Urban microbiome analyses are in their infancy. A small, but rapidly growing number of studies have characterized urban atmospheres, waste treatment systems and the interiors of buildings. They have provided new and unanticipated insights about the types and distributions of bacteria in the built environment, including observations that could improve health outcomes through microbiome-informed building design (e.g., Kembel et al. 2014). Nonetheless, these studies represent just the tip of the proverbial iceberg. In parallel, a larger but still limited number of studies 
embedded in the discipline of urban ecology have begun to define both the unique characteristics of urban ecosystems as well as characteristics shared with unmanaged systems. Again, however, much remains to be done to understand the ecological and biogeochemical dynamics of urban systems. Some of the knowledge gaps and unanswered questions involving urban microbiomes are summarized below.

A.1. What are the major reservoirs of urban microbes (e.g., the atmosphere, plants, soils, humans and other animals, waste treatment systems, exteriors and interiors of buildings) and how does their relative importance vary with space and time within and among urban systems?

2. How do the individual contributors to urban microbiomes interact across space and time?

As noted previously, the composition and dynamics of urban microbiomes remain largely unexplored and thus represent large knowledge gaps. One can surmise that soils are the greatest locus of genetic and functional diversity in urban microbiomes overall, but this assumption has yet to be evaluated empirically and likely varies across and among cityscapes with changes in soil distribution and mass. Although interactions between indoor and outdoor microbiomes as mediated through the urban atmosphere are now being explored, they represent only two of numerous interaction pathways; identifying and analyzing other interactions will be crucial for developing explanatory and predictive models and determining the factors that contribute to changes in them.

Addressing these questions is now feasible using next-gen sequencing approaches and computational advances for metagenetics (16S rRNA and other genes) and metagenomics. With continuing decreases in sequencing costs and the availability of high performance computing platforms, large-scale urban microbiome analyses are not only possible, but should be undertaken along with complementary urban ecological analyses.

B.1. What major biological, ecological and biogeochemical functions occur in urban microbiomes? How do they differ from the microbiomes of unmanaged systems, how do they vary across space and time, and what controls their expression?

2. Can microbiomes of building surfaces and other structures be manipulated or controlled to improve resistance to deterioration or to promote beneficial services (e.g., pollutant remediation)?

If little is known about the diversity of urban microbiomes, even less is known about their functions. A few biogeochemically important functions (e.g., denitrification and methane oxidation) have been identified through process-based approaches, but function is often inferred from phylogenetic marker genes (e.g., 16S rRNA genes), which provide only broad diagnoses and are notoriously unreliable for spe- 
cific processes in specific taxa. Thus, the possibility of manipulating microbiomes or their functions to achieve particular goals, e.g., decreased structural degradation, remains a distant though desirable goal. Greater understanding of function, like greater understanding of microbiome diversity, is now feasible using next-gen sequencing. However, the depth of sequencing necessary for comprehensive analyses, along with constraints of sequence assembly and annotation likely mean that in the near future relative few systems will be characterized in detail. However, this should not delay implementation of metagenomic, metatranscriptomic and metabolomics analyses of urban microbiome function; indeed these studies should be given a high priority.

C.1. How connected with (or isolated from) the microbiomes of surrounding regions are urban microbiomes, and what are the pathways or mechanisms for connections?

Urban systems do not exist in isolation, nor do their microbiomes. The atmosphere represents one obvious route for exchanges between urban systems and their surroundings. A growing body of information has addressed the importance of short- and long-range atmospheric transport as a means for microbe dispersal, but there are other transport mechanisms, the relative importance of which is unknown, but which likely vary among urban systems and for specific microbial groups. For example, riverine transport might be important as a source of some bacteria in some urban systems (e.g., New York, NY; Portland, OR; St. Louis, MO), but play smaller roles in other cities (e.g., Denver, CO, Indianapolis, IN and Phoenix, AZ). Microbial transport directly and indirectly due to fluxes of humans, vehicles and plants and animals into and out of cities might also be important in some cases.

D.1. Can soil microbiomes be manipulated to optimize urban agricultural production while minimizing or eliminating nitrous oxide production and emission?

2. Can the potential health benefits from exposure to rural-agroecosystem microbial aerosols be reproduced in urban environments at scales large enough to benefit urban populations?

While urban agricultural production is attractive for a number of reasons, its success in the context of sustainability will depend on a full accounting of costs and benefits. Greenhouse gases, especially $\mathrm{N}_{2} \mathrm{O}$ and methane, will need to be included in the costs. As a result of their large GWP values, relatively small changes in $\mathrm{N}_{2} \mathrm{O}$ and methane fluxes can either negate or amplify benefits gained from nitrogen recycling, carbon sequestration, and energy efficiencies derived from local agricultural production.

In traditional agricultural settings, significant $\mathrm{N}_{2} \mathrm{O}$ production occurs largely as a result of inefficient fertilizer nitrogen use by plants; agricultural land use also sub- 
stantially reduces atmospheric methane uptake. Similar patterns have been documented for urban land use. Both phenomena add to atmospheric radiative forcing and global warming. While these impacts can be reduced in part by improved management of fertilizer nitrogen applications, they might also be reduced by specific manipulations of rhizosphere and bulk soil microbiomes. The latter has not been attempted for conventional agricultural production, but might be feasible on the scales of urban agriculture, particular in systems designed de novo. Of course, successful manipulation of microbiomes to manage greenhouse gases will require advances in understanding of the structure, function and controls of microbial communities and their activities.

Although not fully understood, a number of observations suggest that asthma incidence can be reduced by exposure to microbes in rural atmospheres, particularly those associated with agriculture. Whether this or other potential health benefits can be reproduced in urban environments is unknown, but important to consider in evaluating the total costs and benefits of urban agriculture. It is worth remembering that urbanization is a recent and growing phenomenon in human history, and that human immunological systems evolved in markedly different environments with exposures to different suites of antigens. Reproducing at least some of those exposures could contribute to larger efforts to improve urban health outcomes and urban sustainability.

\section{Summary}

Microbes are both the foundation and fabric of all life, human life included. Thus, individual microbes have long been a focus of health concerns, and they have also long been exploited beneficially (e.g., Streptomyces griseus for drug production). Nonetheless, microbes exist naturally in complex communities, or microbiomes, and it is in this context that their significance arises. Whether in the human gut or broadly distributed across cityscapes, microbiomes play profoundly important roles in the activities and functions of the hosts and systems they inhabit. The composition and dynamics of urban microbiomes are largely unknown at present, but it is clear that they contribute basic services that make urban life possible. It is also clear that a greater understanding of urban microbiomes is essential for promoting urban sustainability and ensuring the success of rapidly expanding initiatives such as urban agriculture.

\section{References}

Arango CP, Tank JL, Johnson LT, Hamilton SK (2008) Assimilatory uptake rather than nitrification and denitrification determines nitrogen removal patterns in streams of varying land use. Limnol Oceanogr 53:2558-2572

Armougom F, Henry M, Vialettes B, Raccah D, Raoult D (2009) Monitoring bacterial community of human gut microbiota reveals an increase in Lactobacillus in obese patients and Methanogens in anorexic patients. PLoS One 4(9):e7125. doi:10.1371/journal.pone.0007125 
Balvanera P et al (2006) Quantifying the evidence for biodiversity effects on ecosystem functioning and services. Ecol Lett 9:1146-1156

Belimov AA et al (2009) Rhizosphere bacteria containing 1-aminocyclopropane-1-carboxylate deaminase increase yield of plants grown in drying soil via both local and systemic hormone signalling. New Phytol 181:413-423

Bell T, Newman JA, Silverman BW, Turner SL, Lilley AK (2005) The contribution of species richness and composition to bacterial services. Nature 436:1157-1160

Berg G, Mahnert A, Moissl-Eichinger C (2014) Beneficial effects of plant-associated microbes on indoor microbiomes and human health? Front Microbiol 5:15. doi:10.3389/fmicb.2014.00015

Bettez ND, Groffman PM (2012) Denitrification potential in stormwater control structures and natural riparian zones in an urban landscape. Environ Sci Technol 46:10909-10917

Bowers RM, McLetchie S, Knight R, Fierer N (2011) Spatial variability in airborne bacterial communities across land-use types and their relationship to the bacterial communities of potential source environments. ISME J 5:601-612

Braun B, Böckelmann U, Grohmann E, Szewzyk U (2006) Polyphasic characterization of the bacterial community in an urban soil profile with in situ and culture-dependent methods. Appl Soil Ecol 31:267-279

Brodie EL et al (2007) Urban aerosols harbor diverse and dynamic bacterial populations. Proc Natl Acad Sci U S A 104:299-304

Brown KH, Jameton AL (2000) Public health implications of urban agriculture. J Public Health Policy 21:20-39

Cadenasso ML et al (2008) Exchanges across land-water-scape boundaries in urban systems: strategies for reducing nitrate pollution. Ann N Y Acad Sci 1134:213-232

Carvalhais LC et al (2013) Activation of the jasmonic acid plant defence pathway alters the composition of rhizosphere bacterial communities. PLoS One 8:e56457. doi:10.1371/journal. pone.0056457

Corsi RL, Kinney KA, Levin H (2012) Microbiomes of built environments: 2011 symposium highlights and workgroup recommendations. Indoor Air 22:171-172

Di Gregorio S et al (2006) Combined application of Triton X-100 and Sinorhizobium sp. Pb002 inoculum for the improvement of lead phytoextraction by Brassica juncea in EDTA amended soil. Chemosphere 63:293-299

Diaz PI et al (2012) Using high throughput sequencing to explore the biodiversity in oral bacterial communities. Mol Oral Microbiol. doi:10.1111/j.2041-1014.2012.00642.x

Dobrowsky PH, De Kwaadsteniet M, Cloete TE, Khan W (2014) Distribution of indigenous bacterial pathogens and potential pathogens associated with roof-harvested rainwater. Appl Environ Microbiol 80:2307-2316

Doornbos RF, Loon LC, Bakker PAHM (2011) Impact of root exudates and plant defense signaling on bacterial communities in the rhizosphere. A review. Agron Sustain Dev 32:227-243

Ege MJ et al (2011) Exposure to environmental microorganisms and childhood asthma. New Engl J Med 364:701-709

Faith JJ et al (2013) The long-term stability of the human gut microbiota. Science 341:1237439. doi:10.1126/science. 1237439

Faure D, Vereecke D, Leveau JHJ (2008) Molecular communication in the rhizosphere. Plant Soil 321:279-303

Feazel LM et al (2009) Opportunistic pathogens enriched in showerhead biofilms. Proc Natl Acad Sci U S A 106:16393-16399

Fenchel T, King GM, Blackburn TH (2012) Bacterial biogeochemistry, the ecophysiology of mineral cycling, 3rd edn. Academic Press, London

Fierer N et al (2012) From animalcules to an ecosystem: application of ecological concepts to the human microbiome. Annu Rev Ecol Evol Syst 43:137-155

Fujii Y, Fujiwara Y, Kigawa R, Suda T, Suzuki Y (2010) Characteristics and diagnosing technology of biodegradation in wooden historical buildings: a case study on Amida-do in Higashi Hongan-ji Temple in Kyoto. In: World conference on timber engineering, Riva del Garda, Italy, 19-24 June 2010 
Fujimura KE et al (2014) House dust exposure mediates gut microbiome Lactobacillus enrichment and airway immune defense against allergens and virus infection. Proc Natl Acad Sci U S A 111:805-810

Gerhardt KE, Huang X-D, Glick BR, Greenberg BM (2009) Phytoremediation and rhizoremediation of organic soil contaminants: potential and challenges. Plant Sci 176:20-30

Gill SR et al (2006) Metagenomic analysis of the human gut distal microbiome. Science 312:1355-1359

Groffman PM, Pouyat RV (2009) Methane uptake in urban forests and lawns. Environ Sci Technol 43:5229-5235

Groffman PM et al (2002) Soil nitrogen cycle processes in urban riparian zones. Environ Sci Technol 36:4547-4552

Harrison MD, Groffman PM, Mayer PM, Kaushal SS, Newcomer TA (2011) Denitrification in alluvial wetlands in an urban landscape. J Environ Qual 40:634. doi:10.2134/jeq2010.0335

Hassan S, Mathesius U (2012) The role of flavonoids in root-rhizosphere signalling: opportunities and challenges for improving plant-microbe interactions. J Exp Bot 63:3429-3444

Herrera LK, Videla HA (2004) The importance of atmospheric effects on biodeterioration of cultural heritage constructional materials. Int Biodeterior Biodegrad 54:125-134

Herrera LK, Arroyave C, Guiamet P, de Saravia SG, Videla H (2004) Biodeterioration of peridotite and other constructional materials in a building of the Colombian cultural heritage. Int Biodeterior Biodegrad 54:135-141

Hospodsky D et al (2012) Human occupancy as a source of indoor airborne bacteria. PLoS One 7:e34867. doi:10.1371/journal.pone.0034867

Hou J, Cao X, Song C, Zhou Y (2013) Predominance of ammonia-oxidizing archaea and nirKgene-bearing denitrifiers among ammonia-oxidizing and denitrifying populations in sediments of a large urban eutrophic lake (Lake Donghu). Can J Microbiol 59:456-464

Hu S, Dong TS, Dalal SR, Wu F, Bissonnette M (2011) The microbe-derived short chain fatty acid butyrate targets miRNA-dependent p21 gene expression in human colon cancer. PLoS One 6(1):e16221. doi:10.1371/journal.pone.0016221

Illi S et al (2012) Protection from childhood asthma and allergy in Alpine farm environments-the GABRIEL advanced studies. J Allergy Clin Immunol 129:1470.e6-1477.e6. doi:10.1016/j. jaci.2012.03.013

Kaye JP, Burke IC, Mosier AR, Guerschman JP (2004) Methane and nitrous oxide fluxes from urban soils to the atmosphere. Ecol Appl 14:975-981

Kaye JP, Groffman PM, Grimm NB, Baker LA, Pouyat RV (2006) A distinct urban biogeochemistry? Trends Ecol Evol 21:192-199

Kelley ST, Dobler S (2011) Comparative analysis of microbial diversity in Longitarsus flea beetles (Coleoptera: Chrysomelidae). Genetica 139:541-550

Kelley ST, Gilbert JA (2013) Studying the microbiology of the indoor environment. Genome Biol 14:202. doi:10.1186/gb-2013-14-2-202

Kembel SW et al (2014) Architectural design drives the biogeography of indoor bacterial communities. PLoS One 9:e87093. doi:10.1371/journal.pone.0087093

King GM (2014) Urban microbiomes and urban ecology: how do microbes in the built environment affect human sustainability in cities? J Microbiol 9:721-728

King GM, Judd C, Kuske CR, Smith C (2012) Analysis of stomach and gut microbiomes of the Eastern Oyster (Crassostrea virginica) from Coastal Louisiana, USA. PLoS One 7(12):e51475. doi:10.1371/journal.pone.0051475

Klocker CA, Kaushal SS, Groffman PM, Mayer PM, Morgan RP (2009) Nitrogen uptake and denitrification in restored and unrestored streams in urban Maryland, USA. Aquat Sci 71:411-424

Knapp CW, Dodds WK, Wilson KC, O’Brien JM, Graham DW (2009) Spatial heterogeneity of denitrification genes in a highly homogenous urban stream. Environ Sci Technol 43:4273-4279

Kolvenbach BA, Helbling DE, Kohler H-PE, Corvini PF-X (2014) Emerging chemicals and the evolution of biodegradation pathways and capacities in bacteria. Curr Opin Biotechnol $27: 8-14$ 
Langenheder S, Bulling MT, Solan M, Prosser JI (2010) Bacterial biodiversity-ecosystem functioning relations are modified by environmental complexity. PLoS One 5:e10834. doi:10.1371/ journal.pone. 0010834

Larsen N et al (2010) Gut microbiota in human adults with type 2 diabetes differs from nondiabetic adults. PLoS One 5(2):e9085. doi:10.1371/journal.pone.0009085

Li S, Deng H, Rensing C, Zhu YG (2014) Compaction stimulates denitrification in an urban park soil using (15)N tracing technique. Environ Sci Pollut Res Int 21:3783-3791

Livesley SJ et al (2010) Soil-atmosphere exchange of carbon dioxide, methane and nitrous oxide in urban garden systems: impact of irrigation, fertiliser and mulch. Urban Ecosyst 13:273-293

Meadow JF et al (2014) Bacterial communities on classroom surfaces vary with human contact. Microbiome 2:7:microbiomejournal.com/content/2/1/7

Milesi $C$ et al (2005) Mapping and modeling the biogeochemical cycling of turf grasses in the United States. Environ Manage 36:426-438

Papida S, Murphy W, May E (2000) Enhancement of physical weathering of building stones by microbial populations. Int Biodeterior Biodegrad 46:305-317

Pickett ST et al (2008) Beyond urban legends: an emerging framework of urban ecology, as illustrated by the Baltimore Ecosystem Study. Bioscience 58:139-150

Pouyat RV, Szlavecz K, Yesilonis ID, Groffman PM, Schwarz K (2010) Chemical, physical and biological characterization of urban soils. Agron Monogr 55. doi:10.2134/agronmonogr55. c7:10.2134/agronmonogr55.c7

Ramirez KE et al (2014) Biogeographic patterns in below-ground diversity in New York City's Central Park are similar to those observed globally. Proc R Soc B 281:20141988. doi:http:// dx.doi.org/10.1098/rspb.2014.1988

Rawls JF, Samuel BS, Gordon JI (2004) Gnotobiotic zebrafish reveal evolutionarily conserved responses to the gut microbiota. Proc Natl Acad Sci U S A 101:4596-4601

Relman DA, Hamburg MA, Choffnes ER, Mack A (2009) Microbial evolution and co-adaptation: a tribute to the life and scientific legacies of Joshua Lederberg. National Academies Press, Washington, DC, $339 \mathrm{p}$

Riedler J et al (2001) Exposure to farming in early life and development of asthma and allergy: a cross-sectional survey. The Lancet 358:1129-1133

Saiz-Jimenez C (1997) Biodeterioration vs biodegradation: the role of microorganisms in the removal of pollutants deposited on historic buildings. Int Biodeterior Biodegrad 40:225-232

Sears CL (2005) A dynamic partnership: celebrating our gut flora. Anaerobe 11:247-251

Tate RL III (2000) Soil microbiology, 2nd edn. Wiley, New York

Thompson CL, Hofer MJ, Campbell IL, Holmes AJ (2010) Community dynamics in the mouse gut microbiota: a possible role for IRF9-regulated genes in community homeostasis. PLoS One 5(4):e10335. doi:10.1371/journal.pone.0010335

Townsend-Small A, Pataki DE, Czimczik CI, Tyler SC (2011) Nitrous oxide emissions and isotopic composition in urban and agricultural systems in southern California. J Geophys Res 116:10.1029/2010jg001494

Wang H, Edwards MA, Falkinham JO III, Pruden A (2013) Probiotic approach to pathogen control in premise plumbing systems? A review. Environ Sci Technol 47:10117-101128

Webster A, May E (2006) Bioremediation of weathered-building stone surfaces. Trends Biotechnol 24:255-260

Werner JJ et al (2011) Bacterial community structures are unique and resilient in full-scale bioenergy systems. Proc Natl Acad Sci USA. pnas.org/cgi/doi/10.1073/pnas.1015676108

Wittebolle L et al (2009) Initial community evenness favours functionality under selective stress. Nature 458:623-626

Yashiro E, Spear RN, McManus PS (2011) Culture-dependent and culture-independent assessment of bacteria in the apple phyllosphere. J Appl Microbiol 110:1284-1296

Yeager CM, Northup DE, Grow CC, Barns SM, Kuske CR (2005) Changes in nitrogen-fixing and ammonia-oxidizing bacterial communities in soil of a mixed conifer forest after wildfire. Appl Environ Microbiol 71:2713-2722 


\title{
Wild Bees in Cultivated City Gardens
}

\author{
J. Scott MacIvor
}

\section{Introduction}

The pursuit for and production of fresh and local fruits and vegetables is gaining popularity among homeowners and community groups in cities. Cultivating crops allows one to connect to natural processes, invest in food security and gain crucial life skills. It's also relaxing, provides exercise and is a lot of fun. Although gardening is one of the most common activities among homeowners, and many are aware of the role of pollinators in plant reproduction, the various needs of pollinating insects are often overlooked in garden design and maintenance.

Pollination is an essential ecosystem function required to sustain flowering plant diversity, including many edible species we cultivate in cities (Klein et al. 2007; Ollerton et al. 2011). The yield of many of the world's fruits and vegetables, and certainly most of the more tasty, colorful, nutritious and large ones, are dependent on pollinators (Free 1993; Klein et al. 2007; Aizen and Harder 2009). Many crops in cultivated city gardens are also pollinator dependent; for example, a survey of 19 community gardens in New York City found $92 \%$ of crops required pollinators (Matteson and Langellotto 2009). Pollinators in cultivated city gardens include many taxa, such as flies, butterflies, moths, beetles, as well as birds and bats, but by far none are more common or diverse as bees. As small-scale agricultural activities increase in patches of urban green space, vacant lands, and rooftops, the need for pollination services by bees increases (Green 2007).

When many of us think of bees we think of honey bees (Packer 2010; Breeze et al. 2011). Honey bees make hives, wax and honey; we manage them for pollination as part of massive agricultural enterprises and simultaneously in small colonies on urban rooftops and in cultivated city gardens. The common honey bee we

\footnotetext{
J.S. MacIvor $(\varangle)$

Department of Biological Sciences, University of Toronto Scarborough, Toronto, ON, Canada e-mail: scott.macivor@utoronto.ca
} 
encounter in cities (Apis mellifera) is actually but one of many bee species that make up a bee pollinator community. Wild bees, that is, all those that aren't managed, live all around us and our actions greatly impede or encourage their presence and abundance (Kevan 1999). Many elements in cultivated city gardens and urban green spaces in general contribute to the number and type of wild bees present throughout the year. Although bees are sometimes less diverse in urban areas than in non-urban areas (McIntyre and Hostetler 2001; Winfree et al. 2011), designs of urban gardens that explicitly target pollinators by enhancing native plantings and nest site augmentation appear to increase their diversity and abundance (McKinney 2002; Tommasi et al. 2004; Pawelek et al. 2009; Grissell 2010). Another factor is the total area of space being gardened or planted. Smaller urban green spaces tend to support lower bee species diversity than larger ones (Cane et al. 2006; McFrederick and Lebuhn 2006). Other elements might include the garden and neighborhood age, land-use history, the planting arrangement, maintenance, and the distance from other natural or suitable habitat, to name just a few (Fetridge et al. 2008; Hernandez et al. 2009; Matteson and Langellotto 2009; Schüepp et al. 2011).

Including space for the foraging and nesting requirements of wild bees and other pollinators should be integrated into gardening activities (including planning and maintenance/upkeep) in cultivated city gardens. For some bee species this can be pretty easy to accommodate. Although intent to 'help' or house 'bees' is often centered on keeping honey bees and acknowledging their role as urban pollinators (in return, honey rewards the diligent beekeeper), efforts to support wild bee populations are arguably more important for a more resilient urban pollinator community. Can we do both? The answer is, of course, maybe. Fortunately, both honey and wild bees benefit from the higher flower diversity and abundance inherent in some of our cities vs. surrounding areas (Grimm et al. 2008). Furthermore, there are no overlaps in the nesting sites used or the nesting material requirements of honey bees and wild bees (except in the tropics) and so managing honey bees could be used to augment pollination by wild bees (Kremen et al. 2004) but this requires further study.

\section{Why Wild Bees in Cultivated City Gardens?}

The most important benefit to encouraging wild bees in cultivated urban gardens is pollination services. Diverse wild bee populations in cultivated areas have been linked to enhanced quantity, quality, and stability of crops (Kremen et al. 2002; Holzschuh et al. 2012; Klatt et al. 2014), even in systems where honey bees are active pollinators (Greenleaf and Kremen 2006a; Garibaldi et al. 2013). Encouraging insect pollinators in cultivated city gardens ensures that plant pollinator interactions ensue; a mutually beneficial relationship where plants successfully reproduce and bees get to eat. While unintentionally transferring pollen grains (the male sexual gamete) between flowers, from stamen (male organ) to pistil (female organ), bees are gorging themselves on pollen, nectar, and other floral components, as well as packaging it up for transport back to the nest to provision brood cells containing bee 
larva. Plant reproduction and more importantly, genetic variability, is dependent on this elegant arrangement. As stewards of this relationship, we accumulate more and better quality crops. Not all cultivated plants require insect pollination; some (such as tomatoes) can self-pollinate whereas others rely on the wind (e.g. anemophily) or water (e. g. hydrophily) to disperse pollen to other flowers (Ackerman 2000). Most plants that depend on wind or water rather than insects for pollen transfer are grasses and trees. Despite not requiring pollinators, bees and other insects visiting these flowers can still eat, and doing so can enhance the yield and seed set of some of these crop species, such as tomatoes (Greenleaf and Kremen 2006b) (Fig. 1).

Encouraging bees in cultivated city gardens can also indicate to citizens the health of the local environment; as has been demonstrated in traditional agricultural settings (Tscharntke et al. 1998). The abundance and diversity of bee pollinators, especially native ones, is especially important to document in these systems as native pollinators have been demonstrated to be in decline in many habitats around the world (Biesmeijer et al. 2006; Colla and Packer 2008; Potts et al. 2010; Cameron et al. 2011; Ollerton et al. 2014). Declining pollinator populations will have numerous impacts on food security (Klein et al. 2007) and land use (Aizen et al. 2009). Some of the principle drivers of wild bee declines are habitat destruction, degradation and fragmentation, all of which commonly occur in urban landscapes and are implicated in limiting bee foraging, mating and nesting site location and safety (Williams et al. 2010; Ollerton et al. 2011).

Another motivation for enhancing habitat for wild bees in cultivated city gardens is that they are flagship species for conservation biology in all terrestrial environments (Guiney and Oberhauser 2009). Bees are 'charismatic mini-fauna': attractive,
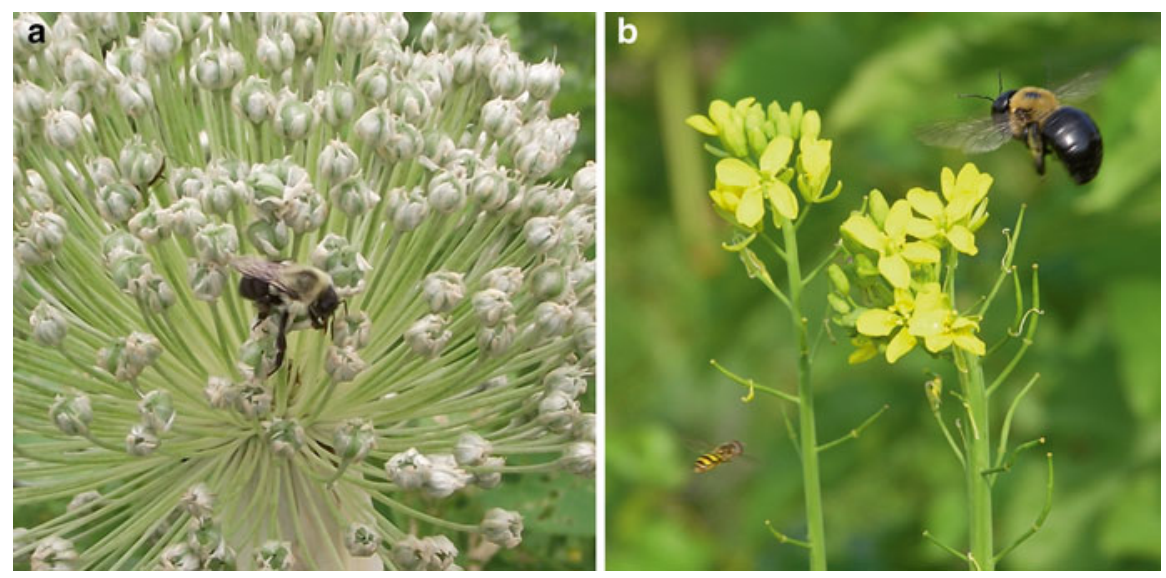

Fig. 1 (a) Bombus impatiens (identified by Sheila Colla) visiting leek (Allium ampeloprasum) flowers. (b) A carpenter bee (Xylocopa virginica) and a syrphid fly visiting the flowers of mustard greens (Brassica sp.). Many bees benefit from cultivated crops not typically associated with pollination. Although we consume the stem and leaves of these plants, pollinators can contribute significantly to seed set and thus increasing the potential number of seedlings available in the next growing season. Photos taken by Susan Berman 
colorful, and interacting with countless other species in most landscapes and thus are important for outreach and education on biodiversity. Doubly important in this respect is that wild bees are diverse and as such, bees can be useful for introducing and educate people on the value of biodiversity and concern for wild species outside the city and beyond. Cultivated city gardens act as a platform in conveying this message and inspire urban citizens to be concerned for the environment.

Does enhancing bee habitat in urban gardens increase the risk of being stung? There are no data to support this claim however neighbors can sometimes illicit negative sentiments towards enhancements for bee pollinators in cultivated city gardens for fear of being stung. For those having allergies this is a very rational concern, but generally if encroaching on a bee, it will want very little to do with you and will fly away as quick as it can. Moreover, male bees don't sting, only females (and even then not all females as the ability to sting has been lost in many bee lineages), reducing the number of potential incidents in a garden. Bees being so diverse too, some are more likely to sting than others. For example, social bees, like honey bees or bumble bees that form castes of queens and workers are much more likely to sting than solitary bees, which make up the majority of bee species in most habitats. Although generally only stinging if threatened, social bees sting to defend their queen, the hive or honey stores - none of which are a concern to the solitary bee. Solitary bees, unlike social bees, provision their own individual nests and so stinging is extremely disadvantageous and 'a last resort' as it puts them in harms way, and thus their potential offspring exposed to predation and parasitism (Krombein 1967).

\section{Forage for Bees in Cultivated City Gardens}

In studies examining both local and landscape factors that influence bee populations, local factors including the quality of the surrounding land cover appear to be most important (Kennedy et al. 2013). Thus, conditions present within a cultivated city garden are important in determining the bee abundance and diversity present (Cane et al. 2006; Smith et al. 2006; Matteson et al. 2013). This means that designing gardens for pollinators will help populations in the local community, especially when efforts are scaled up across households and neighborhoods (Goddard et al. 2010).

Selecting and planting cultivated crops carefully to extend the flower blooming period over the entire season can improve pollination of targeted cultivated crops (Sheffield et al. 2008). When approaching an enhancement strategy for wild bees in cultivated city gardens, it is important to first map out when different plants will flower over the blooming season and spot where there are gaps in the flowering plan. Planting a diversity of native species, including edge plantings, for added aesthetics, or saleable as seeds, cuttings, or flowers for other economic incentive will also ensure there is constancy in blooming in the garden through out the entire growing season (Fig. 2). This is critical for bees; different bee species emerge at 


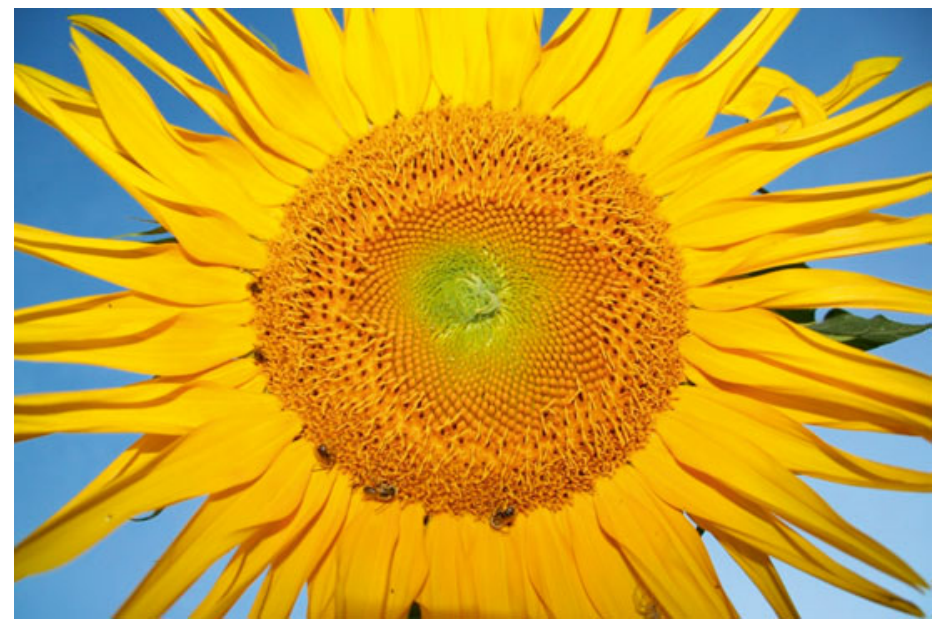

Fig. 2 Several long-horned bees (Melissodes sp.) are seen pollinating a sunflower (Helianthus sp.). Sunflowers are one of the best flowering plants for wild bees in cities; the flowers are large and easy to spot from a distance, and while many flowers bloom and finish within hours or days, sunflower can bloom over much long period. Photo taken by Susan Berman

different times of the year and some (e.g. bumble bees and some sweat bees) are active and hungry all season. Bumble bee (Bombus: Apidae) colonies for example increase in size over the growing season and need increasing quantities of floral resources over the season. Constant blooming is important also to ensure bee groups that are active for only a short period over the entire season have something to eat. For example, Mason bees (Osmia: Megachilidae) are active in spring and the beginning of summer, whereas others, like some leaf-cutting bees (Megachile: Megachilidae) won't begin foraging until mid summer but will stay active until the beginning of the fall while still others, such as goldenrod-loving Colletes (Family: Colletidae) species will only be active late in the year.

As important as the blooming period is the number of flowers available at any one time as well as their positioning in the garden. Intuitively, one study found that pollen deposition on cucumbers by pollinators increased significantly in larger gardens and in those containing more of the same cucumber plants (Werrell et al. 2009). Increasing the number of flowers can be achieved by planting for flowers at different heights in the garden; this could include flowering groundcover, tall perennials and shrubs, as well as deciduous trees. Fruit trees are particularly favorable for enhancing bee habitat in urban community gardens but too many can create excessive shade that will also deter bees - they prefer the sun (Matteson et al. 2008). Trees yield more flowers for bees, as well as more fruit for gardeners than does cultivating small patches of annual or perennial crops. Many fruit bearing trees such as apple and cherry also bloom early in the season, providing essential resources for early emerging bees when pollen resources are less abundant (Bosch and Kemp 2002). Including native and ornamental flowering non-crops as well as tolerating some 
flowering 'weeds' too can increase the number of flowers in the garden at any one time, buffering blooming periods when target crops are not in flower. Many ornamental and native flowers included in cultivated city gardens have long blooming periods; examples include coneflower, brown-eyed susans, evening primrose, and foxglove (Matteson et al. 2008) (Fig. 2). Bees that pollinate these non-cultivated native plants also increase seed set and fruiting structures that provide additional resources for other desirable fauna such as birds especially in winter or other resource limited seasons (Aronson et al. 2014).

Another source of forage for wild bees in cultivated city gardens are the city's cosmopolitan flowering plant community, better known as 'weeds' like Dandelions, Selfheal, and White clover (MacIvor et al. 2014; Larson et al. 2014). In neglected gardens, some weeds, especially those labeled as invasive species, can colonize and will compete with cultivated plants for nutrients, water, space, and light. These are sometimes removed using inorganic herbicides (Kearns et al. 1998); however at manageable densities, colonizing urban plants can enhance garden blooming period and the diversity of resources in the garden, both of which contribute to bee habitat.

Another way is to remove weeds manually. Weeding is sometimes hard work, but worthy exercise and a great community-building activity in cultivated city gardens. As well, it is an opportunity for learning which are 'good' and 'bad' weeds to encourage pollinating insects. That is, which can be left to grow and flower in cultivated city gardens. Constant mowing of lawn grasses or weeding might reduce the floral resources available to local bee populations. However, not all cosmopolitan flowering plants are desirable to bees; some bees might view many of these flowers as a last resort, or avoid them entirely. In most cases, crab grasses and other early successional weedy species (Shepherd's purse, Lamb's quarter, Broad leaf plantain) that cover bare soil should be removed as often as possible (although some of these are edible).

Another group of flowering plants to avoid that are typical of urban gardens are horticultural varieties of flowering plants that hide away their pollen and nectar beneath series of petals and ornamentations, reducing the floral rewards available for bees. One study in gardens in England compared attractiveness of flowering marigolds, snapdragons, pansies, hollyhocks, and other common garden flowers with horticulturally modified versions of each, finding that the latter were visited less frequently by bees and by fewer bee species (Comba et al. 1999). The authors did not attempt to investigate the impact this has on seed set and subsequent value to other species, but without pollinators it is suggested there would be declining wildlife value with the modified versions. Roses are another example of a group of flowers common in urban gardens that range in floral form from basic open flowers that are easily visited by bees to large and complex flower types, having multiple petals folded over the sourced of pollen and nectar; making it too difficult to breach for small bees. 


\section{Honey Bees}

Honey bees are the most managed insect worldwide, having significant economic, cultural and environmental implications for humans (Seeley 1985). Increasingly, honey bees are kept in cities, in part because the necessary equipment and materials to manage a hive are more accessible but also due to global declining populations which has amplified public interest. Honey bees are social, amassing large colonies which are housed in wooden box hives of various designs. Coaxing honey bees into nesting in these particular structures has been a pivotal point in their success in and significance to intensive agriculture; hives can be moved around to where pollination is most needed. In urban environments, hives are usually fixed in place and not moved around.

There are many advantages to keeping honey bees. Honey bee colonies greatly increase the abundance and activity of pollinators in fragmented landscapes like spatially separated urban gardens. They forage further and longer than wild bees, their colonies can be inspected for parasites and disease, and entire colonies, as mentioned, can be re-located when necessary. Keeping honey bees can also increase and diversify the users of community based cultivated city gardens as it teaches different skill sets not common to conventional urban gardening practices.

Few feral honey bee colonies persist in cities, usually ending up in houses and buildings and sometimes in trees, but the majority are managed privately in home and community gardens, industrial parks, municipal properties and research areas, as well as increasingly on building roof tops where they are away from direct contact with most people (Fig. 3). In London, UK, there are hundreds of urban beekeepers and their activity is promoted to have a positive impact on urban food production (Garnett 2000). However, there has been some backlash in London with too many 'novice' bee keepers saturating the city with honey bees, potentially causing competition among them (Benjamin 2011). Moreover, focus on honey bees could in fact, conflate the issue of bee diversity conservation and pollination by drawing enthusiasm and research funding away from native pollinator issues (Ollerton et al. 2012). In urban landscapes, where the distribution and diversity of wild bees is largely unknown, more honey bees might mean more pollinating insects compensating for those lost due to pressures of urbanization.

Keeping bees can also provide saleable products for cultivated city gardeners through honey, wax, propolis, among and other products. For example, a healthy medium sized urban hive may yield 50-80 lbs of honey per year. Honey cultivated from hives managed locally in the city can even fetch premium rates from buyers at local markets and shops - well above the price paid for wholesale honey [ $\$ 3 /$ pound US from 2005 to 2009 (Halter 2010)]. Honey production in managed hives in a cultivated city gardens can add to the economic feasibility of gardening, especially where the objective is to produce crops for sale. However, due to increasing commonness of honey bee keeping in cities, the demand for local honey by consumers is easily met. Grewal and Grewal (2012) compared three intervention models for 

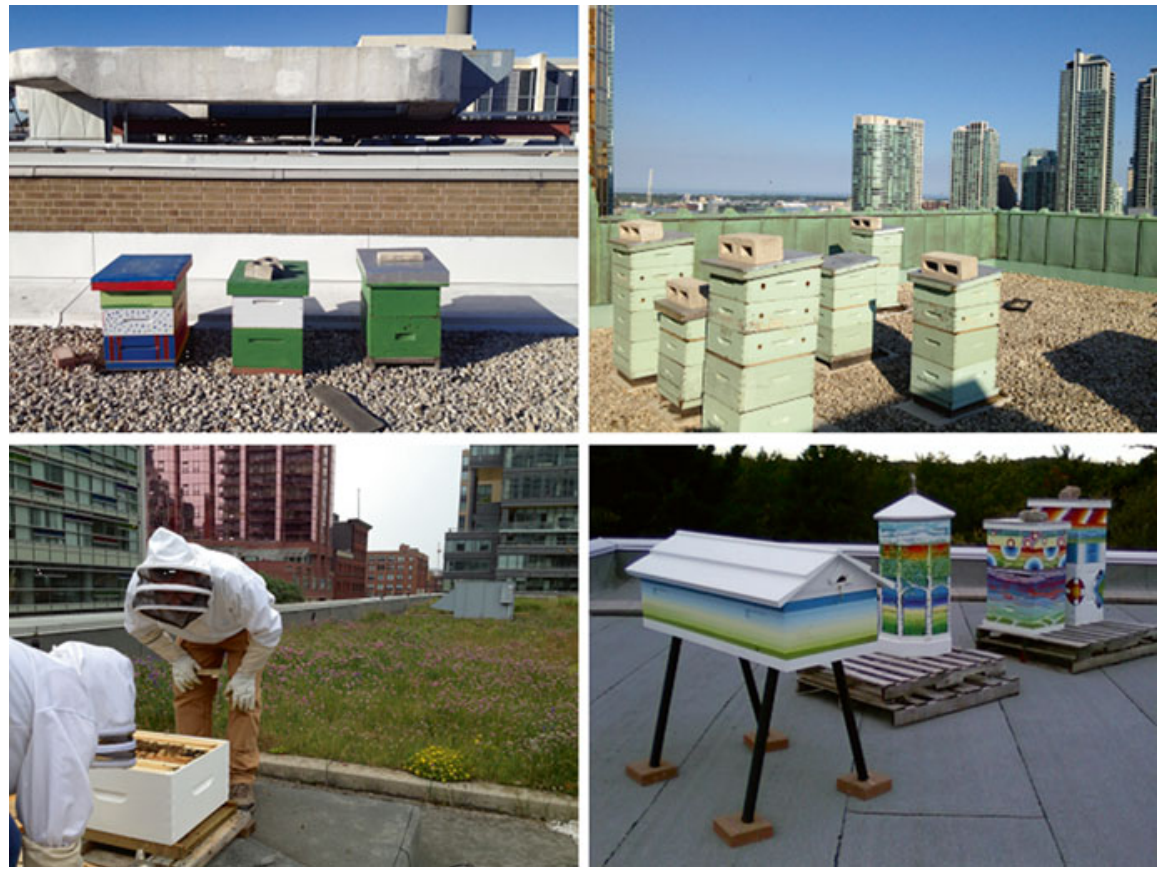

Fig. 3 Some examples of ingenious hive designs and locations in cities. Honey bees don't need to be set up directly in a cultivated city garden for the garden to benefit from the extra pollination services. Honey bees forage within an area around their hive and so more and more people are choosing to set up their hives on roofs. Local ground level plantings benefit from increased pollination while those allergic or who despise bees won't have to experience them up close in large aggregations as they'll fly up onto and off of the roof where crowds of humans aren't

vacant lot development having incremental levels of area dedicated to cultivated crops all of which included honey production. In all three scenarios $100 \%$ of local honey demand was attained, presumably at the expense of other local bee keepers selling their products in the area.

\section{Wild Bees}

Wild bees are diverse (over 20,000 species recorded worldwide) but unfortunately for many species we know very little about their nesting and foraging requirements, including those found around and in urban landscapes. The majority of wild bees are solitary. This means females mate (males die soon after) then go on to provision their nests independently. There are some wild bees that are eusocial (some in Halictidae), which involves cooperative brood care among females, sometimes of different generations. Finally, few are social (some Bombus; bumble bees), like honey bees having a caste system as previously described. 
Wild bees can be divided by their floral requirements, for example, whether they are generalists on many flower types and taxa, or are specialists on particular flowers. Some wild bees have special habitat requirements that may disappear with urbanization and landscape change. These bees have a hard time adjusting to living in these human centered landscapes, unlike generalist bee species that can substitute different foraging and nest building material resources in order to survive and reproduce in areas that are different from the natural landscape within which they evolved (MacIvor and Moore 2013). Bee community surveys in urban landscapes generally indicate that bee floral specialists are scarce (Cane 2005; Cane et al. 2006; McFrederick and LeBuhn 2006; Fetridge et al. 2008; reviewed in Hernandez et al. 2009). Bee species needing this special attention could potentially benefit from scaled up efforts across many cultivated city gardens to conserve the specific foraging (or nesting) requirements of the species.

Generalist bees have more flexibility in the types of forage conditions they need. These include the more common - even 'cosmopolitan' - bee species, and these 'urban adapters' are important even where managed honey bees are abundant. For example, one bumble bee, Bombus impatiens was found to visit $78 \%$ of crop species surveyed in cultivated gardens in New York City (Matteson and Langellotto 2010). Although this species is one exception, more generally wild bees are recorded less often in more isolated urban spaces (Ricketts and Imhoff 2003), and this results in lower crop yield (Cunningham 2000), even when honey bee visitation were unaffected (Garibaldi et al. 2011). One might then posit that cultivated city gardens embedded in highly urbanized landscapes might experience lower yields unless wild bees are present in the local landscape and can find the garden.

Thankfully, several recent studies have demonstrated that both urban and suburban areas, but especially cultivated city gardens can be hotspots for large numbers of certain bee groups. The species are most often generalists, including common bumble bee species (Goulson et al. 2002; Osborne et al. 2008; Matteson and Langellotto 2009) and cavity-nesting bees (Matteson et al. 2008). Giles and Ascher (2006) determined there to be more than 220 bee species in the New York City Area, and over 350 species are thought to be found in the city of Toronto (Grixti and Packer 2006; Packer et al. 2016).

Wild bees are often further delineated from one another by their nesting strategy. The most common division concerns whether bees nest below the ground or above it. Ground nesting bees are most diverse, but in urban landscapes can be the most nest site limited due to excessive paving and foot traffic (Cane 2005). Above-ground nesting bees, called cavity-nesting bees, nest in plant stems and in living or dead wood, preferring dark and dry holes approximately the width of their own body. 


\section{Cavity-Nesting Bees}

Cavity-nesting bees use pre-excavated holes as nesting sites into which they gather material from the local area to create individual brood cells in a line from the back of the cavity to the front. Buildings and management of urban green space can provide many suitable places for nesting by cavity-nesting bees, including walls, eaves, roofs, cut stems, as well as living, dead or dying trees (Fig. 4). Many of these bees will also readily use holes intentionally created for them to enhance their populations, like drilled holes in wood, reed or bamboo shoots, and rolled up paper or cardboard tubes in place of their natural nesting locations (Krombein 1967; Mader et al. 2010). These porous materials act as 'bee hotels', which are analogues to natural nesting conditions and can be set up in a wide range of places including cultivated city gardens to increase nesting opportunities for these wild bees (MacIvor and Packer 2015).

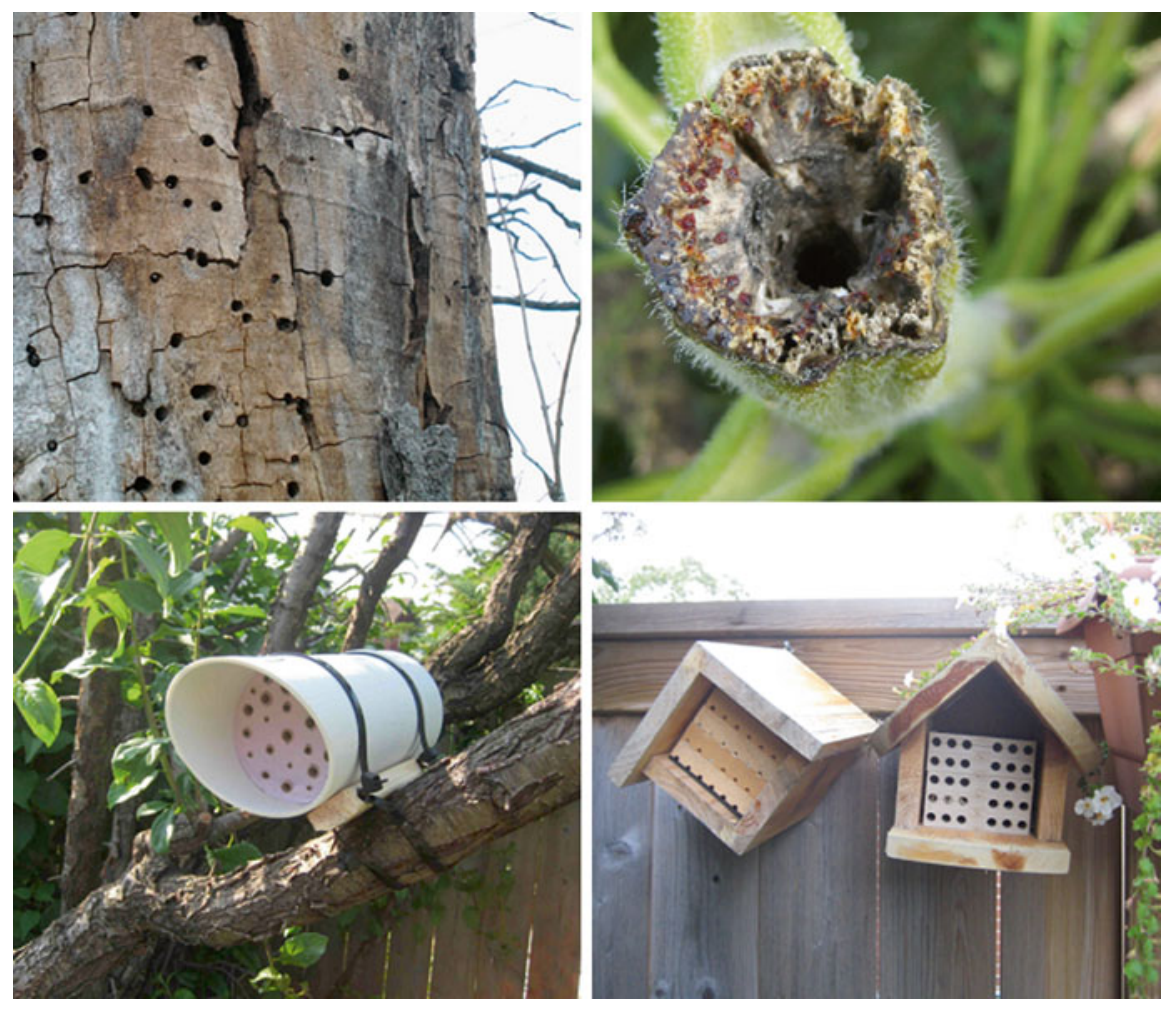

Fig. 4 Cavity-nesting bees look for dark and dry holes found naturally in wood and plant stems, but also those present in infrastructure (e.g. nail and drill holes). Mader et al. (2010) provides an excellent overview of different 'bee hotel' designs and how to construct them 
Natural nesting opportunities for wild bees can be integrated into the cultivated city garden. For cavity-nesting bees, coarse woody debris, especially large, decomposing logs or tree stumps with bark and holes bored into by beetle larvae can become a fantastic place to observe the activity of cavity-nesting bees on warm days. Large pieces of wood, rather than being destroyed by chipping into mulch by municipal or private maintenance crews can act as partitions between plots, as part of a raised bed, seating, or as 'living' art in the garden. Cavity-nesting bees will also benefit from dried plant stems cut $15 \mathrm{~cm}$ or longer. Some can be left in the ground and others cut, bundled together and attached to a fence, stake, or tree where exposed to morning or all-day sunlight. Trimming woody shrubs and small trees that have pithy stems, like Raspberry (Rubus spp.) or Sumac, leaving as close to $15 \mathrm{~cm}$ or more will encourage cavity nesting bees that prefer pithy stems to nest in. Other good plant stems and canes including Teasel, Cup plant, Blackberry, or Elderberry. The main inhabitants of these nest sites will be cellophane bees (Family: Colletidae), if the width is larger $(>4 \mathrm{~mm})$, one might expect mason bees, leaf cutter bees, or wool carder bees to nest (Krombein 1967).

As is with many characters of bees there are exceptions to the rule, and a few species prefer to make the cavities themselves; in gardens, these will be carpenter bees. Ceratina (Family: Apidae), which are small blue-ish black bees that prefer to nest in erect plant stems having soft pith. These bees sculpt the pith neatly around each brood cell in an effort to reduce parasites and predators getting deeper and deeper into the nest. Another common garden bee excavating it's own nest in wood is the related, but much larger carpenter bee (Xylocopa virginica) (Family: Apidae). This bee prefers infrastructure, including grape arbours, or overhangs, awnings, or trellises made of wood on fences or buildings. This bee is one of the few wood chewing bee species common in urban environments.

Although 'bee hotels' (also called nest boxes or trap nests) have been shown to house numerous cavity-nesting bee species it is not clear to what extent they contribute to native bees in urban areas and specifically in cultivated city gardens. Low colonization is one concern; Gaston et al. (2005) found low colonization in nest boxes and suggested they are not particularly useful as habitat in urban gardens, but that there is value as educational tools. Another is the potential proliferation of solitary wasps or exotic bees over native ones, or the aggregation of pests or parasites (Wcislo 1996; MacIvor and Packer, 2015). Maintaining these structures is essential to reduce these impacts and will require cleaning out cavities or replacing them each year to exclude these.

\section{Ground Nesting Bees}

Most bee species nest in the ground. Some ground nesting species, particularly those small sweat bees in the family Halictidae are common and some among the most abundant bees in cities. Some leaf-cutting bees too will nest in the ground and 

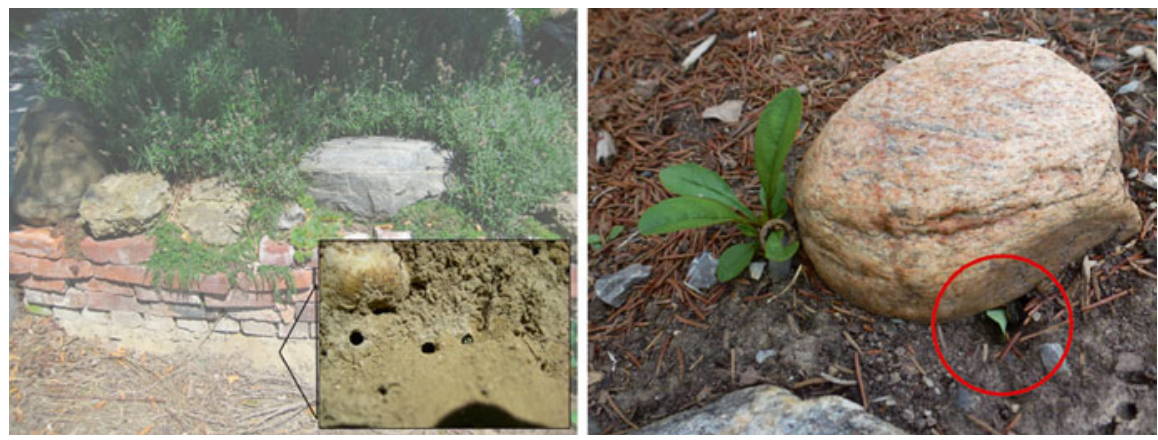

Fig. 5 Some of the non-descript nesting sites used by different ground nesting bees in cultivated city gardens. To the left, a series of sweat bee nests (Dialictus: Halictidae) line the base of a brick retaining wall. Once wild bee nests are noticed in the garden, to encourage them keep vegetation from encroaching over the entrances to the nest. Note also that these bees are nesting on a slight embankment; some bees will prefer flat bare ground whereas others prefer an incline. To the right is a ground nesting leaf cutter bee (Megachile: Megachilidae) taking a leaf piece underground. Large stones can protect a nest from compaction and being covered by mulch. Mulch can prevent bees getting into a nest (or worse, being trapped underground). If mulching, keep some spots clear, or at minimum, wait until the fall to mulch some areas, removing it in the spring

some are very common in diverse, 'naturalized' gardens (Fig. 5). Others, such as mining bees (Family: Andrenidae) and some colletid bees are less often recorded in surveys of wild bee populations in urban areas (Hernandez et al. 2009). Xie et al. (2013) noted a significant decline in ground nesting bee nest sites with increasing human settlement. These bees are limited in urban landscapes by the proportion of impervious paving and coverings on the ground surface as well as human population density and accompanying foot traffic (Cane 2001). Site history and the condition of the soil just below the surface can impact bee colonization of ground. Many urban green spaces contain varying levels of heterogeneity in soil types and in soil profile, compaction, and grading (Edmondson et al. 2011), this can include concrete, and other building materials beneath the soil surface that impedes a bee mid-nest excavation.

Ground-nesting bees are very diverse. Some ground nesting bees prefer bare, dry sandy or loamy soils, others prefer sparse vegetation, old-patchy lawns, or the base of a woody shrub or around the edge of stones (Cane 1991; Sardinas and Kremen 2014) (Fig. 5). In cultivated city gardens, ground-nesting bees also have to contend with minimal amounts of bare soil (coveted by gardeners for new plantings of crops, mulch or grass seed, or configured as walking area) and disruption of soils through perpetual watering, digging and even tilling. Overgrown vegetation can block nest entrances and roots increase difficulty in excavating nests, which vary considerably in shape, size, and burrow direction, depending on the bee species. Thus choosing edges or left alone spots are best, like the soils found along edges of fences or other infrastructure encircling the garden or rockeries, especially if south or southeast oriented. 
Designing walking paths with wooden planks, large flat stones or other "stepping" feature that guide gardeners and visitors such that trampling bare soil and "walking off the trail" is reduced will aid in minimizing soil compaction, encourage bee colonization, and provide unique non-planted design in the garden space. Some ground nesting bees will prefer to nest at the edges of these delineated trails where it is easy enough to dig but compact enough to stay intact. Signage that acknowledges solitary bees in cultivated city gardens can also be helpful for discouraging foot traffic and disruption of the area (many bees use objects like sticks and rocks to orient by enabling them to navigate back to of their nest). Supplementary irrigation too can impact bee nest sites in cultivated city gardens by excess water washing away nest entrances. Finally, excessive mulching with any material can block bee nests, inhibiting foraging bees from returning and those bees trapped below from leaving, ultimately killing any unfortunate bees left inside the nest.

Despite all efforts to provide suitable nesting requirements for them, some ground nesting bees will choose a more tucked away location in cities, especially those making larger sized nests underground, including social bumble bees. Although Matteson et al. (2008) found bumble bees in abundance in cultivated city gardens through out New York City, no nests were located over five years of observation. This suggests smaller sized cultivated city gardens or those experiencing significant human activity, may not be as suitable for nesting bumble bees than would less busy urban meadow, road easements, or urban forest fragments (McFrederick and Lebuhn 2006). The presence of some bee species in community gardens will therefore depend on the connectedness of urban green spaces in the vicinity that supports nesting requirements (Westrich 1996). For large colony forming bees like bumble bees, or solitary colletes bees that aggregate sometimes hundreds of individual nests together, this is probably an optimal relationship, as naturally forming large colonies of bees can be frightening for some people inexperienced with direct contact with bees. Fortunately, larger bee species like bumble bees can forage longer distances (Greenleaf et al. 2007). Small, solitary ground nesting bees are likely to benefit more from nesting sites located in or adjacent to cultivated city gardens, as most prefer to travel the shortest distance possible from nest to foraging resource (Zurbuchen et al. 2010).

\section{Nesting Material}

In addition to a nest site, some bees need to incorporate extraneous materials into the nest to make brood cell linings. These materials enclose individual cells that contain the collected pollen and nectar used as food for the complete development of a single individual bee larva. Leaves, resins, and petals from plants, as well as a variety of other materials like mud and pebbles are also used by different bee species to build their nests, which together with nesting locations likely comprise the most limiting factors for the presence of bees in urban gardens and in cities in general. 

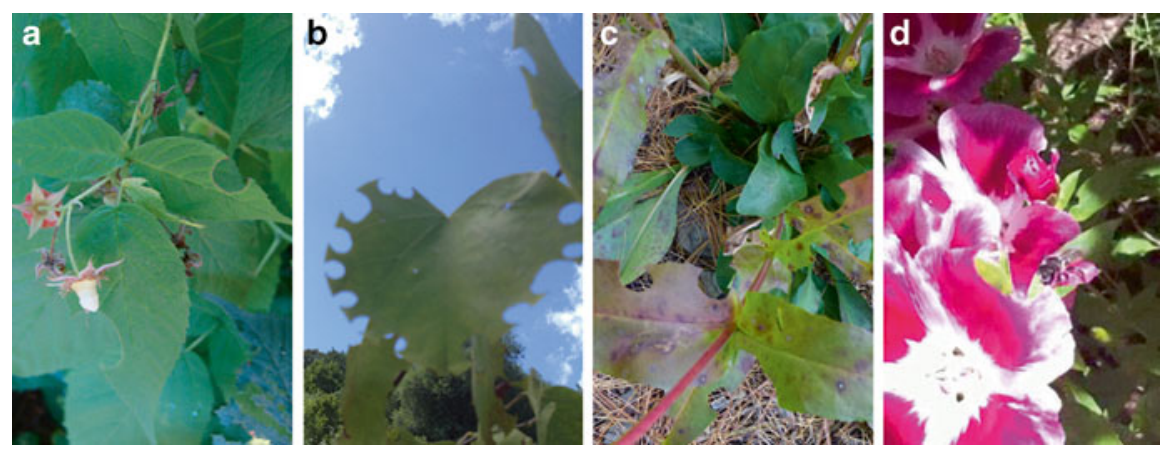

Fig. 6 Different plant, shrub, and tree species used by leaf cutter bees (Megachilidae) in North Eastern North America. Some use a variety of different leaf types while other bees are more particular in the type of leaf used. Here are just a few examples: (a) Raspberry (Rubus sp.) (photo by Sara Schraf), (b) Redbud (Cercis canadensis), (c) Beard-tongue (Penstemon digitalis) (photo by Deborah Chute), (d) Hollyhock flower (Alcea sp.)

Even among solitary bees, there is tremendous variation in the kinds of nest materials collected. Some haven't any collecting to do, they secrete the nesting material themselves (e.g. Hylaeus spp.) or use the chewed pith from stems (e.g. Ceratina spp.). Gardeners can have significant control over the number and types of leaf-cutter bees (family: Megachilidae) found locally; most of these bees cut semicircular sections of leaves and even flower petals from trees, shrubs, and vines but unfortunately there are little data on which species collect which leaf types (Fig. 6) or which leaf characteristics they seek (Horne 1995). Some megachilid bee species (Anthidium spp.) have more unique tastes: they carefully collecting the hairs from the surfaces of plant leaves and stems to line their nests in plant stems or holes in wood. Ensuring there are some 'hairy' leaved plants such as Sage or Lamb's Ear can encourage these bees (as well as having purple flowers as food sources, which they prefer). Mason bees are a little easier to satisfy in urban landscapes as they collect mud and masticated leaves from various plant species (Cane et al. 2007).

\section{Cultivated City Gardens as Wild Bee Boosters}

Cultivated city gardens can be havens for bee diversity. Matteson and Langellotto (2009) found bumble bee populations to be five times greater than that of managed honey bees in New York City community gardens. Cultivated city gardens could be harnessed to contribute to strategies to conserve bee populations. There are countless opportunities for biologists and researchers to study urban ecology by connecting with citizen scientists and a cities' community gardening network. The Toronto 
Community Gardening Network for example, has supported several citizen science research projects on pollinators in urban agriculture including the cataloguing of a local pollen synoptic collection and studies on behaviour and diversity of cavitynesting bees (MacIvor et al. 2014). Managed urban commons that provide high quality bee habitat like cultivated city gardens could aid in the connectedness of urban green space needed for the movement of bees and other pollinating insects. In this regard, community gardening and the cultivation of pollinator requiring crops are cost-effective ways for action supporting local food security and urban biodiversity conservation (Dearborn and Kark 2010).

In collaboration with municipal planners, community members, designers, and ecologists, cultivated city gardens could reduce fragmentation and provide targeted or sustained resources for at-risk species and wild bees more generally. Indeed, urban gardeners tending crops might realize greater pollination and subsequent yield if cultivated plots are maintained in proximity to or clustered with complementary land use types having resources for bees. This could include nesting space for ground nesting or nesting materials for cavity-nesting bees in woodlots, remnant forests, parks, or other natural areas (Westrich 1996; McFrederick and Lebuhn 2006; Colding 2007). Carefully selecting the locations of cultivated city gardens to include complimentary land use types nearby could enhance pollinators without any extra effort by gardeners during the growing season. Since management and maintenance in cultivated city gardens is often the responsibility of the local community and not municipalities, adaptive management that includes information sharing among gardeners so that adjustments can be made based on new findings and trial and error is essential (Colding and Barthel 2013). For example, finding ground nesting sweat bees along a fence bounding the garden could inform when to schedule maintenance and where to rake and/or mulch in the area. Most important is to share the information and experience with other gardeners to ensure the area is conserved and protected.

\section{Limitations for Bees in Urban Landscapes}

One significant limitation in enhancing native bee habitat in cultivated city gardens is the unintended promotion of habitat for exotic species, which could outcompete native bee species for shared resources (e.g. natural nesting sites). This could also lead to cities becoming source populations for exotic bees that then proliferate outward beyond the city limits into natural areas. Cities, both towards the centre and compared to the suburbs tends to have different bee communities than those collected in nearby naturalized or non-urban areas (Fetridge et al. 2008; Matteson et al. 2008). The level of disturbance and change compared to surrounding naturalized areas is dramatic (Pouyat et al. 2007) and too much for native species adapted to 
particular environments to thrive (Dearborn and Kark 2010). Although many native species do persist as urban adapters having specific traits that facilitate their existence (Niemelä et al. 2000; Banaszak-Cibicka and Żmihorski 2012; MacIvor and Moore 2013), certain exotic species can dominate (MacIvor and Packer 2015). For example, some cavity nesting bees, such as Megachile rotundata will readily nest in both plant stems or those created by nails that have fallen out of aging brickwork on a building façade.

Another issue is to determine whether bee habitat enhancement is even worth considering in urban cultivated garden planning, design, and management. Urban landscapes undergo perpetual change and so action taken to protect wild and native pollinators will have to be flexible to potentially unforeseen challenges that present themselves over time. Also, the yields of many abundantly grown crops in cultivated gardens are not pollinator dependent. In many of these species flowering is discouraged; once formed, energy is directed away from foliage production to flower development. For example once flowering begins, lettuces, chards, spinach, and collard greens, are often removed from the garden to make way for another planting. However, seed set by crops cultivated for their foliage is useful to encourage usually in a fraction of the total crop for the next harvest. In these instances, bee and insect pollinator visits to flowers can greatly augment the number of seeds produced per plant. Collecting seeds can cut down on the expenditures incurred in buying seeds from suppliers each year. In cultivated community gardens, seed collecting can become a group activity in the garden and a way to engage the wider neighbourhood through sale or trade at local events (e.g. "Seedy Saturdays"; Baker 2004).

\section{Summary}

Despite the number of cultivated city gardens increasing dramatically in urban landscapes, the empirical data on pollinator diversity, pollen limitation, and overall success of cultivated crops in terms of yield lags far behind. Cultivated city gardens are poised to act as habitat for urban bee diversity and a source of associated benefits accrued by local citizens (e.g. native plant pollination, education). Surveying bees in cultivated city gardens makes apparent that they can host numerous bee species, and are potentially 'hotspots' for bees in landscapes of questionable habitat value. Yet to be determined is the relative impact of different enhancement strategies for pollinators and their pollination services. Nevertheless, supporting wild bee populations and diversity through human intervention, maintenance, and trial and error could have resounding impacts on our urban food production and security. 


\section{Additional Links}

\section{Resources}

Key to the bee genera of Eastern Canada (http://www.biology.ualberta.ca/bsc/ejournal/pgs_03/pgs_03_key.html)

Discover life (http://www.discoverlife.org)

Bug Guide (http://www.bugguide.net)

Managing Alternative Pollinators (http://www.sare.org/Learning-Center/Books/ Managing-Alternative-Pollinators)

PCYU (Packer Collection at York University) (http://www.yorku.ca/bugsrus/)

Pollination Guelph (http://www.pollinator.ca/guelph/)

\section{Organizations}

Xerces Society (http://www.xerces.org)

Pollinator Partnership (http://www.pollinator.org)

Pollinator Stewardship Council (http://pollinatorstewardship.org)

\section{Citizen-Scientist Projects}

Bumblebee watch (http://bumblebeewatch.org)

BeeSpotter (http://beespotter.mste.illinois.edu)

Great Sunflower Project (http://www.greatsunflower.org)

\section{References}

Ackerman JD (2000) Abiotic pollen and pollination: ecological, functional, and evolutionary perspectives. In: Dafni A, Hesse M, Pacini E (eds) Pollen and pollination. Springer, Vienna, pp 167-185

Aizen MA, Harder LD (2009) The global stock of domesticated honey bees is growing slower than agricultural demand for pollination. Curr Biol 19(11):915-918

Aizen MA, Garibaldi LA, Cunningham SA, Klein AM (2009) How much does agriculture depend on pollinators? Lessons from long-term trends in crop production. Ann Bot 103(9):1579-1588

Aronson MF, La Sorte FA, Nilon CH et al (2014) A global analysis of the impacts of urbanization on bird and plant diversity reveals key anthropogenic drivers. Proc $\mathrm{R}$ Soc $\mathrm{B}$ 281(1780):2013-2330

Baker LE (2004) Tending cultural landscapes and food citizenship in Toronto's Community Gardens. Geogr Rev 94(3):305-325 
Banaszak-Cibicka W, Żmihorski M (2012) Wild bees along an urban gradient: winners and losers. J Insect Conserv 16(3):331-343

Benjamin A (2011) Do urban bees have enough to eat? Guardian UK. Available at: http://www. guardian.co.uk/environment/green-livingblog/2011/aug/02/urban-bees

Biesmeijer JC, Roberts SPM, Reemer M et al (2006) Parallel declines in pollinators and insectpollinated plants in Britain and the Netherlands. Science 313(5785):351-354

Bosch J, Kemp WP (2002) Developing and establishing bee species as crop pollinators: the example of Osmia spp. (Hymenoptera: Megachilidae) and fruit trees. Bull Entomol Res 92(1):3-16

Breeze TD, Bailey AP, Balcombe KG, Potts SG (2011) Pollination services in the UK: how important are honey bees? Agric Ecosyst Environ 142(3-4):137-143

Cameron SA, Lozier JD, Strange JP et al (2011) Patterns of widespread decline in North American bumble bees. Proc Natl Acad Sci U S A 108(2):662-667

Cane JH (1991) Soils of ground-nesting bees (Hymenoptera: Apoidea): texture, moisture, cell depth and climate. J Kansas Entomol Soc 64(4):406-413

Cane JH (2001) Habitat fragmentation and native bees: a premature verdict? Conserv Ecol 5(1). http://www.consecol.org/vol5/iss1/art3/

Cane JH (2005) Bees, pollination, and the challenges of sprawl. In: Johnson EA, Klemens MW (eds) Nature in fragments: the legacy of sprawl. New York University Press, New York, pp 109-124

Cane JH, Minckley RL, Kervin LJ et al (2006) Complex responses within a desert bee guild (Hymenoptera: Apiformes) to urban habitat fragmentation. Ecol Appl 16(2):632-644

Cane JH, Griswold T, Parker FD (2007) Substrates and materials used for nesting by North American Osmia bees (Hymenoptera: Apiformes: Megachilidae). Ann Entomol Soc Am 100(3):350-358

Colding J (2007) 'Ecological land-use complementation' for building resilience in urban ecosystems. Landsc Urban Plan 81(1):46-55

Colding J, Barthel S (2013) The potential of 'urban green commons' in the resilience building of cities. Ecol Econ 86:156-166

Colla SR, Packer L (2008) Evidence for decline in eastern North American bumblebees (Hymenoptera: Apidae), with special focus on Bombus affinis Cresson. Biodivers Conserv 17(6): 1379-1391

Comba L, Corbet SA, Barron A et al (1999) Garden flowers: insect visits and the floral reward of horticulturally-modified variants. Ann Bot 83(1):73-86

Cunningham SA (2000) Depressed pollination in habitat fragments causes low fruit set. Proc R Soc B 267(1448):1149-1152

Dearborn DC, Kark S (2010) Motivations for conserving urban biodiversity. Conserv Biol 24(2):432-440

Edmondson JL, Davies ZG, McCormack SA et al (2011) Are soils in urban ecosystems compacted? A citywide analysis. Biol Lett 7(5):771-774

Fetridge ED, Ascher JS, Langellotto GA (2008) The bee fauna of residential gardens in a suburb of New York City (Hymenoptera: Apoidea). Ann Entomol Soc Am 101(6):1067-1077

Free JB (1993) Insect pollination of crops. Academic, London

Garibaldi LA, Steffan-Dewenter I, Kremen C et al (2011) Stability of pollination services decreases with isolation from natural areas despite honey bee visits. Ecol Lett 14(10):1062-1072

Garibaldi LA, Steffan-Dewenter I, Winfree R et al (2013) Wild pollinators enhance fruit set of crops regardless of honey bee abundance. Science 339(6127):1608-1611

Garnett T (2000) Urban agriculture in London, rethinking our food economy. In: Bakker N, Dubbeling M, Gundel S et al (eds) Growing cities, growing food. DSE, Zel, Feldafing

Gaston KJ, Smith RM, Thompson K, Warren PH (2005) Urban domestic gardens (II): experimental tests of methods for increasing biodiversity. Biodivers Conserv 14(2):395-413

Giles V, Ascher JS (2006) A survey of the bees of the Black Rock Forest Preserve, New York (Hymenoptera: Apoidea). J Hymenopt Res 15(2):208-231

Goddard MA, Dougill AJ, Benton TG (2010) Scaling up from gardens: biodiversity conservation in urban environments. TREE 25(2):90-98 
Goulson D, Hughes W, Derwent L, Stout J (2002) Colony growth of the bumblebee, Bombus terrestris, in improved and conventional agricultural and suburban habitats. Oecologia 130(2):267-273

Green M (2007) Oakland looks towards greener pastures: the Oakland Food Policy Council. Edible East Bay. Spring Issue: 36-37

Greenleaf SS, Kremen C (2006a) Wild bees enhance honey bees' pollination of hybrid sunflower. Proc Natl Acad Sci U S A 103(37):13890-13895

Greenleaf SS, Kremen C (2006b) Wild bee species increase tomato production and respond differently to surrounding land use in Northern California. Biol Conserv 133(1):81-87

Greenleaf SS, Williams NM, Winfree R, Kremen C (2007) Bee foraging ranges and their relationship to body size. Oecologia 153(3):589-596

Grewal SS, Grewal PS (2012) Can cities become self-reliant in food? Cities 29(1):1-11

Grimm NB, Faeth SH, Golubiewski NE et al (2008) Global change and the ecology of cities. Science 319(5864):756-760

Grissell E (2010) Bees, wasps, and ants: the indispensable role of Hymenoptera in gardens. Timber Press, Portland

Grixti JC, Packer L (2006) Changes in the bee fauna (Hymenoptera: Apoidea) of an old field site in southern Ontario, revisited after 34 years. Can Entomol 138(2):147-164

Guiney MS, Oberhauser KS (2009) Insects as flagship conservation species. Terr Arthropod Rev 1(2):111-123

Halter R (2010) The incomparable honeybee and the economics of pollination. Rocky Mountain Books, Surrey

Hernandez JL, Frankie GW, Thorp RW (2009) Ecology of urban bees: a review of current knowledge and directions for future study. CATE 2(1): http://escholarship.bc.edu/cate/vol2/iss 1/3

Holzschuh A, Dudenhöffer JH, Tscharntke T (2012) Landscapes with wild bee habitats enhance pollination, fruit set and yield of sweet cherry. Biol Conserv 153:101-107

Horne M (1995) Leaf area and toughness: effects on nesting material preferences of Megachile rotundata (Hymenoptera: Megachilidae). Ann Entomol Soc Am 88(6):868-875

Kearns CA, Inouye DW, Waser NM (1998) Endangered mutualisms: the conservation of plantpollinator interactions. Annu Rev Ecol Syst 29:83-112

Kennedy CM, Lonsdorf E, Neel MC et al (2013) A global quantitative synthesis of local and landscape effects on wild bee pollinators in agroecosystems. Ecol Lett 16(5):584-599

Kevan PG (1999) Pollinators as bioindicators of the state of the environment: species, activity and diversity. Agric Ecosyst Environ 74(1-3):373-393

Klatt BK, Holzschuh A, Westphal C et al (2014) Bee pollination improves crop quality, shelf life and commercial value. Proc R Soc B 281:20132440

Klein AM, Vaissiere BE, Cane JH et al (2007) Importance of pollinators in changing landscapes for world crops. Proc R Soc B 274(1608):303-313

Kremen C, Williams NM, Thorp RW (2002) Crop pollination from native bees at risk from agricultural intensification. Proc Natl Acad Sci U S A 99(26):16812-16816

Kremen C, Williams NM, Bugg RL et al (2004) The area requirements of an ecosystem service: crop pollination by native bee communities in California. Ecol Lett 7(11):1109-1119

Krombein KV (1967) Trap-nesting wasps and bees: life histories, nests, and associates. Smithsonian Press, Washington, DC

Larson JL, Kesheimer AJ, Potter DA (2014) Pollinator assemblages on dandelions and white clover in urban and suburban lawns. J Insect Conserv 18(5):863-873

MacIvor JS, Moore AE (2013) Bees collect polyurethane and polyethylene plastics as novel nest materials. Ecosphere 4(12): http://dx.doi.org/10.1890/ES13-00308.1

MacIvor JS, Packer L (2015) 'Bee hotels' as tools in native pollinator conservation: a premature verdict? PLoS One 10(3): DOI: 10.1371/journal.pone.0122126

MacIvor JS, Cabral JM, Packer L (2014) Pollen specialization by solitary bees in an urban landscape. Urban Ecosyst 17(1):139-147.

Matteson KC, Langellotto GA (2009) Bumble bee abundance in New York City community gardens: implications for urban agriculture. CATE 2(1): http://escholarship.bc.edu/cate/vol2/iss1/5 
Matteson KC, Langellotto GA (2010) Determinates of inner city butterfly and bee species richness. Urban Ecosyst 13(3):333-347

Matteson KC, Ascher JS, Langellotto GA (2008) Bee richness and abundance in New York City urban gardens. Ann Entomol Soc Am 101(1):140-150

Matteson KC, Grace JB, Minor ES (2013) Direct and indirect effects of land use on floral resources and flower-visiting insects across an urban landscape. Oikos 122(5):682-694

McFrederick QS, Lebuhn G (2006) Are urban parks refuges for bumble bees Bombus spp. (Hymenoptera: Apidae)? Biol Conserv 129:372-382

McIntyre NE, Hostetler ME (2001) Effects of urban land use on pollinator (Hymenoptera: Apoidea) communities in a desert metropolis. Basic Appl Ecol 2(3):209-218

McKinney ML (2002) Urbanization, biodiversity, and conservation. Biol Sci 52(10):883-890

Niemelä J, Kotze J, Ashworth A et al (2000) The search for common anthropogenic impacts on biodiversity: a global network. J Insect Conserv 4(1):3-9

Ollerton J, Winfree R, Tarrant S (2011) How many flowering plants are pollinated by animals? Oikos 120(3):321-326

Ollerton J, Price V, Armbuster WS et al (2012) Overplaying the role of honey bees as pollinators: a comment on Aebi and Neumann (2011). TREE 27(3):141-142

Ollerton J, Erenler H, Edwards M, Crockett R (2014) Extinctions of aculeate pollinators in Britain and the role of large-scale agricultural changes. Science 346(6215):1360-1362

Osborne JL, Martin AP, Shortall CR et al (2008) Quantifying and comparing bumblebee nest densities in gardens and countryside habitats. J Appl Ecol 45(3):784-792

MacIvor JS, Cabral JM, Packer L (2014) Pollen specialization by solitary bees in an urban landscape. Urban Ecosyst 17(1):139-147

Packer L, Dumesh S, MacIvor JS, Couto O, Harpur B, Sheffield C, Zayed A (2016) Bees of Toronto: a guide to their remarkable world. City of Toronto Biodiversity Series, Toronto

Pawelek JC, Frankie GW, Thorp RW, Przybylski M (2009) Modification of a community garden to attract native bee pollinators in urban San Luis Obispo, California. CATE 2(1). http://escholarship.bc.edu/cate/vol2/iss $1 / 7$

Potts SG, Biesmeijer JC, Kremen C et al (2010) Global pollinator declines: trends, impacts and drivers. TREE 25(6):345-353

Pouyat RV, Yesilonis ID, Russell-Anelli J (2007) Soil chemical and physical properties that differentiate urban land-use and cover types. Soil Sci Soc Am J 71(3):1010-1019

Ricketts T, Imhoff M (2003) Biodiversity, urban areas, and agriculture: locating priority ecoregions for conservation. Conserv Ecol 8(2):1 [online]

Sardinas HS, Kremen C (2014) Evaluating nesting microhabitat for ground-nesting bees using emergence traps. Basic Appl Ecol 15(2):161-168

Schüepp C, Herrmann JD, Herzog F, Schmidt-Entling MH (2011) Differential effects of habitat isolation and landscape composition on wasps, bees, and their enemies. Oecologia 165(3):713-721

Seeley TD (1985) Honeybee ecology: a study of adaptation in social life. Princeton University Press, Princeton

Sheffield CS, Westby SM, Smith RF, Kevan PG (2008) Potential of bigleaf lupine for building and sustaining Osmia lignaria populations for pollination of apple. Can Entomol 140(5):589-599

Smith RM, Warren PH, Thompson K, Gaston KJ (2006) Urban domestic gardens (VI): environmental correlates of invertebrate species richness. Biodivers Conserv 15(8):2415-2438

Tommasi D, Miro A, Higo HA, Winston ML (2004) Bee diversity and abundance in an urban setting. Can Entomol 136(6):851-869

Tscharntke T, Gathmann A, Steffan-Dewenter I (1998) Bioindication using trap-nesting bees and wasps and their natural enemies: community structure and interactions. J Appl Ecol 35(5):708-719

Wcislo WT (1996) Parasitism rates in relation to nest site in bees and wasps (Hymenoptera: Apoidea). J Insect Behav 9:643-656

Werrell PA, Langellotto GA, Morath SU, Matteson KC (2009) The influence of garden size and floral cover on pollen deposition in urban community gardens. CATE 2(1): http://escholarship. bc.edu/cate/vol2/iss $1 / 6$ 
Westrich P (1996) Habitat requirements of central European bees and the problems of partial habitats. Linn Soc Symp Ser 18:1-16

Williams NM, Crone EE, Roulston TH, Minckley RL, Packer L, Potts SG (2010) Ecological and life-history traits predict bee species responses to environmental disturbances. Biol Conserv 143(10):2280-2291

Winfree R, Bartomeus I, Cariveau DP (2011) Native pollinators in anthropogenic habitats. Annu Rev Ecol Evol Syst 42:1-22

Xie Z, Qiu J, Chen X (2013) Decline of nest site availability and nest density of underground bees along a distance gradient from human settlements. Entomol Sci 16(2):170-178

Zurbuchen A, Landert L, Klaiber J, Müller A, Hein S, Dorn S (2010) Maximum foraging ranges in solitary bees: only few individuals have the capability to cover long foraging distances. Biol Conserv 143(3):669-676 


\title{
Urban Agriculture as Habitat for Birds
}

\author{
Amanda D. Rodewald
}

For many, the idea that cities can support conservation seems near anathema - is not urban development a growing threat to biodiversity? While true that cities are responsible for destroying or degrading countless acres of habitat and that, once developed, are unlikely to provide high quality habitat to species of greatest conservation concern, they are not without value - especially for bird communities. Urban green spaces have potential to support a diverse assemblage of species and, therefore, can contribute to some dimensions of avian conservation. Even small parcels of green space within cities can attract birds of conservation concern, especially when patches are collectively managed as networks of green space (Goddard et al. 2009). Urban green spaces are represented by a wide variety of land uses, including parks, cemeteries, green walls, green roofs, and the focus of this book - urban agriculture (also commonly referred to more generally as "urban gardens"). Urban gardens and agricultural areas comprise a major component of green space within many cities (Loram et al. 2007), reaching an impressive 86 \% in León, Nicaragua (Gonzalez-Garcia and Sal 2008). In some cases, these small gardens can make important contributions to conservation. For example, biologists and managers in the UK are designing green roofs (also called "eco roofs") to provide habitat for the rare and protected black redstart (Phoenicurus ochruros; Grant 2006). Thus, any greening of cities, including by way of urban agriculture, can rightly be viewed as an opportunity to improve the ecological condition and conservation value of our cities.

Few studies have specifically examined bird communities associated with urban agriculture (Goddard et al. 2009), but local habitat attributes are already known to be a primary determinant of urban bird communities (Evans et al. 2009). Likewise, the extent to which birds use gardens generally reflects the extent to which gardens

\footnotetext{
A.D. Rodewald $(\bowtie)$

Cornell Lab of Ornithology and Department of Natural Resources, Cornell University, Ithaca, NY, USA

e-mail: arodewald@cornell.edu
} 
provide the key habitat components (i.e., food, cover, water and space to live). As the plant diversity and vegetation complexity of a garden increase, so too does the likelihood that a species will have its habitat needs met (Fernandez-Canero and Gonzalez-Redondo 2010). The structural complexity of habitat can be increased vertically by including plants of varying heights and growth forms within gardens and horizontally by creating patches of different types of cover (Fig. 1). Planting or retaining even a few overstory trees and/or shrubs within or at the edge of gardens can attract birds that would otherwise avoid simple monoculture crops.

Plant diversity, in particular, has been shown to be one of the strongest predictors of animal diversity in urban agricultural areas and gardens (Daniels and Kirkpatrick 2006; Smith et al. 2006a, b; Gonzalez-Garcia et al. 2009). While high floral diversity is widely known to promote diversity of birds across a variety of habitats, urban gardens are somewhat unique in that they are typically dominated by exotic vegetation (Loram et al. 2007). High diversity of native plants is not equivalent to high diversity of exotic plants, which are known to support fewer native insects than native species (Corbet et al. 2001; Burghardt et al. 2009) and, consequently, are used less by birds (French et al. 2005). Thus, bird diversity in urban gardens may not as reliably track plant diversity as in other habitats.

Fig. 1 A complex planting design with varying heights in close proximity to existing treed areas is a way to maximize the utility of a garden for birds. The plot shown is in a community garden in Brewster, NY

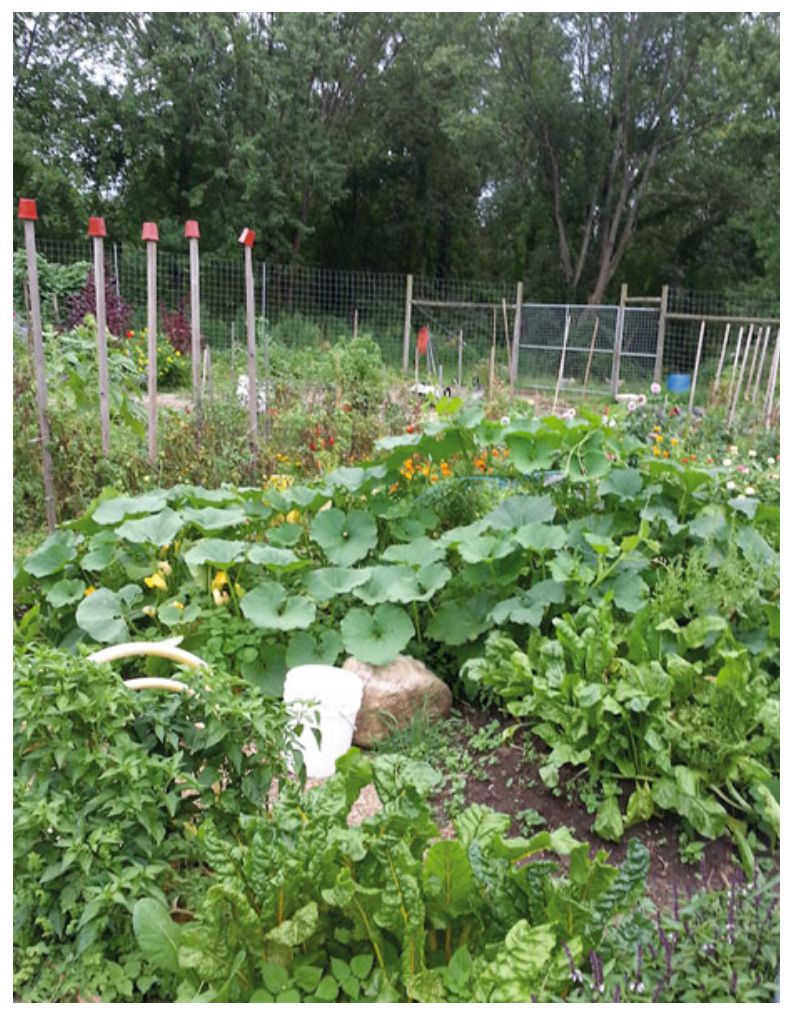


In addition to managing within-garden habitat, explicit consideration of larger spatial scales (e.g., patch size, landscape context) is an important step if one aims to understand patterns as well as identify opportunities for habitat enhancement. As is true across a wide variety of habitats, birds using urban agricultural areas may be sensitive to patch size, with avian diversity increasing with garden size (Thompson et al. 1993; Daniels and Kirkpatrick 2006; Chamberlain et al. 2007). The mechanisms driving this species-area relationship are not always clear, but the positive association between habitat heterogeneity and garden size may be the driver (Loram et al. 2008). Chamberlain et al. (2004) also found that bird diversity in gardens was not solely a function of within-garden attributes, but also was related to features of the surrounding landscape. This means that characteristics of the urban landscape, such as low amounts of forest cover or highly built environments, might preclude some species from occupying urban gardens, even in cases where the perfect local habitat conditions were available. Indeed, some birds simply avoid urban landscapes, irrespective of patch size or local habitat features (Rodewald and Bakermans 2006). Landscape effects also may reflect the pool of species available to use gardens within a landscape. For example, if a garden is adjacent to a large woodland park, then there might be the possibility of attracting certain forest birds for foraging or other activities. Improving the suitability of surrounding landscape matrix will usually enhance the value of the garden to birds. One approach to improving the matrix is to cluster gardens, which is known to increase within-garden biodiversity (Colding 2007). Urban gardens also can play an important role in improving habitat connectivity within urban landscapes (Rudd et al. 2002). Bringing a landscape-scale perspective to urban agriculture can result in synergies among the collective group of gardens that improve the ability of each individual garden to support biodiversity.

Despite the generality of many site- and landscape-scale management principles, urban agricultural areas may be distinct from other urban habitats and rural agricultural areas in a few respects. Sorace (2001) proposed three key advantages to birds using urban gardens that might explain why urban agricultural areas in Rome, Italy had higher abundance, diversity, and richness of birds compared to urban parks and rural agriculture. One, hunting is usually restricted in cities, which may relieve some species from persecution. Two, disturbance from humans may be lower than in heavily visited urban parks. Three, the intensity of use and area covered by urban agriculture are lower than in rural areas, which may result in more heterogeneous and diverse landscapes. Urban agricultural areas also may have different sources of mortality compared to urban parks and rural agriculture. In particular, the close proximity of urban gardens to the built landscape and residential homes means that birds will have a greater likelihood of being killed by free-ranging cats and collisions with windows, towers, and other structures than in rural agricultural lands. More research is needed to identify the distinct ecological influences of urban agriculture on bird communities.

Of course, managing urban gardens for birds can result in social and ecological benefits (e.g., birdwatching, pest control) other than bird conservation, as evidenced by the diverse motivations that people have for wildlife-friendly gardening (Goddard 
et al. 2013). For those interested, there are several programs that support efforts, including National Audubon Society's "Audubon at Home”, the Royal Society for the Protection of Birds' "Homes for Wildlife", and National Wildlife Federation's "Backyard Habitat Certification". There also are increasing opportunities for residents to participate in citizen science projects that both provide useful data that can be used to track avian responses to environmental change and/or habitat management, but also can promote environmental stewardship (Cooper et al. 2007).

\section{References}

Burghardt KT, Tallamy DW, Shriver WG (2009) Impact of native plants on bird and butterfly biodiversity in suburban landscapes. Conserv Biol 23:219-224

Chamberlain D, Cannon A, Toms M (2004) Associations of garden birds with gradients in garden habitat and local habitat. Ecography 27:589-600

Chamberlain DE, Gough S, Vaughan H, Vickery JA, Appleton GF (2007) Determinants of bird species richness in public green spaces. Bird Study 54:87-97

Colding J (2007) 'Ecological land-use complementation' for building resilience in urban ecosystems. Landsc Urban Plan 81:46-55

Cooper CB, Dickinson J, Phillips T, Bonney R (2007) Citizen science as a tool for conservation in residential ecosystems. Ecol Soc 12(2):11. [online] URL:http://www.ecologyandsociety.org/ vol12/iss2/art11/

Corbet S, Bee J, Dasmahapatra K, Gale S, Gorringe E, La Ferla B, Moorhouse T, Trevail A, Van Bergen Y, Vorontsova M (2001) Native or exotic? Double or single? Evaluating plants for pollinator-friendly gardens. Ann Bot 87:219-232

Daniels GD, Kirkpatrick JB (2006) Does variation in garden characteristics influence the conservation of birds in suburbia? Biol Conserv 133:326-335

Evans KL, Newson SE, Gaston KJ (2009) Habitat influences on urban avian assemblages. Ibis 151:19-39

Fernandez-Canero R, Gonzalez-Redondo P (2010) Green roofs as a habitat for birds: a review. J Anim Vet Adv 9:2041-2052

French K, Major R, Hely K (2005) Use of native and exotic garden plants by suburban nectarivorous birds. Biol Conserv 121:545-559

Goddard MA, Dougill AJ, Benton TG (2009) Scaling up from gardens: biodiversity conservation in urban environments. Trends Ecol Evol 25:90-98

Goddard MA, Dougill AJ, Benton TG (2013) Why garden for wildlife? Social and ecological drivers, motivations and barriers for biodiversity management in residential landscapes. Ecol Econ 86:258-273

Gonzalez-Garcia A, Sal AG (2008) Private urban greenspaces or "Patios" as a key element in the urban ecology of tropical central America. Hum Ecol 36:291-300

Gonzalez-Garcia A, Belliure J, Gomez-Sal A, Davilla P (2009) The role of urban greenspaces in fauna conservation: the case of the iguana Ctenosaura similis in the 'patios' of Leon city, Nicaragua. Biodivers Conserv 18:1909-1920

Grant G (2006) Extensive green roofs in London. Urban Habitats 4:51-65

Loram A, Tratalos J, Warren PH, Gaston KJ (2007) Urban domestic gardens (X): the extent \& structure of the resource in five major cities. Landsc Ecol 22:601-615

Loram A, Thompson K, Warren PH, Gaston KJ (2008) Urban domestic gardens (XII): the richness and composition of the flora in five UK cities. J Veg Sci 19:321-330

Rodewald AD, Bakermans MH (2006) What is the appropriate paradigm for riparian forest conservation? Biol Conserv 128:193-200 
Rudd H, Vala J, Schaefer V (2002) Importance of backyard habitat in a comprehensive biodiversity conservation strategy: a connectivity analysis of urban green spaces. Restor Ecol 10:368-375

Smith RM, Warren PH, Thompson K, Gaston KJ (2006a) Urban domestic gardens (VI): environmental correlates of invertebrate species richness. Biodivers Conserv 15:2415-2438

Smith R, Thompson K, Hodgson J, Warren P, Gaston K (2006b) Urban domestic gardens (IX): composition and richness of the vascular plant flora, and implications for native biodiversity. Biol Conserv 129:312-322

Sorace A (2001) Value to wildlife of urban-agricultural parks: a case study from Rome urban area. Environ Manage 28:547-560

Thompson P, Greenwood J, Greenaway K (1993) Birds in European gardens in the winter and spring of 1988-89. Bird Study 40:120-134 


\title{
Improving the Suitability of Urban Farms for Wildlife
}

\author{
Zoe A. Marzluff and John M. Marzluff
}

Urban farms and gardens are increasingly popular and now occur in most major cities of the United States. However, little is known about the relationship between existing wildlife and these agricultural lands. Green spaces in urban surroundings, such as parks, business campuses, and golf courses often serve as de facto wildlife habitats (Donnelly and Marzluff 2004; Cristol and Rodewald 2005; Snep 2009). Can lands managed for human sustenance also provide habitat for other species? Brown et al. (2015) provides a preliminary assessment and we suggest in this chapter further guiding principles for integrating urban farms into the urban ecosystem. We begin with an informal assessment of one farm.

\section{Wildlife Use of an Urban Farm}

The senior author spent the summer of 2013 at an urban farm and education center (Growing Power) in Milwaukee, WI, USA. Growing Power was started 20 years ago by former basketball star Will Allen for the purpose of providing food to an area of Milwaukee that traditionally only had access to fast food. As Growing Power developed, though, it came to serve not just as a food producer, but as an education center as well, leading daily tours around the original farm and running a camp for kids in the summer.

Growing Power provides a number of services to its surrounding community- a weekly CSA, community gardens, farmer's markets, farm and food education, and

Z.A. Marzluff

Knox College, Box 1191, Galesburg, IL 61401, USA

J.M. Marzluff $(\bowtie)$

School of Environmental and Forest Sciences, University of Washington,

Box 352100, Seattle, WA 98195, USA

e-mail: corvid@uw.edu 
jobs. To do so, it has facilities and land throughout Milwaukee. From the three-acre urban farm on Silver Spring Drive to 40-50-acre-large plots 10-20 miles outside of the city, as well as numerous community gardens, Growing Power has a diverse and unique operation. Many of the sites are on land that was donated or abandoned- old schools, warehouses, etc. Instead of altering existing wildlife habitat, most of the urban farm locations have been built on old pavement.

The most important site to Growing Power, and therefore the one where we focused our survey, is the Silver Spring Farm. This is a 3-acre piece of land that houses over 20 hoop-houses, goats, chickens, bees, and aquaponics. It is also the headquarters for Growing Power and what most people see when they visit. We also observed the Westlawn Community Gardens- a new community garden established and run by Growing Power with over 50 raised beds. It is located in the Westlawn government housing projects in Milwaukee. The Jackson farm was the third site observed. Jackson is a 40 acre piece of land 10 miles outside of Milwaukee that produces mostly vegetables.

We found a variety of birds, mammals, and amphibians on lands farmed by Growing Power (Table 1). One of the most interesting and regularly species observed was the house sparrow. These birds foraged among the goats for invertebrates. Other common species were robins, rats, mice, and rabbits, all of which were welcome

Table 1 Vertebrates observed at Growing Power, Milwaukee, WI, by casual observation from June-August, 2013

\begin{tabular}{|c|c|c|c|}
\hline Species & Occurrence & Location & Behavior \\
\hline House Sparrow & \multirow[t]{2}{*}{ Every day } & \multirow{2}{*}{$\begin{array}{l}\text { Chicken coop, inside } \\
\text { hoophouses, in goat pens, } \\
\text { everywhere }\end{array}$} & \multirow{2}{*}{$\begin{array}{l}\text { Foraging, roosting, } \\
\text { perched }\end{array}$} \\
\hline Passer domesticus & & & \\
\hline American Robin & \multirow[t]{2}{*}{ Every day } & \multirow[t]{2}{*}{ Silver Spring farm } & \multirow[t]{2}{*}{ Foraging } \\
\hline Turdus migratorius & & & \\
\hline Red-Tailed Hawk & \multirow[t]{2}{*}{ Twice } & \multirow{2}{*}{$\begin{array}{l}\text { Westlawn Community Gardens, } \\
\text { Silver Spring Farm }\end{array}$} & \multirow[t]{2}{*}{ Hunting, perching } \\
\hline Buteo jamaicensis & & & \\
\hline Northern Cardinal & \multirow[t]{2}{*}{ Occasionally } & \multirow[t]{2}{*}{ Silver Spring Farm } & \multirow{2}{*}{$\begin{array}{l}\text { Feeding in oat } \\
\text { sprout bins }\end{array}$} \\
\hline $\begin{array}{l}\text { Cardinalis } \\
\text { cardinalis }\end{array}$ & & & \\
\hline Rat/Mouse & \multirow[t]{2}{*}{ Every day } & \multirow[t]{2}{*}{ Everywhere } & \multirow[t]{2}{*}{ Foraging, breeding } \\
\hline Rattus/Mus & & & \\
\hline Leopard Frog & \multirow[t]{2}{*}{ Once } & \multirow{2}{*}{ Hoophouse } & \multirow{2}{*}{$\begin{array}{l}\text { Resting on a tomato } \\
\text { plant }\end{array}$} \\
\hline Rana pipiens & & & \\
\hline Garter snake & \multirow{2}{*}{ Occasionally } & \multirow{2}{*}{ Silver Spring Farm } & \multirow{2}{*}{ Basking } \\
\hline Thamnophis & & & \\
\hline Rabbit & \multirow{2}{*}{ Occasionally } & \multirow{2}{*}{$\begin{array}{l}\text { Silver Spring Farm, Jackson } \\
\text { Farm }\end{array}$} & \multirow{2}{*}{ Foraging, breeding } \\
\hline Lepus curpaeums & & & \\
\hline Woodchuck & \multirow[t]{2}{*}{ Once } & \multirow{2}{*}{$\begin{array}{l}\text { Silver Spring Farm, aquaponics } \\
\text { hoophouse }\end{array}$} & \multirow{2}{*}{$\begin{array}{l}\text { Foraging, } \\
\text { burrowing }\end{array}$} \\
\hline Marmota monax & & & \\
\hline Weasel & \multirow[t]{2}{*}{ Twice } & \multirow{2}{*}{$\begin{array}{l}\text { Silver Spring Farm, chicken } \\
\text { coop }\end{array}$} & \multirow[t]{2}{*}{ Hunting } \\
\hline Mustela & & & \\
\hline
\end{tabular}


and tolerated within the urban farm setting. The farms managed by Growing Power also provided a refuge for less common animals, such as the red-tailed hawk and the leopard frog. There were other species, however, that were not tolerated on the farms. An unidentified weasel (probably a long-tailed weasel) that preyed on chickens was killed. A woodchuck was also persecuted because it was getting into and destroying aquaponics systems.

From our experience, urban farms attract local animals and have the potential to help sustain populations of some rare species (e.g., northern leopard frog), apex predators (red-tailed hawk), and many common native (American robin) and introduced (e.g., house sparrow) species (Fig. 1).

With tolerance they may be able to support even more (e.g., weasels, woodchucks). These gathering grounds also provide important places for urban people to interact with wildlife. As with all habitats attractive to wildlife in human-dominated landscapes, urban farms could trap wildlife in unsustainable situations or provide resources that contribute to survival and reproduction. We now offer principles derived from Marzluff (2014), that extend and complement those found in Brown et al. (2015) to increase the ability of urban farms to sustain, rather than reduce wildlife populations. Our suggestions are most pertinent to birds, but largely applicable to other animals as well.

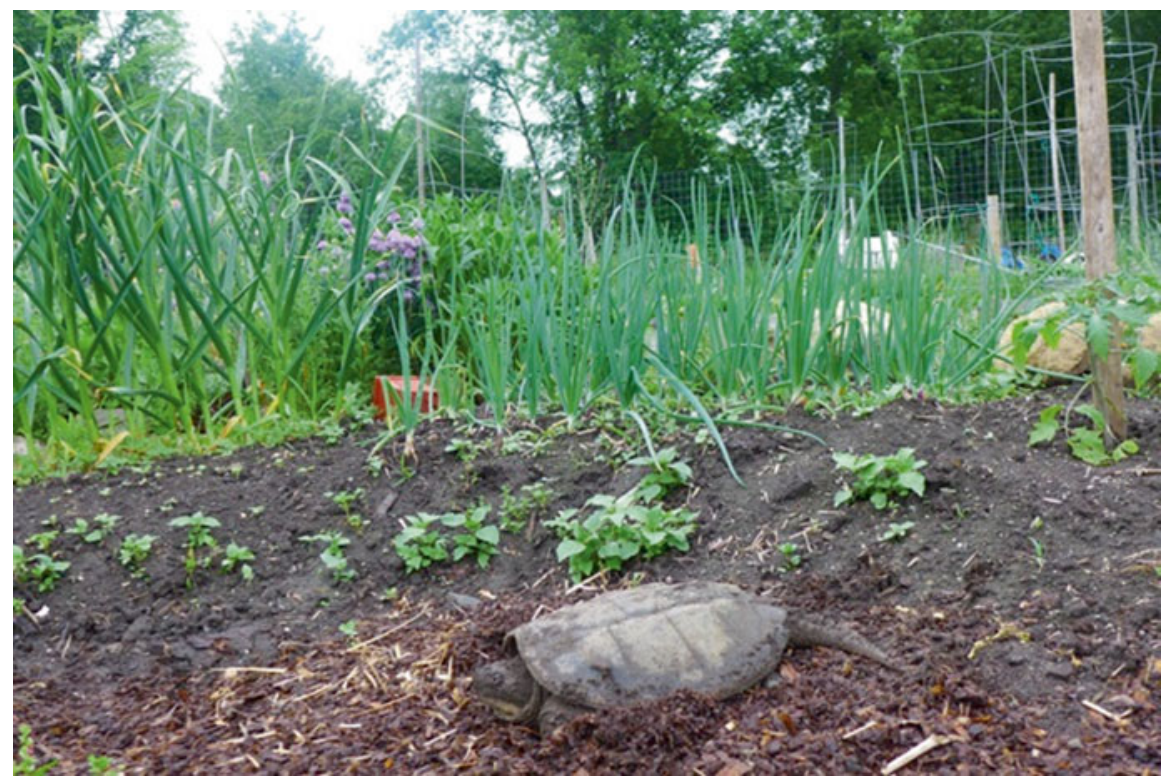

Fig. 1 A snapping turtle laying eggs in a community garden in Brewster, NY (Photo Vicky Zeph) 


\section{Wildlife-Friendly Urban Farms}

The first two principles aim to improve the siting of urban farms.

1. Urban farms can add to, rather than subtract from, urban wildlife habitat if they convert lawn or other impervious surfaces, including roofs, into more heterogeneous land cover. Lawns are ecological disasters of the highest order (Bormann et al. 2001), that are best improved by conversion to more natural settings that feature native plants and structural diversity (shrubs and trees). Siting farms on currently vacant lands is less desirable, as these lands have potential to support early successional species or those requiring open landscapes (Meffert et al. 2012). Siting farms on existing natural areas, diversely planted parks, and other green spaces within urban areas would likely decrease the city's ability to sustain wildlife rather than add to it.

2. Urban farms would enhance wildlife habitat in the city if they nudge up against existing wild places rather than being established in isolation. This suggestion derives from the principle of ecological complementarity developed by Colding (2007). Isolated farms may also serve wildlife, especially if they are large or clustered together with other farms (Brown et al. 2015). Roadways are a major limiting factor for nonvolant wildlife in the city (Mitchell et al 2008) and therefore care should be exercised to not site farms where they may lure wildlife from existing terrestrial and aquatic lands across roads. Where roads come between parks, greenbelts, and farms provision of cross ways, such as tunnels and overpasses, or temporary road closures during peak migration times may reduce mortality and increase safety to drivers.

Once an ecologically suitable site is selected, farms can be made more useful to wildlife by enhancing habitat quality and reducing limiting factors. These aims produce seven additional principles.

3. Edging farms with native shrubs, interspersing shrubs between and within plots, and providing some vegetative cover throughout the year would improve the utility of urban farms for wildlife. These and similar actions would improve urban farms for wildlife because habitat quality is directly related to vegetative complexity (MacArthur and MacArthur 1961) (Fig. 2).

4. Urban farms can bolster bird populations by providing food and shelter in the form of bird feeders and bird nest boxes. These supplements are important attributes of urban ecosystems (Dunn and Tessaglia-Hymes 1999; Faeth et al. 2005; Robb et al. 2008). Subsidies may improve sustainability because a large wildlife population is better able to adapt to the novel selective pressures of an urban environment than is a small population (Marzluff 2012) (Fig. 3).

5. Lighting is extremely disruptive to wildlife (Rich and Longcore 2006), therefore minimizing its use in urban farms would increase their contribution as habitat. If lights are required they can be least disruptive to wildlife by remaining as dim as possible, emitting 'softer' (yellow not blue) spectra, and shining down rather 


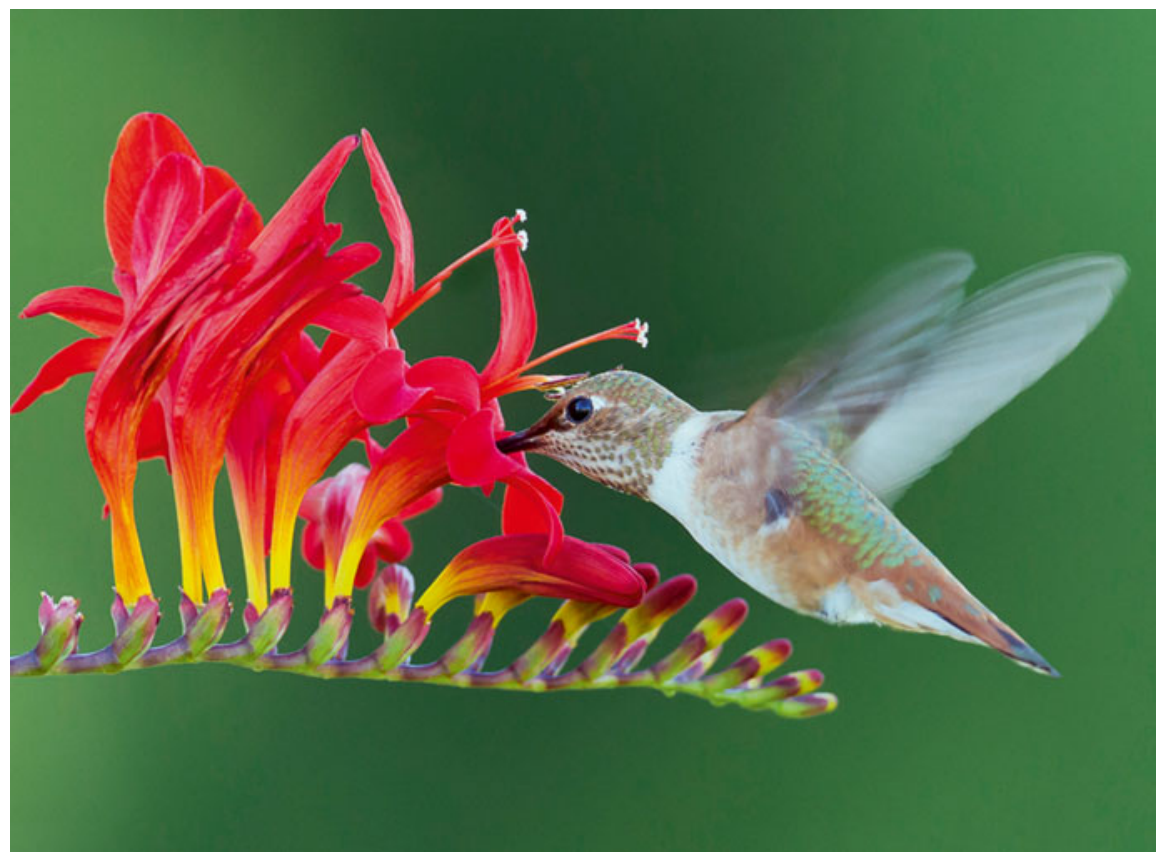

Fig. 2 A hummingbird in an ornamental flowering plant in an urban garden (Photo by Rich Eltrich)

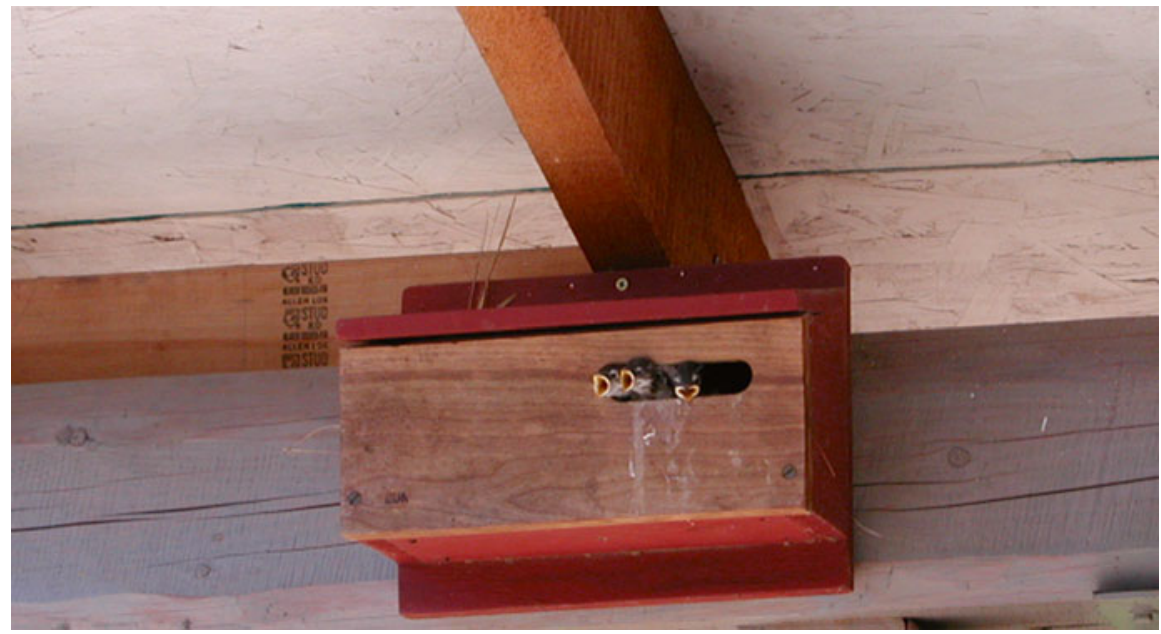

Fig. 3 A bird nest box in a shed in an urban garden (Photo by Betsy Schultz)

than up or to the side (Eisenbeis and Hänel 2009). Towers with steady glowing red lights are particularly deadly to migrating birds and should not be used in urban farms (Gehring et al. 2009; Longcore et al. 2012). 
6. Urban farms may be especially useful to native bees and other pollinating insects. Pesticides, especially neonicotinoid insecticides, should therefore not be used (Mineau and Palmer 2013). Rodenticides that employ second generation anticoagulants are also inappropriate for use in urban farms as they incidentally poison birds and mammalian carnivores and scavengers (Bartos et al. 2011). In contrast to these situations control of mosquitos, which vector diseases harmful to wildlife (e.g., West Nile virus) may be beneficial and should be encouraged on urban farms. Mosquitos can be controlled by limiting the availability of open (unscreened) water sources or by treating large water bodies with mosquito development arrestors (e.g., Bacillus thuringiensis).

7. Reducing clear glass windows affronting farms may greatly improve their contribution to bird populations. Collisions with windows are the second more important mortality source for birds in North America (Calvert et al. 2013; Loss et al. 2014). Making windows visible to birds with UV-reflective decals, taping, or screening reduces this threat (Klem 2009; Marzluff 2014). Covering as little as $5 \%$ of the window surface is effective.

8. Free-ranging domestic cats are the number one limiting factor on birds and other urban wildlife, worldwide (Loss et al. 2013; Calvert et al. 2013). Their feces also vector harmful human diseases, such as toxoplasmosis. These animals should not be tolerated or subsidized in urban farms. Beyond affecting wildlife, allowing cats to live outdoors also reduces their lifespan from an average of 20-10 years (Lacheretz et al. 2002).

The final principle derives from the opportunity that urban farms provide to enhance the ecological literacy of the urban populous and in so doing help build a more widely applied conservation ethic (Dunn et al. 2006).

9. Urban farms can build wonder and tolerance for wildlife by enhancing citizens' and farmers' interest and knowledge of nature. The every day aspects of urban farming brings agriculturalists into contact with a variety of birds, small mammals, reptiles, amphibians, and insects. Their appreciation for these side products of their industry might be increased through the use of interpretive signs that identify common animals and their ecological roles. For example, a better understanding of the weasel's role as a mouser may have lessened its persecution. As appreciation and interest grows, some farmers might want to expand their actions into the realm of citizen science, especially noting, photographing, and cataloging the animals that use the farm (Fig. 4).

\section{Conclusions}

As humans increasingly transition into an urban species our use of land within and surrounding cities is changing. Urban agriculture, for example is increasing. As of 1997, $18 \%$ of the USA's agricultural lands occurred in metropolitan counties (EPA 


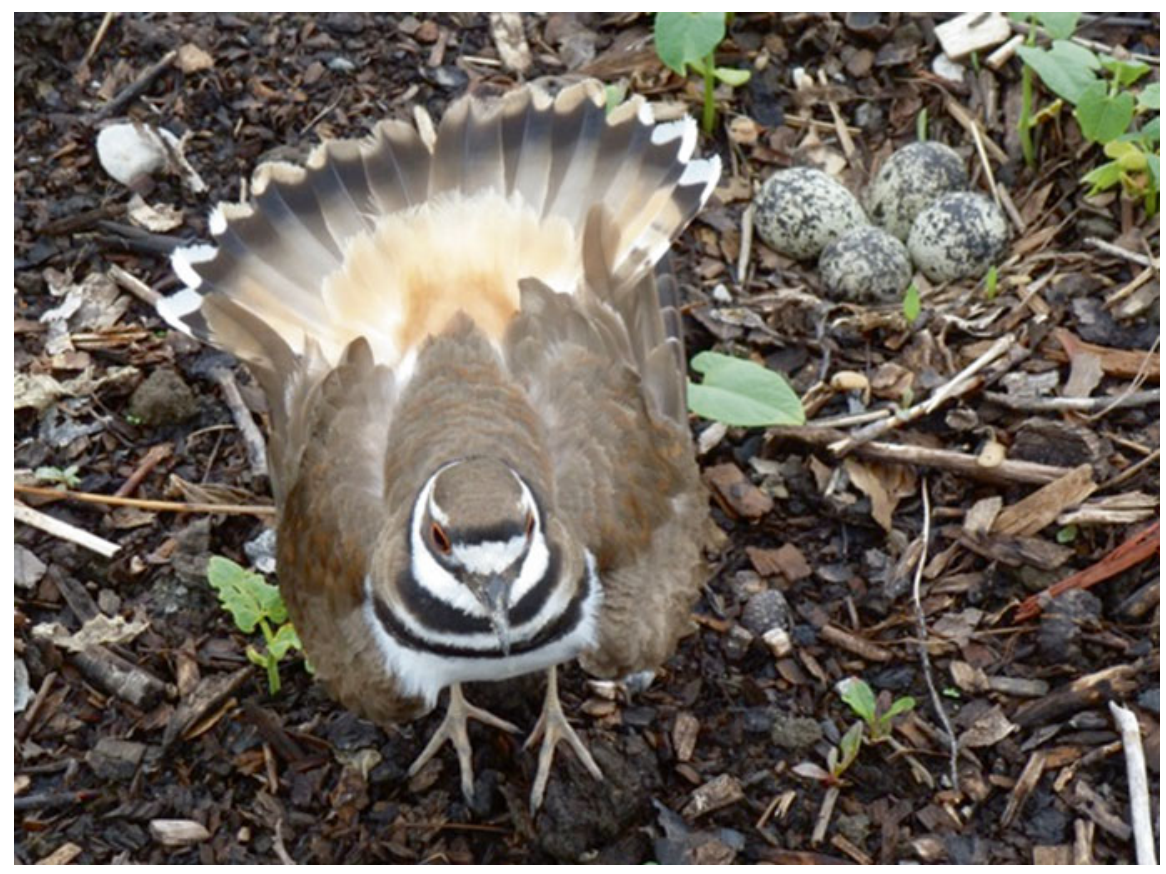

Fig. 4 A killdeer and her nest next to bean seedlings at a community garden plot near Carmel, NY (Photo by Vicky Zeph)

2013). Urban agriculture offers a way to green the city by providing locally sourced food for people. But it can do much more. By carefully siting farms, enhancing the diversity of land cover they provide, reducing common factors that limit wildlife in the city, and encouraging active stewardship of wildlife by farmers urban farms can also improve habitat conditions for other species, and provide a place for humans and nature to interact. Interacting with nature on nearby places, such as urban farms, is a prescription to reduce ecological amnesia-the tendency to forgo ecologically sustainable practices by humans that are disconnected from nature-which is a global threat to biological diversity (Turner et al. 2004; Miller 2005).

\section{References}

Bartos M, Dao S, Douk D, Falzone S, Gumerlock E, Hoekstra S, Kelly-Relf K, Mori D, Tang C, Vasquez C, Ward J, Young S, Morzillo AT, Riley SPD, Longcore T (2011) Use of anticoagulant rodenticides in single-family neighborhoods along an urban-wildland interface in California. Cities Environ 4:1

Bormann FH, Blamori D, Geballe GT (2001) Redesigning the American lawn, a search for environmental harmony, 2nd edn. Yale University Press, New Haven 
Brown B, Mcivor K, Hodges Snyder E (2015) Sowing seeds in the city: Ecosystem and municipal services. Springer, Dordrecht.

Calvert AM, Bishop CA, Elliot RD, Krebs EA, Kydd TM, Machtans CS, Robertson GJ (2013) A synthesis of human-related avian mortality in Canada. Avian Conserv Ecol 8:11

Colding J (2007) ‘Ecological land-use complementation' for building resilience in urban ecosystems. Landsc Urban Plan 81:46-55

Cristol DA, Rodewald AD (2005) Introduction: can golf courses play a role in bird conservation? Wildl Soc Bull 33:407-410

Donnelly R, Marzluff JM (2004) Importance of reserve size and landscape context to urban bird conservation. Conserv Biol 18:733-745

Dunn EH, Tessaglia-Hymes DL (1999) Birds at your feeder, a guide to feeding habits, behavior, distribution, and abundance. W. W. Norton \& Company, New York

Dunn RR, Gavin MC, Sanchez MC, Solomon JN (2006) The pigeon paradox: dependence of global conservation on urban nature. Conserv Biol 20:1814-1816

Eisenbeis G, Hänel A (2009) Light pollution and the impact of artificial night lighting on insects. In: McDonnell MJ, Hahs AK, Breuste JH (eds) Ecology of cities and towns: a comparative approach. Cambridge University Press, Cambridge, pp 243-263

EPA (Environmental Protection Agency) (2013) Land use overview. http://www.epa.gov/agriculture/ ag101/landuse.html

Faeth SH, Warren PS, Shochat E, Marussich WA (2005) Trophic dynamics in urban communities. BioScience 55:399-407

Gehring J, Kerlinger P, Manville AM II (2009) Communication towers, lights, and birds: successful methods of reducing the frequency of avian collisions. Ecol Appl 19:505-514

Klem D Jr (2009) Preventing bird-window collisions. Wilson J Ornithol 121:314-321

Lacheretz A, Moreau D, Cathelain H (2002) Causes of death and life expectancy in carnivorous pets (I). Revue de Médecine Vétérinaire 12:819-822

Longcore T, Rich C, Mineau P, MacDonald B, Bert DG, Sullivan LM, Mutrie E, Gauthreaux SA Jr, Avery ML, Crawford RL, Manville AMII, Travis ER, Drake D (2012) An estimate of avian mortality at communication towers in the United States and Canada. PLoS One 7:e34025

Loss SR, Will T, Marra PP (2013) The impact of free-ranging domestic cats on wildlife of the United States. Nat Commun 4:1396

Loss SR, Will T, Loss SS, Marra PP (2014) Bird-building collisions in the United States: estimates of annual mortality and species vulnerability. Condor 116:8-23

MacArthur R, MacArthur J (1961) On bird species diversity. Ecology 42:594-598

Marzluff JM (2012) Urban evolutionary ecology. Stud Avian Biol 45:287-308

Marzluff JM (2014) Welcome to Subirdia. Yale University Press, New Haven

Meffert P, Marzluff JM, Dziock F (2012) Unintentional habitats: value of a city for the wheatear (Oenanthe oenanthe). Landsc Urban Plan 108:49-56

Miller JR (2005) Biodiversity conservation and the extinction of experience. Trends Ecol Evol 20:430-434

Mineau P, Palmer C (2013) The impact of the nation's most widely used insecticides on birds. American Bird Conservancy, Washington, DC

Mitchell JC, Jung Brown RE, Bartholomew B (eds) (2008) Urban herpetology. Society for the Study of Amphibians and Reptiles, Salt Lake City

Rich C, Longcore T (eds) (2006) Ecological consequences of artificial night lighting. Island Press, Washington, DC

Robb GN, McDonald RA, Chamberlain DE, Bearhop S (2008) Food for thought: supplementary feeding as a driver of ecological change in avian populations. Front Ecol Environ 6:476-484

Snep RPH (2009) Biodiversity conservation at business sites. PhD dissertation, Alterra scientific contributions 28, Wageningen, The Netherlands, Alterra

Turner WR, Nakamura T, Dinetti M (2004) Global urbanization and the separation of humans from nature. BioScience 54:585-590 


\section{Part V \\ Ecosystem Services - Food Production}




\title{
How Much Can You Grow? Quantifying Yield in a Community Garden Plot - One Family's Experience
}

\author{
Michael McGoodwin, Rebecca McGoodwin, and Wendy McGoodwin
}

\section{Introduction}

Here we describe the experiences and lessons learned by a family growing vegetables in local community gardens during the past 13 years. We are not agricultural professionals, though Rebecca is a farmer's daughter who has taught biology and has had a lifelong passion for gardening, both ornamental as well as food producing. Rebecca and Michael have had several private home vegetable gardens over the years, but our current vegetable garden, which we like to call our "patch," is located in a public park in the city of Seattle.

\section{Tools for Optimizing Productivity}

Although there are many intangible but important benefits of having a P-Patch plot, our primary goal is to maximize production of vegetables, and we would be disappointed if the overall yield were low. There is a considerable expenditure of money for frequent driving trips to the plot (walking or biking for us is infeasible), and for purchase of compost, seeds, plants, tools, and supplies. Furthermore, the investment of personal time and energy is also quite high. It is unlikely that most participants will actually save much money by having a P-Patch if all costs are included, especially if you factor in the value of your labor. Nevertheless we are driven by a basic compulsion to make the garden as productive as possible, a worthy goal and a source

\author{
M. McGoodwin $(\bowtie)$ \\ University of Washington School of Medicine, Seattle, WA, USA \\ e-mail:MCM@McGoodwin.net; http://www.mcgoodwin.net/index.html \\ R. McGoodwin • W. McGoodwin \\ P-Patch Gardeners, Seattle, WA, USA


of satisfaction. We offer here our best practical advice and recommendations to optimize production. Our attention to details or expenditures may appear overly elaborate to some, and we fully understand that many gardeners will choose to keep things simpler and less involved.

Please note that although we mention many commercial brand names and websites in the discussion below, the authors affirm that we have no commercial or monetary interest in any of these products and vendors.

\section{Planning}

Rebecca has taught us that effective gardening does not happen by accident, and that planning must begin very early. We have a carefully drawn to scale drawing of our irregularly shaped plot, and use copies of this in December and January to begin planning the next year's succession of spring, summer, and fall crops. Because P-Patch gardening is done on small valuable plots, we believe that every square foot should be put to intensive maximal use. The planning stage gives us a chance to debate what plants to add, cut back on, or eliminate, and how to arrange them, including how many square feet to assign to each crop in each season of the year. We get most of our seeds from catalogs. Starting in the winter we carefully pore over the colorful seed catalogs, a wonderfully positive activity bringing anticipation and a hopeful vision of new spring growth to an otherwise cold and rainy winter day. Good information for our region on which plants to plant and harvest for each month of the year is available in the very readable Maritime Northwest Garden Guide (http://seattletilth.org).

\section{Seeds and Vegetable Starts}

The best vendors provide excellent detailed information, through their websites and extensive catalogs, regarding which plants are the most disease resistant and produce and taste the best. Some catalogs that we use are Johnny's Selected Seeds (http://www.johnnyseeds.com/), Territorial Seed Co. (http://www.territorialseed. com/), and Ed Hume Seeds (http://www.humeseeds.com/), and we like to obtain potatoes from Wood Prairie Farm (http://www.woodprairie.com). Wendy also likes to order heirloom and open pollinated seeds from Uprising Seeds (http://www. uprisingorganics.com/). We place orders for online purchases typically in January, and buy other seeds in local stores a month or two later or when needed. Potted plant "starts" that are ready to go into the ground are purchased locally nearer to the time they are to be planted. In making seed choices, we try to find the right balance between using familiar tried-and-true cultivars versus more exotic, enticing, but unproven offerings. 


\section{Starting Plants Indoors}

We start some of our seeds indoors, initially on a heat mat, and after sprouting they are placed beneath a $1000 \mathrm{~W}$ super metal halide $(\mathrm{MH})$ fixture suspended over a multi-tiered plant stand located in a cool base ment (Fig. 1).

MH and HPS bulbs are known collectively as high-intensity discharge (HID) lamps. The color temperature of standard HPS bulbs is around $2200 \mathrm{~K}$ and they emit more red-orange, whereas $\mathrm{MH}$ bulbs for plants are typically 4000-6500 K and emit more blue. Use of a standard HPS bulb (unenhanced in blue output) may cause plants to have longer internodes and possibly greater overall height. MH bulbs have relatively more blue in their spectrum are optimal for growing seedlings and vegetation. Wendy has chosen instead to use special T-5 fluorescent bulbs in plant growing fixtures that hang at an adjustable distance above her seedlings. This setup consumes less power, though it provides somewhat less light and warmth. Such fluorescents should also be chosen specifically to optimize vegetative growth, thus having a bluer ("cooler") rather than a "warmer" output.

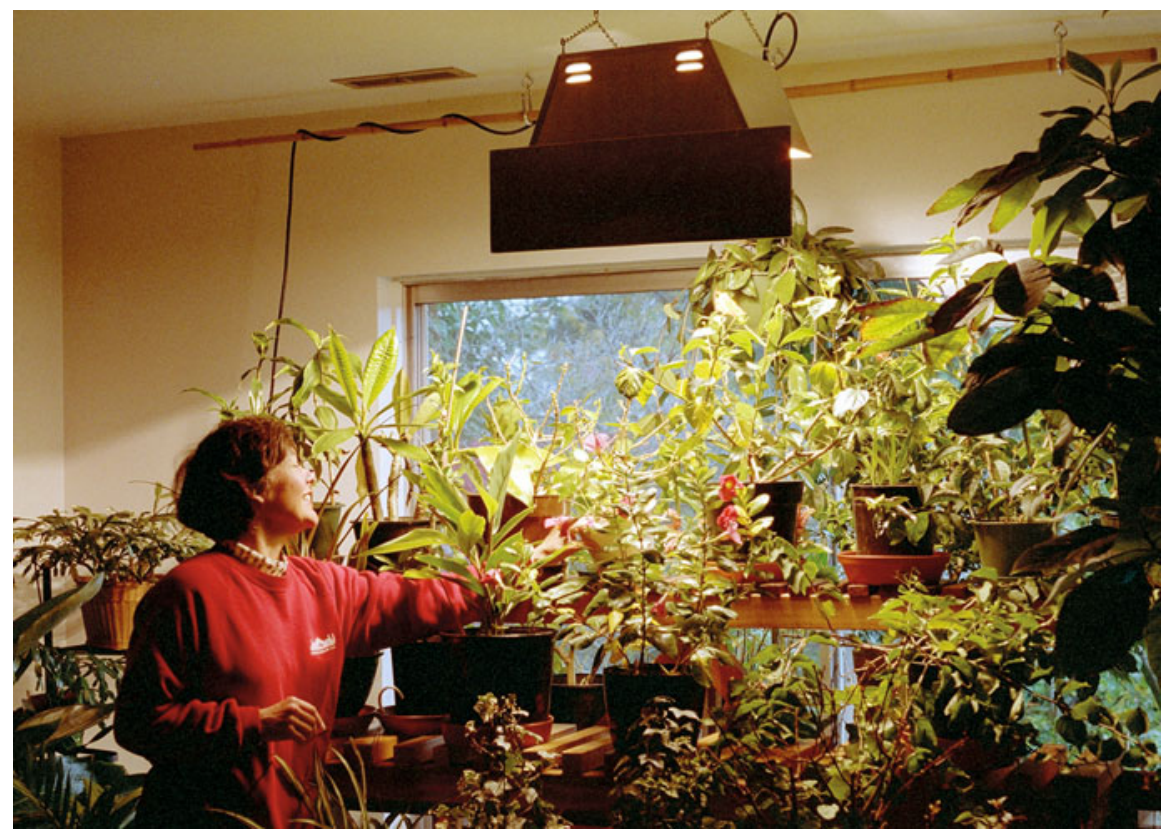

Fig. 1 Rebecca with plant stand and 1000 W HPS plant light 


\section{Garden Beds Design and Preparation}

When a new P-Patch plot like ours is first established, someone will likely need to break up the compacted soil and hardpan, remove rocks and foreign objects, and amend the soil. Michael achieved this for our plot using a pick mattock (a tool combining a pick and an adze, and often called a pickaxe) down to a depth of 12-18 in., a task requiring several years to complete. A rototiller typically cannot reach this depth. Transforming a disturbed or compacted soil into a highly productive soil can take years of effort.

After you have loosened the soil, it is very desirable to improve its fertility with compost. In Seattle, we have the benefit of relatively inexpensive compost made from recycled yard and food waste. We annually order a shared bulk delivery of a mixture of compost and dairy manure that is well composted. The compost we use is wonderfully nutritious as fertilizer and approved for organic produce growing. We apply about 1/2 cubic yard of this beautiful "black gold" per 100 square feet. This process is surprisingly complex to coordinate when done at a public park, especially if you are sharing the delivery with other families. You must be present to receive the order and to direct where it is to be dumped (usually in the adjoining parking lot), and you must be prepared (with multiple wheelbarrows, pitch forks, and shovels available at the P-Patch) to divide up the order and haul it away promptly. We do this in late February or early March, enlist the help of all available ablebodied family members, and always hope the weather will be kind. After spreading it and when the soil is reasonably dry (to avoid clumping), we gently till in the compost with a spading fork (realistically, to a depth of only 6-8 in.). Although you can use a rototiller for this, and we have done this when the soil was in especially poor shape, excessive tilling or rototilling are discouraged when the organic garden has been well maintained, as it destroys the beneficial fungal mycorrhizal networks which help nourish the plants and can cause soil compaction (Figs. 2 and 3).

We have divided our co-gardened 600 square foot plot into 2 halves that are separated by a 3 foot wide path that allows passage of a wheelbarrow or cart. Each half is further subdivided into 4 roughly rectangular beds, each 4-5 feet wide and separated by narrow paths only wide enough to allow tight passage. This arrangement allows access to most of our plants without stepping on bed soil and makes the best use of our limited acreage.

We mound up our beds to improve drainage, assist soil warming, and better delineate the planted areas from the narrow paths. Wendy has chosen for her smaller plot to install raised beds to a height of about 20 in. Raised beds are increasingly popular, especially in private gardens. They can improve drainage and soil warming, and can make weeding easier. They can also alleviate concerns about potential soil contamination by importing topsoil to use on top of existing soils. However, they are more expensive and labor intensive to build, they must be constructed of sturdy materials capable of retaining the heavy soil, and they will eventually rot and 


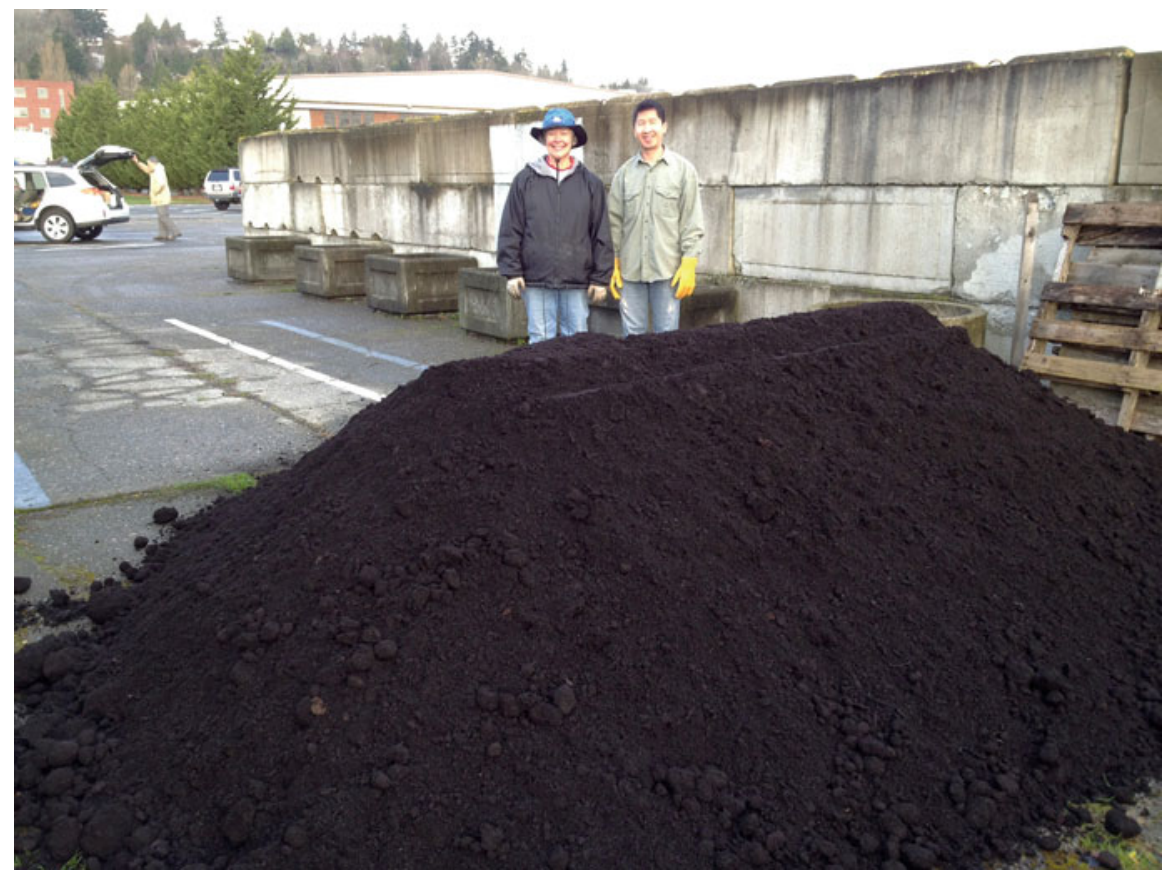

Fig. 2 Bulk compost

require disposal. In a Seattle P-Patch, you are not permitted to use chemically treated lumber to construct these, because of concern that the potentially toxic chemicals will leach into the soil and enter the plants (Fig. 4).

If you are concerned about productivity and serious about putting food on your table, it is our opinion that the smallest plot that would justify the dollar costs and time expended (especially if you must drive to the garden) is about 200 square feet.

\section{Installed Structures and Materials (Temporary and Semi-permanent)}

The P-Patch program discourages permanently installed structures, but we have installed the following removable structures. We believe that successful gardening, particularly of climbing plants like pole beans, cucumbers, and vining squashes, requires sturdy superstructures (trellises) which facilitate necessary vertical growth. These also help to optimize production from limited square footage of soil surface. 


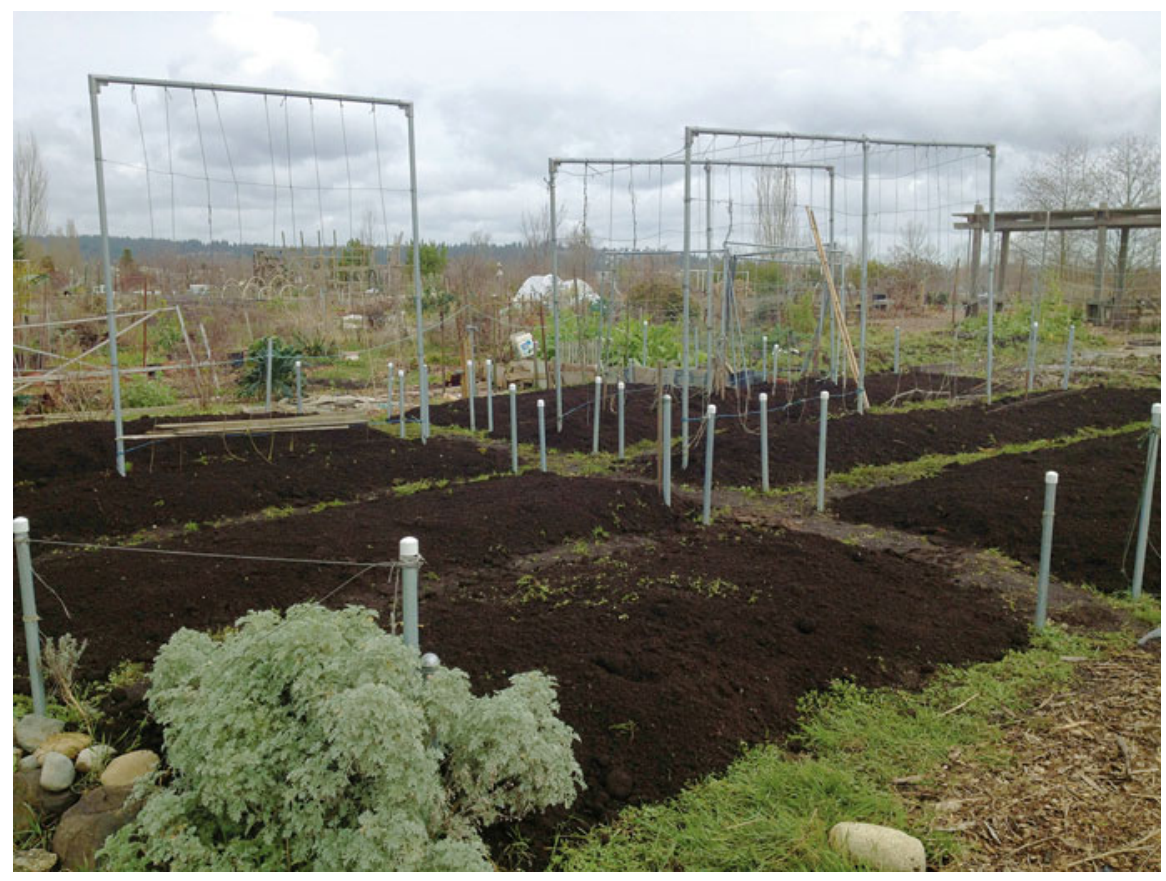

Fig. 3 Garden plot - subdivided into 8 garden beds

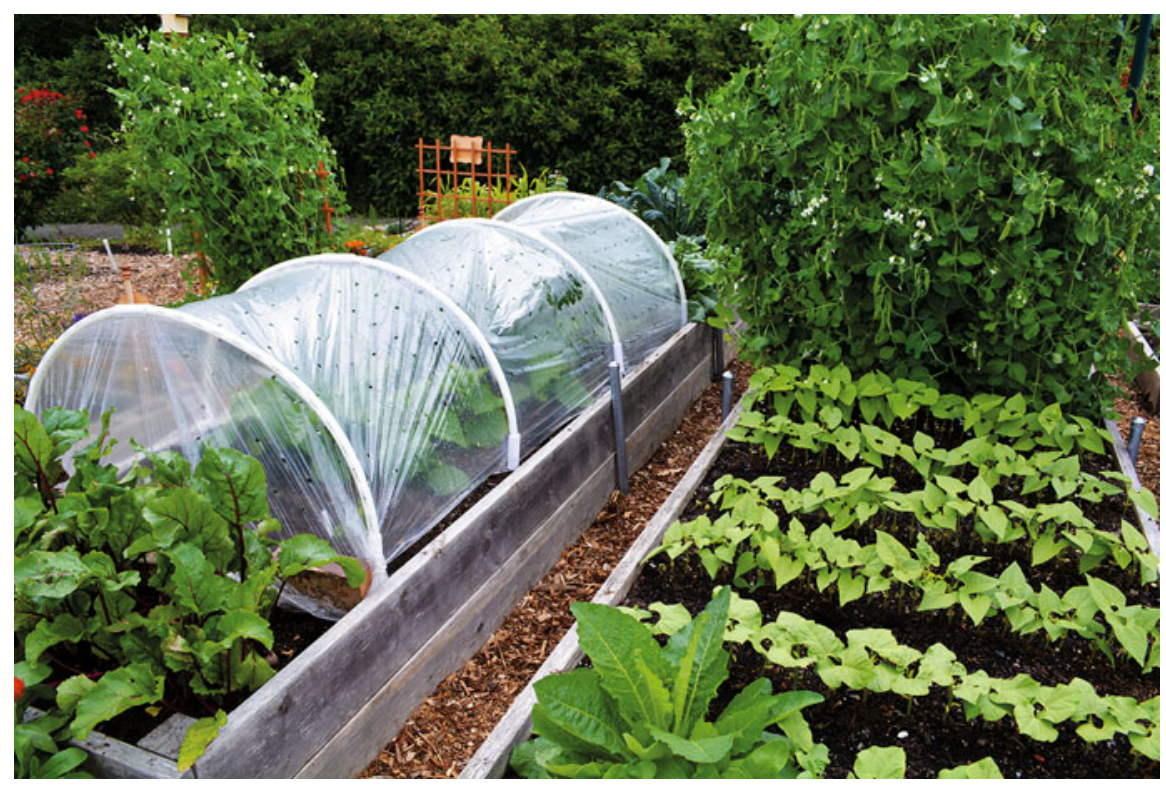

Fig. 4 Raised beds 


\section{Wood Trellises}

We initially tried wood trellises in teepee and other configurations, but these are not durable in soggy Seattle when made with standard inexpensive woods, and as mentioned you cannot use chemically treated wood in an organic garden. We do of course make use of movable wood stakes (Fig. 5).

\section{Conduit Trellises}

We have also used trade size $1 / 2$ in. galvanized steel electrical conduit pipe for temporary trellises. These work well for low $31 / 2-4$ foot high trellises, which are quite easy to remove or reposition. Pipe segments are drilled at the ends and wired together with galvanized steel wire. The horizontal rail is supported by single or dual legs at each end, the latter creating a tent-like shape. However, after we built 7-7 1/2 foot high trellises out of this same type of pipe, we found that they bent over in heavy winds when heavily laden with plants such as pole beans, and we discontinued using these as high trellises (Fig. 6).

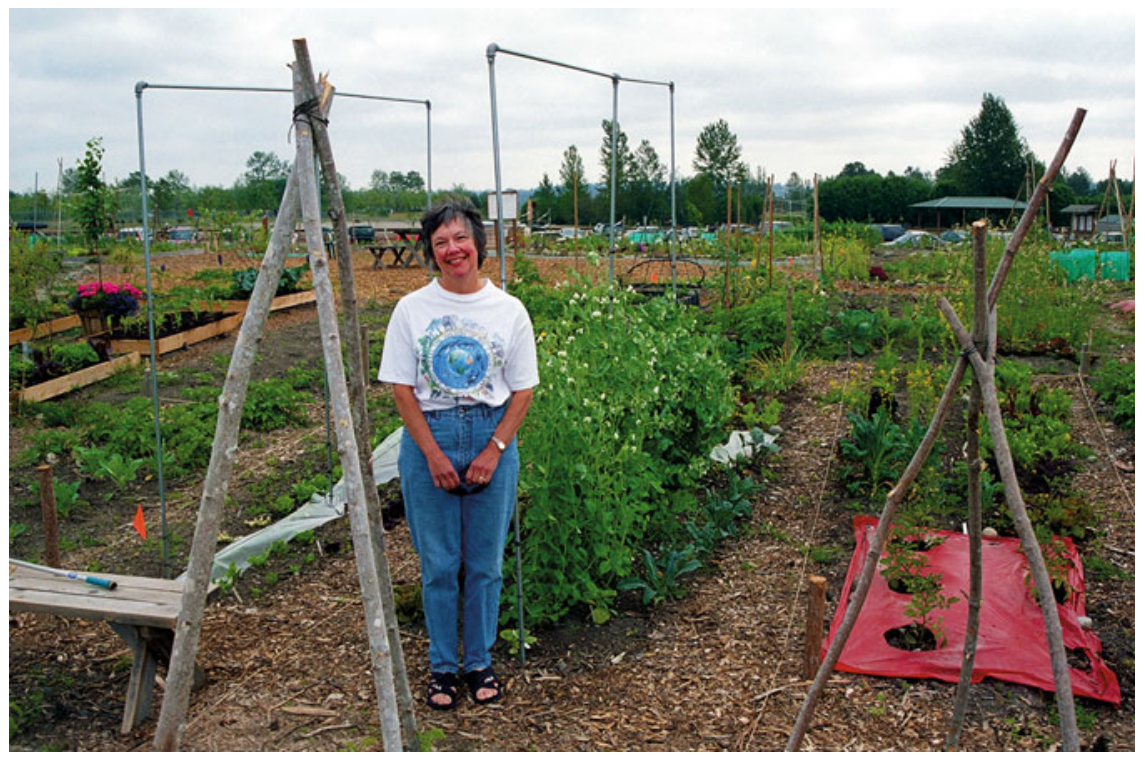

Fig. 5 Suboptimal wood trellises 


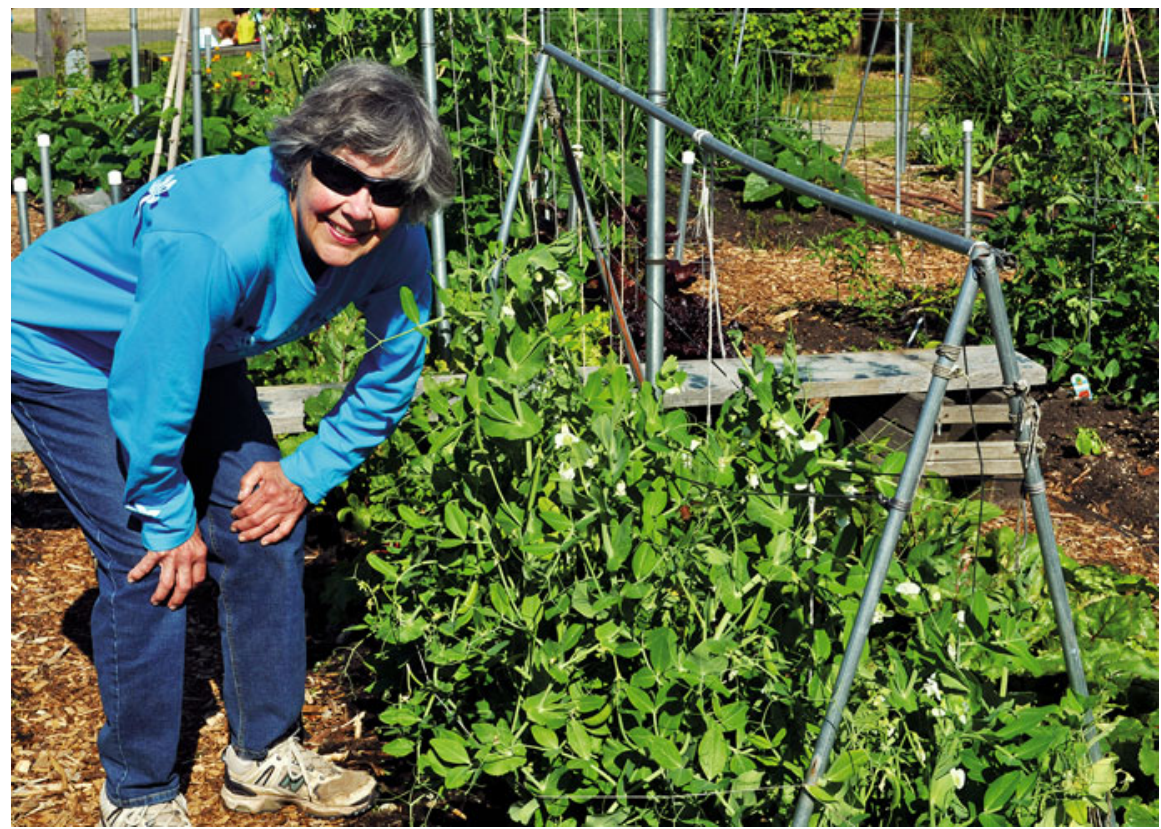

Fig. 6 Electrical conduit trellises

\section{Steel Top Rail Trellises}

Our final and preferred solution for "heavy metal gardening" with tall trellises is to use galvanized trade size $13 / 8$ in. fencing "top rail," available for instance at different hardware stores. These come in 10.5 foot lengths, and often the store can cut it to the desired lengths. You may join vertical posts with horizontal top rails using L-shaped brackets, and there are also line rail clamps available to join two top rail pieces in-line with a vertical post. We sunk the vertical segments to about 2 feet, using our steel bar and a manual post driver, and we do not set them in concretethus they can be removed when needed (with some effort). These 7-7 1/2 foot high trellises have successfully withstood the heavy winds at our plot even when thickly laden to the top and beyond with pole beans. If you erect these, you should assure that you will not be shading your neighbor's plants with such tall trellises. To this end, we erected these only in the relative center of the plot and use lower trellises in the side beds closer to our neighbors. We have these trellises placed at three different locations in our plot, so that we can rotate where we place recurring tall crops.

One year, we had vandals swinging from our tall trellises, and they managed to bend them to the ground. However, we bent them back up and they seemed to be not too much the worse for wear. To prevent this, you should always have horizontally spanning wires or twine that block a person from swinging beneath the high rail. 
We use 14 gauge PVC coated steel wire (often used for clotheslines) to provide a strong spanning cable just above ground level to which vertical twine can be securely tied. Other semi-permanent horizontal spanning segments can be made from bare galvanized steel wire or nylon twine. On any of our trellises, for permanent vertical or horizontal twine segments that climbing plants will adhere to, we are fond of and recommend two highly useful marine products, namely tarred nylon \#72 braided twine and green nylon Evergrip \#42 twine. These non-compostable twines are quite strong, last for many years in the field, and hold knots well. We use compostable jute twine for temporary plant support segments that need to last only a single growing season (Figs. 7 and 8).

\section{Tomato Cages}

We use a variety of sizes of these to support not just our tomatoes but also eggplants, peppers, tomatillos, and any other plant that grows vertically and looks like it could use this kind of help. Large tomato plants need large strong cages, sometimes further supported by stakes or twine tied to our top rail trellises.

Fig. 7 Steel top rail trellises

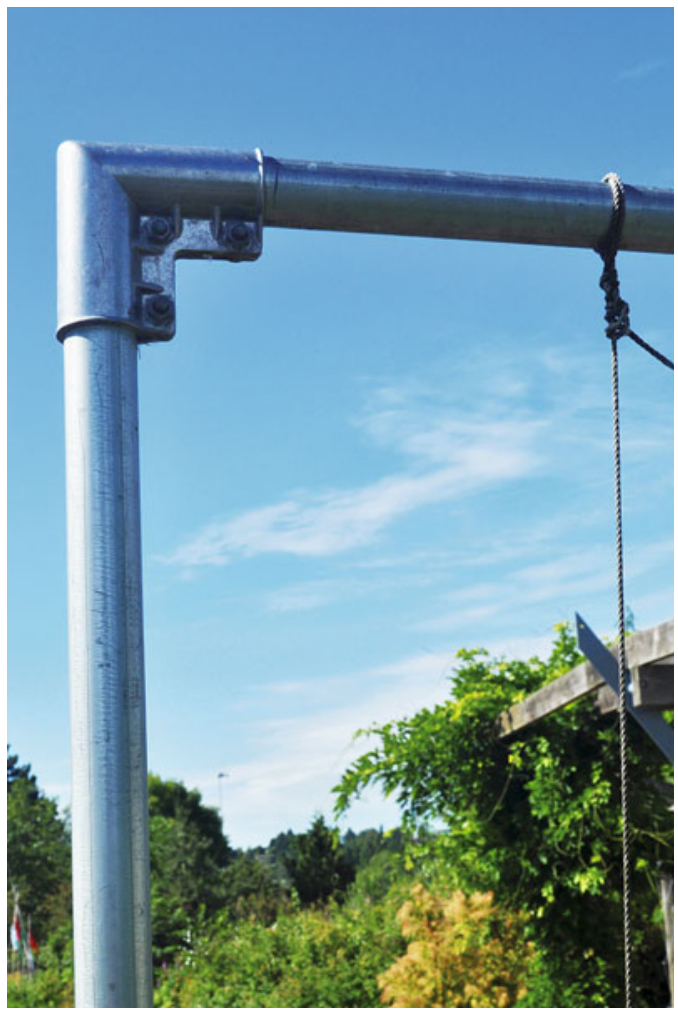


Fig. 8 Grid trellises and tomato cages

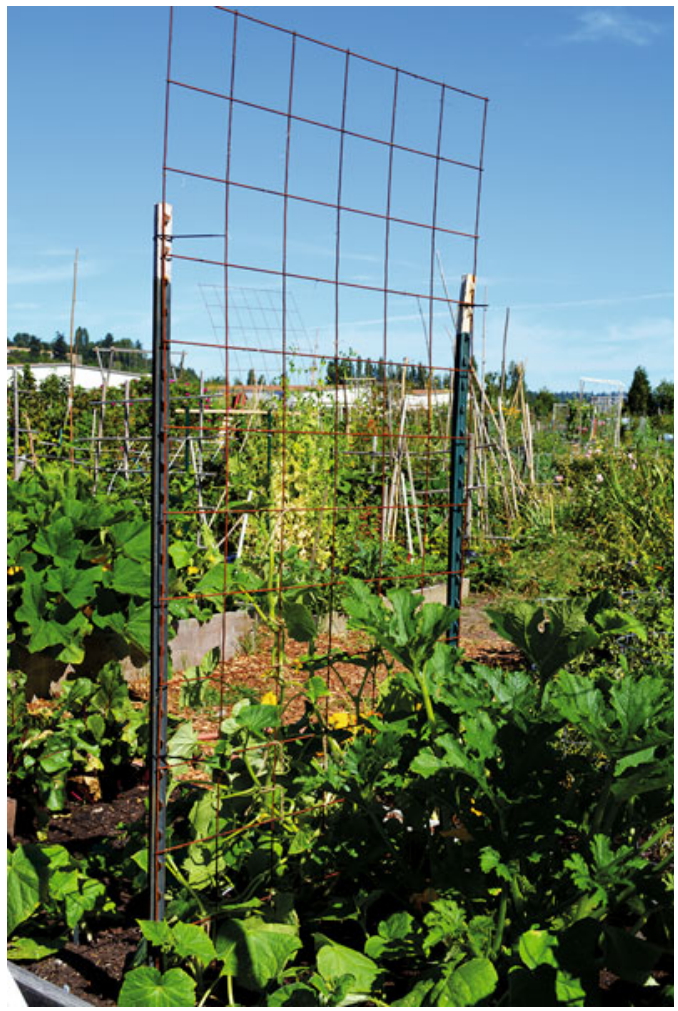

\section{Floating Row Covers, Landscape Fabrics, and Garden Films}

We strongly recommend protecting virtually all newly seeded beds with a floating row cover such as Reemay ${ }^{\circledR}$, which is a lightweight porous spun plastic garden fabric that is held in place with plastic pins or metal garden staples. It is used for protection from insects and crows or other birds that will eat the planted seeds or emerging seedlings. We save this durable material and reuse it for several years, so that there is little waste generated.

Landscaping fabric, a porous thick fabric typically made of polypropylene, can be placed in paths and overlain with chips to reduce weed growth (although we prefer to use cardboard overlain with chips because it is biodegradable).

We have tried using red plastic film below tomato plants to improve production, possibly with some benefit, and there are certainly strong proponents of this. In general, however, we have tried to minimize use of plastic garden films, even though they have the potential of conserving water, improving soil warming, and enhancing growth, etc. Our reluctance to use these is based on esthetic grounds, as we prefer a less plasticized look to the plot, and we object to generating much non-recyclable plastic waste. 


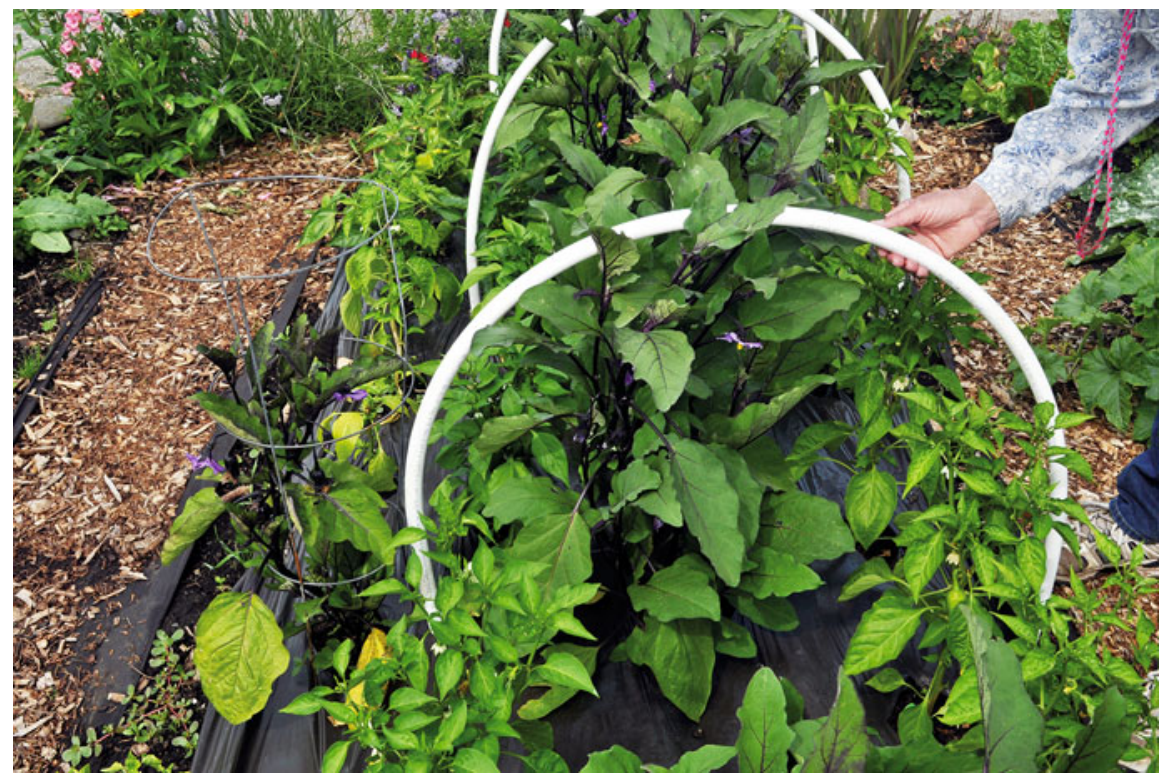

Fig. 9 Eggplant plants at P-Patch grown inside a cloche (on the right, showing taller and much more luxurious growth) versus outside the same cloche (on the left)

\section{Cloches}

In our northern climate, sufficient warmth of air and soil may not arrive until July. You can create what is effectively a small greenhouse over one or more of your beds by constructing a covering structure called a cloche (French for "bell"). A simple, temporary, and effective version starts with curved lengths of PEX plastic pipes. These are held in semicircular hoops by anchoring them on 2 foot long vertically driven rebar stakes. The hoops are covered with Gro-Therm ${ }^{\circledR}$, a perforated transparent plastic film, which is secured with special plastic clips. For maximal soil warming and water retention, the soil may be covered with a brown plastic garden film with a soaker hose beneath. Wendy has made effective use of these in growing heat loving crops such as melons and recommends them (Fig. 9).

\section{Diversification, Redundancy, and Crop Rotation}

Not all crops will be equally and consistently successful from year to year. Many factors help determine the degree of success of any particular crop: variations in weather and microclimates; inherent suitability of specific crops to the growing conditions; seed viability; soil fertility; vulnerability of certain plants to specific 
diseases and pests; etc. We follow the precept that for many types of crops, such as lettuces, tomatoes, potatoes, squashes, or beets, it is desirable to plant several cultivars (i.e., cultivated varieties), so that we will have biological diversification and will not be as disappointed if a particular cultivar proves to be unhappy. Of course, the use of multiple cultivars also provides greater culinary and visual interest and variety to the harvests, and often makes it possible to spread out or stagger crop harvests over a longer period of time (Fig. 10).

It is also desirable to plant more plants and grow more food than one is likely to be able to eat, thus assuring that there will be produce available for the birds and other unseen thieves, for one's friends and relatives, and for the local food bank. As the saying goes (somewhat pessimistically), "plant one for the rabbit, one for the mouse, one for the crow, and one for the house."

We also adhere to the well-established practice of crop rotation (planting repeated crops in different areas of the plot), in order to reduce proliferation of pathogens. This is especially important for:

- Brassicas, such as Brussels sprouts, cabbage, kale, and radishes;

- Legumes such as peas and beans;

- Onions, leeks, and root crops such as carrots; and

- Potatoes, tomatoes, and eggplants.

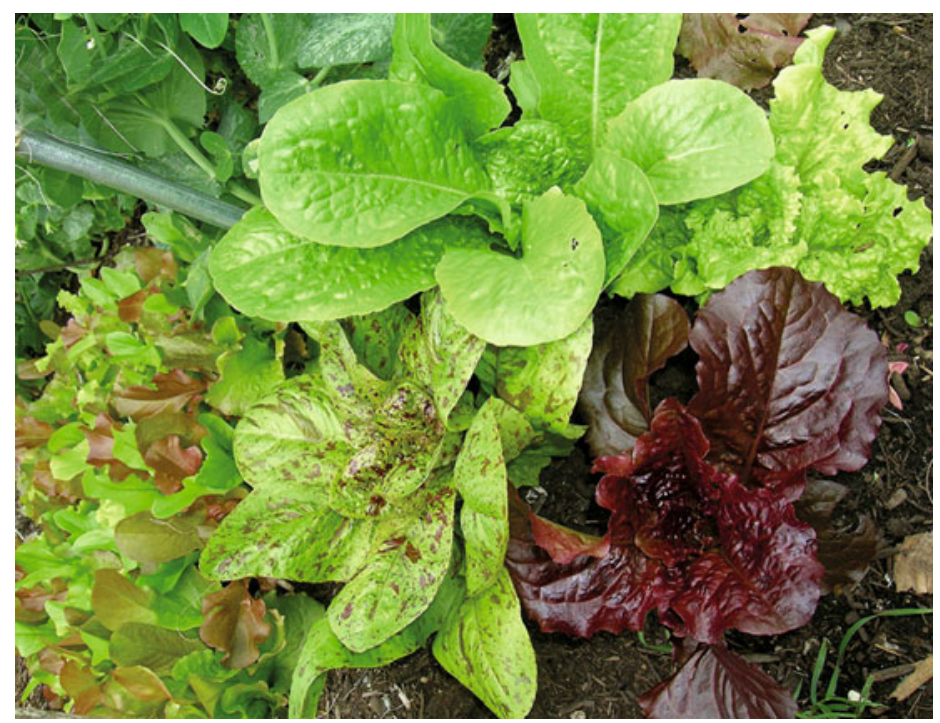

Fig. 10 Variety of lettuces 


\section{Winter Gardening}

Your garden can be more productive if you include crops that can grow and/or be harvested in the milder parts of winter. (In Seattle we garden March to October and prefer to stop gardening from about mid-November to early March.) It is difficult and often unrealistic to garden in the dead of winter, particularly when the water supply has been turned off or freezing temperatures have arrived. Useful and productive crops for late fall and early spring can include leafy vegetables such as kale, arugula, beet greens, lettuce, spinach, and bok choy, as well as other hardy plants such as Brussels sprouts, broccoli, collards, and leeks. We have overwintered leeks, garlics, purple sprouting broccoli, and collards, all of which do fine without special protection. Wendy has experimented with winter gardening under sturdy plastic film cloches, but found the results not worth the significant effort. In recent years, we have gotten lazier, and have chosen to simply put the entire garden to rest with a leguminous cover crop planted in the fall. For this cover crop we especially favor Austrian field peas because they have soft stems and are easily uprooted and/or tilled under. (Alternatively, one may simply place burlap sacks to cover the beds in winter to prevent soil erosion and reduce growth of weeds.)

\section{Thieves, Vandals, and Other Invaders}

Unfortunately, gardeners who grow food in a public park can expect to see some losses due to theft. Practically speaking, some rather boring crops (e.g., leafy vegetables such as lettuce, kale, collards, and bok choy) are less likely to be stolen from a public P-Patch than crops consisting of big or brightly colored or sweet fruits - the latter are just too tempting for some passersby. For example, in 2006 we lost to thieves eight prized brilliantly red winter squashes that we had babied through the hot summer, and this year our P-Patch has had unusually brazen children stealing berries from our neighbors' plots. We therefore try to deploy various defensive and mostly cosmetic countermeasures. For instance, we plant unusual varieties of tomatoes that when mature appear either underripe ('Green Zebra') or overripe and of dubious edibility ('Black Prince'). You can choose squashes that remain green or have a "native hue ... sicklied o'er" (like 'fairy' or white acorn squash) or a bizarre and warty skin texture (like some crooknecks), all of which may appear unhealthy to the amateur thief. Even our little platform benches have been spirited away to other locations in the park (fortunately not too far away).

One should of course expect to put up with a certain level of insect pests, slugs, and snails. In an unusually bad year we were also plagued by rats that ate up many of our potatoes and beets, and in other years we have lost some of our tomatoes and sugar snap peas to rats and birds. (Toxic rodenticide bait stations are not allowed in an organic garden, and even if allowed would pose a threat to birds of prey that consume the poisoned rodents.) 
These downsides to P-Patch gardening, though somewhat tempering our enthusiasm for gardening in such a public environment, have not yet proven intolerable.

\section{Choosing What to Plant and Assessing the Success of Your Crops (Fig. 11)}

One question about community gardens is how much food a small plot can actually product. This will vary based on time, effort, expertise, and luck. Every gardener develops opinions about what plants to grow, based on their desirability and their perceived relative success. However, to put the assessment of success and productivity of crops on a semi-scientific basis, we monitored each crop planted for each year up through 2006 in the following manner. (This process is time consuming, and after learning what we wanted to learn, we discontinued the effort.)

For tabulating our production for a representative year (2005), we define each crop line item by the plant Name and Cultivars planted in this year. For simplicity, we will often group several cultivars (such as spring and fall lettuces) together. The usual common name is given first, followed by the scientific name and various synonyms in \{curly braces\}. The cultivars (or varieties) are then shown in 'single quotes' - these are designated as (1), (2), (3), etc. when there are more than one. For accurate estimates of our overall harvests (yields), we weighed and recorded the number of pounds or ounces produced at each picking for each crop item. Even for

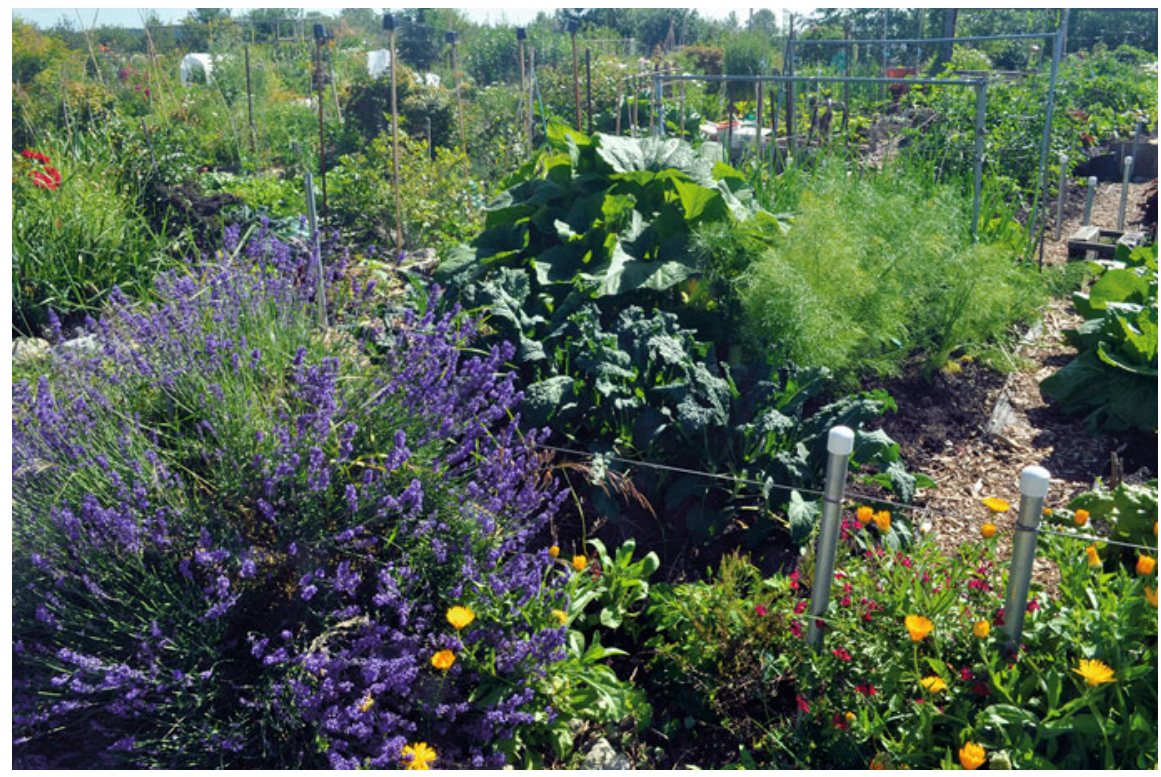

Fig. 11 Various crops growing in a garden 
items that would be priced at the store in other units, we standardized our crop data entry so that yields were expressed only in pounds or ounces. We also determined as best we could a representative retail market price per unit of the organic produce we raised (updated to 2014 prices). The unit market price is commonly expressed at the store as dollars per pound or per ounce. For example, organic heirloom tomatoes are currently sold for an average of $\$ 4$ per pound during the season in which we harvest them. Some vegetables however are sold by the bunch (e.g., beets and parsley) or by the item (e.g., corn, squashes, and artichokes), but for such items, we weighed them at the store and converted the store prices to dollars per pound or ounce. Prices were determined from a nearby Seattle store that carries many organic items, PCC Natural Markets. Where 2014 retail prices were not currently available, we have estimated current prices by using 2005 retail prices adjusted for intervening inflation based on the ratio of Consumer Price Indexes, in this case 233.5/194.5=1.2. Market prices for a crop item vary considerably with the time of year, and we tried to estimate the market price at the time of our maximum production. If we had several widely spaced harvests of a particular crop item involving multiple seasons for a single year, we tried to estimate a representative average market value for the combined periods. Similarly, if a line item consists of several cultivars which vary in price, we tried to arrive at an average price for the group. In valuing our crops, we ideally tried to weigh and compare them in a similar state of trim (e.g., how much of the inedible stems and leaves had been removed) as they are encountered and weighed at the grocery. In estimating retail market value of produce, Washington state sales tax does not apply, but a few states charge at least a partial sales tax on food, and for those states the value of raising your own would be increased. The product of market value per unit (dollars per unit, or "\$/Unit") and the total production for a given year (in units " $U$ ") yields the total retail market value " $\$$ " for a particular crop item for that year (updated to 2014 prices).

We also kept track of the number of square feet that we devoted to a particular crop item each year. The square footage ("SF") that we assigned to a crop (and which we planned on our scale drawing) is only an approximate and relative estimate of how much space the crop item required compared to other crop items. This is because (1) crops are grown at different times of the year but may partially overlap to varying degrees with other crops; (2) the number of square feet consumed by a crop item can vary substantially during its growing season (for example, squashes), and (3) the land occupied is more valuable in the prime parts of the spring and summer growing season than in the early spring and late autumn. As a result of planting multiple successive crops in some parts of the plot, the total square feet shown in our data is somewhat greater than our actual square feet.

To factor in the subjective evaluation or taste of a crop, we also assigned to each crop item what we call the Palatability Index ("P.I.", where 1 is worst, 5 is best). This is assessed upon harvest and consumption. This index is based purely on our personal preferences and how much we actually enjoyed a crop item in the year being evaluated. P.I. will of course vary from person to person, and from year to year.

Finally, we compute what we call a Merit Index ("M.I.") for each crop item, representing the product of its subjective Palatability Index P.I. times its total dollar 
value $\$$ and divided by the square feet SF occupied by the crop item. The Merit Index is a single number reflecting the relative success or productivity of a crop item compared to other crop items, and includes objective measures plus our subjective taste preference. The actual value of the number is not important (and will change from year to year as prices change), but the relative ranking of the items established by their M.I.'s is potentially useful and the goal of this analysis. Each grower will have their own merit index, depending on what they like to eat and conditions at their own plot.

During 2005, we planted 80 different crops. In Table 1, the crops are listed in alphabetical order. The rows and columns shown in the tables are briefly summarized below. Although the data is from 2005, all dollar values have been updated to 2014 prices.

- Name and Cultivars or Varieties: Each row gives the name of the plant or group of similar plants that constitute one of the 80 crop line items

- Production and Units: The number of units (pounds or ounces) that were harvested

- \$/Unit: The updated retail dollar value per unit (ounces or pounds)

- Total Value: The updated total retail value

- Sq. Feet (SF): The square feet of soil we assigned

- U/SF: The units (ounces or pounds) that we actually harvested per square foot of soil

- Pal. Index (P.I.): The subjective Palatability Index we assigned, based on our actual taste experience $(1=$ worst, $5=$ best $)$

- Merit Index (M.I): The Merit Index, a measure of overall success of productivity that was calculated using updated prices (Table 1)

For this particular year, the ranges of Merit Index and crop results are summarized as follows:

- High Merit Index: The highest merit crop items (those falling in the top $20 \%$ of M.I.'s and therefore giving the biggest bang for the buck) had M.I.'s above 32. These crops included a mixture of salad greens, arugula, small and large tomatoes, chives, spring and fall lettuces, zucchini, turnips, cucumbers, Italian basil, carrots, tomatillos, and scarlet runner pole beans.

- Medium Merit Index: The medium quality crop items (those falling in the middle $60 \%$ ) had M.I.'s between 6 and 32. Some of our favorites in this category included snow and edible pod peas, Thai basil, various hot and mild peppers, endive, bok choys, 'Kentucky Wonder' pole beans, beets, several onions, Brussels sprouts, chards, summer lettuces, cilantro, certain winter squashes including 'Delicata', standard and Japanese eggplants, radishes, lemon grass, potatoes, several summer squashes, bush beans, certain types of spring/fall spinaches, rhubarb, kales, dill, pumpkins, artichokes, and parsnips.

- Low Merit Index: The lowest merit crop items (falling in the bottom $20 \%$ ) had M.I.'s below 6. These included Chinese broccoli, other types of spinach, 


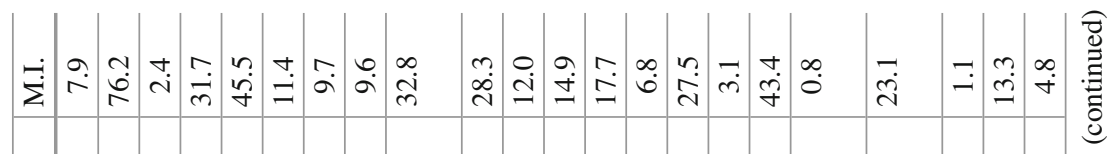

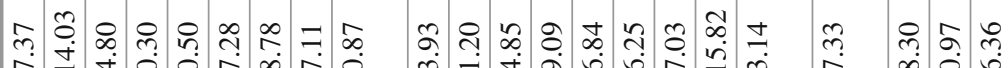

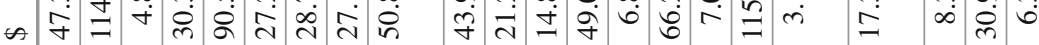

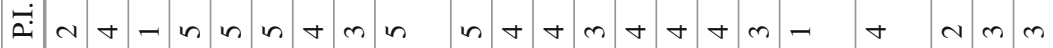

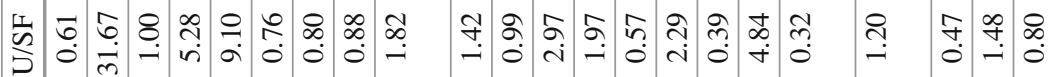

:

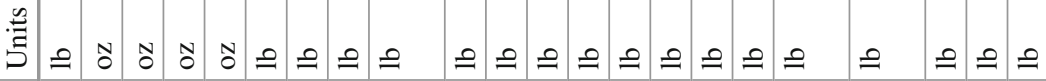

๘

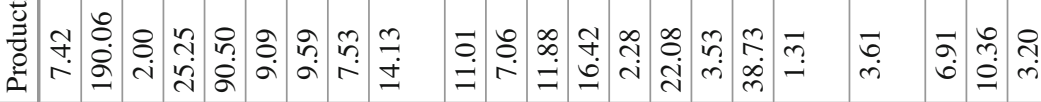

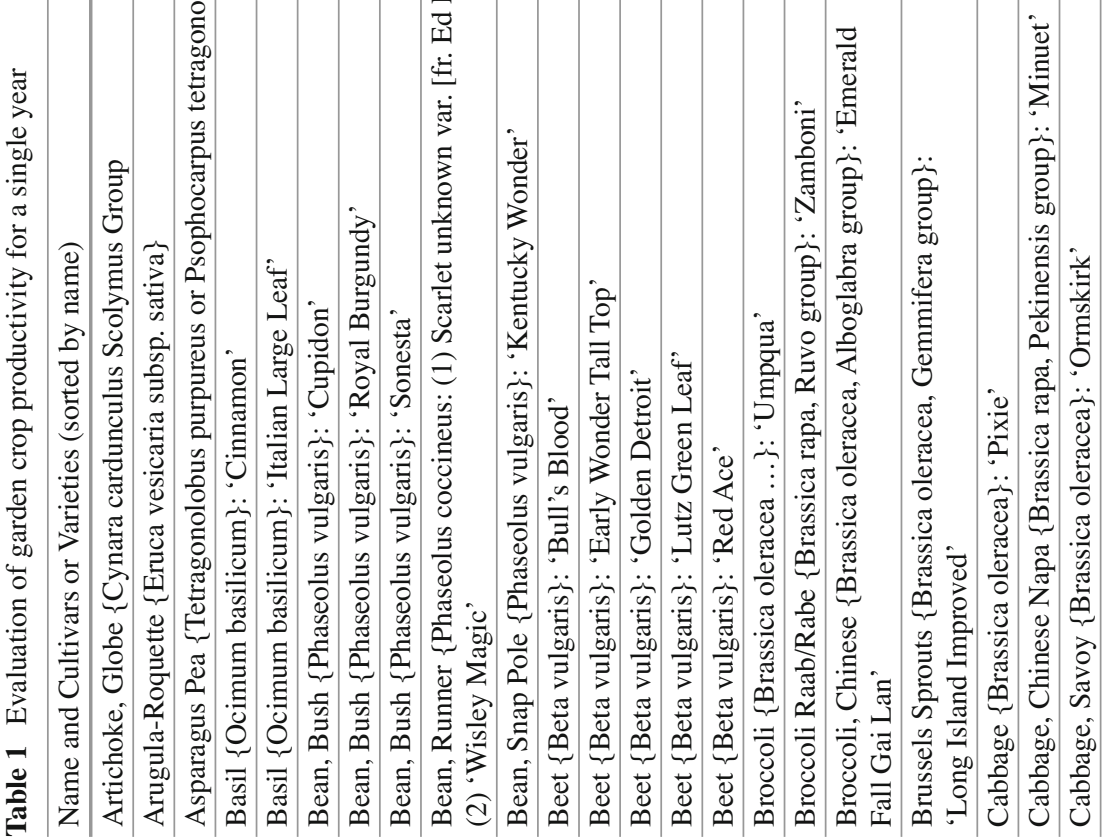




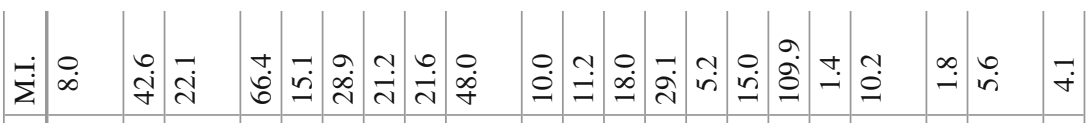

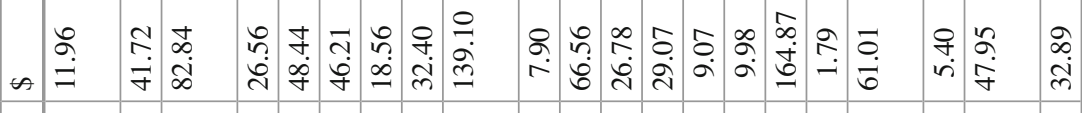

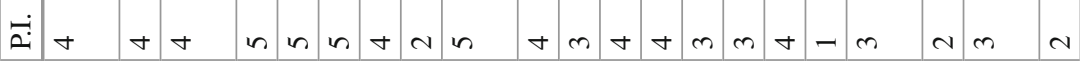

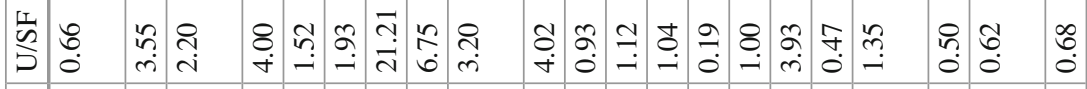

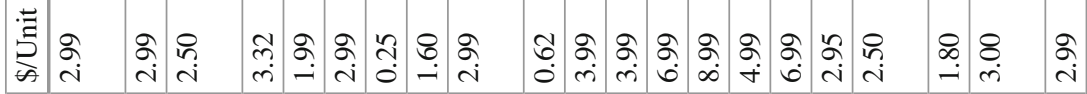

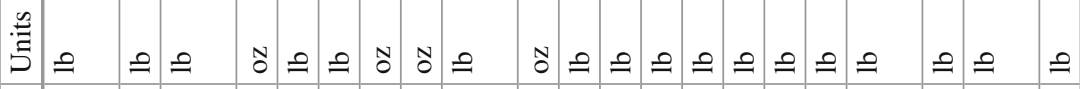
I

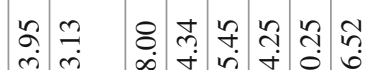

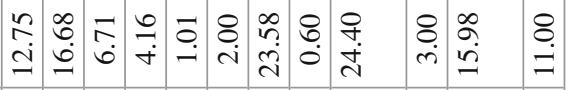

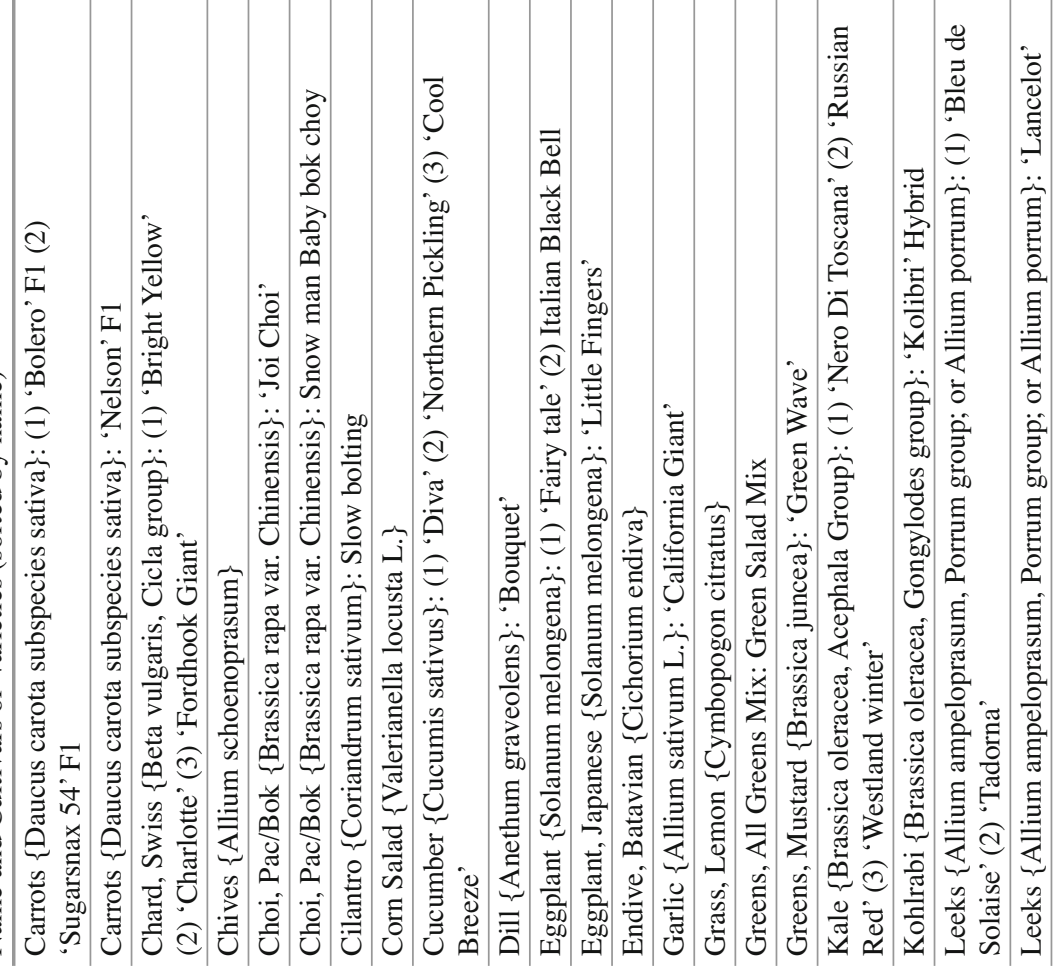




\begin{tabular}{|c|c|c|c|c|c|c|c|c|c|c|c|c|c|c|c|c|c|c|c|c|}
\hline$\stackrel{n}{\beth}$ & 守 & $\stackrel{m}{\sim}$ & $\begin{array}{l}0 \\
\dot{\Xi}\end{array}$ & $\frac{0}{\vec{N}}$ & $\begin{array}{l}\infty \\
\dot{\sim}\end{array}$ & $\stackrel{N}{a}$ & 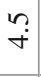 & $\stackrel{N}{r}$ & $\stackrel{9}{=}$ & $\ddot{r}$ & $\frac{a}{m}$ & $\stackrel{?}{=}$ & $\frac{0}{\dot{m}}$ & $\begin{array}{l}\stackrel{0}{ } \\
\text { ते }\end{array}$ & $\begin{array}{l}\infty \\
\stackrel{-}{-}\end{array}$ & $\stackrel{+}{\sim}$ & $\stackrel{y}{\sim}$ & $\underset{\sim}{\sim}$ & 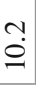 & $\stackrel{\sim}{+}$ \\
\hline$\stackrel{n}{\varrho}$ & 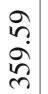 & $\stackrel{ }{\hat{\sigma}}$ & $\frac{\hat{\sigma}}{\dot{\gamma}}$ & $\begin{array}{l}\infty \\
\sim \\
\infty \\
n \\
n\end{array}$ & $\begin{array}{l}\bar{\infty} \\
\vec{\lambda}\end{array}$ & 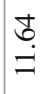 & $\begin{array}{l}\text { రై } \\
\text { లా}\end{array}$ & 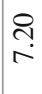 & $\begin{array}{l}\infty \\
ٌ \\
2 \\
-\end{array}$ & 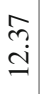 & \begin{tabular}{l}
\multirow{1}{0}{} \\
$\infty$ \\
$\infty$ \\
0 \\
0
\end{tabular} & $\begin{array}{l}\overline{0} \\
\dot{+} \\
\text { in }\end{array}$ & $\begin{array}{l}\infty \\
\infty \\
\text { m } \\
\text { n. }\end{array}$ & $\frac{8}{n}$ & 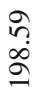 & $\begin{array}{l}2 \\
n \\
0 \\
8\end{array}$ & $\bar{\alpha}$ & $\begin{array}{l}\vec{r} \\
\stackrel{d}{d}\end{array}$ & 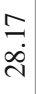 & $\stackrel{\sim}{\rightleftarrows}$ \\
\hline$\nabla$ & in & $\nabla$ & $m$ & in & in & n & in & $\nabla$ & in & $m$ & in & $\nabla$ & in & $\nabla$ & $\nabla$ & - & $\nabla$ & $\nabla$ & $N$ & $m$ \\
\hline $\bar{\sigma}$ & $\stackrel{n}{n}$ & $\begin{array}{l}\hat{6} \\
i\end{array}$ & $\stackrel{0}{=}$ & $\stackrel{\circ}{i}$ & $\begin{array}{l}0 \\
\infty \\
0 \\
0\end{array}$ & $\begin{array}{l}\infty \\
\stackrel{i}{\text { j }}\end{array}$ & $\stackrel{\stackrel{\sim}{+}}{\underset{+}{*}}$ & ñ. & ñ & ñ & $\bar{\sigma}$ & $\vec{\sigma}$ & ஓ̊ & $\begin{array}{l}0 \\
\infty \\
0 \\
0\end{array}$ & $\stackrel{f}{\text { f }}$ & $\frac{0}{6}$ & $\stackrel{8}{\circ}$ & $\begin{array}{c}0 \\
i \\
i\end{array}$ & 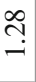 & \begin{tabular}{l}
0 \\
\multirow{0}{0}{} \\
0
\end{tabular} \\
\hline $\begin{array}{l}\triangleright \\
+ \\
+\end{array}$ & $\begin{array}{l}\stackrel{0}{q} \\
\infty\end{array}$ & $\stackrel{2}{2}$ & $\begin{array}{l}8 \\
\dot{+}\end{array}$ & $\stackrel{\partial}{-}$ & $\begin{array}{l}8 \\
0\end{array}$ & $\stackrel{\infty}{\infty}$ & $\begin{array}{l}\text { กิ } \\
\text { ô }\end{array}$ & $\begin{array}{l}8 \\
\dot{m}\end{array}$ & Әे. & $\begin{array}{l}8 \\
\dot{m}\end{array}$ & Әे. & बे. & જे & बे. & 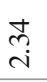 & 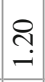 & $\stackrel{\partial}{-}$ & $\stackrel{\Omega}{\sigma}$ & & बे \\
\hline$=$ & 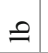 & 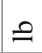 & $=$ & $\bumpeq$ & $=$ & N & N & 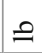 & $\cong$ & $=$ & $=$ & 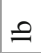 & $=$ & $=$ & 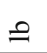 & 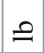 & $=$ & 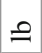 & $=$ & $\triangleq$ \\
\hline
\end{tabular}

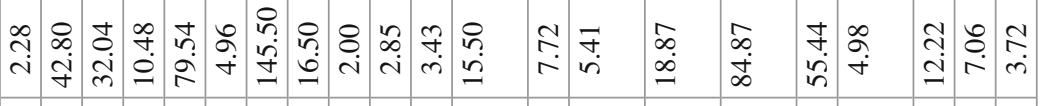

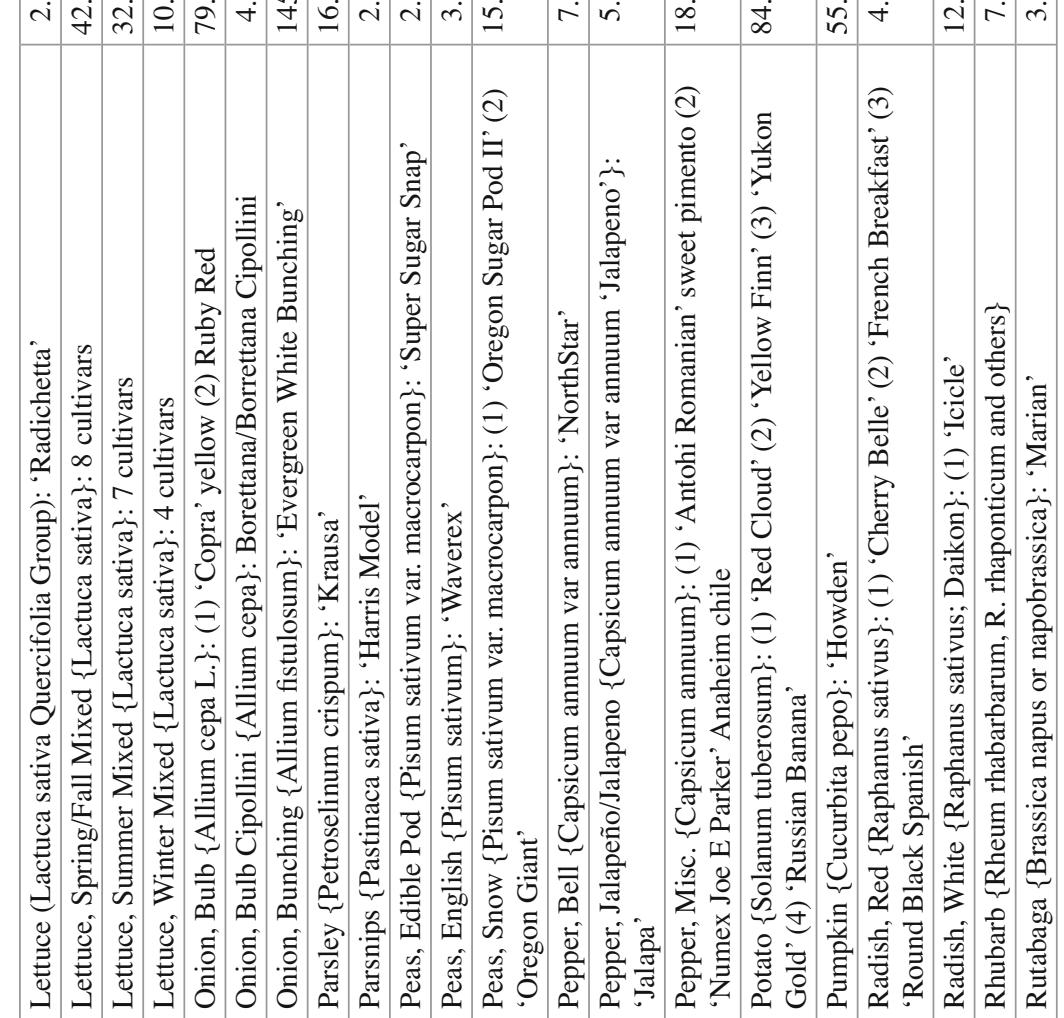




\begin{tabular}{|c|c|c|c|c|c|c|c|c|c|c|c|c|c|c|c|c|c|}
\hline ¿ـ & 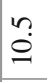 & $\stackrel{\infty}{0}$ & $\begin{array}{l}0 \\
\text { in }\end{array}$ & $\begin{array}{l}0 \\
\dot{2} \\
\end{array}$ & ڤે̀ & ले. & $\ddot{n}$ & $\hat{\stackrel{\sim}{े}}$ & $\vec{a}$ & $\stackrel{n}{\simeq}$ & $\begin{array}{l}0 \\
\text { in }\end{array}$ & $\stackrel{+}{\stackrel{\sim}{d}}$ & $\frac{n}{n}$ & ก) & $\stackrel{⿱}{\dot{q}}$ & $\begin{array}{l}n \\
\vdots \\
n\end{array}$ & \\
\hline$\infty$ & 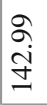 & $\begin{array}{l}\qquad \\
\infty \\
i \\
i\end{array}$ & $\begin{array}{l}\text { J } \\
\infty \\
\text { d } \\
\end{array}$ & $\begin{array}{l}m \\
\infty \\
\dot{m} \\
m\end{array}$ & 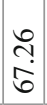 & $\begin{array}{l}m \\
\tilde{n} \\
\tilde{n}\end{array}$ & 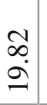 & $\begin{array}{l}\infty \\
\stackrel{0}{0} \\
\stackrel{i}{i}\end{array}$ & $\begin{array}{l}n \\
n \\
n \\
n\end{array}$ & 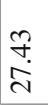 & $\begin{array}{l}1 \\
m \\
\infty\end{array}$ & 挆 & $\begin{array}{l}\text { ర్ } \\
\infty \\
0 \\
0 \\
-0\end{array}$ & 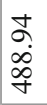 & $\begin{array}{l}\text { f. } \\
\text { o }\end{array}$ & 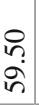 & 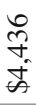 \\
\hline : & in & $n$ & in & in & $\nabla$ & $\nabla$ & $n$ & $m$ & in & $n$ & $\nabla$ & $N$ & $\nabla$ & in & ナ & $m$ & \\
\hline$\frac{\sqrt{1}}{2}$ & $\begin{array}{l}\infty \\
\infty \\
0\end{array}$ & Oo. & $\stackrel{\infty}{\stackrel{\infty}{m}}$ & \& & $\begin{array}{l}n \\
i \\
n\end{array}$ & $\begin{array}{l}0 \\
\stackrel{0}{i}\end{array}$ & ñ & 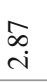 & ڤิ & $\begin{array}{l}0 \\
0 \\
0\end{array}$ & $\tilde{n}$ & 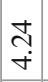 & $\stackrel{n}{\leftrightarrow}$ & $\begin{array}{l}8 \\
i \\
i\end{array}$ & $\begin{array}{l}\tilde{n} \\
i\end{array}$ & $\begin{array}{l}\tilde{b} \\
\dot{6}\end{array}$ & \\
\hline$\frac{\vec{Z}}{\vec{B}}$ & i̊ & iq & बे & $\begin{array}{l}\partial \\
\hat{i}\end{array}$ & $\hat{i}$ & $\begin{array}{l}\stackrel{\partial}{\hat{i}} \\
\end{array}$ & ఫે & $\underset{i}{\stackrel{o}{i}}$ & \& & $\begin{array}{l}8 \\
\dot{r} \\
\dot{m}\end{array}$ & $\underset{\substack{q \\
i}}{ }$ & $\begin{array}{c}q \\
q \\
i\end{array}$ & $\begin{array}{l}\triangleright \\
\stackrel{+}{+}\end{array}$ & $\begin{array}{l}\text { N} \\
i \\
i\end{array}$ & बे. & $\grave{\grave{\lambda}}$ & \\
\hline 党 & $=$ & $=$ & $\cong$ & $=$ & 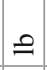 & $\triangleq$ & 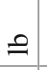 & $\bumpeq$ & $=$ & 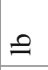 & 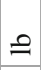 & $=$ & 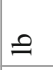 & $=$ & $\bumpeq$ & 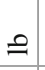 & \\
\hline
\end{tabular}

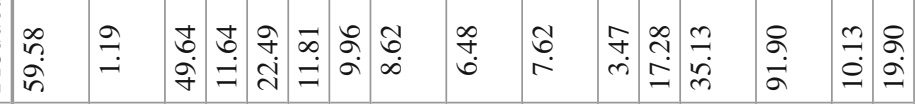

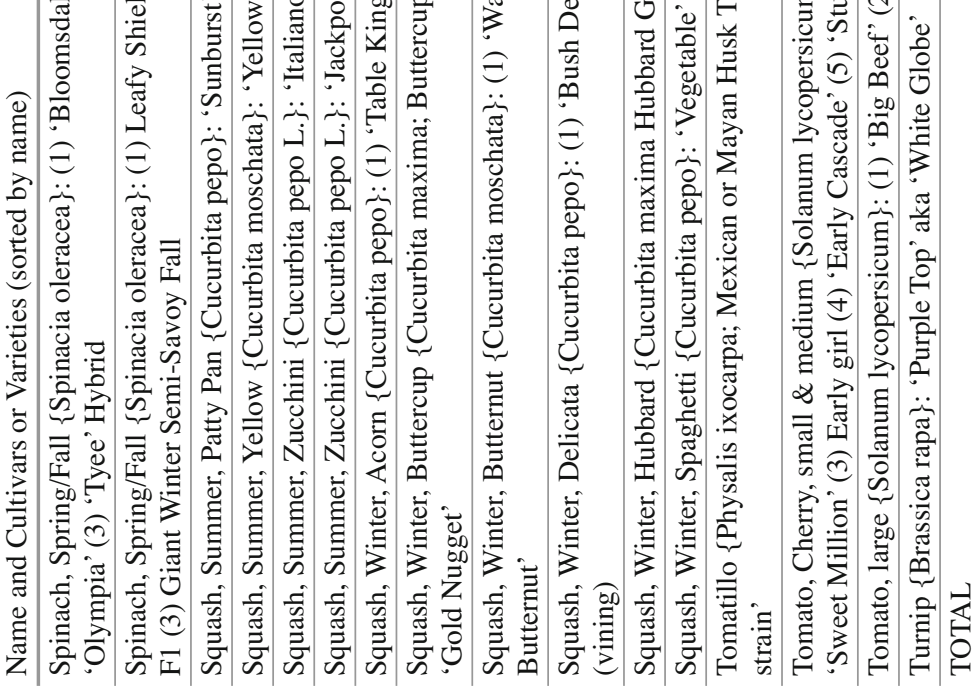


cabbages, mustard greens, kohlrabi, broccoli, leeks, rutabagas, parsley, garlic, English peas, and certain other winter squashes including acorn and Hubbard.

We have chosen not to replant some crops that we tried in earlier years and that had low productivity in our setting - for instance, corn and okra - and these are not included in the current listings. Crop items with M.I.'s below 6 we considered to have rather low success, while those with higher M.I.'s were acceptable. Put another way, if you plan to grow crops in a Seattle area P-Patch, we recommend any of the crops listed above having a Merit Index (M.I.) of 6 or greater (most of which are listed in the High Merit Index or Medium Merit Index categories). However, the data in this table represents our actual experience for only a single year, and other gardeners very likely had or will have different experiences with the same crops items. In addition, we have had greater success with some crops planted in other years, and we continue to plant them-these include broccoli, Chinese Broccoli (Gai Lan), and leeks.

We also have favorites that we continue to plant even if their M.I.'s have been disappointing, in some cases because they are visually interesting or to some extent ornamental. Rebecca would always like to see more flowers in the borders, but growing ornamentals reduces edible production (unless you are raising nasturtiums). We grow some plants, such as borage, not to eat but to assist other plants by attracting pollinating insects and beneficial predatory wasps (Fig. 12).

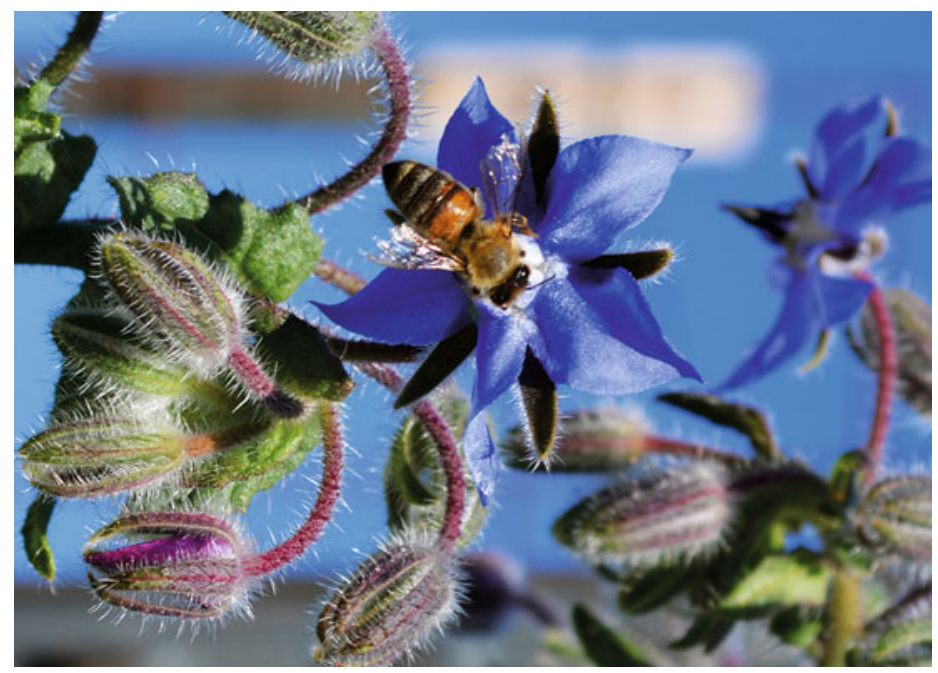

Fig. 12 Borage attracts pollinators to the garden 
When you are planting for the enjoyment and education of young children, it becomes desirable to choose at least some plants that will allow them to participate in planting, tending, observing development, and harvesting. Appropriate choices might include English peas, pumpkins, radishes, pelleted seeds like carrots, and beans.

\section{Estimating the Crop Dollar Value and Costs of P-Patch Gardening}

As emphasized, we are not gardening at a P-Patch primarily to save money. However, it can be instructive to estimate the net economic benefit. The estimated dollar value of our crops for 2005, updated to 2014 dollars and prices, is $\$ 4436$, accurate to perhaps plus or minus $20 \%$.

Our expenses are estimated roughly as follows (Table 2):

Again this total is accurate to perhaps plus or minus $20 \%$. Using these estimates, our net value gained was about $\$ 3320$ for 600 sq. $\mathrm{ft}$. gardened. However, if we were to add in the value of our labor (about $250 \mathrm{~h}$ at $\$ 12 / \mathrm{h}$, or $\$ 3050$ ), our net gain would be less than $\$ 300$ (compared to simply buying the same or similar vegetables in the store). Thus we are close to breaking even in dollar value.

\section{Conclusion}

P-Patch vegetable gardening is hard work, mainly because you must tend the garden frequently, and it will probably not save you much money. However, it can provide many hours of back-to-the-good-earth satisfaction, a practical and useful education

Table 2 Garden expenses

\begin{tabular}{l|l}
\hline Items & Cost \\
\hline $\begin{array}{l}\text { Auto, } 102 \text { trips each of } 2.4 \text { miles round } \\
\text { trip at } \$ 0.60 / \text { mile }\end{array}$ & 147 \\
\hline Rental of plot (includes water) & 81 \\
\hline Compost (bags only in this year) & 60 \\
\hline Supplies and depreciation of tools & 100 \\
\hline Seeds, onion sets, seed potatoes, plants & 625 \\
\hline $\begin{array}{l}\text { Electricity to operate 1 KW plant light } \\
\text { over 75 days }\end{array}$ & 103 \\
\hline Total & $\$ 1116$ \\
\hline
\end{tabular}




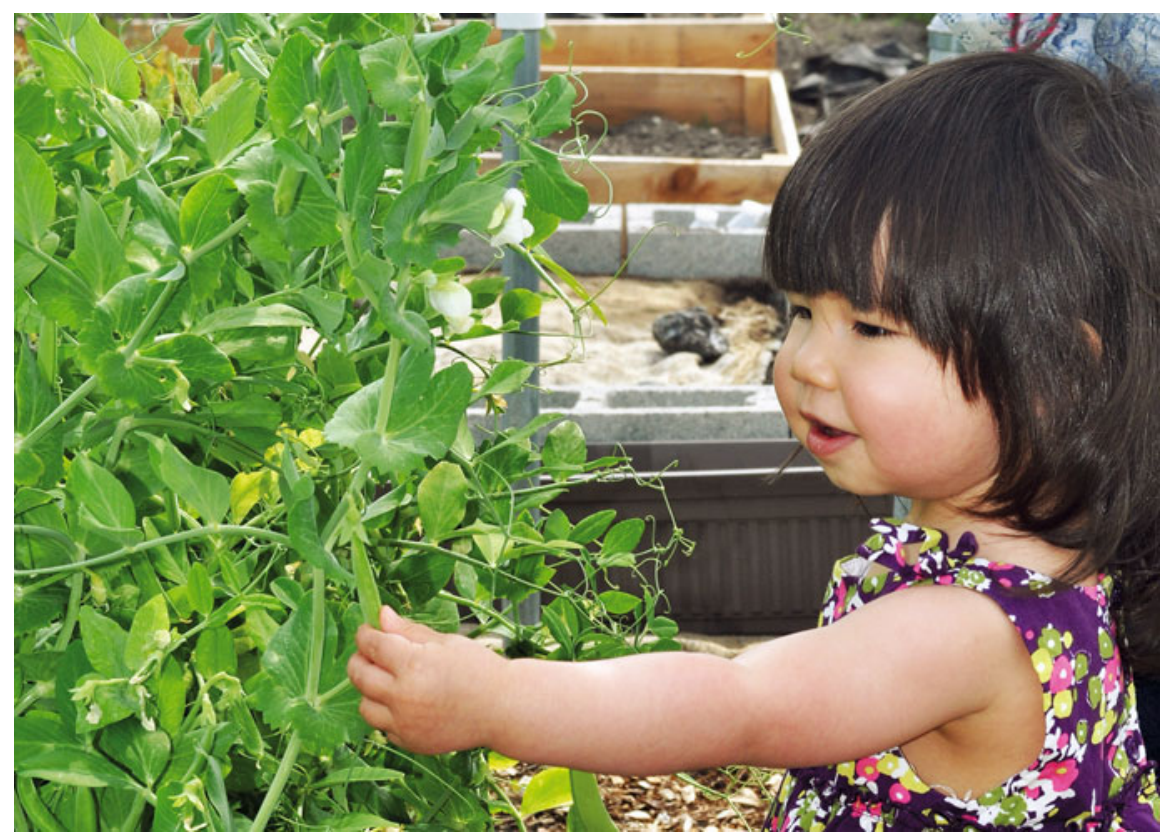

Fig. 13 Future gardener Emily checking out the crops

for you and your children about how plants grow and where food comes from, and entertainment that can help keep you well nourished, your mind constructively occupied, and your spirits mostly upbeat. You should give it a try if you can spare the time (Fig. 13). 


\title{
Applying Permaculture in Alaska: The Williams Street Farmhouse
}

\author{
Saskia Esslinger
}

When you arrive at our home, dubbed the Williams Street Farmhouse, you are greeted by a riot of plants bursting out of a recycled windowpane fence. Stepping up a few slate stairs, under an arbor, and through the gate you arrive in the garden. A small table and chairs sit on an urbanite patio in the shade of an amur chokecherry tree, screened from the street by bush cherry, juneberry, and sea buckthorn bushes. Nestled in a warm microclimate next to the house is a sour cherry tree. An herb and salad clipping bed lies at the base of steps leading up to the kitchen door (Fig. 1).

To the left across the driveway is a lawn surrounded by big garden beds and massive rhubarb plants bordered by a raspberry hedge. To the right the wood chipped path leads to the main garden area surrounding a small solar greenhouse. There is no grass left on this side of the house, having all been replaced with either garden or path (Fig. 2).

This is probably where you will find me. The steps leading up to the front door of the house is where I spend a lot of time in the summer, drinking coffee, eating snacks, or taking a break from garden work. Perched on the steps I can take in the beauty and peacefulness of my garden. Nearby is a sandbox for my toddlers to play and dig in while I tend the garden. You will hear the soft clucking of the chickens as they search through weeds and straw for worms and other tasty bits (Fig. 3).

Our little garden oasis is unexpected in a city like Anchorage, which is known for its short summers, pickup trucks, oil executives, and big-box stores. Of course there are many people who have a 4 by 8 raised bed in their backyard where they grow a few veggies, but this is food production on a whole new level. What's more, our gardens were created out of a barren lawn in just 3 years by utilizing little more than local "waste." They are designed to minimize water runoff while creating habitat for urban life, including ourselves.

\footnotetext{
S. Esslinger $(\square)$

Red Edge Design, Anchorage, Alaska

e-mail: alaskasaskia@gmail.com 


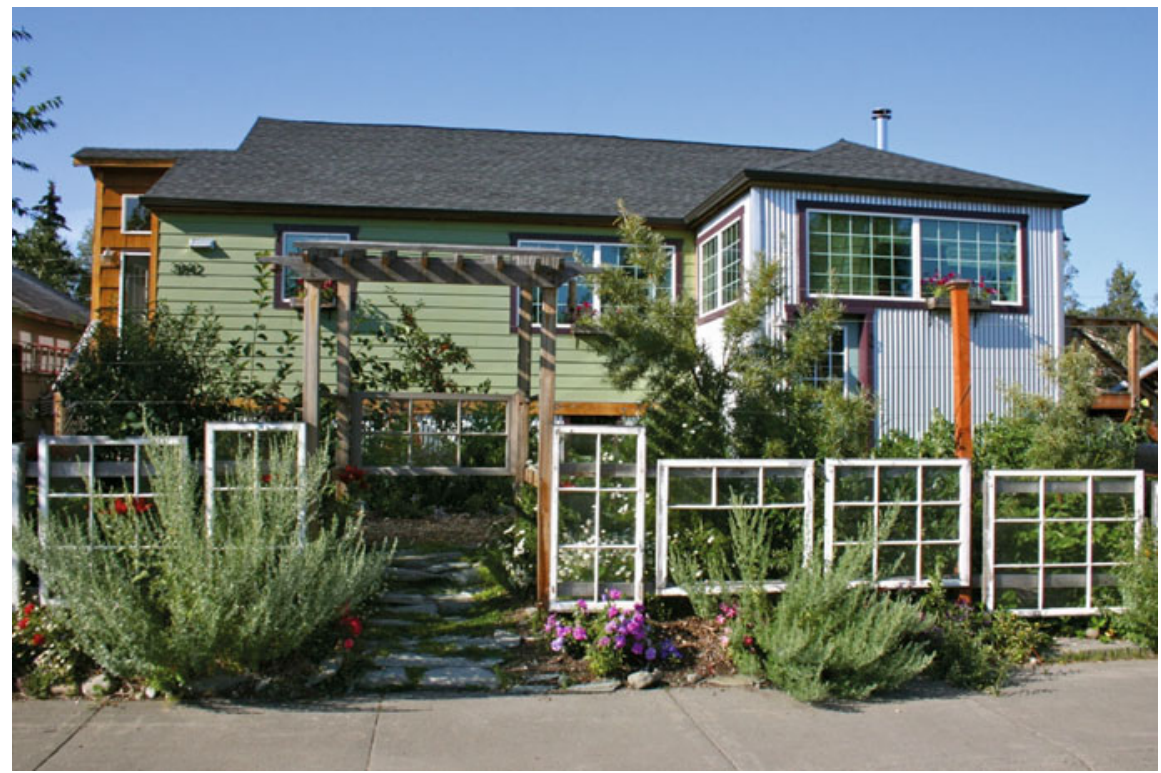

Fig. 1 The Williams Street Farmhouse, framed by a fence of reclaimed windowpanes, is a beautiful and inviting feature of its urban Anchorage, Alaska neighborhood

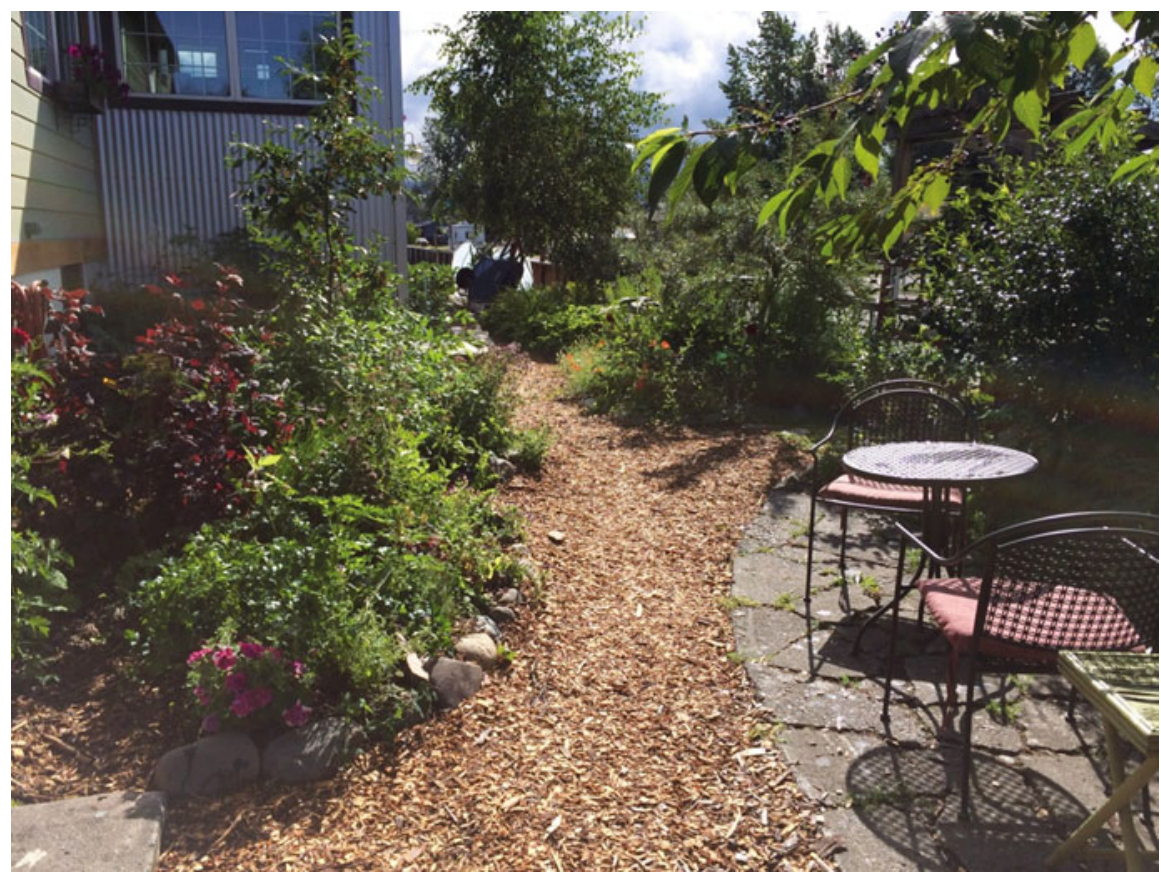

Fig. 2 The garden is not only a place for work and harvest, but also a place for rest and relaxation. In this area of the author's urban farm, a small table and chairs sit on an urbanite patio in the shade of an amur chokecherry tree, screened from the street by bush cherry, juneberry, and sea buckthorn bushes 
Fig. 3 One of the author's tiniest gardeners says "forget 'farm to table', try 'garden to mouth",

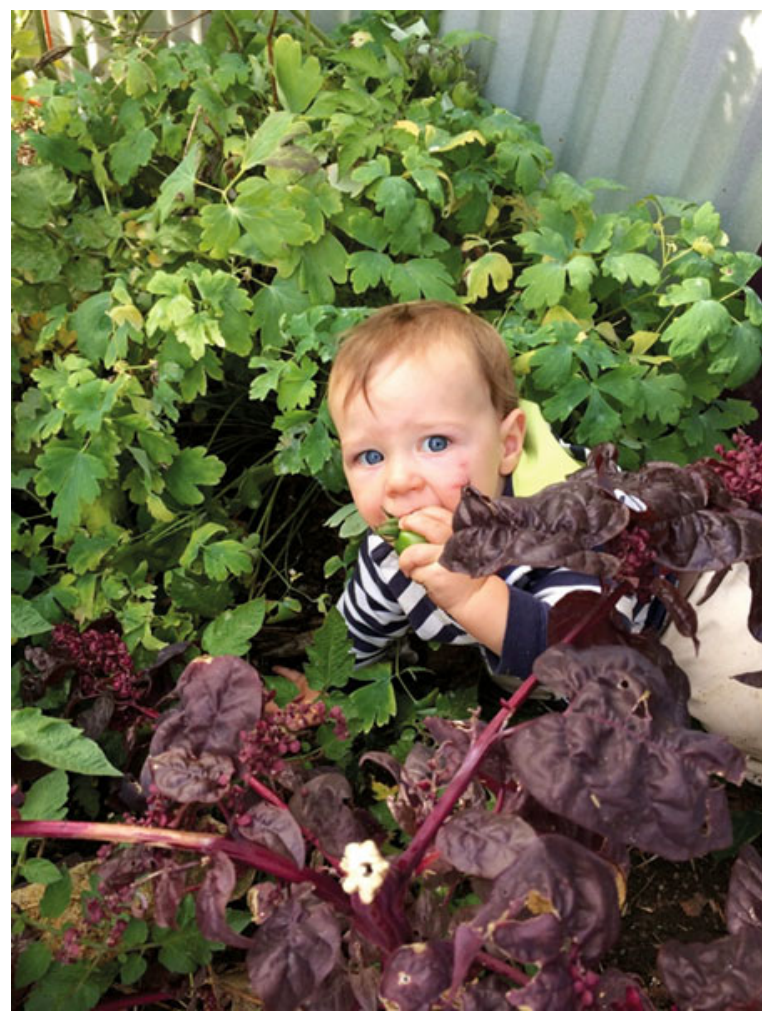

\section{What Is Permaculture?}

The design system we utilized to create the Williams Street Farmhouse is called permaculture. A conjunction of the words "permanent" and "culture", permaculture employs natural principles to create designs that work with nature instead of against it. It is based on the ethics of "people care" (caring for people's basic needs of food, water, shelter, meaningful work, and convivial human contact,) "earth care" (caring for all of the earth's natural systems and striving to heal the earth) and "fair share" (taking no more than we need and putting our extra resources into people and earth care) (Mollison, Bill. Introduction to Permaculture. Tyalgum: Tagari, 1991).

Permaculture seeks to maximize useful connections between the elements in a system so that the needs of one thing are provided for by another element in the system. It values multifunctional elements such as chickens that can provide more than one service. It minimizes human input and maximizes output through thoughtful design.

Permaculture was developed in Australia and is often idealized by the image of a designer grabbing a passion fruit while lounging in a hammock. This is a pretty far stretch up here in Alaska, but the ethics and principles still apply. 
My husband, Matt, and I had both studied permaculture and were eager to put theory into practice. We were tired of hearing about how tough Alaska's climate was and how we could never provide for our own food needs as a community. We had a vision of our barren yard turned into an oasis.

\section{The Design}

We began our design by taking stock of our goals. We wanted a garden that was inspiring to others. We wanted to provide for as much of our food needs as possible. We wanted our garden to be as low maintenance as possible, knowing that we were going to start a family soon and time would be more limited. We wanted it to also be beautiful, because beauty is inspiring to us and to others. No one wants to imitate something ugly, no matter how practical.

We then analyzed our site, looking at sunlight, wind, water, people flows, and aesthetics. We looked at everything we wanted to include; gardens, orchard, chickens, etc, and looked at how we could fit those elements together. We made a master plan and prioritized what we wanted to do first.

\section{The Installation}

We were in our house almost a full year before I was able to start working on the gardens. Enthused and energetic, I decided to try the sheet mulching or lasagna gardening method of installing garden beds. In this method you smother the grass using cardboard and then build up layers of organic material, much like you would build a compost pile, finishing with a thin layer of soil/compost and a layer of top mulch, such as leaves and/or straw.

I rented a trailer and hooked it up to my ' 77 Ford pickup, drove an hour to a local farm and picked up a huge load of goat manure mixed with bedding. I lay down food scraps, cardboard, then piled on the manured bedding. I finished with a bit of sandy soil that was left over from planting trees.

We dug up some sod in another area of the garden to plant our potatoes and carrots. It was a cold, wet summer and everyone was complaining about how awful their gardens were doing, but our sheet mulch garden was doing great. The zucchini were huge, and we even had tomatoes and pumpkins, two things that are not easy in our climate. Meanwhile, the potatoes and carrots out back were doing terrible. Despite adding lots of compost and manure, they struggled. That bed has never done as well as our sheet mulch beds, despite annual additions.

Since then, every bed we have made has been a sheet mulch bed. We have used various materials with different degrees of success. We found that the more variety of materials used, the more micronutrients in the soil and the healthier the beds. Food scraps, coffee grounds, green garden waste, spent grain, and chicken, rabbit or 
goat manure work great for nitrogen sources. Leaves are the most readily available carbon source, and can be found bagged up on the side of the road.

The garden beds are permanent, and designed so we can reach into them to tend them from the pathways. This way we never walk on the soil, compacting where the roots are growing and soil life flourishing. We also keep a top-mulch on the beds to keep the soil loose and moist. In the spring we loosen the soil with a manure fork, rake it smooth, and then plant.

The pathways are made by extending the cardboard and putting down woodchips. After about 3 years the woodchips break down into rich, dark soil. Then we shovel that soil onto the garden beds and replace the woodchips. We can get the woodchips delivered for free from the tree trimming companies. It takes a whole 10 -yard load to cover all of our pathways 3 in. thick. This material would otherwise go to the dump.

\section{The Greenhouse}

We wanted to have a greenhouse for raising starts in the spring, growing warm weather crops in the summer, and extending the season. We designed a three season passive greenhouse, which has glazing on just the south side, with the other three walls and the roof being very insulated. The idea was to keep the temperature more consistent instead of typical greenhouses that heat up too much during the day and cool down too much at night. We also installed a soil heat battery; perforated pipe that runs through the soil beneath the greenhouse. A small fan pulls warm air through it during the day, heating up the soil, and pushes the warm air out at night. This is to further even out the temperature (Fig. 4).

Adding another layer, the chickens have their coop in a fenced-off corner with a small hole that serves as the door to the run in the back of the greenhouse. The idea here is that the chickens provide warmth both from body heat and from their litter composting, as well as carbon dioxide for the plants. We found that the loss of heat from their door counteracted any heat they might give. But it is nice to have a snowfree place to collect eggs in the winter.

While the greenhouse is a good place for plant starts, we find we still need to start things inside the house because there is not enough solar radiation to keep it warm through the night. We also find that due to the limited glazing, the warm weather plants actually do better outside in low tunnels or other microclimates. Furthermore, our seasonal shift in fall and spring is very rapid, so the most we can extend our seasons is about a month.

I say this because I want to be very clear that having a greenhouse is NOT essential to gardening in Alaska. Especially given the high costs of building a greenhouse and the amount of space it takes up, I would urge other urban gardeners to utilize inexpensive low tunnels. A low tunnel is a small hoop house made out of plastic pipe bent over a bed with clear plastic stretched over it. We have great success growing tomatoes, cucumbers, beans, basil and peppers in these. 


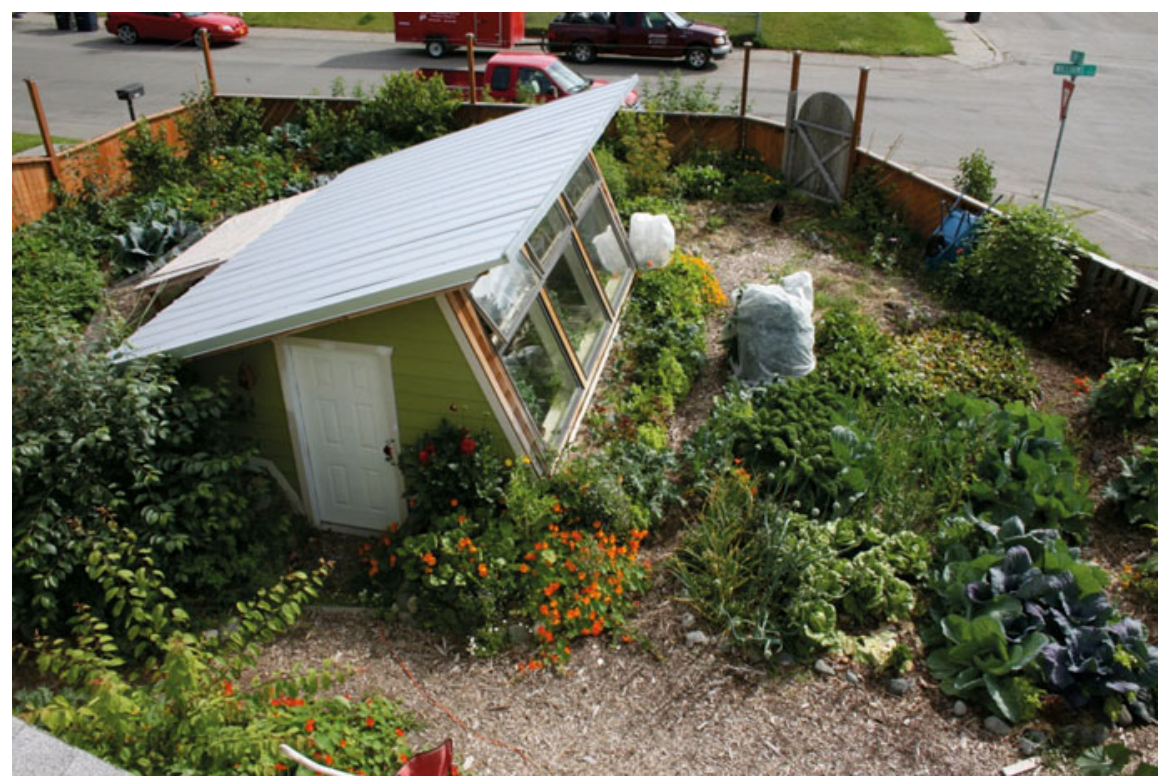

Fig. 4 An aerial view of the author's passive greenhouse. Hidden behind the greenhouse, and connected via a small opening, is the chicken run

We also grow tomatoes around a chicken wire compost ring placed right in the garden. We tie the tomatoes right to the chicken wire. The tomatoes love the heat from the compost pile and I love the convenience of having a place to throw my weeds right in the garden. At the end of the season I remove the chicken wire and push the pile over so it can finish decomposing right in the garden over the winter. No wheelbarrow required!

\section{The Gardens}

In Anchorage the summers are short and cool, but we have few insects or diseases to cope with. Cool season crops do great and grow very fast with our 18-h days. Reliable crops include potatoes, carrots, beets, parsnips, turnips, broccoli, cauliflower, cabbage, lettuce, kale, and even zucchini (Fig. 5).

We have great success starting crops early with a product called floating row cover, a spun polyester fabric which is permeable to water, light and air. It lays on top of the ground like a blanket, trapping heat and slowing evaporation. Seeds germinate faster and better using this. When the plants start to grow they push it up, so no support is needed.

We use floating row cover for everything we plant in the spring. We start our greens in April, as soon as the snow has melted off our warmest beds. We are eating 
Fig. 5 Author Saskia Esslinger enjoys working in her own urban Alaska homestead

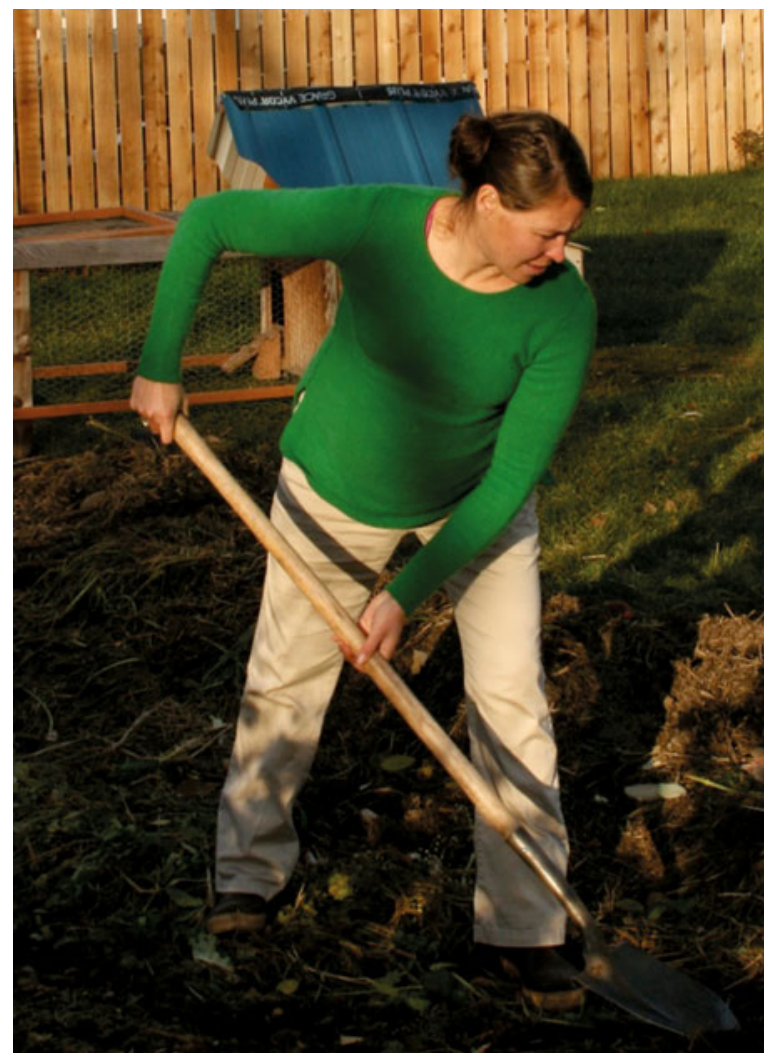

salads before most people are even thinking about planting their gardens. Floating row cover is also essential for keeping cabbage root maggots out of plants in the brassica family. We bury the edges in the garden so the flies cannot land on the plants and lay eggs.

Along with the garden beds we rotate among the annual crops, a number of them are planted with perennials. In our perennial beds we try to mimic natural forests by planting species that compliment each other's needs to reduce maintenance and maximize production. We look for plants that provide more than one function such as edible, medicinal, fertilizer, nectary, or ground cover.

For example, one bed has an apple tree with a gooseberry bush growing in its dappled shade. Behind it is a Siberian pea shrub, which fixes nitrogen from the air and grows high-protein peas. When I chop the branches off and give them to the chickens, some of the roots die back and fertilize the plants around it. Borage, an edible and medicinal flower, self-seeds itself underneath, providing nectar for pollinators as well as beauty. Dandelion and comfrey, dynamic accumulators, draw up nutrients from deep in the soil. I chop off their leaves several times a season and drop them around other plants as mulch and feed them to the chickens. 
Fig. 6 One of the productive apple trees in the author's yard. This tree, in combination with two others, provided 10 gallons of apples over the 2014 growing season

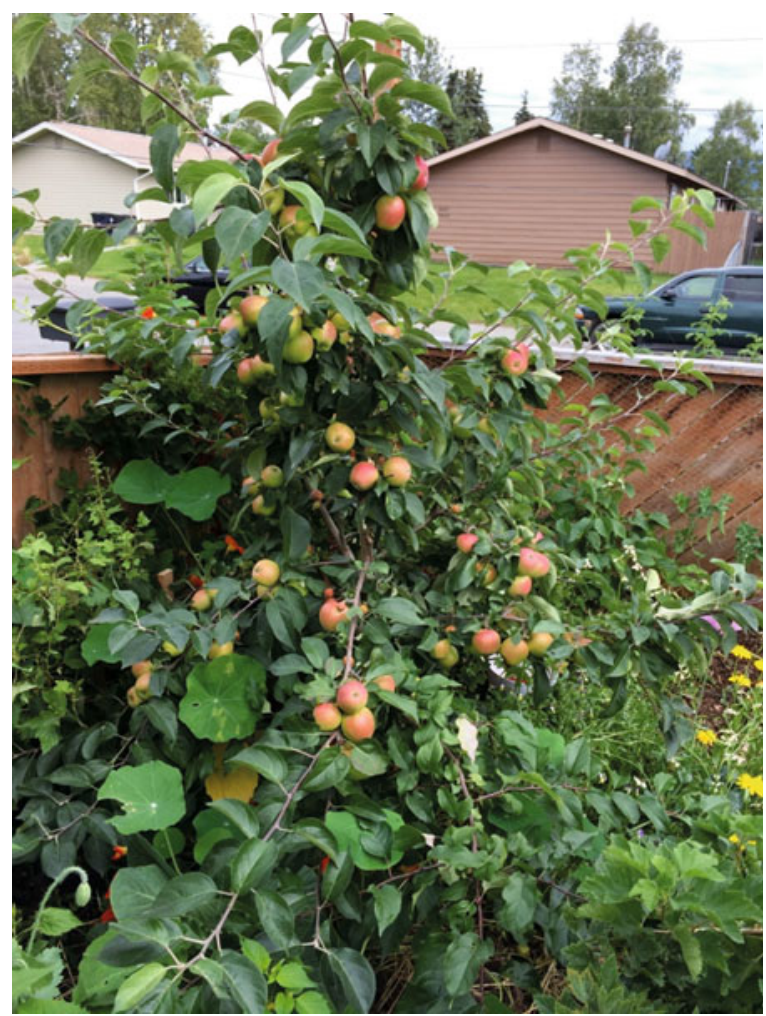

Our apple trees are just coming into production, but we harvested about 10 gallons off of 3 trees this year. We also harvested gooseberries, red currants, black currants, sour cherries, bush cherries, juneberries, seaberries, strawberries and raspberries. In the future, we will also harvest hascaps, aronia, and hardy kiwi. Other edible perennials include Jerusalem artichokes, sorrel, horseradish, good king henry, watermelon berry, tarragon, chives, lovage, and ferns (Fig. 6).

\section{The Birds and the Bees}

Our chickens are an integral part of our gardens, providing nutritious eggs, clean meat, valuable fertilizer, and endless entertainment. They also perform work in the garden by eating slugs, turning compost, eating weeds, and digging beds. The challenge is setting up the system so they create less work, not more.

We find that maintaining deep litter in the chicken coop keeps them healthier and makes cleanup a breeze. The litter (we use straw and sometimes leaves) soaks up the 
manure and keeps it from caking up. As it becomes dirty, we just add more straw on top. We clean out the coop 2-3 times a year, and get several wheel-barrel loads of nitrogen-rich straw that can be incorporated into beds before planting, put directly on top of existing beds in thin layers, or composted. Since it is not straight manure, it will not burn the plants.

Behind the greenhouse is the chicken run. There is a low roof over part of it to provide a snow-free area for them in the winter. We put leaves and straw in their run as well as tossing them garden waste. What they don't eat gets mixed in with the straw and leaves and becomes in effect a huge compost pile. Worms and other insects living in here provide an important source of protein for the chickens. There are also a few logs in the run that I turn over occasionally for access to even more insects. Once or twice a year I will mine the run for beautiful, rich compost.

In the spring and fall I will let the chickens into select areas of the garden using a chicken tractor or temporary fencing. A chicken tractor is a mobile house on wheels with a caged-in outdoor area where they can search for weeds, seeds, and bugs. As they scratch, they turn in their own manure and fluff up the soil (Fig. 7).

We keep a hive of bees on top of the garage so they are out of the way. Our primary purpose is for the honey, a delicious natural sweetener, but we also are happy to take advantage of their pollination services. Our honey harvests have been small so far, only a few gallons each year. Beekeeping in Alaska is not easy, but it is fascinating to learn! We have had no problems with our neighbors over the bees, and only a few accidental stings.

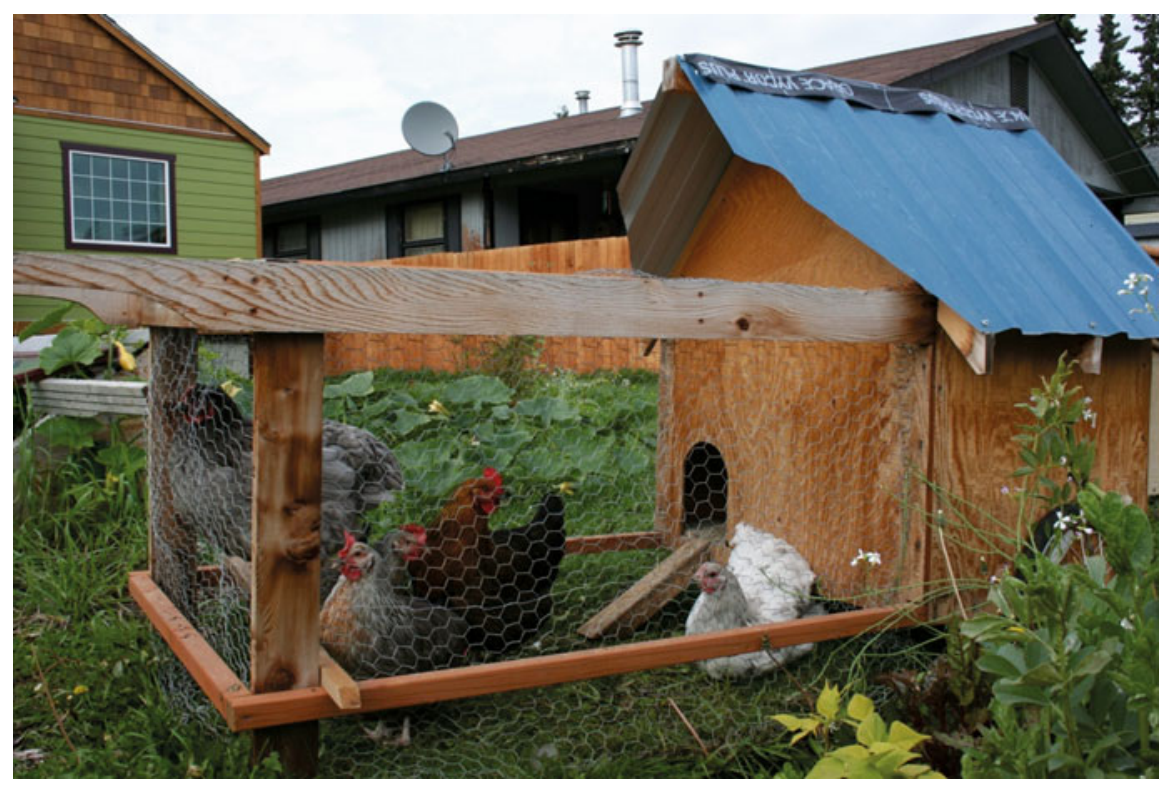

Fig. 7 Chickens roam strategically selected areas of the garden in a "chicken tractor", while eating weeds and slugs, tilling the soil, and turning in their own manure 


\section{Food Production and the Alaska Food Challenge}

In 2011, Matt and I decided to take our commitment to eating and growing local to a whole new level. Along with a group of like-minded people, we pledged to eat all local food for an entire year. We allowed ourselves to source food from all over the state, with as much as possible coming from our own property.

We joined forces with our downstairs tenants to grow our biggest garden ever. We kept track of everything we harvested. We grew over 1600 pounds of vegetables, worth over $\$ 5500$. We also provided all of our own eggs and 7 meat chickens.

We made a root cellar in the back of our unheated garage by insulating a small room and putting in a heater on a thermostat to keep it just above freezing. We put our potatoes in boxes made of cedar fence pickets and all our other root vegetables in damp sand. Onions and garlic were hung in mesh bags. We also kept crocks of fermented vegetables, although we have now found that they last better in smaller jars.

We canned a few things like tomatoes and applesauce. Most herbs (including some for tea) went into the dehydrator. Everything else went into the freezer: berries, herb pastes, and vegetables such as broccoli, cauliflower, greens, leeks, celery, and green beans.

I was so afraid that we were going to run out of green things to eat in the winter that I blanched and froze over 40 pounds of kale. Needless to say, we didn't end up eating it all, and shared a lot of it with others doing the food challenge. In fact, we ended up with a lot of extra food.

Since then we have refined our food growing and preservation to reflect more what we eat over a winter. We find this is constantly changing with our growing family, but we estimate the best we can. We also realized that we grow too much food for our own family, so we now have two interns who work with us throughout the growing season in exchange for garden produce. We also share with family, friends, and the local soup kitchen.

This year we froze about 45 pounds of vegetables and 13 gallons of berries. In our root cellar we have approximately 7 gallons of carrots, 8 gallons of potatoes, 3 gallons of beets, 3 gallons Jerusalem artichokes, 4 gallons parsnips, and 4 gallons of apples. We have 4 cases of sauerkraut, 3 cases of fermented tomatillo salsa, and a few jars of pickles. We canned 24 pints of tomatoes and 16 pints of applesauce. We have 10 winter squash decorating the house that we will eat all winter long. We also have 2 gallons of honey from our bees and a (somewhat) steady supply of eggs. All this is from a 9000 square foot city lot. 


\section{Conclusion}

Growing and preserving our own food is time consuming, but it is a lifestyle choice. We enjoy working in the garden and sharing it with our children and other people. We get fresh air, exercise and connect with nature. We get enormous satisfaction from eating food we grew ourselves. The food tastes better, is more nutritious, has more variety, and is pesticide-free. We save a significant amount of money and reduce our environmental impact. We are less reliant on outside sources of food and could feed ourselves for a long time should the food supply in Alaska be interrupted. Our gardens are as beautiful as they are productive, providing habitat for birds and bees. When I add up all the benefits from our gardens, I can't help but think... "Why aren't more people doing this?" 


\title{
Seed Libraries
}

\author{
Melissa Desa
}

\section{What Is a Seed Library?}

Seed libraries are sprouting up around the world in various forms as a means to share and preserve seeds within a community. Locally based seed libraries have an important role in protecting and sharing heirloom and other regionally appropriate seed, while also engaging growers in a meaningful way that inspires a sense of community. These are important facets of a resilient and food secure system (Figs. 1 and 2).

Generally, there are two models of seed library operation. The first is a free community seed exchange, typically hosted in a public space where seeds are offered in a self-serve manner, easily checked in and out by the user. Seeds are usually free, or available for a very small membership donation, with the philosophy that seeds are a shared community resource, not a commodity. The other approach to seed library operation is a membership-based model where seed is grown locally with an emphasis on regional varieties and it may be sold or made available based on membership level. The membership dues or retail sale of seeds is necessary to cover costs of increased labor and oversight as compared to the free and open model. Within the two general models, there is much variation for each unique library, reflecting the mission, demand, available resources, and needs of the community it serves.

M. Desa $(\bowtie)$

Forage Farm, Gainesville, FL, USA

e-mail: melissadesa@gmail.com 


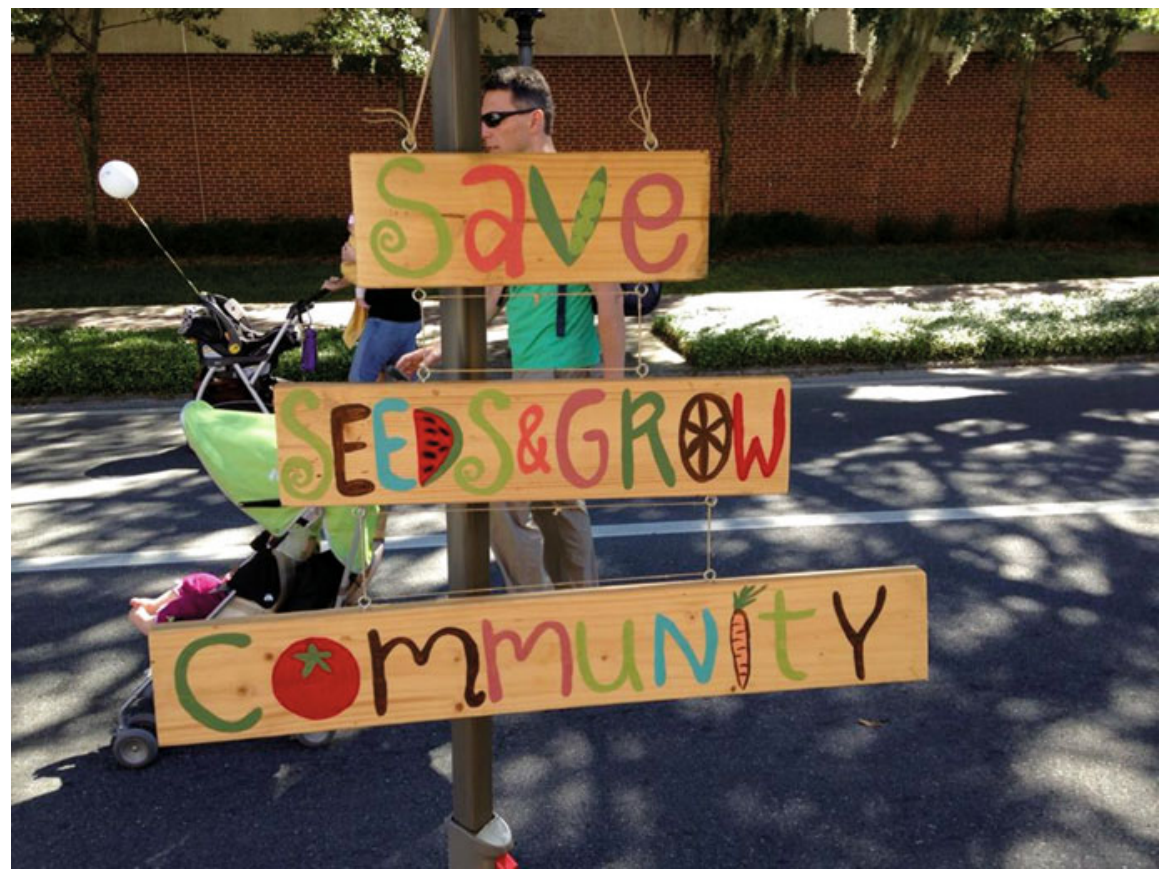

Fig. 1 Seed libraries not only provide a means for sharing and preserving seeds, but also function to promote food security, protect heirloom and regionally important seeds, and foster a sense of community

\section{Structural Organization}

A first step to founding a seed library is site selection. Unfortunately, the needs for the social aspect do not match that of the seed storage needs. Ideally seeds are stored in a refrigerator or freezer, but in open community space systems, they may only be held at room temperature which reduces longevity and viability. If they are distributed quickly and planted within a year or two, then this problem is not much of a concern. In this case, facilitating the social and sharing aspects is selected over ideal seed storage conditions. Common locations are public libraries, churches or community centers. Depending on the facility and organizational structure, there may be regular open hours, or set limited hours based on seasonality or convenience (Fig. 3).

An important component to any seed library is the labor involved which may include staff, volunteers, or both. Many seed libraries are free resources run by nonprofit organizations or individuals; with the donation of labor, seeds and funding critical to their operations. Any operation depending on volunteers can be a challenge, as volunteer labor tends to ebb and flow. One or two critical organizers must remain dedicated to keeping the operation viable. The self-serve system helps reduce this strain, although some work is still involved in maintaining inventory of 


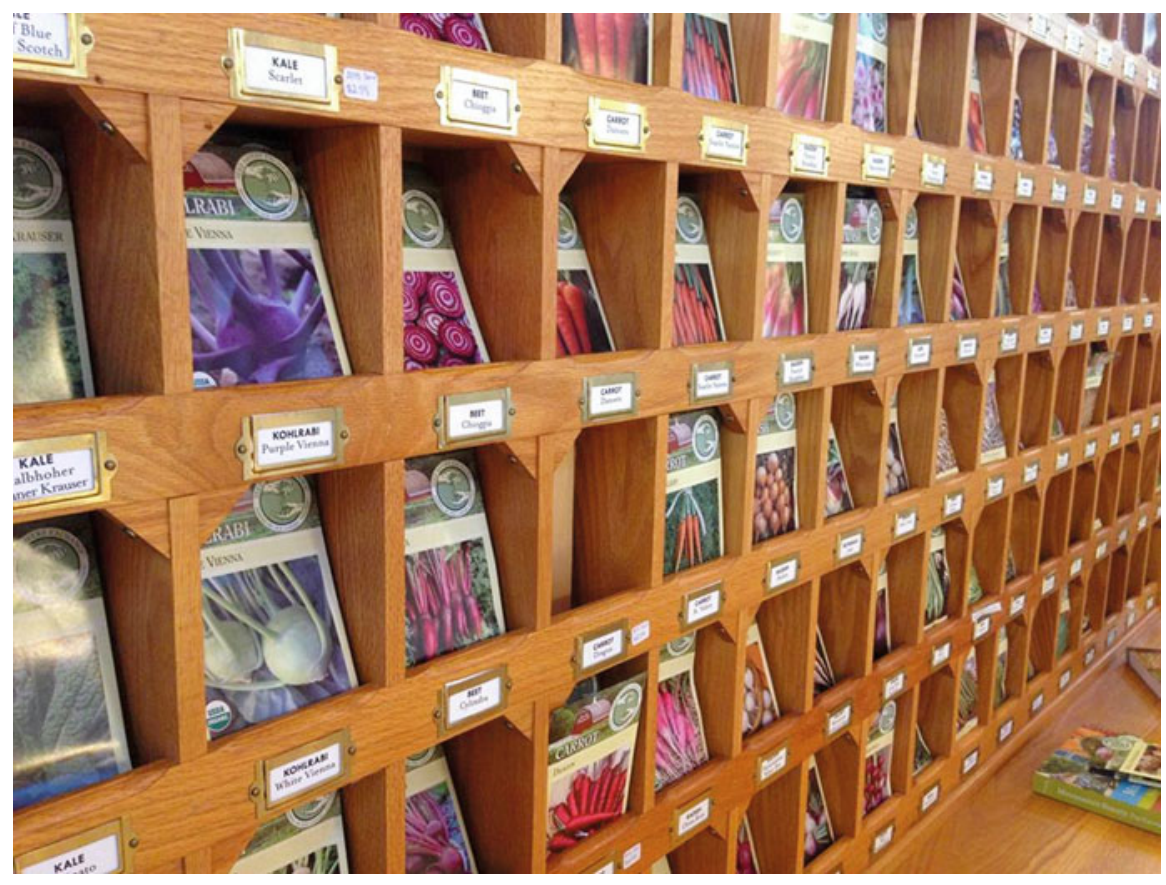

Fig. 2 Seed libraries can be sited in a variety of places (e.g., a public library, church, or community center), with key features being easy public access, organization, a well-stocked selection of quality seeds, and a visually appealing display

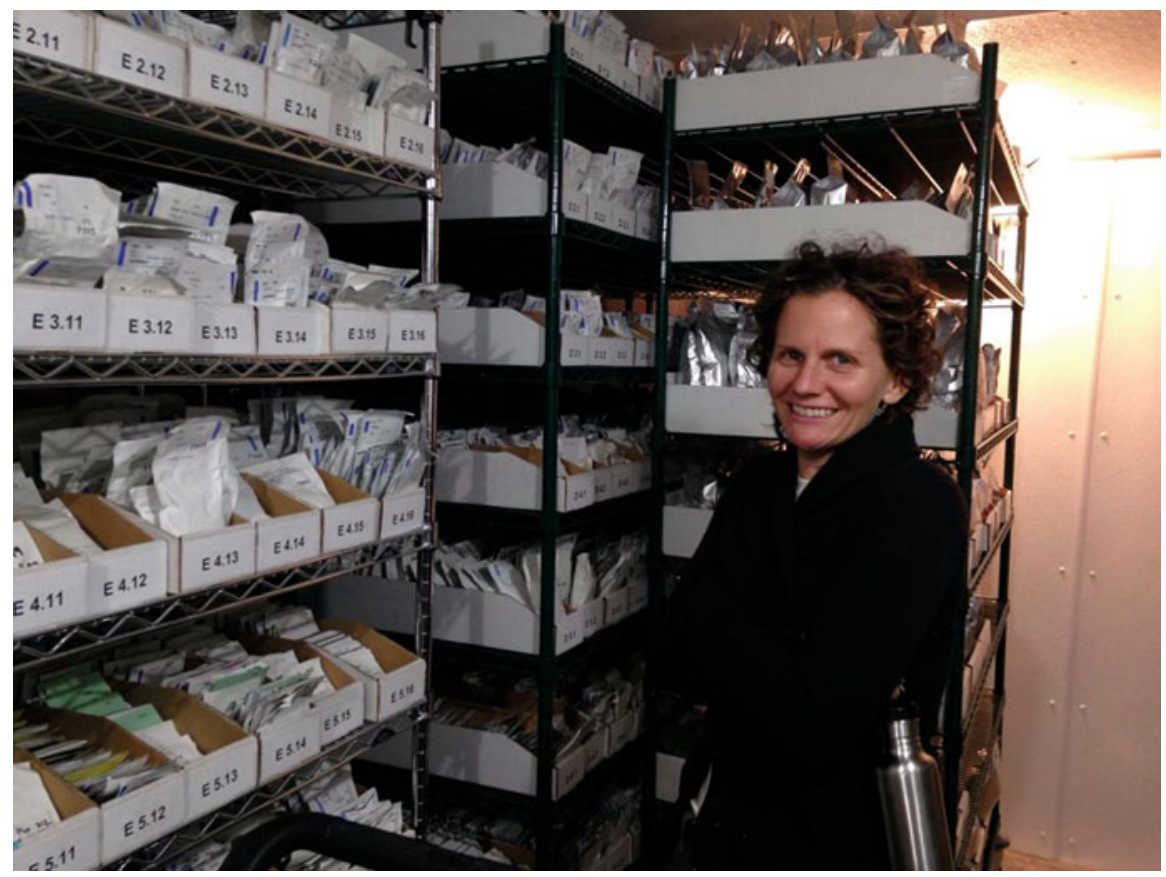

Fig. 3 Author Melissa DeSa visits a well-stocked, refrigerated seed storage unit 
seeds, materials and other supplies. Those hosted in pubic libraries have the advantage of existing paid staff to oversee the operation, although volunteers may still be used.

Seed library organizers should establish early on what their seed collection goals are, and strive to maintain an inventory for the public to view. An organization that is dedicated to preserving biodiversity and protecting heirlooms should keep closer track of their seed stock and its origin, as compared to an organization that is selfserve and offering a wide variety of seed from various resources. Establishing goals at the beginning and communicating them clearly to the public is important. Is the goal to accept any and all seed donations simply to encourage a diverse seed exchange, or to focus only on open-pollinated and/or heirloom crops especially those locally adapted to the climate? In the latter case, there will be restrictions on what seeds are accepted, and these requirements should be made clear.

Each seed library must decide how they will distribute seeds. Those supported by real brick and mortar public libraries distribute seed in a similar manner as other library items that are borrowed and returned. This approach has provided public libraries with an additional service to offer, a welcome addition to a business that sees fewer visitors with increased digital content available. It also has the distinct advantage of drawing the interest of a diverse demographic. Other seed libraries may offer seed seasonally with restricted hours, or at specific events (i.e., a seed swap) overseen by staff or volunteers. If the seed collection is in an open community space that is self-serve, the availability is wide open. Some libraries distribute seed based on membership, and seed is picked up in person or mailed out the member.

Organizers must also decide how to display, categorize and collect information about seeds. For example, seeds may be sorted by family, alphabetically by common name, by seed type (e.g., organic, heirloom, hybrid, vegetable, flower, etc.) Check in and out forms are necessary for any operation to collect information about the seed being borrowed or donated. For donated seed, such forms are a good way to decide if seed should be kept in the collection, or removed. Information to consider collecting is: common name and variety; Latin name; year harvested; garden location; grower's name (maybe a contact, too); seed collected from how many plants; if seed was selected for vigor/health; isolation distance; description. If many of these fields are left unanswered, it may be best to eliminate the seed as the grower may not have basic seed saving knowledge to have collected high quality seed. This information can become an integral part of seed heritage stories, tracing where seed has come from and the cultural stories behind them.

Getting people to return seed can be a significant challenge to an open community model that depends on donations to maintain inventory. Most gardeners would rather buy new seeds every year. This is entirely reasonable, as seed saving requires some basic knowledge to begin, but can get very complicated and scientific. It also requires setting aside space and plants, which many smaller home gardeners cannot spare. The library might consider using incentives to encourage more seed returning, as well as identifying willing gardeners and farmers with space and expertise to help. This is likely why some seed libraries grow their own seed specifically for the 
library and have adopted more of a membership retail model, rather than depending solely on donations of previously purchased or self-saved seed. Seed library organizations may collaborate with farmers and gardeners in the region to grow seed, thus providing a unique product; locally grown and adapted crop varieties that will be of higher quality and appeal.

All seed libraries will have some operation costs, no matter the scale of the project. Funds may be received through grants, donations of money and resources, and membership fees. Expenses may include a refrigerator and associated energy costs, envelopes, plastic bags, jars or other storage containers, bins, filing cabinets or drawers, labels, pens, paper, a printer, educational materials, seed sorting/threshing equipment and rent for using a public space. This assumes there are no paid staff members, only volunteers. Memberships can help cover the costs of operating a seed library. Some libraries have a one time or annual membership fee which includes access to all seeds and services. The retail models tend to have an annual membership fee that may vary from as low as $\$ 10$ to upwards of $\$ 200$, which then provides access to products and services for a discounted rate plus some free seed packs (Fig. 4).

There is no one way to run a seed library, as each will vary depending on its mission, resources, demand and input of the local community and its organizers.

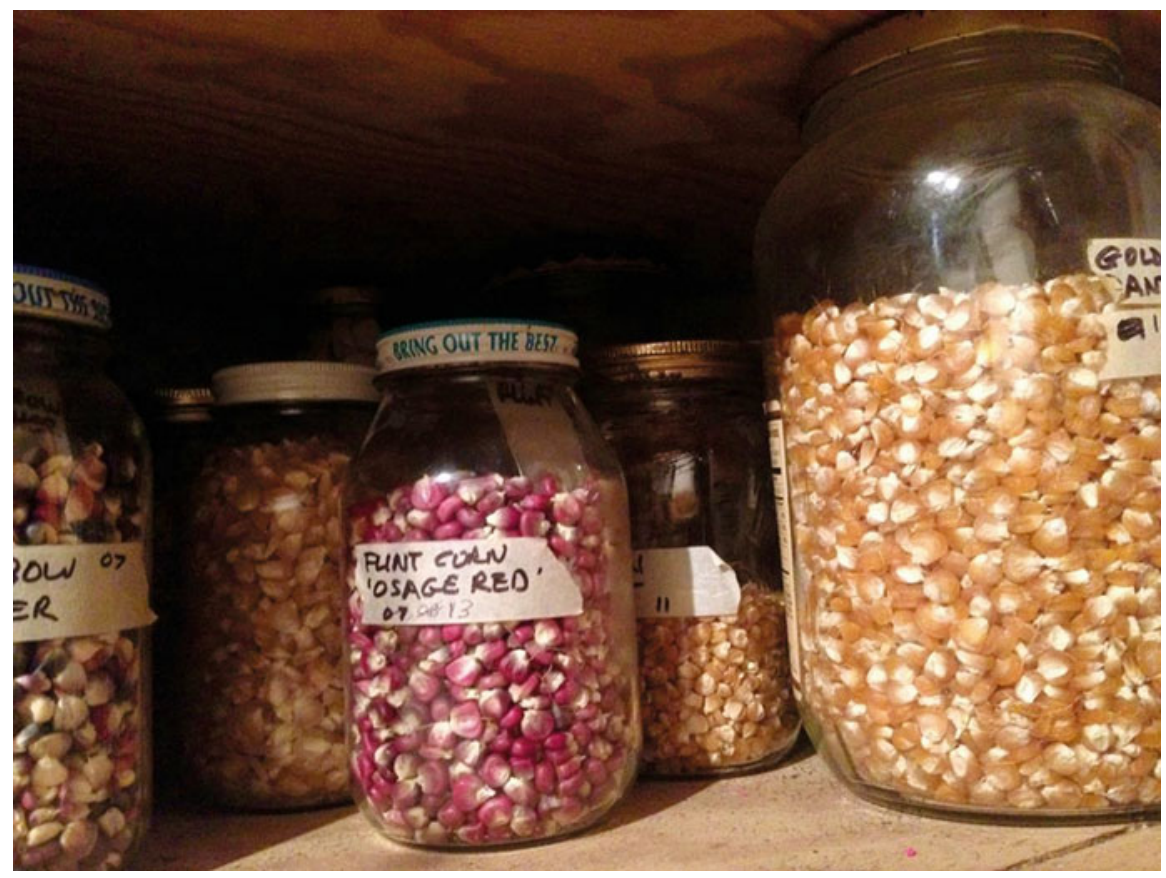

Fig. 4 A seed library need not be fancy. Repurposed jars labeled with masking tape can be both functional and beautiful 


\section{Education and Seed Quality Oversight}

Education and empowerment is key for community seed sharing and saving efforts to be successful. While many people have started home gardens and have learned to grow food at home, seed saving is a skill that has largely been lost and forgotten. Seed can be purchased cheap and fresh each year, and the reality is that saving seed from a small home garden is often not feasible. However, many people want to learn and with the right encouragement, will become dedicated seed savers that can in turn share their knowledge with others.

For any library that relies in part on member-saved seed, two significant challenges include lending out more seed than is returned, and having poor seed quality donations (e.g., cross-pollinated, hybrid, aged, or improperly stored seed). These challenges can be overcome with a combination of yearly inventory management, education, empowerment and incentives.

At least once per year, organizers should purge their seed collection, discarding anything that is more than a few years old, moldy or has signs of insect damage. For aged seed, it may be valuable to perform a germination test before discarding. Germination tests are simple and instructions on how to perform them can be found easily online. Anything with less than $50 \%$ germination should probably be discarded. Anything below $75 \%$ should be made clear to participants, with suggestion that they plant thicker to compensate. It is best to be upfront and clear about unknown seed quality, to avoid disappointing gardeners who may become frustrated with a failed crop.

Some organizations offer public workshops ranging from 1-h sessions covering the basics, to several days-long intensives that are aimed at the more advanced and dedicated seed savers. The organization may also consider a mentor-matching program, where more seasoned seed growers are paired with novices wanting to learn. There are a few basic principles to teach that can get anyone started on the right path. A consideration for any library is to require seed donors to complete a seed saving course prior to donation. The course need not be complicated, but provide a solid foundation for seed saving that can be covered in a 1-2 h workshop (Figs. 5 and 6).

Most libraries provide guidelines for seed donations, which may be available online as well as at the seed kiosk. As previously mentioned, a detailed check-in slip is typically filled out by the donor asking for information about the seed. This information can assist seed library organizers with a decision about categorization of the seed donation, or whether to even keep it. Educational resources should always be available to users including seed saving literature, posters and videos. Self-serve systems should be clearly organized to facilitate seed saving, indicating which are "super easy", "easy" and "difficult" to save. This will help novice seed growers pick from the level they are capable of saving.

Incentives are a great way to encourage more thoughtful seed saving and returning. Trusted seed donors may gain wider access to the seed inventory, discounts off of seed or products (if they are for sale normally) or prizes. The library may also 
Fig. 5 Students gather around a busy, outside table to learn the basics of seed saving

have a simple rule that to borrow seed, you must return seed. This is a very strict and limiting rule that may be more suitable for an organization whose mission is to protect local heirloom seed.

\section{Examples of Seed Libraries in the US}

The following is a listing of only a few prominent libraries; there are many more but these serve as a diverse example of how various libraries function.

The Hudson Valley Seed Library in New York has an annual membership fee of \$5 that entitles members to discounts off of seed purchases in addition to other perks. The library's founders grow a significant portion of the seed themselves on a 3 acre farm, and work with area farmers and gardeners and some wholesalers to provide the rest. Each year a crop variety is selected as one that members are all encouraged to save in the same year, thus adding an abundance of seed to the collection. Members are provided with tips on how to grow and save that particular seed. The Seed Library also has a donation program, donating seeds to community garden projects and individuals in need. A unique part of this program is their partnership with local artists to create beautiful and unique seed art packs. 
Fig. 6 Seed saving is also an excellent opportunity to involve youth in gardening activities, and to educate young growers about the science and social aspects of food production

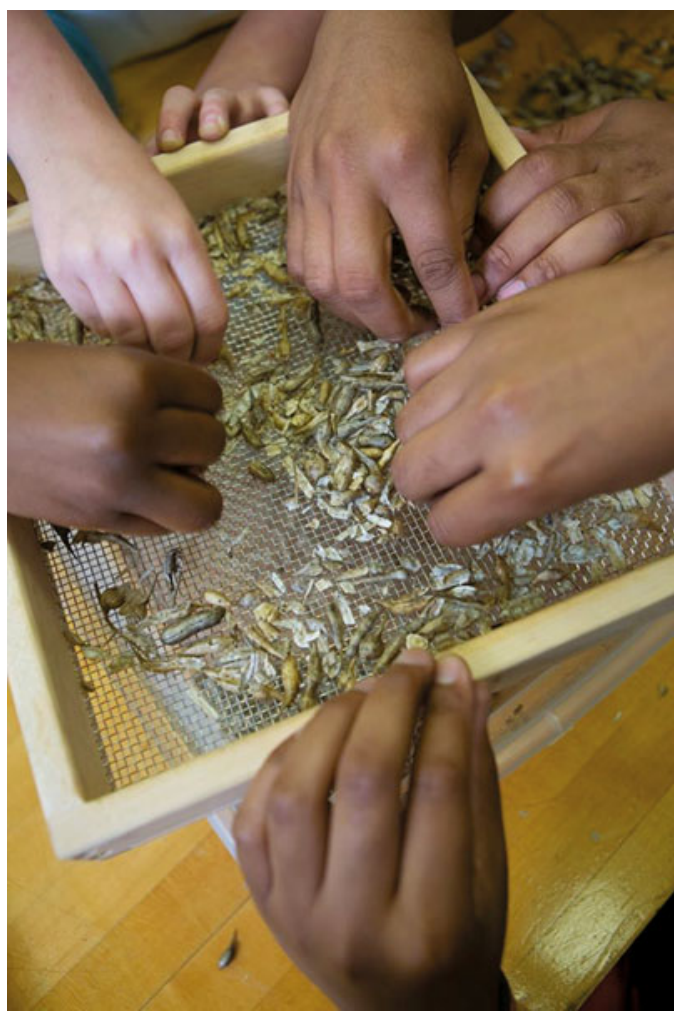

Native Seed/SEARCH is a non-profit seed conservatory based in Tuscon AZ and has a free open-source community seed library as well as online and in-store retail seeds. Varieties are grown and selected from traditional and locally adapted varieties of the American southwest and northwest Mexico. Membership options range from $\$ 30$ to $\$ 1000$ annually, with members receiving discounts and other perks.

The Seed Library of Los Angeles (SloLA) accepts new members for a lifetime fee of $\$ 10$, which then entitles them to check in and out, freely, any seeds in the collection. Seeds are donated by members which may be self-saved or purchased from a seed company. SLoLA provides many opportunities for gardeners to learn about seed saving through workshops, and educational material provided when seeds are checked out.

The Southern Heritage Seed Collective in Gainesville, FL has an annual membership donation of $\$ 25$ which entitles members to two season's worth of seeds, which in Florida, covers a full year of growing. Seeds are primarily bulk purchased from retail organizations and re-packaged for individual distribution. This provides gardeners with an increased selection of varieties for a more affordable price than purchasing individual retail packets. Some seed is locally saved with the long-term goal of having more local seed in the collection, with a 


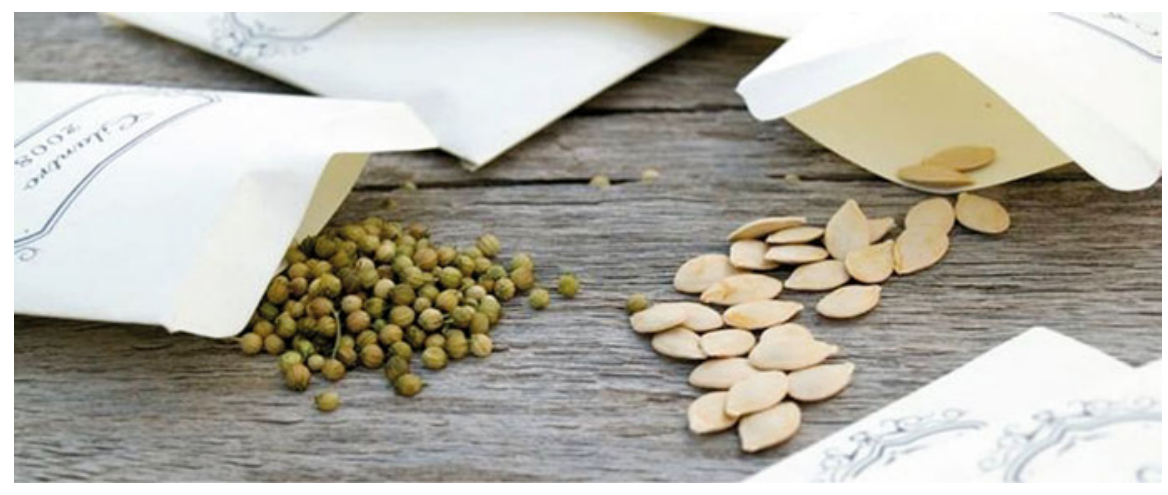

Fig. 7 Some organizations, like the Southern Heritage Seed Collective, purchase seeds in bulk from retail organizations and re-package them for individual distribution. This approach provides gardeners an increased selection of varieties at an affordable price

focus on traditional heirloom varieties of the southeast. This library is in transition as it shifts focus to community seed saving efforts (Fig. 7).

Southern Seed Legacy encourages local seed saving efforts and maintains a seed bank for southern crop varieties threatened with extinction. Based in Denton, Texas this group focuses on crops at risk in the southern states, by coordinating existing seed saving exchanges in a network wherein different organizations select a manageable group of crops in each agroecoregion as their focus for preservation. They maintain a seed bank from which members can order. Seeds are loaned out with the express expectation that if a successful crop is grown, 1/3 of the seeds are returned to the program, 1/3 can be kept for the grower themselves and the other $1 / 3$ can be shared with another gardener. The seed stock is stored in ideal storage conditions at the University of Georgia. Annual membership dues range from $\$ 15$ to $\$ 250$ or more. Each level includes various perks and access to seeds.

Richmond Grows Seed Library based in Richmond, California is a non-profit seed library hosted at a public library, and is a free community seed lending and returning library. They provide excellent information and resources for their users on how to borrow and return seed. They also offer helpful information for other organizations wishing to start a seed library including video links on how to use the library, and how to save seeds. Their sister library, BASIL is run in a similar fashion but is not hosted in a public library.

\section{Resources}

Seed Matters and Seed Savers Exchange provide toolkits to seed libraries (sifting screens, envelopes and labels) as well as detailed information on seed saving and starting a community seed bank. Their documents can be downloaded for free and 
Fig. 8 Screens are an important tool for any seed saver

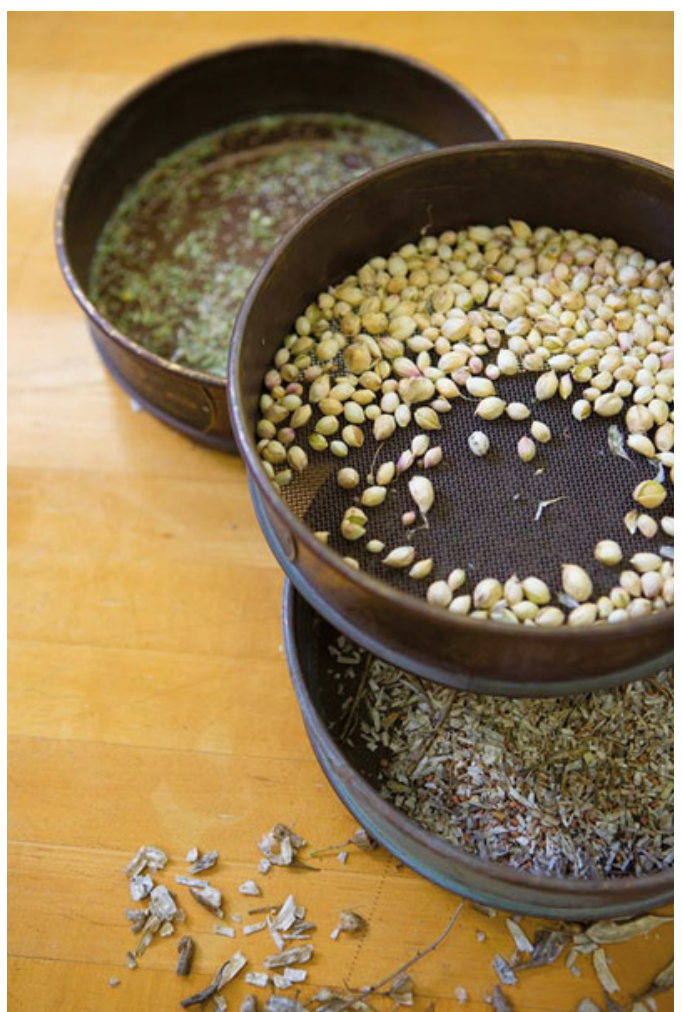

the application for the toolkit is also available off of their website. They have an excellent overview of seed libraries with tips on how to get started, how to organize, challenges, funding etc. http://www.seedmatters.org (Fig. 8).

The Seed Savers Exchange has an archive of webinars. They mostly focus on seed saving techniques, but have great webinars for starting community seed banks, storing seed, and starting your own collection. http://www.seedsavers.org/Education/ Webinar-Archive/.

The Seed Libraries Social Network is a great way to connect with other seed savers. They have downloadable presentations, handouts, envelope examples, library organization documents and other useful information. http://seedlibraries. org/.

Richmond Grows Seed Library based out of Richmond, California has detailed resources available about staring a seed library. Most of their resources can be downloaded from the SeedLibraires.org resource listed above. http://www.richmondgrowsseeds.org/.

Native Seeds Seed School is for those wishing to really learn the nitty gritty about seed saving and organizing. Offered several times a year in various parts of the country, this days-long course is worth considering. http://shop.nativeseeds. org/. 
Winter Sown is an interesting online resource that allows people from all over the country to mail in their extra, unused and self-saved seed. They re-distribute it by mailing seed to organizations and individuals for free. http://www.wintersown. org/. 


\title{
Recirculating Aquaculture Systems (RAS) and Aquaponics for Urban Food Production, with a Pictorial Guide to Aquaponics
}

\author{
Miles Medina, Krish Jayachandran, Mahadev Bhat, and David Specca
}

\section{Introduction: Global Context of Modern Aquaculture}

The United Nations projects that the global population will reach 8.9 million by 2050 and that $99 \%$ of this growth will occur in Asia, Africa, and Latin America (United Nations Department of Economic and Social Affairs 2004). With rising population and incomes, the consumption of fish in developing regions increased more than fourfold from 1980 to 2010 (from 25.0 to 104.3 million tonnes per year), while consumption in developed countries remained relatively stable during the same period, below $30 \mathrm{Mt}$ per year (Food and Agriculture Organization of the United Nations [FAO] 2012a). Because capture production is not expected to substantially increase, FAO predicts that the increasing global demand for fish will have to be met entirely by aquacultural production (2012b).

Aquaculture is the farming of fish, crustaceans, mollusks, and aquatic plants. Since the 1980s it has emerged as the fastest growing form of agriculture worldwide. Global aquacultural production of fish and other animals grew at an average annual rate of $6.3 \%$ from 34.6 Mt in 2001 to $59.9 \mathrm{Mt}$ in 2010, while capture production plateaued at around $90 \mathrm{Mt}$ per year during the same period (Fig. 1). Asia consistently leads aquacultural production, with 53.3 Mt representing $89.0 \%$ of global

\footnotetext{
Pictures and captions provided by: David Specca

M. Medina $(\square) \bullet$ K. Jayachandran $\bullet$ M. Bhat

Agroecology Program, Department of Earth and Environment, Florida International

University, 11200 SW 8th St, Miami, FL 33199, USA

e-mail:mmedi066@fiu.edu; jayachan@fiu.edu; bhatm@fiu.edu

D. Specca

Bioenergy Technologies \& Controlled Environment Ag EcoComplex, Rutgers University,

Brunswick, NJ, USA

e-mail: specca@AESOP.Rutgers.edu
} 


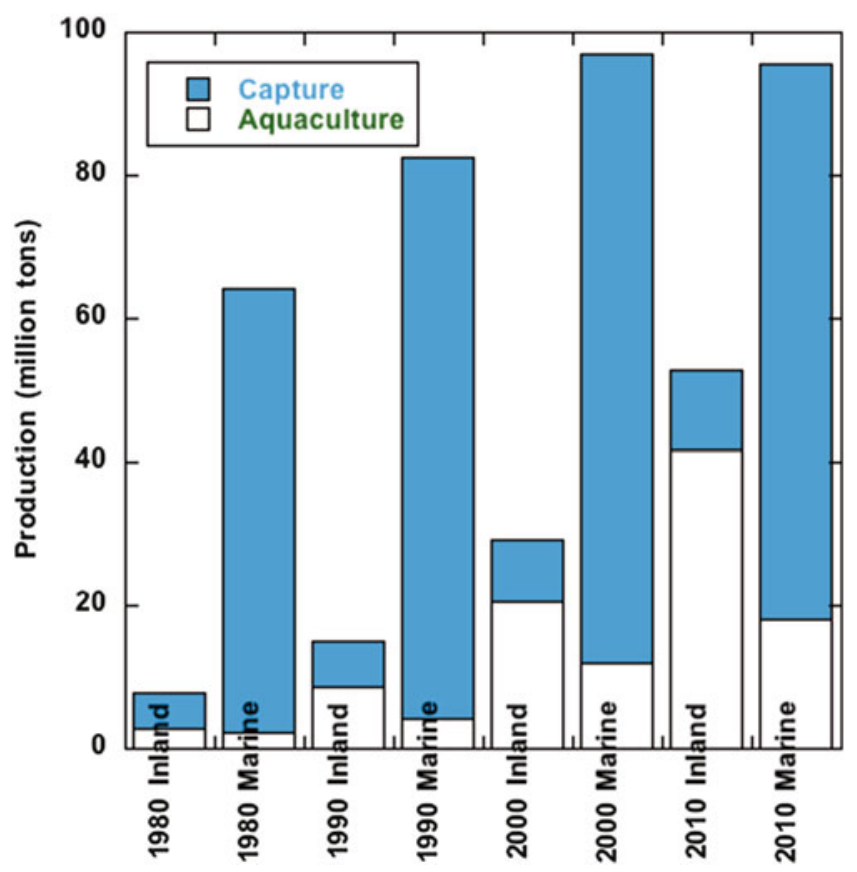

Fig. 1 Annual production (metric tons) of fish and other aquatic animals from capture and aquaculture from both inland and marine waters (Data from the figure is from FAO, Fishery and Aquaculture Statistics: 2010)

production in 2010. Global production of aquatic plants was 19.9 Mt in 2010, with 95.5\% coming from aquaculture (FAO 2012a).

Aquacultural operations are primarily categorized in terms of the waters in which they occur. Marine cultivation occurs within net pens in coastal or open ocean waters, while inland cultivation occurs within pens in freshwater ecosystems or within ponds, raceways, or tanks (Lovelace 2009; Pilay 2004). In 2010, inland cultivation accounted for the bulk of global aquacultural production (69.6\%) with 41.7 Mt (Fig. 1) (FAO 2012a).

Aquacultural operations are also categorized in terms of the intensity of management as extensive, semi-intensive, or intensive. Under extensive cultivation, fish receive nutrition from naturally occurring food sources such as detritus and plankton; management efforts focus on controlling predators and competitors. Semi-intensive cultivation involves some level of supplementation to the natural food supply, or fertilization to increase the natural food supply. Under intensive cultivation, fish receive nutrition exclusively from formulated, high-protein aquafeeds. Greater intensity implies higher stocking densities, concentrated waste, greater risk of disease outbreak, and higher yields per unit of area (Beveridge and Little 2002; Naylor et al. 2000). Within these categories lie a diversity of practices, but the global trend is 
toward intensification: Aquafeed production was $29.2 \mathrm{Mt}$ in 2008 and is expected to grow to $71.0 \mathrm{Mt}$ by 2020 (FAO 2012b).

Fish farming alleviates pressure on fisheries to the extent that demand for fish is met by aquacultural production. However, to the extent that aquaculture depends on fishmeal as an input, it may contribute to overfishing and the degradation of marine food webs (Naylor et al. 2000). Fishmeal (from capture) is a major component of many aquafeeds, because it is rich in protein and fatty acids and increases yields. The cultivation of fish at higher trophic levels (such as salmon) requires larger amounts of fishmeal than the cultivation of herbivorous or omnivorous fish (such as tilapia) for which partial substitution for fishmeal is possible without reductions in yield. Fishmeal substitutes include plant and microbial proteins and byproducts from meat production (El-Sayed 1999, 2004, 2006; Olsen and Hasan 2012).

\section{Inland Aquaculture: From Wastewater-Fed to Recirculating Aquaculture}

Semi-intensive wastewater-fed pond aquaculture has been practiced for centuries throughout Asia and remains common in undeveloped areas where unpolluted freshwater is unavailable. These operations tend to appear downstream from sewage discharge sites. Although the discharged wastewater is typically untreated, the destruction of pathogens can be achieved relatively quickly by retaining wastewater in a series of stabilization ponds before it reaches the fishpond. Upon reaching the fishpond, nutrient-rich wastewater acts as fertilizer to stimulate production of plankton and other organisms that provide a natural food supply for fish. The fishpond effluent, often of higher quality than the influent, may be used to irrigate downstream crops, trees, or pasture. Thus, the application of wastewater to downstream aquaculture can serve as a productive and environmentally sustainable component of urban and peri-urban wastewater treatment. Covering 12,500 hectares, the East Kolkata Wetlands in West Bengal are the world's largest complex of wastewater-fed wetlands and include the world's only large-scale wastewater-fed aquaculture system currently in operation (Bunting et al. 2005, 2010; Edwards 2005).

Most wastewater-fed pond operations are small-scale operations that provide poor families with food security and income, and many are integrated fish-plant systems. Unfortunately, the urbanization on which they depend often also leads to their displacement. As industry grows in and around urban centers, toxic industrial waste mixed into the flow of residential waste renders the wastewater unfit for fish cultivation. Further, as a more profitable land use, growing industry often competes with farms for land. Finally, farms are susceptible to the loss of their nutrient source when wastewater infrastructure improvement changes the flow of the water by creating canals or relocating the point of discharge (Edwards 2005; Bunting et al. 2010; Little and Bunting 2005). As countries like China develop and urbanize, it is likely 
inevitable that wastewater-fed pond culture systems will be replaced by higher-tech, intensive production systems.

Currently over $50 \%$ of the global population resides in urban areas, and the United Nations projects that by 2050 this figure will surpass two-thirds. This trend toward urbanization applies to both developed and developing regions, whose populations were $77.5 \%$ and $46.0 \%$ urban in 2010, respectively; by 2050 , urban populations in developed and developing regions are projected to exceed $85 \%$ and $64 \%$, respectively (United Nations Department of Economic and Social Affairs 2011). Thus, it is appropriate to develop aquacultural methods suited to modern urban and peri-urban environments considering both the requirements and the opportunities that arise from this emerging production setting.

The development of recirculating aquaculture systems (RAS) is particularly relevant for urban areas, because RAS is highly productive and can be located virtually anywhere, relatively independent of climate and water resource availability. Whereas flow-through production systems (such as ponds and raceways) require nearby sources of water, filtration typically allows RAS to reuse over $90 \%$ of its culture water. Thus, RAS discharges minimal effluent, and filtered sludge can be used to generate biogas or applied as fertilizer at nearby farms or gardens. And while pond systems are open and susceptible to disease and contamination, the RAS environment is contained and highly controlled. Further, while pond aquaculture may not be feasible in areas where consumer demand favors marine species, freshwater and marine cultures are both possible under RAS. The higher cost of urban land is a constraint to urban RAS, but this may be offset by consistent, year-round production; improved feed conversion ratios; proximity to market and reduced transportation costs; price premiums for safe, environmentally friendly, and locally produced fish; and favorable policy instruments or tax incentives (Bunting et al. 2005; Tal et al. 2009; Timmons 2005).

Aquaponics is an emerging form of RAS in which fish effluent is recirculated to fertilize hydroponic crops. As such, the filtration process allows for the indefinite recycling of water while producing a marketable crop. Common crops include culinary herbs such as basil and mint, salad greens such as lettuce and chard, and fruiting crops such as tomato and strawberry. Commercial aquaponic farms currently operating throughout the United States and abroad achieve crop yields equal to or greater than those under traditional field production (Bailey et al. 1997; Lewis et al. 1978; McMurtry et al. 1997; Rakocy et al. 2006).

Because it does not depend on soil, hydroponics is arguably the most soilconserving method of crop production (Lal 2013). As demand for food increases, hydroponic production can relieve pressure to convert forested land to agriculture, just as aquaculture relieves pressure on fisheries. In urban environments, aquaponics offers the potential to convert land with contaminated or infertile soils to highly productive agriculture. Space efficiencies can be achieved through vertical orientation or stacking of hydroponic components in order to multiply growing space and yield per area.

Aquaponics is also highly efficient in its use of water, only requiring replacement of water lost to evaporation and transpiration. Compared to other forms of 
recirculating aquaculture, aquaponics can reduce water usage by $93 \%$ or more, with a daily replacement rate as low as $<1 \%$. Further, aquaponic crop production can be up to ten times more water-efficient than irrigated field production (Al-Hafedh et al. 2008; Lovelace 2009; Masser et al. 1999; McMurtry et al. 1997).

\section{Aquaponics for the Home, School, and Community Garden: Structure, Function, and Maintenance}

Aquaponic systems range in size from large commercial systems, like FarmedHere's 90,000 square-foot Chicago warehouse operation with 5 vertical levels of artificially lit raft hydroponics, to smaller systems for the backyard, school, or community garden. While patented "turn-key" aquaponic units are offered for sale, various do-it-yourself design specifications are available for free online. They are commonly constructed from plastic 55-gallon drums or plastic IBC totes and other materials readily available at hardware stores. If you are technically inclined, constructing your own system will allow you to better understand its mechanics, tinker to improve upon the design, and add features. Online and local communities of aquaponic gardeners are eager to share insights and resources.

In the classroom, aquaponics projects offer superb opportunities for hands-on experiential learning. Involvement in the design, construction, and maintenance of an aquaponic system stimulates students' curiosity and promotes interest in science, math, engineering, and technology as well as environmental issues, ecological processes, and sustainability. Maintenance efforts can help students build cooperation and leadership skills while learning concepts in chemistry, biology, agronomy, environmental science, and data collection and analysis.

\section{Structure and Functions}

A basic aquaponic system is composed of a submersible pump, a fish tank, a solids filter, a biofilter, and a hydroponic grow bed. While configurations vary, water flows through plumbing and is typically pumped up from the fish tank (or sump) and down through the other components by gravity. The solids filter is a relatively small component that mechanically removes larger organic waste particles, including fecal matter and uneaten food, and it may take several forms such as a mesh filter or a settling tank (Rakocy et al. 2006). Once removed, solid wastes may be composted for use as fertilizer elsewhere at the garden or farm.

Next, water flows through the biofilter. This is the engine of the system, composed of naturally occurring bacteria that break nutrients down into inorganic forms that can be used by plants. During the two-step biological nitrification process, bacteria convert ammonia released by fish into nitrate that is taken up by plants' roots. 
Ammonia, which may be highly toxic to fish, is oxidized into nitrite $\left(\mathrm{NO}_{2}{ }^{-}\right)$by Nitrosomonas bacteria, and Nitrobacter bacteria oxidize toxic nitrite into nitrate $\left(\mathrm{NO}_{3}{ }^{-}\right)$, which is relatively safe for fish (Bernstein 2011; Foesel et al. 2008; Keuter et al. 2011; Rakocy et al. 2006). Because the bacteria inhabit the system's submerged surfaces, the biofilter's surface area is substantially increased by filling its volume with media such as clay pellets or pea gravel. A particle size between 0.5 and $2.0 \mathrm{~cm}$ is recommended to maximize biological surface area without reducing void space to the point that it impedes the flow of water (N. Storey, personal communication, 2014).

Finally, water enters the hydroponic component, which may take several forms: deep-water culture (DWC), nutrient film technique (NFT), and media culture. Under DWC, plants are held in place by a rigid sheet or "raft" (e.g. polystyrene) with roots suspended in the trough below (typically $30 \mathrm{~cm}$ in depth). Under NFT culture, plants are cultivated in a shallower trough or pipe in which a "film" of water $(1 \mathrm{~cm}$ or so) passes over the roots. NFT is more appropriate for crops with relatively low nutrient requirements, such as lettuce and herbs, than for fruiting crops. Under media culture, in contrast, plants grow in beds or towers that contain media, eliminating the need for a separate biofilter component (Bernstein 2011; Rakocy et al. 2006). Water may pass through the media bed/biofilter under a constant flow regimen (i.e. with a steady volume of water maintained) or a reciprocating flow regimen (i.e. with a periodic "flood and drain" cycle regulated by a timer or siphon mechanism). Lennard and Leonard observed significantly higher yields of lettuce (Lactuca sativa) under media culture than DWC during a 21-day trial (2006). And in a separate 21-day trial, a significantly higher yield of the lettuce, greater $\mathrm{pH}$ buffering capacity, and higher levels of dissolved oxygen were observed under the constant vs. reciprocating flow regimen (Lennard and Leonard 2004).

\section{Water Quality}

Water is added to the aquaponic system at the initial establishment phase, during emergency water changes, and periodically to replace water lost to evaporation. The source water's $\mathrm{pH}$, carbon dioxide concentration, and mineral content should be determined, especially when adding larger volumes. Harvested rainwater and well water are the preferred sources, since surface waters (from lakes or rivers) may contain pollutants, and municipal water will most likely contain chlorine and may contain chloramine (check with the municipality). If municipal water is the only available source, chlorine can be removed with an inline dechlorinating filter, or by evaporation if the water is stored for $48 \mathrm{~h}$ before being added. Removal of chloramine requires a carbon or UV filter (Bernstein 2011).

As part of regular maintenance, water temperature, dissolved oxygen (DO), $\mathrm{pH}$, and nutrient levels must be monitored (Bernstein 2011; Rakocy et al. 2006). Water temperature is affected most by ambient temperature, so local climate is an impor- 
tant factor to consider when choosing a fish species. Within the wider range of temperatures that fish can tolerate, there is a narrower optimal range in which they thrive. Because bacteria and most crops prefer warmer water temperatures, greenhouse production and electric heating equipment are common at northern latitudes. A heat sink (i.e. a deep tank of water that warms up during the day and releases heat at night) is a low-tech method of retaining heat in the greenhouse-a replacement water storage tank can serve as a heat sink. Another innovative approach involves composting organic wastes directly outside the greenhouse (along and against the exterior walls) so that the heat generated by decomposition is transferred inside (Allen 2013).

Fish, plants, and bacteria all require oxygen for respiration, and a consistently high DO concentration (6 mg/l or greater) is recommended (Rakocy et al. 2006). Adequate oxygenation is often achieved from the mixing of air into the water as flowing or falling action disturbs its surface, but supplementary aeration equipment may be used (Lennard and Leonard 2004; Masser et al. 1999). Since inputs of oxygen are relatively stable under normal circumstances, a sudden drop in DO often indicates an unusual consumption of oxygen from the decomposition of a dead fish or of diffuse organic material that has built up over time.

A near-neutral $\mathrm{pH}(6.5-7.0)$ is recommended for the health of fish, plants, and bacteria and for the maximum availability of nutrients to plants (Rakocy et al. 2006). Because nitrification gradually acidifies the water by adding $\mathrm{H}^{+}$ions, periodic supplements of a base (such as potassium hydroxide or calcium hydroxide) may be necessary to maintain the desired $\mathrm{pH}$. When plants uptake nitrate, their roots release hydroxide $\left(\mathrm{OH}^{-}\right)$or bicarbonate $\left(\mathrm{HCO}_{3}^{-}\right)$ions that may help offset acidification from nitrification (Lennard and Leonard 2004). As an aquaponic system matures, buffering capacity develops to keep $\mathrm{pH}$ more stable. Also, the $\mathrm{pH}$ of larger systems is more stable than the $\mathrm{pH}$ of smaller ones.

Because ammonia and nitrite are toxic to fish, their concentrations must be frequently monitored to ensure they remain at or near zero. An inexpensive aquarium testing kit (with drops and a color chart) will provide hundreds of tests. Immediately after feeding, concentrations of ammonia and nitrite can be expected to increase, but persistent concentrations above $0 \mathrm{mg} / \mathrm{l}$ indicate a problem with the biofilter that requires intervention. Nutrients other than nitrogen are not typically monitored individually, but the concentration of total dissolved solids (TDS), a measure of the total nutrient concentration, should not exceed $2000 \mathrm{mg} / \mathrm{l}$ (Rakocy et al. 2006). Nutrient deficiencies in plants become apparent in deformed or discolored leaves and may make plants more vulnerable to pests. However, a deficiency of a particular nutrient does not necessarily indicate a shortage of the nutrient in solution $-\mathrm{pH}$ may be the culprit, as a nutrient that is present in sufficient quantity will not be available for plant uptake if the $\mathrm{pH}$ of the culture water moves beyond a certain range. Alternatively, an overabundance of certain nutrients may interfere with the availability of other nutrients. For example, a potassium deficiency may be due not to a lack of dissolved potassium but to a relative overabundance of calcium or magnesium in solution. 


\section{System Design and Integration}

Management of nutrients begins with good system design and a staggered cropping schedule. Component ratios are important: The biofilter must be large enough to accommodate the fish stocking rate and feeding rate, and the hydroponic growing area must be large enough in relation to the fish tank to remove nutrients and avoid excessive nutrient accumulation (Al-Hafedh et al. 2008; Rakocy et al. 2006). For a beginner, it is wiser to choose among system designs with good track records than to design a system from scratch. Many good designs are available online.

As opposed to a batch cropping schedule, in which all seedlings are introduced at once and later harvested at once, a staggered schedule stabilizes plant biomass and nutrient concentrations by moving plants through the system in cohorts (Rakocy et al. 2006). For example, let us consider an aquaponic system that can accommodate 100 lettuce plants that take 4 weeks to harvest. Under batch production, 100 seedlings are transplanted into the system on Day 1 of each growth cycle, and 100 mature plants are harvested on Day 28. Early in the cycle, the small seedlings remove only a small portion of the nutrients available in the culture water, but as they grow the plants remove more nutrients more quickly. Therefore, assuming a steady feeding rate under batch production, the levels of nutrients in the water fluctuate with plant growth and harvests. In contrast, under staggered production, 25 lettuce seedlings are transplanted into the system each week, and 25 mature plants are harvested each week. Thus, assuming a steady feeding rate under staggered production, the total amounts of plant material and dissolved nutrients remain relatively constant throughout the cycle. And depending on your goals, smaller weekly harvests may be preferable to larger monthly harvests.

Finally, aquaponic systems may be integrated with the urban or household waste stream to enhance sustainability. Aquafeeds generated on-site from local organic wastes can serve as an alternative or supplement to formulated feeds. For example, culled produce from the garden as well as food scraps from the home kitchen, school cafeteria, supermarket, and restaurant may be composted to generate highprotein earthworms and black soldier flies. Gray water from the home may be used to fertilize a pond to generate algae, duckweed or fodder fish.

\section{Pest Management}

As with other forms of gardening and farming, pest management is of vital importance in aquaponics. Fortunately, the lack of soil virtually precludes the development of weeds and soil borne insect pests, and the high level of microbial diversity in a well-run system helps protect plants from disease (N. Storey, personal communication, 2014; Rakocy et al. 2006). Nonetheless, pests such as aphids and 
whiteflies can be expected, and fruiting crops like tomatoes tend to experience more pest problems than shorter-cycle leafy crops and aromatic herbs. Since most pesticides are harmful or toxic to fish, aquaponic pest management requires an integrated or layered approach, and prevention is primary. Proper maintenance of water quality is the first line of defense, because healthier plants are better able to ward off infections and infestations. The next line of defense is biological control, or the deployment of pests' natural enemies such as predators and parasites, including ladybugs, lacewings, parasitic wasps, minute pirate bugs, and others. Since many of these beneficial insects can survive on nectar and pollen, providing a nearby food source (flowers) will keep them around at times when pests are scarce.

If an infestation develops, more aggressive intervention with pesticide sprays may be necessary. Acceptable sprays are most effective when used in combination and rotated, in order to discourage pesticide resistance. While most pesticides cannot be used in aquaponic systems, a few organic sprays such as azadirachtin (from neem oil), Bt (Bacillus thuringiensis bacteria), and Beauveria bassiana (fungal spores) are considered relatively safe for fish (Bernstein 2011; Gillman 2008). However, pesticides should not to be assumed to be safe simply by virtue of their classification as "organic" or "natural" - soaps, oils, and homemade concoctions may be extremely harmful to fish, and any broad-spectrum pesticide may harm beneficial insects. All pesticides must be used with caution and as instructed on the product label in order to minimize risks and maximize effectiveness. Generally, pesticides should be applied immediately before sundown and when flowers are closed.

In order to protect the fish, one can perform calculations to determine how much of a particular pesticide, if any, can safely be applied to the aquaponic system (N. Storey, personal communication, 2014). First, for each active ingredient one should determine the upper limit (mg) that can be allowed to enter the system's culture water, by multiplying the ingredient's lethal concentration $(\mathrm{mg} / \mathrm{l})$ for fish with the system's total water volume (liters). Lethal concentration (LC50) data for many common pesticides are available online but values may vary; to be conservative, one should base calculations on the lowest value. Next, one can calculate the mass of the active ingredient (mg) that must be applied for an effective spray (based on the product label instructions). Based on an assumption about how much of the applied pesticide will end up in the culture water (again, be conservative), one would then compare this amount with the upper limit for lethality. If the amount of pesticide expected to end up in the culture water is not well below the limit, it would be best not to use it. For homemade pesticides such as vermicompost tea, for which ingredient concentrations and LC50 data are unknown, the conservative approach involves applying a very small dose and gradually increasing the dosage as long as no negative effects are observed. 


\section{Conclusions}

Controlled production of aquatic fish for human consumption has increased dramatically in recent years. Urban production of fish, alone or in combination with plant production, offers the potential for highly efficient closed systems. These systems are complex and can require significant capital investment with a level of expertise to operate and maintain. They also demand frequent monitoring. With that said, if properly run, aquaponics is a means to produce fish and produce for urban agriculture (Figs. 2, 3, 4, 5, 6, 7, 8, 9 and 10).

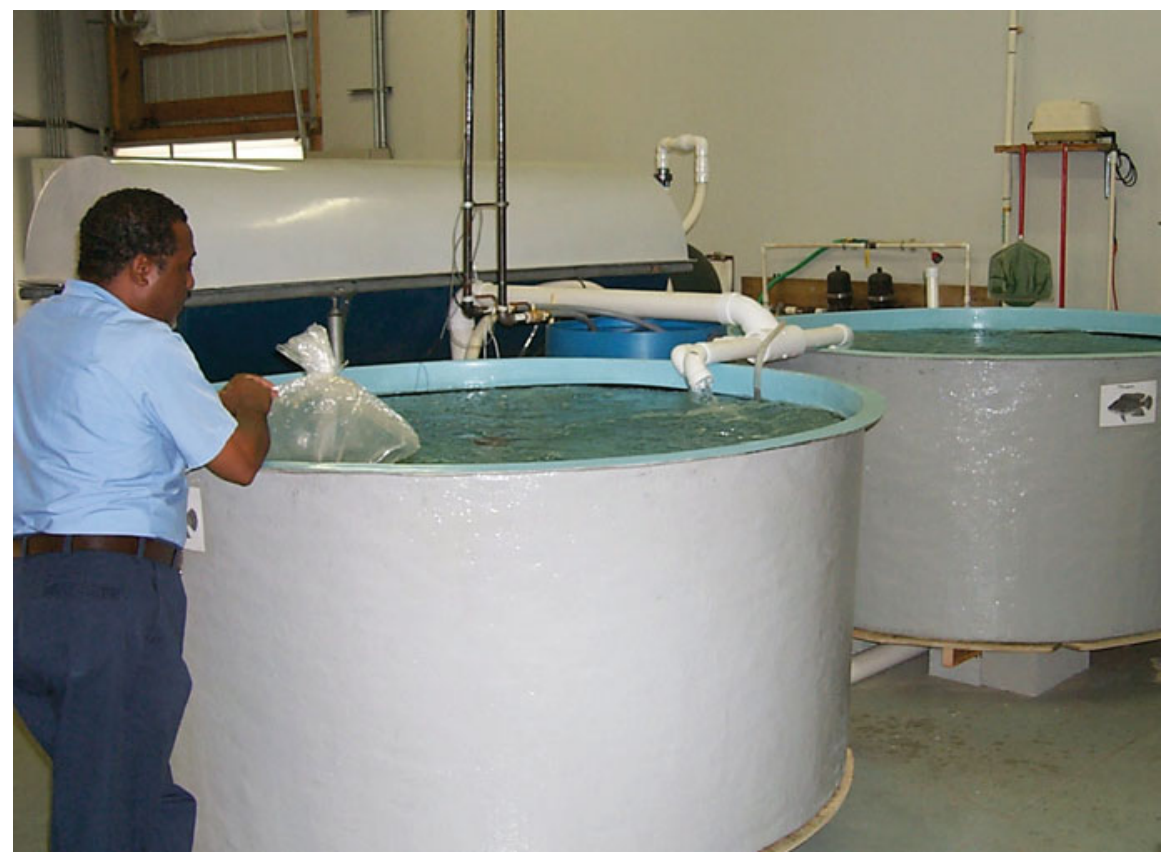

Fig. 2 Nursery Tanks - The aquaponic system at the Rutgers EcoComplex had two 600 gallon tanks for rearing the fingerlings for the first 12 weeks. This system had a separate floating bead solids filter and biofilter and was not connected to the hydroponic system. The entire system was based on the outdoor system designed and operated by Dr. Jim Rakocy and his research team at the University of the US Virgin Islands, St Croix Research Station and modified for use in the greenhouse 


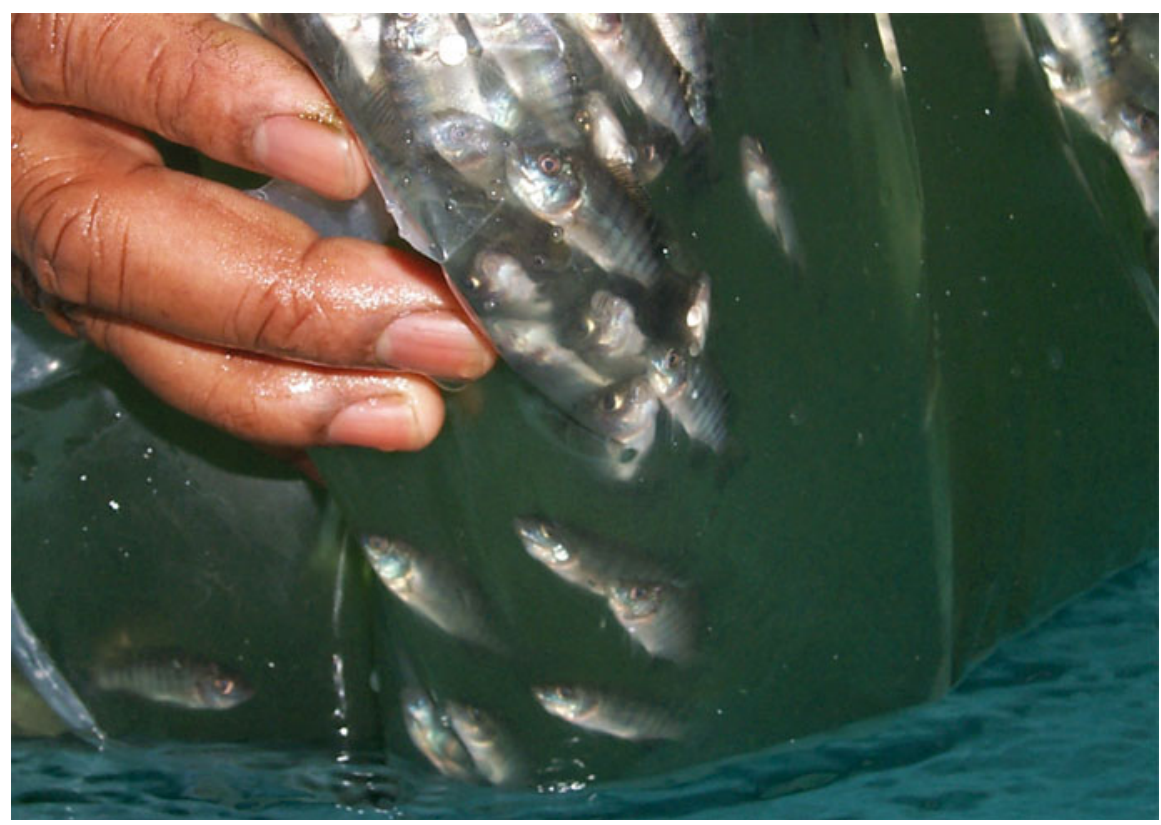

Fig. 3 Fingerlings - These all male tilapia fingerlings were shipped from Louisiana to New Jersey via air freight. Each fingerling was $2-5 \mathrm{~g}$ in weight. We received a new crop of fingerings every 6 weeks

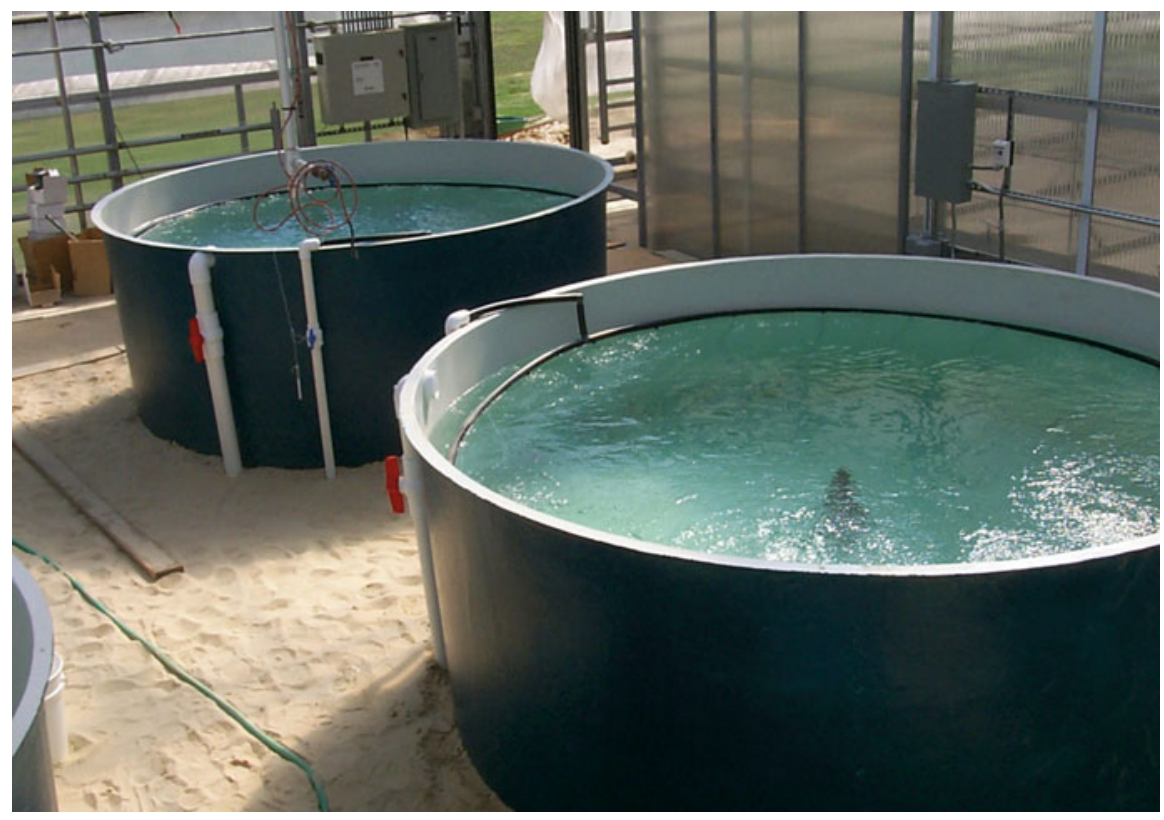

Fig. 4 Production tanks - After 12 weeks in the nursery tanks, the tilapia were approximately $50 \mathrm{~g}$ each and were then moved to the 2000 gallon production tanks located in the greenhouse. There were four production tanks (two are pictured here). The tilapia were raised in these tanks for 24 additional weeks at which point they were 9 months old and approximately 1.5 pounds $(0.7 \mathrm{~kg})$ each 


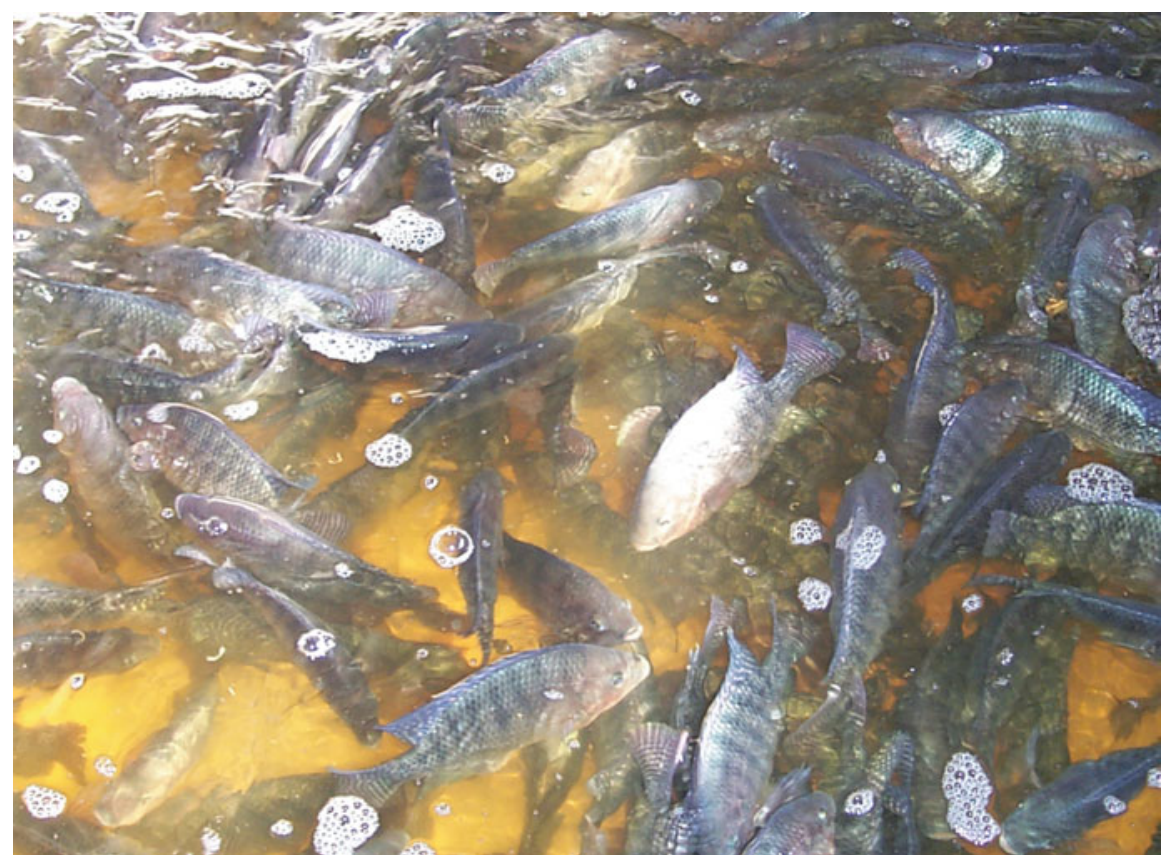

Fig. 5 Purge Tank - When the tilapia crop reached their saleable weight of 1.5 pounds each, they were "purged" in clean water and not fed for one week before shipping to eliminate any off flavors that may have developed. Pictured here are mature tilapia ready for the live market in Philadelphia, PA

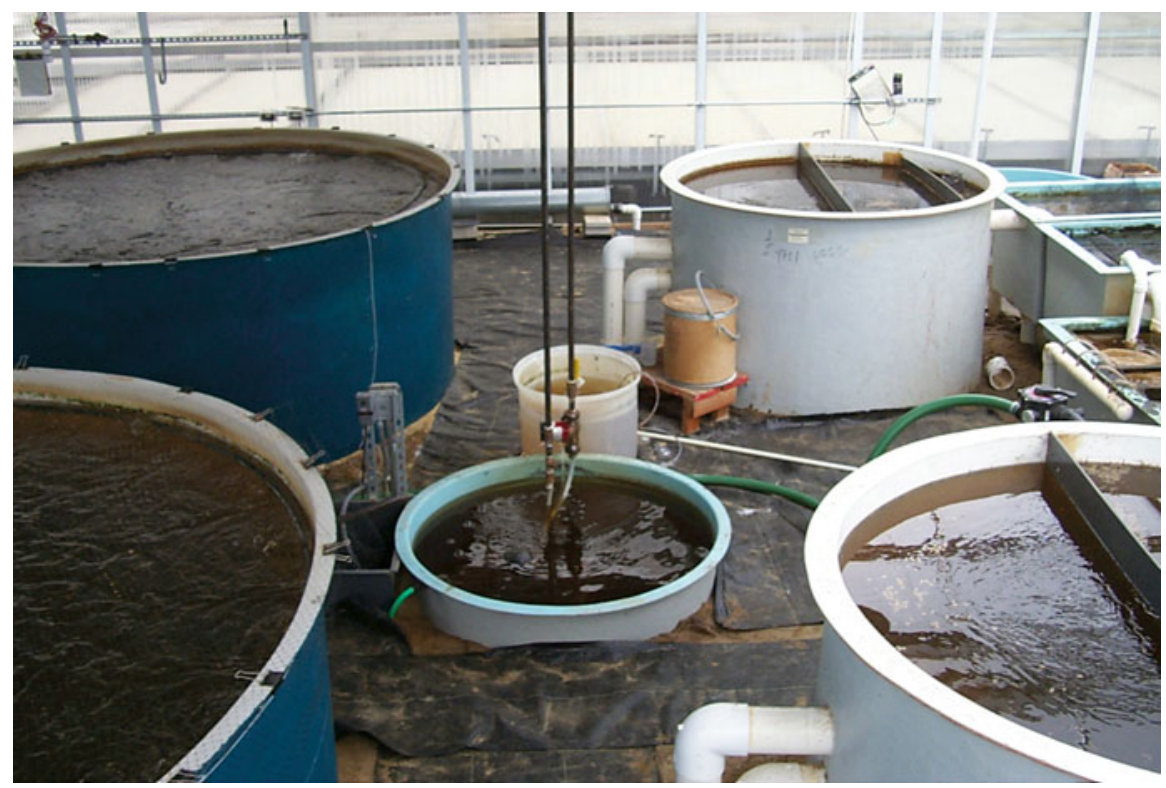

Fig. 6 Production tanks, sump tank, solids filters - An important part of any aquaponic system is a series of filters to remove the suspended particles from the water (solids filter) and to convert the ammonia excreted by the fish to nitrate nitrogen (biofilter). This picture contains the production tanks on the left and the solids filters on the right. In the center, is the heated sump tank where the water flowed into after leaving the hydroponic troughs. From here, the water was lifted into the production tanks using a high efficiency pump 


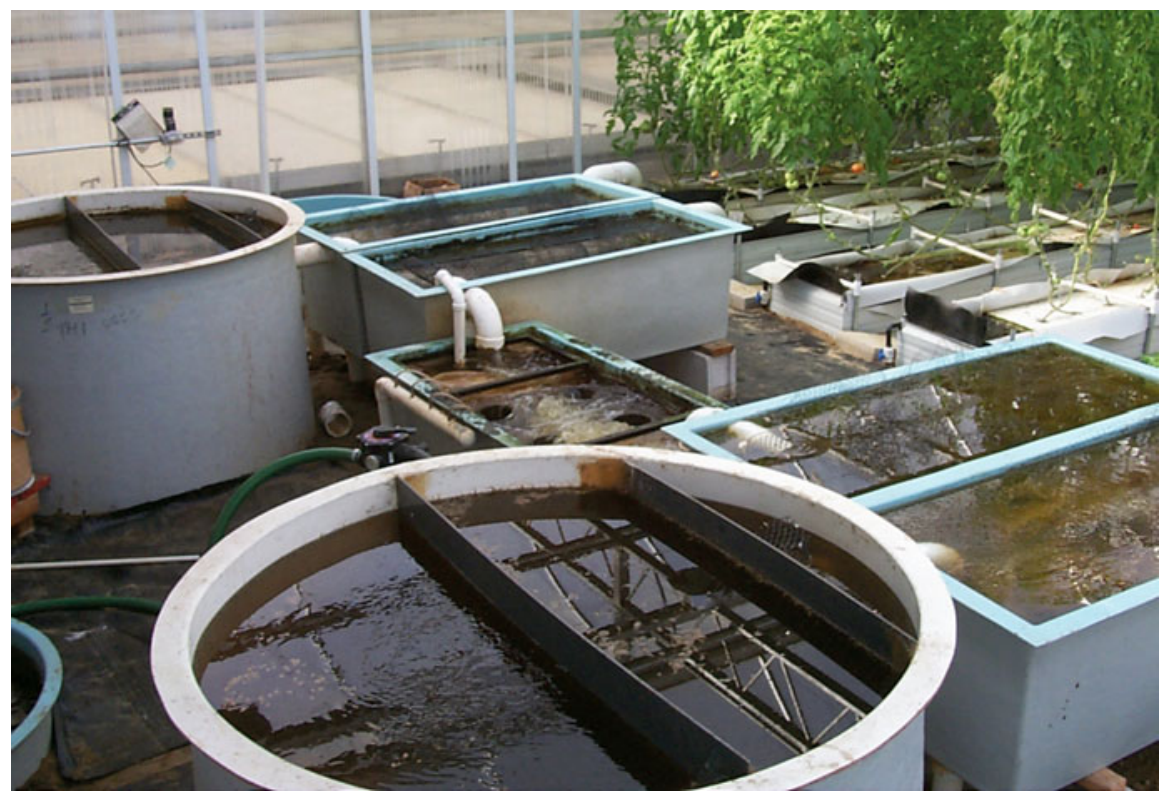

Fig. 7 Solids filter, biofilter, degassing box and hydroponic troughs - Seen in this picture are the solids filters (on the left), biofilters, degassing and distribution box (in the center) that aerated the water and distributed the filtered water to the hydroponic troughs, and the hydroponic troughs (upper right). These components are a very important part of an aquaponic system and should not be omitted

Fig. 8 Aquaponic

Tomatoes - The tomatoes were grown using a

Styrofoam raft system and a lean-and-lower pruning method. The troughs were aerated with air stones every $8 \mathrm{ft}$ to keep oxygen levels in the water as high as possible. We observed a reduction in plant nutrient levels of approximately 10 $\%$, through removal by the roots, from the inlet to the hydroponic troughs to the outlet back to the fish tanks

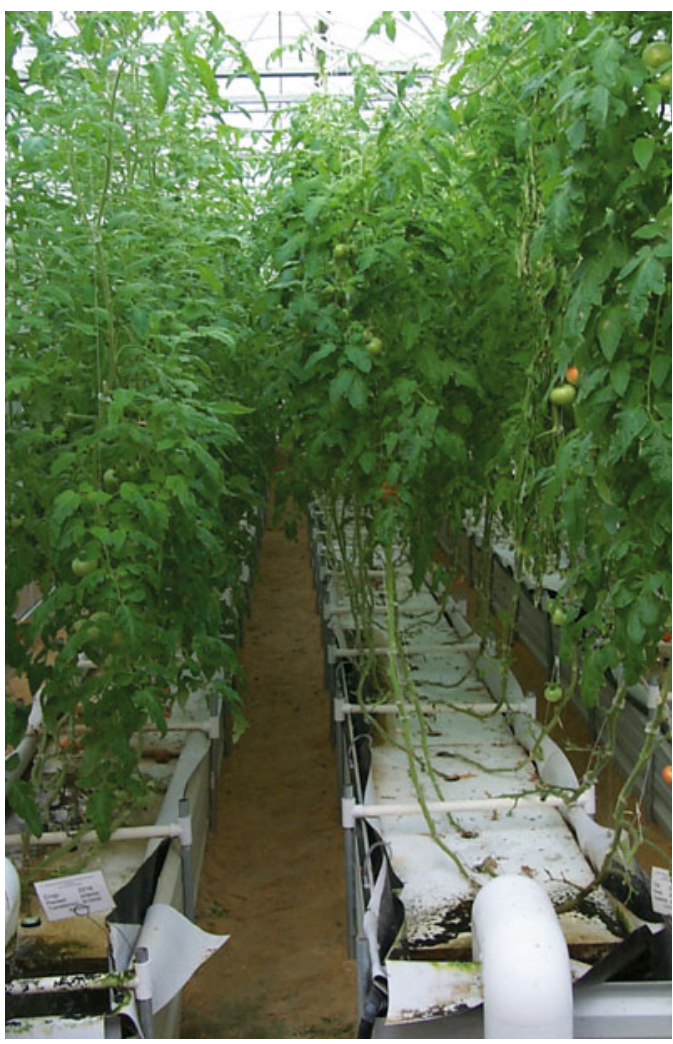




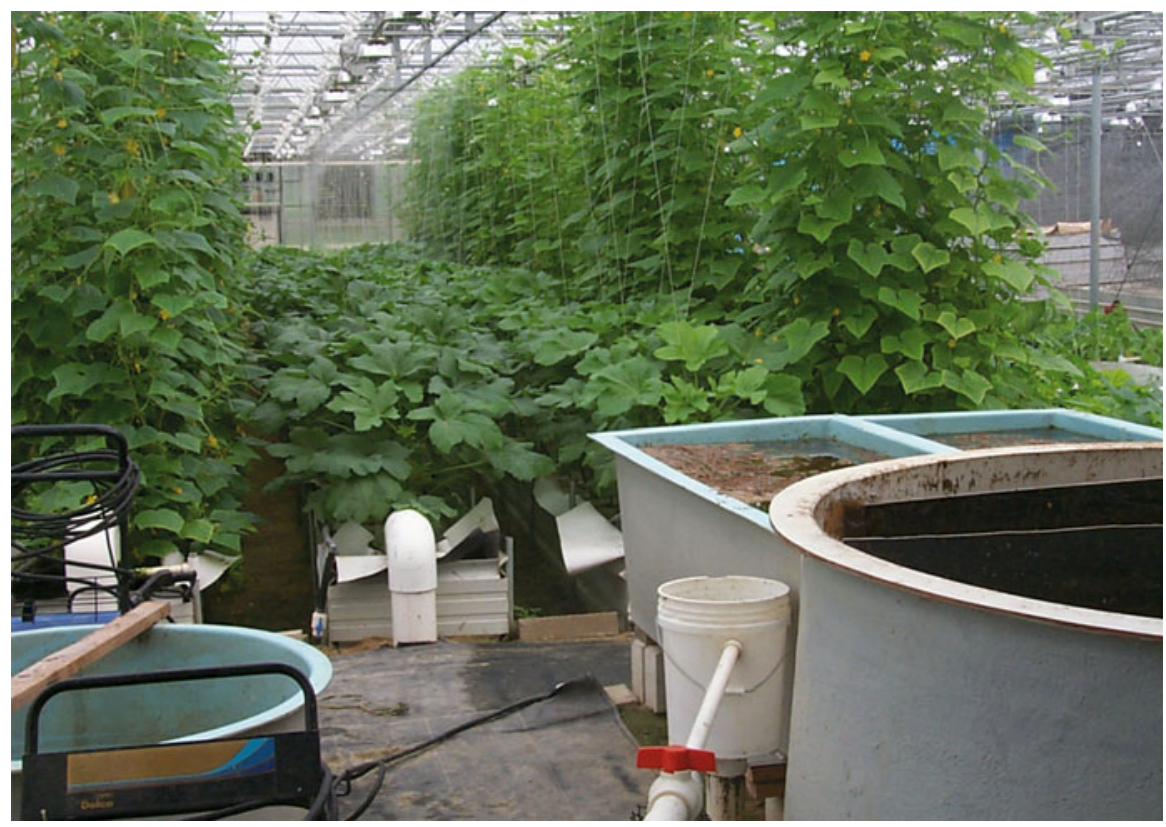

Fig. 9 Aquaponic Cucumbers and Okra - These crops seemed especially well suited for aquaponics as seen in this picture. The shorter season crops (4-8 weeks) tended to perform better in the aquaponic system than the longer season crops (3-6 months)

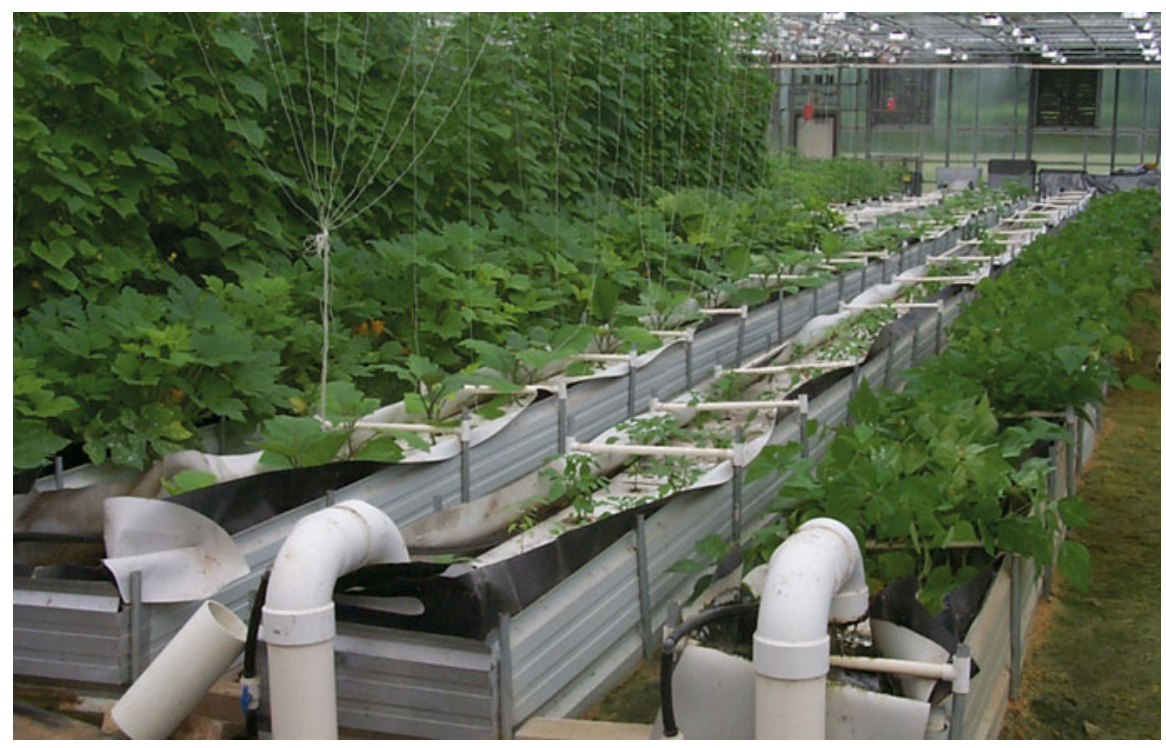

Fig. 10 Aquaponic snap beans, peppers, eggplant and zucchini (right to left)- These crops grew well in the aquaponic system but, as a business, you must be careful to select for crops with high yields and market price. Other crops that grew well in the aquaponic system included lettuces and herbs 
Acknowledgment The authors would like the thank the USDA for providing funding support through NIFA's Hispanic Serving Institutions Higher Education Grant \# 2011-38422-30804.

\section{References}

Al-Hafedh YS, Alam A, Beltagi MS (2008) Food production and water conservation in a recirculating aquaponic system in Saudi Arabia at different ratios of fish feed to plants. J World Aquacult Soc 39(4):510-520. doi:10.1111/j.1749-7345.2008.00181.x

Allen W (2013) Growing the good food revolution. Presented at University of Miami, Miami, FL

Bailey DS, Rakocy JE, Cole WM, Shultz KA (1997) Economic analysis of a commercial-scale aquaponic system for the production of tilapia and lettuce. In: Fitzsimmons K (ed) Tilapia aquaculture: proceedings of the fourth international symposium on tilapia in aquaculture, vol 2, Publication NRAES-106. Northeast Regional Agricultural Engineering Service, Ithaca, pp 603-612

Bernstein S (2011) Aquaponic gardening: a step-by-step guide to raising vegetables and fish together. New Society Publishers, Gabriola Island

Beveridge MCM, Little DC (2002) The history of aquaculture in traditional societies. In: CostaPierce BA (ed) Ecological aquaculture: the evolution of the blue revolution. Blackwell Science Ltd, Oxford, pp 3-29

Bunting SW, Kundu N, Mukerjee M (2005) Peri-urban aquaculture and poor livelihoods in Kolkata, India. In: Costa-Pierce B, Desbonnet A, Edwards P, Baker D (eds) Urban aquaculture. CAB International, Oxfordshire, pp 61-76

Bunting SW, Pretty J, Edwards P (2010) Wastewater-fed aquaculture in the East Kolkata Wetlands, India: anachronism or archetype for resilient ecocultures? Rev Aquac 2(3):138-153. doi:10.1111/j.1753-5131.2010.01031.x

Edwards P (2005) Development status of, and prospects for, wastewater-fed aquaculture in urban environments. In: Costa-Pierce B, Desbonnet A, Edwards P, Baker D (eds) Urban aquaculture. CAB International, Oxfordshire, pp 45-60

El-Sayed AFM (1999) Alternative dietary protein sources for farmed tilapia, Oreochromis spp. Aquacul Environ 179(1):149-168. doi:10.1016/S0044-8486(99)00159-3

El-Sayed AFM (2004) Protein nutrition of farmed tilapia: searching for unconventional sources. In: Bolivar RB, Mair GC, Fitzsimmons K (eds) New dimensions on farmed tilapia: proceedings of the sixth international symposium on Tilapia in aquaculture. ISTA Publications, Manila, pp 364-378. Retrieved from http://ag.arizona.edu/azaqua/ista/ista6/ista6web/pdf/364.pdf

El-Sayed AFM (2006) Tilapia culture. CAB International, Wallingford

Foesel BU, Gieseke A, Schwermer C, Stief P, Koch L, Cytryn E, de la Torré JR, van Rijn J, Minz D, Drake HL, Schramm A (2008) Nitrosomonas Nm143-like ammonia oxidizers and Nitrospira marina-like nitrite oxidizers dominate the nitrifier community in a marine aquaculture biofilm. FEMS Microbiol Ecol 63(2):192-204. doi:10.1111/j.1574-6941.2007.00418.x

Food and Agriculture Organization of the United Nations (2012a) Fishery and aquaculture statistics: 2010. Retrieved from http://www.fao.org/docrep/015/ba0058t/ba0058t.pdf

Food and Agriculture Organization of the United Nations (2012b) The state of world fisheries and aquaculture: 2012. Retrieved from http://www.fao.org/docrep/016/i2727e/i2727e.pdf

Gillman J (2008) The truth about organic gardening: benefits, drawbacks, and the bottom line. Timber Press, Portland

Keuter S, Kruse M, Lipski A, Spleck E (2011) Relevance of Nitrospira for nitrite oxidation in a marine recirculation aquaculture system and physiological features of a Nitrospira marina-like isolate. Environ Microbiol 13(9):2536-2547. doi:10.1111/j.1462-2920.2011.02525.x

Lal R (2013) Beyond intensification. Paper presentation at the ASA, CSSA, \& SSSA International annual meetings, Tampa, FL

Lennard WA, Leonard BV (2004) A comparison of reciprocating flow versus constant flow in an integrated, gravel bed, aquaponic test system. Aquac Int 12(6):539-553. doi:10.1007/ s10499-005-8528-x 
Lennard WA, Leonard BV (2006) A comparison of three different hydroponic sub-systems (gravel bed, floating and nutrient film technique) in an aquaponic test system. Aquac Int 14(6):539_ 550. doi:10.1007/s10499-006-9053-2

Lewis W, Yopp JH, Schramm HL Jr, Brandenburg AM (1978) Use of hydroponics to maintain quality of recirculated water in a fish culture system. Trans Am Fish Soc 107(1):92-99. Retrieved from http://opensiuc.lib.siu.edu/cgi/viewcontent.cgi?article=1063\&context=fiaq_pubs

Little D, Bunting S (2005) Opportunities and constraints to urban aquaculture, with a focus on South and Southeast Asia. In: Costa-Pierce B, Desbonnet A, Edwards P, Baker D (eds) Urban aquaculture. CAB International, Oxfordshire, $\mathrm{pp} 25-44$

Lovelace JK, United States Geological Survey (2009) Methods for estimating water withdrawals for aquaculture in the United States, 2005 (Scientific investigations report 2009-5042). Retrieved from http://pubs.usgs.gov/sir/2009/5042/pdf/sir2009-5042.pdf

Masser MP, Rakocy JH, Losordo TM, Southern Regional Aquaculture Center (1999) Recirculating aquaculture tank production systems: management of recirculating systems (Publication No. 452). Retrieved from http://aqua.ucdavis.edu/DatabaseRoot/pdf/452RFS.PDF

McMurtry MR, Sanders DC, Cure JD, Hodson RG, Haning BC, St. Amand BC (1997) Efficiency of water use of an integrated fish/vegetable co-culture system. J World Aquacult Soc 28(4):420 428. doi:10.1111/j.1749-7345.1997.tb00290.x

Naylor RL, Goldburg RJ, Primavera JH, Kautsky N, Beveridge MCM, Clay J, Folke C, Lubchenco J, Mooney H, Troell M (2000) Effect of aquaculture on world fish supplies. Nature 405:10171024. doi: $10.1038 / 35016500$

Olsen RL, Hasan MR (2012) A limited supply of fishmeal: impact on future increases in global aquaculture production. Trends Food Sci Technol 27(2):120-128. doi:10.1016/j.tifs.2012.06.003

Pilay TVR (2004) Aquaculture and the environment, 2nd edn. Blackwell Publishing, Ltd, Oxford

Rakocy JE, Masser MP, Losordo TM, Southern Regional Aquaculture Center (2006) Recirculating aquaculture tank production systems: aquaponics-integrating fish and plant culture (Publication No. 454). Retrieved from website: https://srac.tamu.edu/index.cfm/getFactSheet/ whichfactsheet/105/

Tal Y, Schreier HJ, Sowers KR, Stubblefield JD, Place AR, Zohar Y (2009) Environmentally sustainable land-based marine aquaculture. Aquaculture 286(1-2):28-35. doi:10.1016/j.aquaculture.2008.08.043

Timmons MB (2005) Competitive potential for USA urban aquaculture. In: Costa-Pierce B, Desbonnet A, Edwards P, Baker D (eds) Urban aquaculture. CAB International, Oxfordshire, pp 137-158

United Nations Department of Economic and Social Affairs (2004) World population to 2300. Retrieved from http://www.un.org/esa/population/publications/longrange2/WorldPop2300final.pdf

United Nations Department of Economic and Social Affairs (2011) World urbanization prospects, 2011 Revision: percentage of population residing in urban areas, 1950-2050 [XLS file]. Retrieved from website: http://esa.un.org/unup/CD-ROM/Urban-Rural-Population.htm 


\section{Part VI \\ Integration into Municipal Infrastructure - Location Options}




\title{
Community Garden Basics
}

\author{
Kristen McIvor
}

\section{What Is a Community Garden?}

Community gardens are the face of urban agriculture. Small plots in shared spaces have been the traditional location for food cultivation in cities where multi family housing and high density have limited the potential for growing food on traditional large- scale farms. But it is not only in high-density neighborhoods where there is interest in community gardening. In fact, community gardens are becoming common even where single- family dwellings are the predominant housing structure. These typically have sufficient space for food production in front and back yards as well as parking strips. Despite this, community members are choosing to garden collectively and community gardens are expanding in cities across the country. The reasons for this expansion are multiple but the critical common factor is fact that these gardens bring together multiple individuals in a community setting.

Community gardens grow flowers, herbs, vegetables, and community. The American Community Gardening Association (https://communitygarden.org/) defines community gardens broadly. A community garden can be urban, suburban, or rural. It can grow any type or types of crops including ornamentals. It can be one community plot that is jointly farmed, or many individual plots. It can be located at a school, hospital, or in a neighborhood. Another way of thinking about community gardens are as "community-managed open spaces." These differ from a park or public space where some other entity ultimately decides the purpose of the site and maintains it. Community gardens are where the residents of a community are empowered to design, build, and maintain spaces in the community. The most important step in building a community garden is to assemble a community of people. A community garden without interested gardeners is just a vacant open space.

\footnotetext{
K. McIvor $(\bowtie)$

Program Director - Harvest Pierce County, Pierce Conservation District, Puyallup, WA, USA

e-mail: KristenM@piercecountycd.org
} 


\section{Organizing a Community Garden}

The initial process of starting a community garden involves identifying a community of people to participate. There are many ways to do this, beginning with asking neighbors if they, or anyone they know, might be interested. A second step or option is to work through existing organizations or neighborhood groups to identify gardeners. Examples include places of worship, school related organizations, or other community groups. Social media is another alternative to identify people who are interested in participating (Fig. 1).

Assembling a community of people interested in jointly turning an open space into a community garden is the most critical step in creating a community garden. This is often a time consuming process, however the initial time investment required to build relationships will sustain the site long term. Gardens require a varied range of roles and skills and so an assemblage of individuals is required to build and sustain a garden. Some needs are common to almost all gardens:

Fig. 1 A beautiful sign to attract neighborhood residents - Tacoma, WA

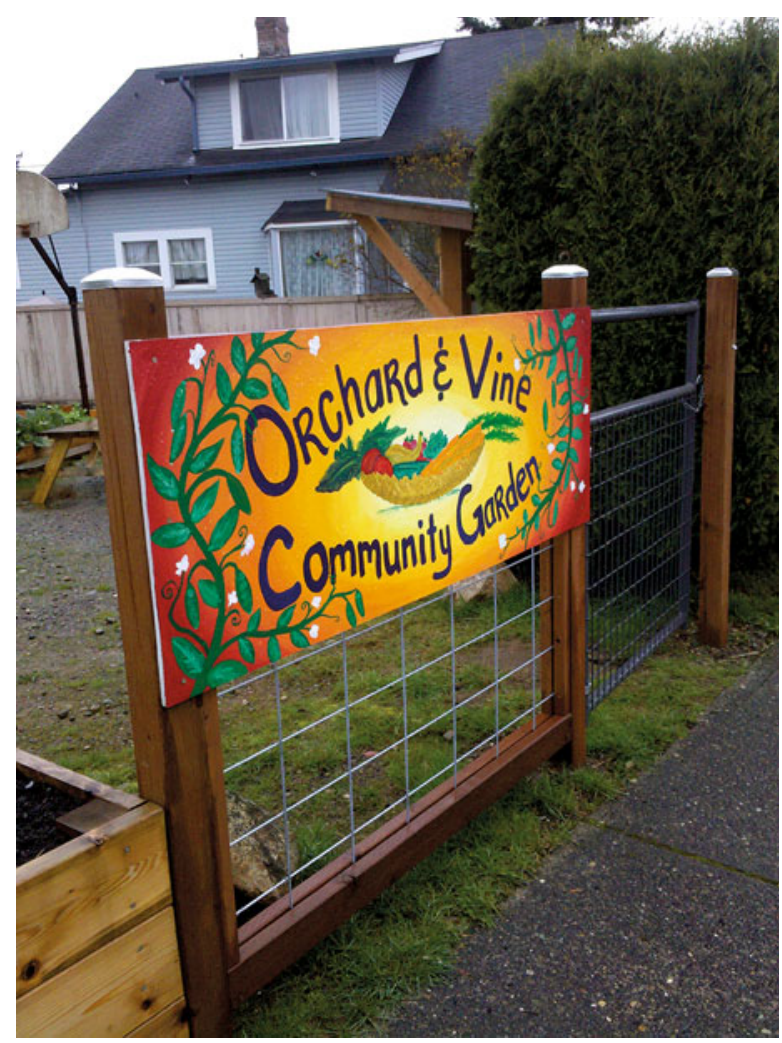




\section{Early Leadership}

Starting a community garden can take a lot of planning meetings and discussions, so it's essential to have community members willing to take a leadership role early on. The success of a garden long-term often depends on being able to share leadership with all participants. But in the beginning, it's important to have a small group of committed people who are willing to do the hard work of organizing and getting the project off the ground.

\section{Building the Garden}

Gardens typically have some built structures. These can include fencing, sheds, irrigation systems and raised beds. People knowledgeable in construction that have the tools required to build are important for making the garden a reality. These people may or may not be interested in gardening. In some cases when gardens are managed by municipalities or non-profits, access to construction equipment and people able to carry out construction may be provided.

\section{Long-Term Gardeners}

Many people like the idea of having a community garden in the neighborhood but don't intend to garden there themselves. It is wonderful to have the support of these individuals, but it is also important to have a roster of people who will participate as gardeners and steward the garden long-term. Sometimes these people won't be interested in the leadership or community meetings and process needed to get a garden started. But without them, it will be difficult to sustain a garden.

\section{General Community Support}

It's important to have the support of the local community, even those who don't intend to garden. Neighbors can keep an eye on the site, local businesses can donate food or other resources for work parties, community members can donate art or teaching skills or help haul excess produce to the food bank. Make a list of some local businesses and reach out to them for support, and encourage community members to think of ways they can contribute. After all, a community garden has a much better potential for success if it creates a community within the garden and is integrated into the existing local community (Fig. 2).

Once a group has been identified it is critical to work together to define a common vision. Each garden may have a different vision and purpose. There is no "right 


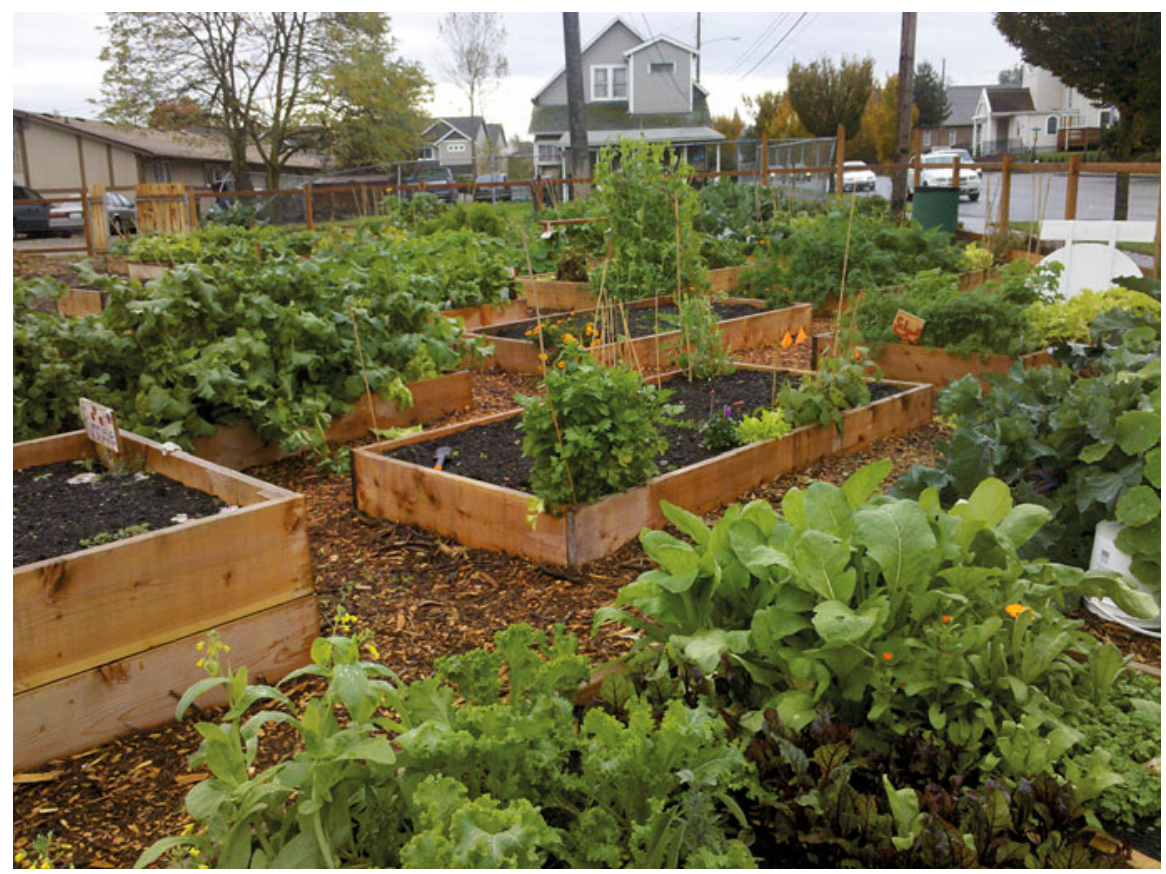

Fig. 2 Community garden in Tacoma, WA

way" or strict formula to decide this or to organize the garden, however there are some common issues that apply to almost all gardens that should be decided before building. Face-to-face meetings and conversations where questions are asked and answered on the goals and set up of the garden are the best way to work through this process. For example, a garden may want to have a common space for growing food or socializing. There may be a desire to have a place built to sit and relax. Community discussions are the best means to define the goals and structure of the garden to accommodate these interests and come to a common agreement. It's crucial that as many people as possible feel included in this process. A visual format for these meetings can work to help a greater diversity of people feel comfortable.

\section{Best Practices in Community Garden Development}

\section{Defining a Purpose/Vision}

There are about as many good reasons for having a community garden as there are gardeners. For some, it's a chance to meet their neighbors; others are excited about learning to garden; some gardeners want to create a safe place for kids to be.

A group of gardeners doesn't have to agree on a single purpose, but a discussion should be held about what the purpose (or purposes) of the garden are, as this will 
help with many of the design decisions. A garden whose purpose is to maximize the amount of fresh food delivered to the food bank will look very different from a garden designed to foster community interaction. Getting clarification early on in the process is a good idea to minimize conflict.

\section{Planning in Communal Space}

One of the primary organizing factors in community gardens is the distinction between individual plots and communal areas. Individual plots are areas that gardeners rent to do with as they choose. Most choose to grow food for home consumption, with excess given to food banks. Many gardens have at least a portion of their garden in individual plots, while others are entirely that way. Other gardens are designed to have a portion of the space cared for by the entire community. That is, the group works together to maintain the communal plot and shares in the benefits (Fig. 3).

Some examples of communal plot areas are:

- Herb garden

- Flower garden

- Orchard

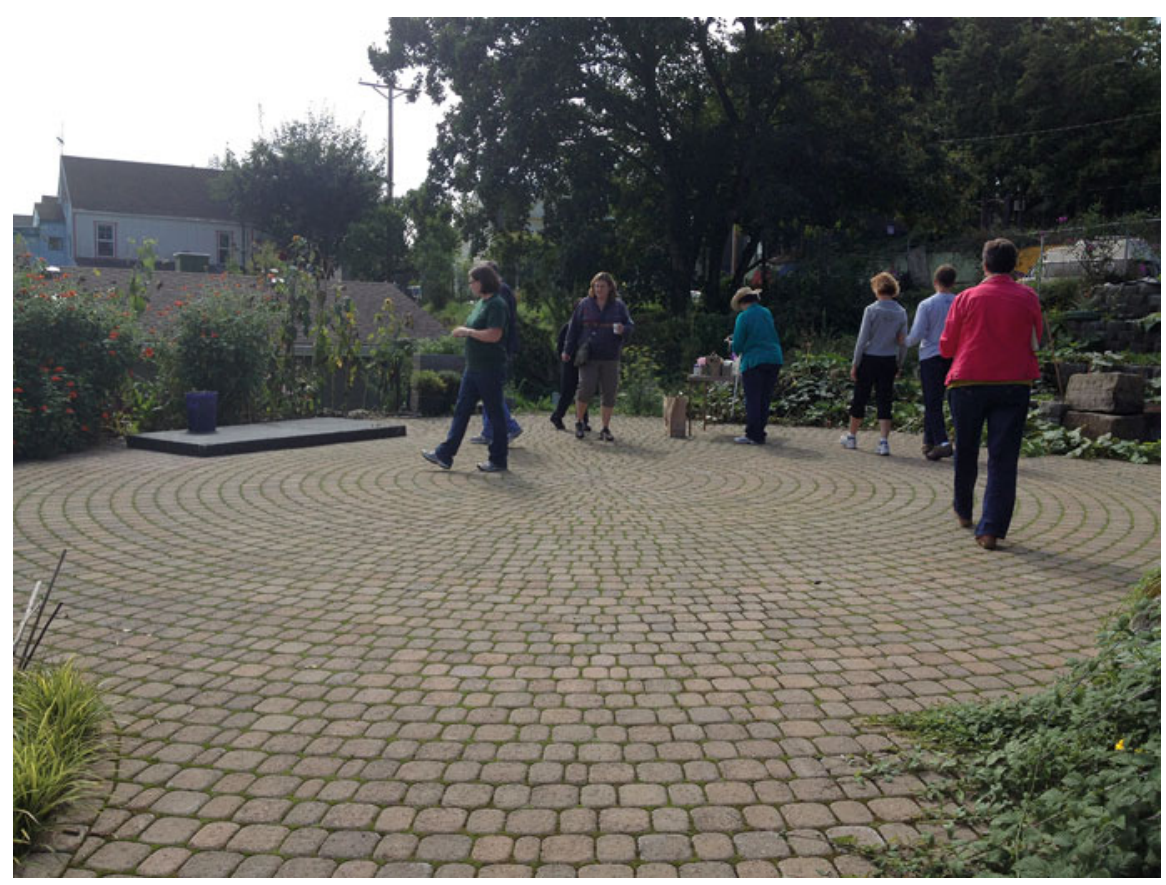

Fig. 3 Communal gathering spaces allow for community events 
- Native plant garden

- Gathering place

- Children's garden

- Children's play area

- Demonstration garden

Communal or shared space can be very important to the development of a sense of community within and around the garden. Research has shown that levels of social capital tend to be higher in gardens that reserve some area for communal space. And the space can be used for many different activities: gardening for donation, planting of demonstration gardens, and classes or community events (Fig. 4).

\section{Shared Leadership}

As a shared space involving multiple individuals it is also critical to devise an organizational or leadership structure for the garden. Often, a strong leader is present who's capable of doing much of what is needed and making many of the decisions.

Fig. 4 Flower gardens at a community garden

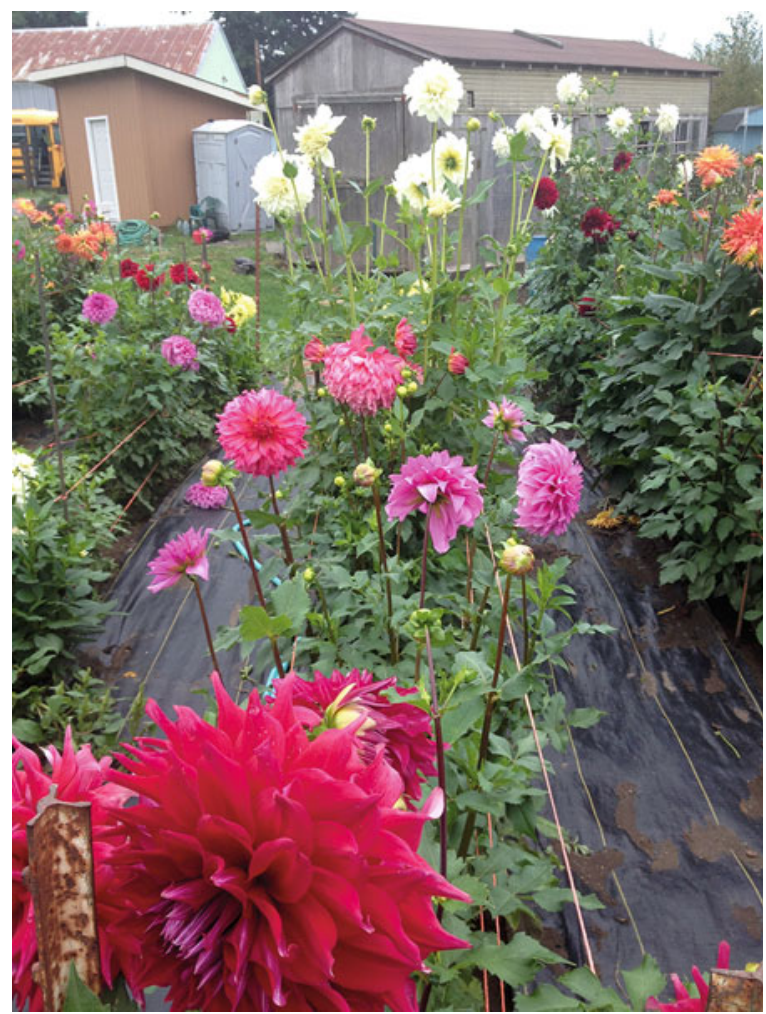


But this can also be a hinderance to including others and inviting others to share their skills. When you invite people to be involved with a project such as a community garden, you need to invite them into leadership and decision-making processes, too, or they may get frustrated.

Sharing leadership can be challenging, but it's vital for long-term success. Far too many gardens rely on the leadership of a single, committed individual, and these gardens may fail when that person gets tired or needs to attend to other responsibilities. Community gardens require an incredible amount of work, so sharing leadership will spread the work and responsibility around. In addition, groups tend to make better decisions when they hear from multiple people. There are many forms of decision-making processes that can work for community groups, but whatever the group decides to use, it must be transparent. When participants feel like decisions are being made in secret, or in some other way that's invisible or inaccessible to them, they may feel frustrated and withdraw from the project.

\section{Conflict Resolution Procedures}

Many groups come to a project such as a garden with excitement and positive feelings about getting to know neighbors, so it can be hard to imagine a time when conflict might arise around a decision. But successful community gardens represent thousands of small and large decisions, so it's inevitable that at some point disagreement will emerge.

Having clearly defined conflict resolution procedures in place can greatly reduce the amount of stress and tension that occurs when a group does run into conflict. Many times these procedures won't be needed, but having them is good insurance that if a group does run into conflict, it won't run the project off the road.

\section{Building a Community Garden}

Community gardens can thrive in a diversity of sites including abandoned lots, areas in public parks, and rooftops. The most important thing is that the site works for the community of gardeners who will manage it. Several important considerations need to be taken into account when choosing a site for a community garden.

\section{Visibility}

It's beneficial to place a community garden in a visible location where people naturally gather and pass by. This will work to keep the garden alive and to maximize its impact on the community. Some of the most successful gardens are that way because they're situated in a place where the community naturally gathers and thus serve as community gathering areas. Gardens that are tucked out of the way, in places people 
would not go normally, can prevent a garden from being used by the community and recognized as an asset. It's also important for safety reasons to locate the garden in a place where passersby can have "eyes" on the site, to discourage any unwanted behavior.

\section{Access}

In addition to being visible, the garden needs to be accessible to both gardeners and large vehicles such as delivery trucks. Things to consider are available access for parking or bus routes. It can be important to make sure that a site is accessible so that someone with limited physical mobility could enter the site. Gardens typically use large amounts of compost and other soil amendments and so access for a large truck trying to deliver products is another factor. You may not be able to have all these things, but they are important to consider.

\section{Sun}

The vast majority of vegetables and fruits don't do well without at least 6-8 h of full sunlight daily. Look to the south for large buildings or trees that will shade the site. Some shade on the site can be nice relief on hot summer days. But a very shady site will be a challenge for growing vegetables (Fig. 5).

Another major consideration when choosing a site is the landowner. Different types of landowners present different benefits and challenges to the garden, both in initial development and long-term stability. While many landowners are potentially willing to host a community garden, the differences between them most often boil down to the differences between public landowners, such as a city, and private landowners, such as a citizens' group, and individual, or an agency like a church.

Some considerations that relate to the type of landowner include:

\section{Water}

There are three costs related to water. The first is access to a water meter, this can be one of the largest upfront costs. A public agency may be better able to pay for installation of a water meter than a private citizens' group. The second cost is installing pipes to convey water from the meter to the garden's location, and then throughout the garden. This can often be done for relatively low cost. Public agencies often have staff qualified to do this work, or private citizens can do it with volunteer labor, 
Fig. 5 Sunflower thriving in a community garden

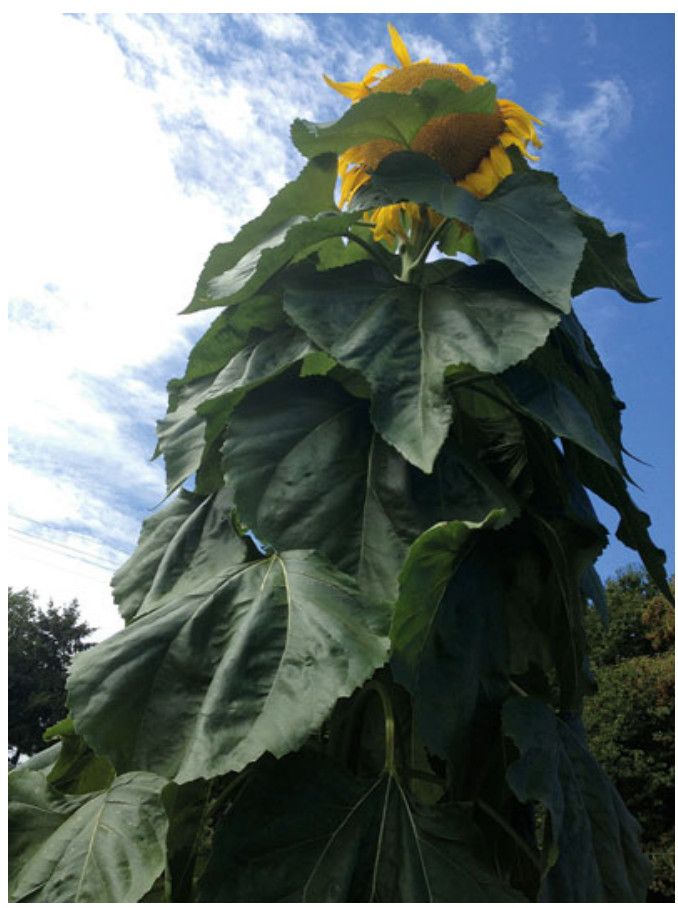

but it helps to have a skilled volunteer. The third cost is the ongoing cost of the water. No matter who the landowner is, gardeners are usually held responsible for the cost of the water they use throughout a growing season, unless their is a program supporting them.

\section{Insurance}

Different types of landowners will have different requirements regarding insurance. If the owner is a public agency that is used to insuring its public spaces, then treating the garden like a public space (and/or having gardeners sign a waiver) can often satisfy the agency's requirements. Churches or other land-owning non-profits are also familiar with the costs of insuring the land they own, and changes may not be necessary to turn parts of their land into a garden. A private citizen, however, may not be interested in buying additional insurance to let a group of gardeners use his or her land. In this case, it may be best to seek out a third party that would be willing to support the community garden by handling the insurance. 


\section{Access to Resources}

Different ownership structures may make you eligible for different resources to assist with building the garden. In general, it's easier to access public dollars if the garden is on public land. Private dollars can be sought to develop a garden on either public or private land. Keep in mind that many grant resources are restricted to groups that are affiliated with official non-profits that have a 501c3 designation. It may be wise to partner up with an existing group that has similar goals (like a food bank or church) or inquire to see if your municipality has any supporting programs.

\section{Urban Gardening At a P-Patch: One Family's Experience}

Michael McGoodwin, Rebecca McGoodwin, and Wendy McGoodwin

\section{What Is a P-Patch?}

P-Patch Community Gardens are urban communal public sites providing small plots or gardening allotments to individuals for raising plants, mostly vegetables, fruits, and flowers. The term "P-Patch" was coined in Seattle and derives not from peas but from Picardo Farm, the site of the original Seattle P-Patch (officially established in 1973) (http://www.seattle.gov/neighborhoods/ppatch/documents/HistoryP-Patch.pdf). The term and concept appears to be gradually spreading to a number of nearby communities. There are more than 80 of these sites scattered throughout Seattle. They are of markedly varying sizes, with each being divided into as few as 9 or as many as 259 plots. Each individual P-Patch plot measures typically between 40 and 400 sq. ft. The P-Patch Program is the community gardening program of the City of Seattle's Department of Neighborhoods, and is open to all Seattle residents. Plots are leased annually for a modest rental fee that includes use of tools, water, and other resources. In recent years an increasing effort has been made to accommodate the needs of our more under-served or disadvantaged residents (for whom the rental fee may be waived and barriers reduced). P-Patch gardeners must donate a designated number of volunteer hours to the P-Patch, and many give much more of themselves than the minimal requirement. They must adhere to a set of reasonable rules to assure that:

(1) The crops are raised organically without use of synthetic chemicals,

(2) The beds and borders are weeded and soil and water are conserved,

(3) Neighborly relations are maintained,

(4) Food is not wasted, etc.

The well-run extensive Seattle program, which surely serves as a model for other communities to emulate, is fully described on their website. 


\section{Purposes of a P-Patch Including Intangible Benefits}

The primary purpose of having a P-Patch plot is to make possible the growing of fresh vegetables and fruits by individuals. Store-bought vegetables are becoming increasingly expensive, and the quality may be unknowable or unsatisfactory, especially in "food deserts." Organic food raised free of synthetic pesticides and herbicides is healthful and increasingly desirable, and Seattle P-Patches require all produce to be raised organically (Fig. 6).

A major additional benefit of raising vegetables is the deep satisfaction that comes from returning to the basics of tilling the soil and raising crops, thereby addressing our most primitive needs for sustenance. The rules forbid us from selling P-Patch produce, so what "profits" you make must be noncommercial or intangible. For persons who may have limited travel opportunities, getting to the P-Patch nearby can provide a welcome respite from the urban rat race and seem a little like a trip to the country. The relatively open space of a P-Patch can be esthetically pleasing and calming in a city otherwise increasingly dominated by traffic and commercial development. Although public parks can also offer vigorous athletic activities, members of the populace in a more reflective mood can benefit from the usually tranquil atmosphere of a P-Patch. P-Patch gardening can be very fulfilling, even though it is often hard

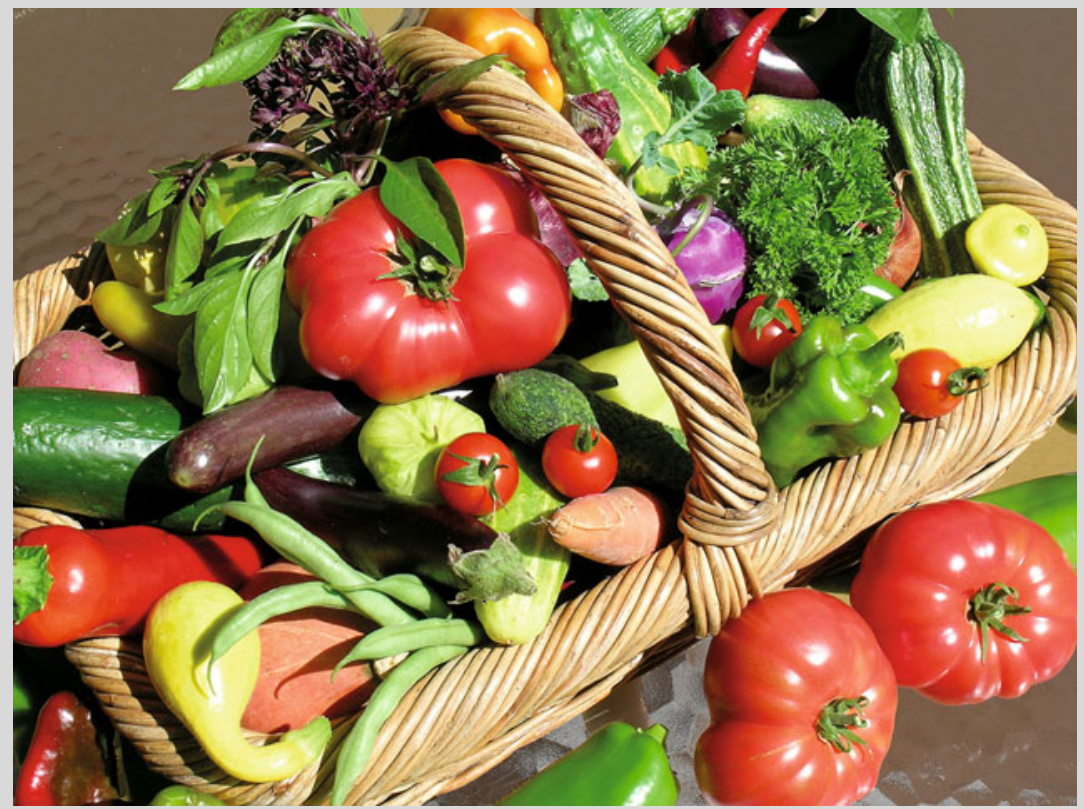

Fig. 6 Vegetable bounty from P-Patch 2006

(continued) 
work, and not everyone has the time and energy needed to take on this laborintensive activity. But raising an honest sweat and getting your hands dirty growing vegetables in the garden helps you feel like you have returned to the agrarian roots of your forebears.

\section{Gardening on Communal Public Land (Versus on Personally Owned Private Land)}

Most people when considering vegetable gardening would probably assume that the garden should ideally be under their full control and on their own private property. This certainly has significant advantages in terms of convenience, freedom, and relative security regarding theft. Unfortunately, not every city dweller has ready access to private cultivable land. We signed up for our first P-Patch plot in 2001, initially because we lacked space for a vegetable garden at home. We began with 400 square feet, had to move to a $100 \mathrm{SF}$ plot at a different location in 2002, moved up to a somewhat better 400 $\mathrm{SF}$ in 2003, and acquired our current $600 \mathrm{SF}$ plot in 2004. We mention these details because you should not be discouraged if your initial plot assignment is a little disappointing. Over the years we have come to appreciate that a P-Patch offers a special atmosphere and advantages not found on private land. Fortunately, these benefits tend to overshadow the disadvantages.

P-Patches in Seattle provide shared and communal resources such as tools, hoses and water, sometimes compost, and of course the land. But they also allow a great deal of social interaction with gardeners and even casual passersby. We have enjoyed the numerous opportunities to get together at the P-Patch with fellow gardeners, from merely chatting with our P-Patch neighbors to informal potluck suppers. These encounters allow the exchange of ideas and advice on what and when to plant, on pest and weed management, and on other gardening essentials, but they also simply let us just enjoy the camaraderie of friends and acquaintances we have made there. There are also volunteer aspects, such as growing food to contribute to the Food Bank for the needy, which add appeal for civic-minded participants.

One pleasant and unanticipated surprise has been the remarkable extent to which our patch has become a magnet for visiting friends and relatives. We take them all down for the tour-children, young adults, even our elderly guests can easily navigate the paths of a P-Patch. All seem to enjoy the outing and in season take inspiration from the obvious bounty on view, some of which they may partake of at the next meal. Often we put our visitors to work, picking snow peas, pole beans, or cherry tomatoes. Our particular P-Patch is quite public and colorful to tour, and we always marvel at the variety of layouts, structures, and crops to be found in the more than 100 plots (Fig. 7). 


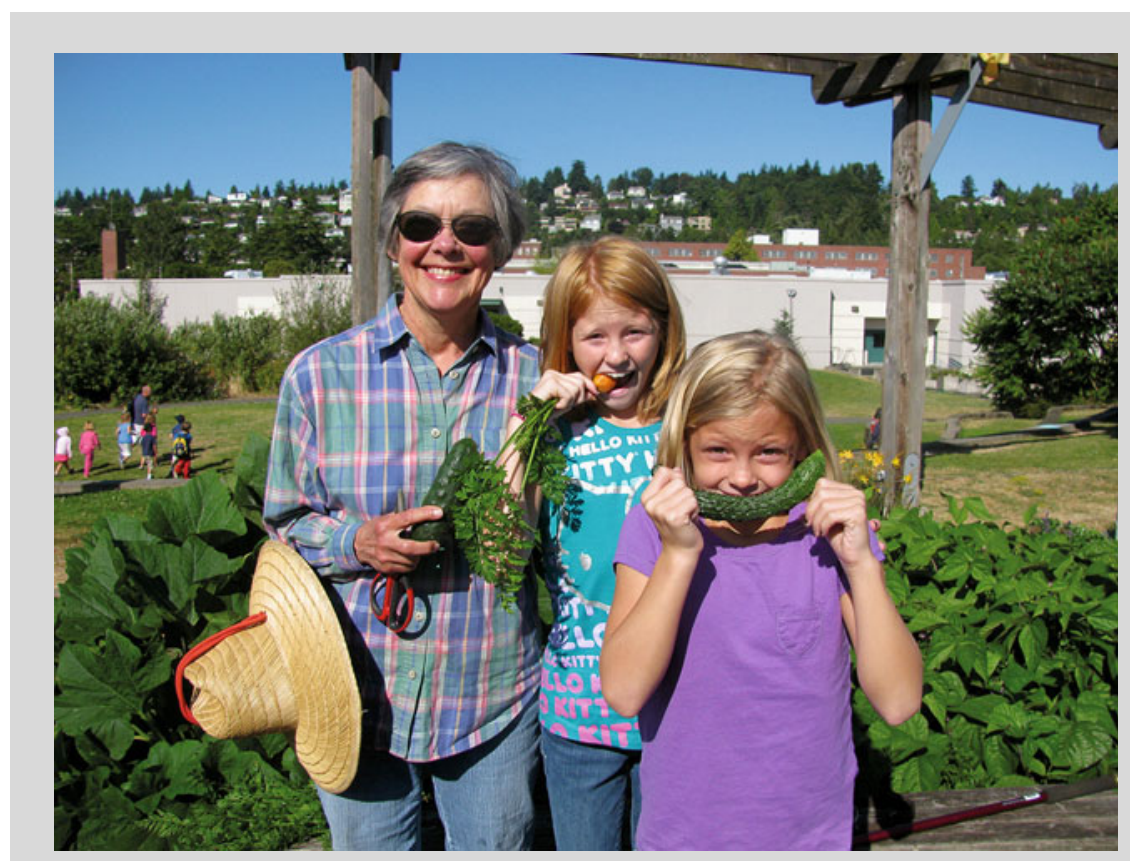

Fig. 7 Rebecca McGoodwin and visiting family

An interesting new development in 2014 is that a second family has joined us in co-gardening our physically undivided plot. This was brought about by new rules requiring downsizing of larger plots, part of the P-Patch program's efforts to make more plots available. We adapted to this new policy and are delighted with the infusion of new energy, ideas, and labor that our new cogardeners have brought to the shared plot. Although the logistics are a bit more complex, co-gardening overall seems a positive development which gardeners might wish to consider for larger plots. 


\title{
Up on the Roof: Considerations for Food Production on Rooftops
}

\author{
Leigh Whittinghill and Olyssa Starry
}

Green roofs are increasingly common. Planting on a rooftop is a way to insulate buildings, reduce stormwater flows, and potentially provide space for birds, bees and people to congregate. Engineered media has been developed that allow for planting on green roofs. Green roofs have also been recognized as a place to grow food. Rooftop agriculture can be as varied as the many types of in-ground and greenhouse agriculture that are more familiar to most people. For example, row farming, container gardening, and hydroponics are all possible under open sky as well as in greenhouses. Each type of cultivation can be carried out on a roof surface as well as on the ground. Different forms of cultivation come with their own set of advantages and disadvantages. Greenhouse and hydroponic production are both much more highly managed and controlled systems, and the potential differences between rooftop and ground level production are therefore likely to be smaller. Rooftop agriculture under an open sky, either as row farming or container production is likely to be more different than in-ground operations of this type than either greenhouse or hydroponic operations because they are more exposed to the novel environment of the rooftop. Our discussion of rooftop agriculture will be focusing on the row farming and container gardening operations that are open to the sky. These types of rooftop agriculture may use pre existing green roof technology.

Green roofs can be extensive (shallow and requiring very little maintenance) or intensive (deeper and requiring more maintenance). Installation of soil media as well as planting techniques also vary. Green roof technology makes use of specific engineered layers to support plant life on rooftops while protecting the underlying roof layers. Green roofs can be installed using three different methods: as pre-grown

\author{
L. Whittinghill, Ph.D. ( $\varangle)$ \\ Department of Biological Sciences, Rowan University, Glassboro, NJ, USA \\ e-mail: leigh.whittinghill.grr@gmail.com \\ O. Starry, Ph.D. \\ Urban Ecology, Portland State University, Portland, OR, USA \\ e-mail: ostarry@pdx.edu
}


mats, modules or as a continuous roof. Pre-grown sedum mats are shallow and can be rolled like sod for transportation and instillation. Modules vary in size and can also be pre-grown or planted after instillation. A continuous green roof is installed one layer at a time, then planted from seed or plugs. Agricultural rooftops tend to use either modular or continuous green roof systems.

\section{The Strengths}

There are many benefits associated with rooftop agriculture particularly in an urban setting. These strengths, including available space and absence of soil contamination, may make roof top agriculture a desirable alternative to ground level agriculture in urban areas.

\section{Underutilized Space}

The rooftop space in a city is one of its most underutilized resources and can account for much of the cities surface area, especially in densely developed neighborhoods. In New York City, for example, there are 38,256 acres of rooftop (Ackerman et al. 2011). Finding land for production is also one of the biggest challenges for urban agriculture (Graefe et al. 2009; Nugent 2002; Vagneron 2007). A city's unused roofs therefore have the potential to become a vast array of parks, gardens, and farms. The use of rooftops for agriculture will also have to be weighed against other uses of the space, such as production of solar power. Luckily, green roofs and these other uses need not be mutually exclusive. Green roofs and solar panels, for example, can be installed on the same roof. Solar panels provide protection from the harsh environment of the roof for more sensitive plants, while the cooling effect of a green roof enables solar panels to work more efficiently (Witmer and Brownson 2011).

\section{Food Miles, Food Security, and Waste Streams}

For some consumers, the distance that food has to travel between the farm where it was grown and their table is an important consideration. It has been estimated that food typically travels $2080 \mathrm{~km}$ (1300 mi) between the farm and consumers (Peters et al. 2009). This not only requires energy for transportation across such long distances, but impacts the freshness of the produce when it reaches the consumer. The distance food travels could be reduced to $49 \mathrm{~km}$ if the food system were reorganized (Peters et al. 2009). This has also become a selling point for restaurants that pride themselves on serving locally produced foods. It doesn't get more local than grown 
on the roof of the restaurant. There are a number of restaurants in the United States that are using this business model, such as Uncommon Ground in Chicago, IL (UG 2010) and Rosemary's in New York City (Rosemary's NYC 2013). Local production of food can also alleviate food insecurity issues, by enabling access to fresh, nutritious produce that might not otherwise be available (Enete and Achike 2008; Graefe et al. 2009; Nugent 2002; Whittinghill and Rowe 2012; Widome et al. 2009; de Zeeuw et al. 1999). Neighborhoods in New York City, such as Brownsville and Crown Heights, fit a pattern of inadequate access to healthy food coupled with high incidents of diet-related diseases. They also have greater percentages of vacant land and many community gardens, so need, opportunity and interest are all present (Ackerman et al 2011). Another added benefit of urban and rooftop agriculture is a change in waste streams. Many rooftop farms use compost as a source of nutrients for plant growth. This compost is often made locally from waste collected from local sources, such as restaurants. The Intercontinental Barclay New York hotel, for example, composts food scraps from the kitchen for use on their rooftop (IHR 2013) (Fig. 1).

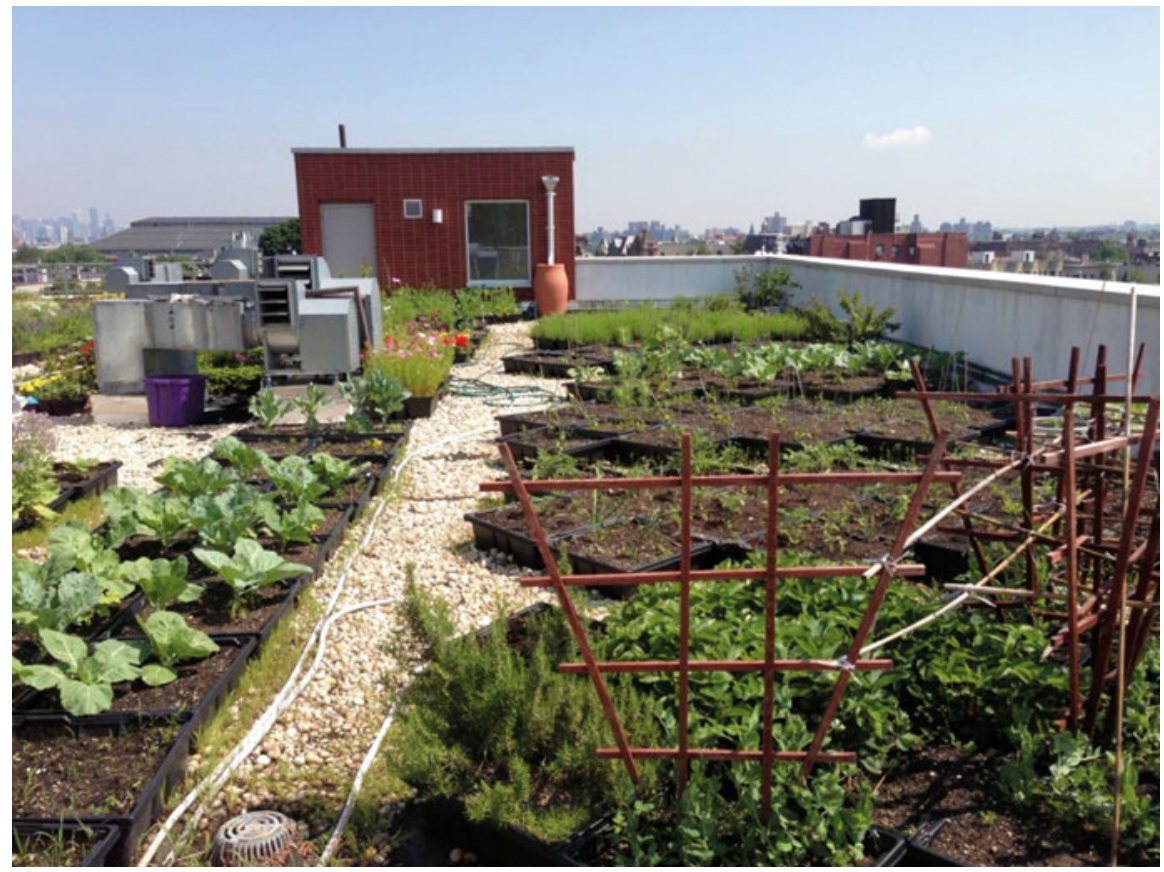

Fig. 1 Seeds to feed rooftop farm, managed by community, counseling and mediation. The vegetables produced on this roof are used by the residents of the building (Photograph by Leigh Whittinghill) 


\section{Environmental Benefits}

Two of the major environmental benefits of green roofs are stormwater management and mitigation of the urban heat island. It is thought that rooftop farms will have these benefits as well. Stormwater management by green roofs can take two forms: retention of stormwater and improvement of water quality. Depending on the depth of media and the types of plants growing on a green roof, they can hold between 52 and $100 \%$ of rain (Czemiel Berndtsson 2010; Getter et al. 2007; Hathaway et al. 2008; Rowe 2011; VanWoert et al. 2005). Green roofs are able to improve the quality of runoff water as well (Berndtsson et al. 2006; Czemiel Berndtsson 2010; Rowe 2011). This is dependent on management practices, which will be addressed in the following section on weaknesses. It is still unclear how the use of irrigation and fertilizers in crop production will affect these benefits.

The Urban Heat Island effect is an increase in the temperature of an urban area above the temperatures of a surrounding rural area (Alexandri and Jones 2008; Getter and Rowe 2006; Memon et al. 2008). Urban greening is one method of mitigating this increased temperature. Trees and plants create a cooling effect in two ways. First they intercept sunlight that would normally be absorbed or reflected by other urban surfaces (Akbari 2002; Alexandri and Jones 2008). If absorbed, this energy increases surface temperatures and is re-radiated as heat (Memon et al. 2008). Second, transpiration by plants creates a cooling effect around them (Akbari 2002; Alexandri and Jones 2008; Getter and Rowe 2006). This is also true of green roofs, which reduce surface temperatures (Wong et al. 2007) and could reduce urban temperatures by $1-2{ }^{\circ} \mathrm{C}$ if planted in large numbers (Bass et al. 2003). Rooftop farms would likely contribute to this cooling.

\section{The Weaknesses}

\section{Structural Concerns}

The choice to put greenery, whether for food, recreation or aesthetics, on a rooftop may seem like a simple one, but it can be more complicated. One of the biggest concerns is the roofs' ability to hold the weight of a rooftop farm. Many agricultural green roofs have been reported to have much deeper growing media, between 17.8 and $45.7 \mathrm{~cm}$ (7-18 in) deep (GRC 2011). Green roofs with these depths are considered intensive green roofs, which commonly weigh between 35 and $300 \mathrm{lb} / \mathrm{ft}^{2}(171$ and $\left.1465 \mathrm{~kg} / \mathrm{m}^{2}\right)$, which is heavier than the $146 \mathrm{~kg} / \mathrm{m}^{2}\left(30 \mathrm{lb} / \mathrm{ft}^{2}\right)$ most flat roofs are considered able to hold (Dillion 2010). This does not even include the weight of people or equipment that may need to be on the roof to operate the farm. Currently, it is hard to determine the load capacities of a city's existing building stock. Some estimates can be made from building regulations. In New York City, for example, buildings with flat roofs constructed between 1938 and 1968 were required have a 
live roof load of $40 \mathrm{lb} / \mathrm{ft}^{2}\left(195 \mathrm{~kg} / \mathrm{m}^{2}\right)$ (DOB 1938). After 1968 this was reduced to $30 \mathrm{lb} / \mathrm{ft}^{2}\left(146 \mathrm{~kg} / \mathrm{m}^{2}\right)$ (DOB 1968). In order to get more specific, a structural engineer is needed to assess the suitability of a given building. When considering a roof for a farm, it is important to consider additional factors including the weight a roof is capable of holding, the slope of the roof, how the rooftop space is broken up into different stories or sections, how much infrastructure (elevator shafts, HVAC units, etc) is on the roof, and the accessibility of each section. These factors not only reduce the potential size of the farm a rooftop is suited to, but may represent safety hazards which will need to be overcome. Of the 38,256 acres of rooftop space in New York City, only 3079 acres are estimated to be suitable for rooftop farming (Ackerman et al. 2011).

\section{Cost}

The second barrier to rooftop farming that also affects ornamental green roofs is that they can be very expensive to install. A green roof will generally be between two and six times more expensive than a conventional roof (Wong et al. 2003). The actual expense associated with a particular roof installation will depend on a wide variety of factors including ease of access to the roof for installation, the roof load capacity, type of drainage system, depth and type of media used, an irrigation system if required, and the type of green roof system to be installed (C. L. Rugh, personal communication, February 5, 2010). These factors can be distilled and expressed as the number of resources and the amount of labor required, which are at least in part dependent on what the desired nature of the rooftop farm is going to be. The cost of maintaining the roofing layers should also be considered, but is comparable to the cost of maintaining a conventional roof, when considered over the lifespan of the roof (Wong et al. 2003) (Fig. 2).

\section{Harsh Environmental Conditions}

The first big challenge to operating a rooftop farm is the harsh environment. Conditions on a rooftop are often much more extreme than those in nearby ground level areas. Winds are often higher than at ground level which can have several negative effects. Growing tall plants, such as corn or staked vine plants may be more difficult especially in shallow media and any large plants may need extra support so they are not blown over and damaged (FLL 2002). Soil/substrate erosion may also become a problem in high wind areas, especially if crops are planted in rows or areas are left fallow for too long. For conventional green roofs mulching is recommended to prevent erosion of the substrate (FLL 2002). The issue of erosion may also apply to any fertilizers or additives that are top-dressed. Shading or lack of shading can also be a problem on a roof. Not all plants do well under full sun of full 


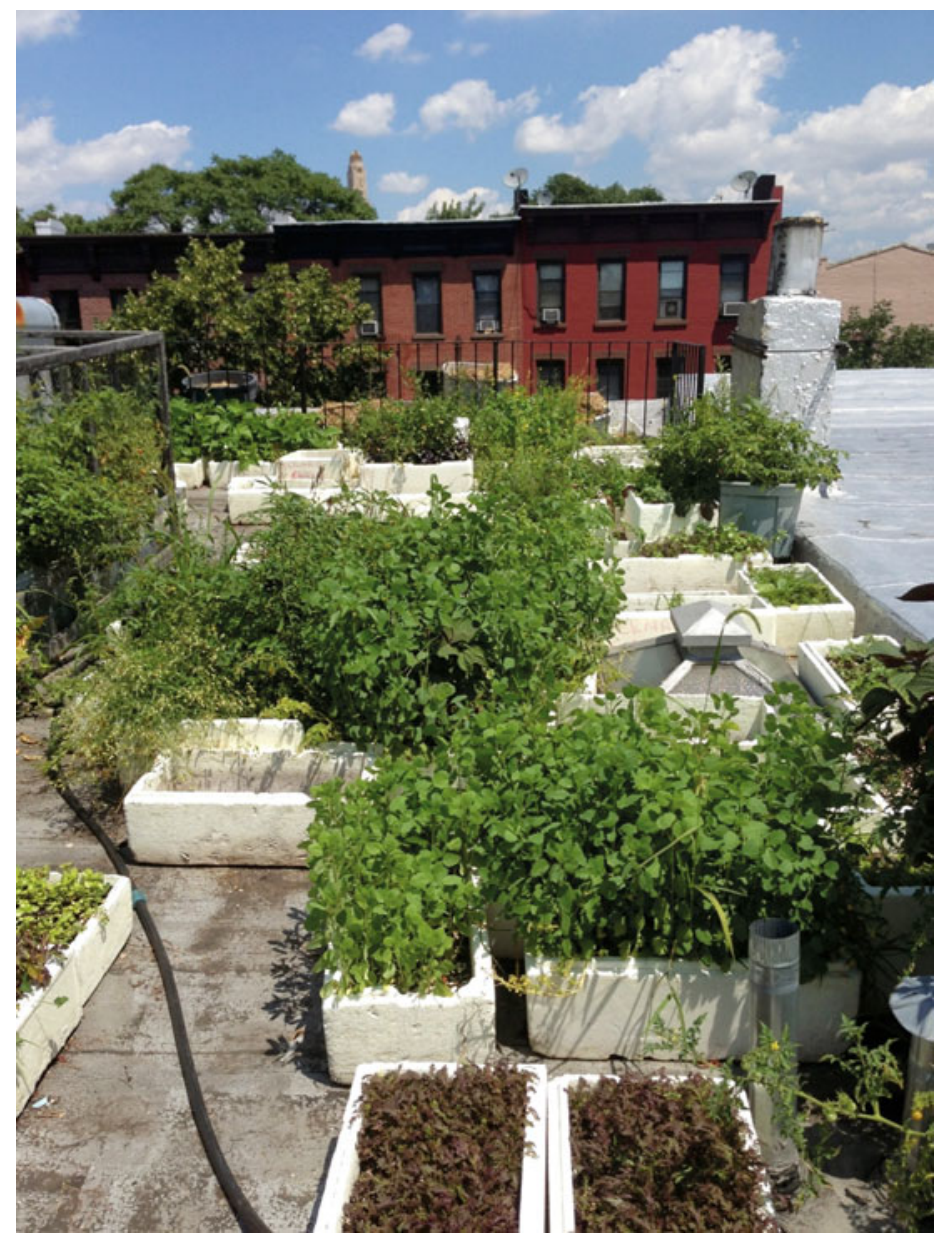

Fig. 2 A rooftop farm on a private residence constructed from recycled materials (Photograph by Leigh Whittinghill)

shade conditions. For this reason it is not recommended that farms are started on roofs with taller buildings, in proximity to buildings that might become taller or near vacant lots on which taller buildings might be built to the south (Mandel 2013). Conversely, it may be necessary to place a shade cloth over very young plants to protect them from the sun. High rooftop temperatures not only lead to greater demand for water by plants, but could extend the growing season in the spring and fall and impact plant health and development in the hottest parts of the growing season. With increased wind, and heat, and the probability of high sun conditions, water becomes especially important in rooftop farming. Herbaceous perennials and other plants that require large amounts of water often don't survive on green roofs 
without irrigation (Durhman et al. 2006; Monterusso et al. 2005). The same is likely true of vegetable plants.

\section{Management Challenges}

The differences in the environmental conditions on a rooftop highlight the other big weakness to operating a rooftop farm: a lack of established practices or recommendations for rooftop agriculture. Most recommendations for fertilizers and irrigation are designed for natural soils or potting mixes at ground level, not the specially made green roof substrates. Although some of these recommendations, especially those for container gardening may apply depending on the soil/substrate used, row crop farming on green roofs may require greater changes to existing recommendations. How these recommendations should be altered for optimum production on a roof, which has different environmental conditions than at ground level, or for production in the specially made green roof substrates used in some rooftop farms is not well understood. One of the biggest benefits of green roofs and one of the biggest challenges associated with growing on a green roof is water management. More research will be necessary to fully understand the relationship between the amount and frequency of irrigation applied to crops, plant water use, and stormwater retention. Nutrient management will also be a tricky balance between plant needs and the impact on runoff water quality. Green roof substrates are designed for plants with low nutrient needs, with recommended nutrient application rates of $5 \mathrm{~g}$ of nitrogen (N) per m2 (FLL 2002). Recommended application rates for nitrogen are much higher for vegetables, 4.5-22.5 g N/m² (Warncke et al. 2004) which is likely to impact the quality of runoff from those roofs. Green roofs can be a source of nutrients such as nitrogen in runoff water (Berndtsson et al. 2006; Hathaway et al. 2008), depending on the amount of organic matter in the substrate (Hathaway et al 2008), the use of fertilizers (Emilsson et al. 2007; Rowe 2011), roof age (Rowe 2011), and the vegetation grown (USEPA 2009). More research examining nutrient application rates, timing, and frequency would also enable informed recommendations to rooftop farmers that would maintain acceptable yields and reduce the impact on runoff water quality.

\section{Opportunities}

\section{The Promise of Small Farms}

Despite these challenges, numerous opportunities could bolster rooftop agriculture. At the global scale, research suggests that small farms may be better than larger ones for equity and poverty reduction due to a number of factors including their 
high demand for labor (Nugent 2002; Hazell et al. 2007). Furthermore, small urban farms may be at a special advantage if they can align themselves with small to medium urban manufacturing and processing firms, noted for their greater ability to innovate and as key players in a new food economy (Blay-Palmer and Donald 2006).

\section{Specialty Crops}

The demand for specialty crops has grown in recent years, and the ability to grow these types of plants on rooftops represents an untapped opportunity. It is estimated that one in five U.S. households can be classified as a medium to heavy consumer of specialty food items (Kezis et al. 1997). Research into "ethnic" foods that thrive in warmer, drier, climates may prove especially fruitful. A survey of four consumer groups estimated the total ethnic produce market on the East Coast at $\$ 1$ billion (Govindasamy et al. 2006). Finally, a discussion of specialty products that can be harvested from rooftops need not be limited to plants. Some roofs are able to host honey bees, poultry or small livestock such as rabbits (Fig. 3).

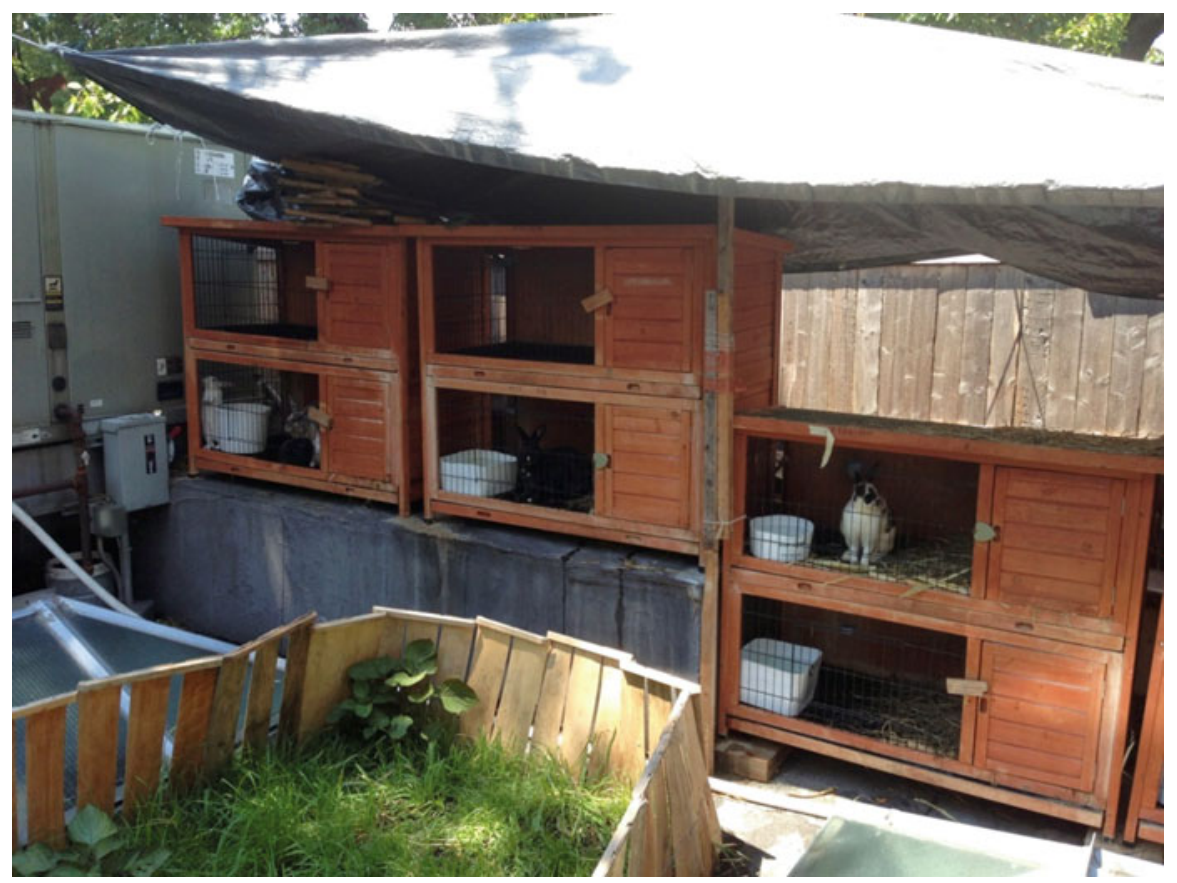

Fig. 3 Rabbits raised on the roof of a private residence (Photograph by Leigh Whittinghill) 


\section{Green Jobs}

The national effort to support green jobs (Jones 2008) represents another opportunity. American Rivers suggests that 190,000 new jobs could be created if just $1 \%$ of roof space was greened in every community with a population greater than 50,000 (Green Roofs for Healthy Cities 2013). Beyond all the new jobs that the construction of small rooftop farms would create, on-site employment can remain ongoing. Rooftop farms will need staff to manage and distribute produce.

\section{Education}

Rooftop agriculture presents interesting opportunities for education and outreach with urban dwellers of all ages. There are numerous organizations which provide education programs centered on growing food. Growing Chefs is one example from New York City that uses numerous locations, including the Eagle Street rooftop farm to host educational programs on farming, gardening and cooking (Growing Chefs 2013). On a less formal level, many rooftop farms offer tours to groups such as students from local schools and have open hours or volunteer days, where members of the community can visit, purchase produce, and/or get involved in the farming. Volunteer days give community members the opportunity to get outside, participate in a community activity, and learn something, but also enable farms to bolster their work force. The Hell's Kitchen Farm Project, for example is run almost entirely by volunteers (HKFP 2013) (Fig. 4).

\section{Threats}

\section{Safety}

Proponents of rooftop agriculture will also need to be aware of certain threats. Many of these threats are related to safety issues related to the fact that being on rooftops carries with it an associated risk of falling. This concern is greatest during roof garden construction (Behm 2012), but is also valid for those performing roof maintenance (Omar et al. 2013) and harvesting.

Another potential threat that is less supported by research, but still merits consideration, is the possibility of heavy metal accumulation in rooftop produce. Results on metal accumulation in produce grown on the ground in urban areas are mixed and dependent on the type of heavy metal, the vegetable species, the part of the plant that is eaten (Arora et al. 2008; Sharma et al. 2009; Srinivas et al. 2009; Yang et al. 2009). Heavy metals are non-biodegradable, so they accumulate in the body (Chimbira and Moyo 2009) and it can take years of exposure for their negative 


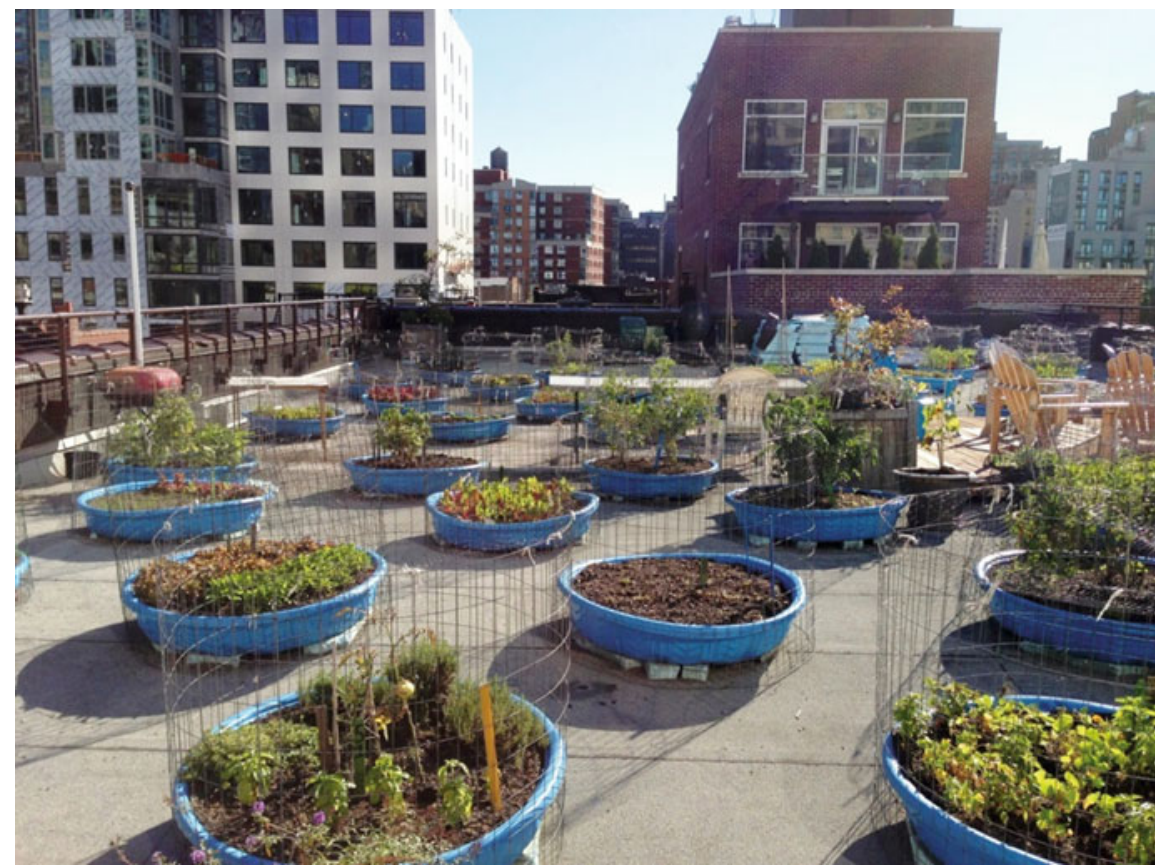

Fig. 4 Hell's Kitchen Farm Project, an example of a rooftop farm run by volunteers (Photograph by Leigh Whittinghill)

effects to become apparent (Chimbira and Moyo 2009; Sharma et al. 2009). Heavy metal contamination is frequently caused by growing in contaminated soils (Agbenin et al. 2009; Hu and Ding 2009) or the use of contaminated water for irrigation (Graefe et al. 2009; Nugent 2002). These are not likely to be issues in rooftop agriculture, but atmospheric deposition, another source of heavy metals in urban agriculture (Sharma et al. 2009; Srinivas 2009), could be. These concerns are less likely to be significant in the US with regulations on water quality and particulate emissions. Dust from historically contaminated soils is also unlikely to be carried to rooftops.

A growing number of papers have investigated metal cycling on green roofs, though the focus is mostly on metal concentration in roof runoff; the findings are variable, but runoff concentrations meet US drinking water standards for most storms (Alsup et al. 2013; Speak et al. 2012). More research is needed to ascertain metal concentration in edible green roof plants. Results will depend on numerous factors including environment and roof design; for example Sedum species grown on a roof in recycled brick were found to be inedible after their first year (Ye et al. 2008). 


\section{Legislation}

Though more research is needed on this subject, rooftop gardening will likely be subject to the same types of legal challenges as urban gardens on the ground. Rights of urban farmer are often minimal (de Zeeuw et al. 1999), uncertain (Thornton 2009), and frequently transient due to changing land uses and termination of informal use agreements (Thornton 2009; van Averbeke 2007). Lack of formal agreements over water use rights has led to conflict between municipalities and urban farmers (van Averbeke 2007). Understandably, urban farmers must meet the same food production and processing standards required of their rural counterparts; they must obtain the same licenses and permits and also undergo inspection (Conservation Law Foundation and CLF Ventures 2012). Yet, due to their location in densely population areas, these gardens may be subjected to additional scrutiny. They many need to be approved as part of local comprehensive plans (Erickson et al. 2009). They may need special approval to install new facilities like hoop houses or fences; they may face challenges getting their farms insured (Castillo et al. 2013). Though many cities like Boston, Seattle, and Chicago (Conservation Law Foundation and CLF Ventures 2012; Erickson et al. 2009; Castillo et al. 2013) are recognizing the shortcomings of planning practices that separate food production from areas of demand and are updating their local codes accordingly, more work is needed to address this challenge in other places.

\section{Conclusions}

In this chapter, we have attempted to present a balanced mini-review of rooftop agriculture. Though we feel strengths and opportunities with these practices outweigh weaknesses and threats, we also caution those who are overly optimistic about their potential. In order to fully realize all of the benefits that rooftop agriculture might provide, the next generation of urban rooftop farmers will need to be prepared to take some calculated risks, make strategic decisions, and strive to improve practices through research and development efforts.

\section{References}

Ackerman K, Plunz R, Conard M, Katz R, Dahlgren E Culligan P (2011) The potential for urban agriculture in New York City: growing capacity, food security, and green infrastructure. Urban Design Lab, Columbia University, New York

Agbenin JO, Danko M, Welp G (2009) Soil and vegetable compositional relationships of eight potentially toxic metals in urban garden fields from northern Nigeria. J Sci Food Agric 89:49-54 
Akbari H (2002) Shade trees reduce building energy use and CO2 emissions from power plants. Environ Pollut 116:S119-S126

Alexandri E, Jones P (2008) Temperature decreases in an urban canyon due to green walls and green roofs in diverse climates. Build Environ 43:480-493

Alsup S, Ebbs S, Battaglia L, Retzlaff W (2013) Green roof systems as sources or sinks influencing heavy metal concentrations in runoff. J Environ Eng 139:502-508

Arora M, Kiran B, Rani S, Rani A, Kaur B, Mittal N (2008) Heavy metal accumulation in vegetables irrigated with water from different sources. Food Chem 111:811-815

Bass B, Krayenhoff ES, Martilli A, Stull RB, Auld H (2003) The impact of green roofs on Toronto's urban heat island. In: Proceedings of 1st North American Green Roof Conference: greening rooftops for sustainable communities, Chicago, 29-30 May, 2003, The Cardinal Group, Toronto

Behm M (2012) Safe design suggestions for vegetated roofs. J Constr Eng Manag 138:999-1003

Berndtsson JC, Emilsson T, Bengtsson L (2006) The influence of extensive vegetated roofs on runoff water quality. Sci Total Environ 335:48-63

Blay-Palmer A, Donald B (2006) A tale of three tomatoes: the new food economy in Toronto, Canada. Econ Geogr 82(4):383-399

Castillo SR, Winkle CR, Krauss S, Turkewitz A, Silva C, Heinemann E (2013) Regulatory and other barriers to urban and peri-urban agriculture: a case study of urban planners and urban farmers from the greater Chicago metropolitan area. J Agric Food Syst Commun Dev 3(3):155-166

Chimbira C, Moyo DZ (2009) The effect of single and mixed treatment of lead and cadmium on soil bioavailability and yield of Brassica napus irrigated with sewage effluent: a potential human risk. Afr J Agric Res 4(4):359-364

Conservation Law Foundation and CLF Ventures (2012) Growing green: measuring benefits, overcoming barriers, and nurturing opportunities for urban agriculture in Boston (report sponsored by the Boston Foundation). Available at Web site http://www.clf.org/blog/maine/ the-promise-of-urban-agriculture-new-growing-green-report/

Czemiel Berndtsson J (2010) Green roof performance towards management of runoff water quantity and quality: a review. Ecol Eng 36:351-360

de Zeeuw H, Guendel S, Waibel H (1999) The integration of agriculture in urban policies. RUAF foundation international workship on urban agriculture: growing cities, growing food- urban agriculture on the policy agenda. Available at Web site http://www.ruad.org/index. php?q=node/62. Accessed 31 Jan 2009

Department of Buildings (DOB) (1968) 1968 Building Codes of the City of New York. City of New York, Department of Buildings

Deptartment of Buildings (DOB) (1938) 1938 Build Code. City of New York, Department of Buildings

Dillion RM (2010) Urban gardeners versus zoning laws. Associated Press, February 16. http:// www.csmonitor.com/The-Culture/Gardening/2010/0216/Urbangardeners-versus-zoning-laws. Accessed 15 Apr 2010

Durhman AK, Rowe DB, Rugh CL (2006) Effect of watering regimen on chlorophyll fluorescence and growth of selected green roof plant taxa. HortSci 41:1623-1628

Emilsson T, Czerniel Berndtsson J, Mattsson JE, Rolf K (2007) Effect of using conventional and controlled release fertilizer on nutrient runoff from various vegetated roof systems. Ecol Eng 29:260-271

Enete AA, Achike AI (2008) Urban agriculture and urban food insecurity poverty in Nigeria: the case of Ohafia, south-east Nigeria. Outlook Agric 37(2):131-134

Erickson L, K Griggs, Maria M, H Serebrin (2009) Urban agriculture in Seattle: policy and barriers (the City of Seattle Department of Neighborhoods P-Patch Program and Department of Planning and Development)

FLL (Forschungsgesellschaft Landschaftsentwicklung Landschaftsbau) (2002) Guidelines for the planning, execution and upkeep of green-roof sites. Forschungsgesellschaft 
Landschaftsentwicklung Landschaftsbau. Bonn, Germany. Accessed 6 May 2013. http://www. greenroofsouth.co.uk/FLL\%20Guidelines.pdf

Getter KL, Rowe DB (2006) The role of extensive green roofs in sustainable development. HortSci 41(5):1276-1285

Getter KL, Rowe DB, Andresen JA (2007) Quantifying the effect of slope on extensive green roof stormwater retention. Ecol Eng 31:225-231

Govindasamy R, VanVranken R, Sciarappa W, Ayeni A, Puduri VS, Pappas K, Simon JE, Mangan F, Lamberts M, McAvoy G (2006) Demographics and the marketing of Asian and Hispanic produce in the eastern coastal USA. New Jersey Agricultural Experiment Station P-02903-2-07. New Brunswick, New Jersey

Graefe S, Schlecht E, Buerkert A (2009) Opportunities and challenges of urban and peri-urban agriculture in Niamey, Niger. Outlook on Agric 37(1):47-56

Green roofs for healthy cities. http://www.greenroofs.org/index.php/about/greenroofbenefits. Accessed 12 Oct 2013

Greenroofs.com (2011) The green roof and wall project database. http://www.greenroofs.com/ projects. Accessed 2 Mar 2012

Growing Chefs (2013) Growing chefs ...food education from farm to fork. Accessed 1 Aug 2013. http://growingchefs.org/

Hathaway AM, Hunt WF, Jennings GD (2008) A field study of green roof hydrologic and water quality performance. Am Soc Agric Biol Eng 51(1):37-44

Hazell P, Poulton C, Wiggins S, Dorward A (2007) The future of small farms for poverty reduction and growth. International Food Policy Research Institute. Washington, DC, 38pp

Hell's Kitchen Farm Project (HKFP) (2013) Accessed 9 Sept 2013. http://www.hellskitchenfarmproject.org/\#!home/mainPage

Hu X, Ding Z (2009) Lead/cadmium contamination and lead isotopic ratios in vegetables grown in peri-urban and mining/smelting contaminated sites in Nanjing, China. Bull Environ Contam Toxicol 82:80-84

Intercontinental Hotels \& Resorts (IHR) (2013) Sustainability at the Intercontinental New York Barclay. Accessed 1 Aug 2013. http://www.intercontinentalnybarclay.com/new-york-greenhotel.aspx

Jones V (2008) Green collar economy: how one solution can fix America's two biggest problems. HarperCollins, New York, p 238 pp

Kezis A, Crabtree D, Cheng H, Peavey S (1997) A profile of the specialty food retailing industry in the East-ern U.S. J Food Distrib Res 28(1):82-91

Mandel L (2013) Eat up: the inside scoop on rooftop agriculture. New Society Publishers, Gabriola Island

Memon RA, Leung DYC, Liu C (2008) A review on the generation, determination and mitigation of urban heat island. J Environ Sci 20:120-128

Monterusso MA, Rowe DB, Rugh CL (2005) Establishment and persistence of Sedum spp. and native taxa for green roof applications. HortSci 40:391-396

Nugent R (2002) The impact of urban agriculture on the household and local economies. RUAF Foundation International Workshop of Urban Agriculture: Growing Cities, Growing Food. Available at Web site http://www.ruaf.org.index.php?q=node/57. Accessed 31 Jan 2009

Omar MS, Quinn MM, Buchholz B, Geiser K (2013) Are green building features safe for preventive maintenance workers? Examining the evidence American. J Ind Med 56:410-423

Peters CJ, Bills NL, Lembo AJ, Wilkins JL, Fick GW (2009) Mapping potential foodsheds in New York State: a spatial model for evaluating the capacity to localize food production. Renew Agric Food Syst 24(1):72-84

Rosemary's NYC (2013) Accessed 19 Mar 2013. http://rosemarysnyc.com/

Rowe DB (2011) Green roofs as a means of pollution abatement. Environ Pollut 159(8-9):2100-2110

Sharma RK, Agrawal M, Marshall FM (2009) Heavy metals in vegetables collected from production and market sites of a tropical urban area of India. Food Chem Toxicol 47:583-591 
Speak AF, Rothwell JJ, Lindley SJ, Smith CL (2012) Urban particulate pollution reduction by four species of green roof vegetation in a UK city. Atmos Environ 61:283-293

Srinivas N, Rao SR, Kumar KS (2009) Trace metal accumulation in vegetables grown in industrial and semi-urban areas- a case study. Appl Ecol Environ Res 7(2):131-139

Swiader JM, Ware GW (2002) Producing vegetable crops, 5th edn. Interstate Publishers, Inc, Danville

Thornton A (2009) Pastures of plenty?: land rights and community-based agriculture in Peddie, a former homeland town in South Africa. Appl Geogr 29:12-20

U.S. Environmental Protection Agency (2009) Green roofs for stormwater runoff control: EPA-600-R-09-026. USEPA, Washington, DC

Uncommon Ground (UG) (2010) Accessed 19 Mar 2013. http://www.uncommonground.com/

Vagneron I (2007) Economic appraisal of profitability and sustainability of peri-urban agriculture in Bangkok. Ecol Econ 61:516-529

van Averbeke W (2007) Urban farming in the informal settlements of Atteridgeville Pretoria, South Africa. Water SA 33(3):337-342

VanWoert ND, Rowe DB, Andresen JA, Rugh CL, Fernandez RT, Xiao L (2005) Green roof stormwater retention: effects of roof surface, slope, and media depth. J Environ Qual 34:1036-1044

Warncke D, Dahl J, Zandstra B (2004) Nutrient recommendations for vegetable crops in Michigan. Michigan State University Extension Bulletin E2934

Whittinghill LJ, Rowe DB (2012) The role of green roof technology in urban agriculture. Renew Agric Food Syst 27:314-322

Widome R, Neumark-Sztainer D, Hannah PJ, Haines J, Story M (2009) Eating when there is not enough to eat: eating behaviors and perceptions of food among food-insecure youths. Res Pract 99(5):822-828

Witmer L, J Brownson (2011) An energy balance model of green roof integrated photovoltaics: a detailed energy balance including miroclimatic effects. 40th ASES national solar conference 2011, SOLAR 2011, Raleigh, NC, 17-20 May 2011

Wong NH, Tay SF, Wong R, Ong CL, Sai A (2003) Life cycle cost analysis of rooftop gardens in Singapore. Build Environ 38:499-509

Wong NH, Tay SF, Chen Y (2007) Study of thermal performance of extensive rooftop greenery systems in the tropical climate. Build Environ 42:25-54

Yang Y, Zhang FS, Li HF, Jiang RF (2009) Accumulation of cadmium in the edible parts of zix vegetable species grown in Cd-contaminated soils. J Environ Manag 90:1117-1122

Ye J, Chuanyin L, Zhaod Z, Yuqi L, Shixiao Y (2008) Heavy metals in plants and substrate from simulated extensive green roofs. Ecol Eng 55:29-34 


\title{
Brownfields as Sites for Urban Farms
}

\author{
Ann Carroll
}

Urban agriculture has been receiving renewed interest since 2008. A major focus of this renewed interest is ensuring access to healthier, fresher food in urban population centers in the United States to improve public health. It is likely that urban agriculture can expand to meet a significant portion of this (Brown and Jameton 2000; Mogk et al. 2010). Certainly, it has been found to be successful in improving food security in Cuba and in developing countries (Altieri et al. 1999; Zezza and Tasciottie 2010). Securing access to land can be an obstacle to developing urban agriculture. The EPA and corresponding State and Tribal Brownfield program may assist in that development by converting former Brownfields sites into areas safe and suitable for food production.

\section{History of the Brownfields Program}

The Brownfields program began as a pilot program in the mid-1990s as an outgrowth of the EPA Comprehensive Environmental Response and Compensation Liability Act (CERCLA or Superfund). This act authorized the Superfund program, creation of the National Priorities List and response and remediation activities under the law and national efforts to identify and initiate cleanup at some of the most the complicated contaminated sites in the country. This was further complicated with a court decision, 'United States v. Fleet Factors Corp.' (Citation: 19 ELR 20529, No. No. CV687-070, 724 F. Supp. 955/29 ERC 1011/(S.D. Ga., 12/22/1988) in which "the court holds that a lender is not an owner or operator of a hazardous waste site under $\S 107$ (a) of the Comprehensive Environmental Response, Compensation, and

\footnotetext{
A. Carroll (ه)

U.S. Environmental Protection Agency, Office of Brownfields and Land Revitalization,

Washington, DC, USA

e-mail: Carroll.ann@epa.gov
} 
Liability Act (CERCLA), but the lender's activities in connection with an auction after foreclosure may be sufficient to impose liability." For further discussion of the impacts of this decision, please see:

Nicholas M. Kublicki Shockwave: Lender Liability Under CERCLA After United States v. Fleet Factors Corporation, 18 Pepp. L. Rev. 3 (1991) Available at: http://digitalcommons.pepperdine.edu/plr/vol18/iss $3 / 4$

EPA publications regarding liability and enforcement can also be found at: http:// www2.epa.gov/enforcement/brownfields-and-land-revitalization-cleanup-enforcementpublications

This decision prompted mayors, community leaders, advocates, developers and lenders to request EPA to clarify environmental liability provisions of Superfund.

While the environmental liability requirements of CERCLA or Superfund hold property owners liable of cleanup of environmental contamination 'they caused or contributed to', this court decision had a chilling effect on investment, development and lending in historical industrial areas where contamination was suspected. Brownfield sites are less contaminated and more numerous than Superfund sites on the National Priorities List (NPL) and also require environmental attention, prompting new efforts to clarify liability and create incentives for investment, site investigation and property cleanup for safe reuse.

The EPA's Brownfields program was initiated as a pilot program to provide grants and technical assistance to local governments and other governmental entities and community based programs to assist them in identifying, investigating and addressing Brownfield sites (or reduce exposures to them), prompting their safe reuse. From an initial pilot grant to Cuyahoga County in 1995, when the Brownfields program targeted 'abandoned and underused commercial and industrial property', the program was codified with the Small Business Liability Relief and Brownfields Revitalization Act of 2001. This act amended CERCLA with Brownfield amendments which were signed into law in 2002. These amendments expanded the definition of Brownfields to include:

real property, the expansion, redevelopment, or reuse of which may be complicated by the presence or potential presence of a hazardous substance, pollutant, or contaminant.

The same amendments that established a new grant program, cleanup grants and expand funding authorizations for Brownfield grants, also expanded the EPA definition of Brownfield sites to include properties contaminated with petroleum and 'low-risk' such as abandoned gas stations, controlled substances ('meth labs'), and mine-scarred lands as eligible for Brownfield grant funds for assessment or cleanup. Superfund sites, federal facilities and those properties undergoing administrative enforcement action were excluded from receiving Brownfields funds.

Updated annually, a list of EPA-funded Brownfield grant properties can be found listed with other contaminated sites found on EPA's Envirofacts (http://www.epa. gov/enviro/) (link OK) or Land Cleanups in My Community website (http://www2. epa.gov/cleanups/cleanups-my-community) or specific grantees can also be found 
through the grant fact sheet tool on the Brownfields homepage (http://cfpub.epa. gov/bf_factsheets/index.cfm). Though not an exhaustive list Brownfields depicted here can include sites identified by EPA or State and Tribal programs through past funding, or where EPA funds were directed to local governmental or other entities for investigation and cleanup. Not all potential sites are listed. Each year, the EPA's annual competition reviews applications and awards approximately $\$ 60$ million in grants to urban and rural governmental organizations and community based groups seeking funds to investigate, assess and clean properties for their safe reuse.

Many communities seek funds for properties abandoned due to tax foreclosure or proposed for donation to determine if environmental pollutants or contaminants are present and if found does proposed reuse, pose public health or environment risks as governed by state or tribal environmental cleanup programs which oversee cleanups. State or tribal cleanup programs also may issue a 'no further action' letters once cleanup standards appropriate to the reuse have been met.

Once assessed and/or cleaned, many governmental entities offer properties up for sale or redevelopment while others are contributed to expand parks, recreational areas or for other community or non-profit purposes.

While private investors and developers can fund site cleanup independently, many benefit and comply with the clear and delineated steps required for a Phase I environmental site assessment as established in ASTM E-1527-13 (earlier -05) that provides a CERCLA liability defense to property owners if conducted prior to property acquisition. Past property use and history must also be reviewed to determine the nature of potential contamination and recognized environmental conditions. Further environmental site assessment (Phase II) and subsequent environmental site assessment may also be needed to sample media on the property in order to characterize the type and extent of contamination (or document no or limited contamination).

Common Brownfields examples familiar to most communities include the abandoned gas stations that dot our highways and secondary roads, scrap yards, industrial or commercial properties where contamination is likely due to the industrial processes or the age of the building that might suggest lead-based paint, asbestos tile or insulation, caulk contained PCBs or heating, fuel oil and waste tanks for heating or to power industrial machinery. Strip malls with dry cleaners or dry cleaning properties are also common due to the nature of the solvents used and their volatility and hazard.

\section{Brownfields and Urban Agriculture}

The abandoned, underused and vacant structures and parcels where environmental contamination is known or suspected - offer new opportunities for urban agriculture. While estimates vary, the U.S. Conference of Mayor's drew on the historical General Accounting Office (GAO) estimate of 400,000 Brownfields in their 
Recycling Land Report published in 2010 (http://www.usmayors.org/pressreleases/ uploads/November2010BFreport.pdf).

Since the EPA Brownfields program was developed as a pilot program in, the EPA has provided grants and technical assistance to Tribes and towns from rural to urban settings. Not all of EPA's projects have focused on urban agriculture related projects as seen in this publication on building vibrant communities (http://www. epa.gov/Brownfields/policy/comben.pdf.) However, the EPA experience and that of State and Tribal environmental cleanup programs have yielded a number of successful urban agricultural projects as well as cautionary tales.

Brownfields vary nationwide but they offer distinct advantages for community reuse, including urban agriculture:

- land may be available at lower cost;

- land and/or structures to support agricultural production are located in areas where investment and revitalization is needed which may generate community support for urban agriculture projects and leverage further public or private investment support;

- Brownfields redevelopment acknowledges the possibility of contamination upfront. This admission includes specific steps to identify and determine the likelihood, type and scale of contamination allowing growers to respond to customers and potential market questions with answers that can allay food safety concerns; and,

- Brownfields sites may be more common in underserved areas so locating in areas where few alternatives exist may be targeted as the local food movement, public health, sustainability advocates seek to expand local production and improve access to fresh and healthy food; and,

- Brownfields have a defined and specific process that municipal governments, property markets, developers, investors and lenders and environmental regulators are familiar with which reduces uncertainty and financial, environmental and human health risk.

There are, however, hurdles to the use of Brownfields for urban agriculture and food production, for example:

- The concern, often valid, that growing food in potentially contaminated areas may taint or adulterate the food with contamination during the growth or harvesting reducing consumer confidence in the safety of urban food production.

In general and to protect public health, Brownfield practitioners and environmental regulators caution food production in urban land until the extent and nature of contamination is understood. Under the program, this is done while simultaneously trying to provide technical support and not to dissuade growing advocates. Based on their knowledge and experience with past contaminated site investigations, they recognize how historical industries, commercial production processes 
and even our use and disposal of consumer goods have left contamination footprints. Once understood, if extensive contamination is identified it will be removed, treated to reduce exposures or consolidated and covered in a way that does not allow exposure. If only one or two areas have elevated levels of contamination or minimal or moderate contamination is found, it will be managed to ensure those active on site are not exposed. For example, contamination that does not migrate may be consolidated and buried in a location where a parking lot, shed or structure will be placed to restrict exposures. Grants both from within the Brownfields program or external to the program can be applied for and used to facilitate site remediation.

One of the biggest hurdles to this process can be that the volunteer and community organizations focusing agricultural initiatives in urban areas aren't always experienced in working on Brownfields sites or prepared to scrutinize areas or recognize environmental contamination. While comfortable discussing soil or agronomic parameters such as $\mathrm{pH}$, organic content, NPK ratios or cation exchange, testing for metal, polycyclic or polynuclear aromatic hydrocarbons (PAH) contamination, or recognizing asbestos-contaminated building materials, or underground storage tanks locations and piping may not be an area of attention. They may be less equipped to forge the necessary partnerships to address environmental hazards, secure funding and the necessary technical support from local government, community and economic development agencies experienced in cleanup or revitalization. Residents may not be aware that a site is contaminated when they start to grow or farm on abandoned lands. Abandoned and contaminated lands that have not received past funding for assessment or cleanup also may not be currently listed in the Brownfield program web listings. Even if sites are currently not listed, there is the potential for contamination to be present. Working with local or other relevant government activities, there is also the potential for Brownfield funds to be enlisted to help with a clean up.

Despite these potential complications there are many examples of active urban farms operating on Brownfield sites. Several examples are outlined below but additional project and other educational resources can be found at: http://www.epa. gov/Brownfields/urbanag. In particular, the Resources section discusses how EPA Brownfield grants and technical assistance or State technical assistance and support have contributed to urban agriculture and community garden successes at:

- Lynchburg Grows, Lynchburg, Virginia (http://www.lynchburggrows.org/)

- Urban Oaks Farm, New Britain, Connecticut, http://www.urbanoaks.org/

- Greensgrow Farms, Philadelphia, Pennsylvania (http://www.greensgrow.org/)

- Groundwork Lawrence, Lawrence, Massachusetts http://www.groundworklawrence.org/

- Youth Urban Agriculture project, Fresno, California 


\section{Case Studies}

Several examples are outlined below but additional project and other educational resources can be found at: http://www.epa.gov/brownfields/brownfieldspublications. In particular, the Resources section discusses how EPA Brownfield grants and technical assistance or State technical assistance and support have contributed to urban agriculture and community garden successes at the sites listed above.

\section{Greensgrow Farm}

Greensgrow Farm was founded on a 1 acre former contaminated zinc galvanizing plant, Boyle Galvanizing. When the factory closed, the contaminated soil remained at the site but community concern and information about the site prompted an EPA emergency removal action in 1995 resulting in excavation of contaminated soil, backfilling and capping the remaining material with clean soil. Contaminants found at the site included lead, zinc, cadmium and arsenic. Because it was considered an immediate hazard and potential Superfund site, sampling and remediation costs were covered by the Superfund program with potential cost recovery from Boyle Galvanizing (http://cumulis.epa.gov/supercpad/cursites/cactinfo.cfm?id=0305001). Sampling and clean up at the site were costly, with EPA spending over $\$ 500,000$ for soil sampling and analysis. At this time, the soon-to-be Greensgrow Farm cofounders Mary Seton Corboy and Tom Sereduk were growing crops in nearby in New Jersey while exploring urban farming options. When they found the litter strewn lot, the local entrepreneurs signed a 2 year lease with then property owner, New Kensington CDC and the Greensgrow Farm was born in 1997 (Fig. 1).

A timeline of this urban agriculture adventure and a film about the farm and the founding farmers can be viewed on the Greensgrow Farm website - http://www. greensgrow.org/about-us/history/. Operating for over 13 years now, the history of this site and their continued efforts to serve as an oasis in a food desert can be found at: http://www.greensgrow.org/. A community perspective about another former contaminated property garden example from Philadelphia, the Northern Liberty gardens can be found at: http://designer-in-exile.blogspot.com/2011/03/wonderfulland-of-liberty.html

\section{The Former Ron Mandella Garden, Sacramento, California}

The former Ron Mandella garden in Sacramento, California was established and operated as a community garden for over 30 years. While owned by the City and zoned for housing, as undeveloped land, it was taken over by residents and 


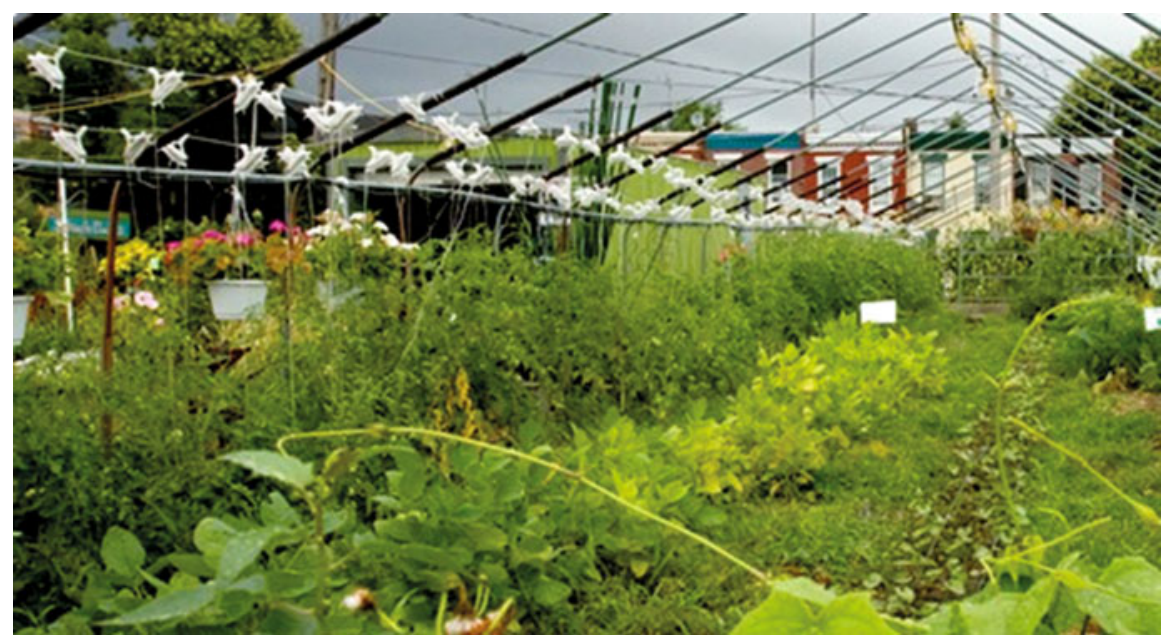

Fig. 1 The Greensgrow farm in Philadelphia, Pennsylvania

'guerrilla gardened'. In 2001 the Capitol Area Development Authority (CADA) proposed a portion of the garden be turned into residential housing that required reducing the size of the existing garden and developing a new garden in another location to supplement land lost to the redevelopment project. While community gardeners were upset at the loss of garden space that had served as a valued community gathering space, soil testing required to convert the garden land to residential housing identified additional issues. Soil contamination by lead, pesticides and aromatic hydrocarbons above EPA and California environmental standards required cleanup for garden operations to continue. The City of Sacramento's CADA applied for and received an EPA Cleanup grant of $\$ 200,000$ and was able to leverage an additional $\$ 400,000$ in cleanup and redevelopment dollars for the garden construction. Today, the Fremont Community garden is tested, safe and has incorporated garden plots that comply with the Americans with Disability Act as well as public art and other amenities such as bocce courts.

For additional information on CADA, the Fremont Garden or EPA Brownfield resources for the cleanup, please see: http://www.cadanet.org/projects/fremontmews, http://sacpedart.com/?p=852,

\section{The Emerson Street Garden, Portland, Oregon}

A vacant lot in a nice residential area with homes on three sides was the location proposed for a community garden on Emerson Street in Portland, Oregon. Earlier a residential home had fallen into disrepair and been demolished on the site, so when the site was proposed for growing food testing for lead was anticipated as a first 
step. The City of Portland's Brownfield program used an existing assessment grant. This grant provided funds that allowed site testing that indicated lead was an issue due to lead paint and an unanticipated finding; lead battery breaking that had occurred on site. However, apart from lead hotspots, no additional recognized environmental conditions were present (Fig. 2).

The City worked with Groundwork Portland and a range of partners to consolidated contaminated soils in a restricted area of the garden for further research into remedial options while uncontaminated areas continued to be proposed for a community garden in concert with the community vision. Learn more about the Emerson Street Garden and how the City and EPA Brownfields program contributed to this community story at http://www.epa.gov/Brownfields/success/BF-SS-EmersonStreet-032911.pdf and Groundwork Portland, Portland, Oregon, http://www. groundworkportland.org/.

\section{Bridgeport, Connecticut, Boot Camp Farm}

With a groundbreaking ceremony, September 6, 2013, Boot Camp Farm is the newest Brownfield and contaminated land example that is being proposed for urban agriculture. As with many project examples here and cited elsewhere, community commitment and partnership with community, City, State and Federal programs have helped move this project forward - assessing and cleaning a complex contaminated site and creating a healthy and safe alternative that will improve healthy food access while employing veterans and area residents. For more information about this project, please see: http://www.governor.ct.gov/malloy/cwp/view. asp?Q=524548\&A=4010 or listen to recent media accounts and stories about the conversion of 'Mount Trashmore' to an urban farm. http://wshu.org/post/formerdump-site-be-converted-urban-farm (Fig. 3).

\section{So, How Do Community Organizations or Local Leaders Convert a Brownfield to Urban Agriculture or Other Food Uses?}

Join the Brownfields to urban agriculture movement. The first step is to become familiar with the local or State or Tribal Brownfields program. To find out if your communities had received a past Brownfield grant, you can review grant fact sheets for all EPA's grants to communities at: http://cfpub.epa.gov/bf_factsheets/. You can contact the local government or Brownfield program for questions on a specific site. They can answer your questions and outline the necessary steps to convert your Brownfield to safe and healthy growing space. EPA has developed a range of educational materials for organizations and individuals interested in developing 

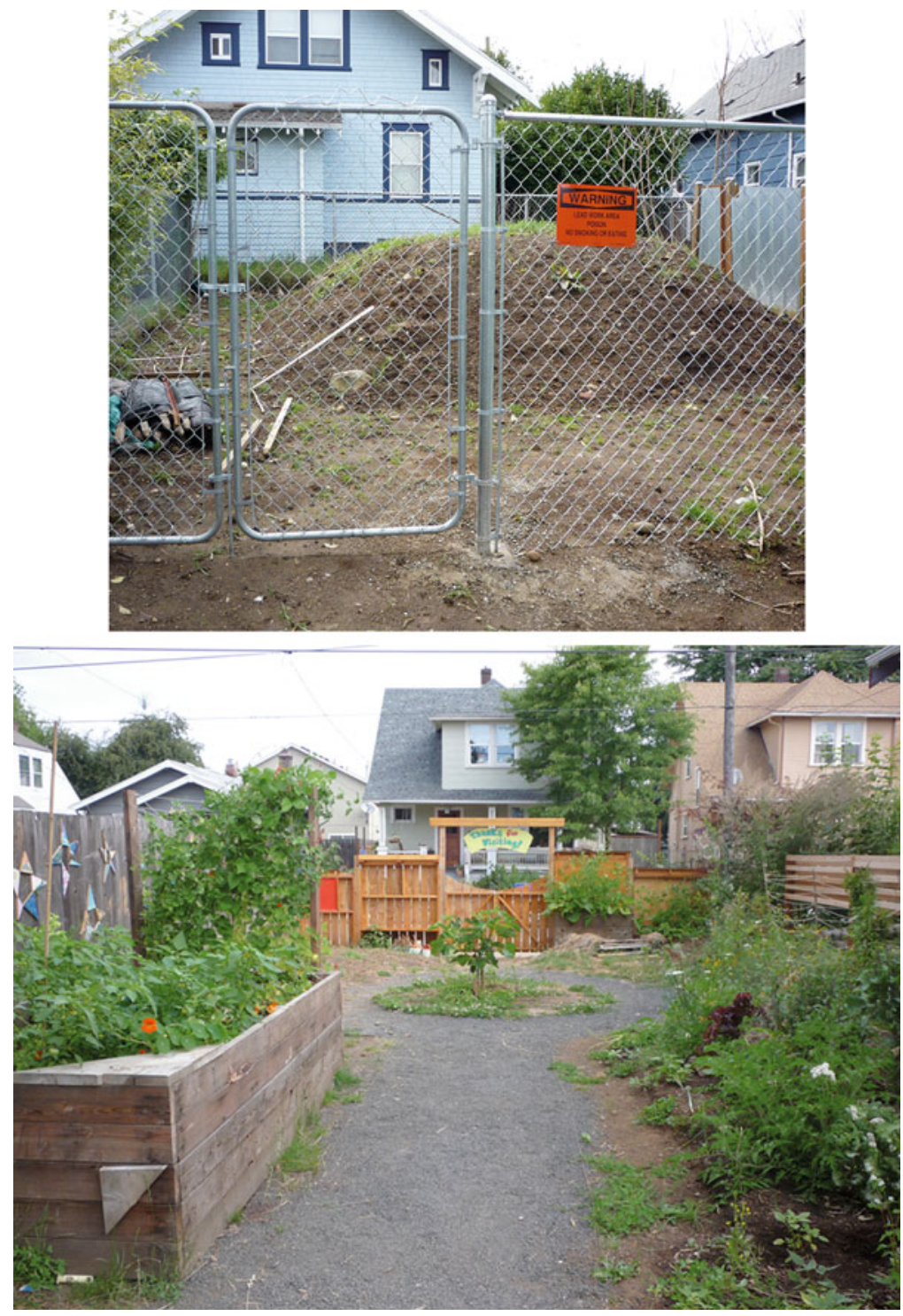

Fig. 2 The Emerson garden in Portland. The first picture shows the garden prior to clean up and the next two pictures shows the garden as it is now (Photos from Jenn Bildersee and http://www. groundworkportland.org/programs/page-brownfield/emmerson-garden/) 


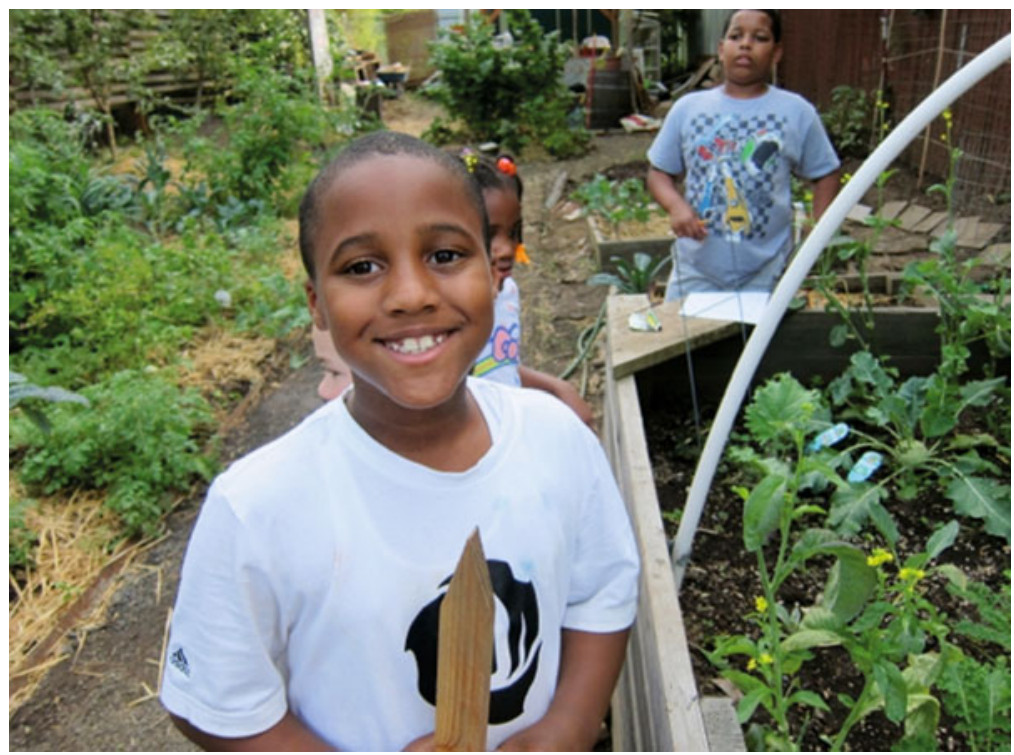

Fig. 2 (continued)

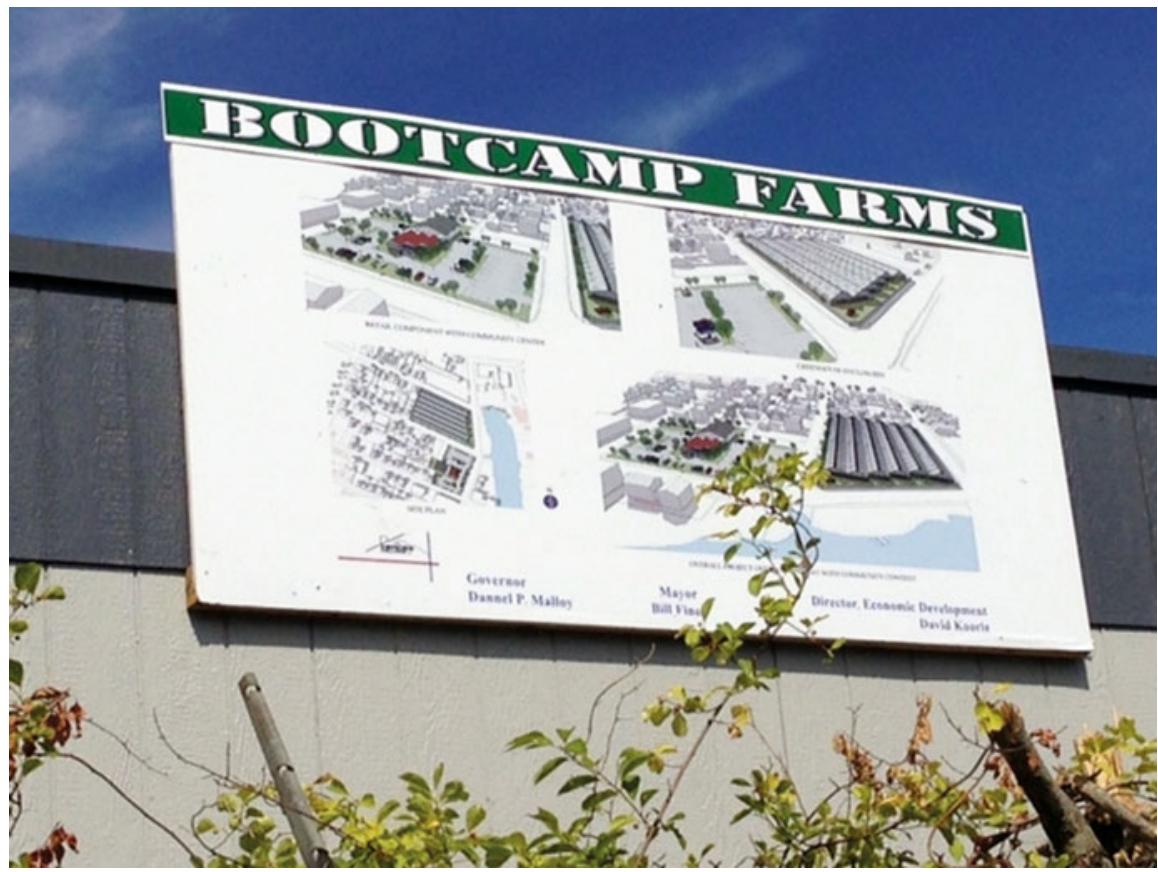

Fig. 3 Sign describing the plans for the upcoming garden in Bridgeport, Connecticut 
community gardens or urban agriculture operations at a larger scale in potential or confirmed Brownfield areas. Resource materials and interim guidelines from EPA can be found at: http://www.epa.gov/brownfields/brownfields-publications.

Please note, while EPA has established soil screening levels as part of the Superfund program to examine the types of exposures residents may experience from contaminated sites (Brownfields and other contaminated sites) and to assist in assessment and cleanup of contaminated sites for their safe reuse, Tribal and State organizations may have more stringent standards for cleanup based on types of reuse such as residential housing, child care centers or schools and hospitals as compared to industrial sites. This may also apply to food production. However, neither the EPA nor most State cleanup programs have established standards for soil contaminant levels that are safe for growing food. The U.S. Department of Agriculture (USDA) and the Food and Drug Administration (FDA) administer most laws and regulations governing food production and food safety in the United States. These agencies have also not set specific standards. International standards of the World Health Organization (WHO) and the Food and Agriculture Organization (FAO) Codex Alimentarius govern contaminant levels allowed in food for international sale and trade and may serve as a useful guide for market producers. For additional information about the World Health Organization and food safety, please see: http://www.who.int/foodsafety/codex/en/.

\section{References}

Altieri MA, Companioni N, Cañizares K, Murphy C, Rosset P, Bourque M, Nicholls CI (1999) The greening of the "barrios": urban agriculture for food security in Cuba. Agric Hum Values 16:131-140

Brown KH, Jameton AL (2000) Public health implications of urban agriculture. J Public Health Policy 21(1):20-39

Mogk JE, Kwiatkowski S, Weindorf MJ (2010) Promoting urban agriculture as an alternative land use for vacant properties in the city of Detroit: benefits, problems and proposals for a regulatory framework for successful land use integration. Wayne Law Rev 56:1-61

Zezza A, Tasciotti L (2010) Urban agriculture, poverty, and food security: empirical evidence from a sample of developing countries. Food Policy 35:265-273 


\title{
Curbside Gardens
}

\author{
Craig Cogger and Sally Brown
}

Curbside parking strips along residential streets are part of the land base available for growing food in cities. Suitability of curbside strips varies, depending on the width of the strip, exposure to vehicle traffic, sunlight, and, soil quality. Ideal curbside strips for food production are at least $5 \mathrm{ft}$ wide, are in low-traffic neighborhoods, receive enough sunlight for growing vegetables, and have well-drained soils free of contaminants, debris, and compaction. Some cities were laid out with wide curbside strips that are still intact, and have a substantial land area along the parking strips (Fig. 1).

\section{Considerations for Curbside Gardens}

\section{Soil}

Soils in curbside strips are likely to be disturbed from street construction, utility installation and repairs, and traffic. Curbside soils are often compact and variable in texture and color, a result of cutting and filling from construction activities. They are often low in nutrients because they have not been fertilized. Curbside soils may also have little organic matter, although curbside strips that have been in healthy turfgrass can have higher levels of organic matter in the upper few inches.

Contamination is another consideration for curbside soils. Most gasoline contained lead until the 1970s, and lead from exhaust accumulated along roadsides.

\footnotetext{
C. Cogger

Department of Crop and Soil Sciences, Washington State University, Pullman, WA, USA

e-mail: cogger@wsu.edu

S. Brown $(\square)$

School of Environmental and Forest Sciences, University of Washington, Seattle, WA, USA

e-mail: slb@uw.edu
} 


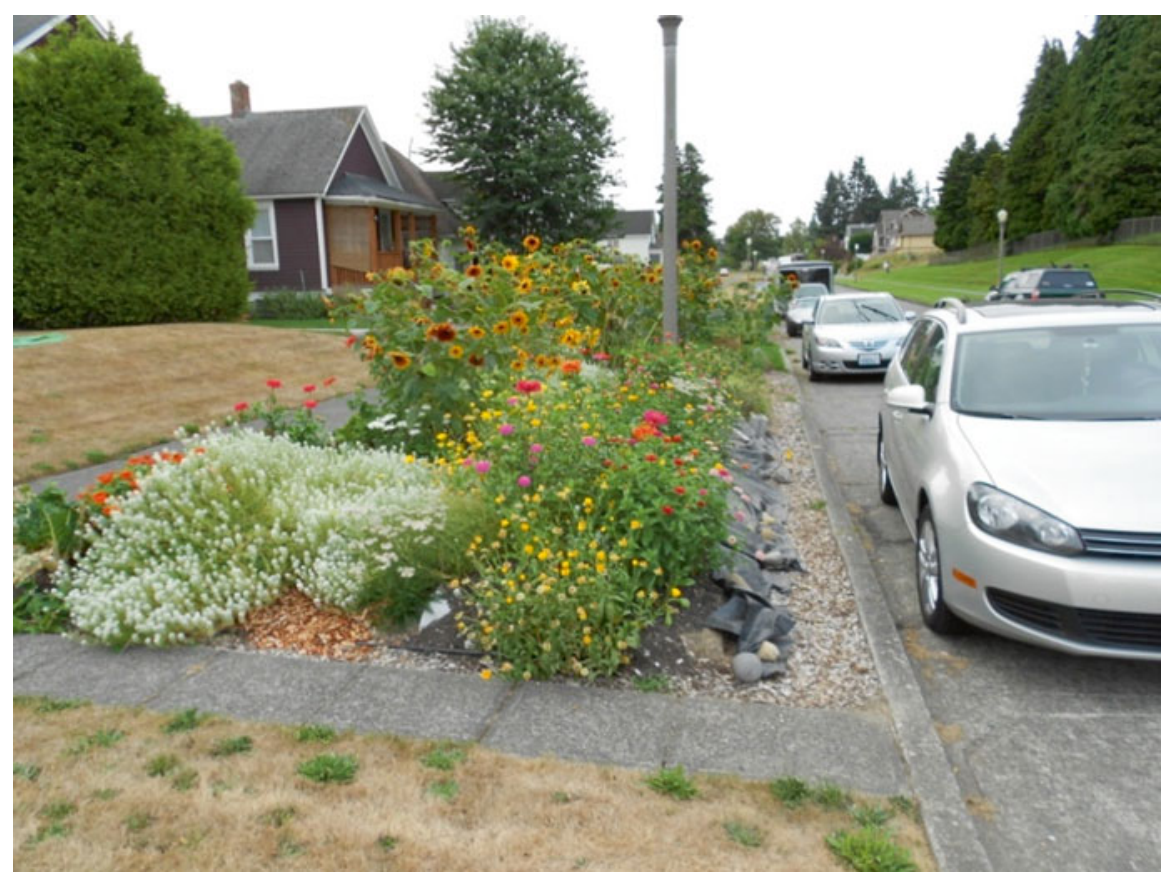

Fig. 1 Curbside garden in amended native soil. The garden includes both food and pollinator crops. Notice the mulched buffer adjacent to the curb. This garden is part of the Hilltop Urban Gardens in Tacoma, WA

Accumulation of lead from gasoline can be significant adjacent to heavily travelled roads, but does not appear to be a problem along low-traffic residential streets. A study of curbside soils in century-old residential neighborhoods in Tacoma, WA showed only a slight elevation of lead from background levels, not enough to affect food quality or gardening practices (Fig. 2).

\section{How to Prepare a Curbside Soil for Food Production}

When selecting sites for curbside food gardens, evaluate the soil for texture, compaction, drainage, and potential rooting depth. Dig to a depth of one foot in several locations along the curbside strip. A mixture of colors and textures and presence of debris indicates soil disturbance. Gray subsoil with rusty-looking mottles is a sign of poor drainage. Also collect a representative soil sample to send to a lab to assess $\mathrm{pH}$ and available nutrients. If contamination is suspected, also test for lead. 


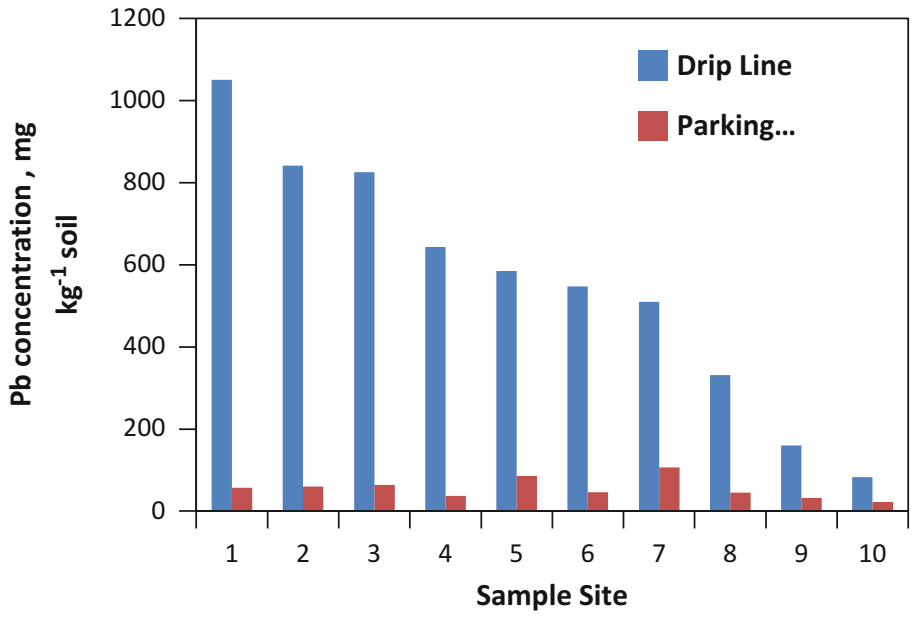

Fig. 2 Total lead concentrations in curbside soils and residential soils from a low traffic neighborhood in Tacoma, WA. The residential soils were all collected from the drip line, the area adjacent to the home where stormwater drips to the soil. Homes sampled were older and had been painted, presumably with lead based paints

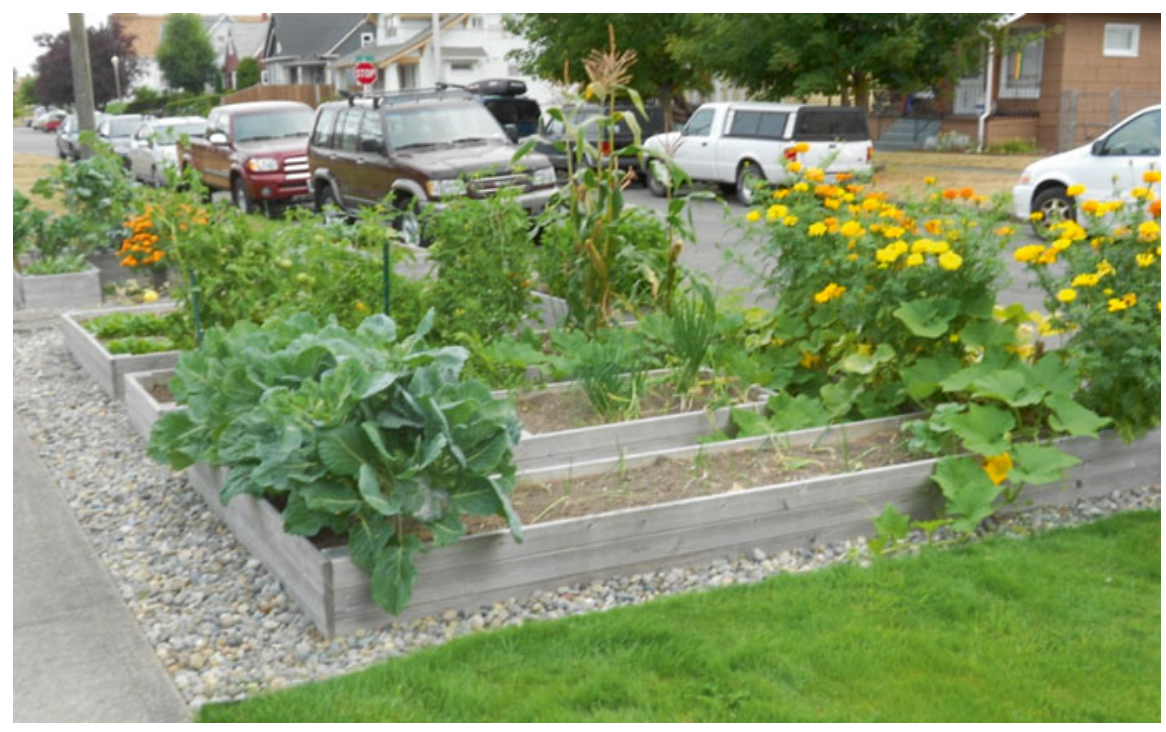

Fig. 3 Raised bed curbside garden with buffer

Soils that have adequate rooting depth can be improved by incorporating organic amendments to reduce compaction, increase organic matter, supply nutrients, and restore the soil ecosystem. Raised beds are a good alternative for curbside soils that are limited by inadequate depth, poor drainage, or contaminants (Fig. 3). 


\section{Crops}

Most vegetable and small fruit crops are suitable for curbside gardens. When gardens are close to street intersections and driveways, it is important to plant lowgrowing crops that do not block the view of drivers and pedestrians. Taller crops are more suitable in curbside strips without driveways (Fig. 4).

It is also important to keep plants and fruit drop away from streets and sidewalks. Plants with vigorous vegetative growth, such as vine-type pumpkin and winter squash, need to be trained within the parking strip, and may not be suitable for narrow curbside gardens. Fruit trees are often not suitable in curbside areas, because their canopy spreads over sidewalks and streets as they grow, leading to fruit drop on rights of way.

Because curbside gardens are located next to heat-absorbing pavement, they can have a slightly warmer microclimate than areas removed from pavement or buildings. This can be a disadvantage in hot-summer areas where plants are already at risk of heat stress, but it may be a benefit for growing heat-loving crops in areas with mild summers.

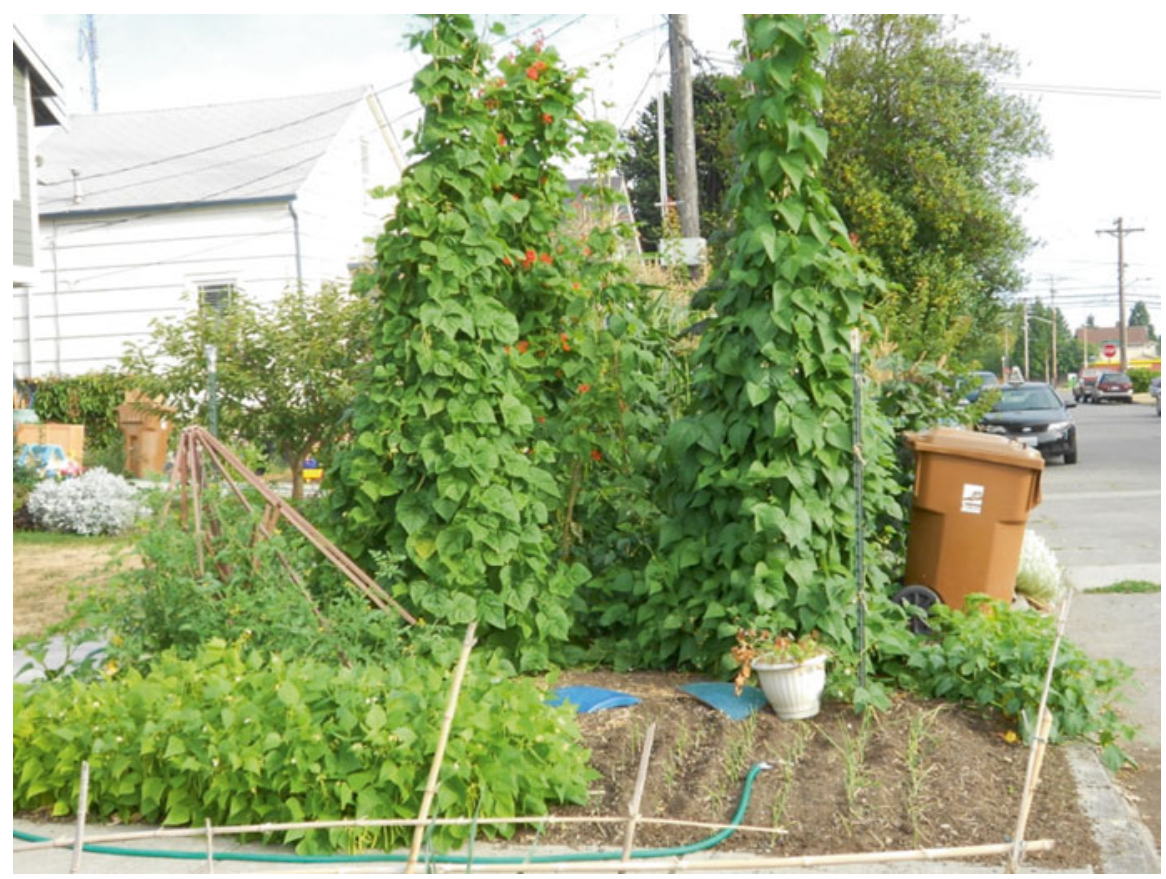

Fig. 4 Productive curbside garden in amended native soil. Tall plants are only suitable on curbside strips without driveways, such as this one 


\section{Protecting Water Quality}

Since curbside areas are adjacent to paved surfaces where water runs into storm drains, it is important to reduce the risk of runoff of nutrients and organic matter from the garden area onto pavement. Gardeners have a number of options for protecting water quality while growing productive curbside gardens (Fig. 5).

Framed raised beds or framed borders around the curbside garden provide a physical barrier to keep soil and runoff within the garden area. A less expensive option is to use grass or mulched buffers around the garden area. Buffers can be effective for wider curbside areas, where there is enough area for both a garden and a buffer. Growing cover crops or mulching garden areas during the winter also helps keep soil, water, and nutrients within the garden beds. It is also important to be careful when applying fertilizers and soil amendments, to keep them on the growing area and away from paved surfaces (Fig. 6).

One concern with curbside gardens is the potential for neighbors and passers by to take or taste from the garden's bounty as they go past. This can potentially be addressed by including signage in the garden that encourages but limits the amount that the gardener is willing to share or asks that produce not be collected. Theft can also be reduced by planting crops that do not encourage pilfering. Root crops such as potatoes, carrots and beets are examples. In contrast, certain plants including cherry tomatoes and raspberries are easy to sample (Fig. 7).

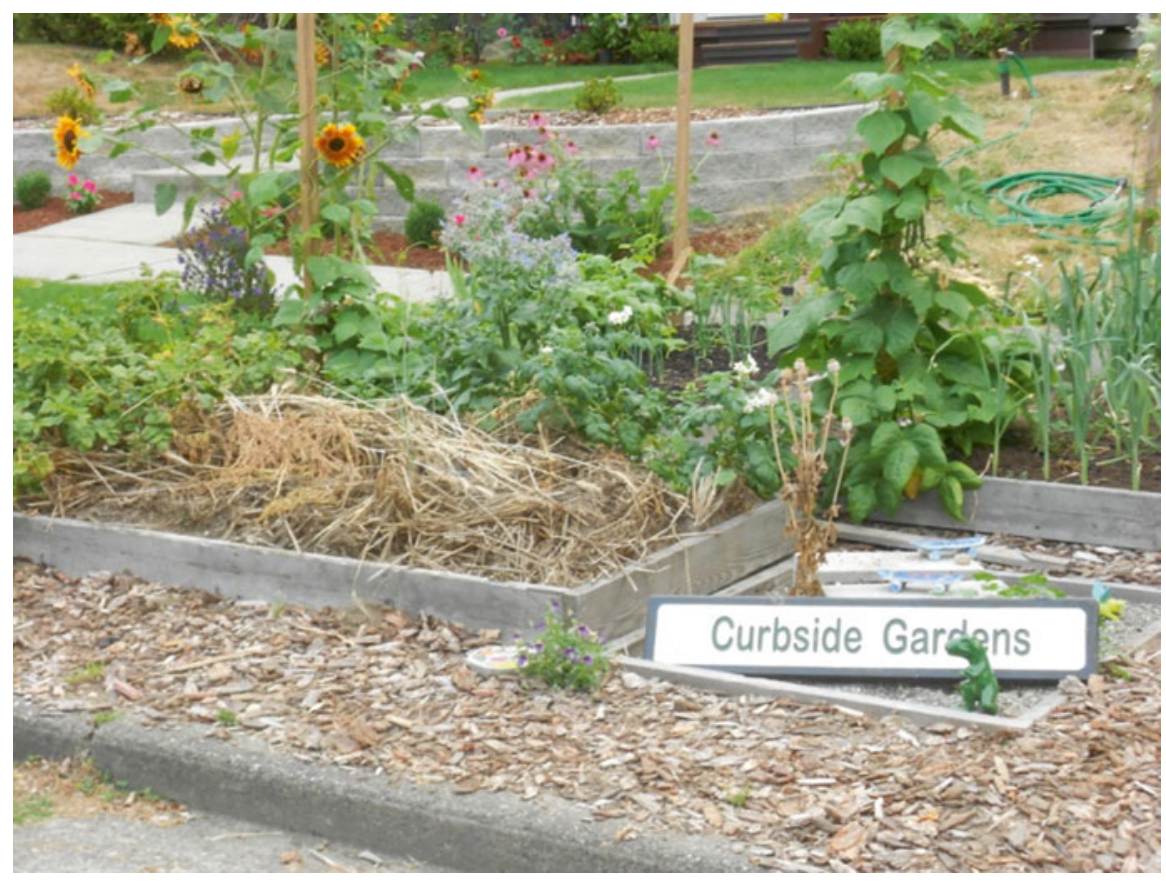

Fig. 5 Mulched buffer and raised beds reduce risk of runoff and erosion into storm drains. Garden is part of the Hilltop Urban Gardens in Tacoma, WA 


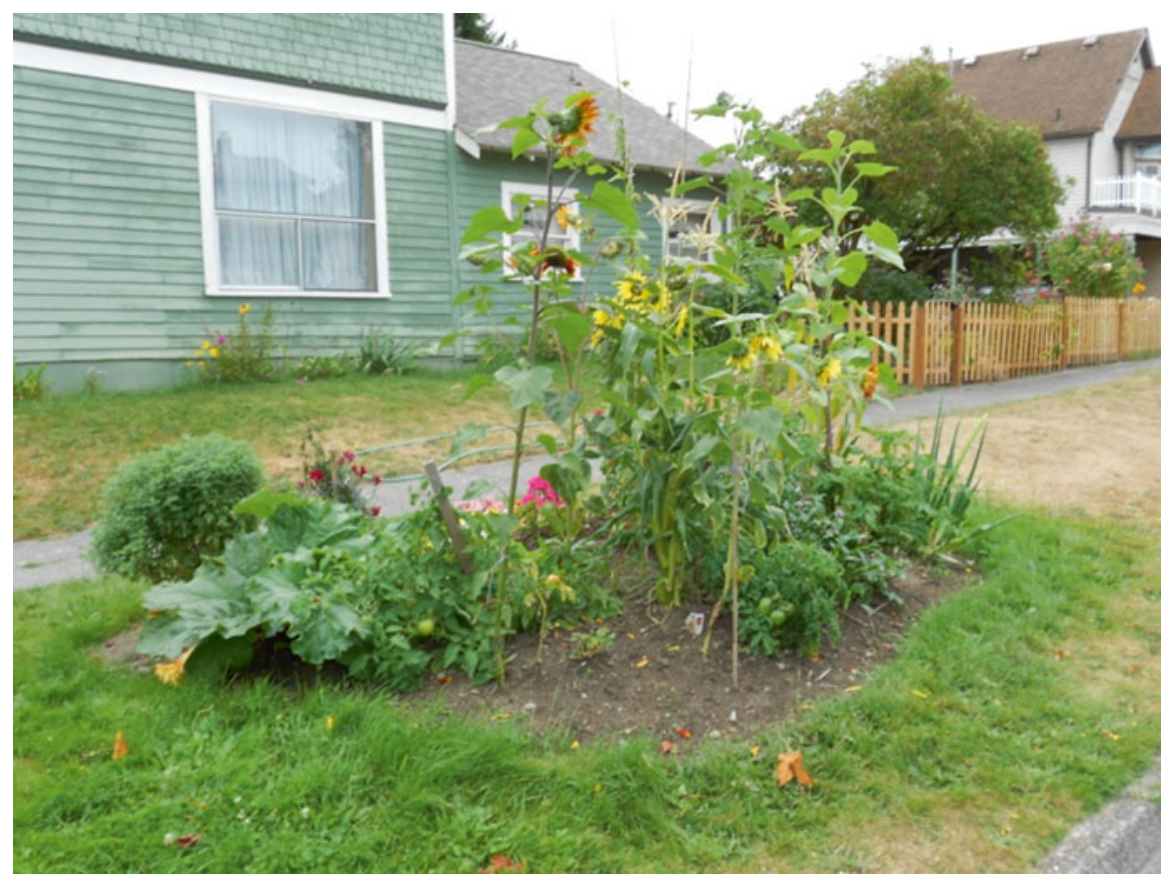

Fig. 6 Simple curbside garden in amended native soil with grass buffer

\section{Curbside Gardens in Seattle}

In Seattle, parking strips areas are owned by the city but the maintenance is the responsibility of the property owner. Prior to 2008 there had been restrictions on the use of these lands in order to protect site lines as well as to keep the sidewalks clear. Use of parking strips is further complicated by the range of agencies within the city who have responsibility for these areas. Different agencies within the City have jurisdiction over the parking strip right of way. Seattle City Light is in charge of utility and electric lines that run overhead or underneath these sections. The City arborists are responsible for trees planted in the parking strip. The Department of Transportation is responsible for any work done on these plots. Seattle Public Utilities is responsible for work relating to stormwater infrastructure. Finally the Department of Neighborhoods is responsible for historic site preservation.

The City now encourages people to use parking strips for gardens. This change came about as a result of high demand and limited space within the City's P- Patch program.

Seattle, Washington hosts the P-Patch community garden network. This network was established in 1973 with the goal of providing Seattle residents with space to garden. It currently provides 4400 gardeners with garden plots. There are 78 community gardens on 13.5 acres of land with an additional 31 acres of land for growing food associated with the program. In 2008 there was a waiting list of over 1700 people for plots in P-Patch gardens. The Seattle City Council voted in 2008 to allow and encourage use of parking strips for growing food and flowers as a way to open additional areas for gardening and meet public demand. 

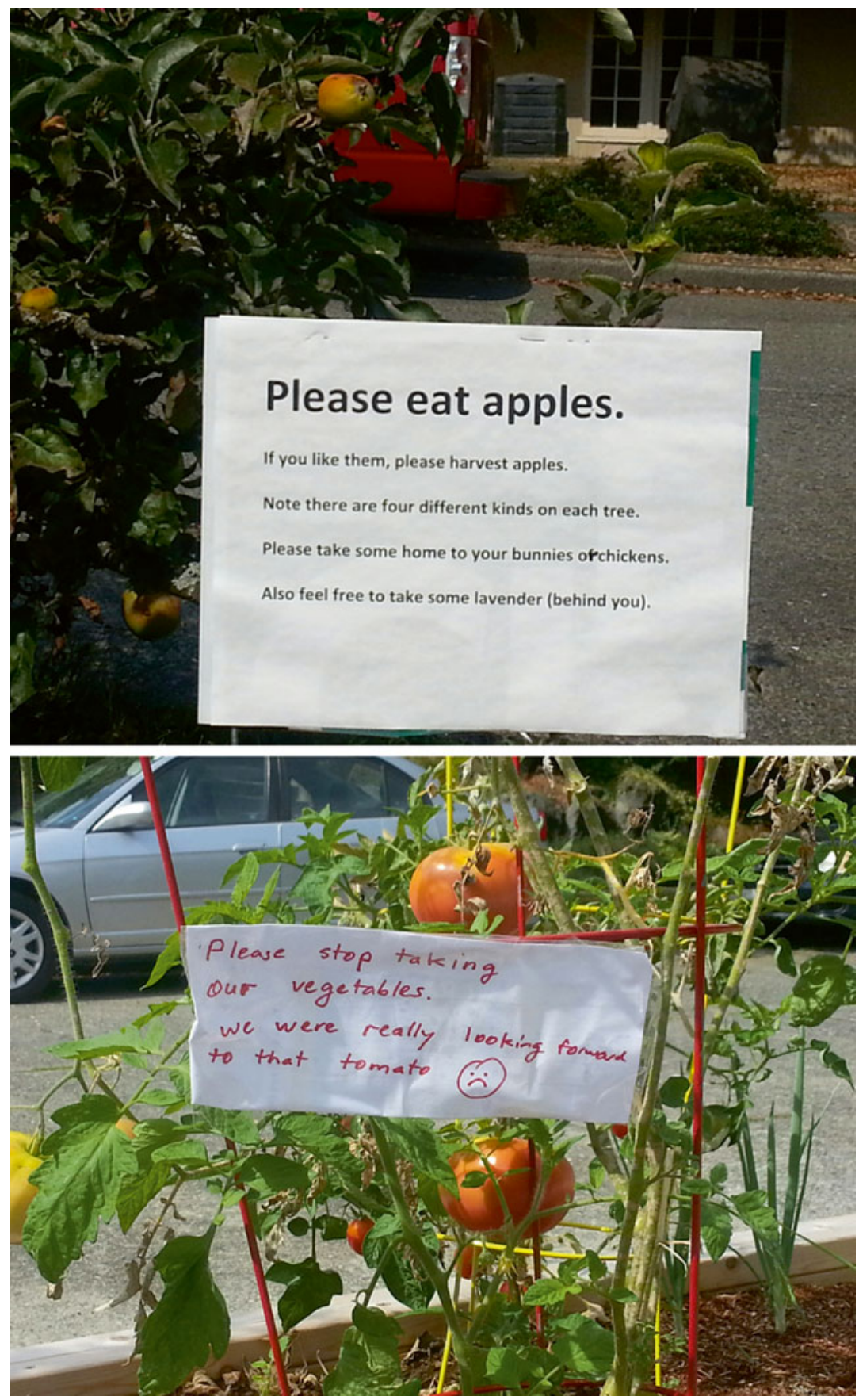

Fig. 7 Signs in a residential neighborhood in Seattle showed that some urban growers expect and encourage sharing of the harvest while others have experienced unwanted pilfering of produce 
A recent MS thesis at the University of Washington measured the area available for urban agriculture in parking strips in a subset of Seattle neighborhoods (Murphy 2012). The study found that the area covered by parking strips within this area was more than $3 \mathrm{x}$ the area available in community P-Patch and associated gardens in the City (Fig. 8, Table 1).

Lead concentrations were also measured as part of this study. Here areas sampled were divided into three different traffic categories: Low, Medium and High. While the High traffic classification had the highest variability and highest values for total soil lead, the median values for all three classifications were similar and generally below 400 parts per million, a concentration that has been cited as a cause for concern for children's play areas by US EPA. The survey also found that lead concentrations were only mildly elevated in parking strips in comparison to back yard samples from the corresponding homes (Figs. 9 and 10).

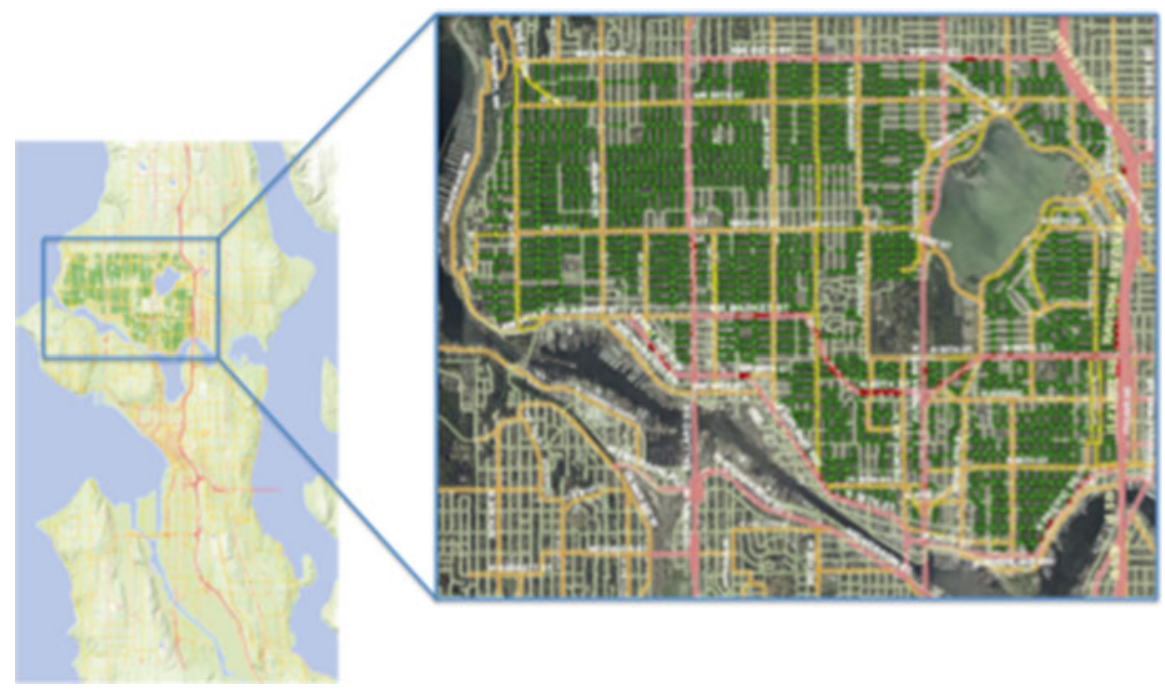

Fig. 8 A map of Seattle with the subsection included in the parking strip quantification. The area highlighted in green includes the Ballard, Crown Hill, Phinney Ridge, Greenwood, Greenlake, Fremont and Wallingford neighborhoods (Murphy 2012)

Table 1 Total area associated with parking strops in a subsection of Seattle (Murphy 2012)

\begin{tabular}{l|l}
\hline Total street segments & 4072 \\
\hline Mean width of parking strips & $2.4 \mathrm{~m}$ \\
\hline Mean length of parking strips & $77.3 \mathrm{~m}$ \\
\hline Total length & $315 \mathrm{~km}$ \\
\hline Total area & $57 \mathrm{ha}$ \\
\hline
\end{tabular}




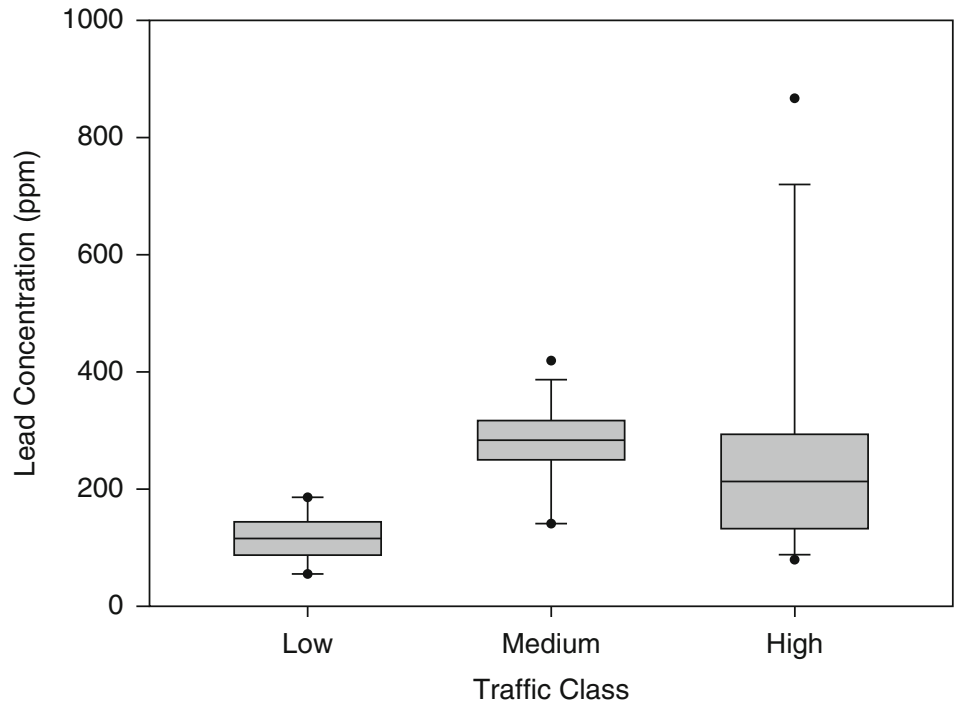

Fig. 9 Total soil lead in parking strip soils collected from different traffic patterns across neighborhoods in Northwest Seattle (Murphy 2012)

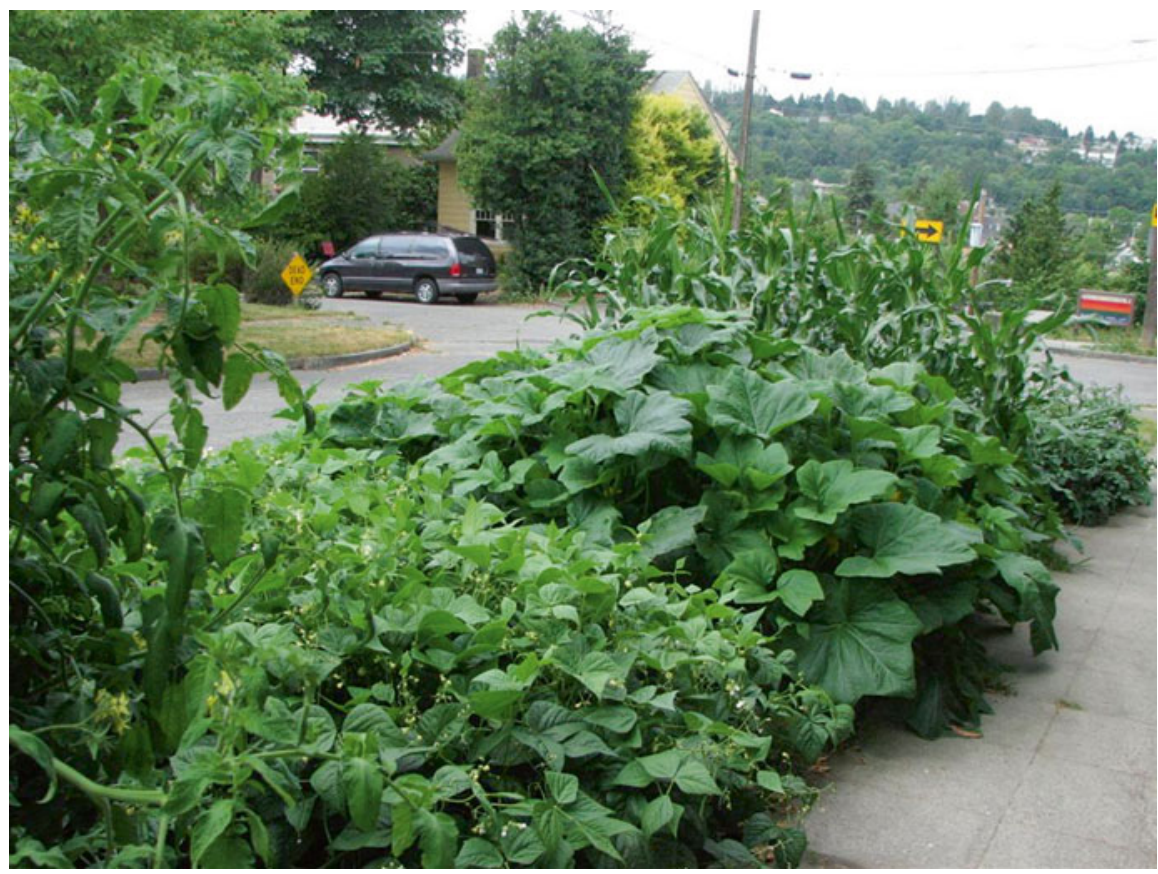

Fig. 10 A parking strip garden in Seattle. Raised beds were constructed and the garden soil was amended with a locally available biosolids compost prior to planting 


\section{Conclusions}

Curbside areas in cities offer a viable and significant alternative to community gardens for urban agriculture. These spaces have their challenges including compacted and potentially contaminated soils, zoning restrictions, and theft. Amending soils or using raised beds can improve soil properties and make soil safe for food production. More and more cities are changing zoning to allow for use of these strips for food production Planting appropriate crops can assure that these gardens don't reduce visibility for vehicles. Signage can help to encourage sharing and reduce the potential for food theft.

\section{Reference}

Murphy KA (2012) Evaluation of northwestern Seattle parking strip soil for urban horticulture land use and urban food production. MS thesis, Seattle, WA: University of Washington 


\section{Part VII \\ Integration into Municipal Infrastructure - Zoning and Legal \\ Considerations}




\title{
A Case Study: Zoning and Urban Agriculture in Michigan
}

\author{
Megan Masson-Minock
}

City governments regulate uses, like urban agriculture, through zoning ordinances as well as many of the physical structures outlined in previous chapters. Zoning ordinances are municipal laws that specify what types of land uses go where; the location, height, and size of buildings and structures; the architecture of buildings and what other things must happen on the land such as landscaping, trash receptacles and screening, truck loading spaces and parking spaces. The purpose of zoning ordinances are to protect health, safety and welfare of residents and the community.

From a technical point of view, regulating urban agriculture seems to be a pretty straightforward matter. The nuisances - activities or side effects that makes on a bad neighbor are the same as most other land uses - noise, odor, dust, traffic, unsightliness and attraction of vermin (think restaurant dumpster). These nuisances are either eliminated or mitigated through tools already used in municipal zoning: restrictions on the type of use or time of day for noise (no roosters or no farming before 6 a.m.), restrictions on number of animals for odor, required distances from areas of activity to homes, performance standards for dust (soil cannot be blown or drain across property lines), and location and storage requirements for unsightliness as well as attraction of vermin (all materials stored inside and a certain distance from other uses or buildings and food or seed in a sealed container). Also, many communities already have urban agriculture uses in their communities, with working regulations to keep the peace. So, we have effective, tested tools.

However, adopting those tools into zoning is a political act since the locally elected governing body, usually a city council, must pass the legislation. Zoning approvals and amendments are inherently affected by state and federal law, local history, culture, economy and differences within the municipality. Urban agriculture has been a growing trend in Michigan cities since the turn of twenty-first

M. Masson-Minock ( $\square)$

ENP and Associates, Ann Arbor, MI, USA

e-mail: megan@enp-associates.com 
century. The following case study explores how zoning for urban agriculture had to go beyond the technical in three Michigan cities - Flint, Detroit and Battle Creek.

\section{The Michigan Right to Farm Act}

In order to understand zoning of urban agriculture in Michigan, you must be familiar the Michigan Right to Farm Act (RTFA). This legislation was passed in 1983 to address nuisance complaints being brought against agricultural operations by new residents moving into the countryside. The RFTA states that a farm or farm operation shall not be found to be a nuisance if it conforms to generally accepted agricultural management practices (GAAMPs). No municipality can tell a farm operation how to be a good neighbor, the GAAMPs do that. The GAAMPs are determined by the Michigan Department of Agriculture and are reviewed annually by the Michigan Commission of Agriculture, an appointed body. Further, the RTFA exempts farms that existed before residential uses moved to land within one mile of the farm. Farms that were there first are exempt from nuisance complaints, as long as the farm was not a nuisance before the new residents moved in. The law is silent on the instance when other uses already exist, such a residential neighborhood, and a farm is then established.

While the law itself does not deal with that situation, case law does. Since its adoption, multiple court cases have come to the Michigan Supreme Court under the RTFA. The back and forth of decisions and amendments to the act have decreased the number and types of zoning tools local municipalities can use to regulate agriculture. For instance, the Michigan Court of Appeals invalidated the minimum lot size provisions for different types of farm operations, in that case a 1.074-acre chicken farm when local zoning required in the case of Charter Township of Shelby versus Papesh in 2005 (MI Court of Appeals 2005). In the mid 2000s, cities considering zoning changes to allow urban agriculture faced losing local control over new farm operations to a state agency, particularly unpalatable to those cities facing a state-appointed emergency manager. Detroit urban agriculture advocates began a push to change the RTFA to exempt activities in their community, at a minimum.

In January 2012, the Michigan Department of Agriculture changed the GAAMPs to not apply to any municipality with a population over 100,000 , in response to concerns about urban agriculture. According the 2010 U.S. Census, only seven municipalities in Michigan, of the 1773 cities, villages and townships, had a population of over 100,000 and were empowered to plan and zone for urban agriculture without the potential for RTFA to trump their jurisdiction. While this change has enabled changes in some of those cities, the GAAMPs are revised and amended annually by an appointed board. Since the GAAMP change, an advocacy group has coalesced to advocate for changes that offer RTFA protection for all urban farms, no matter what the size of the community. Even with the changes to the GAAMPs, municipalities faced an unstable environment where some local control could be taken away by a state body or agency far from their influence. In fact, some legal 
experts have stated that without changes to RTFA to allow municipalities to plan and zone for urban agriculture, "a very real risk exists that additional growth in urban agriculture could be stopped cold" (Norris et al. 2001).

\section{Flint}

In 2007, a small youth development organization in Flint, Urban Community Youth Outreach (UCYO), received a grant to erect a hoop house so the young people in the program could raise seedlings for their established community garden. Using the hoop house, which consists of bent metal 'hoops' covered in plastic, the organization could grow vegetables most of the winter without an additional heat source. The Genesee County Land Bank, a nationally recognized leader, gave UCYO six vacant residentially-zoned lots, originally platted for homes, across the street from the garden for the hoop house.

When the UCYO went to get a building permit, they found nothing would be simple. The Flint Zoning Ordinance, which had not been updated for decades, was ambiguous as to what agricultural uses were allowed in residential districts and with what design parameters. The Zoning Ordinance allowed "customary agricultural uses including noncommercial nurseries and greenhouses, but expressly excludes the keeping of farm animals" in its residential and commercial zones (Flint Zoning Ordinances, p. 26). However neither "noncommercial nursery" nor "customary agricultural uses" were defined in the Zoning Ordinance. Thus, the Planning Commission had to deliberate whether the UCYO hoop house was a noncommercial nursery and then determine what parking and screening were required. The ambiguity cost UYCO time, money and stress. Between the Planning Commission approval and the requirements of the Building Department, the UYCO erected their hoop house nearly 2 years behind schedule.

When the hoop house was finally up, Christina Kelly, Lead Planner for the Genesee County Land Bank, visited the site on a summer day. Volunteers were bringing water to the site. The City has refused to give them a water permit since no one lived on site. Volunteers were also taking trash away, since the City would only pick up trash at a residence. She said that it was as if every city service was not available.

In 2009, ENP and Associates was hired by the Genesee County Land Bank and the Ruth Mott Foundation to analyze Flint's ordinance and suggest changes to encourage urban agriculture. They found that many of Flint's other ordinances were outright barriers to urban agriculture. The "Animals and Fowl" ordinance only allowed agricultural animals to be kept at slaughterhouses and specifically restricted chickens in residential areas. The nuisance ordinance did not have specific language to allow for composting. The ordinance governing refuse, did not specify a whether the city trash service or a private company could pick up refuse at a community garden or urban farm. 
The Planning Commission asked ENP to go out the community and ask about three things before proceeding with any actions - hoop houses, keeping of animals and farming for profit. Two community sessions were held over the summer of 2010 with over 160 people in attendance. What was encountered were strong supporters and strong detractors. These sessions merely scratched the surface of why people felt so strongly either for or against. By the end of those sessions, we found that agriculture or farming were loaded terms and we changed the discussion to urban gardening. The only regulations passed in the process allowed water taps and trash pickups at community gardens, but amendments to allow keeping of animals (chickens and bees) and to expand urban gardening beyond non-profits failed.

Continued conversations with Genesee County Land Bank staff and food activists in Flint found that the older African-American community had a strong reaction to urban farming rooted in their or their families' flight from share cropping the Southern United States during the Great Migration in World War II. Also, the future of Flint and its vision of itself was tied up in the reactions to urban agriculture. For many, allowing farms to take over abandoned, vacant lots was a declaration of defeat, leaving behind previous plans made by the community. To others, urban agriculture was integral part of Flint becoming a twenty-first century sustainable city. Until a vision for the Flint of the future, accepted by all aspects of the community, was agreed upon, urban agriculture regulations would continue to be a divisive debate.

The master plan for Flint, Imagine Flint!, adopted in 2013 did establish a vision for the city that includes appropriate locations for urban garden and farms. Small scale agriculture in the form of community gardens and private gardens are shown as part of Green Neighborhoods in Imagine Flint! More intense and commercial agricultural uses such as farms and aquaculture are shown in twelve Green Innovation Areas. The implementation steps for this land use state that the City's zoning ordinance should be updated to allow for structures, like hoop houses, vital to food production (Flint Master Plan 2013). While the master plan creates the context for the zoning, the development of those regulations will need community engagement. Megan Hunter, the Chief Planning Officer for the City Flint, has said that carefully crafted zoning and land sales will be essential to ensure the compatibility of new businesses, like urban agriculture, in the community and context of Flint (Popovitch 2013).

\section{Detroit}

Detroit has had a different experience establishing urban agriculture within its boundaries. Until March 2013, agriculture was not a permitted use anywhere in the City of Detroit under its zoning ordinance. However, over 600 community gardens had been established in the City previously (Georgia Organics report 2011). By 2011, the planners at the Detroit City Planning Commission that were leading 
development of regulations for urban agriculture did not keep a map of active urban farms in Detroit because technically they were illegal.

The process for developing these regulations began in 2009, when the City of Detroit Planning Commission engaged farmers and gardeners in the City to develop language for an urban agriculture ordinance that would meet the needs of the City while complying with state law (Ignaczak 2014). City Planning Commission staff worked closely with the Detroit Food Policy Council and jointly held rounds of listening sessions and working meetings in a variety of locations across the community. While the process took 4 years, it was inclusive and transparent. The zoning amendments passed without loud public protest.

Detroit now has comprehensive zoning that sets regulations for urban agriculture at a variety of sizes and scales. Uses are defined and allowed in different zones. For instance, urban gardens are defined as lots less than an acre used to grow crops for personal and group use. Urban farms are described as lots over one acre where crops are raised for personal or group use. Both are allowed to have an accessory farm stand where products grown on-site can be sold. Urban gardens are permitted by right - just like a house - in any residential zone, where urban farms are conditional land uses (requiring additional permitting and scrutiny from the City) in singlefamily zoning districts but are permitted by right in more dense residential areas. Both are conditional land uses in the downtown and industrial districts as well as in overlay districts with architectural design requirements. Review procedures are clearly spelled out for agricultural uses as well as requirements and regulations for signs and lighting.

The 2012 exemption from Right to Farm protections for large cities like Detroit allowed the regulations to be tailored to the urban context of Detroit. Farm animals, certain tree species and crops that attract rodents (oats, wheat and rye), except when used as a winter cover crop and not grown to maturity, are prohibited. Distances for locations of buildings and cultivation areas from property lines for urban gardens and farms are specified. Urban farms and urban gardens permitted as a conditional use must give the property owner or occupant of abutting properties written notice with the name and contact information of owner or person responsible for the agricultural use and a description of what will be grown within 30 days of starting site preparation. A local government could not enforce any of these requirements for a farm with RTFA protection.

Zoning amendments, like those adopted by the City of Detroit, change the regulatory context but not the cultural context. Planners, food activists, urban growers and elected and appointed officials in Detroit still wrestle with issues of race, power and access with urban agriculture. The sale of city-owned land for the Hantz Farm project, finalized in 2014, offers a glimpse into how an urban farm can stir deep political and racial waters.

The project was originally announced in 2009 as the world's largest urban farm by John Hantz, the white owner of banking group who has lived in an eastside Detroit neighborhood for over 20 years. The farm was to be a 170-acre commercial operation with apple orchards and vegetable production. Vacant and blighted cityowned lots were a large part of the acreage targeted for the urban farm. 
In the summer of 2012, the media reported that the Hantz Farm project was near a purchase agreement with the City for over 1900 city-owned lots at the price of approximately $\$ 300$ per lot. The reported sale generated controversy, including a memorandum of protest from the staff of the Detroit City Planning Commission (CPC) and a report based on a public listening session from the Detroit Food Policy Council (DFPC) requesting that the City change its public land sale process. Both CPC staff and DFPC were concerned that zoning had not been amended yet to legally allow an urban farm. Both groups also expressed concern that the amount of property for the price represented a fundamental policy change that could result in unequal access (Detroit Food Policy Council 2012). In December 2012, the Detroit City Council approved the sale. The Detroit Black Food Security Network was vehemently opposed the sale, viewing it as a land grab to increase the wealth of the already wealthy. They questioned whether African-Americans would have the same opportunities as Mr. Hantz to purchase city-owned land at the same price (Yakini (on video) 2014). The protest was not centered on whether a farm should be allowed, but who owned the land and whether the process by which was acquired was fair, transparent and just, continuing themes in Detroit's history. In January 2014, now the Hantz Woodlands, a tree farm on 150 acres of non-contiguous lots, began work officially with city approvals and sales completed.

\section{Battle Creek}

In 2012, ENP and associates was hired by an urban gardening network in Battle Creek, Michigan to be their advocate in obtaining zoning approvals for an urban farm with a hoop house. The situation was very similar to the UCYO garden in Flint. A local non-profit working with youth and food production, Sprout Urban Farms, had acquired residential lots from the county land bank to establish an urban garden or farm. The firm researched the local regulations to avoid the surprises encountered by UCYO in Flint. They found that both the master plan and the zoning ordinance allowed for agriculture in the city boundaries so the proposal already had a method of approval, unlike in Detroit and Flint where local governments had to write and pass regulations for urban farming proposals.

Sprout Urban Farms had been running a youth jobs program employing local at-risk youth working in community gardens scattered throughout the City of Battle Creek, Michigan. Battle Creek, located in the southwestern portion of Michigan, had a population of 52,347 according to the 2010 Census. The Kellogg Company is headquartered there. While the corporate offices remain, many of the manufacturing facilities for the food processing company had moved from Battle Creek, and large areas of Battle Creek have experienced population loss. The North Central/ Washington Heights neighborhood, where the proposed urban farm was located, experienced a $17.5 \%$ decline in population between 1990 and 2000 plus an additional $3.8 \%$ decline from 2000 to 2010 (Battle Creek Annual Action Plan 2014-2015). 
The Calhoun County Land Bank had offered to lease a 2.12-acre site to Sprout Urban Farms. The organization wanted to consolidate their operations in a single location with a three-phase project: a community garden in the spring of 2012; hoop houses, a fruit orchard and a farm stand in fall 2012, and community barn for classes, food sales, and a commercial kitchen.

The site, located in the northern part of Battle Creek, was zoned R-2, a zoning district intended for residential neighborhoods with one and two-family dwellings. However, greenhouses, nurseries and truck gardens were allowed in the R-2 zoning district as special land use, which required a public hearing by the Planning Commission and approval by the City Commission. Agricultural uses were allowed in Agriculture and Rural Residential zoning districts, which are hold overs from when the city merged with the adjoining rural township in 1982. The city's master plan, adopted in 1997, used agriculture as way to constrain sprawl and planned agricultural uses for the southern end of Battle Creek. However, the special land use option for an approval of agricultural uses on the site opened the regulatory door just enough.

After researching the master plan and zoning, Sprout Urban Farms staff and ENP planners met with the Planning and Community Development staff. The best option for approval was clarified - to pursue a special land use permit. Planning and Community Development staff provided information on application requirements, including meeting with the neighborhood planning council. As the consultant, ENP and Associates reviewed and prepared the application package for the special land use. The goal was for the application to contain all the information needed by city staff and officials so the decision would not be delayed for bureaucratic reasons. Sprout Urban Farms met with the neighborhood planning council before their public hearing at the Planning Commission. They also met with neighbors and conducted a survey of 200 homes in the immediate area about where they purchased groceries. At the public hearing, the organization was able to show letters of community support and documented need in the neighborhood for the fresh produce the urban farm would provide. Finally, a variety of people representing diverse groups spoke on behalf of the proposal. The County Treasurer, a white older woman, spoke in favor stating how the land bank, under her office, was excited to re-use vacant land in Battle Creek since building housing was not always an option. The executive director of Sprout Urban Farms, a white community organizer, presented the proposal and answered questions from the Planning Commission. An AfricanAmerican pastor spoke in favor of the proposal and said that his service fraternity was scheduled to help remove brush from the site. Finally, two African-American youth shared how the jobs program had changed the way they ate and their attitude towards Battle Creek as a positive place. The special land use was recommended unanimously by the Planning Commission and approved by City Council in the following months.

The urban farm, named Bright Star Farm for the church that once occupied the site, now functions as headquarters for Sprout Urban Farms. A hoop house was erected in the summer of 2013. The organization continues to innovate and grow, establishing a mobile market in a truck that bring fresh produce to sell in 
neighborhoods or housing complexes with limited or no access to stores providing fruits and vegetables.

\section{Conclusions}

Zoning, for urban agriculture or any other land use, must be tailored for each community in order to be enacted and then to ultimately work well. If legislation, like the Michigan Right to Farm Act, constrains the abilities of municipalities to regulate, they will be tempted to not create regulations to allow urban agriculture. The good news is that policies, laws and ordinances can be changed. When a city official says no, it is always and option to ask what needs to change in order for them to say yes.

When the policy framework is open for tailored regulation, creation of these rules is not only a technical exercise but a political act in the cultural context of that particular place. In Flint, the city government was not ready to enable urban agriculture since a vision for the city's future was unclear and the issue hit cultural nerves. In Detroit, a community-based process resulted in regulations acceptable to citizens and officials in the City. The lesson is that creation of regulations is a dialogue between policy makers and all stakeholders, including those for and against, to assure that urban agricultural uses will be good neighbors. The opposition may have concerns that you find surprisingly sympathetic. Be sure to ask them if there any circumstances where an agricultural use would be acceptable to them as a neighbor.

Finally, policy change moves slowly. In Flint and Detroit, policy changes to enable urban agriculture took years. Be sure to inquire with local officials and city staff about regulations when you are just beginning to plan an urban agriculture project. However, as seen in Battle Creek, when the regulations and opportunity align, great things can happen within a growing season.

\section{References}

Charter Township of Shelby v. Papesh, 704 N.W.2d 92, 102 (Mich. Ct. App. 2005)

Detroit Food Policy Council (2012) Public land sale process in detroit: a community perspective. December 2012

Flint Zoning Ordinance, Article II, Section 50-17, page 26

Georgia Organics report - "Urban Agriculture Policy for the City of Detroit (STATUS REPORT)." City Planning Commission, City of Detroit

Ignaczak N (2014) No strangers to urban agriculture, detroit makes it official with new zoning ordinance. Seedstock. http://seedstock.com/2013/04/09/no-stranger-to-urban-agriculture-detroit-makes-it-official-with-new-zoning-ordinance/. Accessed at on 26 Feb 2014

Imagine Flint! City of Flint Master Plan, Adopted October 28, 2013. http://www.imagineflint.com/ Documents.aspx. Accessed at on 27 Feb 2014 
Norris P, Taylor G, Wycoff M (2001) When urban agriculture meets Michigan's right to farm act: the pig's in the parlor. Michigan State Law Review, 2001, Rev. 365

Popovitch T "From cars to crops: city of Flint, MI Looks to urban agriculture for economic revitalization." Seedstock. http://seedstock.com/2013/11/07/from-cars-to-crops-in-flint-miformer-company-town-looks-to-urban-agriculture-for-economic-revitalization/. Accessed at 27 Feb 2014. http://www.detroitagriculture.org/GRP_Website/Home_files/uaw_official_ UrbanAgPolicyDraft1-1.pdf. Accessed 20 Mar 11

The City of Battle Creek 2014-2015 Annual Action Plan for HUD, submitted May 9, 2014. http:// battlecreekmi.gov/ArchiveCenter/ViewFile/Item/62 . Accessed on 5 January 2016

Why detroiters oppose Hantz farms. Video with Malik Yakini. http://www.ubmfuturecities.com/ video.asp?section_id=404\&doc_id=524883. Accessed at 27 February 2014 


\title{
A Case Study: Urban Agriculture in Portland, Oregon 2002-2012
}

\author{
Molly M. Hatfield and Steve Cohen
}

Researched and written by Molly M. Hatfield and Framework provided

by Steve Cohen

\section{Introduction}

Portland, Oregon houses approximately 587,865 residents in an area of roughly 400 square miles (Metro n.d.; Portland State University Population Research Center 2012). The city is known for its dense development; at the same time, however, Portland has become an example for its advancement of urban agriculture within city boundaries (Mendes et al. 2008). This begs an obvious question: how does a city with high population growth and steep competition for land foster small-scale food production and distribution in urban spaces?

This chapter is based on conversations with over a dozen community members, government actors, and nonprofit representatives. And over the course of this research, one thing has become very clear: Portland boasts (and has for a number of decades) a highly engaged and vocal citizen base. Without the ongoing leadership, participation, and pressure from its residents, the city would not be in the position it is today with regard to urban agriculture. To be sure, local government has done an admirable job of proactively (and creatively) responding to constituents, and there are some elements - a long history of City-supported community gardens programs, for example, and a commission form of government that made it somewhat easier to establish food issues on the municipal agenda - that have helped Portland's urban agriculture efforts find traction. That said, the importance of an engaged citizenry cannot be overstated.

M.M. Hatfield

Portland, OR, USA

S. Cohen $(\bowtie)$

City of Portland Bureau of Planning and Sustainability

Portland, OR, USA

e-mail: steve.cohen@ portlandoregon.gov 
The following sections will discuss the political and historical context for urban agriculture in Portland before focusing more specifically on the boom in interest and activity that occurred between 2002 and 2012. It concludes with an overview of the lessons learned from Portland's experience with fostering urban agriculture within it growth boundary.

It should be noted that this research is not meant to be a comprehensive overview of every food-related activity or initiative that has occurred in Portland, Oregon. Rather, it should be read as a survey that spotlights the challenges and opportunities that come when promoting urban agriculture in a densely-populated, land-scarce urban area.

\section{Urban Agriculture Pre-2002}

It is fair to say that Portland is a city with deep agricultural roots. Early settlers found the soils well suited to fruits and vegetables, grains, and livestock and dairy production; indeed, remnants of these early operations can still be found within city boundaries (Mickle and Starin 2009). Around the turn of the twentieth century, however, heavy urban migration and residential development displaced many of these agricultural activities.

While there was a brief boom in small-scale food production with the Victory Garden movement during World War II, ${ }^{1}$ the current surge in interest in urban agriculture is largely a recent development. Even so, the years preceding 2002 laid significant groundwork for food issues in Portland. This section discusses some of the important political and historical context that shaped the city's food policies and programs leading up to the twenty-first century.

\section{Urban Growth Boundary}

One of the defining features of the City of Portland is its urban growth boundary (UGB): this boundary restricts urban development to within a defined limit, promoting high-density growth and protecting surrounding areas from urban sprawl. Developed in response to the statewide Oregon Land Conservation and Development Act of 1973 (SB 100), ${ }^{2}$ the Portland metropolitan area UGB was devised in 1978 and approved in 1981 (Nelson and Moore 1993). Policymakers revisit the boundary regu-

\footnotetext{
${ }^{1}$ During World War II, the US Department of Agriculture popularized the concept of "Victory Gardens": individual gardens designed to ease pressure from overburdened transportation and food production systems (USDA 1943). The Oregon State College (now Oregon State University) Extension Service took charge of promoting Victory Gardens in Oregon; their efforts yielded a marked increase in city gardens and a "splendid" ( McWhorter 1943) support of the war effort.

${ }^{2}$ Oregon SB 100 mandated that cities adopt comprehensive plans regarding their urban development and implement zoning (and other) regulation in support of these plans (State of Oregon 1973).
} 
larly and have expanded it numerous times over the decades (Metro n.d.). The UGB remains a contentious topic: efforts to repeal its foundation legislation started as early as 1976, and modern ballot measures still seek to amend or challenge the management of the UGB (Oregon Department of Land Conservation and Development).

The UGB has shaped the progress of urban agriculture in Portland to a considerable degree. While the boundary was initially conceived as a way to protect farmland from encroachment by urban sprawl (Abbott 1993), it had some unintended side effects: by limiting the amount of land available for urban development, policymakers increased the demand for-and value of - open land within the UGB. ${ }^{3}$ Agricultural use of this property was effectively de-prioritized in favor of residential and employment uses (Balmer and Rhoads 2006; Mendes et al. 2008; Metro n.d.).

As community interest in urban agriculture increased, then, policymakers have been forced to find creative ways to accommodate this demand for local food production (J. Johnson). In the beginning, the discussion was largely confined to community gardens and the recreation, food security, and community that they foster. In the early 2000s, however, the conversation shifted to a broader range of food production and distribution within the city: activities such as commercial gardens, food-buying clubs, and farmers markets (W. Miller, L. Pohl-Kosbau, J. Volk) The following sections will discuss how the City of Portland-with essential guidance and support of community members and organizations-has fostered these activities in an urban area where, by design, open land is scarce and development compact.

\section{Portland Community Gardens}

Portland's Community Gardens program began in 1975 with Ordinance No. 139598, which authorized the Bureau of Parks to promote community gardens on unused urban properties (City of Portland 1975). The ordinance was developed in response to demand from the newly-formed Neighborhood Association (now called the Office of Neighborhood Involvement) (L. Pohl-Kosbau).

From the very beginning, the limited amount of available land was an issue. Leslie Pohl-Kosbau, who directed the Portland Community Gardens program for 35 years, remembers:

The challenge was to find good locations that would fit, that would be available, that weren't being used for other Park purposes, that were walkable, and also that had decent soil and good sun and so forth.

The Program started with just three sites: Fulton, Sewallcrest, and Johns. By 1999, it had expanded to 23 gardens around the city; by 2013, there were 50 sites in

\footnotetext{
${ }^{3}$ Research also indicates that Portland's relatively high housing prices-housing prices unrelated to the UGB - may also play a role in creating a premium for undeveloped city land (Nelson et al. 2002).
} 
total (Portland Parks and Recreation; Schukoske 2000). Even with this growth, however, the supply of land for community gardens does not keep pace with demand: in December 2013, the waiting list for space was over 1000 families long (Portland Parks and Recreation).

Neighborhood support and participation have been hallmarks of Portland's Community Gardens program since its inception ("[otherwise], what's the point?" observes Pohl-Kosbau. ${ }^{4}$ This participation has been essential to the continued existence of the Program: in response to 1985s proposed budget cuts, for example, the nonprofit Friends of the Portland Community Gardens (FPCG) formed as an advocacy and fundraising organization (Friends of Portland Community Gardens n.d.). Each of the three times that there have been proposals to de-fund Portland Community Gardens (the most recent of these attempts was in 2005) FPCG has mobilized support and community action to save the Program (Hess and Winner 2005).

Portland's Community Gardens program cemented community support for and illustrated the public advantages of food-related activities within the urban setting. It allowed generations of Portlanders to experience growing food in a city context and to see-and demand - a City role in providing these opportunities. And in turn, policymakers and other City actors were given a concrete demonstration of the educational and community-building benefits that such activities provided.

\section{Zenger Farms}

Before 2002, the Community Gardens program was Portland's main outlet for foodrelated activities in the city (L. Pohl-Kosbau). A handful of independent organizations-Growing Gardens, for example, an award- winning nonprofit that has worked since 1996 to promote gardening in neighborhoods and schools (Growing Gardens n.d.) - sought to promote food awareness and skills among Portlanders, and there was indeed some movement around small-scale commercial farming and farmers markets inside the urban growth boundary (M. Boucher-Colbert,, L. Pohl-Kosbau,). These efforts, however, were few. Even so, one initiative during this time does deserve particular mention: the development of the Zenger property into a smallscale urban farm and educational facility.

The 16-acre Zenger Farm property is located in the Lents neighborhood of Portland, well within the city's urban growth boundary. Formerly a commercial dairy farm, its owner (Ulrich Zenger, Jr., who had inherited the farm from his father) sought to protect the property from development (Friends of Zenger Farm n.d.). Five years after Zenger Jr.'s death in 1989, the family sold the farm to the Bureau of

\footnotetext{
${ }^{4}$ While the City provides infrastructure services such as water, fencing, and soil testing-as well as a list of guidelines that plot holders must follow-participants have direct control over the dayto-day management of their garden systems (L. Pohl-Kosbau, Portland Parks and Recreation 2013).
} 
Environmental Services (BES); BES intended the land for use as a stormwater management site (Gragg 2013).

In fall of 1996, Marc Boucher-Colbert (on behalf of his Urban Bounty Farm operation $^{5}$ ) approached BES with the idea of using the farm as an educational tool and community resource. Boucher-Colbert recalls his first visit to the property:

It had a magic and a history to it. We realized pretty much from first sight that we were looking at something unique in a city. A major American city having something like this within its boundaries? That was a treasure.

The idea of a private, for-profit enterprise entering into a lease on public land was a relatively novel one at the time (M. Boucher-Colbert). Instead of cash rent, however, the Farm proposed a program that taught agricultural skills and food system knowledge to local public school students (Gragg 2013). While the details of the lease took some time to solidify, BES agreed to rent Boucher-Colbert two acres of land for both agricultural and educational use.

After two years of operation, Boucher-Colbert and his cohort recognized that Zenger Farm represented something unique in the urban landscape. "We were realizing that this was an important asset for the city, for urban agriculture, for local farming education. We had to get something in place to keep this going."

To protect and maintain the property, several stakeholders came together to form the nonprofit Friends of Zenger Farm. Boucher-Colbert sold his farming operations to this organization, and in 1999 the nonprofit entered into a 50-year lease with the Bureau of Environmental Services. From that time, Friends of Zenger Farm has managed the property and used it as a hands-on educational resource for the community.

Zenger Farms is an important touchstone in Portland's agricultural landscape: its historical significance, educational mission, and unique partnership with City agencies make the organization an impactful part of the narrative around urban agriculture in Portland. It set an important precedent for City land being used for agricultural purposes, and it serves as another clear example of the role of private citizens in shaping the agricultural landscape within city boundaries.

\section{Urban Agriculture 2002-2012}

In the early 2000s, public interest in food systems and urban agriculture skyrocketed (M. Boucher-Colbert, J. Johnson, L. Pohl-Kosbau,; A. Rhoads, J. Volk,). As it turned out, some important City officials shared this interest: Commissioner Dan Saltzman and then-Commissioner Sam Adams, for example, were proactive in promoting food issues on the City agenda from very early on (S. Cohen, B. Finn). And because of the city commission form of government-where a group of electeds set

\footnotetext{
${ }^{5}$ At the beginning of its lease at the Zenger property, the Urban Bounty Farm consisted of Marc Boucher-Colbert, Beth Rasgorshek, and apprentices Tanya Murray and John Tecklin.
} 
policy and run bureaus, rather than a "strong" mayor-these commissioners were able to promote a legislative agenda that spotlighted food issues.

Three initiatives stand out in this process, exemplifying the transition of food issues and urban agriculture from a peripheral, compartmentalized concern to an integral, multi-bureau priority for the City of Portland. Early on, the creation of the Portland Multnomah Food Policy Council and the Diggable City project codified food policy as part of the municipal agenda and raised the profile of food systems and its importance among Portland city residents and bureaus. Later, the food zoning code revision brought stakeholders together to pinpoint and address specific bureaucratic barriers to urban agriculture: this effort acknowledged the essential role that food plays in the city environment, as well as the important part that local governments can play in fostering its development.

\section{Portland Multnomah Food Policy Council}

In 2002, the City of Portland and Multnomah County responded to the swell of public interest in food issues by convening a Food Policy Forum that involved over a hundred community members, interest groups, and elected officials (Portland City Council Resolution No. 36074). One of the chief byproducts of this meeting was the creation of the Portland Multnomah Food Policy Council. The Food Policy Council (FPC), established by City and Multnomah County resolutions, was intended to serve as a resource for policymakers, tasked with "provide[ing] ongoing data collection and analysis, and recommendations to local governments regarding policies, programs, operations, and land use rulings related to local food issues" (Portland City Council Resolution No. 36074).

In the creation of the FPC, Portland was following the lead of Knoxville, Hartford, Toronto and other cities with already-established Food Policy Councils (Harper et al. 2009). In Portland's case, however, explicit ties to City and County government were codified in the belief that such ties would make for a more effective advisory body. ${ }^{6}$

The Portland Multnomah FPC turned into a powerful advocate for City and County food issues, and has been credited for moving forward both the Diggable City project and the food zoning code revisions (discussed below) (S. Cohen, K. Kolker, A. Rhoads). "Frankly, at that time there wasn't a lot of expertise within city bureaus, and the Food Policy Council needed to provide that," explains Steve Cohen, who was hired in 2005 into a full-time Food Policy and Program position in the City's Office of Sustainable Development (OSD).

The FPC really set that overriding policy agenda. They spent a tremendous amount of time with the Bureau of Planning and other offices, talking to leadership and explaining the

\footnotetext{
${ }^{6}$ The Portland Multnomah Food Policy Council was a subcommittee of the Portland Multnomah County Sustainable Development Commission.
} 
connections between city policy and food systems. In this nascent movement, they were the champions for so much of the work to come.

The role of the FPC did evolve over the years, and the body was ultimately dissolved in 2012. ${ }^{7}$ However, the important part the body played, especially in the early 2000s-coalescing the food movement, educating policymakers, and maintaining urban agriculture as a municipal priority—should be emphasized.

Also important to note is the creation of the Food Policy and Program position in the Office of Sustainable Development (now the Bureau of Planning and Sustainability). One of the early challenges in City planning around food systems was that there was "no clear champion, no clear entity in the City charged with that" (M. Walkiewicz). Creating the official Sustainable Food Program under the auspices of OSD allowed staff to "own" the issue, pinpoint those areas over which the City could exert influence, and create overarching City goals and strategies related to food systems. Indeed, it was through both the FPC and the OSD Sustainable Food Program that food issues became as thoroughly integrated into bureau work in the City of Portland.

\section{The Diggable City Project}

In 2003, community members in Portland's Sellwood neighborhood partnered with the Bureau of Parks and Recreation in a campaign to turn a 100-by-100-foot parcel of City-owned land into a community garden. After months of effort, this vision became a reality: what was previously a Water Bureau pump station lot had become the Sellwood Community Garden (Johns 2006). Upon completion of the project, Sellwood resident Sheila Strachan presented her results to the Portland City Council.

"It was like light bulbs went on over their heads," she said.

Galvanized by Strachan's report, Commissioner Dan Saltzman developed and introduced Resolution No. 36272. Acknowledging the direct link between agricultural activity and the health, community, and overall wellbeing of Portland residents, the resolution called for an inventory of unused City-owned lands that could potentially "be suitable for community gardens and other agricultural uses" (Portland City Council, Resolution No. 36272) The resolution passed unanimously on 24 November 2004; the project subsequently became known as The Diggable City.

\footnotetext{
${ }^{7}$ By this time, the City of Portland had shifted toward more short-term, project-oriented collaboration with community interests (the Bureau of Planning and Sustainability's work with the Code Development Advisory Group during the zoning code revisions is an example of this approach) (Hatfield 2012). County policymakers pursued a different strategy for community engagement, and FPC members themselves sought to develop an alternative model for influencing local or regional policy (Portland Multnomah Food Policy Council minutes, 9-12-12and 7-11-12).
} 


\section{Diggable City Phase I}

To address the twin obstacles of staffing and $\operatorname{cost}^{8}$ —and to abide by the 6-month timeframe mandated by the resolution-the City enlisted support from Portland State University's Nohad A. Toulan School of Urban Studies and Planning. The Diggable City project team comprised eight graduate students working toward their Masters of Urban and Regional Planning (MURP) and was managed by Brendan Finn, Commissioner Saltzman's Bureau Liaison.

There were challenges from the beginning. "We had to really make the connection for our professors about why this was a planning project," explains Amanda Rhoads, one of the MURP students who spearheaded the research. Because food systems were rarely thought of in the context of city planning ("at the time it was a new concept"), faculty approval was an uphill battle.

The novelty of the project also impacted collaboration with bureaus that had never before considered their land with an eye toward public use.

Marie Walkiewicz, Program Coordinator for the City of Portland (and a Senior Planner for the Bureau of Planning at the time of the project), sums up some of the difficulty:

In the Oregon land use policy structure that we have, the whole idea is focusing growth within the urban growth boundary so that we save farm, forest, and natural resources outside of it. So this whole idea of urban agriculture [...] how did that fit into Oregon's land use planning system and policies? That was an interesting, provocative, and sometimes challenging question.

To foster cooperation, a technical advisory committee (TAC) was formed. This committee consisted of 12 members that included City staff (including representatives from the Bureau of Environmental Services, the Bureau of Planning, the Office of Transportation, Portland Parks and Recreation, and the Water Bureau) as well as multiple community stakeholders who were familiar with the Portland food system (Balmer et al. 2005).

The MURP students inventoried 289 discrete City-owned locations over the 6-month duration of the project. In the final report, the project team outlined five recommendations for fostering urban agriculture on City-owned land:

1. Develop an inventory management plan for those City parcels deemed suitable for urban agriculture.

2. Expand the inventory and develop evaluation criteria.

3. Create an urban agriculture commission to review plans and make policy recommendations regarding issues around urban agriculture.

4. Adopt a formal policy on urban agriculture to establish a solid vision for the future.

5. Conduct a comprehensive review of policy and zoning obstacles (Balmer et al. 2005).

${ }^{8}$ Phase I of the Diggable City project took place before the creation of the Food Policy and Program Manager position. 


\section{Diggable City Phase II}

The Portland City Council adopted the Diggable City project team's final report in June 2005. However, no funding was allocated to support the implementation of the project team's recommendations ("we could provide land, which is an asset, but we couldn't provide any dollars" (B. Finn). It was here that community involvement again proved invaluable: the Council was able to turn to the FPC for recommendations on next steps for fostering urban agriculture on City lands (Portland Multnomah Food Policy Council 2006).

To carry out this request, the FPC formed the Urban Agriculture Subcommittee. Another technical advisory committee, this one comprising over 20 community and City actors, formed to assist the Subcommittee in its work. The process involved extensive research and conversations with over 50 community stakeholders (MacKenzie and Cohen 2007). Indeed, this stakeholder involvement was a powerful driver of the project. Amanda Rhoads explains:

I think a big strength of what we did was that we were so connected to stakeholders and doing so much public involvement in the process, galvanizing people to get involved in different ways. There was such a movement going on. It was a natural fit for us to connect that community energy with a project that was designed to help the City do some really cool things.

Three different properties were developed as pilots for the Diggable City project during Phase II: a commercial garden on a former landfill site owned by the Bureau of Parks and Recreation, a community garden on Portland Water Bureau land, and an expansion of Zenger Farms onto Bureau of Environmental Services property (MacKenzie and Cohen 2007). The FPC also developed proposals to advance Diggable City even further: a framework for evaluating applications to use City land, and a deeper review of zoning challenges and how to address them (A. Rhoads).

\section{Diggable City Phase III}

The final phase of Diggable City addressed the remaining recommendations from Phase I: namely, an expansion of the original inventory and the identification of those lands with the greatest potential for urban agriculture. With grant money from the US Department of Agriculture Risk Management Agency, the City of Portland Office of Sustainable Development (OSD) worked to refine the original inventory of City-owned land, report on the progress of the three pilot projects developed from Phase II, and generate recommendations for strategies that would better foster urban agriculture activities in Portland (MacKenzie and Cohen 2007). 
Working with multiple City bureaus, ${ }^{9}$ OSD identified 27 City-owned sites where urban agriculture projects might be possible, and 13 sites where such projects are "definite[ly]" possible (MacKenzie and Cohen 2007). However, the report underlined the fact that "relatively little City-owned land is available" and that, given bureau policies, "the vast majority of properties in the original inventory are serving a particular City purpose that negates additional use."

As with the first phase of the Diggable City project, the final report outlined recommendations for going forward:

1. Pursue urban agriculture partnerships with City bureaus.

2. Expand the scope of potential properties by working with other public agencies.

3. Integrate urban agriculture into City policies.

\section{Diggable City Outcomes}

After Phase III of Diggable City, the nonprofit MercyCorps Northwest was able to secure land from the Bureau of Planning and Sustainability for a program that promoted for-profit market gardening among refugee populations from Bhutan (J. Haines). However, the main byproduct of the Diggable City project turned out not to be any major increase in available land. ${ }^{10}$ While there is still potential to develop unused City properties - and a general desire that this be done- the expected boom in projects did not manifest (S. Cohen, B. Finn, A. Rhoads) (Fig. 1).

"It isn't to say that there isn't any land out there that could be more utilized" comments Ms. Walkiewicz “[but] as a general rule, the City doesn't have-and shouldn't have-surplus land. We have land that we're using now or that we need to use in the future" (M. Walkiewicz). There are also reasonable discussions about whether urban agriculture, which involves a limited number of active participants, is the "highest and best" use of public land that could potentially accommodate parks, housing, or other services that serve a broader range of Portlanders.

Instead, to many, the main value of Diggable City was the project's success in capitalizing the enthusiasm around food issues and raising consciousness of urban agriculture among both community members and City actors: "it was a catalyst for thinking about our city in a different way" (M. Walkiewicz). Diggable City firmly cemented food as a City concern and a planning concern, and it illustrated the many (sometimes unconventional) possibilities around growing food within the urban

\footnotetext{
${ }^{9}$ The Bureau of Environmental Services, the Department of Transportation, Portland Parks and Recreation, and the Portland Water Bureau.

${ }^{10}$ It should be mentioned that the County Digs program — an initiative of Multnomah Countybegan work in 2010 to donate tax-foreclosed properties for urban food production and green space. While unrelated to the Diggable City project, it successfully transferred six properties for use as community gardens between 2010 and 2012. All of these donated properties are within the urban growth boundary (K. Lynd).
} 
Fig. 1 A gardener at the for profit garden for refugees from Bhutan

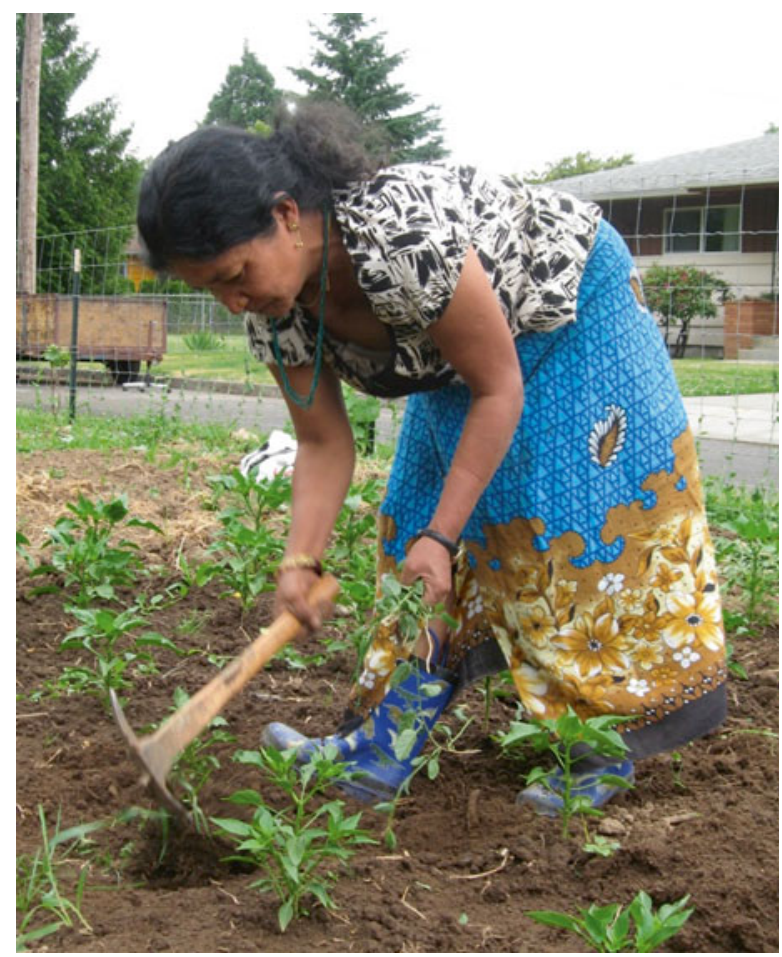

growth boundary (S. Cohen, A. Rhoads, M. Walkiewicz) (these lessons could in turn be applied to partnerships with schools, nonprofit organizations, faith-based institutions, and private landownders). Diggable City was also an important stepping stone for the zoning code revision of 2010, discussed in further detail below.

\section{Portland Zoning Code Revision}

From its founding, the Portland Multnomah Food Policy Council advocated for improved land use policies with regard to urban agriculture (Simantel 2003). Phases I and II of the Diggable City project echoed this sentiment: project teams emphasized the need for a review of the zoning code as it pertained to food activities within city boundaries (Balmer et al. 2005; Portland Multnomah Food Policy Council 2006). The reports highlighted that the zoning code did not adequately recognize uses related to urban agriculture: no distinction was made between smallscale and large-scale operations, while food distribution activities such as farmers markets, buying clubs, and community-supported agriculture (CSAs) received no mention at all (Portland Multnomah Food Policy Council 2006).

While it should be noted that urban agriculture did thrive in Portland prior to the zoning code revisions, the "cumbersome and unclear" (City of Portland Bureau of 
Planning and Sustainability 2011) regulation created an air of uncertainty around these activities, and in some cases acted as a barrier to their implementation (Gisler et al. 2011; K. Kolker).

With the merging of the Office of Sustainable Development and the Bureau of Planning in 2008, however, the City's Sustainable Food Program finally found itself in a position to address these issues with the zoning code (City of Portland Bureau of Planning and Sustainability 2010). Discussion started in the Food Policy Council's 2009 Urban Agriculture subcommittee and received vocal support from then-Mayor Sam Adams; in 2010, the City's Bureau of Planning and Sustainability secured funding for the project (Portland Multnomah Food Policy Council meeting minutes 5-10-10. This funding came in part from the Multnomah County Health Department through a Center for Disease Control and Prevention Communities Putting Prevention to Work grant; this grant also secured participation from the Oregon Public Health Institute over the course of the project.

Based on recommendations from the FPC, project staff focused on five areas in particular: market gardens, community gardens, farmers markets, food membership distribution, and animals/bees (City of Portland Bureau of Planning and Sustainability 2011). Community participation was paramount throughout the process. Project advisory group meetings drew over 60 community participants, two comment periods opened drafts to public review, and a Code Development Advisory Group (CDAG) provided specialized input from 18 community stakeholders (City of Portland Bureau of Planning and Sustainability, 2012; n.d.) (Fig. 2). ${ }^{11}$

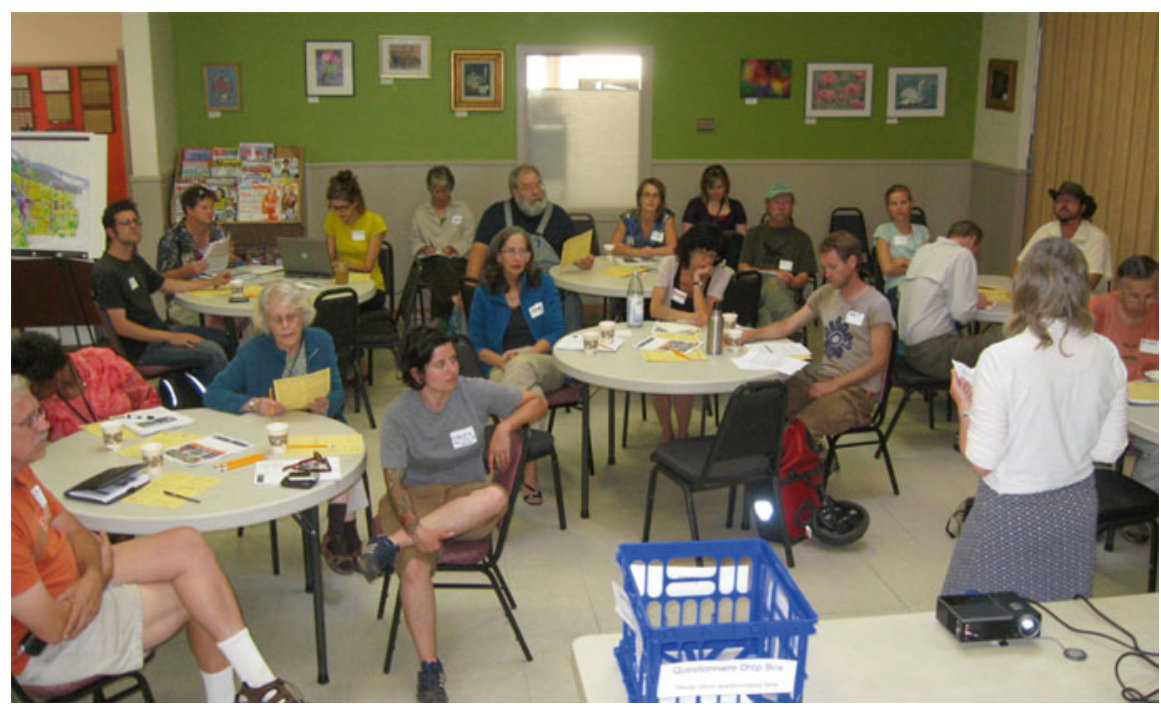

Fig. 2 Citizen participation in the City of Portland Code Amendment process

\footnotetext{
${ }^{11}$ This public process-in particular, the close collaboration with the Code Development Advisory Group - was considered an integral part (and one of the major successes) of the project (S. Cohen, J. Johnson, K. Kolker; Hatfield 2012).
} 
Table 1 Adopted zoning code changes

\begin{tabular}{l|l|l}
\hline Topic Area & Original & Revised \\
\hline Market gardens & $\begin{array}{l}\text { Classified as agricultural use, } \\
\text { only allowed in a few zones }\end{array}$ & $\begin{array}{l}\text { Allowed in all zones with } \\
\text { regulations to mitigate impacts }\end{array}$ \\
\hline Community gardens & Allowed in all zones & $\begin{array}{l}\text { Allowed in all zones with } \\
\text { regulations to mitigate impacts }\end{array}$ \\
\hline $\begin{array}{l}\text { Food membership } \\
\text { distribution sites }\end{array}$ & Not mentioned in code & $\begin{array}{l}\text { Allowed in all zones with } \\
\text { regulations to mitigate impacts }\end{array}$ \\
\hline Farmers markets & Regulated as a temporary use & $\begin{array}{l}\text { Add specific farmers market } \\
\text { temporary use regulations }\end{array}$ \\
\hline
\end{tabular}

Adapted from urban food zoning code update

After nearly 2 years of effort, the City Council approved the proposed zoning code amendments, which are summarized below (Table 1).

Observed results were almost immediate. Katy Kolker, Founder and Director of the Portland Fruit Tree Project, explains:

[The zoning code revisions] made it possible, just within the past two years, for folks to feel legitimate in their endeavors, to be able to publicize more broadly what they're doing, and just to do their work a lot more openly. And also have more easy access to land: most of the urban farmers I know are using land that is not owned by them. Just knowing their endeavors are legal makes a difference.

\section{Conclusion/Next Steps}

The landscape around urban agriculture has changed drastically since the early 2000s: where there used to be only a few individuals and organizations that focused on food systems and urban agriculture, we now see a profusion, with more established every day (S. Cohen, W. Miller, J. Volk).

A number of grassroots coalitions have formed to secure land and develop projects that foster community gardens and other urban farming activities: these initiatives have occurred entirely outside the scope of City or County efforts, and have provided hundreds of Portlanders with access to land and resources (D. Beller, A. Rosner). Other individuals and organizations work to implement innovative projects on plots unsuitable for conventional production: fruit and nut orchards, for instance, or rooftop gardens (M. Boucher- Colbert, K. Lynd).

However, these independent activities still face a number of barriers to project implementation. In conversations with individuals involved in the various aspects of Portland urban agriculture arena, it is clear that several challenges remain to food production and distribution within city boundaries:

- Land availability and land tenure (either current or projected)

- The limited profitability of urban farming

- The availability of skilled human capital 
- Food safety and testing

- Utility costs (especially water)

- Jurisdictional complexities (e.g., among City bureaus, City/County/Metro, etc.)

Local government plays an important role in addressing these issues. And while Portland has done a respectable job in utilizing its limited land resources to promote food production and distribution, it is clear that further conversations must take place about the size, type, and quantity of agricultural activities that policymakers wish to foster within city limits (J. Johnson, J. Volk, M. Walkiewicz).

The tension between urban development and urban food production will certainly continue to exist in Portland. But in the words of local farmer Josh Volk:

That tension is just in terms of where the line is. There can be space for both of us.

Many individuals were interviewed for this article. Their names and titles are shown below.

David Beller: Founder and Director, Grow Portland

Marc Boucher-Colbert: Founder, Urban Agriculture Solutions

Steve Cohen: Food Policy and Program Manager, City of Portland Bureau of Planning and Sustainability

Brendan Finn: Chief of Staff, Commissioner Dan Saltzman's Office

John Haines: Executive Director, MercyCorps Northwest

Jim Johnson: Land Use and Water Planning Coordinator, Oregon Department of Agriculture

Katy Kolker: Founder and Executive Director, Portland Fruit Tree Project

Katie Lynd: Sustainable Purchasing Coordinator (former), Multnomah County

Weston Miller: Community and Urban Horticulturalist, Oregon State University

Extension Service

Tanya Murray: Farm Manager (former), Sauvie Island Organics

Leslie Pohl-Kosbau: Director (former), City of Portland Community Garden Program Amanda Rhoads: City Planner, City of Portland Bureau of Development Services Ari Rosner: Treasurer, Urban Farm Collective

Josh Volk: Founder, Slow Hand Farm

Marie Walkiewicz: Program Coordinator, City of Portland Bureau of Environmental Services

\section{References}

Abbott C (1993) The Politics of Land-Use law in Oregon: Senate Bill 100, Twenty Years After. Or Hist Q 94(1):4-35

Balmer K, Rhoads A (2006) The Diggable City. PSU Sustainable Community Media

Balmer KJG, Kaplinger H, Miller J, Peterson M, Rhoads A, Rosenbloom P, Wall T, (2005) The Diggable City: Making Urban Agriculture a Planning Priority. Nohad A. Toulan School of Urban Studies and Planning, Portland

City of Portland (1975) Oregon, Ordinance No. 139598 
City of Portland Bureau of Planning and Sustainability (2010) Need for Strategic Code Package in 2010. City of Portland Bureau of Planning and Sustainability

City of Portland Bureau of Planning and Sustainability (2011) Urban Food Zoning Code Update Concept Report. City of Portland Bureau of Planning and Sustainability, Portland

City of Portland Bureau of Planning and Sustainability (n.d.) Project Advisory Group Wraps Up Discussions on the Five Topic Areas. Planning and Sustainability

City of Portland Bureau of Planning and Sustainability, Urban Food Zoning Code Update (2012) City of Portland Bureau of Planning and Sustainability, Portland

Friends of Portland Community Gardens (n.d.) About. Friends of Portland Community Gardens. http://portlandcommunitygardens.org/about/. Accessed 26 Dec 2013

Friends of Zenger Farm (n.d.) A Century Old Working Urban Farm. Zenger Farm. http://www. zengerfarm.org/about-the-farm. Accessed 13 Dec 2013

Gisler J, Cohen S, Gilroy A (2011) Memo to urban food zoning code update advisory group. City of Portland Bureau of Planning and Sustainability, 25 Apr 2011

Gragg R (2013) Zenger Farm Grows Community Ties. Portland Monthly Magazine, 03 Jun 2013

Growing Gardens (n.d.) About us. Gardening in Portland Oregon. http://growing-gardens.org/ about-us/. Accessed 08 Jan 2014

Harper A, Shattuck A, Holt-Gimenez E, Alkon A, Lambrick F (2009) Food Policy Councils: Lessons Learned. Institute for Food and Development Policy. Oakland, California

Hatfield M (2012) City Food Policy and Programs: Lessons Harvested from an Emerging Field. City of Portland Bureau of Planning and Sustainability, Portland

Hess DJ, Winner L (2005) Case studies of community gardens and urban agriculture. Vanderbilt University, Nashville

Johns A (2006) City to community gardeners: dig this. Portland Tribune, 02 May 2006

MacKenzie M, Cohen S (2007) The diggable city phase III: implementation strategies and recommendations. City of Portland, Portland

McWhorter O (1943) What the extension service of Oregon state college is doing on the victory garden program. Oregon State College, Oregon

Mendes W, Balmer K, Kaethler T, Rhoads A (2008) Using land inventories to plan for urban agriculture: experiences from Portland and Vancouver. J Am Plan Assoc 74(4):435-449

Metro (n.d.) Urban growth boundary. Metro: Making a great place. http://www.oregonmetro.gov/ index.cfm/go/by.web/id=277. Accessed 03 Dec 2013

Mickle L, Starin N (2009) East portland historical overview and historic preservation study. City of Portland Bureau of Planning and Sustainability, Portland

Nelson AC, Moore T (1993) Assessing urban growth management: the case of Portland, Oregon, the USA's largest urban growth boundary. Land Use Policy 10(4):293-302

Nelson AC, Pendall R, Dawkins C, Knaap GJ (2002) The link between growth management and housing affordability: the academic evidence, Discussion paper. Brookings Institution Center on Urban and Metropolitan Policy, Washington, DC

Oregon Department of Land Conservation and Development. History of Oregon's land use planning. http://www.oregon.gov/LCD/Pages/history.aspx. Accessed 02 Jan 2014

Portland City Council (2002) Resolution No. 36074

Portland City Council, Resolution No. 36272. 2004.

Portland Multnomah Food Policy Council (2006) The diggable city phase II: urban agriculture inventory findings and recommendations. City of Portland, Portland

Portland Multnomah Food Policy Council. FPC minutes 7-11-12. Portland Multnomah FPC 2012 meeting minutes, $11 \mathrm{Jul}$ 2012. http://www.portlandoregon.gov/bps/article/406124. Accessed 09 Jan 2014

Portland Multnomah Food Policy Council. FPC minutes 9-12-12, Portland Multnomah FPC 2012 meeting minutes, 12 Sep 2012. http://www.portlandoregon.gov/bps/article/421369. Accessed 09 Jan 2014

Portland State University Population Research Center, Certified Population Estimates (2012) College of Urban and Public Affairs, 2012. http://www.pdx.edu/prc/population-estimates-0. Accessed 06 Jan 2014 
Portland Parks and Recreation (2013) Community gardens policies and procedures. Portland Parks and Recreation

Portland Parks and Recreation, Community Garden Facts. Parks and Recreation (n.d.) http://www. portlandoregon.gov/parks/article/388440. Accessed 19 Dec 2013

Schukoske JE (2000) Community development through gardening: state and local policies transforming urban open space. N Y Univ J Legis Public Policy 351:3

Simantel M (2003) Report with recommendations to the Portland/Multnomah Food Policy Council from the land use subcommittee. Portland/Multnomah Food Policy Council, Portland

State of Oregon (1973) Oregon Land Conservation and Development Act

US Department of Agriculture (1943) Victory garden leader's handbook. US Department of Agriculture, Washington, DC 


\title{
A Case Study: Legalizing Commercial Agriculture in Boston - A Logical Step Towards Integrating Farming into Urban Life
}

\author{
Michele Kaufman and John Read
}

\section{The Path to Article 89}

In 1830, after many years of city farming, Mayor Harrison Gray Otis outlawed grazing on the Boston Common. In the 1920s, the Common was converted to victory gardens. In 1943, Boston's first community gardens were set up by the city, lining the Back Bay Fens and spreading out across the City of Boston. Today, Boston is home to nearly 200 community gardens, six urban farms comprising twelve plots, dozens of community orchards, and over 100 school gardens. However, commercial urban agriculture wasn't mentioned in Boston's existing zoning code prior to 2013, and was, therefore, implicitly not legal. In the fall of 2013, the City successfully passed a new zoning article, Article 89, which allows for commercial urban agriculture, and defines use regulations in the city's various zoning districts (http://www. bostonredevelopmentauthority.org/planning/planning-initiatives/urban-agriculturerezoning). The anticipated outcomes of Article 89 are far reaching-local employment opportunity, increased access to nutritious food, a more resilient food economy, and an increase in fresh food access - to name a few. The 3-year process that led to Article 89 featured extensive community conversation with advocates and dissenters, organizations and individuals. After an extensive pilot project and community outreach effort, eleven neighborhood meetings, a twitter chat, eighteen Urban Agriculture Working Group meetings, and multiple drafts of Article 89, it was passed by the Zoning Commission in December 2013. The adoption of Article 89 represents Boston's first substantive policy decision that supports urban agriculture, reflecting the expansion of an urban agriculture movement in Boston, the state, and the nation.

M. Kaufman • J. Read ( $₫)$

Urban Agriculture Americorps VISTA, Food Initiatives, Office of the Mayor,

Boston, MA, USA

e-mail: john.read@boston.gov 
The article itself was written by planners at the Boston Redevelopment Authority, Boston's planning and economic development agency, but the process was a truly collaborative effort between multiple municipal and non-governmental stakeholders. The Mayor's Urban Agriculture Working Group, the body that guided the content of Article 89, brought together a diverse group of individuals from agencies and organizations engaged in increasing food access. These include the Mayor's Office of Food Initiatives (http://www.cityofboston.gov/food), Massachusetts Department of Agriculture (http://www.mass.gov/agr), Boston Public Health Commission (http://www.bphc.org), The Food Project (thefoodproject.org), Boston Natural Areas Network (http://www.bostonnatural.org), City Growers (http://citygrowers. wordpress.com), The Move (http://getoutma.org/themoveteam), National Association of Industrial and Office Properties of Massachusetts (http://www. naiopma.org), Green Dorchester (http://www.greendorchester.org), MIT (http:// web.mit.edu), Top Sprouts (http://www.topsprouts.com), Warner Larson Landscape Architects (http://warnerlarson.com), Boston Public Market (http://bostonpublicmarket.org), and Chefs Collaborative (http://www.chefscollaborative.org).

This effort in support of urban agriculture in Boston was made possible, in large part, because of the diversity of food and agriculture initiatives that were simultaneously coming to fruition, calling on the need for systemic change across government agencies. These initiatives took place on the local level-the establishment of a central Public Market in the city, an increase in farmers markets throughout Boston, including two winter markets, the introduction of Boston Bounty Bucks (a matching program for Supplemental Nutrition Assistance Program (SNAP)) — and on the national level through conversations around healthy food led by first lady Michelle Obama, Michael Pollan, and the USDA, to name a few.

The national discussion has led to an increased visibility around food issues, with help from the Mayor's Food Policy Task Force, housed in the US Conference of Mayors; and founded/chaired by Boston's Mayor Tom Menino. Widespread support is evident in the $\$ 1.2$ million grant from the EPA to prepare a site for the Dudley Greenhouse in Boston (managed by The Food Project) along with $\$ 350,000$ from Communities Putting Prevention to Work, secured by the Boston Public Health Commission, for the build-out of the greenhouse and development of community outreach and education programs (Fig. 1).

This local and national dialogue led to the creation of the Office of Food Initiatives in 2010. The Mayor's Office of Food Initiatives (OFI) was started in 2010 with one of its directives being to increase food accessibility. One of the primary means by which the OFI seeks to achieve this end is through moving forward the conversation around urban agriculture, and providing the programmatic support that will allow these farms to survive and thrive.

Boston's history with farming and progressive policies, combined with an unusually engaged and vocal citizenry ensured that support for this process was distinctly top-down and bottom-up. The creation of Article 89 speaks to the city's commitment to the issues of food access, job creation, and sustainability. Placing urban agriculture into a concrete, regulatory document articulates Boston's (constituents 


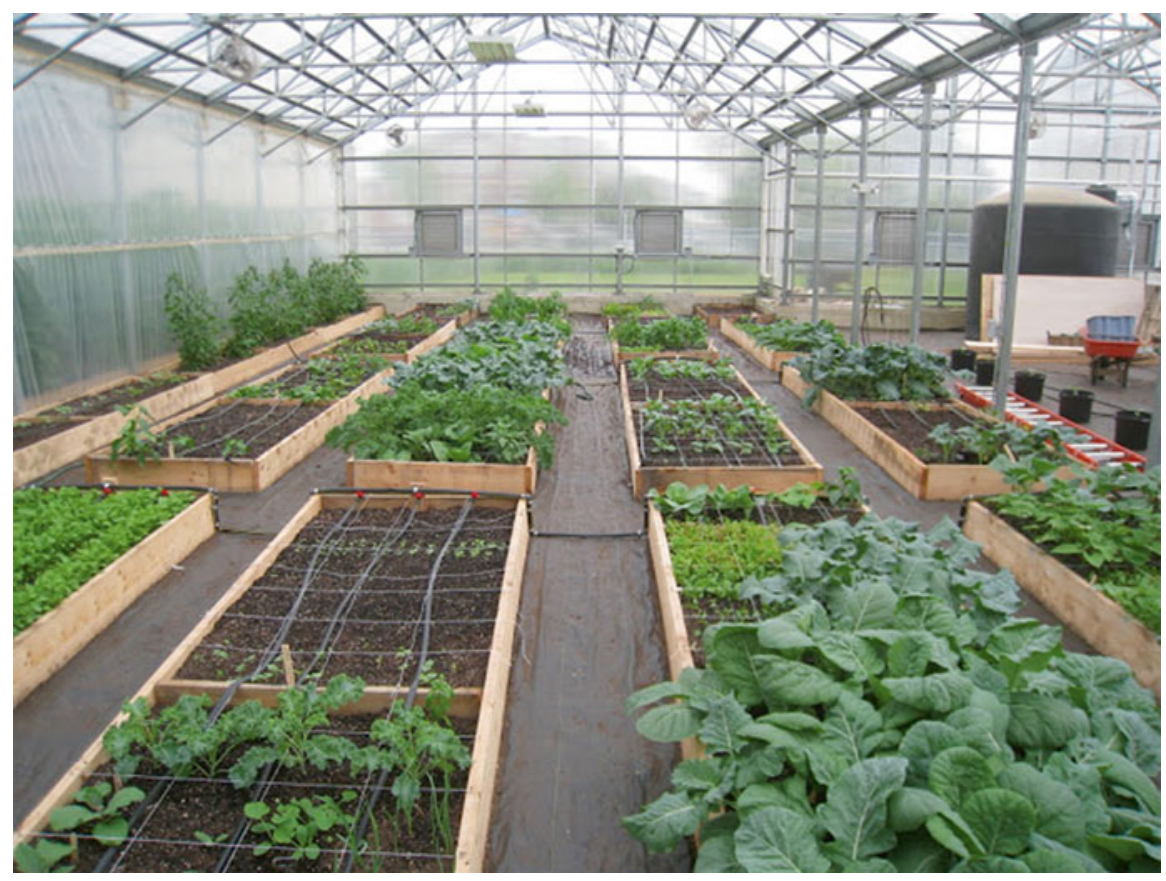

Fig. 1 Raised bed plots in the Dudley greenhouse. Funding for the greenhouse came from US EPA for site preparation and Communities Putting Prevention to Work for build out and community outreach and education programs

and city officials alike) pledge to make healthy, local food accessible. This sort of collective community action isn't new. Previous examples of the City's efforts merging with community interests include Boston Bounty Bucks, bostonCANshare (a fundraiser to support Boston Bounty Bucks and low income households in need), the Healthy on the Block Corner Store Initiative (increasing healthy food stores in food deserts throughout the city), and food trucks (which are required to offer healthy items if they are parked in publicly owned locations). In Boston, power emanates from the neighborhoods. Constituents drive change. Through merging political action with community action, Boston is able to create sustainable solutions backed by its constituents.

\section{What Makes Boston Unique?}

To many people, Boston is the city that invented America, so the fact that its citizens are civically and politically engaged should not come as a surprise. The commitment to urban agriculture that helped usher Article 89 into existence is a function of 
those constituents and stalwart leadership of the former longstanding Mayor Thomas M. Menino, as well as the city's emphasis on transparency and openness, on innovation, and on listening to constituent concerns.

The Urban Agriculture Working Group provided a space for farmers to come to the table, share their thoughts and concerns, and play a part in developing the policy around zoning for urban agriculture. John Stoddard, co-founder of Higher Ground rooftop farm, initially thought the zoning code would be too restrictive, and as a result of his participation in the working group, he now feels that the benefits outweigh the costs because the concreteness of a zoning code articulates that this movement is not a fad, and shows that the City will provide farmers with policy and programming support.

The Boston metropolitan area contains 60 colleges and universities- 30 within Boston's city limits. One in three living in Boston is between the ages of 20 and 34, the highest ratio of any major city in the country (www.onein3boston.com). Boston's youth and young adult populations bring an idealistic and passionate mentality to the city that is a necessary aspect of successful social and environmental activism. Young people in Boston have involved themselves in food in a number of ways. They are food truck owners, non-profit employees, students involved in communitybased courses, entrepreneurs at any of Boston's several thousand food start-ups, and beginning farmers. Since commercial urban agriculture is a relatively new concept in Boston, recent graduates are drawn to the conversation. They want to be a part of the healthy, local food revolution.

Mayor Thomas M. Menino played a critical role in the successes of food initiatives in the city. He was the city's longest serving mayor, in office for 20 years, during which time, he engaged deeply with constituents around food, and moderated a sustained conversation around food access. As City Councilor, Menino helped establish the Roslindale Farmers Market, one of the first markets to accept food stamps. Well aware of the correlation between socio-economic status, food access, and health, he was committed to insuring that new supermarkets, healthy corner stores and farmers markets were located in food deserts such as Grove Hall and Jackson Square. Beginning farms in these neighborhoods is a natural extension of these policies.

Transparency was always a focus for Mayor Menino and the Office of Food Initiatives. True transparency in city government allows the people of Boston to trust and engage with their municipal authority. Glynn Lloyd, a Boston food entrepreneur, along with a number of other constituents throughout the city, capitalized on the open relationship with city government. Four years ago, Glynn and his counterparts around the city wanted to begin growing food for their businesses on abandoned lots. They approached the city about converting abandoned lots into farms, and found that commercial agriculture was not mentioned in the zoning code. When the OFI got word of their initial failed attempts, the Mayor made re-zoning for urban agriculture a priority. It was at this point that the Mayor formed the Urban Agriculture Working Group (Fig. 2). 


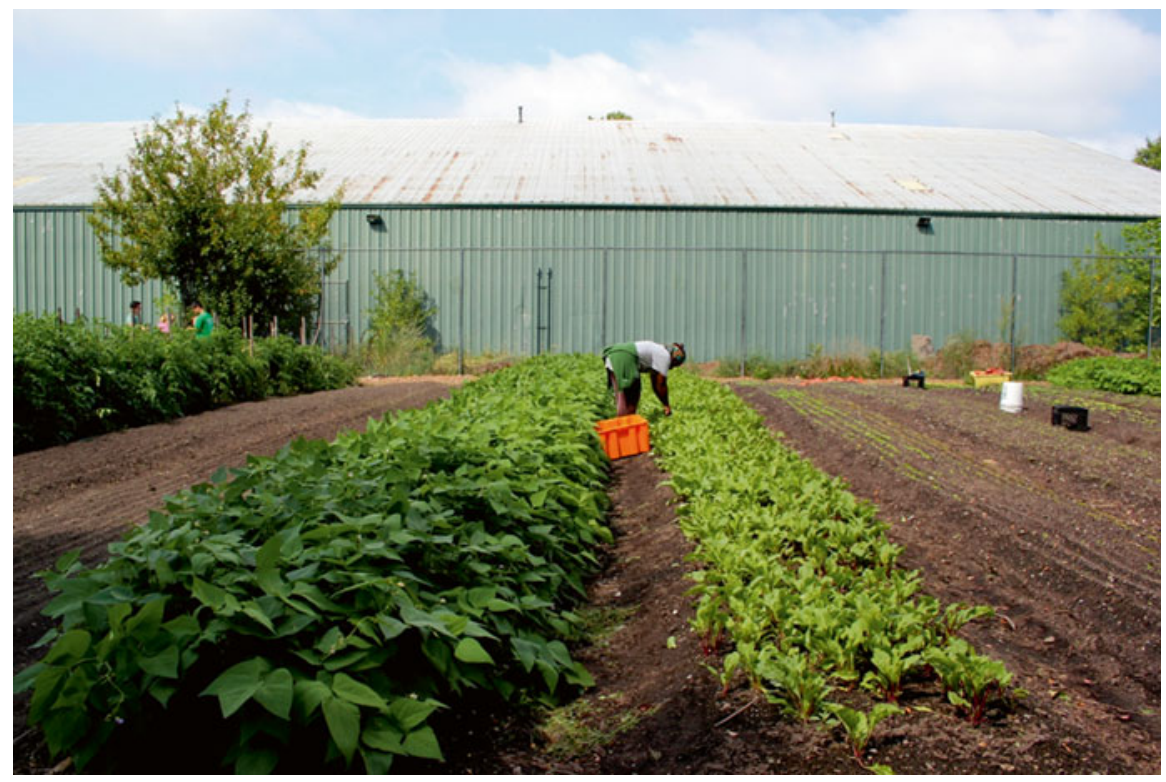

Fig. 2 One of City Growers' six farms - this one located behind a tennis club in Dorchester

Urban growing, however, has been occurring in Boston prior to Article 89. Community gardens continue to thrive and grow today, though Boston had community gardens well before the recent resurgence in local food and urban farming. The city has nearly 200 community gardens, attracting individuals across the city to over 5000 individual and shared plots. In fact, Boston has one of the largest numbers of community gardens per capita of any city in the country. Valerie Burns, former President of Boston Natural Areas Network, a non-profit organization that operates most of the community gardens in the city, provides a temporal perspective on community gardens. In the 1970 s, community gardens were part of a strategy to fight blight in the city. Throughout the 1980s and 1990s, gardens became more of an amenity that neighborhoods expected, and people became more focused on growing food for themselves and their neighbors. More recently, constituents have capitalized on community gardens' ability to address public health issues including diabetes, obesity, and food insecurity. Not only has the community garden effort generated support for urban agriculture, but it demonstrates the potential for fruitful urban growing. For people who may be hesitant to believe that a city is an appropriate place to grow food, community gardens provide proof that it can be done. Boston's unyielding support is apparent in that fact that the city has spent $\$ 10$ million refurbishing land for community garden use. The Nightingale Street plots in Dorchester exemplify this effort as they were expanded from 30 to 130 community garden plots in 2011. 
Community Garden Box: BNAN owns 59 of the city's community gardens, though they coordinate community garden programs across the City. Based out of downtown Boston, BNAN is central to the garden transformation of the city. Those not owned by BNAN are owned by a variety of city and state organizations ranging from the State Depart of Conservation and Recreation to Boston Department of Parks and Recreation to Boston Public Schools. BNAN provides support in a variety of forms- they are available for individual consultation, they provide youth education programs, and courses open to the public around gardening.

BNAN offers workshops throughout the year, covering topics ranging from vegetable gardening, to beekeeping and composting. They also work closely with the city around backyard composting. BNAN offers courses about what food scraps to compost, how to build compost bins, and how best to use the end product. BNAN then works closely with the City of Boston's Department of Public Works (DPW). Twice a year, DPW conducts a yard waste collection, processes the yard waste into usable compost, and provides the compost for the City's community gardens. In addition, they coordinate the soil testing of the compost before it is given to community gardeners. While BNAN is a non-profit organization, they work collaboratively with the City and Boston's constituents (Fig. 3).

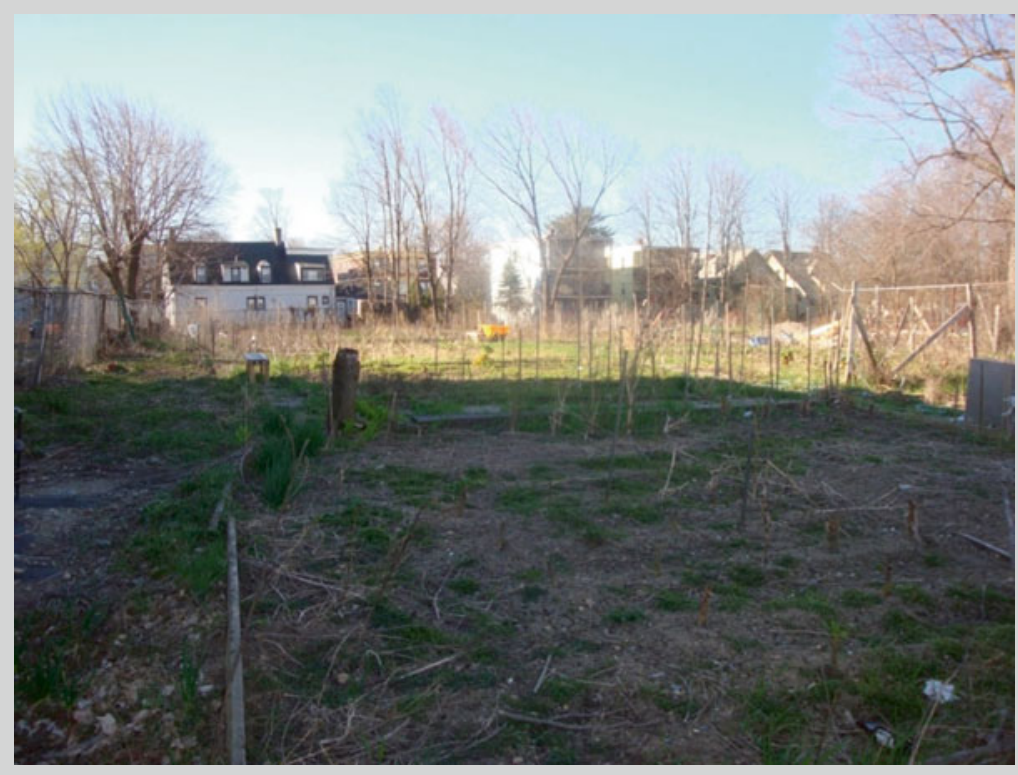

Fig. 3 The before and after transformation of the Nightingale Street community garden plots 


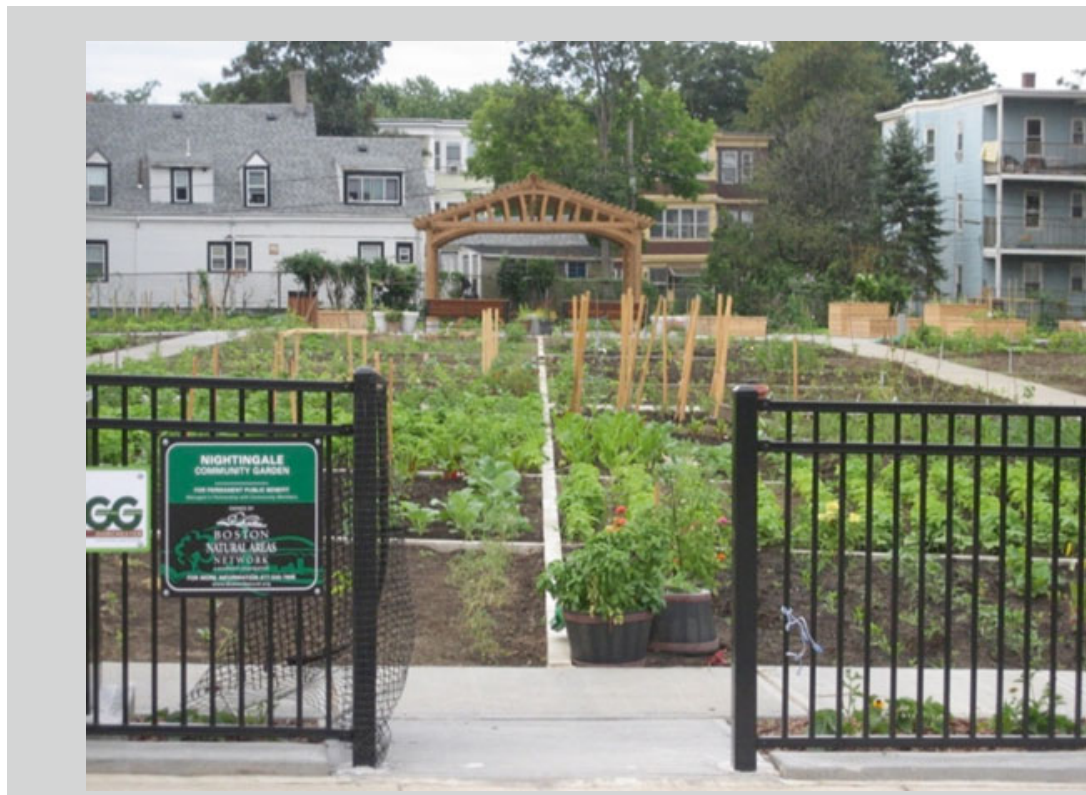

Fig. 3 (continued)

As with any city, spatial constraints in Boston have required Boston's current farmers to re-examine what it means to be a farm. Growing food in a small dense city necessitates alternative farming techniques including hydroponics, aquaculture, freight containers, and rooftop farms (Figs. 4 and 5).

Danielle Andrews, greenhouse manager for The Food Project in Boston, expresses both the opportunities and challenges associated with planting in the middle of a rapidly developing cityscape. While greenhouses have the potential to be much more productive than ground farms, she explains that they also come with increased risk of disease and pests due to the close proximity of plants. Danielle has had to learn the nuances of greenhouse farming, and she illustrates the fact that farmers in Boston learn unique ways of farming in order to be productive. The hope for Boston is continued agricultural innovation that includes a variety of growing methods in order to best capitalize on the small land parcels spread across the city.

\section{The Preamble to Article 89}

Previous agriculture efforts throughout Boston set the stage for the creation of Article 89. Six farms have been running in Boston, some for over 20 years- all of which the City was aware of but not all of which held the same farming permit. Prior to Article 89, the City addressed permitting for each farm as they needed, leading to varying levels and kinds of permits. Some have gone before the Zoning Board of 


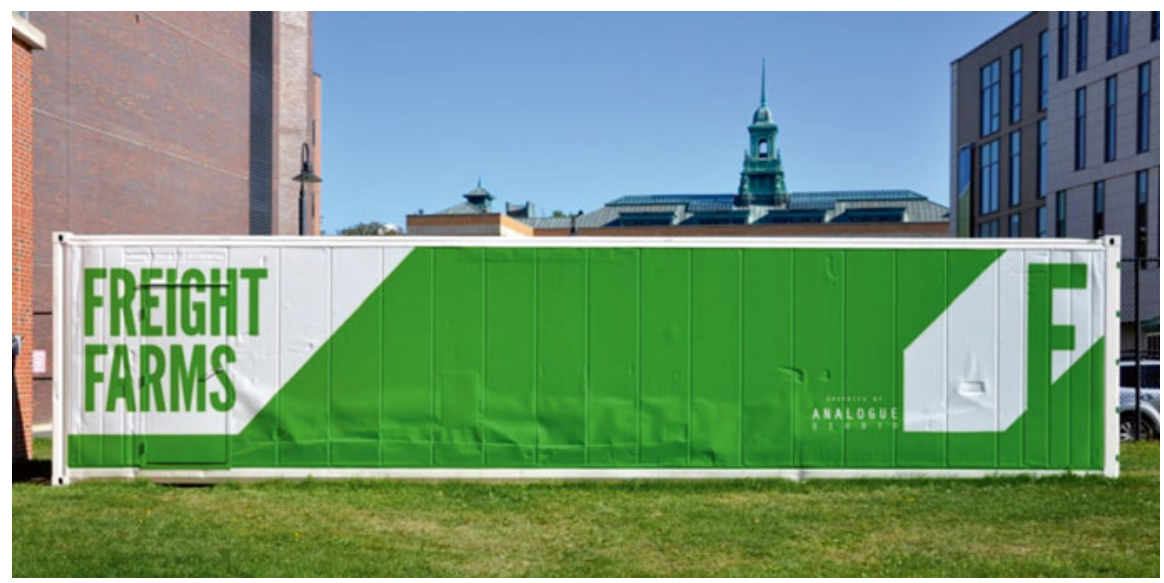

Fig. 4 A freight container used for hydroponics in urban environments

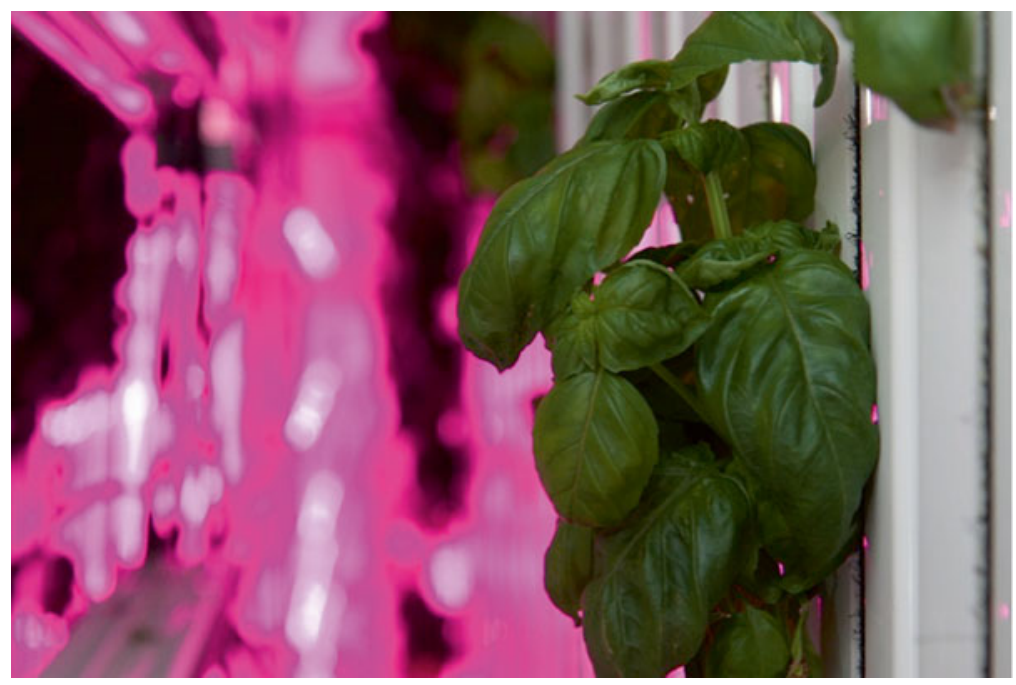

Fig. 5 Basil growing under grow lights inside a freight container

Appeals and while others attained the necessary permit through Boston Inspectional Services (ISD). The Food Project, ReVision Urban Farm (http://www.vpi.org/revision), Serving Ourselves Farm (https://www.localharvest.org/serving-ourselvesfarm-M16003), City Growers (http://citygrowers.wordpress.com/), Allandale Farm (http://www.allandalefarm.com/), and Higher Ground Farm (http://www.higherground-farm.com) all applied for varying permits, except for Allandale Farm which was exempt from city statute because they are over two acres. These farms are a benefit for the city and no city agencies have attempted to shut them down, still they are not included in the zoning code. Each farm offers a unique approach to addressing critical urban food issues- by their methods and focuses. 
The mission of The Food Project, started in 1991, is to create a thoughtful and productive community of youth and adults from diverse backgrounds who work together to build a sustainable food system. They engage with youth in and around the city, grow food for restaurants, community members, and food pantries, and offer a learning experience for youth around food access and the Metro Boston food system.

ReVision Urban Farm was started in 1990 as a part of Victory Programs - a registered 501(c)(3) organization that provides support to individuals who are homeless, abuse substances, or have chronic health issues. ReVision began growing food for their shelter and rehabilitation center, and has since expanded to selling to broader communities, including lower Dorchester and Mattapan, two of the most underserved neighborhoods in Boston.

Serving Ourselves Farm is unique in that it was started by the Boston Public Health Commission and continues to be operated by them. The farm is located on Long Island with the goal of providing job training to individuals living in the accompanying Long Island Homeless Shelter. They run a CSA program and sell at a farmers market. The farm applied for a zoning variance and acquired a special Use of Premises Permit in order to operate.

City Growers, co-founded by Glynn Lloyd (the aforementioned entrepreneur), grows produce primarily for local restaurants and bodegas. City Growers works closely with City Fresh, its sister organization, which prepares and provides meals to underserved individuals and organizations (hospitals, senior centers, schools).

Allandale Farm is probably best described as peri-urban, though it is located partially within the city limits, and is Boston's longest running working farm.

Higher Ground Farm, Boston's first rooftop farm, started growing in the spring of 2013. What started with a milk crate growing system will be transformed into a 55,000 square foot green roof production site. Higher Ground grows produce for local restaurants and food trucks throughout Boston.

In addition to the efforts by these farms, there were many efforts by interested individuals that led to the discussion of regulatory change. In early discussions in 2010 it became clear that intrinsic to the movement's success would be collaboration among diverse organizations and individuals. For example, the Boston Redevelopment Authority, Department of Neighborhood Development, Boston Public Health Commission, local farmers, and social and environmental non-profit organizations such as The Kendall Foundation, began to meet bi-monthly at the Boston Food Policy Council, and bounce ideas off of one another, merging their areas of interest such as public health, environmental health, and social justice.

After initial meetings of the Urban Agriculture Working Group, it became clear that a pilot project should be executed to advance urban agriculture in the city.

\section{The History and Making of Article 89}

The Urban Agriculture Rezoning Initiative was rolled out in two phases. Phase I, the Pilot Urban Agriculture Rezoning Initiative, focused on a small number of City owned properties in South Dorchester, a part of the city where the City's Department 
of Neighborhood Development owns significant amounts of vacant land, and that is home to many families of limited income. A collaborative effort between the OFI, the Department of Neighborhood Development (DND), and the BRA, the Pilot Urban Agriculture Rezoning Project involved the creation of an Urban Agriculture Neighborhood Design Overlay District on two city-owned properties in Dorchester and the issuance of a Request for Proposals (RFP) to identify prospective farmers. Extensive community participation including five community meetings and regular dialogue with community leaders was involved in the rezoning process, RFP process, and selection of the farmers. Both sites lay down a geotextile barrier, and brought in outside soil as a growing medium. The City provided support in this process through testing imported compost, providing results to the farmers, allowing them to choose which compost they wanted to use on their site, and funding the delivery of the compost. Boston's history of lead contamination combined with concerned community members led to the creation of an extensive soil safety protocol, unlike that of any other city in the country. The outcome of Phase I was the establishment of two farms, one operated by a private operator, City Growers, and the other operated by the nonprofit organization, Victory Programs. Both farms planted their first crops in spring, 2012.

Phase II, begun in January 2012 and known as the Citywide Urban Agriculture Rezoning Initiative, involved a more far reaching, comprehensive undertaking to amend the City of Boston's Zoning Code to support a wide array urban agricultural activities all across the city. Together with the Mayor's Office of Food initiatives, the BRA launched Phase II through a "Kickoff and Visioning" meeting in downtown Boston, where keynote speaker and Growing Power founder and CEO Will Allen an audience of over 270 members of the public - one of the BRA's largest public meetings in recent memory. After receiving inspiration from Will Allen's message of knitting strengthening communities through the cultivation of food, members of the public were invited to describe their vision for the future of urban agriculture in Boston. Many of their ideas would find their way into Article 89, the new Zoning Code chapter for Urban Agriculture.

Following the Kickoff and Visioning Meeting, the BRA convened the first series of meetings of the Mayor's Urban Agriculture Working Group, comprised of 22 farmers, farming advocates, experts from different arms of the food industry, and neighborhood representatives whose role was to advise and guide the OFI staff and the BRA in the development of Article 89.

By May, 2013, after 17 Working Group meetings, each of which was attended by anywhere from 30 to 50 members of the public, the Working Group felt that it had a set of draft recommendations for Article 89 that could be presented to Boston's neighborhoods. Accordingly, the BRA scheduled a series of eleven neighborhood meetings and one twitter chat in June and July 2013, capturing every neighborhood in the City. Nearly 250 persons attended these meetings, and the response was generally very positive.

The BRA Board held a public hearing in November 2013 to petition the Boston Zoning Commission to approve Article 89. Public support for Article 89 was made clear by the fact that the vast majority of speakers voiced enthusiastic support for it. The same was true for the Zoning Commission in December. 
The final version of Article 89, available on the project webpage at http://tinyurl. com/BRARezoneUrbanAgriculture/, contains the following key provisions:

Ground-level Farms up to one acre will be allowed by right in every zoning district in the City. Farms over an acre will be allowed by right in industrial areas and conditional everywhere else.

Roof-level Farms up to 5000 square feet will be allowed by right in every zoning district in the City. Above 5000 square feet roof level farms will be allowed in industrial, institutional, and large-scale commercial zoning districts and conditional in all other districts. All roof level farms will require a Fire Inspector Report prior to permitting.

Comprehensive Farm Review (CFR), a staff level design review that will be conducted by the BRA intended to make sure farms make good neighbors, will be required for ground level farms larger than 10,000 square feet and roof level farms larger than $5000 \mathrm{sf}$, with some exceptions for farms in industrial and institutional districts.

Accessory composting is allowed on any urban farm as long as the composting does not occupy more than $7.5 \%$ of the farm area. The limit is intended to discourage commercial composting, which would require special permitting by the Commonwealth of Massachusetts.

Soil Safety Protocol will apply to all urban farms in Boston that grow in soil. Farmers must plant in clean soil, and any imported soil must be tested. All farms using soil must comply with the Soil Safety Protocol published by the Boston Public Health Commission (http://www.bostonredevelopmentauthority.org/ getattachment/d37db157-5bc8-479c-aa73-dc462441519a).

Aquaculture and Aquaponics facilities, as a primary use, are allowed in industrial zones, forbidden in residential zones, and conditional in all other zoning districts. Use regulations for accessory facilities (that is, occupying $25 \%$ or less of a lot) are more permissive (see Article 89, Section 89-11).

Hydroponics facilities as a primary use are allowed in all zoning districts, with the exception of residential districts where they are conditional. As an accessory use, hydroponics facilities are allowed in all zoning districts.

Freight containers for Controlled Environment Growing as a primary use are allowed by right in industrial districts; conditional in institutional, large scale commercial and small scale commercial districts; and, forbidden in residential districts. Somewhat less restrictive use regulations apply for freight containers as an accessory use.

Farmers Markets will be allowed in any area where retail is allowed by underlying zoning (which includes most non-residential zoning districts) and conditional everywhere else.

Accessory farm stands up to 200 square feet will be allowed wherever any urban farm is allowed as well as in any district where retail uses are allowed. Otherwise, farm stands are conditional.

Accessory keeping of hens and bees was already addressed in Boston Zoning Code prior to Article 89 and is not allowed in most zoning districts. Article 89 
does not change this. Where the keeping of hens and bees is conditional, Article 89 defines the permissible size of beehives and coops, numbers of allowed hens and beehives, and other size and maintenance requirements. Changing the use regulations for the keeping of hens and bees is a decision left up to individual neighborhoods and can be done by petitioning the BRA. (See Article 89, Section 89-9 and Section 89-10.)

While one cannot overstate the importance of Article 89 in terms of removing barriers and paving the way for commercial farming in Boston, still more work needs to be done within the city to facilitate permitting of farms.

All meeting materials and notes, background reports and related publications for this initiative are posted on the BRA's project webpage at: http://www.bostonredevelopmentauthority.org/document-center?program $=60$

\section{Challenges and Future Visions}

The OFI is providing programmatic support to new farmers through collaboration with municipal agencies, non-profit organizations, for profit organizations, and supporting foundations. As with any socially and environmentally focused initiative, time and resources play a vital role in the success of urban agriculture in the city. Boston will need to explore solutions to the fact that many constituents hope that urban agriculture will be able to provide affordable food to people in the city, and simultaneously allow urban farmers to make a living or supplement another job's income through farming. Along similar financial lines, Boston needs to find a successful balance regarding land development and other neighborhood benefits. With many vacant parcels available, the city must balance urban agriculture endeavors with housing development. This presents a difficult decision around land use- urban agriculture aims to stimulate the economy and increase food access and community engagement. Meanwhile housing for all incomes is in great demand across Boston.

The re-zoning initiative in Boston illustrates the city's commitment to a longstanding, growing, urban agriculture initiative. It is important to note, however, that some farmers are wary of the regulatory process, and fear that it may restrict their growing efforts and plans. To address the concerns of farmers, the city is working with Harvard Food Law \& Policy to create a "permitting roadmap" that is designed to make explicit and transparent all the permitting steps involved in permitting a farm in the city. The Office of Food Initiatives has also gained two AmeriCorps VISTA members to provide permitting and resource support to new farmers. The OFI has applied to multiple sustainable agriculture grants in order to provide support to beginning farmers for soil cost, marketing assistance, physical farm infrastructure, and farm and business training. In order to ensure than an otherwise technical document is accessible to the lay person, the BRA has created an "Article 89 Made Easy" that takes the information from Article 89 and puts it in more accessible and readable language. 
Boston's constituents have high hopes for the evolution of commercial agriculture in the city. To get there, city residents need an increased awareness about the extensive economic, social, cultural, and health benefits that urban agriculture can bring to the city. Education around these benefits is going to be critical to the success of the program particularly in low-income neighborhoods. The city needs to support interested farmers of all backgrounds and means so that they can capitalize on the urban agriculture opportunities, thus providing food for all of Boston. Boston is welcoming to all people, and hopes to create a diverse and flourishing community and economy by which urban agriculture plays a vital role.

Acknowledgements We interviewed many individuals to hear their perspective about urban agriculture in Boston. Thank you to:

Andy Kendall-The Kendall Foundation

Bruce Fulford-City Soil

Catalina Lopez-Ospina-Serving Ourselves Farm

DanielleAndrews-The Food Project

Edith Murnane-Mayor's Office of Food Initiatives

Glynn Lloyd-City Growers

Greg Watson-Massachusetts Department of Agricultural Resources

Howard Leibowitz-Mayor's Office

Jay Lee-Department of Neighborhood Development

Jean Morgan-Tufts New Entry Farmer

John Stoddard-Higher Grounds Farm

Mark Smith-Brookwood Community Farm

Sara Brown-Department of Neighborhood Development

Shani Fletcher-ReVision Urban Farm

Sheila Dillon-Department of Neighborhood Development

Stephen Chan-The Boston Foundation

Tad Read-Boston Redevelopment Authority

Valerie Burns-Boston Natural Areas Network 


\section{Index}

A

Acceptance, 46, 60, 61, 97, 118-119, 122, 123 Agriculture, 27, 42-51, 53, 54, 105, 138, 141, $147,153-155,157,158,161-168,191$, 198, 202, 213, 229-232, 241, 293, 296, 325-327, 331, 333-335, 339, 341-343, 346-349, 363-366, 368-370, 373, 374, 377-378, 380, 381, 383-386, 389, 390, $392,395,397,398,400,401$

Amendment, 36, 37, 40, 42, 43, 48, 95, 96, 98, $115,119,145-147,149-151,153,154$, $157,158,166,318,384$

Anaerobic digestion, 108-110, 121-123, 142

Animals, 5, 14, 18, 28, 56, 94, 127, 174, 181, 193, 195, 200, 201, 237, 240, 293, 294. $363,365-367,384$

Aquaponics, 236, 237, 293-307, 399

Archaea, 181, 188, 189, 193, 196, 197

Article 89, 389-391, 393, 395-400

Available area, 358

\section{B}

Bacteria, 28, 29, 35, 39, 178-181, 183-185, 187-189, 193, 196, 199, 201, 297, 299, 301

Bees, 61, 207-222, 236, 240, 276-279, 325, $332,366,384,399$

Best practices, 314-317

Biogeochemical transformations, 195
Biosolids, 6, 15, 28, 32, 35, 37, 40, 42-49, 57, 58, 93-97, 99-101, 109, 113, 119, 146-151, 153-158, 166, 186, 198, 359

Bird

communities, 229, 231

diversity, 230, 231

Brownfields, 339-343, 346, 349

C

Canning, E., 11

Carbon dioxide $\left(\mathrm{CO}_{2}\right), 15,28,47,48,66,94$, $112-115,121,122,133,145,154,165$, $175,186,198,273,298$

Carbon sequestration, 15, 113, 114, 145, 147, 149, 151, 157, 166, 201

Carbon storage, 147, 149, 150, 158, 198

Centralized compost, 107, 110, 115, 117, 119, 120,122

Chickens, 13, 18, 49, 61, 73, 186, 236, 237, $269,271-273,275-278,365,366$

City of the future, 1-20

Climate, 2, 5, 16, 31, 47, 69, 84, 89, 114, 145, $153-155,165,176,177,187,255,272$, 284, 296, 298

Climate change, 47, 145-151, 153-155

Cloches, 255, 257

Clopyralid, 141

Commercial agriculture, 389-401

Commercial organics, 128, 135, 136 
Communal space, 315, 316

Community

agriculture, 161-168

garden, 2, 7, 8, 11, 12, 14-17, 43, 46, $100-102,137,140,161,163,164,166$, $167,207,211,213,219,220,222,230$, 235-237, 241, 245, 258, 287, 297, 311-323, 327, 343-346, 349, 356, 360, $365,366,368,369,373,375,376,379$, $381,382,384,385,389,393,394$

planning, 314

Compost(ing), 35-37, 40, 42, 47-49, 58, 75, $87,93,95-105,107-113,115-123$, $125,126,128-142,146,148-151$, 153-158, 163, 165-167, 188, 245, 248, 249, 266, 272-274, 276, 277, 299, 318, $322,327,359,365,394,398,399$

technologies, 131-136, 141

Conflict resolution, 317

Conservation, 16, 26, 60, 76, 93, 99, 188, 209, 213, 221, 229, 231, 240, $335,374,394$

Contaminants/contamination, 25, 27, 28, 33, $55-57,59,69,73,76,95,99,122,136$, 138-139, 142, 248, 296, 326, 334, 340-345, 351-353, 398

Conventional agriculture, 2, 3

Crop selection, 289, 398

Cultivated city garden, 207-222

Cultural, 2-5, 7-11, 14-17, 20, 25, 213, 284, $367,370,401$

Curbside, 19, 48, 56, 108-110, 119, 122, 125, $126,128,129,133,136,192,351-360$ gardens, 354, 355

\section{D}

Diggable City, 378-383

Diversity, 18, 192, 193, 195-196, 199, 200, 208-210, 212, 213, 220, 222, 230, 231, $238,241,294,317,390$

$\mathbf{E}$

Ecological, 4, 12, 20, 61, 200, 229, 231, 238, $240,241,297$

Economics, 1, 5, 17, 18, 54, 60, 66, 93, 107-123, 141, 192, 210, 213, 266, $343,390,401$

Ecosystem services, 1-20, 25, 94, 188, 192

Education, 99, 136, 137, 139, 210, 222, 235, 266, 286-287, 290, 307, 333, 377, 390, $391,394,401$
Emissions, 14-16, 47, 66, 101, 108, 110, $112-115,121,122,145,153-158,161$, $163-168,198,334$

Environmental benefits, 66, 158, 328

Environmental Protection Agency (EPA), $15,43,57,64-66,95,99,107,113$, $114,119,155-157,167,240$, 339-346, 349, 358, 390, 391

Exposure, 4, 73, 84, 119, 199, 201, 202, 333, 343,351

\section{F}

Fish, 133, 293-297, 299-302, 304, 305 farming, 295

Flower, 11, 208, 210, 212, 215, 220, 222, 275, $284,315,316$

Food challenge, 278

Food miles, 326-327

Food Policy Council (FPC), 378, 379, 381, 384

Food production, 1, 5, 8-16, 18, 20, 32, 46, $49,56,101,102,153,158,167,192$, $269,288,311,335,339,342,349,351$, $360,366,368,373-375,385,386$

Food security, 207, 209, 221, 282, 295 , 339,375

Food waste, 42, 48, 74, 95, 107-123, $125,126,128,131,149,153$, $165-168,248$

Funding, 8, 213, 282, 290, 307, 340, 341, 343, $381,384,391,398$

Fungi, 28, 29, 87, 181-185, 187-189, 196, 197

\section{G}

Garden

bed, 250, 269, 272, 273, 275, 355

films, 254

GHG. See Greenhouse gas (GHG)

Government, 8, 70, 72, 74, 75, 102, 141, 236, $340,342,343,363,367,368,370,373$, $378,386,390,392$

Graywater, 69-76

Green buildings, 8-9

Greenhouse, 46, 93, 99, 101, 108, 112-116, $122,151,153-154,158,161-168,191$, 195, 201, 202, 255, 269, 273-274, 277, $299,302,303,325,390,391,395$

Greenhouse gas (GHG), 46, 93, 99, 101, 108, 112-115, 122, 151, 153-158, 161, 163, 164, 166-168, 191, 195, 201, 202 
Green jobs, 122, 333

Green rooftop, 8

Greenspace, 153

Grey water, 53, 54, 57, 59-61, 65

\section{H}

Habitat, 2-4, 7, 10, 16, 35, 89, 173, 176, 177, 184, 188, 208-212, 215, 217, 221, 222, 229-232, 235, 236, 238, 241, 269, 279

Harvest, 3, 4, 8, 16, 49, 66, 82, 85, 86, 89, $164,167,168,222,246,259,270,276$, 300,357

Heirloom, 246, 259, 281, 282, 284, 287, 289

Honey, 11, 14, 47, 207, 208, 210, 213-215. $220,277,278,332$

Hydroponics, 296, 297, 325, 395, 396, 399

I

Inland aquaculture, 294-297

Integrated landscapes, 10, 15

Irrigation, 28, 34, 36, 37, 50, 53-55, 59, 60, 62, 64-66, 69-76, 79, 82, 84, 87-90, $101,162-165,167,219,313,328$, $329,331,334$

L

Landfill, 15, 108, 114, 116-118, 120-122, 125, $126,128,129,131,133,136,138,142$, $153-158,165,166,381$

Landscape fabrics, 254-255

Lasagna gardening, 272

Leadership, 297, 313, 316-317, 373, 379, 392

Legislation, 335, 363, 364, 370, 375

Lettuce, 141, 161-168, 257, 274, 296, 298, 300, 335

Life cycle assessment, 26, 66, 154, 161, 167

M

Methane, 46, 112-114, 117, 153-155, 157, $166,167,200-202$

Microbes, 28, 40, 42, 73, 173-189, 191-200, 202

Microbial

biomass, 195

diversity, 195, 300

ecology, 173-189

Microbiome, 191, 193-194, 199-201
$\mathbf{N}$

Nesting, 208, 209, 213-221

Non-potable, 53-66, 101

No till, 4, 149

Nuisance, 72, 364, 365

Nutrient, 10, 20, 25, 33, 38-42, 74, 82, 94, 121-122, 148, 158, 166, 174, 175, 177, 181, 184, 186-188, 192, 196, 295, 298-300, 305, 331

content, 148

\section{O}

Open community model, 284

Operation costs, 285

Ordinance, 365-368, 375

Organic content, 74, 343

Organic matter, 26-28, 30, 31, 35, 38, 39, $41,42,46,56,57,87,89,94,96$, 97, 99, 113, 145, 148, 150, 174, $175,177,184,186-188,331$, $351,353,355$

Organic residuals, 93, 101, 153, 154, 158

Organic waste, 93, 110, 122, 153, 154, 158, 297, 299, 300

Organics collection, 125, 127-129

Organizing, 290, 312-315

\section{$\mathbf{P}$}

Parking strips, 7, 311, 351, 356, 358

Pathogens, 28, 43, 56, 57, 59, 72, 76, 94, 95, 97-99, 141, 180, 185, 189, 193, 194, 199, 256, 295

Permaculture, 5, 10, 12, 15, 61, 271-272

Permitting, 8, 60, 367, 395, 399, 400

Pest management, 47, 300

Plant diversity, 207, 230

Plant health, 65, 173, 184, 185, 330

Plant interaction, 36, 119, 174, 191, 196, 199, 208, 322

Policy, 296, 323, 342, 367, 368, 370, 378-381, $383,384,386,389,390,392,397,400$

Pollen, 208, 211, 212, 219, 221, 222, 301

Pollination, 47, 207-210, 213, 214, 221-223, 277

Pollinator, 2, 11, 16, 207-209, 213, 221-223, 352

P-Patch, 8, 245, 246, 248, 249, 255, 257, 258, $265,266,320-323,356,358$

Precipitation, 37, 54, 55, 80, 175 
Predators, 217, 237, 294, 301

Productivity, 25, 27, 33, 50, 93, 99, 145-149, 151, 196, 245-247, $249,258,260,265$

Provisioning, 2, 3, 16

Public health, 95, 195, 339, 341, 342, 393, 397

\section{R}

Rain, 4, 15, 28, 36, 55, 56, 75, 79-84, 86, 88, $89,162,167,328$

Rainwater, 9, 28, 53-55, 58-59, 66, 72, $79,80,82,84,85,88,133,162$, $165,168,298$

Raised bed, 6, 32, 34, 43, 49, 162, 192, 217, $236,248,250,269,313,353,355,359$, 360,391

Reclaimed water, 53, 54, 57, 58, 63-66, 73

Regulating, 2, 11, 14-16, 25, 134, 196, 363

Remediation, 200, 339, 343, 344

Reuse, 59-61, 64, 69-76, 95, 101, 254, 296, 340-342, 349

Rezoning, 389, 397, 398

Right to Farm Act (RTFA), 364-365, 367, 370

Roof, 60, 66, 84, 88, 89, 213, 214, 273, 277, 325-329, 331-334, 397, 399

Rooftop, 5, 8, 9, 11, 15, 325-331, 333-335, $385,392,395,397$

Row covers, 254-255, 274, 275

Runoff, 3-5, 8, 10, 15, 16, 20, 35, 72, 81-89, $196,269,328,331,334,355$

\section{S}

Seedlings, 72, 209, 241, 247, 254, 300, 365

Seeds

distribution, 16, 288, 289

exchange, 281, 284

library, 281, 282, 284-286, 288-290

quality, 286

saving, 284, 286-290

Shared space, 311,316

Sheet mulching, 272

Site selection, 282

Soil

carbon, 15, 26, 35, 46, 115, 145-151, 153,158

components, 27,28

formation, 26, 148

health, 26, 46, 188

microbes, 28, 39, 42, 145, 173, 174, 177, $178,180,181,184-188,196$ nutrients, 28, 174, 187

profile, 30, 31, 50, 75, 89, 182, 187, 218

properties, $27,51,360$

Stormwater, 5, 10, 15, 16, 19, 53-57, 59, $65,66,99,137,325,328,331$, $353,356,377$

Structural concerns, 328-329

Superfund, 94, 126, 339, 340, 344, 349

System design, 300, 302

$\mathbf{T}$

Theft, 257, 322, 355, 360

Transportation, 14, 20, 47, 108, 140, 141, 153, $155,158,163-164,167,296,326,356$, $374,380,382$

Treatment, 2, 10, 20, 25, 43, 44, 55-59, 61, 63-66, 70, 73, 75-76, 93-95, 97, 99, 100, 105, 107-110, 117, 119-122, 153-155, 168, 194-196, 198-200, 295

Trees, 5, 7, 9, 11, 15, 19, 47, 56, 61, 70, 76, 82-85, 87-90, 141, 148, 209, 211, $213,216,217,220,230,238,272$, 276, 295, 318, 328, 354,356

Trellises, 249, 251-254

U

Urban agriculture, 1, 7-19, 27, 42, 49, 51, 53, 54, 57, 64, 93, 95, 97, 99, 101, 105, $140,151,153,156,158,181,191$, 195, 196, 198, 199, 202, 221, 229, 231, 240, 302, 311, 326, 334, 339, 341-344, 346, 358, 360, 363-367, 370, 373-386, 389-393, 397, $398,400,401$

Urban farm, 7-10, 15, 19, 20, 43, 46-48, $161,163,165-168,235-238,240$, 241, 270, 332, 335, 343, 344, 346, 364-369, 376, 385, 389, $393,399,400$

Urban food production, 140, 213, 222, 342, 382,386

Urban growth boundary, 374, 376, 380, 382-383

Urban heat island effect, 15

Urban landscape, 5, 209, 214, 215, 218, 220, $222,231,377$

Urban life, 191, 202, 269

Urban sprawl, 374, 375 
V

Value, 5, 7, 10, 16, 17, 25, 26, 42, 73, 74, 99,

$102,103,105,116,119,148,151,210$,

$212,217,222,229,231,245,259,260$, $266,301,375,382$

Vertical farm, 10, 11

W

Waste collection, 119, 125, 126, 129, 394

Waste conversion, 94, 105

Waste management, 107-123, 126, 153, 158

Waste reduction, 125,126

Wastewater, 43, 53, 55-58, 60, 63, 66, 69, 70, 72, 73, 80, 93-95, 99, 100, 105, 107-110, 114, 119-122, 131, 153-155, 198, 295-297

Water, 25, 27, 28, 30, 31, 33, 34, 36-39, 43, 50, 53-66, 69, 70, 72, 74-76, 79-82, 84-90, 93-95, 99, 101, 107, 108, 111, $117,118,122,161,164-165,168$, 174-177, 180, 183, 184, 186-189, 194, 196, 198-199, 209, 212, 219,
230, 240, 254, 255, 257, 266, 269, 271, 272, 274, 295-301, 304, 305, 318-320, 322, 328, 330, 331, 334, 335, 355-356, 365, 366, 376, 379-382, 386

quality, 58, 64, 65, 70, 84, 298-299, 301, $328,331,334,355-356$

Wildlife, 89, 212, 231, 232, 235-241

$\mathbf{Y}$

Yard waste, 15, 46, 93-98, 101, 111, 125-128, $131,132,134,141,148,149,155,156$, 166,394

Yield, 42, 50-51, 54, 167, 207, 209, 211, 213, 215, 221, 222, 245-266, 295, 296, 298

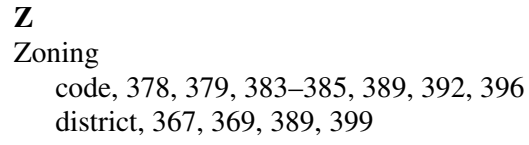

